UNIVERSIDADE DE SÃO PAULO

INSTITUTO DE GEOCIÊNCIAS

VALENTINA ESPINEL ARIAS

Eolianitos Quaternários do Nordeste do Brasil

São Paulo

2020 
UNIVERSIDADE DE SÃO PAULO

INSTITUTO DE GEOCIÊNCIAS

Eolianitos Quaternários do Nordeste do Brasil

VALENTINA ESPINEL ARIAS

Tese apresentada ao Programa de

Geoquímica e Geotectônica para obtenção do título de Doutora em Ciências

Área de concentração: Geotectônica

Orientador: Prof. Dr. Paulo Cesar Fonseca

Giannini

SÃO PAULO

2020 


\author{
UNIVERSIDADE DE SÃO PAULO \\ INSTITUTO DE GEOCIÊNCIAS
}

\title{
Eolianitos Quaternários do Nordeste do Brasil
}

\section{VALENTINA ESPINEL ARIAS}

Orientador: Prof. Dr. Paulo César Fonseca Giannini

Tese de Doutorado

$\mathrm{N}^{\mathrm{o}} 631$

COMISSÃO JULGADORA

Dr. Paulo César Fonseca Giannini

Dr. Vinicius Ribau Mendes

Dr. Nicolas Misailidis Strikis

Dr. André Marconato

Dra. Helenice Vital

Dr. André Zular

SÃO PAULO

2021 
Autorizo a reprodução e divulgação total ou parcial deste trabalho, por qualquer meio convencional ou eletrônico, para fins de estudo e pesquisa, desde que citada a fonte.

Servico de Biblioteca e Documentaça do IGc/USP Ficha catalogrática gerada automaticamente com dados fornecidos pelo(a) autor(a) via programa desenvolvido pela Seçäo Técnica de Informática do ICMC/USP

Bibliotecários responsáveis pela estrutura de catalogação da publicação: Sonia Regina Yole Guerra - CRB-8/4208 | Anderson de Santana - CRB-8/6858

Bepinel-Arias, Valentina

Bolianiton Quaternsrion do Nordeate do Branil

Valentina Bapinel-Arias; orientador Paulo Ceas

Fonseca Giannini. -- Säo Paulo, 2020.

$280 \mathrm{P}$.

Tene (Doutorado - Programa de P6a-Graduaçio eGeoquimica e Geotect8nica) -- Inatituto de

Geociencias, Univeraidade de São Paulo, 2020.

1. Eolianiton - 2. Dataçoen. 3. Nivel Relativo do Mar. 4. Paleoclima quaternario. 5. Cimentação

mbldica.. I. Fonseca Giannini, Paulo Ceasar, orient.

II. Título. 

"Never consider study as an obligation, Gut as the opportunity to penetrate the beautiful and wonderful world of knowledge."

Albert Einstein 


\section{Agradecimentos}

Ao meu orientador Giannini, por me cativar mais pela sedimentologia e a pesquisa, e por guiar meu caminhar desde o 2013 me orientando no mestrado e incentivando este longo processo de doutorado que me permitiu chegar hoje neste momento que sinto que aprendi e realizei muitas coisas que não imaginei que conseguiria, infinitamente grata pela paciência, entusiasmo e dedicação nesses momentos difíceis, obrigada pela confiança e acreditar em mim. A minha família por me apoiar nesta decisão de ficar longe deles para empreender minha vida de cientista, vocês sempre foram e serão a maior inspiração na minha vida. A Jairo, meu companheiro, amigo e parceiro, que além de me apoiar em todas minhas determinações nestes sete anos, foi meu suporte nos momentos de depressão e saudade e continua me ensinando do Brasil. Às meninas dos laboratórios Legal e LabSed que me ajudaram com tantas coisas, à agencia CAPES, pela bolsa de doutorado que me permitiu a dedicação completa na pesquisa. Ao Prof. Dr. Rodolfo Angulo e ao CNPq com a ajuda financeira de algumas analises cronológicas, ao Prof. Dr. Vinicius Ribau pela ajuda e sugestões desde o mestrado, e em geral a todo o pessoal do IGc, diretivos e trabalhadores que sempre com um sorriso no rostro me ajudaram. Aos meus amigos e companheiros pelos momentos de alegrias e ócio, e na Colombia ao Prof. Dr. Carlos Guzmán por me incentivar na realização do doutorado e por me ensinar a amar a sedimentologia. Com certeza ficaram muitas pessoas sem mencionar, mas que sou muito grata por me ajudar neste longo processo.

Obrigada a TODOS!! 


\section{Resumo}

A costa do Nordeste do Brasil encontra-se sob influência dos ventos que sopram para a Zona de Convergência Intertropical (ZCIT) e que têm favorecido a formação, no Quaternário tardio, de sistemas deposicionais eólicos. Nas áreas com aporte bioclástico, como Piauí e parte de Ceará e Rio Grande do Norte, na porção continental da costa, e o Arquipélago de Fernando de Noronha, na porção insular, estes sistemas incluem eolianitos, os quais foram aqui caracterizados quanto a paleoventos, fácies deposicionais, granulometria, petrografia, MEV, teor de carbonato, minerais pesados e cronologia via ${ }^{14} \mathrm{C}$ e LOE. Os eolianitos continentais associam-se à plataforma interna mista em rampa, de caimento suave $\left(<1^{\circ}\right)$, a qual se prolonga na área emersa, onde gera amplo espaço de acumulação eólica e favorece o desenvolvimento de planícies deflacionárias com quilômetros de extensão; os afloramentos resultam extensos, com poucos metros de espessura, dominados por fácies com estratificações cruzadas de ângulo baixo, atribuídas sobretudo a rastros lineares residuais. Os eolianitos insulares associam-se a plataforma carbonática isolada estreita (menos de $10 \mathrm{~km}$ ), com bordas recifais e taludes acentuados; por se tratar de ilhas de rochas vulcânico-piroclásticas de idade quaternária, com relevo acidentado, a área de acumulação eólica é limitada, o que faz com que os afloramentos sejam menos extensos e de maior espessura, predominando fácies de cruzadas de ângulo alto, inclusive com preservação da crista da forma de leito. Eolianitos continentais e insulares têm em comum a presença de algas vermelhas como tipo de grão intraclástico dominante e de cimento calcítico precoce, formado em condições meteóricas vadosas, nos depósitos holocenos, e vadosas a freáticas, nos pleistocenos. Principalmente nos eolianitos pleistocenos, inversões de idades ${ }^{14} \mathrm{C}$ entre bioclasto e cimento, associadas à presença de pseudomorfos de bioclastos formados por preenchimento móldico, indicam que a história diagenética teve pelo menos três fases: cimentação micrítica interpartícula precoce, sob condições de relativa aridez; dissolução móldica em fase de aumento e/ou de auge de umidade; e preenchimento dos poros por espato ou microespato no início do novo ciclo de queda de umidade. Dentre os eolianitos continentais, as idades variam entre 7,0 ka e 14 anos, nos afloramentos menos consolidados, com forma preservada de cordão; e entre 86,2 a 40,7 ka, compatíveis com os MIS 5 e 3, nos fortemente consolidados, que ocorrem em falésias costeiras. Já nos eolianitos insulares, duas modas de idades ${ }^{14} \mathrm{C}$ (entre 46,1 e 21,7 ka cal AP e de 18,7 a 5,3 ka cal AP) foram encontradas, a primeira delas inclusive em bioclastos sem inversão de idade com o cimento, o que permite sugerir deposição no evento MIS 3. 
Palavras chave: paleodunas carbonáticas, algas vermelhas, datações, nível relativo do mar, paleoclima quaternário, cimentação móldica. 


\begin{abstract}
The coast of Northeast Brazil is under the influence of the winds that blow towards the Intertropical Convergence Zone (ITCZ) and that have favored the formation of eolian depositional systems in the late Quaternary. In areas with bioclastic contribution, such as Piauí and part of Ceará and Rio Grande do Norte, on the coast of the continental portion, and the Fernando de Noronha Archipelago, in the insular portion, these systems include eolianites, which were characterized here as for: paleowinds, depositional facies, granulometry, petrography, SEM, carbonate content, heavy minerals and chronology via ${ }^{14} \mathrm{C}$ and OSL. The continental eolianites are associated with an inner shelf in mixed ramp, with a smooth inclination $\left(<1^{\circ}\right)$, which extends in the emerged area, generating large space for eolian accumulation, and favors the development of deflation plains with kilometers of extension; the outcrops are extensive, a few meters thick, dominated by facies with low angle cross stratifications, attributed mainly to trailing ridges. Island eolianites are associated with a narrow isolated carbonate shelf (less than $10 \mathrm{~km}$ ), with reef edges and sharp slopes; because the islands are supported by volcanic-pyroclastic rocks of Quaternary age, with rugged relief, the area of eolian accumulation is limited, which means that the outcrops are less extensive and of greater thickness, with predominance of high angle cross stratifications, sometimes with preservation of bedform crests. Continental and island eolianites have in common the presence of red algae as the dominant intraclast grain and of early calcitic cement, formed in meteoric vadose conditions in Holocene deposits and phreatic conditions in the Pleistocene ones. Mainly in Pleistocene eolianites, inversions of ${ }^{14} \mathrm{C}$ ages between bioclast and cement, associated with the presence of bioclast pseudomorphs formed by moldic filling, indicate that the diagenetic history had at least three phases: early interparticle micritic cementation, under conditions of relative aridity; moldic dissolution in the phase of increase and/or peak of humidity; and filling of pores with spar or microspar at the beginning of the new cycle of falling humidity. Among continental eolianites, ages vary between $7.0 \mathrm{ka}$ and 14 years, in less consolidated outcrops, with a preserved ridge shape; and between 86.2 to $40.7 \mathrm{ka}$, compatible with MIS 5 and MIS 3, in the strongly consolidated outcrops, which occur on coastal cliffs. In insular eolianites, two ${ }^{14} \mathrm{C}$ age ranges were found (between 46.1 and $21.7 \mathrm{ka} \mathrm{cal} \mathrm{AP}$ and from 18.7 to $5.3 \mathrm{ka} \mathrm{cal} \mathrm{AP),} \mathrm{the} \mathrm{first}$ of them containing bioclasts without age inversion with the cement, which allows suggesting deposition in the MIS 3 event.
\end{abstract}

Keywords: carbonate paleodunes, red algae, dating, relative sea level, Quaternary paleoclimate, moldic cementation. 



\section{SUMARIO}

1 INTRODUÇÃO

1.1 Delimitação do Problema e Perguntas por Responder ......................... 1

1.2 Relevância do Tema e da Abordagem ................................................. 4

1.3 Localização das Áreas de Estudo ................................................... 4

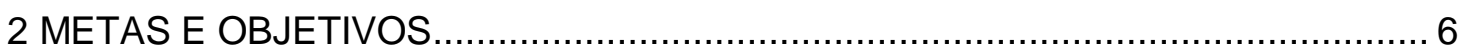

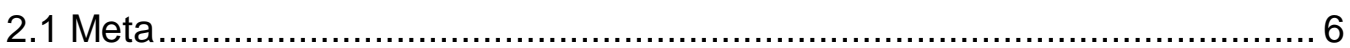

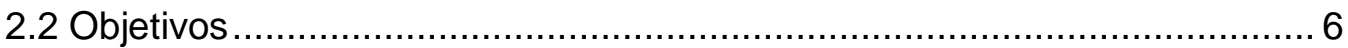

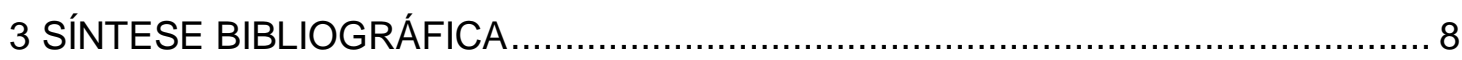

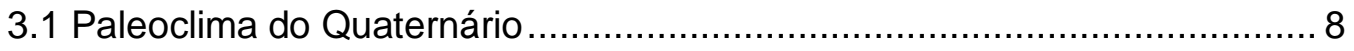

3.2 Fatores Controladores de Sedimentação Eólica...................................... 9

3.3 Tipologia de elementos morfológicos eólicos costeiros .......................... 11

3.4 Controles particulares na formação de eolianitos .................................. 15

3.5 Eolianitos quaternários ao redor do mundo ....................................... 17

3.6 Distribuição no Tempo dos Depósitos Eólicos Quaternários do Brasil..... 20

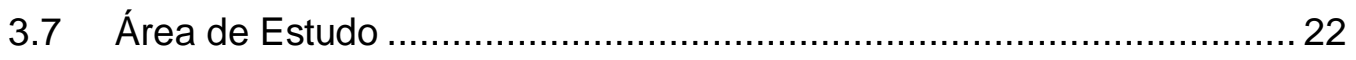

3.7.1 Geomorfologia e geologia 22

3.7.2 Fontes potenciais de sedimentos carbonáticos na área submersa $\quad 25$

$\begin{array}{ll}\text { 3.7.3 Clima e paleoclima } & 27\end{array}$

$\begin{array}{ll}\text { 3.7.4 Variação do NRM } & 31\end{array}$

$\begin{array}{ll}\text { 3.7.5 Ondas e deriva litorânea } & 33\end{array}$

4 ATIVIDADES REALIZADAS: MEIOS, MATERIAIS E MÉTODOS......................... 34

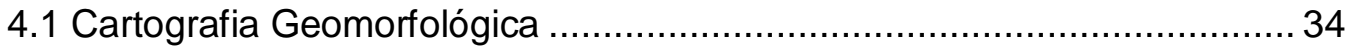

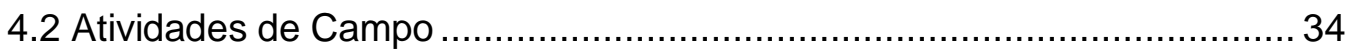

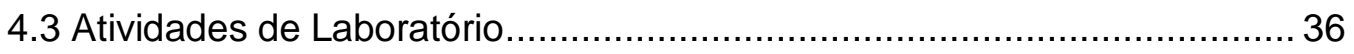

4.3.1. Granulometria 36

4.3.2. Proporção de bioclastos por classe granulométrica 36 
$\begin{array}{ll}\text { 4.3.3. Datações } & 37\end{array}$

$\begin{array}{ll}\text { 4.3.4 Petrografia } & 40\end{array}$

4.3.5 Microscopia eletrônica de varredura 41

4.3.6 Dosagem de carbonato 42

4.3.7. Separação e análise microscópica de minerais pesados 42

4.3.8. Identificação de bioclastos e moluscos 44

4.4 Tratamento Gráfico-Estatístico dos Dados .......................................... 44

4.4.1 Resultados de campo $\quad 44$

4.4.2 Resultados analíticos laboratoriais $\quad 45$

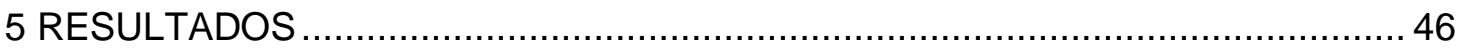

5.1 Mapeamento e Aspectos Morfológicos dos Sistemas Eólicos em Estudo 46

5.1.1 Morfologia dos sistemas eólicos e dos eolianitos do Rio Grande do Norte 48

5.1.2 Morfologia dos eolianitos e os sistemas eólicos de Fernando de Noronha 51

5.2 Descrição de Fácies Deposicionais........................................................ 57

$\begin{array}{ll}\text { 5.2.1 Eolianitos } & 57\end{array}$

$\begin{array}{ll}\text { 5.2.2 Fácies associadas } & 60\end{array}$

5.3 Distribuição Espacial dos Eolianitos e Associações de Fácies Deposicionais

5.3.1 Rio Grande do Norte 63

5.3.2 Arquipélago de Fernando de Noronha 76

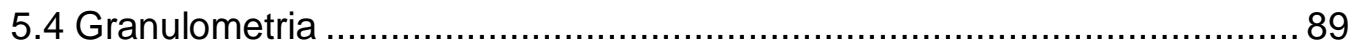

$\begin{array}{lr}\text { 5.4.1 Eolianitos continentais } & 89\end{array}$

$\begin{array}{ll}\text { 5.4.2 Eolianitos insulares } & 91\end{array}$

5.5 Proporção de Bioclastos por Casse Granulométrica .............................93

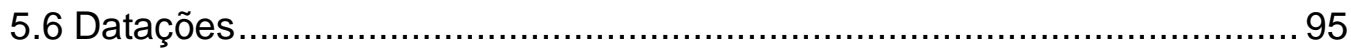

5.6.1 Rio Grande do Norte 95

5.6.2 Arquipélago de Fernando de Noronha 100

5.7 Análise Petrográfica .................................................................. 104 
$\begin{array}{ll}\text { 5.7.2. Arquipélago de Fernando de Noronha } & 118\end{array}$

5.8 Microscopia Eletrônica de Varredura.............................................. 133

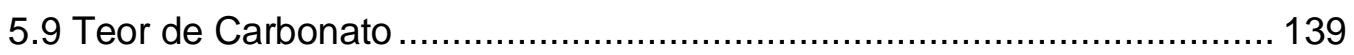

5.10 Análise de Minerais Pesados ..................................................... 145

5.10.1 Caraterização da assembleia de eolianitos continentais 145

5.10.2. Variação espacial dos minerais e índices mineralógicos dos eolianitos $\begin{array}{ll}\text { continentais } & 150\end{array}$

5.10.3 Caraterização da assembleia de eolianitos insulares 152

5.10.4 Variação espacial dos minerais e índices mineralógicos dos eolianitos insulares 160

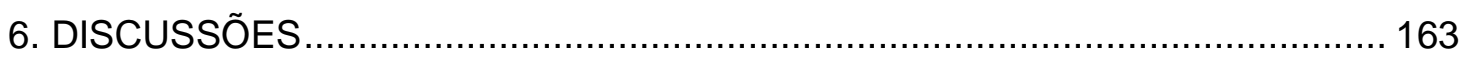

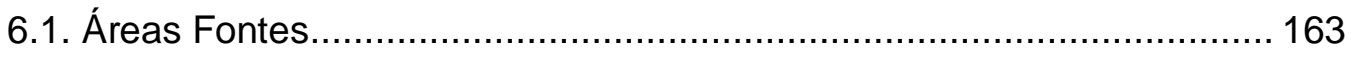

6.2. Área de Acumulação e Elementos Morfológicos ................................ 169

6.2.1. Morfologia do sistema eólico e dos corpos de eolianito 169

$\begin{array}{ll}\text { 6.2.2. Fácies e associações de fácies nos eolianitos } & 173\end{array}$

6.2.3. Fácies e associações de fácies nos depósitos associados aos eolianitos

6.3. Petrografia e Efeitos da Diagênese nos Eolianitos

6.4. Distribuição dos Eolianitos no Tempo 194

6.4.1. Limitações e significados dos resultados geocronológicos 195

$\begin{array}{ll}\text { 6.4.2 Idades versus NRM } & 202\end{array}$

$\begin{array}{ll}\text { 6.4.3. Idades vs clima } & 208\end{array}$

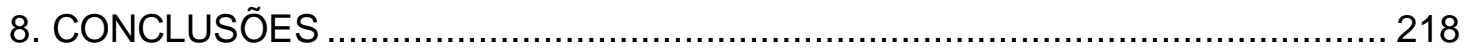

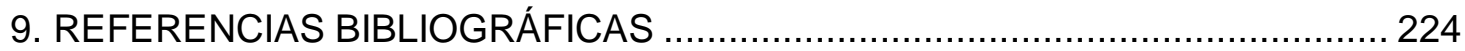

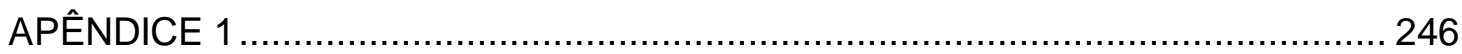

Granulometria, Separação de Minerais Pesados e Teor de Bioclastos dos Eolianitos Continentais 246

APÊNDICE 2 248 
APÊNDICE 3

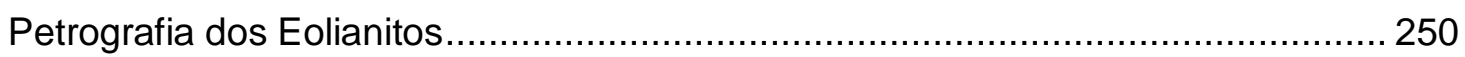

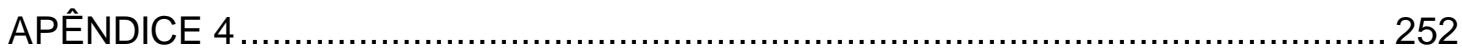

Contagem de Minerais Pesados nos Eolianitos Continentais .............................. 252

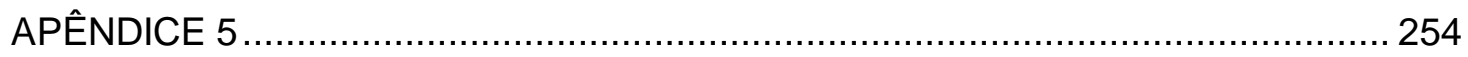

Contagem de Minerais Pesados nos Eolianitos Insulares ................................ 254

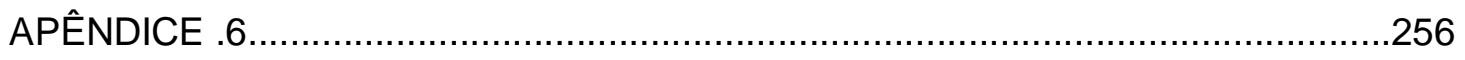

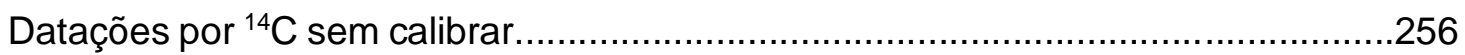

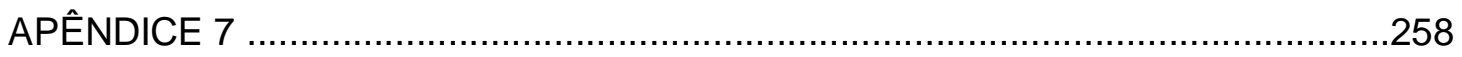

Datações por LOE nos eolianitos continentais...................................................258

\section{Lista de Figuras}

Fig. 1.1. Localização das áreas de ocorrência de eolianitos estudadas nesta tese.......................................5

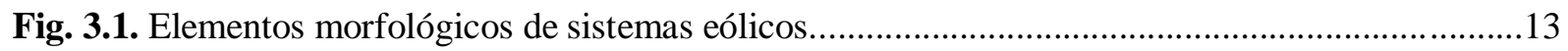

Fig.3.2. As três associações de elementos morfológicos em sistemas eólicos costeiros ativos do

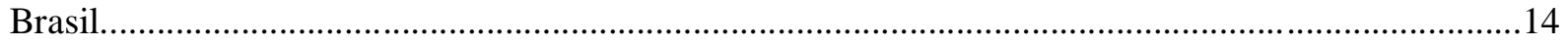

Fig. 3.3. Tipos de sistemas eólicos costeiros do Brasil, sob condição de vento efetivo transversal à linha

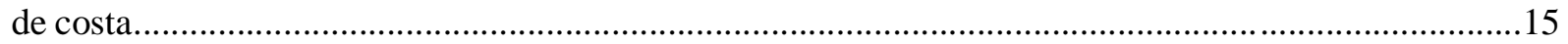

Fig. 3.4 Correntes oceânicas e distribuição de carbonatos marinhos rasos.............................................17

Fig. 3.5. Geologia da região de estudo no Rio Grande do Norte...........................................................23

Fig. 3.6. Exemplos de lagos associados à obstrução de drenagens costeiras pelo avanço ao interior de

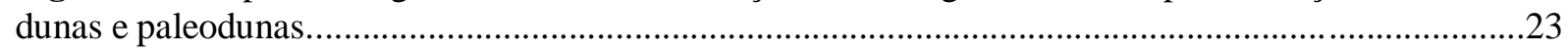

Fig. 3.7. Geologia do Arquipélago de Fernando de Noronha.............................................................24

Fig. 3.8. Plataforma continental da área de estudo, com representação dos tipos de sedimentos nos

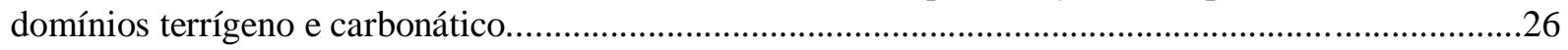

Fig. 3.9. Mapa batimétrico do arquipélago de Fernando de Noronha e arredores..................................27

Fig. 3.10. Quatro cenários da ZCIT e o comportamento dos alísios.......................................................28

Fig. 3.11. Mapas de ventos nos estados de PI, CE e RN, para o período de 1983 a 1999......................30

Fig. 3.12 Histograma azimutal das intensidades dos ventos no AFN..................................................31

Fig. 4.1. Esquema de um diagrama em caixa (boxplot), ferramenta de estatística descritiva utilizado neste trabalho. 
Fig. 5.1. Elementos morfológicos com influência morfodinâmica da vegetação observados nas áreas de estudo.

Fig. 5.2. Elementos morfológicos de campo de dunas, sem influência morfodinâmica da vegetação.

Fig. 5.3. Áreas de estudo no RN. .50

Fig. 5.4. Tipos de afloramentos de eolianitos na costa do RN. . .51

Fig. 5.5. Localização dos afloramentos baixos de eolianitos no AFN. .52

Fig. 5.6. Afloramento baixo de eolianito, na Pedra da Bigorna, AFN. .52

Fig. 5.7. Localização dos afloramentos altos de eolianitos em AFN................................................53

Fig. 5.8. Exemplo de afloramento alto de eolianito em Atalaia, AFN...............................................53

Fig. 5.9. Praia da Caieira, AFN, e dunas eólicas associadas...........................................................55

Fig. 5.10. Praia do Atalaia, AFN, e feições eólicas associadas.........................................................56

Fig. 5.11. Fácies deposicionais de ângulos altos observadas nos eolianitos......................................59

Fig. 5.12. Fácies deposicionais com estratificações de baixo ângulo observadas nos eolianitos......59

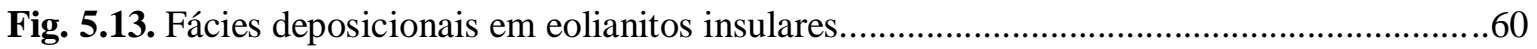

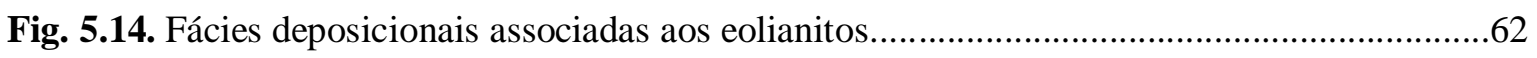

Fig. 5.15. Associação de fácies na falésia ERN 18, pertencente aos Três Irmãos................................64

Fig. 5.16. Associação de fácies na falésia ERN 20, pertencente a Três Irmãos..................................65

Fig. 5.17. Associação de fácies na falésia ERN 19, pertencente aos Três Irmãos..............................66

Fig. 5.18. Associação de fácies na falésia ERN 21, pertencente a Três Irmãos..................................67

Fig. 5.19. Histograma circular de azimutes de mergulho de estratificações cruzadas nos eolianitos de

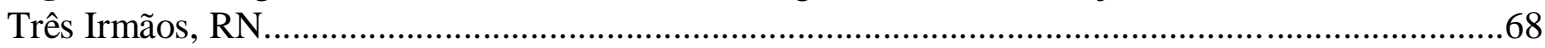

Fig. 5.20. Associação de fácies de eolianito encontrada em Guajiru, RN..........................................70

Fig. 5.21. Detalhes de afloramento e rosas de areia dos eolianitos encontrados em Guajiru, RN......71

Fig. 5.22. Associação de fácies encontrada em Enxu Queimado, RN..............................................73

Fig. 5.23. Detalhes de campo e rosa de areia dos eolianitos de Enxu Queimado, RN......................74

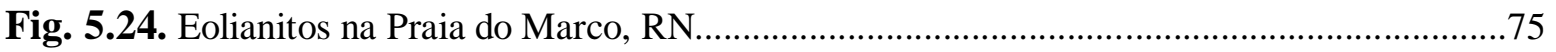

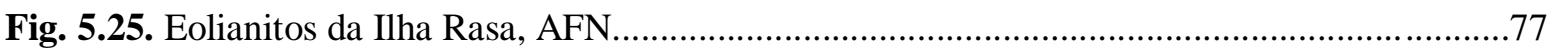

Fig. 5.26. Sucessão de fácies do afloramento EFN 02, na Pedra da Bigorna.....................................79

Fig. 5.27. Associações de fácies de eolianitos, em Enseada da Caieira, AFN com ênfase na seção WSW-

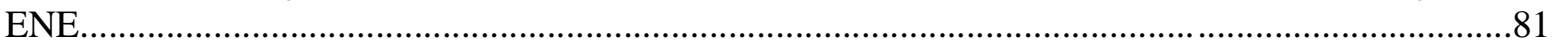

Fig. 5.28. Associações de fácies de eolianitos, em Enseada da Caieira, AFN, seções NNW-SSE e WNWESSE.

Fig. 5.29. Histogramas circulares de azimutes de mergulho para os eolianitos de Enseada da Caieira, AFN.

Fig. 5.30. Associação de fácies deposicionais em Atalaia, AFN.. .84 
Fig. 5.31. Detalhes de afloramento e histogramas circulares para as fácies de eolianito de Atalaia, AFN.

Fig. 5.32. Associação de fácies na Ponta das Caracas, com ênfase na seção NE-SW... . .86

Fig. 5.33. Associação de fácies na Ponta das Caracas, com ênfase na seção SE-NW. .87

Fig. 5.34. Associação de fácies em Forte de São Joaquim do Sueste. . .88

Fig. 5.35. Gráficos de densidade de distribuição granulométrica retida da fração areia para as amostras de eolianito de Macapá, PI..

Fig. 5.36. Gráficos de densidade de distribuição granulométrica retida da fração areia para as amostras de eolianito de Três Irmãos, RN.

Fig. 5.37. Gráficos de densidade de distribuição granulométrica retida da fração areia para as amostras de eolianito de Guajiru, RN.

Fig. 5.38. Gráficos de densidade de distribuição granulométrica retida da fração areia para as amostras de eolianito de Enxu Queimado, RN.

Fig. 5.39. Variação das proporções das frações granulométricas retidas de areia, para o conjunto de amostras de planície deflacionária das quatro áreas selecionadas para análise.

Fig. 5.40. Gráficos de densidade de distribuição granulométrica retida da fração areia para as amostras de eolianito de Enseada da Caieira, AFN.

Fig. 5.41. Gráficos de densidade de distribuição granulométrica retida da fração areia para as amostras de eoloanito de Ponta das Caracas, AFN.

Fig. 5.42. Gráficos de densidade de distribuição granulométrica retida da fração areia para as amostras de eolianito de Atalaia, AFN.

Fig. 5.43. Variação das proporções das frações granulométricas retidas de areia, para o conjunto de amostras de eolianitos altos, das áreas selecionadas para análise...

Fig. 5.44. Variação do teor estimado de bioclastos por fração granulométrica das amostras de eolianito de Macapá, PI.

Fig. 5.45. Variação do teor estimado de bioclastos por fração granulométrica retida das amostras de eolianito de Três Irmãos, RN.

Fig. 5.46. Variação do teor estimado de bioclastos por fração granulométrica retida das amostras de eolianito de Guajiru, RN.

Fig. 5.47. Variação do teor estimado de bioclastos por fração granulométrica retida das amostras de eolianito de Enxu Queimado, RN.

Fig. 5.48. Distribuição por amostra das idades em eolianitos do Rio Grande do Norte. .98

Fig. 5.49. Distribuição por amostra das idades medianas mais novas que $7,0 \mathrm{ka}$ em eolianitos do Rio Grande do Norte. . .98

Fig. 5.50. Gráfico boxplot das datações por fácies com e sem rizoconcreções . .99

Fig. 5.51. Histogramas de distribuição de frequências de idades em eolianitos do RN.. . .99

Fig. 5.52. Datações obtidas nos eolianitos de Fernando de Noronha, listados de NE para SW. 101

Fig. 5.53 Gráfico de caixa comparando as idades obtidas quanto a tipo de material datado. 102

Fig. 5.54. Variação da idade em função da altura no afloramento, em Atalaia. 102 
Fig. 5.55. Variação da idade em função da altura no afloramento, em Ponta das Caracas e Forte de São Joaquim.

Fig. 5.56. Histogramas de distribuição de frequências de idades em eolianitos do AFN..................103

Fig. 5.57. Seção delgada da amostra ERN 09, com destaque para a segregação granular do arcabouço 104

Fig. 5.58. Variação das proporções dos componentes texturais nos eolianitos do RN .105

Fig. 5.59. Feições principais da petrotrama dos eolianitos do RN... 106

Fig. 5.60. Exemplos de tipos de porosidade observados nos eolianitos do RN. 106

Fig. 5.61. Variação das proporções dos tipos genéticos de grãos do arcabouço nos eolianitos do RN

Fig. 5.62. Principais componentes do arcabouço dos eolianitos do RN. 108

Fig. 5.63. Variação das proporções dos principais componentes do arcabouço nos eolianitos do RN 109

Fig. 5.64. Variação das proporções dos tipos de grãos intrabacinais no arcabouço dos eolianitos de Enxu Queimado, RN....

Fig. 5.65. Diagrama de caixa dos tipos de grãos intrabacinais no arcabouço dos eolianitos de Guajiru, RN

Fig. 5.66. Variação das proporções dos tipos de grãos intrabacinais no arcabouço dos eolianitos de Três Irmãos, RN

Fig. 5.67 Razão Pe/Al (peloides / algas vermelhas) nas áreas de Enxu Queimado, Guajiru e Três Irmãos, $\mathrm{RN}$

Fig. 5.68. Tipos de trama de cimento microespático presentes nos eolianitos do RN 113

Fig. 5.69. Tipos de trama de cimento espático em eolianitos do RN

Fig. 5.70. Variação das proporções das tramas de cimento nos eolianitos de Enxu Queimado, RN...115

Fig. 5.71. Variação das proporções das tramas de cimento nos eolianitos de Guajiru, RN. 115

Fig. 5.72. Variação das proporções das tramas de cimento nos eolianitos de Três Irmãos, RN........116

Fig. 5.73. Seção delgada do beach rock da área de Enxu Queimado, RN

Fig. 5.74. Seção delgada do beach rock de Três Irmãos, RN.

Fig. 5.75. Aspecto geral do arcabouço dos eolianitos do AFN 118

Fig. 5.76. Aspectos da petrotrama dos eolianitos do AFN

Fig. 5.77. Tipos de porosidade intergranular observados nos eolianitos do AFN

Fig. 5.78. Variação das proporções dos componentes texturais dos eolianitos do AFN 120

Fig. 5.79. Variação das proporções dos componentes texturais dos eolianitos de Enseada da Caieira, AFN..

Fig. 5.80. Variação das proporções dos componentes texturais dos eolianitos de Atalaia, AFN.

Fig. 5.81. Variação das proporções dos componentes texturais dos eolianitos de Ponta das Caracas, AFN...... 
Fig. 5.82. Variação das proporções dos componentes texturais dos eolianitos de Forte de São Joaquim, AFN. 122

Fig. 5.83 Principais componentes do arcabouço dos eolianitos do AFN.... 123

Fig. 5.84. Outros componentes do arcabouço dos eolianitos do AFN. 124

Fig. 5.85. Variação das proporções dos componentes do arcabouço dos eolianitos do AFN. 125

Fig. 5.86. Variação da razão peloides / algas vermelhas (Pe/Al), por área, no AFN. 126

Fig. 5.87. Principais tramas de cimento carbonático em eolianitos do AFN. 126

Fig. 5.88. Outras tramas de cimento em eolianitos do AFN. 127

Fig. 5.89. Tramas de cimentos espáticos em eolianitos do AFN. 127

Fig. 5.90. Variação das proporções das tramas de cimento nos afloramentos baixos do AFN. 128

Fig. 5.91. Variação das proporções de tramas de cimentos nos afloramentos altos do AFN 128

Fig. 5.92. Variação das proporções dos tipos de tramas de cimento nos eolianitos de Enseada da Caieira, AFN.

Fig. 5.93. Variação das proporções dos tipos de tramas de cimento nos eolianitos de Atalaia, AFN.

Fig. 5.94. Variação das proporções dos tipos de tramas de cimento nos eolianitos de Ponta das Caracas, AFN.

Fig. 5.95. Variação das proporções dos tipos de tramas de cimentos nos eolianitos de Forte de São Joaquim, AFN.

Fig. 5.96 Fotomicrografias a polarizadores paralelos de fácies associadas a eolianitos na área da Pedra da Bigona. 132

Fig. 5.97 Cimentos carbonáticos presentes nas fácies associadas a eolianitos do AFN. 133

Fig. 5.98. Feições de dissolução e cimentação em bioclastos de alga vermelha de amostras in natura

Fig. 5.99 Pseudomorfismo ou neomorfismo (substituição de calcita Mg por calcita) de bioclasto de alga vermelha. 136

Fig. 5.100. Eletromicrografia de retroespalhados da lâmina EFN 04A 137

Fig. 5.101. Comparação entre os teores de $\mathrm{Mg}$ em algas vermelhas com diferentes concentrações de $\mathrm{MgCO}_{3}$ 138

Fig. 5.102. Comparação entre os teores em massa de carbonato, determinados por ataque com $\mathrm{HCl}$, nos eolianitos do RN

Fig. 5.103. Comparação entre os teores em massa de carbonato nas fácies associadas a eolianitos, no RN.

Fig. 5.104. Variação do teor em massa de carbonato nos eolianitos, por área geográfica do RN. Enxu Queimado. 142

Fig. 5.105. Variação do teor em massa de carbonato nos eolianitos, por área geográfica do AFN. Forte de São Joaquim.. 143

Fig. 5.106. Gráfico de dispersão de teor de carbonato vs distância à praia. 144 
Fig. 5.107. Gráfico de dispersão de teor de carbonato $v s$ a distância à praia dos eolianitos do AFN...144

Fig. 5.108. Distribuição da assembleia de minerais pesados dos eolianitos continentais......................146

Fig. 5.109. Minerais pesados dominantes ou abundantes nos eolianitos continentais..........................147

Fig. 5.110. Minerais pesados comuns nos eolianitos continentais......................................................148

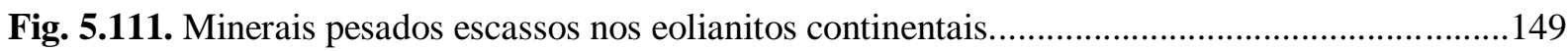

Fig. 5.112. Minerais pesados escassos nos eolianitos continentais.....................................................150

Fig. 5.113. Índice zircão/rutilo (ZRi) das quatro áreas principais de ocorrência de eolianitos

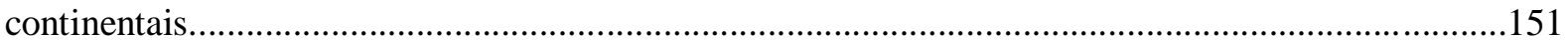

Fig. 5.114. Índice turmalina/hornblenda (THi) das quatro áreas principais de ocorrência de eolianitos continentais.

Fig. 5.115. Índice estaurolita/epídoto (EsEpi) das quatro áreas principais de ocorrência de eolianitos continentais.

Fig. 5.116. Índice zircão/turmalina (ZTi) das quatro áreas principais de ocorrência de eolianitos continentais. .152

Fig. 5. 117. Assembleia de minerais pesados transparentes não micáceos do $A F N$. 153

Fig. 5.118. Minerais pesados dominantes ou abundantes nos eolianitos insulares. 155

Fig. 5.119. Minerais pesados comuns nos eolianitos insulares. .156

Fig. 5.120. Minerais pesados escassos ou raros nos eolianitos insulares. 157

Fig. 5. 121. Assembleia de minerais pesados transparentes não micáceos de Enseada da Caieira, AFN..

Fig. 5. 122. Assembleia de minerais pesados transparentes não micáceos de Ponta das Caracas, AFN..

Fig. 5. 123. Assembleia de minerais pesados transparentes não micáceos de Forte de São Joaquim, AFN......

Fig. 5. 124. Assembleia de minerais pesados transparentes não micáceos de Atalaia, AFN 159

Fig. 5.125. Índice titanita/olivina (TiOli) dos quatro afloramentos altos do AFN, apresentados de $\mathrm{NE}$ para SW 160

Fig. 5.126. Índice titanita/augita (TiAui) dos quatro afloramentos altos do AFN, apresentados de NE para SW. .161

Fig. 5.127. Índice hornblenda/augita (HbAui) dos quatro afloramentos altos do AFN, apresentados de NE para SW

Fig. 5.128. Índice titanita/allanita (TiAli) dos quatro afloramentos altos do AFN, apresentados de $\mathrm{NE}$ para SW. 162

Fig. 6.1. Diferenças morfológicas entre as plataformas carbonáticas que atuaram como fontes de sedimentos para os eolianitos. 163

Fig 6.2 Distribuição mundial de fábricas modernas de carbonato marinho em águas rasas.. 167

Fig. 6.3 Tipo óptico de hornblenda dominante nos eolianitos: a. continentais; $\mathbf{b}$. insulares................168

Fig. 6.4. Afloramentos dos eolianitos continentais extensos e pouco espessos. .170 
Fig 6.5. Mapa apresentando os ângulos e comprimento das planícies deflacionárias .171

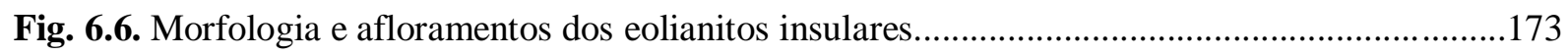

Fig. 6.7. Fácies deposicionais preferencialmente representadas nos eolianitos. .174

Fig. 6.8. Histogramas circulares de azimutes de mergulho de estratificações cruzadas em eolianitos continentais. 175

Fig. 6.9. Hipótese da formação de eolianitos associados a migração de dunas parabólicas.

Fig 6.10. Histograma circular de azimutes de mergulho geral das estratificações cruzadas nos eolianitos da região de Enseada da Caieira-AFN......

Fig 6.11. Histogramas circulares e rumos de estratificação das fácies presentes nos eolianitos altos. 179

Fig 6.12. Boxplot da razão Pe/Al nos eolianitos insulares e continentais.

Fig. 6.13. Graficos boxplot dos clastos intrabacinais dos eolianitos: a. insulares e b. continentais.....186

Fig. 6.14. Diferenças granulométricas entre os eolianitos: a. continentais e b. insulares.

Fig. 6.15. Boxplot das diferenças dos arranjos de cimentos carbonáticos dos eolianitos: a. continentais e b. insulares. 188

Fig. 6.16 Eolianitos com diferentes idades e graus de consolidação...... 192

Fig. 6.17. Hipótese de estágios de diagênese dos eolianitos pleistocenos. 193

Fig. 6.18 Gráfico de caixa de idades ${ }^{14} \mathrm{C}$ e LOE dos eolianitos insulares e continentais. 194

Fig. 6.19. Gráfico de caixa comparando as idades obtidas nos eolianitos pleistocenos do AFN e RN........

Fig. 6.20. Comparação dos resultados de datação de eolianitos insulares obtidos nesta pesquisa e em trabalhos anteriores.

Fig. 6.21. Hipótese do desenvolvimento dos eolianitos pleistocenos que apresentam inversão estratigráfica de idades. 200

Fig. 6.22. Distribuição de idades ${ }^{14} \mathrm{C}$ e LOE nos afloramentos de Três Irmãos. 201

Fig. 6.23. Distribuição das idades LOE e ${ }^{14} \mathrm{C}$ de eolianitos continentais do Nordeste. .202

Fig. 6.24. Curva-envelope global da variação do NRM de Waelbroeck et al. (2002), com todas as idades, e respectivas margens de erro, dos eolianitos pleistocenos. 206

Fig. 6.25. Esquema cronológico comparando as idades LOE/TL de gerações de paleodunas eólicas costeiras terrígenas de idades pleistocenas de Maranhão e Rio Grande do Norte. .206

Fig. 6.26. Idades dos eolianitos continentais holocenos do Nordeste, lançadas junto à curva do NRM de Caldas et al. (2006), para o Rio Grande do Norte... .208

Fig. 6.27. Esquema cronológico comparando as idades LOE/TL de gerações de paleodunas eólicas costeiras terrígenas de idades holocenas de Maranhão, Piauí, Ceará e Rio Grande do Norte... 208

Fig. 6.28. Comparação entre idades de eolianitos e indicadores paleoclimáticos para os últimos 85 ka..

Fig. 6.29. Estágios de formação dos eolianitos de Três Irmãos, RN...................................................212

Fig. 6.30. Estágios de formação de eolianitos insulares.. 214 
Fig. 6.31. Comparação entre idades de eolianitos e indicadores paleoclimáticos para o Holoceno.....216

Fig. 6.32. Estágios de formação dos eolianitos continentais holocenos.

\section{Lista de Quadros}

Quadro 1. Definições para feições eólicas costeiras formadas sob influência morfodinâmica da vegetação.

Quadro 2. Definições para feições eólicas costeiras formadas sem influência morfodinâmica significativa da vegetação..

Quadro 3. Proposta de correlação entre gerações de campos de dunas de diferentes regiões costeiras do Brasil...

Quadro 4. Sequência de preparação de amostras para medição de dose acumulada..........................37

Quadro 5. Sequência de passos utilizados no protocolo SAR ..............................................................38

Quadro 6. Sumário de descrição de fácies deposicionais em eolianitos.............................................58

Quadro 7. Sumário de descrição de fácies nos depósitos sedimentares associados aos eolianitos.....61

Quadro 8. Classificação nominal para as frequências porcentuais médias de minerais pesados dos eolianitos continentais.

Quadro 9. Principais minerais pesados presentes nos eolianitos continentais e suas características dominantes.....

Quadro 10. Classificação nominal para as frequências porcentuais médias de minerais pesados dos eolianitos insulares.

Quadro 11. Principais minerais pesados presentes nos eolianitos insulares e suas características dominantes.

Quadro 12. Interpretação das fácies deposicionais dos eolianitos 180

Quadro 13. Interpretação das fácies deposicionais associadas aos eolianitos. 184

Quadro 14. Critérios e classificação das petrofácies dos eolianitos. 188

Quadro 15. Sumário das petrofácies atribuídas aos eolianitos, com sua distribuição geográfica e cronológica 


\section{Lista de Tabelas}

Tabela 1. Eolianitos quaternários insulares no mundo, com suas principais características. .18

Tabela 2. Eolianitos quaternários continentais no mundo, com suas principais características............19

Tabela 3. Datações por LOE-SAR e ${ }^{14} \mathrm{C}$ AMS obtidas para as áreas do Rio Grande do Norte.............97

Tabela 4. Datações por ${ }^{14} \mathrm{C}$-AMS obtidas para as áreas de Fernando de Noronha...............................100

Tabela 5. Análise química semiquantitativa por EED na seção delgada da amostra EFN 04A..........137

Tabela 6. Teores de carbonato, determinados por ataque com $\mathrm{HCl}$, nas amostras de eolianitos do $\mathrm{RN}$........

Tabela 7. Teores de carbonato, determinados por ataque com $\mathrm{HCl}$, nas amostras de eolianitos do AFN.

Tabela 8. Teores de carbonato, determinados por ataque com $\mathrm{HCl}$, nas amostras de fácies associadas. 


\section{INTRODUÇÃO}

\subsection{Delimitação do Problema e Perguntas por Responder}

Reconstruções paleoclimáticas no Quaternário em costas continentais ou ilhas oceânicas específicas podem contribuir para a compreensão do cenário paleoambiental em escala global. Isto se baseia no fato de que mudanças climáticas, muitas vezes opostas, ocorrem em diferentes regiões de modo sincrônico, controladas pelo deslocamento dos grandes elementos de circulação atmosférica, como a Zona de Convergência Intertropical (ZCIT) e a Zona de Convergência do Atlântico Sul (ZCAS). Desse modo, estudos regionais, quando devidamente situados em relação a estes elementos, ganham significado na interpretação de mudanças climáticas globais.

Do ponto de vista da geologia sedimentar quaternária, as costas de Piauí (PI), Ceará (CE), Rio Grande do Norte (RN) e Arquipélago de Fernando de Noronha (AFN) têm em comum a presença de eolianitos e são as únicas regiões em que se tem registro deste tipo de depósito no Brasil até o momento. O termo eolianito, introduzido por Sayles (1931) no Quaternário das Bermudas, designa depósitos eólicos cimentados por calcita em condições meteóricas, formados em áreas costeiras com acumulações de areias biogênicas (Fairbridge \& Johnson 1978, Pye 1983, Tucker \& Wright 1990). Em vista desta origem, os eolianitos refletem controle exercido pelo clima e pelo nível relativo do mar (NRM) na sua formação (Brooke 2001). Este controle manifesta-se de dois modos: no acúmulo de material carbonático biogênico, incoeso; e na exposição deste material à ação de ventos com competência para transportá-los.

A plataforma continental do PI, CE e RN é composta por sedimentos mistos terrígenocarbonáticos, ricos (mais de 50\%) em cascalhos de algas coralináceas ramificantes (Kowsmann e Costa 1979). Os eolianitos desaparecem no Estado do Maranhão, onde a plataforma passa a ser de constituição essencialmente terrígena (Kowsmann e Costa 1979), e no oeste do RN, onde a representatividade de fácies carbonáticas na plataforma volta a decair. Mas reaparecem no nordeste do mesmo estado, que retorna a ter fácies carbonáticas na plataforma. Assim, a presença de fácies carbonáticas na plataforma continental é um fator relevante na distribuição dos eolianitos do Nordeste continental em escala regional. Já a zona submersa adjacente ao AFN, a exemplo de outras ilhas vulcânicas brasileiras, como as de Trindade e de São Pedro e São Paulo (Angulo et al. 2013b), é rica em sedimentos carbonáticos, dada a área de captação 
limitada dos rios e, portanto, o escasso aporte terrígeno (Almeida 1955, Angulo et al. 2013a). Assim, toda a sua sedimentação costeira, inclusive a eólica, é essencialmente carbonática. Dentro deste contexto, a primeira questão-problema desta tese de doutorado é: quais as diferenças, em termos de constituição do arcabouço, entre os eolianitos da costa continental entre PI e RN e os do AFN?; e como estas diferenças se refletem quanto a cimentação, litificação e petrofácies?

Em escala de mais detalhe, dentro de um campo de dunas, por exemplo, ou de um campo de dunas para outro, a distribuição espacial de eolianitos é controlada pelo tempo hábil para a cimentação calcítica, relacionado com a idade do depósito, e pela concentração aerodinâmica de bioclastos carbonáticos, o que pode ter relações com a forma, o tamanho e a densidade destes clastos. Com relação a este segundo aspecto, os eolianitos brasileiros, tanto do Nordeste continental (Baptista 2010, Espinel-Arias 2015, Espinel-Arias et al. 2015, Cagliarani et al. 2015) quanto do AFN (Almeida 1955, Angulo et al. 2013a), são frequentemente constituídos por areia média a grossa. No PI e oeste do CE, estes eolianitos de granulação relativamente grossa correspondem a fácies residuais de deflação, principalmente rastros lineares (EspinelArias et al. 2015, Espinel-Arias 2015, Cagliarani et al. 2015), mas no AFN e no RN a faciologia não está ainda bem estabelecida. Assim, a segunda questão-problema deste projeto de doutorado é: que fatores controlam a disponibilidade de material carbonático e a formação de eolianitos em escala local, no caso continental (Nordeste brasileiro) e no oceânico (AFN)?; a suposta relação dos eolianitos da costa continental com fácies de planície de deflação tem relação com a distribuição granulométrica dos bioclastos carbonáticos?; e quais são as semelhanças e diferenças entre os eolianitos do caso continental e oceânico quanto aos processos deposicionais (fácies) representados?

Para os sistemas eólicos costeiros terrígenos, a morfoestratigrafia e distribuição de idades em diferentes setores costeiros do Brasil permite reconhecer pelo menos quatro gerações, incluindo a ativa, as quais têm reconhecida influência do comportamento do NRM e da linha de costa (Giannini et al. 2005, 2007, Mendes et al. 2015, Rodrigues et al. 2020). Porém, fatores ligados ao clima local ou regional, como por exemplo precipitação e intensidade dos ventos, podem ter sido tão ou mais importantes, seja no desencadeamento seja na estabilização de dunas costeiras (Mendes et al. 2015). Para as paleodunas do Holoceno, todas formadas sob um mesmo contexto de nível do mar alto, por exemplo, resultados de datação por luminescência opticamente estimulada (LOE) na Ilha Comprida (Sawakuchi et al. 2008) e Santa Catarina 
(Mendes 2012, Andrade 2012, Zular et al. 2012, Mendes et al. 2015, Rodrigues et al. 2020) apontam nessa direção. O exemplo mais claro, porém, parece estar no Pleistoceno do Maranhão, onde a geração de maior representatividade em área possui idades LOE concentradas em torno de 17 ka AP (Maia et al. 2011, Guedes 2012, Hilbert et al. 2016, Guedes et al. 2017), época coincidente com o último evento (estádio) paleoclimático Heinrich (H1). Esta coincidência tem levado à hipótese, aventada por Guedes et al. (2011, 2017), de que sua estabilização tenha sido determinada pela umidificação do clima e enfraquecimento dos ventos ocorrida no território brasileiro por ocasião deste estádio (Cruz et al. 2005, 2009). Aceita esta hipótese, a estabilização das dunas terrígenas pode ocorrer em resposta ao aumento de umidade e coesão da areia e, por decorrência, da cobertura vegetal, bem como da redução do potencial eólico associada (Mendes e Giannini 2015). A cimentação das areias das dunas viria em seguida, numa escala de séculos a milênios, como consequência da infiltração de matéria orgânica derivada da cobertura vegetal, com desenvolvimento de espodossolos (Boski et al. 2015, Martinez et al. 2018).

No caso dos eolianitos, porém, a cimentação carbonática em ambientes vadosos e freáticos é possivelmente mais precoce e pode desempenhar, junto com a vegetação, papel importante na estabilização das dunas. Além disso, ao aumentar a resistência dos depósitos eólicos aos eventos erosivos sobrepostos, eleva o seu potencial de preservação ao longo do tempo. Em parte, por esta razão, eolianitos quaternários podem apresentar estratigrafia mais completa e, ao mesmo tempo, mais complexa que os sítios de sedimentação eólica terrígena, como bem exemplificado na costa oeste da Austrália (Hearty e O’Leary 2008).

Assim, a outra grande questão que motiva esta pesquisa de doutorado é: quais as semelhanças e diferenças na maneira como nível do mar, linha de costa, clima e dinâmica autogênica do sistema controlam a iniciação e a estabilização das dunas eólicas carbonáticas em comparação com as terrígenas? Esses fatores controladores agem de modo distinto na costa continental e na insular? Os processos pedogênicos envolvidos na estabilização, e seu contexto paleovegetacional e paleoclimático, são análogos ou distintos daqueles descritos em paleodunas terrígenas? 


\subsection{Relevância do Tema e da Abordagem}

Pelo menos dois aspectos justificam a realização de estudos acerca de depósitos eólicos carbonáticos no Quaternário do Brasil. O primeiro é o uso dos sistemas eólicos como fonte de informação para a elaboração e validação de modelos climáticos na escala de séculos a dezenas de milhares de anos. A esse respeito, é ilustrativo lembrar que a grande maioria das variáveis que supostamente controlam a morfodinâmica dunar está ligada ao clima, de modo seja direto (ventos, umidade e ondas), seja indireto (NRM, nível freático, estabilização pela vegetação). A influência do clima ressalta-se ainda mais no caso de eolianitos, cujas areias bioclásticas pressupõem a presença e/ou exposição de plataformas carbonáticas biogênicas, estas fortemente controladas por fatores ambientais de fundo paleoclimático como turbidez, temperatura da água e proveniência das ondas. O segundo aspecto é a escassez de estudos morfológicos, petrográficos e cronológicos em eolianitos no Brasil e o interesse acadêmico em estender o conhecimento sobre distribuição de feições eólicas costeiras (Maia 1998, Hesp 2000, Giannini et al. 2005, 2011, 2014, Martinho et al. 2006, Carvalho et al. 2008), e seu registro sedimentar, ao caso das dunas carbonáticas.

\subsection{Localização das Áreas de Estudo}

Esta pesquisa de doutorado ocupa-se dos dois domínios conhecidos de ocorrências de eolianitos quaternários no Nordeste brasileiro, sendo um continental, o litoral desde PI até RN, e outro insular marinho, o AFN. A área situada nos estados do PI e CE (Fig. 1.1.A), entre os municípios de Luís Correia - PI (latitude 2॰52'58”S e longitude 41 93'54”W), a W, e Paracuru-

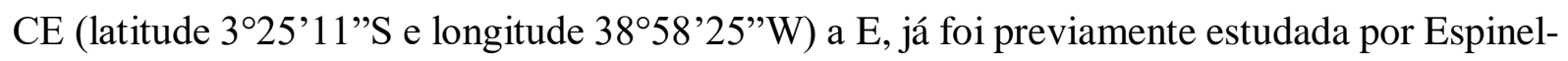
Arias (2015) e é abordada agora sobretudo quanto à revisão e tratamento estatístico do acervo de dados acumulados (datações, paleoventos e petrografia sedimentar); em paralelo, 18 amostras coletadas nesses dois estados são, nesta tese, submetidas a análise quantitativa de minerais pesados.

A área do RN com ocorrências de eolianitos (Fig. 1.1B) situa-se na costa norte do estado, de orientação W-E, entre Diogo Lopes, município de Macau (latitude 505’35”S e longitude $36^{\circ} 27^{\prime} 34^{\prime}$ W), e Praia do Marco, município de São Miguel do Gostoso (latitude $05^{\circ} 04^{\prime} 40^{\prime}$ 'S e longitude $35^{\circ} 47^{\prime} 43^{\prime \prime} \mathrm{W}$ ). 
O AFN (Fig. 1.1C) localiza-se nas coordenadas aproximadas $03^{\circ} 54^{\prime} \mathrm{S}$ e $32^{\circ} 25^{\prime} \mathrm{W}$, distando aproximadamente $350 \mathrm{~km}$ de Natal (RN) e $545 \mathrm{~km}$ de Recife (PE).

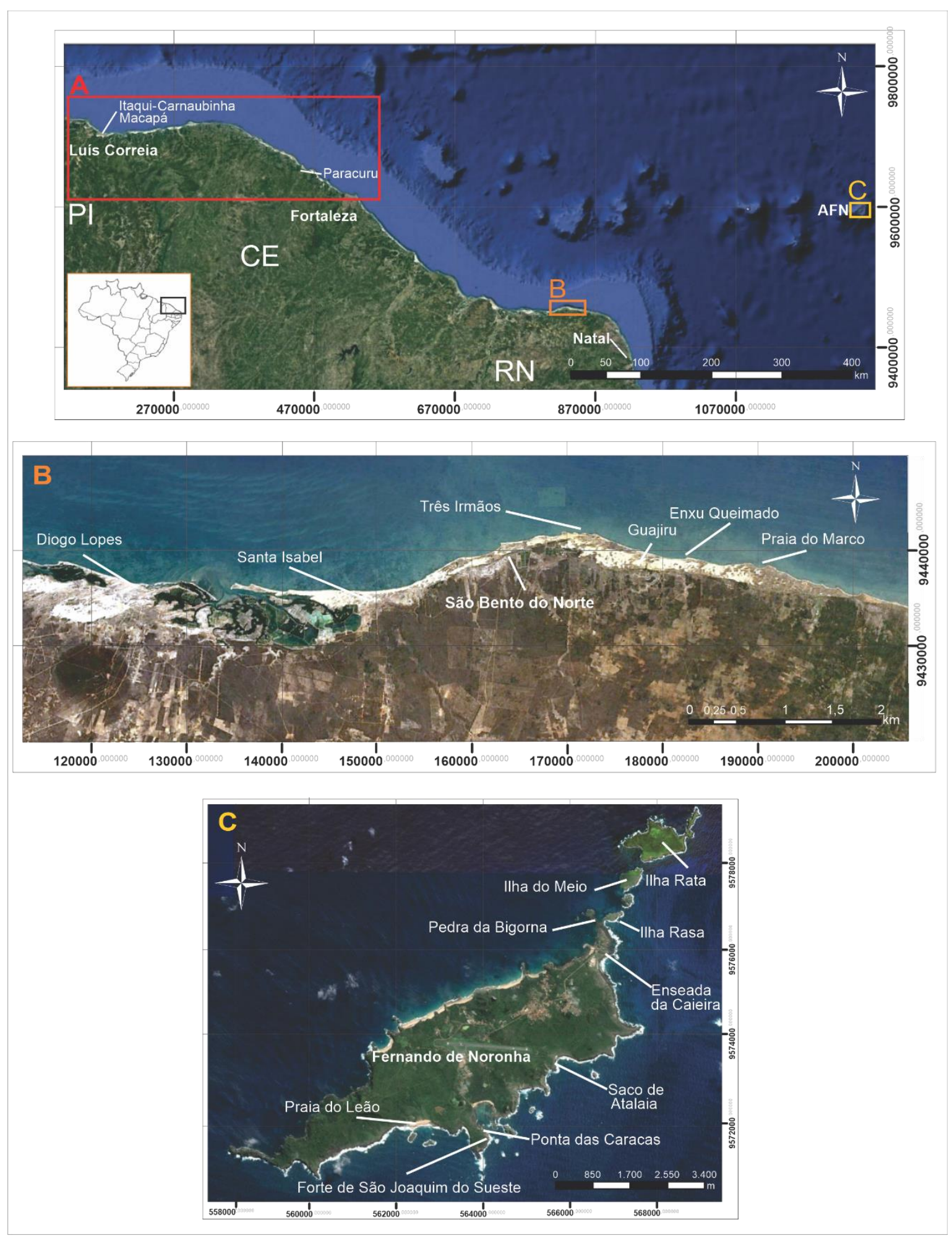

Fig. 1.1. Localização das áreas de ocorrência de eolianitos estudadas nesta tese, com destaques para: (A) costa do Piauí e Ceará; (B) litoral norte de Rio Grande do Norte, entre Diogo Lopes e Praia do Marco; e (C) arquipélago de Fernando de Noronha. 


\section{METAS E OBJETIVOS}

\subsection{Meta}

Entende-se por meta, ou objetivo geral, a contribuição final a ser alcançada e que abrange uma série de objetivos específicos a se realizar; nesse sentido, a meta desta pesquisa é estabelecer a cronologia detalhada dos sistemas deposicionais eólicos costeiros quaternários de constituição carbonática ou mista, no litoral do Nordeste brasileiro entre PI e RN e no AFN, como ferramenta para compreender os fatores e processos controladores de sua iniciação, evolução, estabilização, diagênese, preservação e decorrente distribuição espacial.

\subsection{Objetivos}

Os objetivos são entendidos como aquilo que se planeja executar, de modo a alcançar a meta estabelecida. Nesse sentido, os seguintes objetivos específicos, na ordem planejada de consecução, foram enumerados:

1. Definir, com base em levantamento bibliográfico e cartográfico e em análise de imagens de satélite, a geometria e distribuição espacial das ocorrências de eolianitos nas áreas propostas para estudo e situá-las em relação aos elementos morfológicos eólicos ativos e às paleodunas de areia terrígena, bem como em relação às suas áreas fontes carbonáticas potenciais na plataforma continental interna.

2. Realizar análise de fácies deposicionais, inclusive paleoventos, e levantamento estratigráfico em eolianitos escolhidos na etapa anterior, e inferir os tipos de elementos morfológicos a que correspondem.

3. Fazer a caracterização sedimentológica macro e microscópica dos eolianitos, por fácies e/ou região, para comparação.

4. Realizar uma análise cronológica de formação e estabilização dos eolianitos, e suas associações com eventos climáticos, inclusive eustáticos, globais.

5. Avaliar a possibilidade de contrastes sedimentológicos e petrográficos (de granulometria, mineralogia, tipo de grão bioclástico e tipo de material intersticial) entre depósitos eólicos de 
diferentes fácies, gerações ou constituições (e.g. terrígenos versus carbonáticos), bem como em relação a beach rocks, e deduzir seus processos e fatores controladores.

6. Integrar o conjunto de resultados morfoestratigráficos, faciológicos, sedimentológicos e cronológicos, de modo a avaliar possíveis relações entre idades e variações de aporte sedimentar, bioclástico ou terrígeno, e assim comparar estas variações com mudanças ligadas a NRM, clima e, se for o caso, neotectônica ou herança morfoestrutural. 


\section{SÍNTESE BIBLIOGRÁFICA}

\subsection{Paleoclima do Quaternário}

O Quaternário, último período geológico da história da Terra, tem seu início atualmente colocado em 2.58 Ma atrás. Ele começa com o desenvolvimento de geleiras permanentes no hemisfério Norte, seguido de uma série de eventos glaciais-interglaciais relacionados a fases de expansão e retração das calotas polares, os quais foram fortemente modulados por ciclos orbitais de Milankovitch (excentricidade, obliquidade e precessão; Ruddiman 2004). Inicialmente identificados em pequeno número (quatro a seis), no registro geológico continental do hemisfério Norte, esses eventos glaciais e interglaciais só começaram a ser mais bem documentados e compreendidos a partir das medidas de $\delta^{18} \mathrm{O}$ realizadas por Emiliani (1955) em foraminíferos bentônicos coletados de testemunhos marinhos, e que refletem o efeito combinado da mudança de temperatura dos oceanos, da salinidade e, sobretudo, do volume de água isotopicamente empobrecida retida na forma de gelo (Schackleton 1967). A partir das excursões de $\delta^{18} \mathrm{O}$, Emiliani (1955) delimitou períodos conhecidos como Estágios Marinhos Isotópicos (MIS, na sigla em inglês), balizados por variações extremas de temperatura na superfície dos oceanos e do volume de gelo nos polos, por sua vez relacionadas a variações de insolação provocadas pelos ciclos orbitais de Milankovitch. Raymo et al. (1989) publicaram a primeira serie isotópica continua de $\delta^{18} \mathrm{O}$ realizada em foraminíferos bentônicos para os últimos 3,2 milhões de anos, em adição com dados de IRD (da sigla em inglês ice rafted debris, e os quais são interpretados como sedimentos transportados pelo gelo durante episódios glaciais), e ressaltaram a ocorrência destes horizontes de sedimentos a partir de 2,75 milhões de anos, concomitante ao estabelecimento de variações sazonais de esfriamento e expansão do gelo.

Com base nas series isotópicas de $\delta^{18} \mathrm{O}$ e na concentração de poeira em testemunhos de gelo, foi possível constatar que a temperatura e a intensidade dos jatos polares variaram periodicamente ao longo do último ciclo glacial, de condições frias, conhecidas como fases estadiais, para períodos de clima mais ameno, denominados de interestadiais (Dansgaard et al. 1982, Broecker et al. 1985, Ruddiman 2008, Clement \& Peterson 2008, Rasmussen et al. 2014).

Com base na correlação de testemunhos do Atlântico Norte, Heinrich (1988) reconheceu seis níveis de alta concentração de IRD próximo à costa de Portugal, no registro pleistoceno superior, os quais foram relacionados com estadiais marcados por expansão para o 
sul da zona de ocorrência de iceberg sobre o Atlântico Norte (Andrews 1998). Desde então, os eventos representados por estas camadas de IRD foram denominados eventos Heinrich e numerados sequencialmente como $\mathrm{H} 1, \mathrm{H} 2$ e assim sucessivamente. De acordo com Bond et al. (1999), a enorme quantidade de icebergs necessária para produzir o efeito observado durante a deposição de uma camada Heinrich requer processos estritamente glaciológicos, possivelmente associados a uma acentuada expansão ou colapso do gelo da geleira Laurentida, situada no nordeste do Canadá.

Baseados nos picos de aumento de concentração de IRD, junto com uma reconstrução de alta resolução da temperatura superficial do mar (TSM) do Atlântico Norte, suportada em análises populacionais e isotópicas de foraminíferos planctônicos e bentônicos, Bond et al. (1997) determinaram períodos de resfriamento abrupto similares no Holoceno, que são referidos na literatura como eventos Bond (de Bond 1 até Bond 6).

\subsection{Fatores Controladores de Sedimentação Eólica}

Kocurek \& Havholm (1993) apresentaram um modelo de descrição de sistemas deposicionais eólicos contemplando a questão do saldo ou balanço sedimentar e do espaço para estocagem (espaço de acumulação) deste saldo, de acordo com o enfoque sistêmico e com o arcabouço conceitual da estratigrafia de sequências. O saldo, no caso, refere-se à diferença entre entradas e saídas de sedimentos eólicos, ou influxo e efluxo, respectivamente. O influxo pode ser entendido como a deriva eólica efetiva, isto é, combinação de deriva eólica potencial (Bagnold 1941, Fryberger et al. 1979) com suprimento sedimentar disponível para o transporte pelo vento (Giannini et al. 2005, 2014). O espaço de acumulação é determinado pela posição do nível freático relativa à superfície deposicional, controlada basicamente pelo clima e pela taxa de subsidência, os quais, nos casos costeiros, agem combinadamente através do NRM (Kocurek \& Havholm 1993).

Em escala macroambiental, o saldo sedimentar eólico depende do aporte primário, isto é, da disponibilidade de sedimentos no sistema costeiro que atua como fonte, controlado por variáveis imediatas (locais e de curto prazo) e variáveis mediatas (regionais e de longo prazo). Entre as variáveis imediatas que favorecem o aporte primário necessário à formação de sistemas eólicos, destacam-se a chegada de sedimentos no sistema fonte (incluindo efeito da deriva 
litorânea longitudinal, dependente da energia e orientação das frentes de ondulações), o grau de exposição desses sedimentos, em estado incoeso, à ação do vento onshore (ligado, no caso costeiro, ao grau de dissipatividade da praia) e a escassez de vegetação ligada a fatores climáticos, como direção, intensidade e persistência dos ventos e falta de chuvas (Giannini 2007).

As variáveis mediatas que controlam o aporte primário e seu potencial de transferência para o sistema eólico costeiro quaternário abrangem clima, condições antecedentes (e.g. herança fisiográfica), dimensões do sistema eólico, tempo de interação do sistema (sensu Ewing \& Kocurek 2010), aporte sedimentar e geometria da área fonte (Giannini 2007, Ewing \& Kocurek 2010). Estas variáveis mediatas são determinadas por controles geológicos, climáticos e oceanográficos que são, muitas vezes, inter-relacionados entre si. Assim, de forma mais generalista, podem-se destacar três fatores controladores principais: condições climáticas (ventos, precipitação e tempestuosidade), NRM e contexto fisiográfico regional das áreas de fornecimento e de acumulação (Goldsmith 1978, Carter 1988, Pye \& Tsoar 1990, Lancaster 1995, Sawakuchi 2006, Giannini 2007).

A formação de sistemas eólicos costeiros é em tese favorecida em tratos de sistema de mar alto (Cooper 1958, Roy \& Thom 1981, Thom et al. 1981, Pye \& Bowman 1984, Giannini 1993, Giannini \& Santos 1994, Giannini et al. 2001b, Sawakuchi 2003, Lees 2006, Giannini et al. 2007), tendo em vista o aumento de sedimentos em circulação no prisma costeiro, sob linha de costa pouco variável. Porém, momentos de NRM baixo, sob linha de costa estável, não somente são também favoráveis à formação como propícios à preservação destes depósitos, posto que são seguidos por elevação rápida do NRM e do nível de base de erosão (Mendes 2012, Guedes 2012, Mendes et al. 2015). Além disso, a aparente maior representatividade de sistemas eólicos costeiros de mar alto seria, em parte, decorrente de um viés de observação, isto é, o fato de estarmos atualmente numa fase de mar alto (Mendes et al. 2015).

Quanto à fisiografia, a formação de sistemas eólicos costeiros é favorecida em plataformas de baixo declive (menor que $0,8^{\circ}$, aproximadamente), desde que acima do ângulo mínimo necessário para o transporte eficiente de areia pelas ondulações rumo à zona intermarés (em torno de $0,1^{\circ}$, segundo Roy et al. 1994). 


\subsection{Tipologia de elementos morfológicos eólicos costeiros}

De acordo com Hesp (2000), os depósitos eólicos costeiros podem ser classificados em quatro grandes tipos: dunas frontais, rupturas de deflação (blowouts), dunas parabólicas (termos definidos no Quadro 2) e campos de dunas livres. A estes quatro tipos, pode-se acrescentar ainda um quinto, os lençóis de areia (sand sheets) (Giannini et al. 2005). Todos estes tipos são encontrados nas áreas de estudo (Fig. 3.1).

Embora útil em enfoques mais generalistas, a classificação nestes cinco grandes tipos de depósitos eólicos abarca escalas distintas, já que dunas frontais (Fig. 3.1a), rupturas de deflação e dunas parabólicas (Fig. 3.1b) são frequentemente feições ou formas de leito simples, individuais, enquanto campos de dunas livres e lençóis de areia são geralmente compostos e com dimensões muito maiores.

Campos de dunas livres correspondem a depósitos de areia eólica de grande escala (hectométrica ou maior), em movimento rumo ao interior ou, mais raramente, subparalelo à costa (Giannini et al. 2005, Martinho et al. 2006). Os campos de dunas que se movem ao interior transversalmente à costa são designados campos de dunas transgressivos (transgressive dune fields), termo introduzido por Gardner (1955). Os campos de dunas livres brasileiros contêm, invariavelmente, cordões de precipitação (ver definição no Quadro 2), no limite interior, e/ou dunas de orientação transversal ao vento efetivo, com crista linear, em meia lua (barcanas) ou sinuosa (barcanoides) (Giannini et al. 2005, Giannini 2007).

Lençóis de areia (sand sheets) são massas de areia eólica em movimento com pouco relevo, isto é, sem superimposição de dunas com faces de avalanche (Kocurek \& Nielson, 1986). Podem possuir, porém, feições como nebkhas (Quadro 1) e protodunas (Quadro 2). Em áreas com elevada relação entre energia eólica e suprimento ou com trânsito rápido de sedimentos, lençóis de areia desenvolvem-se no lugar ou a barlavento de campos de dunas livres (Tomazelli 1990, Giannini 2007, Giannini et al. 2014).

Abordagens mais detalhadas, inspiradas em exemplos brasileiros, e baseadas no grau de influência morfodinâmica da vegetação, foram propostas por Giannini et al. (2005, 2011, 2014), Martinho et al. (2006) e Giannini (2007). Estas propostas, adotadas nesta tese, abrangem várias outras classes de depósitos, além das cinco citadas. Entre aquelas com influência morfodinâmica da vegetação (Quadro 1), destacam-se: rastros lineares residuais, retrocordões (Fig. 3.1e), nebkhas, planícies interdunas (Fig. 3.1c e d) e montes residuais, além das já 
mencionadas dunas frontais e dunas parabólicas. E entre os sem influência da vegetação

(Quadro 2), destacam-se dunas barcanas e cadeias barcanoides.

Quadro 1. Definições para feições eólicas costeiras formadas sob influência morfodinâmica da vegetação, segundo Steenstrüp (1894 apud Howell 1960), Hesp (1983, 1999, 2000), Giannini et al. (2005), Martinho et al. (2006) e Giannini (2007). Modificado de Hilbert (2013).

\begin{tabular}{|c|c|c|}
\hline Feição eólica & $\begin{array}{c}\text { Termo usual na } \\
\text { literatura } \\
\text { internacional }\end{array}$ & Definição \\
\hline Duna frontal & Foredune & $\begin{array}{l}\text { Depósito formado na pós-praia ou na antepraia superior, como } \\
\text { resultado da retenção de areia costeira pela vegetação pioneira (Fig. } \\
\text { 3.1a). Pode passar de incipiente a estabelecida, com o aumento } \\
\text { relativo de altura, complexidade morfológica e diversidade de } \\
\text { cobertura vegetal }\end{array}$ \\
\hline $\begin{array}{c}\text { Ruptura de } \\
\text { deflação }\end{array}$ & Blowout & $\begin{array}{l}\text { Feição mista (erosivo-deposicional), gerada por retirada, via } \\
\text { deflação e redeposição local pelo vento, de depósitos arenosos } \\
\text { preexistentes, como dunas frontais ou cristas praiais. A ruptura faz- } \\
\text { se através da produção de bacia deflacionária, delimitada por paredes } \\
\text { erosivas subparalelas que se fecham, rumo sotavento, em lobos } \\
\text { deposicionais em forma de U, contendo faces de avalancha ou } \\
\text { slipfaces }\end{array}$ \\
\hline Duna parabólica & Parabolic dune & $\begin{array}{l}\text { Feições com geometria em planta em U ou V, com convexidade } \\
\text { voltada para sotavento (Fig.3.1b), formada por evolução, via } \\
\text { migração, da ruptura deflacionária (blowout), da qual diferem pelo } \\
\text { maior alongamento das paredes (sugere-se aqui mais que três vezes } \\
\text { a largura); estas adquirem forma de rastro linear residual }\end{array}$ \\
\hline Nebkha & Nebkha & $\begin{array}{l}\text { Montículo de areia depositados em meio a vegetação (Fig. 3.1c). } \\
\text { Pode ser assimétrico, quando recebe o nome de duna de sombra } \\
\text { (shadow dune) ou piramidal }\end{array}$ \\
\hline Monte residual & Remnant knob & $\begin{array}{l}\text { Morrote, em meio a campo de dunas, remanescentes da erosão de um } \\
\text { depósito eólico, geralmente antigo cordão de precipitação }\end{array}$ \\
\hline $\begin{array}{l}\text { Cordão de } \\
\text { precipitação }\end{array}$ & $\begin{array}{l}\text { Precipitation } \\
\text { ridge }\end{array}$ & $\begin{array}{l}\text { Depósito de forma piramidal e alongada, localizado ao longo das } \\
\text { margens laterais e, às vezes, frontais, dos campos de dunas livres. }\end{array}$ \\
\hline $\begin{array}{l}\text { Planície } \\
\text { interdunas }\end{array}$ & Interdune plain & $\begin{array}{l}\text { Área aproximadamente plana situada entre dunas transversais ou } \\
\text { barcanóides, onde a deflação predomina sobre a deposição eólica e } \\
\text { onde processos deposicionais não eólicos são tão ou mais atuantes } \\
\text { que os eólicos (Fig. 3.1d) }\end{array}$ \\
\hline $\begin{array}{l}\text { Rastro linear } \\
\text { residual }\end{array}$ & Trailing ridge & $\begin{array}{l}\text { Cordão resultante da fixação, por vegetação, de braço alongado de } \\
\text { dunas parabólicas, ou da terminação de duna barcana ou cadeia } \\
\text { barcanoide parabolizada, deixados para trás à medida que as dunas } \\
\text { migram (Fig.3.1e) }\end{array}$ \\
\hline $\begin{array}{l}\text { Retrocordão (ou } \\
\text { marca de } \\
\text { migração dunar) }\end{array}$ & $\begin{array}{l}\text { Gegenwillen, } \\
\text { residual dune } \\
\text { ridge }\end{array}$ & $\begin{array}{l}\text { Cordão deixado na margem barlavento de campos de dunas livres, } \\
\text { em meio a vegetação da planície deflacionária, com tendência a } \\
\text { formação sucessiva, sazonal, controlada pela umidade da areia e } \\
\text { força do vento (Fig. } 3.1 \text { e) }\end{array}$ \\
\hline
\end{tabular}


Quadro 2. Definições para feições eólicas costeiras formadas sem influência morfodinâmica significativa da vegetação, segundo Kocurek et al. (1992), Hesp (2000), Giannini et al. (2005), Martinho et al. (2006) e Giannini (2007). Modificado de Hilbert (2013).

\begin{tabular}{|c|c|l|}
\hline Feição eólica & $\begin{array}{c}\text { Termo usual na } \\
\text { literatura } \\
\text { internacional }\end{array}$ & \multicolumn{1}{|c|}{ Definição } \\
\hline Protoduna & Protodune & $\begin{array}{l}\text { Forma de leito eólica dômica ou alongada com orientação } \\
\text { transversal ao vento efetivo, com até poucos metros de altura e } \\
\text { sem face de avalancha }\end{array}$ \\
\hline Duna barcana & Barchan dune & Duna em meia lua com concavidade voltada para sotavento \\
\hline Cadeia barcanoide & $\begin{array}{c}\text { Barchanoid } \\
\text { chain, crescentic } \\
\text { dune }\end{array}$ & $\begin{array}{l}\text { Conjunto de dunas barcanas lateralmente coalescidas, com } \\
\text { crista sinuosa transversal ao vento efetivo. }\end{array}$ \\
\hline Depressão interdunas & $\begin{array}{c}\text { Interdune } \\
\text { depression }\end{array}$ & $\begin{array}{l}\text { Zona de perfil ligeiramente côncavo para cima, situadas entre } \\
\text { o costado de uma duna e a frente da duna à retaguarda }\end{array}$ \\
\hline Lobo deposicional & Depositional lobe & $\begin{array}{l}\text { Frente de avanço principal de um campo de dunas, com } \\
\text { formato parabólico, que migra, sobre terreno vegetado ou } \\
\text { rochoso, no rumo do vento efetivo }\end{array}$ \\
\hline
\end{tabular}

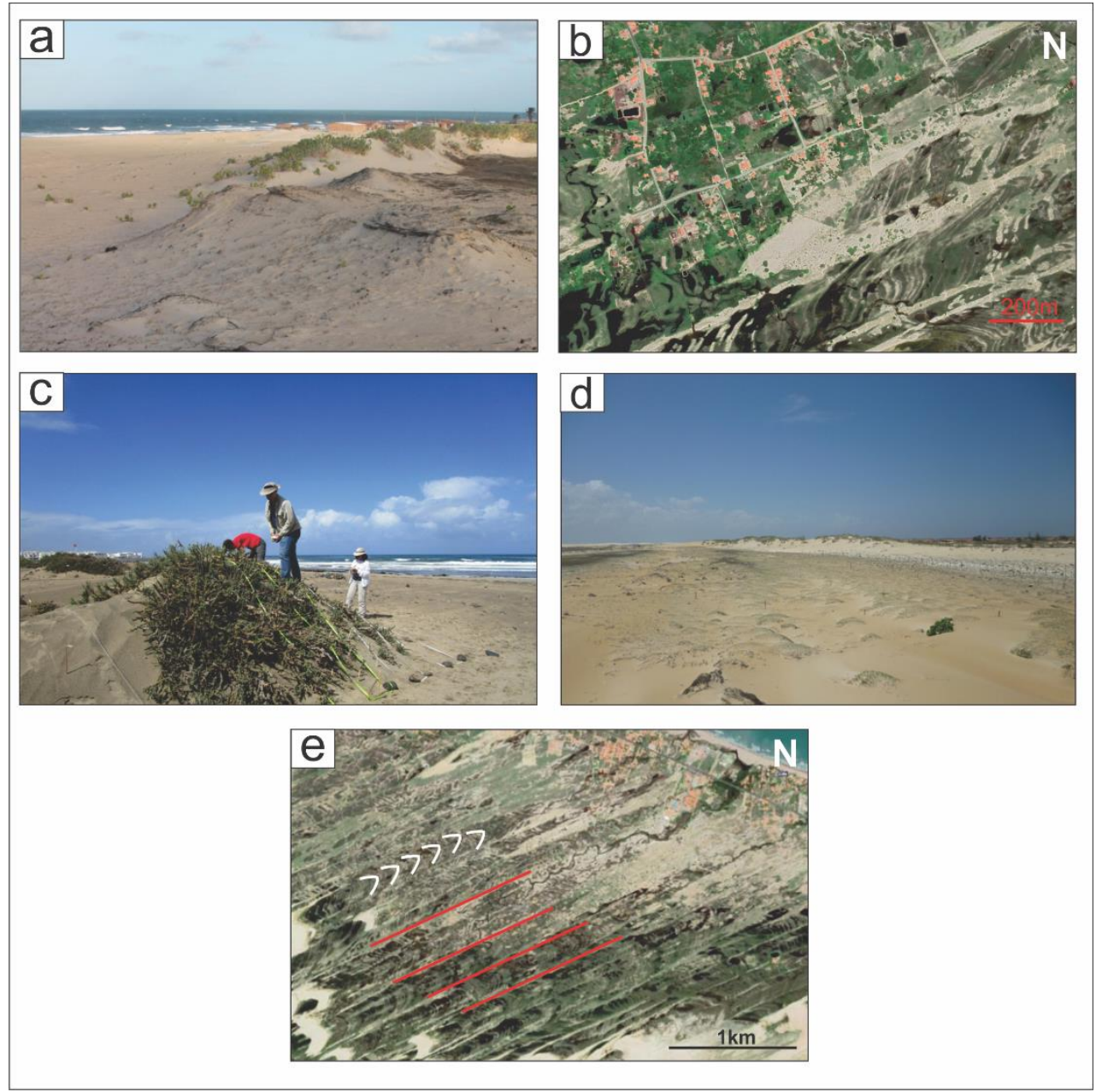

Fig. 3.1. Elementos morfológicos de sistemas eólicos; a. duna frontal, na praia de Itaqui -PI; b. duna parabólica (imagem de satélite Google Earth); c. nebkha; d. planície interdunas, (c e d obtidas na internet); e. rastros lineares residuais (linhas vermelhas) e retrocordões (curvas brancas), na região de Luís Correia-PI (imagem de satélite Google Earth). 
Usando enfoque sistêmico, Giannini (2007) e Giannini et al. (2011, 2014) dividem os elementos morfológicos identificados nos depósitos eólicos costeiros do Brasil, quanto à sua função, em quatro grupos, de barlavento para sotavento (Fig. 3.3): 1. de estoque inicial (dunas frontais, protodunas, lençóis de areia e dunas sem vegetação de orientação transversal ao vento); 2. de deflação (rupturas de deflação, rastros lineares residuais, retrocordões e dunas parabólicas); 3. de superposição ou cavalgamento (dunas barcanas e cadeias barcanoides); e 4. de avanço (cordões de precipitação e lobos deposicionais).

Segundo esses autores, sob condição de desequilíbrio construtivo (influxo maior que efluxo) em dado grupo funcional de elementos morfológicos, o excesso de areia tende a ser consumido na formação e alimentação de grupo a sotavento. Os grupos funcionais constituem, portanto, domínios espaciais interligados, com posição e morfologia definidas dentro do sistema, e sob esse aspecto, constituem associações de elementos deposicionais. Desse modo, os elementos de estoque inicial compõem a associação praia-duna; os elementos de deflação reúnem-se na associação planície deflacionária; e os elementos de cavalgamento e de avanço definem a associação campo de dunas livres (Fig. 3.2). Giannini (2007) e Giannini et al (2011, 2014) propõem uma classificação de oito estágios de sistemas eólicos costeiros brasileiros sob condição de vento efetivo transversal à linha de costa; os estágios desta classificação representam, de 1 a 8 , aumento progressivo do saldo eólico relativo, ou seja, a razão entre o saldo absoluto de sedimentos eólicos (influxo menos efluxo, diretamente proporcional à relação entre aporte e energia do vento) e o espaço de acumulação eólica (Fig.3.3).

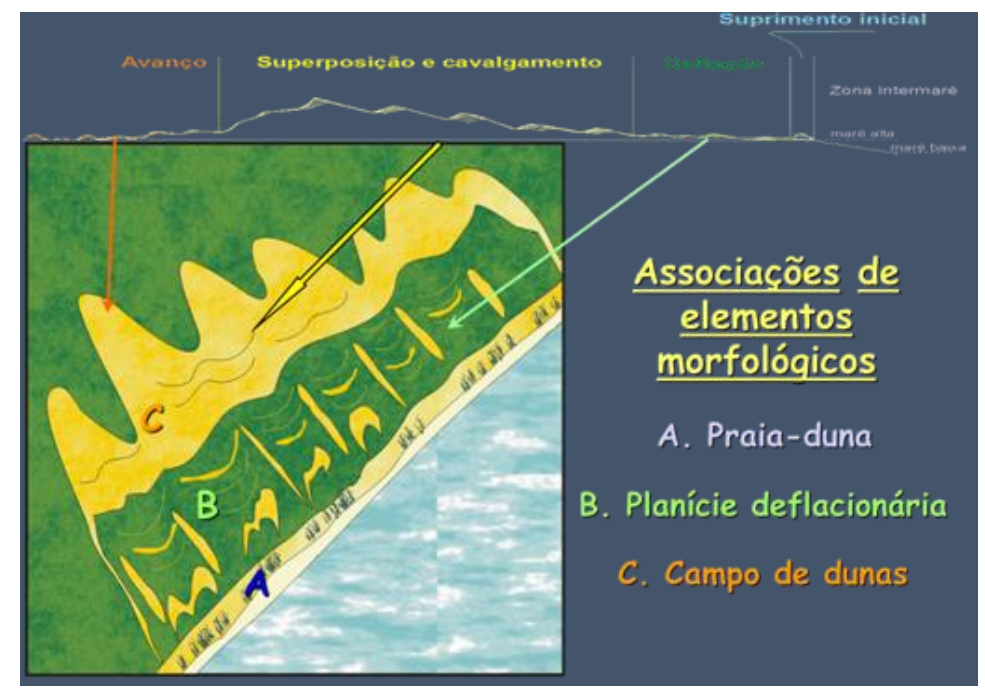

Fig.3.2. As três associações de elementos morfológicos em sistemas eólicos costeiros ativos do Brasil (A, B e C) e suas funções no funcionamento do sistema (perfil no alto da figura). Adaptado de Giannini (2007). 


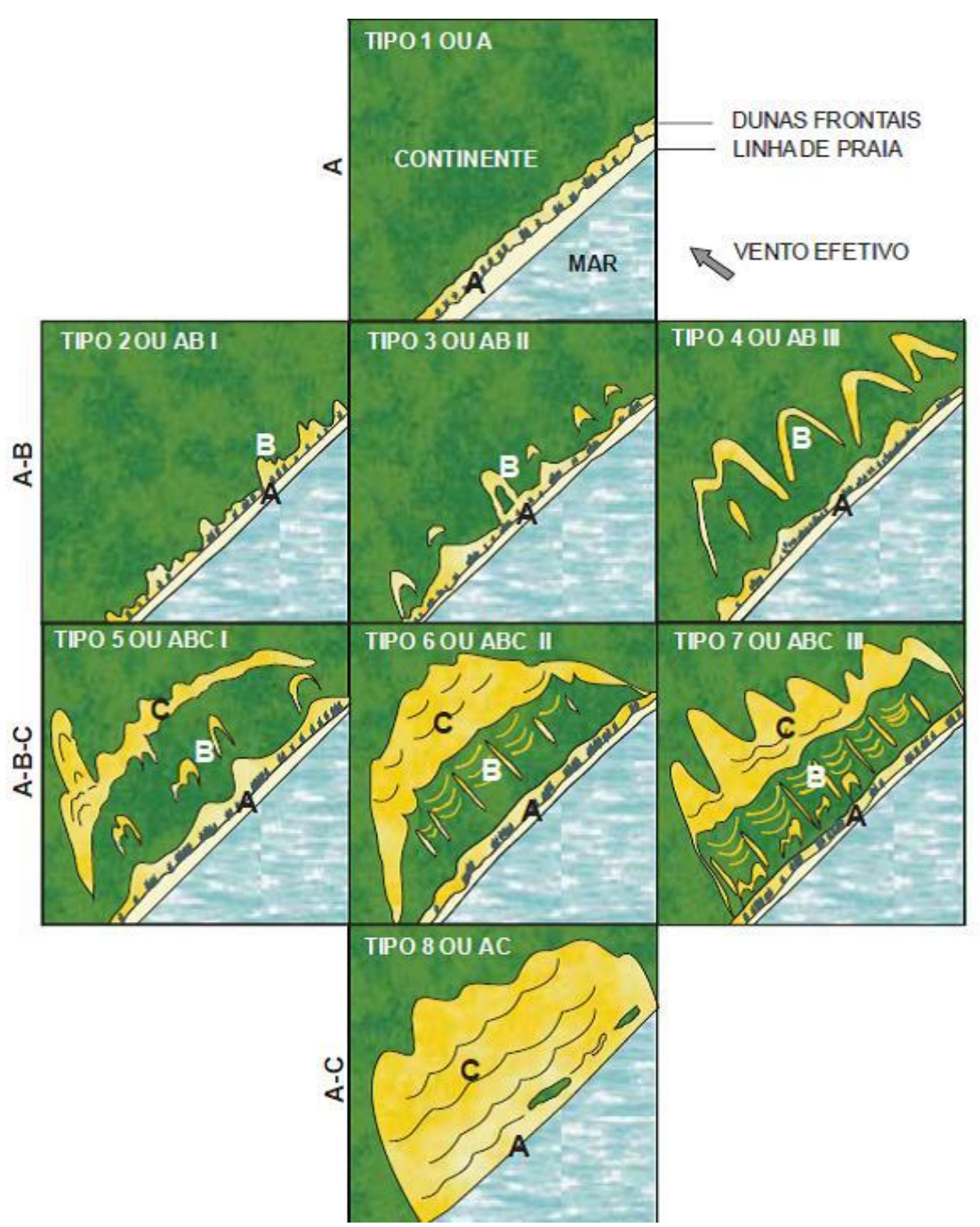

Fig. 3.3. Tipos de sistemas eólicos costeiros do Brasil, sob condição de vento efetivo transversal à linha de costa. A, B e C são associações de elementos morfológicos: praia-duna, planície deflacionária e campo de dunas livres, respectivamente, conforme Fig. 3.2. Do tipo 1 ao 8, tem-se crescimento no saldo sedimentar eólico relativo (aporte eólico / espaço de acumulação). Extraído de Giannini et al. (2014).

\subsection{Controles particulares na formação de eolianitos}

No caso específico dos eolianitos, os fatores de formação são em tese os mesmos de dunas costeiras terrígenas, porém com uma particularidade fundamental, que é a dependência de aporte biogênico carbonático. Este aporte propicia-se pela presença prévia ou contemporânea de plataformas com baixo suprimento terrígeno, favorecida sob clima quente e relativamente seco (McKee \& Ward 1983). 
Em termos de distribuição espacial em escala global (Fig. 3.4), a concentração de eolianitos na faixa de média latitude (subtropical) estaria ligada à conjunção de baixo aporte terrígeno com clima quente e pouco úmido (Brooke 2001). E o suposto aumento na formação de eolianitos no Quaternário pode ser vinculado ao aumento e intensificação de oscilações climáticas nesse período (item 3.1), com aparecimento recorrente de clima mais seco nessas regiões. O Sudeste do Brasil constituiria grande exceção à regra de eolianitos em média latitude, dada a presença da Zona de Convergência do Atlântico Sul (ZCAS), o que acaba por determinar clima regional anomalamente úmido. Deste modo, é nas áreas de baixa latitude da Região Nordeste, fora da influência da ZCAS e às margens da ZCIT, que se encontram as ocorrências relatadas de eolianitos do país (Fig. 3.4).

Variações menores de temperatura, limpidez e salinidade das águas determinam o tipo de sedimento carbonático na plataforma (McKee \& Ward 1983), classificado por James (1997) em duas associações: Photozoa e Heterozoa; a Associação Photozoa é formada por organismos bentônicos fotossintetizantes, como clorófitas e rodófitas, além de corais, ooides e peloides. A Heterozoa caracteriza-se por grande diversidade de organismos não recifais, com destaque para moluscos e foraminíferos. Já Laugie et al. (2019), baseados na compilação de dados de mais de 200 documentos relatando recifes de corais e sedimentos carbonáticos, elaboraram um modelo quantitativo global de tipos de fábricas de carbonato e suas respectivas afinidades ambientais. Neste modelo, quatro tipos de fábricas previamente reconhecidos por Michel et al. $(2018,2019)$ têm sua distribuição mapeada: a Photozoa-T, com ocorrência em zonas tropicais caracterizadas por temperaturas superficiais do mar (SST) altas e constantes; a Photozoa-C, de zonas de latitude médias, com SST fortemente sazonal durante o ano e salinidade do mar (SSS) relativamente alta; a Heterozoa-C, ou fábrica de fundo de carbonatos de "aguas frias", com valores tanto de SST como SSS variáveis e produtividade marinha alta; e, finalmente, a fábrica bioquímica, que corresponde a águas quentes e salinas, chegando a $30^{\circ} \mathrm{C}$ de SST no verão, com altos valores de SSS. Brooke (2001) aventou a hipótese de que a distribuição geográfica global dos eolianitos possua relação estreita com a distribuição da Associação Heterozoa (Fig. 3.4). 


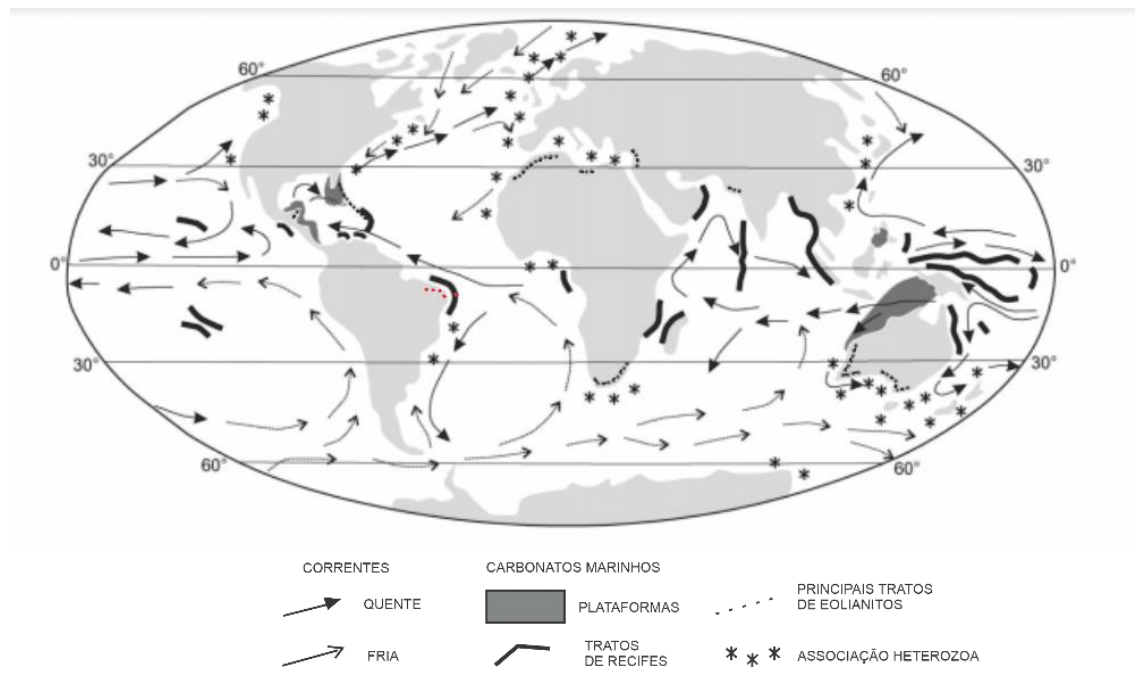

Fig. 3.4 Correntes oceânicas e distribuição de carbonatos marinhos rasos (segundo James 1997), com indicação das ocorrências de eolianitos (Brooke 2001). De acordo com Brooke (2001), os grandes tratos de eolianitos são marginais às principais províncias de carbonato de heterozoários. Notar, porém, que os eolianitos brasileiros aparentam ser exceção a esta regra.

Nos eolianitos do Brasil, entretanto, a representatividade dos organismos relacionados às associações Heterozoa e Photozoa ainda não está completamente quantificada. Nos da costa nordestina continental, Castro et al. (1998) detectaram a presença de testas de foraminíferos bentônicos (das classes Miliolida e Rotaliida) no CE, enquanto Espinel-Arias (2015) observou principalmente algas vermelhas, seguidas de foraminíferos bentônicos (Miliolida), no PI e CE. Nos eolianitos do AFN, Santos (2002) e Valença et al. (2005) detectaram predomínio de algas vermelhas, associadas a foraminíferos, mesmos organismos encontrados por Angulo et al. (2013a). Estes últimos autores vincularam os eolianitos do Holoceno da ilha ao aumento na formação de recifes de corais, favorecido pela criação de espaço de acomodação sedimentar via transgressão marinha.

\subsection{Eolianitos quaternários ao redor do mundo}

A importância da Associação Heterozoa na formação de eolianitos (Brooke 2001) tem sido reforçada por novos estudos sobre a composição deste tipo de rocha ao redor do mundo, conforme sugerido nas Tabelas 1 e 2; em ilhas oceânicas, no entanto, o predomínio é da Associação Photozoa (algas vermelhas). Em relação à cronologia atribuída aos depósitos, notase nestas duas tabelas tendência de associação a momentos de nível do mar alto, sendo a maioria 
dos eolianitos pleistocênicos atribuídos ao MIS 5 e os holocênicos, datados entre 10ka e 500 anos A.P. (Tabelas 1 e 2).

Tabela 1. Eolianitos quaternários insulares no mundo, com suas principais características. Significado das siglas para tipos de datação absoluta: ${ }^{14} \mathrm{C}$-AMS (rádio-carbono, com espectroscopia de massa acelerada), LOE (luminescência oticamente estimulada), AAR (raceminização de aminoácidos), U-Th (Urânio-Tório)

\begin{tabular}{|c|c|c|c|c|c|}
\hline Localização & Idade & $\begin{array}{l}\text { Tipo de } \\
\text { datação }\end{array}$ & Composição & $\begin{array}{c}\text { Morfologia do } \\
\text { depósito ou do } \\
\text { afloramento }\end{array}$ & $\begin{array}{c}\text { Referências } \\
\text { bibliograficas }\end{array}$ \\
\hline \multirow{10}{*}{ Bahamas } & $10 \mathrm{ka}$ & Relativa & & Dunas parabólicas & $\begin{array}{c}\text { White \& } \\
\text { Currant (1989) }\end{array}$ \\
\hline & $5 \mathrm{ka}$ & \multirow{3}{*}{${ }^{14} \mathrm{C}$} & \multirow{3}{*}{ Ooides e bioclastos } & \multirow{3}{*}{$\begin{array}{l}\text { Cordões paralelos } \\
\text { à costa, de } 4 \mathrm{~m} \text { de } \\
\text { altura }\end{array}$} & \multirow{3}{*}{ Kindler (1992) } \\
\hline & $3 \mathrm{ka}$ & & & & \\
\hline & $500 \mathrm{a}$ & & & & \\
\hline & MIS 5e & ${ }^{14} \mathrm{C}$ & Ooides e bioclastos & $\begin{array}{c}\text { Afloramentos de } 3 \\
\text { km de extensão } \\
\text { por } 10 \mathrm{~m} \text { de } \\
\text { espessura }\end{array}$ & $\begin{array}{c}\text { Kindler \& } \\
\text { Hearty (1995) }\end{array}$ \\
\hline & $\begin{array}{c}\text { Pleistoceno } \\
\text { (calcretes) }\end{array}$ & \multirow[t]{2}{*}{ Relativa } & \multirow{2}{*}{$\begin{array}{l}\text { Ooides, intraclastos, } \\
\text { gastrópodes, } \\
\text { peloides }\end{array}$} & \multirow{2}{*}{$\begin{array}{l}\text { Afloramentos de } 5 \\
\text { a } 6 \mathrm{~m} \text { de espessura }\end{array}$} & \multirow{2}{*}{$\begin{array}{l}\text { Aalto \& Drill } \\
\quad(1996)\end{array}$} \\
\hline & Holoceno & & & & \\
\hline & $5 \mathrm{ka}$ & $\begin{array}{c}{ }^{14} \mathrm{C}, \mathrm{AAR}, \\
\mathrm{U}-\mathrm{Th} \\
\end{array}$ & & & Mylroie (2008) \\
\hline & MIS 5a-5e & \multirow[b]{2}{*}{ AAR } & \multirow[b]{2}{*}{$\begin{array}{l}\text { Moluscos e } \\
\text { terrígenos }\end{array}$} & & \multirow[b]{2}{*}{$\begin{array}{l}\text { Deely et al. } \\
\text { (2011) }\end{array}$} \\
\hline & 3,9-7,1 ka & & & & \\
\hline Chipre & $\begin{array}{c}\text { Holoceno } \\
\text { tardio, } \text { e.g. } \\
1,51 \mathrm{ka} \\
\end{array}$ & LOE & & $\begin{array}{c}\text { Afloramentos com } \\
1 \text { a } 14 \mathrm{~m} \mathrm{de} \\
\text { espessura } \\
\end{array}$ & $\begin{array}{l}\text { Erginal et al. } \\
\qquad(2011)\end{array}$ \\
\hline Ilha Shidao, China & MIS 3 & U-Th & $\begin{array}{l}\text { Foraminíferos algas, } \\
\text { moluscos }\end{array}$ & $\begin{array}{l}\text { Testemunho de } 22 \\
\text { m de comprimento }\end{array}$ & Li et al. (2018) \\
\hline Havaí & $\begin{array}{l}\text { MIS 5e-5a e } \\
\text { Holoceno }\end{array}$ & AAR & $\begin{array}{c}\text { Algas, foraminiferos, } \\
\text { moluscos e } \\
\text { equinodermos }\end{array}$ & $\begin{array}{l}\text { Afloramentos de } \\
1,5 \text { a 2,0 m de } \\
\text { espessura }\end{array}$ & $\begin{array}{c}\text { Fletcher III et } \\
\text { al. (2005) }\end{array}$ \\
\hline $\begin{array}{l}\text { Ilha da Madeira } \\
\text { (Porto Santo) }\end{array}$ & $<20 \mathrm{ka}$ & Relativa & $\begin{array}{c}\text { Algas vermelhas } \\
\text { coralináceas e líticos } \\
\text { vulcânicos }\end{array}$ & & $\begin{array}{l}\text { Silva \& Gomes } \\
\text { (2016) }\end{array}$ \\
\hline $\begin{array}{l}\text { Ilha de Sal, } \\
\text { Cabo Verde }\end{array}$ & $\begin{array}{l}\text { Neógeno- } \\
\text { Quaternário }\end{array}$ & Relativa & $\begin{array}{l}\text { Algas vermelhas } \\
\text { coralinas, moluscos } \\
\text { e foraminíferos }\end{array}$ & $\begin{array}{l}\text { Afloramentos de } 1 \\
\text { a } 3 \mathrm{~m} \text { de espessura }\end{array}$ & $\begin{array}{l}\text { Dabrio et al } \\
\quad(2006)\end{array}$ \\
\hline $\begin{array}{c}\text { Menorca, } \\
\text { Mar Mediterrâneo }\end{array}$ & $\begin{array}{c}136-56 \mathrm{ka} \\
5495-4380 \\
\mathrm{a}\end{array}$ & $\begin{array}{c}\text { LOE } \\
{ }^{14} \mathrm{C}-\mathrm{AMS}\end{array}$ & $\begin{array}{l}\text { Algas vermelhas, } \\
\text { moluscos, } \\
\text { equnodermas, } \\
\text { foraminíferos } \\
\text { briozoários } \\
\end{array}$ & $\begin{array}{l}\text { Afloramento com } \\
20 \text { a } 50 \mathrm{~m} \text { de altura }\end{array}$ & $\begin{array}{l}\text { Pomar et al. } \\
\qquad(2017)\end{array}$ \\
\hline Tufia, Canárias & $31-39 \mathrm{ka}$ & AAR & $\begin{array}{l}\text { Algas vermelhas e } \\
\text { moluscos }\end{array}$ & $\begin{array}{l}\text { Afloramentos de } \\
\text { até } 12 \mathrm{~m} \mathrm{de} \\
\text { espessura }\end{array}$ & $\begin{array}{l}\text { Mangas et al. } \\
\text { (2008) }\end{array}$ \\
\hline $\begin{array}{l}\text { Ilha do Canal, } \\
\text { California, EUA }\end{array}$ & $120-80 \mathrm{ka}$ & $\begin{array}{c}\mathrm{LOE},{ }^{14} \mathrm{C}- \\
\mathrm{AMS} \\
\text { AAR }\end{array}$ & $\begin{array}{l}\text { Bioclastos marinhos } \\
\text { (teor de } \mathrm{CaCO}_{3} \text { na } \\
\text { rocha: } 25-80 \% \text { ) }\end{array}$ & $\begin{array}{l}\text { Afloramentos de } \\
\text { até } 20 \mathrm{~m} \text { de } \\
\text { espessura }\end{array}$ & $\begin{array}{l}\text { Muhs et al. } \\
\quad \text { (2018) }\end{array}$ \\
\hline
\end{tabular}


Tabela 2. Eolianitos quaternários continentais no mundo, com suas principais características. Significado das siglas para tipos de datação absoluta: ${ }^{14} \mathrm{C}$ (rádio-carbono), LOE (luminescência oticamente estimulada), AAR (raceminização de aminoácidos), U-Th (Urânio-Tório)

\begin{tabular}{|c|c|c|c|c|c|}
\hline Localização & Idade & $\begin{array}{l}\text { Tipo de } \\
\text { datação }\end{array}$ & Composição & $\begin{array}{c}\text { Morfologia } \\
\text { do depósito } \\
\text { ou do } \\
\text { afloramento }\end{array}$ & $\begin{array}{c}\text { Referências } \\
\text { bibliograficas }\end{array}$ \\
\hline \multirow{7}{*}{$\begin{array}{c}\text { Austrália } \\
\text { (Oeste) }\end{array}$} & & AAR & & & Hearty (2003) \\
\hline & $\begin{array}{c}\text { Até } 500 \mathrm{ka} \\
\text { (MIS } 11,9,7 \text {, } \\
5,3,1)\end{array}$ & U-Th, LOE & $\begin{array}{l}\text { Quartzo e } \\
\text { bioclastos }\end{array}$ & $\begin{array}{l}\text { Afloramentos } \\
\text { de até } 1 \mathrm{~km}\end{array}$ & $\begin{array}{c}\text { Lipar \& Webb } \\
\text { (2014) }\end{array}$ \\
\hline & $\begin{array}{c}77-27 \mathrm{ka} \\
120-103 \mathrm{ka} \\
\text { (MIS 5e-5a) }\end{array}$ & LOE & & $\begin{array}{c}\text { Afloramentos } \\
\text { com } 9 \text { a } 45 \mathrm{~m} \\
\text { de espessura }\end{array}$ & $\begin{array}{l}\text { Brooke } \text { et al. } \\
\quad(2014)\end{array}$ \\
\hline & MIS 11 e $5 \mathrm{e}$ & Relativa & $\begin{array}{l}\text { Bivalves e } \\
\text { biota } \\
\text { subtropical } \\
\text { heterozoária }\end{array}$ & $\begin{array}{c}\text { Afloramentos } \\
\text { com } \\
\text { espessuras } \\
\text { metricas }\end{array}$ & $\begin{array}{c}\text { James \& Bone } \\
\text { (2015) }\end{array}$ \\
\hline & MIS 11 a 5 & Relativa & & & $\begin{array}{c}\text { Lipar \& Webb } \\
(2015)\end{array}$ \\
\hline & $31-49,5 \mathrm{ka}$ & LOE & \multirow{2}{*}{$\begin{array}{c}\text { Quartzo, } \\
\text { bioclastos, } \\
\text { foraminíferos, } \\
\text { algas, } \\
\text { moluscos } \\
\end{array}$} & \multirow{2}{*}{$\begin{array}{l}\text { Afloramento } \\
\text { ao longo de } \\
\text { trecho de } \\
1000 \mathrm{~km} \mathrm{da} \\
\text { costa sudoeste }\end{array}$} & \multirow{2}{*}{$\begin{array}{l}\text { Lipar et al. } \\
\quad \text { (2017) }\end{array}$} \\
\hline & 8150 a & ${ }^{14} \mathrm{C}$ & & & \\
\hline \multirow[b]{2}{*}{ África do Sul } & & & & $\begin{array}{l}\text { Eolianitos } \\
\text { submersos }\end{array}$ & $\begin{array}{c}\text { Cooper \& } \\
\text { Green }(2016 a) \\
\end{array}$ \\
\hline & Holoceno & Relativa & $\begin{array}{l}\text { Bioclastos } \\
\text { marinhos }\end{array}$ & $\begin{array}{c}\text { Afloramentos } \\
\text { lineares } \\
\text { extensos, } \\
\text { paralelos à } \\
\text { costa } \\
\end{array}$ & $\begin{array}{c}\text { Cooper \& } \\
\text { Green }(2016 b)\end{array}$ \\
\hline Egito & $25 \mathrm{ka}$ & $\begin{array}{l}\text { AAR, }{ }^{14} \mathrm{C}, \\
\text { série do } \mathrm{U}\end{array}$ & $\begin{array}{c}\text { Moluscos, } \\
\text { foraminíferos } \\
\text { e ooides }\end{array}$ & $\begin{array}{l}\text { Cordões } \\
\text { paralelos à } \\
\text { costa }\end{array}$ & $\begin{array}{l}\text { El-Asmar } \\
\text { (1994) }\end{array}$ \\
\hline $\begin{array}{c}\text { Golfo } \\
\text { Arábico }\end{array}$ & $\begin{array}{l}\text { Holoceno e } \\
\text { Pleistoceno } \\
\end{array}$ & Relativa & & & $\begin{array}{c}\text { El-Asmar \& } \\
\text { Wood }(2000) \\
\end{array}$ \\
\hline Israel & $\begin{array}{c}\text { Plioceno - } \\
\text { Quaternário }\end{array}$ & Relativa & & & $\begin{array}{c}\text { Sivan et al, } \\
\text { (1999) }\end{array}$ \\
\hline Índia & $\begin{array}{l}\text { Plestoceno } \\
\text { tardio e } \\
\text { Holoceno } \\
\text { inicial }\end{array}$ & Relativa & $\begin{array}{c}\text { Bioclastos } \\
\text { marinhos, } \\
\text { principalmente } \\
\text { miliolídeos }\end{array}$ & $\begin{array}{c}\text { Cordões } \\
\text { lineares } \\
\text { paralelos à } \\
\text { costa, sobre } \\
\text { embasamento } \\
\text { vulcânico }\end{array}$ & $\begin{array}{c}\text { Dasgupta \& } \\
\text { Bandyopadhyay } \\
(2008)\end{array}$ \\
\hline $\begin{array}{l}\text { México } \\
\text { (Cancun) }\end{array}$ & Holoceno & Relativa & Bioclastos & & $\begin{array}{c}\text { Loucks \& Ward } \\
(2001)\end{array}$ \\
\hline Tunísia & $\begin{array}{l}\text { Holoceno, } \\
\text { e.g. } 8 \mathrm{ka}\end{array}$ & ${ }^{14} \mathrm{C}$ & $\begin{array}{l}\text { Peloides, } \\
\text { quartzo, } \\
\text { ooides, } \\
\text { bioclastos } \\
\end{array}$ & & $\begin{array}{l}\text { Fréboug et al. } \\
\qquad(2010)\end{array}$ \\
\hline Turquia & $\begin{array}{c}138 \mathrm{ka} \text { (MIS } \\
5 \mathrm{e})\end{array}$ & LOE & Ooides & $\begin{array}{c}\text { Afloramentos } \\
\text { com } 3,5 \text { a } 8,0 \\
\text { m de } \\
\text { espessura } \\
\end{array}$ & $\begin{array}{l}\text { Erginal et al. } \\
\quad(2013)\end{array}$ \\
\hline
\end{tabular}




\subsection{Distribuição no Tempo dos Depósitos Eólicos Quaternários do Brasil}

O uso de critérios estratigráficos, geomorfológicos e geocronológicos, (principalmente

${ }^{14} \mathrm{C}$, termoluminescência - TL e LOE, ainda sem uso do protocolo SAR - single aliquot regeneration dose) permitiu inicialmente o reconhecimento de pelo menos quatro gerações de areias eólicas quaternárias em três diferentes áreas costeiras do Brasil com campos de dunas livres: no CE (Claudino Sales 2002) e RN (Barreto et al. 2004); no trecho que vai desde Sergipe ao norte da Bahia, incluindo a foz do São Francisco (Bittencourt et al. 1982, Dominguez et al. 1996); e no centro-sul de Santa Catarina (Giannini 1993, Giannini et al. 2001, 2007, Sawakuchi 2003). A comparação entre as idades inferidas ou determinadas para estas gerações em cada uma dessas três áreas possibilitou o traçado de correlações entre elas, balizadas por episódios transgressivos e/ou de variação de NRM, de extensão inter-regional (Giannini et al. 2005, 2007; Quadro 3).

A geração de dunas mais antiga (D5 de Claudino Sales (2002), no CE; tênues ou dissipadas de Barreto et al. (2004), no RN; Qe1 de Bittencourt et al. (1982) e Dominguez et al. (1996), nos estados de Sergipe e Bahia; e geração1 ou G1 de Giannini (1993) e Giannini et al. (2007), no centro-sul de Santa Catarina) é seguramente anterior ao máximo transgressivo do Holoceno e tida também, pelo menos junto à foz do rio São Francisco (SE) e no centro-sul de Santa Catarina, como anterior ou aproximadamente contemporânea ao máximo NRM de 120 ka AP. A segunda geração (D4, tênues ou nítidas, Qe2, G2) apresenta-se como anterior ou aproximadamente contemporânea à máxima inundação ligada ao NRM mais alto do Holoceno. A terceira geração (D3, nítidas, Qe3 de Barbosa 1997, G3) corresponde às dunas inativas posteriores a esta máxima inundação. E a última geração (D1, Qe4, G4) compreende as dunas ativas, com iniciação estimada em poucos séculos, nas áreas de menor aporte, ou vários milênios, nas áreas com aporte eólico elevado, como Lençóis Maranhenses (Quadro 3). 
Quadro 3. Proposta de correlação entre gerações de campos de dunas de diferentes regiões costeiras do Brasil. ( $\left.{ }^{\mathrm{x}}\right)$ Datações por luminescência sem uso do protocolo SAR. ${ }^{\left({ }^{x}\right)}$ Datações por luminescência sem uso do protocolo SAR. Modificado de Giannini et al. (2007).

\begin{tabular}{|c|c|c|c|c|c|}
\hline $\begin{array}{l}\text { ESTADO E } \\
\text { REGIÃO }\end{array}$ & \multicolumn{5}{|c|}{$\begin{array}{l}\text { GERAÇÃO EÓLICA E RESPECTIVA IDADE INFERIDA OU } \\
\text { MEDIDA POR TL /LOE }\left({ }^{x}\right)\end{array}$} \\
\hline $\begin{array}{c}\text { Ceará } \\
\text { (Claudino Sales } \\
\text { 2002) }\end{array}$ & $\begin{array}{l}\text { D5: anterior } \\
\text { à } \\
\text { transgressão } \\
\text { holocena }\end{array}$ & $\begin{array}{c}\text { D4: } \\
\text { contemporânea } \\
\text { à transgressão } \\
\text { holocena }\end{array}$ & $\begin{array}{c}\text { D3: } \\
\text { Holoceno } \\
\text { médio a } 1,2 \\
\text { ka }\end{array}$ & $\begin{array}{l}\text { D2: ativa, } \\
\text { iniciada } \\
\text { entre } 1,2 \mathrm{e} \\
0,3 \mathrm{ka}\end{array}$ & $\begin{array}{c}\text { D1: ativa, } \\
\text { iniciada após } \\
0,3 \mathrm{ka}\end{array}$ \\
\hline $\begin{array}{c}\text { Maranhão } \\
\text { (Guedes 2012, } \\
\text { Zular 2016, } \\
\text { Guedes et al. } \\
\text { 2017) }\end{array}$ & $\begin{array}{c}\text { G0: } 258,9+/- \\
24,6 \mathrm{ka}^{\mathrm{xx}} \\
\text { G1: } 88,0+/- \\
8,6 \mathrm{ka}^{\mathrm{xx}}\end{array}$ & $\begin{array}{l}\text { G2: anterior à } \\
\text { máxima } \\
\text { inundação do } \\
\text { Holoceno: } \\
\text { 27,2-10,4xx }\end{array}$ & \multicolumn{3}{|c|}{ Depósitos eólicos recentes } \\
\hline $\begin{array}{l}\text { Rio Grande do } \\
\text { Norte } \\
\text { (Barreto et al. } \\
\text { 2004, Zular 2016) } \\
\end{array}$ & $\begin{array}{l}\text { Tênues ou } \\
\text { dissipadas: } \\
149 \mathrm{ka}^{\mathrm{x}}\end{array}$ & $\begin{array}{c}\text { Tênues ou } \\
\text { nítidas: } \\
\text { 10,8-9,1 } \mathrm{ka}^{\mathrm{x}} \mathrm{e} \\
6,5-5,6 \mathrm{ka}^{\mathrm{x}} \\
\end{array}$ & $\begin{array}{l}\text { Nítidas: } 3,5- \\
2,5 \mathrm{ka}^{\mathrm{x}} \mathrm{AP}\end{array}$ & \multicolumn{2}{|c|}{$\begin{array}{c}\left\langle 0,5 \mathrm{ka}^{\mathrm{x}} \text { : dunas transgressivas }\right. \\
\text { durante o último episódio de } \\
\text { subida do NRM durante o } \\
\text { Holoceno }\end{array}$} \\
\hline $\begin{array}{c}\text { Bahia-Sergipe } \\
\text { Foz de São } \\
\text { Francisco e } \\
\text { Salvador } \\
\text { (Bittencourt et } \\
\text { al.1982, } \\
\text { Dominguez et } \\
\text { al. 1996, Barbosa } \\
\text { 1997) } \\
\end{array}$ & Qe1: >120 ka & Qe2: >5,1 ka & $\begin{array}{l}\text { Qe3: }<3,7 \\
\operatorname{ka}^{\mathrm{x}}\end{array}$ & \multicolumn{2}{|c|}{$\begin{array}{l}\text { Qe4: ativa, formada nos } \\
\text { últimos } 0.4 \mathrm{ka}\end{array}$} \\
\hline $\begin{array}{c}\text { Santa Catarina } \\
\text { Imbituba- } \\
\text { Jaguaruna } \\
\text { (Giannini 1993, } \\
\text { Giannini et al. } \\
\text { 2001, 2007, } \\
\text { Sawakuchi 2003) }\end{array}$ & $\begin{array}{c}\text { G1: iniciada } \\
\text { antes ou } \\
\text { durante a } \\
\text { última } \\
\text { transgressão } \\
\text { pleistocena } \\
174,8-50,8 \\
\mathrm{ka}^{\mathrm{x}}\end{array}$ & $\begin{array}{l}\text { G2: iniciada } \\
\text { antes ou } \\
\text { durante o alto } \\
\text { NRM pós- } \\
\text { glacial 10,9- } \\
4,9 \mathrm{ka}^{\mathrm{x}}\end{array}$ & $\begin{array}{l}\text { G3: fixada } \\
\text { após a } \\
\text { transgressão } \\
\text { holocena } \\
6,3-0,2 \mathrm{ka}^{\mathrm{x}}\end{array}$ & \multicolumn{2}{|c|}{ G4: ativa } \\
\hline
\end{tabular}

A obtenção de datações LOE-SAR demonstrou a existência de depósitos eólicos com idades correlatas a estas quatro gerações em outras áreas costeiras, como no Maranhão (Guedes et al. 2011, 2017; Quadro 3) e no centro-norte e no extremo sul de Santa Catarina (Zular et al. 2012, Mendes et al. 2015, Rodrigues 2017, Rodrigues et al. 2020), porém com indícios de existência de gerações mais antigas e de influência de eventos climáticos na iniciação ou estabilização dessas gerações.

Na costa do Maranhão, Guedes (2012) e Guedes et al. (2011, 2013, 2017) encontraram, em afloramentos de paleodunas terrígenas com espessura de dezenas de metros, idades LOE sugestivas de várias gerações antigas (118,6 \pm 9,9, 145,3 \pm 12,6 e 239,8 \pm 20,4 ka). A geração eólica mais velha (G1/G0, Guedes 2012) é encontrada com frequência em contato com o topo da Formação Barreiras, este identificado pela abundância de crostas ferruginosas. Ela apresenta 
intercalações das areias bem selecionadas com depósitos areno-conglomeráticos subaquosos, cuja frequência e espessura decrescem nos níveis acima (Guedes 2012). Corresponde ao que em alguns mapas da região (Aguiar \& Gomes 2004) é descrito como "Pós-Barreiras" e que tem expressão em grande parte da Região Nordeste.

Ainda no Maranhão, dezenas de idades obtidas em superfície (Guedes 2012, Guedes et al. 2011, 2013, 2017), correspondentes à última geração de paleodunas, caem todas dentro de um intervalo restrito de tempo, de 19 a 14 ka, com tendência para idades cada vez mais novas à medida que se afasta da costa. Estas idades, interpretadas como de estabilização do campo de dunas, coincidem grosso modo com o H1, tido como de deslocamento da ZCIT para sul na América do Sul (Arz et al. 1999, Weldeab et al. 2006, Baker et al. 2009), com aumento pronunciado de umidade em todo o território brasileiro (Cruz et al. 2009), e considerada por Guedes et al. $(2013,2017)$ ainda como de enfraquecimento dos ventos alísios na região.

Pesquisas recentes realizadas por Zular et al. (2016) em campos de dunas no Maranhão e RN indicam idades desde o MIS 5 (132 ka, no Maranhão, e 94,7 ka, no Rio Grande do Norte), e com taxas de acumulação que sugerem aumento do estoque de areias em três períodos considerados pelos autores como de NRM baixo e plataforma exposta: 67-58 ka, 33-26 ka e 2322 ka. Há que se considerar, porém, que os dois primeiros períodos incidem no início e no final do trato de mar alto (mais baixo que o atual) do MIS 3 (Rabineau et al. 2006, Siddall et al. 2008). Mesmos autores registram também uma geração de campos de dunas transgressivos no RN formada no último episódio de subida do NRM durante o Holoceno.

\section{7 Área de Estudo}

\subsubsection{Geomorfologia e geologia}

Segundo Barreto et al. (2004), a cobertura sedimentar quaternária do litoral entre PI e $\mathrm{RN}$ compreende depósitos eólicos, como dunas ativas e inativas e lençóis de areia inativos, e marinhos, estes incluindo sedimentos regressivos pleistocenos, rochas praiais holocenas e sedimentos da planície de maré atual (Fig. 3.5). De acordo com mesmos autores, esta cobertura repousa sobretudo sobre a Formação Barreiras, de suposta idade miocena (Rossetti e Dominguez, 2011).

No PI, CE e RN, a planície litorânea apresenta desembocaduras flúvio-estuarinas e de canais de escoamento de maré associados a manguezais, turfas e areias, com destaque, entre 
estas, para dunas eólicas ativas e inativas (Souza 2000, Aguiar \& Gomes 2004) ou "fixas" (Claudino Sales 2002). Corpos lacustres remanescentes de antigos estuários também podem ocorrer em meio à planície litorânea, inclusive como resultado da obstrução de drenagens costeiras pelo avanço ao interior de dunas e paleodunas (Souza 2000, Zular et al. 2018). Exemplos de lagos barrados pelos depósitos eólicos no RN podem ser vistos junto às povoações de Canto da Ilha de Cima e Canto de Baixo, em Enxu Queimado (Fig. 3.6).

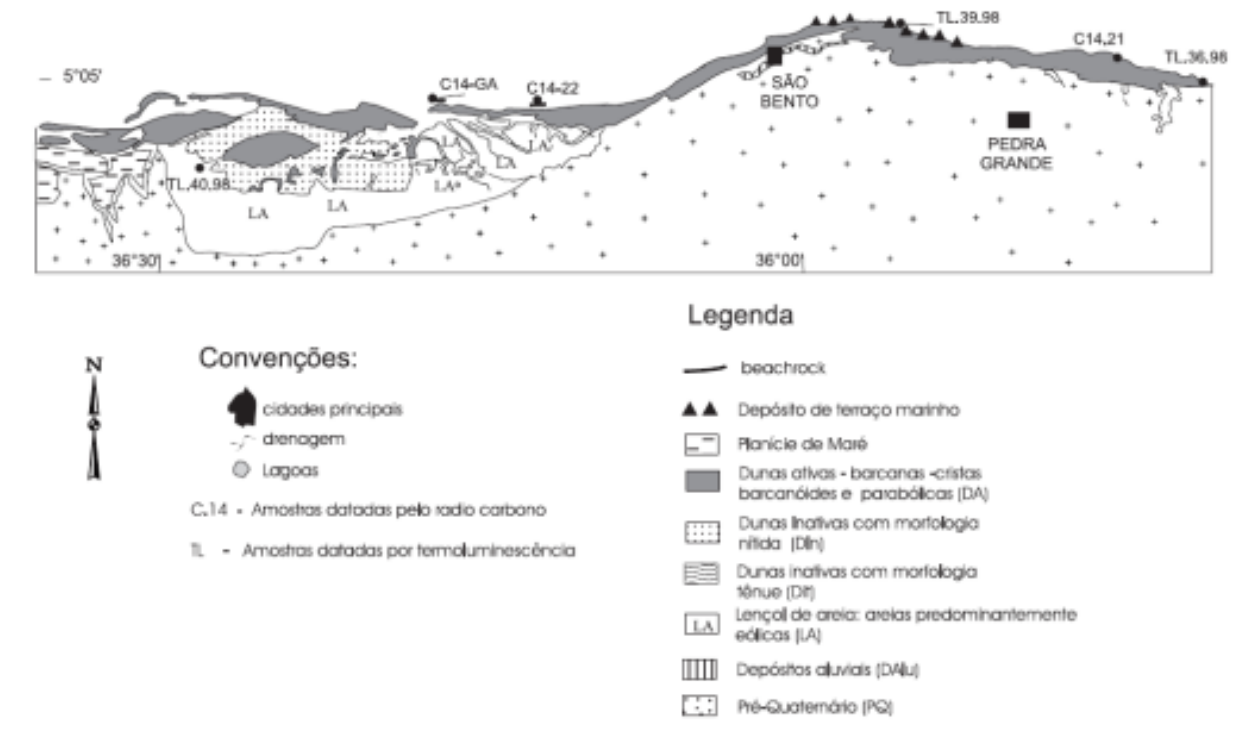

Fig. 3.5. Geologia da região de estudo no Rio Grande do Norte. Extraído de Barreto et al. (2004).

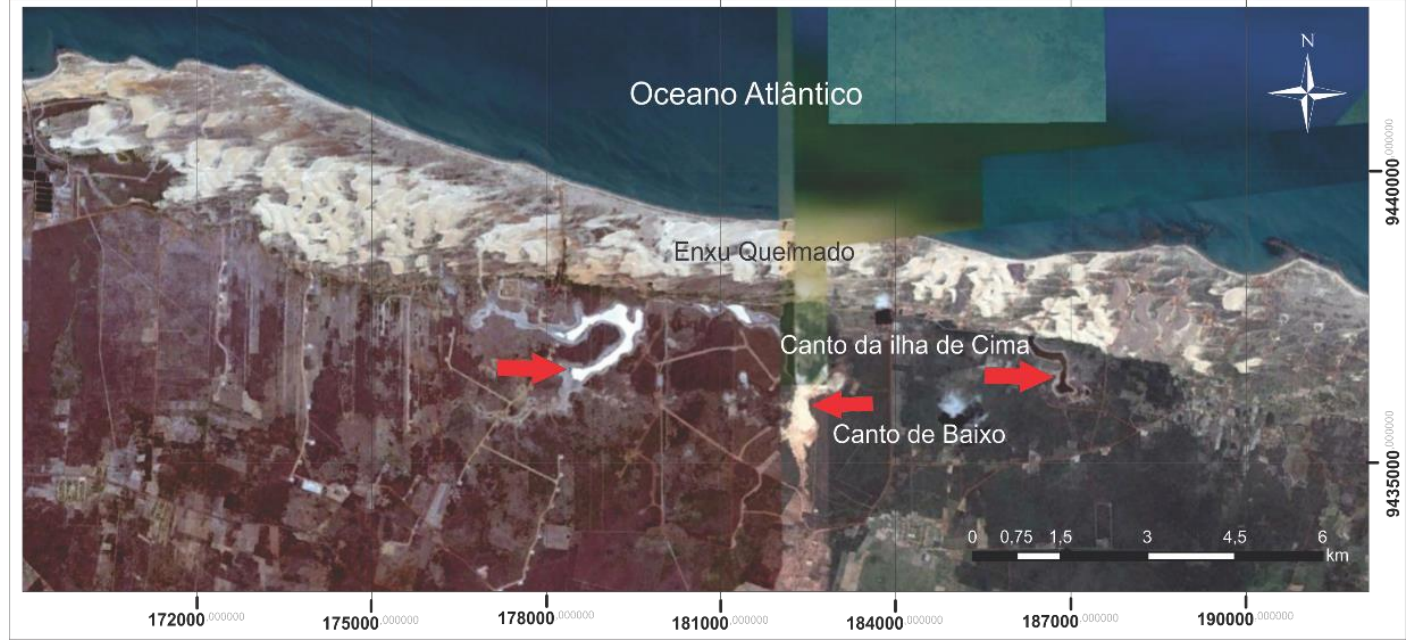

Fig. 3.6. Exemplos de lagos associados à obstrução de drenagens costeiras pelo avanço ao interior de dunas e paleodunas (setas vermelhas), em Enxu Queimado (município de São Miguel do Gostoso), RN. 
Já o AFN é constituído por três formações de rochas vulcânicas e piroclásticas, denominadas Formação Remédios, Formação Quixaba e Formação São José, com idades entre o Mioceno Médio e o Pleistoceno Inferior (Perlingueiro et al. 2013); a Formação Remédios, mais antiga, constitui-se de um substrato de rochas piroclásticas de composição intermediária alcalina (traquitos, fonolitos, essexitos), cortadas por diques, soleiras, domos e plugs de rochas de composição alcalina subsaturada (basanitos, álcali-basaltos e lamprófiros), que, após prolongado hiato, foram recobertas pelos derrames de basanitos e álcali-basaltos, da Formação São José, e por rochas básico-ultrabásicas nefelínicas (ankaratitos ou melanofelinitos) e seus depósitos piroclásticos associados, da Formação Quixaba (Almeida 1955, Ulbrich 1993, Perlingueiro et al. 2013; Fig. 3.7). Além das rochas ígneas e piroclásticas, são encontrados depósitos sedimentares mais novos, tanto autóctones (recifes algálicos, guano) quanto alóctones epiclásticos, estes originados seja pela erosão do edifício vulcânico, seja por processos costeiros, inclusive eólicos (Almeida 1955, Ulbrich 1993, Wildner \& Ferreira 2012; Fig. 3.7). Entre eles, destacam-se, respectivamente: conglomerados vulcanoclásticos, bioconstruções e calciarenitos (beach rocks e eolianitos) e dunas inconsolidadas. Estes depósitos cobrem menos de $7,5 \%$ do arquipélago, com ocorrência preferencial em porções restritas do perímetro da ilha (Angulo et al. 2013a).

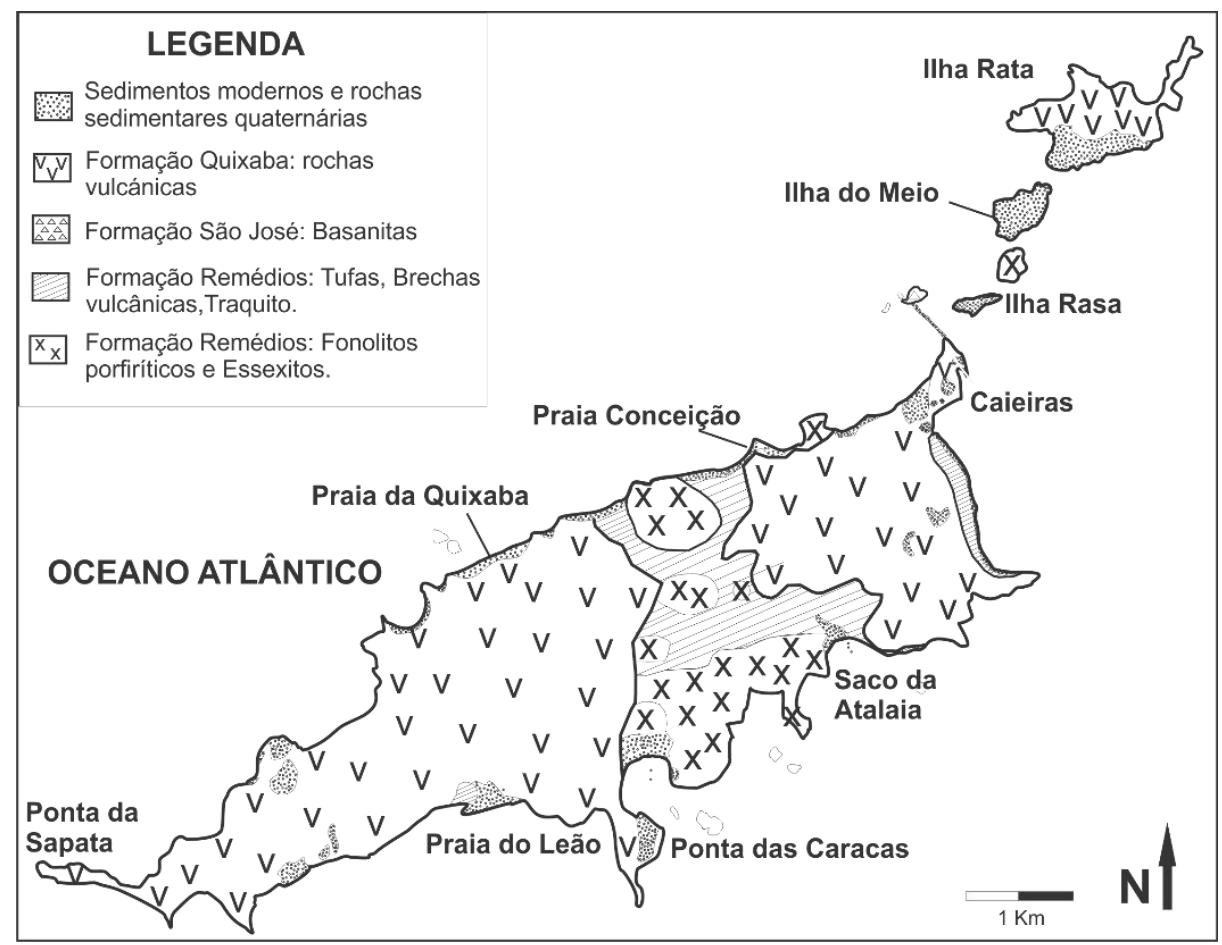

Fig. 3.7. Geologia do Arquipélago de Fernando de Noronha. Adaptado de Almeida (1955) por Ulbrich (1993). Extraído de Wildner \& Ferreira (2012). 


\subsubsection{Fontes potenciais de sedimentos carbonáticos na área submersa}

As áreas submersas que podem atuar como fontes de sedimentos carbonáticos para os eolianitos do Nordeste estão na plataforma continental, do PI ao RN, e em plataformas sobre substrato vulcânico-piroclástico, que circundam as ilhas, no AFN.

A plataforma continental nordestina é estreita, com média de $63 \mathrm{~km}$ de largura, e geralmente é mais rasa que $200 \mathrm{~m}$. Em contraste com outras plataformas tropicais, a presença de recifes de corais é inexpressiva, já que apenas alguns dos gêneros construtores de recifes estão presentes. Os sedimentos terrígenos são, na sua grande maioria, relíquias, retrabalhados pelo menos desde o início do Holoceno (Kowsmann \& Costa 1979) e, na interpretação de Vital (2005), sua semelhança composicional com os sedimentos recentes sugere que no Pleistoceno o clima teria sido similar ao atual, hipótese cuja verificação requer estudos cronológicos e mineralógicos mais detalhados. No Nordeste brasileiro, a amplitude de marés (mesomaré) e os ventos fortes de quadrantes de leste dão alta energia à frente da plataforma. Tendo como base a morfologia e a distribuição dos tipos de sedimentos, Coutinho et al (1976) divide a plataforma do Nordeste em interna (até a isóbata de 20m), média (entre as isóbatas de 20 e 40m), de relevo bem mais regular, e externa (mais profunda que 40m). Segundo Araújo (2011), a plataforma cearense atinge sua largura máxima de $75 \mathrm{~km}$ junto a Camocim, e a mínima no oeste do Ceará; de acordo com Kowsmann \& Costa (1979), a plataforma continental no litoral do PI e CE é composta principalmente por sedimentos carbonáticos na granulação cascalho, dominados por algas coralináceas, inclusive rodólitos; já no RN, entre Macau e São Miguel do Gostoso (ponta Santo Alberto), segundo mesmos autores, os sedimentos carbonáticos na granulação areia ou cascalho são dominados por foraminíferos bentônicos, moluscos e algas recifais (Fig. 3.8). A plataforma brasileira contém as mais extensas coberturas de rodólitos do mundo (Amado Filho et al. 2012), especialmente bem desenvolvidas na Região Nordeste.

O edifício vulcânico-piroclástico do AFN sustenta uma elevação submarina de cerca de $4000 \mathrm{~m}$ de altura, cujo topo, com aproximadamente $40 \mathrm{~km}$ de extensão E-W varia entre $500 \mathrm{~m}$ de profundidade, na zona deprimida central, e 180m de altitude, no Morro do Pico, a E (Fig. 3.9). A zona deprimida central separa duas áreas de plataforma rasa, isto é, com declividade mais suave e menos de 100 m de profundidade: uma a W, chamada Alto Fundo Drina, e outra a E, que é mais extensa (quase $20 \mathrm{~km}$ ) e abrange a zona emersa do arquipélago (Fig. 3.9). O limite da plataforma ocorre no entorno da isóbata de $100 \mathrm{~m}$, podendo ser identificado pela 
aproximação das isolinhas de profundidade e uma assimetria na largura da plataforma, com estreitamento na porção setentrional (Ambrosio 2019). Na plataforma adjacente de Fernando de Noronha, Ottmann (1960) menciona a ocorrência de fragmentos algálicos de Lithothamnium e Halimeda em profundidades de $58 \mathrm{~m}$.

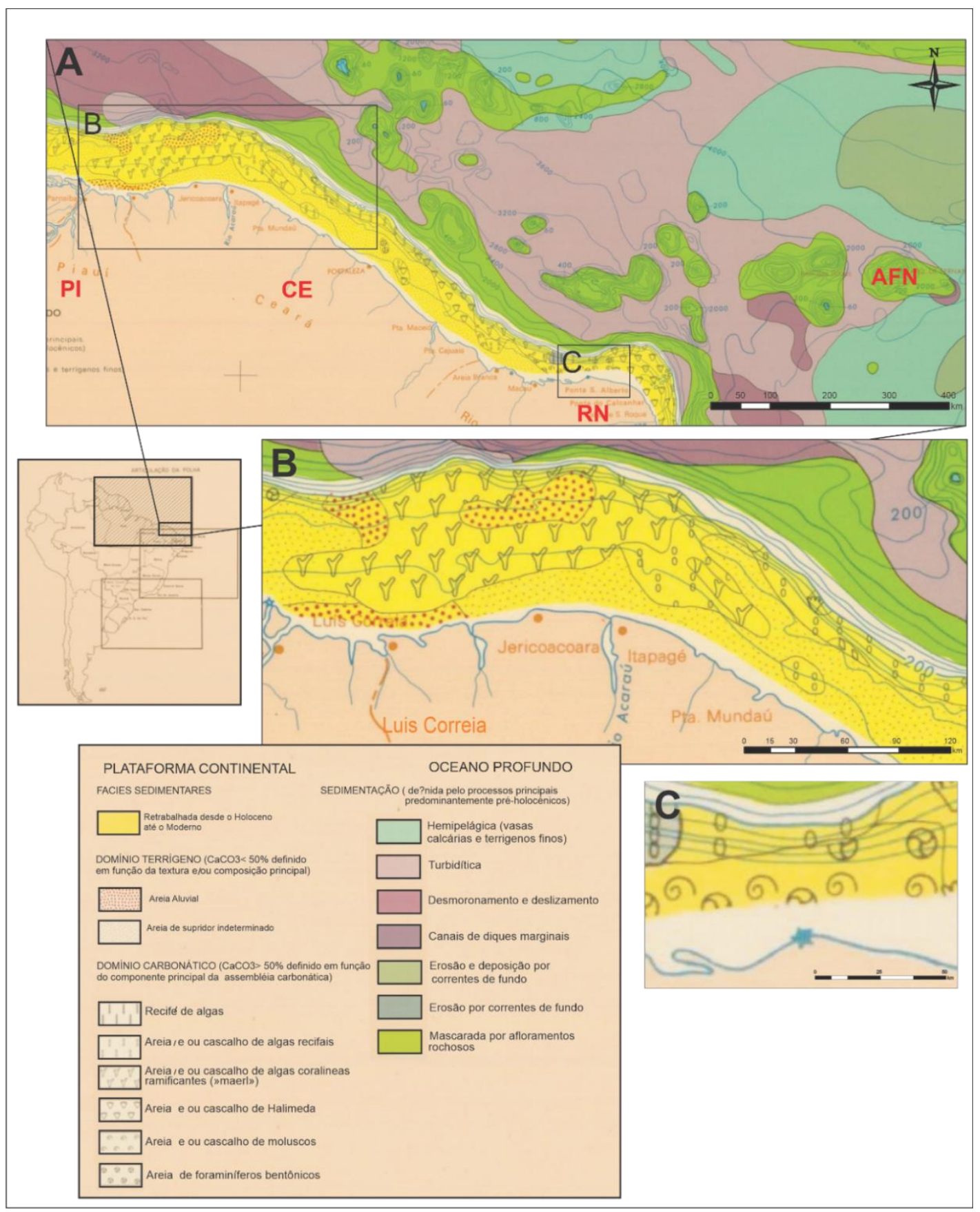

Fig. 3.8. Plataforma continental da área de estudo, com representação dos tipos de sedimentos nos domínios terrígeno e carbonático. Extraído do Projeto Remac (Kowsmann e Costa 1979). 


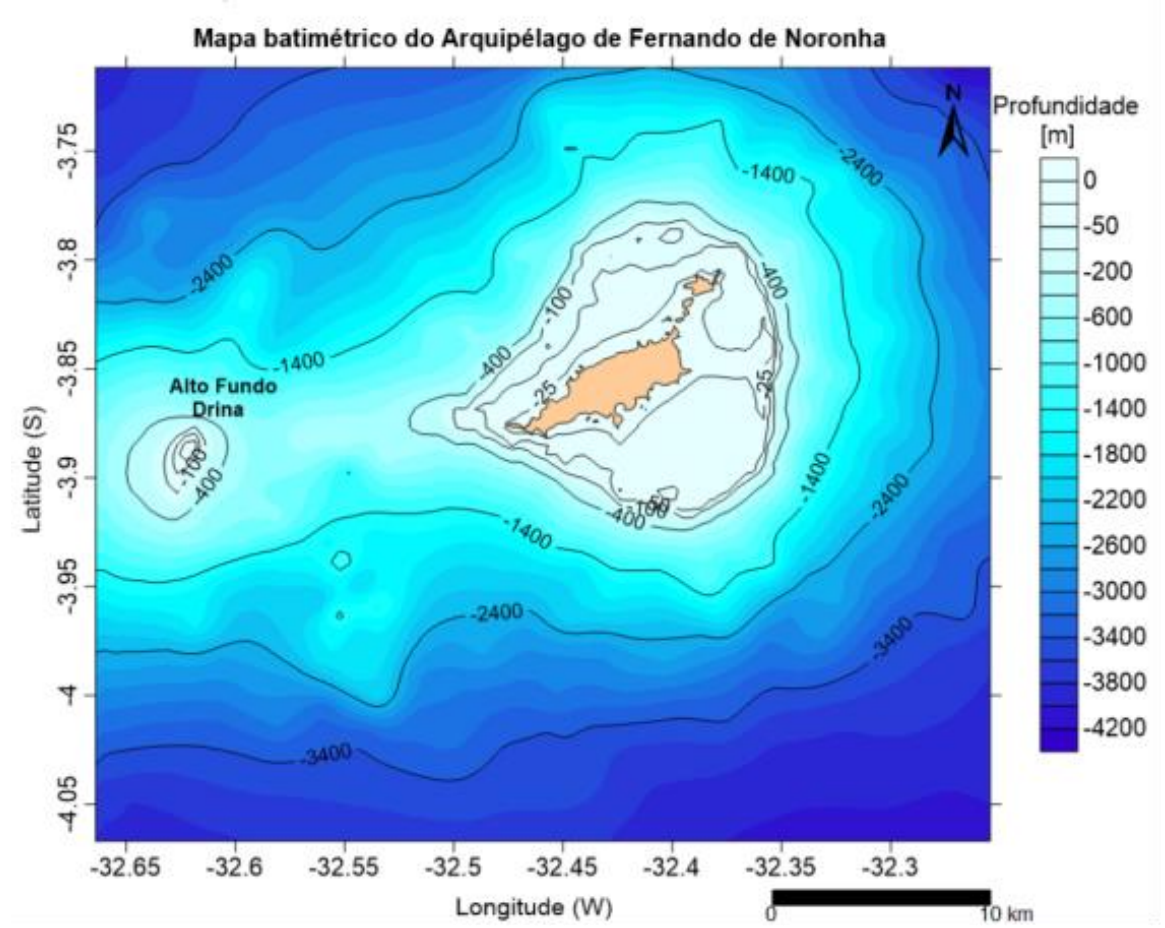

Fig. 3.9. Mapa batimétrico do arquipélago de Fernando de Noronha e arredores (extraído de Ambrosio 2019). Notar duas áreas de plataforma rasa, uma a W (Alto Fundo Drina) e outra a E, junto ao arquipélago.

\subsubsection{Clima e paleoclima}

O clima da Região Nordeste do Brasil é fortemente influenciado pela variação da Zona de Convergência Intertropical (ZCIT), faixa de mínima pressão, alta umidade e intensa atração de ventos de baixa troposfera, cuja posição é controlada pelo gradiente de temperatura da superfície marinha (TSM) entre o Atlântico Sul e o Norte (Uvo 1989, Garreaud et al. 2009, Melo et al. 2009). Este gradiente térmico, por sua vez, é influenciado pela circulação termohalina impulsionada pela diferença de salinidade da água e ligada à célula de revolvimento meridional do Atlântico, comumente referida pela sigla AMOC, da expressão em inglês Atlantic Meridional Overturning Circulation (Clement \& Peterson 2008).

A faixa de umidade da ZCIT é atraída para as zonas de aumento de temperatura. Assim, apresenta variação sazonal, com posição mais ao norte durante o verão do hemisfério Norte e posição mais ao sul durante o verão austral (Cavalcanti et al. 2009). No verão, a ZCIT no sudoeste da Amazônia alcança os Andes e de lá é defletida para SE, o que caracteriza o Sistema de Monções da América do Sul (SMAS), levando umidade para a Zona de Convergência do 
Atlântico Sul (ZCAS). O auge das monções no verão favorece uma zona de baixa pressão na média a alta troposfera sobre a costa do Nordeste, o Cavado do Nordeste (Satyamurty et al. 1998), o que na prática retarda o máximo deslocamento da ZCIT rumo sul nesta região para o final do verão austral e o início do outono (março/abril: Fig. 3.10). As costas do PI, CE e RN situam-se ao sul da posição média da ZCIT ao longo de todo ano, exceto justamente nesse período de posição meridional máxima (Fig. 3.10), quando são diretamente afetadas pela faixa de umidade; por esta razão, têm suas chuvas concentradas (acima de 100 mm/mês) entre o verão (janeiro) e o outono (maio). Já o AFN situa-se sempre ao sul da ZCIT, com período de chuvas intensificadas quando a ZCIT está mais a sul sobre o oeste do Atlântico subequatorial, ou seja, entre março e junho (Climate Data 2020).
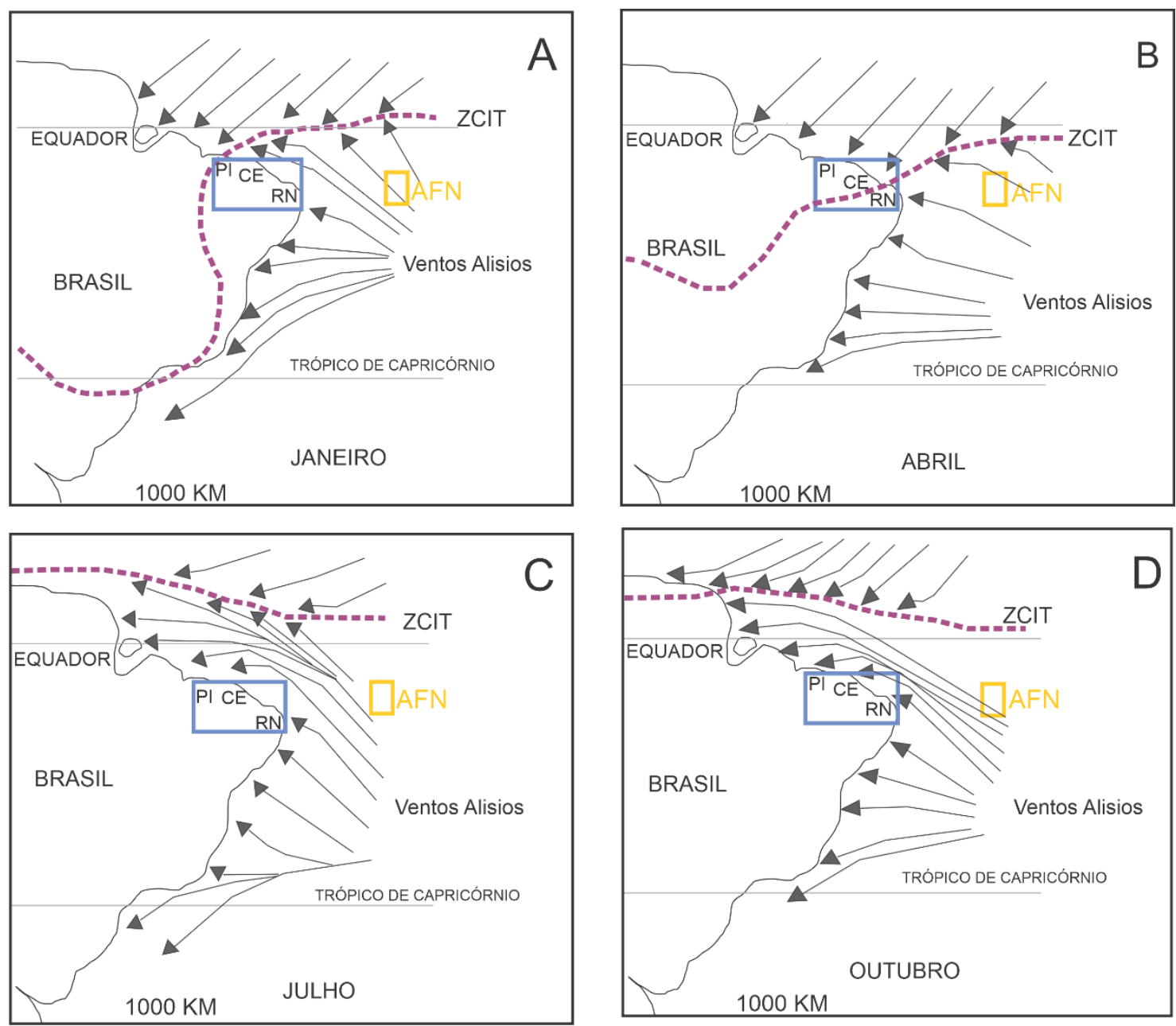

Fig. 3.10. Quatro cenários da ZCIT (linha roxa) e o comportamento dos alísios, com destaque para as áreas onde se encontram os eolianitos continentais (retângulo azul) e insulares (retângulo amarelo) do Nordeste brasileiro. Adaptado de Martin et al. (1998 apud Ellis 2015). 
Acredita-se que o efeito do deslocamento da ZCIT verificado sazonalmente ocorra também em escalas de tempo mais duradouras, por efeito de mudanças de insolação ligadas aos ciclos orbitais (e.g. precessão), principalmente no último ciclo de excentricidade (Wang et al. 2004, 2006, Cruz et al. 2005, 2009). Assim, o avanço para sul da ZCIT no oeste da Amazônia, com intensificação do SMAS e da ZCAS, nos últimos 5000 anos, por efeito do aumento de insolação do meio ciclo de precessão verificado no hemisfério Sul ao longo do Holoceno teria implicado umidificação do clima no Sul e no Sudeste do país, em prejuízo da umidade na Região Nordeste. Em trabalhos mais recentes, Cheng et al. (2013a) revelam uma relação espacial complexa entre a forçante de insolação e a variabilidade de chuvas de monções na América do Sul na escala orbital.

Já o deslocamento da faixa de umidade da ZCIT nos momentos de resfriamento do hemisfério Norte ligados a eventos milenares como Heinrich e Bond, por terem outros mecanismos controladores envolvidos, por exemplo, enfraquecimento da AMOC, podem ter implicado aumento de umidade tanto no Sul da América do Sul quanto na Região Nordeste do Brasil (Strikis 2011)

A modificado da posição da ZCIT altera não só a distribuição geográfica de umidade a ela associada, mas também o azimute e a intensidade dos ventos alísios que convergem nesta zona (Cruz et al. 2009, Tsoar et al. 2009). Na costa continental abordada neste estudo, com média mensal mínima de temperatura de $22^{\circ} \mathrm{C}$ e máxima de $32^{\circ} \mathrm{C}$, dominam os ventos alísios de NE, no PI, passando gradualmente a E, no Ceará, e a SE, no sul do RN, com velocidades médias de 6 m/s a 9 m/s (Amarante et al. 2002; dados para o período de 1983 a 1999: Fig. 3.11); já no $\mathrm{AFN}$, com temperatura média de $28^{\circ} \mathrm{C}$, e amplitude térmica média de apenas $4^{\circ} \mathrm{C}$, dominam os ventos alísios de SE durante todo o ano (Fig. 3.12), mais fortes entre os meses de junho e agosto e mais fracos de janeiro a março, estes associados às máximas de temperatura (Wildner \& Ferreira 2012). A variação sazonal dos dados meteorológicos ao longo da costa da Região Nordeste sugere que os ventos alísios se intensificam nos momentos de ZCIT mais distante, e portanto precipitação mais baixa, e enfraquecem quando ela está mais próxima. Desse modo, momentos de mais ventosidade no Nordeste parecem coincidir com fases de menos umidade, o que favorece a atividade eólica, e vice-versa. 

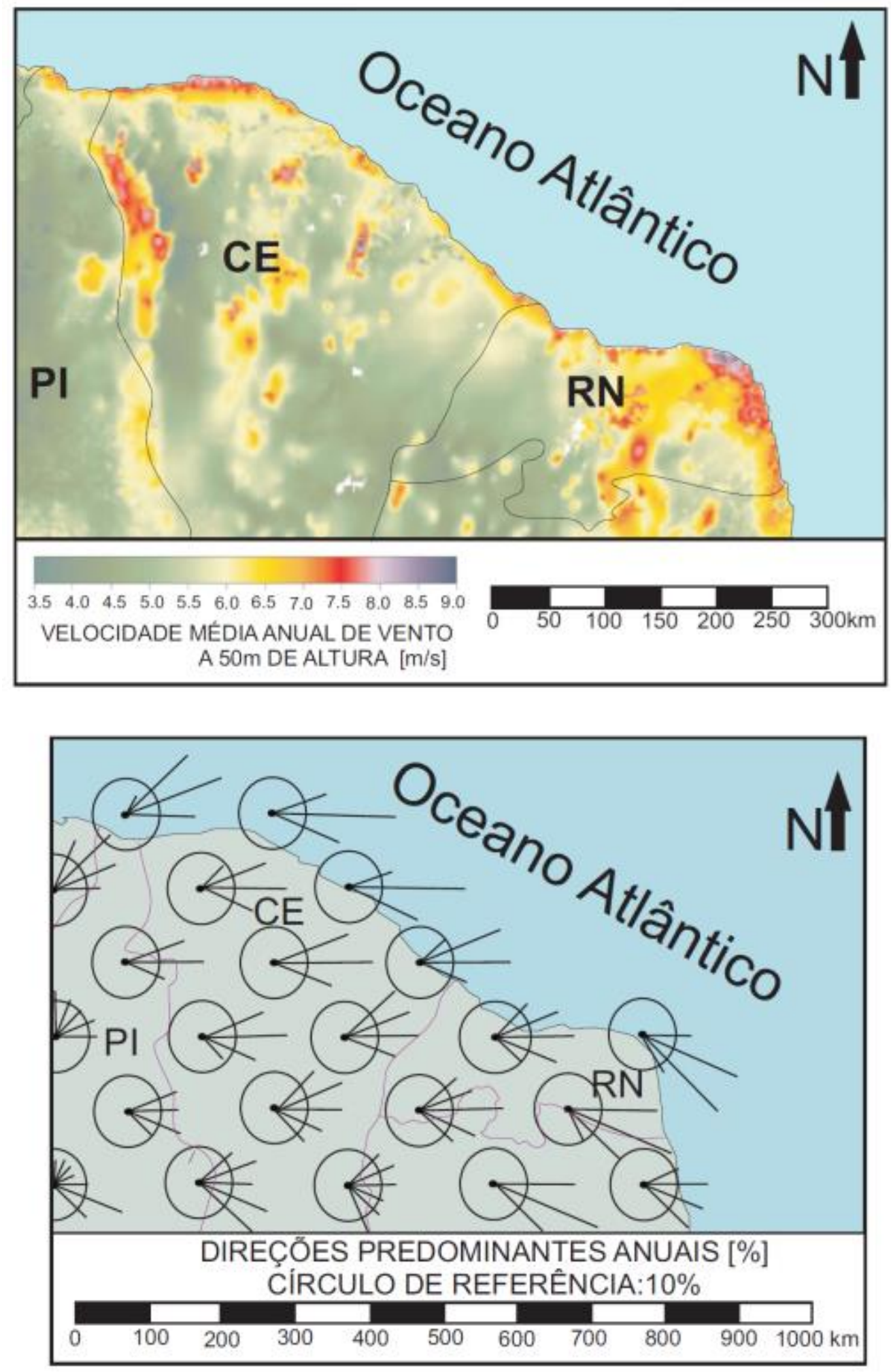

Fig. 3.11. Mapas de ventos nos estados de PI, CE e RN, com a velocidade média (superior) e os azimutes predominantes (inferior), para o período de 1983 a 1999. Extraído de Amarante et al. (2002). 


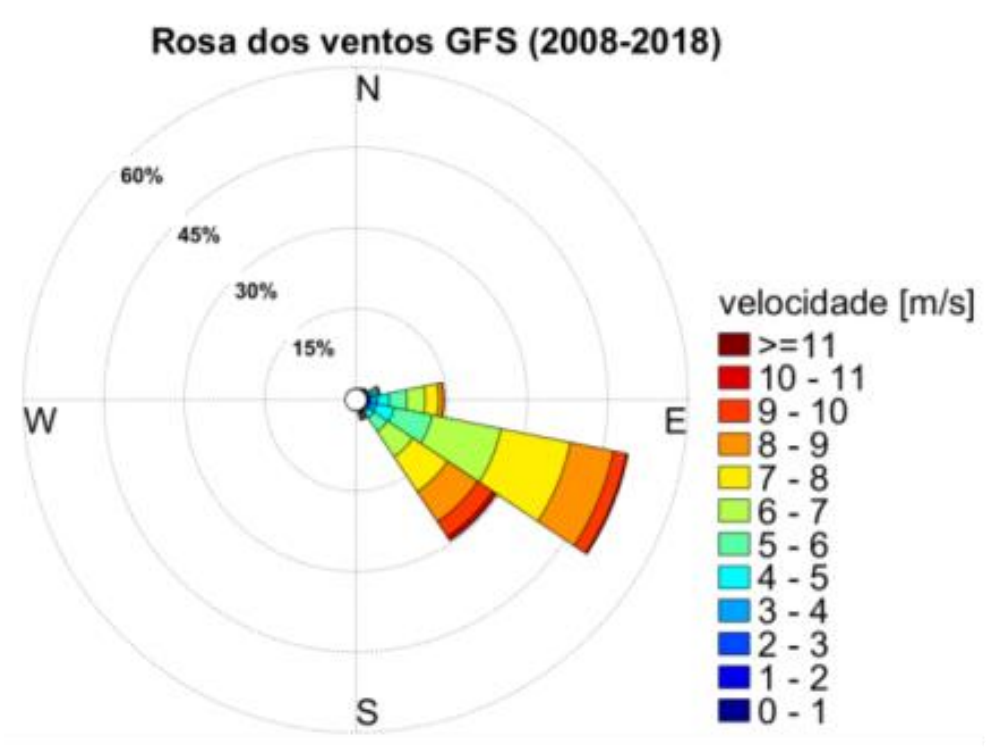

Fig. 3.12 Histograma azimutal das intensidades dos ventos no AFN, extraídos do modelo atmosférico global GFS, representativos do período de 2008 a 2018 (extraído de Ambrosio, 2019)

\subsubsection{Variação do NRM}

O NRM máximo admitido na costa do Brasil para o Penúltimo Interglacial (120 ka AP) é de $8 \mathrm{~m} \pm 2 \mathrm{~m}$ acima do nível atual (Suguio et al. 2005), estimado a partir das altitudes de terraços de construção marinha essencialmente arenosos e na datação U/Th de fragmentos de corais neles encontrados no Estado da Bahia (Bernat et al. 1983).

Para o Holoceno, a curva teórica de NRM de Milne et al. (2005), modelada para o Caribe e a América do Sul com base em cálculos de transferência de massa das calotas de gelo para o oceano mais ajustes hidro-isostáticos regionais, indica taxa de subida do NRM de 7 a $8 \mathrm{~mm}$ por ano até 7000 anos A.P., com desaceleração abrupta a partir de então. Desse período até o presente, o modelo sugere variações de no máximo $1 \mathrm{~m}$ no nível eustático, com possibilidade, porém, de variações locais a sub-regionais pouco maiores, por conta de ajustes isostáticos.

Em análise crítica de indicadores biogênicos (vermetídeos) disponíveis na literatura até então para o litoral entre Paraná e Pernambuco, Angulo et al. (2006) deduziram declínio suave de NRM após o máximo de 3 a 4 m, alcançado entre 7000 e 5000 anos cal A.P.. Tendência semelhante foi encontrada por Caldas et al. (2006) no litoral do RN, utilizando datações de beach rocks e sedimentos lagunares, e também por Vasconcelos et al. (2014), no CE, com datações de beach rocks. Segundo estes autores, o NRM durante o Holoceno no Nordeste brasileiro não foi superior a $3 \mathrm{~m}$ acima do atual. 
Também na costa cearense, Irion et al. (2012), com base no nivelamento de beach rocks, não encontraram evidências de paleonível holoceno mais alto que o atual e inferiram que o NRM nessa costa continuaria em elevação, o que atribuíram a componente glácio-eustática do NRM. O nivelamento, porém, não foi feito em relação às fácies homólogas, como metodologicamente recomendável (Angulo \& Souza 2015). Além disso, não há clara menção ao tipo de material datado, se bioclasto (fornecedor de idade máxima) ou se cimento (fornecedor de idade mínima). Desse modo, estes dados não permitem reconstituição precisa do comportamento do NRM. Para o PI, não existem curvas de variação no NRM holoceno específicas.

Para a costa do RN, Suguio et al. (2011) realizaram datações por LOE e TL em barreiras costeiras arenosas e encontraram dois grupos de idades: 200-230 ka e 100-130 ka, interpretadas como correlacionáveis com os eventos MIS 7c e MIS 5e, respectivamente, os quais corresponderiam à antepenúltima e penúltima transgressões da costa brasileira. Falta, no entanto, nesse trabalho, uma análise de fácies suficientemente detalhada que permita a atribuição segura destes depósitos mais antigos à deposição marinha rasa. Já para o Holoceno, Bezerra et al. (2003), com base em datações por ${ }^{14} \mathrm{C}$, inferiram curva do NRM, a qual apresenta desvios em relação à curva média da costa brasileira a sul (por exemplo, pequena oscilação, submétrica, do nível do mar por volta de 2100 e 1100 anos cal AP), o que foi atribuído pelos autores à neotectônica. As oscilações interpretadas, porém, estão dentro da margem de erro dos indicadores utilizados pelos autores.

As curvas de NRM holoceno de Angulo et al. (2006), Caldas et al. (2006) e Vasconcelos et al. (2014) são compatíveis entre si, em suas linhas mais gerais, bem como com o modelo teórico de Milne et al. (2005). Serão, por esta razão, as adotadas nesta pesquisa para a costa continental de CE, PI e RN.

Já no que se refere ao AFN, indicadores de paleonível marinho levantados por Angulo et al. (2013a), isto é, paleorrecifes algálicos, paleopraias (beach rocks) e entalhes de abrasão marinha (notches), mostram que o NRM tem-se mantido similar ao atual desde o Holoceno médio, com evidências de estabilidade durante pelo menos os últimos 5000 anos. Este comportamento do NRM, diferente do inferido na costa continental adjacente, permite sugerir leve subsidência do arquipélago em relação ao continente (Angulo et al. 2013a). 


\subsubsection{Ondas e deriva litorânea}

A região em estudo expõe-se à ação de ondulações (swell waves) de $\mathrm{N}$, geradas nos ciclones extratropicais do hemisfério Norte, e de vagas (wind sea waves), que, no RN e no AFN, são forçadas pelos ventos alísios de NE a E, e de SE, respectivamente (Pianca et al. 2010, Costa 2014). No AFN, ondulações de S também são importantes (Costa 2014), com frequência de ocorrência, período e alturas similares às de N (Ambrosio 2019).

A atuação das ondulações de $\mathrm{N}$ concentra-se no verão austral, quando ocorre ainda a ampliação para sul da zona de influência das vagas geradas pelos alísios de NE. No restante do ano, dominam as vagas de E a SE (Pianca et al. 2010) que, no AFN, podem ser acompanhadas de ondulações de S, estas mais atuantes no inverno austral (Ambrosio 2019). As vagas geradas por ventos alísios favorecem a deriva litorânea para $\mathrm{W}$ na costa setentrional do Nordeste brasileiro, rumo no qual se observa tendência para aumento da proporção de terrígenos na sedimentação costeira. 


\section{ATIVIDADES REALIZADAS: MEIOS, MATERIAIS E MÉTODOS}

\subsection{Cartografia Geomorfológica}

A cartografia teve como finalidade principal situar as ocorrências de eolianitos em relação a feições morfológicas de campos de dunas ativos e fósseis. Baseou-se em imagens de satélite obtidas dos softwares de livre acesso Google Earth $^{\circledR}$ (resolução espacial de cerca de 1 m) e Timelapse, este especificamente nas áreas continentais. A comparação de imagens de diferentes datas e o uso do Timelapse permitiram caracterizar o comportamento dos sistemas eólicos presentes nas áreas de estudo nos últimos 30 anos e ajudou a inferir, por analogia, possíveis comportamentos dos sistemas eólicos no passado mais remoto. Junto com informações de campo e referências bibliográficas, a análise de imagens de satélite possibilitou o mapeamento geomorfológico, com uso do software Arc Gis

\subsection{Atividades de Campo}

Realizaram-se duas campanhas de campo, a primeira no AFN, entre 1 e 7 de agosto de 2015, e a segunda, no RN, entre 22 e 29 de julho de 2017. Ao longo destas jornadas de campo, coletaram-se 113 amostras para análises sedimentológicas e 15 amostras (do RN) para datação por LOE. Das 113 amostras sedimentológicas, foram depois selecionadas 32 para separação de alíquotas destinadas a datação por ${ }^{14} \mathrm{C}$ (item 4.3.3.2).

Foram explorados os conceitos de fácies morfológicas e fácies deposicionais, conforme proposta de Martinho et al. (2006) e Giannini (2007) para depósitos eólicos quaternários, estes por sua vez compilados dos trabalhos de Walker (1976, 1992), Anderton (1985) e Miall (1985, 1999). De acordo com esta proposta, as fácies morfológicas são unidades de descrição de campo, voltadas à interpretação da relação processo-forma, enquanto as fácies deposicionais visam à relação entre forma e produto deposicional. As fácies morfológicas (por exemplo, as paredes, a bacia e o lobo de um blowout) agrupam-se em elementos morfológicos (o próprio blowout), assim como as fácies deposicionais agrupam-se em associações de fácies (elementos arquitetônicos, por exemplo, planície de deflação e campo de dunas). A integração das fácies morfológicas com as deposicionais permitiu deduzir as relações processo-produto, fundamentais em qualquer abordagem sedimentológica genética. 
Com base nesse enfoque, as principais atividades que foram executadas durante as campanhas de campo nos eolianitos, e em outros tipos de depósitos eólicos e/ou costeiros a eles associados, podem ser assim enumeradas:

1. Identificação e descrição de fácies morfológicas previamente reconhecidas por análises de imagens aéreas.

2. Análise de fácies deposicionais e associações de fácies (elementos arquitetônicos), correspondentes, respectivamente, às fácies morfológicas e elementos morfológicos identificados. Esta análise foi feita em cortes naturais (de deflação ou erosão subaquosa) ou artificiais (de estradas e cavas de extração de areia).

3. Coleta sistemática, por fácies e/ou horizonte estratigráfico, de medidas de espessura e atitude de estratificação cruzada, com trena e bússola, e amostragem seletiva de sedimentos destinados a datação (item 4.3.3), caracterização petrográfica, textural e mineralógica (itens 4.3.4 a 4.3.7).

A análise de fácies deposicionais foi aplicada tanto aos eolianitos quando a depósitos não eólicos ou não carbonáticos associados, isto é, que ocorrem na mesma sucessão estratigráfica ou nas suas porções lateralmente correlatas.

Em campo, definiram-se como eolianitos os depósitos considerados eólicos, litificados ou semi-consolidados, com presença de cimento carbonático verificada pela efervescência ao $\mathrm{HCl}$. O caráter eólico, por sua vez, foi identificado com base na presença conspícua e pervasiva de laminação de espessura milimétrica a submilimétrica, ressaltada por cimentação e por erosão diferenciais, com segregação de grãos quanto a tamanho e com boa seleção granulométrica por lâmina. Esta estrutura sedimentar corresponde à pin stripe lamination (laminação risca de giz), definida por Fryberger \& Shenk (1988), e considerada por esses autores como a mais diagnóstica das feições de deposição eólica.

De modo análogo, consideraram-se como beach rocks os depósitos sedimentares atribuídos a berma, antepraia ou face litorânea, litificados pela precipitação de cimentos carbonáticos. Depósitos deste tipo são comuns na Região Nordeste do Brasil, onde levam com frequência à formação de cristas parcialmente emersas nas zonas de arrebentação ou de espraiamento atual, com orientação paralela ou subparalela à linha de costa (Junior, et al 2018; Neto et al 2011 e Vieira 2005). 
Maior parte das amostras coletadas neste trabalho, ou estudadas de trabalhos anteriores, recebeu código alfanumérico com o formato geral "E - duas letras maiúsculas - número letras finais" (e.g. ERN 01 br, EFN 02 F) onde: E refere-se ao objeto central de estudo do projeto, os eolianitos; as duas letras maiúsculas indicam o local de coleta, sendo RN, para o Rio Grande do Norte, FN, para Fernando de Noronha, CE, para o Ceará, e PI, para o Piauí; o número refere-se aos pontos na ordem de realização em campo; e as letras finais, à localização no perfil ou afloramento $(\mathbf{E}$ : leste; $\mathbf{C}$ : centro; W: oeste ou à posição estratigráfica $(A, B, C, D$, E, F, G, H, I, J, de baixo para cima) ou à feição geológica (r: rizoconcreção; br: beach rock; x: feição a investigar). Outras amostras, cujo código é representado apenas pelo nome da localidade acompanhado de um número (e.g. CHAPÉU 02) foram coletadas por Rodolfo José Angulo e Maria Cristina de Souza (UFPR) durante a mesma campanha de campo no AFN, com réplica cedida a esta pesquisa de doutorado.

\subsection{Atividades de Laboratório}

\subsubsection{Granulometria}

Para a análise granulométrica, foram selecionadas e preparadas 38 amostras de eolianitos continentais, começando com elutriação por fluxo hidráulico ascendente, seguido por peneiramento a seco em intervalos de 0,5 phi, entre 1,0 e 4,0 phi, e posterior pesagem em balança de precisão de cada fração granulométrica.

\subsubsection{Proporção de bioclastos por classe granulométrica}

O conteúdo de bioclastos foi estimado visualmente, na lupa estereoscópica, em 26 amostras de eolianitos do Nordeste continental localizados nas planícies deflacionárias das principais áreas estudadas. A finalidade foi detectar possíveis concentrações preferenciais de bioclastos carbonáticos por fração granulométrica, o que poderia ajudar a explicar a formação de eolianitos nessa associação de elementos morfológicos (hipótese de trabalho levantada no item 1.1). Este estudo foi feito em frações de 0,5 phi, no intervalo de 1,0 até 3,0 phi. 


\subsubsection{Datações}

\subsubsection{Luminescência}

A preparação das oito amostras destinadas à datação por LOE seguiu os passos descritos no Quadro 4 e foi realizada no Laboratório de Espectrometria Gama e Luminescência (Legal) do Instituto de Geociências da Universidade de São Paulo (IGc-USP).

Quadro 4. Sequência de preparação de amostras para medição de dose acumulada

\begin{tabular}{|c|c|}
\hline Passo & Descrição \\
\hline 1 & $\begin{array}{c}\text { Abertura dos tubos de coleta sob luz vermelha e descarte dos } \\
\text { sedimentos das extremidades (aproximadamente } 2,5 \mathrm{~cm} \text { ), expostos à } \\
\text { luz durante a amostragem em campo }\end{array}$ \\
\hline 2 & Separação da fração $180-250 \mu$ m por peneiramento via úmida \\
\hline 3 & Tratamento com $\mathrm{H}_{2} \mathrm{O}_{2} 35 \%$ para eliminação da matéria orgânica \\
\hline 4 & Ataque com $\mathrm{HCl} 10 \%$ para eliminação de carbonatos \\
\hline 5 & $\begin{array}{c}\text { Ataque com } \mathrm{HF} 40 \% \text { por } 40 \text { minutos para eliminação de feldspatos e } \\
\text { da porção externa dos grãos de quartzo afetada pela radiação } \alpha\end{array}$ \\
\hline 6 & $\begin{array}{c}\text { Separação de feldspato (potássico) remanescente por flutuação em } \\
\text { metatungstato de lítio à densidade } 2,62 \mathrm{~g} / \mathrm{cm}^{3}\end{array}$ \\
\hline 7 & $\begin{array}{c}\text { Separação de minerais leves e pesados por flutuação em } \\
\text { metatungstato de lítio à densidade } 2,75 \mathrm{~g} / \mathrm{cm}^{3}\end{array}$ \\
\hline
\end{tabular}

O protocolo utilizado para determinar a dose de radiação recebida pelos grãos de quartzo desde sua última exposição à luz solar foi o SAR, descrito por Murray \& Wintle (2000), que consiste em comparar o sinal LOE natural ( $\mathrm{De}=$ dose equivalente) com o sinal de doses conhecidas (D1 a D4), por interpolação simples. Os sinais de luminescência foram medidos em leitores Riso TL/OSL reader model DA-20 system, equipados com fontes de radiação beta $\left({ }^{90} \mathrm{Sr} /{ }^{90} \mathrm{Y}\right)$ com taxas de dose de $0,088 \mathrm{~Gy} / \mathrm{s}$ e $0,108 \mathrm{~Gy} / \mathrm{s}$. O sinal de luminescência foi obtido pela integração dos primeiros $0,8 \mathrm{~s}$ de emissão de luz e utilizaram-se os últimos $10 \mathrm{~s}$ da curva de decaimento LOE para cálculo do background. A adequação do protocolo às amostras estudadas foi avaliada por teste de recuperação de dose (dose recovery test) para três magnitudes de dose diferentes. O protocolo SAR utilizado está resumido no Quadro 5. 
Quadro 5. Sequência de passos utilizados no protocolo SAR (Murray \& Wintle 2000) para determinar a dose acumulada das 13 amostras datadas por LOE neste estudo

\begin{tabular}{|c|c|}
\hline Passo & Tratamento \\
\hline 1 & Aplicar dose Di (para sinal natural, i $=0$ e D0 $=$ dose natural) \\
\hline 2 & Pré-aquecer a $160{ }^{\circ} \mathrm{C}$ por $10 \mathrm{~s}\left(5^{\circ} \mathrm{C} / \mathrm{s}\right)$ \\
\hline 3 & Estimular com LED azul por $40 \mathrm{~s} \mathrm{a} 125{ }^{\circ} \mathrm{C}\left(5^{\circ} \mathrm{C} / \mathrm{s}\right)$ \\
\hline 4 & Dar dose teste, $\mathrm{Dt}$ \\
\hline 5 & Aquecer a $160{ }^{\circ} \mathrm{C}\left(5^{\circ} \mathrm{C} / \mathrm{s}\right)$ \\
\hline 6 & Estimular com LED azul $90 \%$ por $40 \mathrm{~s}$ a $125^{\circ} \mathrm{C}$ \\
\hline 7 & Estimular com LED azul $90 \%$ por $40 \mathrm{~s}$ a $280{ }^{\circ} \mathrm{C}$ \\
\hline 8 & Retornar a passo 1 \\
\hline D1<D2<D3<D4, D5 $=0 \mathrm{~Gy}, \mathrm{D} 6=\mathrm{D} 1, \mathrm{D} 7=\mathrm{D} 1$ (com estimulação por infravermelho antes da estimulação LOE) \\
\hline
\end{tabular}

Cada alíquota foi submetida a três testes de validação: a) contaminação por feldspato, onde a razão entre sinais medidos com e sem estimulação por infravermelho devia ser menor que $10 \%$; b) reciclagem, para verificar se há variação de sensibilidade na amostra após ciclos de irradiação, aquecimento e fotoesvaziamento (onde a razão entre os sinais das doses D6 e D1 deve ser menor que 10\%); e c) recuperação, no qual o sinal correspondente à dose zero deve ser no máximo 5\% do sinal natural. A dose equivalente das amostras foi calculada pelo modelo estatístico da idade central (Central Age Model - CAM), proposto por Galbraith et al. (1999), revisto por Roberts et al. (2000). A dose equivalente para amostras saturadas (em que não foi possível fazer a interpolação das doses administradas) foi calculada a partir do ajuste da curva exponencial que descreve a relação entre o sinal de luminescência e a dose (curva dose-resposta OSL), segundo a Equação 4.1 (fórmula da dose equivalente de amostras saturadas).

\section{Equação 4.1 $\quad \mathrm{ABi}=[\mathrm{A} /(\mathrm{A}+\mathrm{B})] \times 100$}

As medidas de taxa de dose anual de radiação por espectrometria gama foram feitas por detector de germânio de alta pureza (HPGe), após pesagem do material úmido e seco (para determinação da umidade da amostra), desfragmentação e acondicionamento em recipiente plástico selado e armazenado por no mínimo 28 dias (para que os radionuclídeos de $\mathrm{Rn}$ entrassem em equilíbrio). Os valores de ${ }^{238} \mathrm{U}$ (ppm), ${ }^{232} \mathrm{Th}(\mathrm{ppm}) \mathrm{e}{ }^{40} \mathrm{~K}(\%)$ foram convertidos em taxa de dose anual (mGy/ano) pela fatoração de Guérin et al. (2011). Já a contribuição da radiação cósmica nestas taxas de dose anuais foi calculada segundo Prescott \& Hutton (1994), 
usando informações de coordenadas geográficas, altitude, profundidade de coleta e densidade de cada amostra, com erro total da dose anual calculado de acordo com a lei gaussiana de propagação de erro, conforme os procedimentos de rotina do laboratório.

Considerando o efeito de absorção da radiação ionizante exercida pelo carbonato, Mauz \& Hoffmann (2014) sugerem um protocolo para corrigir alterações químicas pós-deposicionais em idades LOE obtidas em amostras ricas neste material; porém, destacam que quando formado na diagênese precoce, o cimento carbonático não altera consideravelmente o resultado final; sendo este o caso do cimento presente nos eolianitos de RN, PI e CE (Espinel-Arias 2015, Espinel-Arias et al 2015, Cagliarani et al. 2015 e esta tese), estas correções não foram aqui implementadas.

\subsubsection{2 ${ }^{14} \mathrm{C}$}

Datações por ${ }^{14} \mathrm{C}$ foram feitas em 32 amostras, 22 do $\mathrm{AFN}$ e 10 do RN, em 15 das quais se separaram alíquotas pareadas de cimentos carbonáticos e bioclastos (principalmente algas indeterminadas, provavelmente vermelhas em vista da identificação petrográfica feita em paralelo); tanto as algas como os cimentos foram analisados com difratometria de Raios-X (DRX), para conhecer sua composição mineralógica (calcita), o que ajudou a deduzir que as algas eram rodofíceas (já que algas verdes são aragoníticas). A finalidade de datar bioclastos e cimento foi obter o que seriam, em tese, as idades máxima e mínima da deposição, respectivamente. A premissa foi a de que o cimento é formado por dissolução e reprecipitação do carbonato dos próprios bioclastos, porém rejuvenescido por carbono da matéria orgânica de solos ou paleossolos estabelecidos sobre o depósito. Na datação de bioclastos e cimento de amostras de eolianito do CE e do PI (Espinel-Arias 2015), esta premissa foi reforçada pelos resultados obtidos, nos quais o cimento se mostrou sistematicamente mais novo que os bioclastos de mesma amostra.

A separação das amostras foi feita à lupa estereoscópica, sem contato manual, com uso de pinças e instrumentos odontológicos, no Laboratório de Petrografia Sedimentar do IGc-USP (Labpetro). Em uma amostra (EFN 06), em que os bioclastos apresentavam maior tamanho (acima de $1 \mathrm{~mm}$ ), o cimento foi extraído com a ajuda de equipamento de micropulverizador com controle óptico (Micromill), no Laboratório de Sistemas Cársticos do IGc/USP. As alíquotas assim separadas foram enviadas ao Poznan Radiocarbon Laboratory da Foundation of the 
Adam Mickiewicz University, em Poznań, Polônia, onde se realizaram as datações por ${ }^{14} \mathrm{C}$ com espectrometria de massa acelerada (AMS). As massas submetidas à datação variaram entre 0,5 e $5 \mathrm{mg}$. As idades de radiocarbono foram normalizadas para um $\delta^{13} \mathrm{C}$ de $-25 \%$ VPDB e

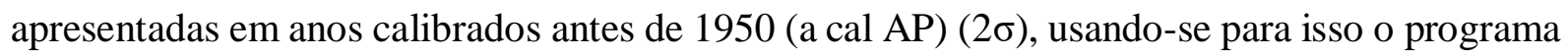
CALIB 6.0 e a curva Intcal09 (Reimer et al. 2009).

\subsubsection{Idades citadas e representadas}

As idades LOE e ${ }^{14} \mathrm{C}$ citadas ao longo do texto referem-se aos valores máximos e mínimos, considerada a margem de erro, e os valores representados nos gráficos de resultados, quando não mostrada a barra de erro, correspondem aos valores medianos do intervalo.

\subsubsection{Petrografia}

Confeccionaram-se 66 lâminas delgadas, das quais 55 são de eolianitos e 11 pertencem a fácies a eles associadas; as amostras foram impregnadas a vácuo com resina colorida, a qual visa à distinção entre poros verdadeiros e poros artificiais (induzidos durante a laminação). A porosidade foi avaliada por estimativa visual ao microscópio com aumento de 100x e 200x; o desvio padrão da distribuição granulométrica foi estimado visualmente, na escala phi de Krumbein (1938), segundo a carta de Pettijohn et al. (1972) e, com base nele, determinou-se o grau de seleção. A esfericidade e arredondamento foram classificados de acordo com a carta de Powers (1953), o índice de fechamento do empacotamento (IP) foi determinado segundo a fórmula de Kahn (1956), e a porosidade secundária descrita conforme Choquette e Pray (1970) e Schmidt et al. (1977). Para a classificação dos calcários clásticos de acordo com o percentual de arcabouço, matriz e cimento, e com o tamanho e a tipologia de grãos, utilizaram-se de modo combinado as classificações de Folk $(1959,1962)$ e Dunham $(1962)$, com adaptações para a presença dominante de terrígenos (Dott 1964), quando necessário (caso das amostras do RN).

A análise petrográfica de depósitos e rochas carbonáticos ao microscópio de luz polarizada foi aplicada não só aos eolianitos, mas ao material de fácies subaquosas que possam ter atuado como fontes de material biogênico (e.g. recifes, beach rocks), onde acessíveis para amostragem. Utilizou-se o conceitos de microfácies, definido, com base em Flügel (2004), como as características composicionais, de trama e de textura dos componentes deposicionais (arcabouço e matriz) de uma porção de uma fácies, pequena o suficiente para ser examinada 
em seções delgadas; utilizou-se também o conceito de petrofácies, que, segundo Gesicki (2007), é um agrupamento de rochas sedimentares que possuam atributos similares de mineralogia, textura e petrotrama, resultantes da combinação e sobreposição de aspectos deposicionais por aspectos diagenéticos, tais como tipos de cimento. A análise petrográfica teve as seguintes finalidades: complementar a caracterização de fácies deposicionais e possibilitar seu refinamento, via subdivisão em petrofácies; permitir inferências sobre as áreas fontes carbonáticas, com base na identificação de microfósseis de hábito conhecido quanto a salinidade, limpidez e profundidade das águas; caracterizar a composição e história diagenética de diferentes gerações de paleodunas com base em análise de petrofácies; buscar identificar sucessões de microfácies que indiquem mudanças na natureza do aporte sedimentar, e, por extensão, de paleogeografia, linha de costa ou agente deposicional.

Durante a análise petrográfica, procurou-se quantificar as feições descritas, tais como tipos de grãos do arcabouço e tipos de tramas e texturas de cimentos, tendo em vista a apresentação gráfico-estatística dos dados; para a tipologia de grãos intrabacinais, seguiu-se a nomenclatura de Folk $(1959,1962)$, com o uso adicional do termo peloide, definido nesta tese no seu sentido descritivo, isto é, agregado maciço de carbonato micrítico (McKee \& Gutschick 1969). No caso específico dos eolianitos estudados, os peloides identificados são de caráter clástico, arredondados, esféricos ou semiesféricos, e suspeita-se corresponderem, pelo menos em parte, a algas vermelhas que perderam sua estrutura interna diagnóstica por conta de micritização eodiagenética ou outra forma de alteração. Em vista desta possível origem, calculou-se a razão PeAl entre peloides (Pe) e algas vermelhas (Al) com base na Equação 4.2, com o propósito de testar a presença de alguma tendência que indique a conversão das algas vermelhas em peloides.

\section{Equação 4.2 $\quad \mathrm{PeAl}=\mathrm{Pe} /(\mathrm{Pe}+\mathrm{Al}) * 100$}

\subsubsection{Microscopia eletrônica de varredura}

As análises de microscopia eletrônica de varredura (MEV) e de análise química por EED (espectroscopia por dispersão de energia) foram feitas no equipamento LEO 440I do Departamento de Geologia Sedimentar e Ambiental do Instituto de Geociências da USP (Labmev), O principal objetivo foi entender porque algumas datações ${ }^{14} \mathrm{C}$ de cimento apresentaram idades mais velhas do que os bioclastos, na maioria das amostras do AFN; para 
isso, foram analisadas duas amostras de rocha bruta, três seções delgadas e duas de grãos de bioclastos previamente separados para a datação.

Cada amostra, após colada no suporte $(s t u b)$ metálico, foi previamente recoberta por carbono, cuja finalidade é permitir o escoamento dos elétrons. As análises incluíram a captura de imagens de elétrons secundários (SE), que refletem a microtopografia e, portanto, informam sobre a morfologia dos grãos e do cimento, e de elétrons retroespalhados (BSE), as quais refletem o peso atômico médio da porção superficial das amostras.

\subsubsection{Dosagem de carbonato}

O teor em massa total de carbonato de cálcio das 81 amostras foi quantificado pelo método de ataque com $\mathrm{HCl} 10 \%$ a quente, conforme procedimentos descritos por Melo et al. (2004). Dados sobre teor de carbonato foram obtidos também da análise petrográfica via óptica das amostras consolidadas (itens 4.3.4 e 5.7), neste caso com distinção entre bioclastos e cimento. A principal finalidade da quantificação de carbonato foi verificar a influência da composição original do sedimento da área fonte na formação e composição dos eolianitos.

\subsubsection{Separação e análise microscópica de minerais pesados}

A partir das análises granulométricas, determinou-se que a moda da fração areia, nos sedimentos estudados, se situa na classe areia fina, entre 3 e 2 phi, da escala de Wentworth (1922) - Krumbein (1938). Com base neste resultado, e considerando que a maior massa e variedade de minerais pesados transparentes ocorre até um phi abaixo (mais fino) da moda granulométrica do quartzo (Rittenhouse 1943), a classe granulométrica escolhida para a análise de minerais leves e pesados foi a areia muito fina, situada entre 4 e 3 phi.

A pré-preparação das 60 amostras (38 continentais e 22 insulares) destinadas à análise de minerais pesados foi realizada submetendo-se a classe areia muito fina à separação quanto a densidade, por flutuação e afundamento em bromofórmio $\left(\mathrm{CHBr}_{3}, \mathrm{~d} \sim 2,83\right)$, empregando-se álcool como solvente. Da fração de grãos afundados, separaram-se os minerais magnéticos, por atração ao ímã de mão; a fração magnética foi arquivada e a não magnética encaminhada para a confecção de lâminas de imersão, em montagem permanente, utilizando-se bálsamo do Canadá natural como meio. 
As assembleias de minerais pesados de cada amostra foram quantificadas em valores percentuais, por contagem de no mínimo 300 grãos transparentes não micáceos, ao longo de faixas horizontais contínuas e completas, ao microscópio petrográficos; o reconhecimento optico de minerais por petrografia convencional segue a recomendação de Mange \& Maurer (1992), segundo a qual a especificação do mineral determinado, dentro de um grupo isoestrutural (como os clinopiroxênios: augita, augita-Ti e diospídio), só deve ser feita caso se disponha de métodos de determinação mais conclusivos; assim, a suspeita de determinação mineral, com base apenas em características ópticas (cor, relevo etc.) insuficientes para sua determinação segura, deve ser feita na "forma adjetivada"; por exemplo, um clinopiroxênio de cor mais rosa será classificada como augita-Ti, e se for mais esverdeada será identificada só como augita, uma vez que a variação da cor natural do mineral ao estudo petrográficos pode ser influenciada por fatores como espessura da lâmina, luminosidade etc. Grãos minerais demasiado alterados para sua devida identificação óptica foram contabilizados como alteritas (van Andel 1955). A quantificação de opacos e semi-opacos (e.g. agregados de óxi-hidróxidos de titânio ou leucoxênio, e de ferro, ou limonita) foi realizada até a totalização de 100 grãos.

A finalidade da análise quantitativa de minerais pesados de eolianitos de diferentes idades e regiões foi detectar mudanças composicionais no tempo e no espaço com significado potencial quanto a área-fonte, seleção aerodinâmica e/ou dissolução pós-deposicional. Essas mudanças constituem indícios potenciais de rumos de transporte dominante e ou de separação entre gerações de eolianitos.

Índices de pares de minerais pesados $\mathrm{ABi}$, nos moldes dos propostos por Morton \& Hallsworth (1999) foram utilizados para avaliar três fatores controladores fundamentais da assembleia mineralógica: proveniência, dissolução pós-deposicional e seleção "hidráulica" (neste caso, hidro e/ou aerodinâmica). O cálculo do índice é feito conforme a Equação 4.3, onde A e B são as concentrações de contagem de dois minerais pesados de comportamento similar quanto a dois dos três fatores controladores, mas contrastantes quanto ao terceiro.

$$
\text { Equação 4.3 } \mathrm{ABi}=[\mathrm{A} /(\mathrm{A}+\mathrm{B})] \times 100
$$

Para as amostras continentais, o índice ZR (zircão-rutilo) foi tentativamente utilizado como indicador de proveniência, como proposto por Morton \& Hallsworth (1994), uma vez que ambos os minerais têm estabilidade química e densidade similares, mas fontes distintas. Quanto à seleção hidráulica, optou-se pelo índice ZT (zircão-turmalina), que é um par mineral de mesma estabilidade e fonte, mas que envolve diferentes densidades (4,6 no zircão versus 3,2 na 
turmalina). Para dissolução pós deposicional, foram testados dois índices, TH (turmalinahornblenda) e EsEp (estaurolita-epídoto), já que hornblenda e epídoto têm estabilidade química menor em relação a turmalina e estaurolita, respectivamente.

Já para as amostras insulares, foram analisadas só as amostras dos afloramentos com altitudes acima de $10 \mathrm{~m}$. Utilizou-se o índice TiAl (titanita-allanita) como indicador de proveniência, na premissa de que estes dois minerais apresentam estabilidade química e densidade parecidas, mas rochas fontes diferentes. Para seleção hidráulica, foi usado o índice $\mathrm{HbAu}$ (hornblenda-augita), por se tratar de dois minerais de estabilidade e fontes parecidas, mas densidades diferentes; e a dissolução pós-deposicional foi avaliada através dos índices TiOl titanita-olivina) e TiAu (titanita-augita), já que se trata de minerais com densidades e fontes parecidas, mas estabilidades distintas (titanita mais estável que olivina e augita).

\subsubsection{Identificação de bioclastos e moluscos}

Os bioclastos observados nos eolianitos, tanto na lupa como no microscópio de luz polarizada, foram conferidos no Guia Petrográfico dos Carbonatos do Brasil (Dias-Brito 2017), e para o reconhecimento e determinação dos moluscos presentes nas fácies associadas aos eolianitos, foi consultado o biólogo PhD Rafael Casati.

\subsection{Tratamento Gráfico-Estatístico dos Dados}

\subsubsection{Resultados de campo}

Histogramas circulares (rosas de frequências ou rosas de areia) foram utilizados para representar medidas de rumo de mergulho de superfícies de truncamento e de planos de estratificação cruzada por área. Eles foram obtidos através do emprego do programa Stereonet, o qual permitiu calcular o vetor médio e intervalo angular de confiança para uma probabilidade de $95 \%$. A finalidade foi identificar o padrão da distribuição (unimodal, bimodal, bipolar etc) e a orientação das modas. Na subdivisão interna dos histogramas em circunferências concêntricas, representativas das frequências de ocorrência de cada classe de azimutes, utilizaram-se intervalos de 5\%. A circunferência externa equivale a 20\%. Calculou-se também o ângulo médio de mergulho. De posse dos dados de padrão de distribuição e ângulos de mergulho, e de informações sobre o vento efetivo por região, tentou-se inferir a fácies ou elemento morfológico correspondente a cada conjunto de medidas. 


\subsubsection{Resultados analíticos laboratoriais}

Ao término das análises laboratoriais de granulometria, quantificação de carbonato, mineralogia e petrografia óptica, foram executados balanços de massa (nos casos da granulometria e do teor de carbonato por ataque ácido) ou de volume (nos demais casos), em valores de distribuição porcentual.

Dois tipos de testes gráfico-estatísticos foram aplicados aos resultados; o primeiro foi a construção nos softwares Origin 8.0 e Excel de diagramas de dispersão desses resultados combinados dois a dois entre si ou em função de outros critérios quantificáveis como idade e distância à costa. $\mathrm{O}$ objetivo foi identificar nuvens de pontos com possível significado faciológico ou cronológico e avaliar a correlação linear (r) entre as variáveis, com nível de significância estatística (p ou erro I), calculado através do teste t unicaudal de Student, sendo que quanto mais baixo o valor de $\mathrm{p}$, maior a significância. O segundo foi a caracterização de agrupamentos de amostras, estabelecidos quanto aos mesmos critérios, através da construção de diagramas em caixa (boxplot). Neste tipo de gráfico (Fig. 4.1), a caixa representa o intervalo interquartis e a linha horizontal no seu interior, a mediana; as linhas verticais (bigodes) unem o valor máximo e mínimo observados, dentro de 1,5 vez o intervalo interquartil; e os dados anômalos (outliers), em asterisco, representam valores observados fora dos bigodes. Para a confecção destes diagramas, foram usados os softwares Minitab 17 e Origin 8.0.

Tanto nos gráficos de dispersão como nos boxplots, foram utilizadas abreviaturas e/ou eliminados os prefixos EPI, ERN e EFN das amostras para facilitar suas leituras.

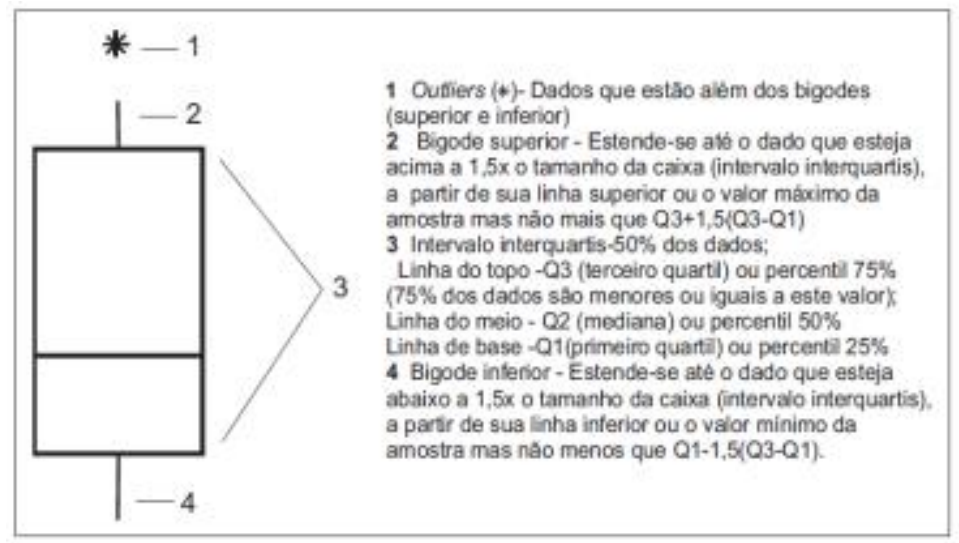

Fig. 4.1. Esquema de um diagrama em caixa (boxplot), ferramenta de estatística descritiva utilizado neste trabalho (extraído de Menezes 2009). 


\section{RESULTADOS}

Neste tópico, são apresentados os principais resultados obtidos e as relações entre os diferentes tipos de dados. Incluem-se análises na escala tanto macroscópica (morfologia e fácies deposicionais), quanto microscópica (petrografia, MEV e minerais pesados), bem como datações.

\subsection{Mapeamento e Aspectos Morfológicos dos Sistemas Eólicos em Estudo}

Os principais elementos morfológicos eólicos ativos encontrados nas áreas de estudo (Figs. 5.1 e 5.2) foram: no PI, CE e RN, duna frontal, planície interdunas, duna parabólica, rastro linear residual, retrocordão, nebkha, barcana e cadeia barcanoide; e no AFN, duna frontal, nebkha, duna parabólica e blowout. Lobos deposicionais de frente de campo de dunas ocorrem na costa continental, mas são pouco proeminentes. 

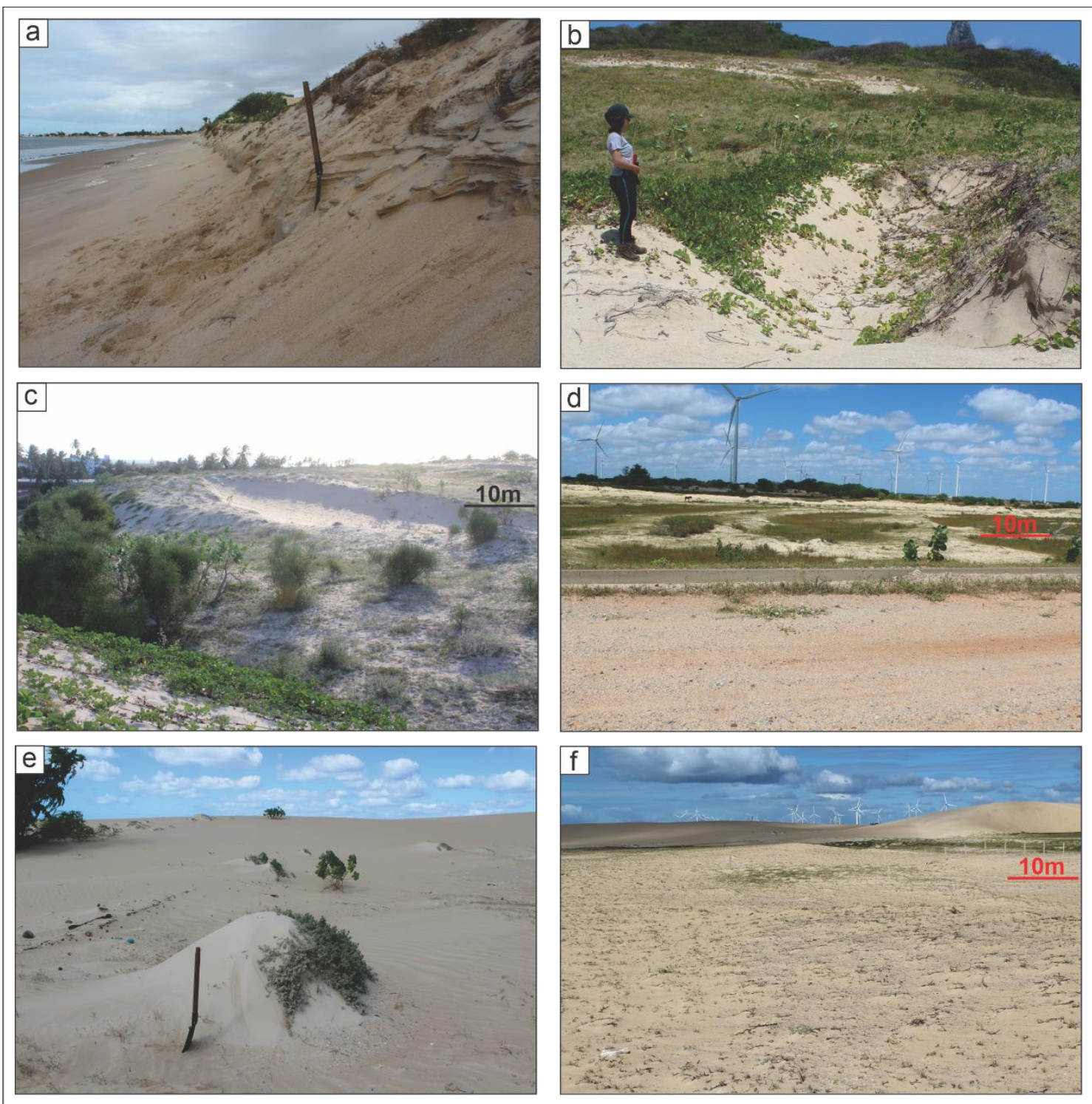

Fig. 5.1. Elementos morfológicos com influência morfodinâmica da vegetação observados nas áreas de estudo: a. duna frontal, em Praia do Marco, RN; b. blowout; em Caieira, AFN; c. duna parabólica, em São Bento do Norte, RN; d. retrocordões, em meio a planície deflacionária, em Santa Isabel, RN; e. nebkha e f. planície interdunas, com retrocordões ao fundo, em Santa Isabel, RN. 


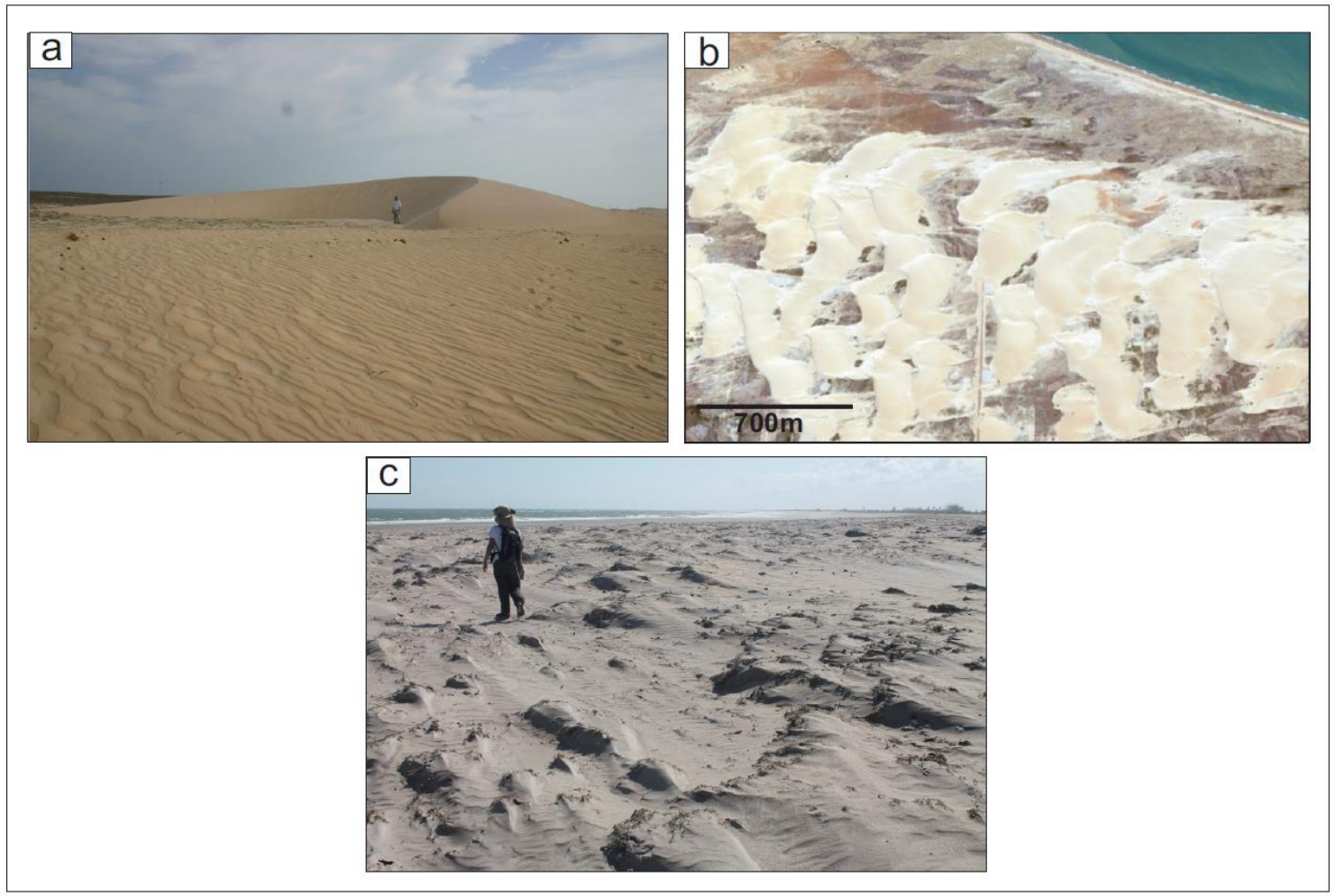

Fig. 5.2. Elementos morfológicos de campo de dunas, sem influência morfodinâmica da vegetação (a e b), e de lençol de areia (c), ilustrados por exemplos da costa do PI e RN. a. duna barcana, em Luís Correia, PI; b. cadeias barcanoides, em Guajiru, RN (imagem de satélite Google

Earth, 2017); c. campo de nebkhas compondo lençol de areia, na praia de Carnaubinha, PI.

\subsubsection{Morfologia dos sistemas eólicos e dos eolianitos do Rio Grande do Norte}

Os eolianitos estudados no RN distribuem-se em quatro áreas geográficas, de $\mathrm{W}$ para E: Três Irmãos, Guajiru, Enxu Queimado e Praia do Marco (Fig. 5.3). As praias adjacentes apresentam morfodinâmica costeira intermediária, tendendo a reflexiva em Três Irmãos e Praia do Marco, e a dissipativa, em Guajiru e Enxu Queimado. As quatro áreas têm em comum também a presença de sistemas eólicos ativos, em que se destacam a orientação de ENE para WSW do vento efetivo e do avanço dos campos de dunas e a orientação dos arcos praiais em ângulo baixo (no máximo $30^{\circ}$ ) com a direção do vento. A associação de elementos praia-duna (sensu Giannini et al. 2014, cf. item 3.2) tem extensão no rumo do vento que varia entre $100 \mathrm{~m}$ e $300 \mathrm{~m}$, com dunas frontais incipientes de até $5 \mathrm{~m}$ de altura ou lençóis de areia. A associação de elementos planície deflacionária apresenta extensão variável entre 1,2 km e cerca de 4 km, incluindo rastros lineares, retrocordões e, na área de Guajiru, uma duna parabólica. A associação de elementos campo de dunas livres, com até 4,5 km de largura, é dominada por 
dunas barcanas e cadeias barcanoides. Lobos deposicionais pouco alongados (até cerca de 200 m) podem ser observados em sua porção distal em Guajiru e Três Irmãos.

A linha de costa em Três Irmãos, cuja orientação geral é E-W, difere da dos demais setores por ser constituída por três arcos praiais pequenos (menos de $1 \mathrm{~km}$ ), todos de orientação dominante WNW. No sistema eólico ativo, a associação praia-duna é formada por dunas frontais e por lençóis de areia, estes com até 300m de extensão na direção do vento. O ângulo entre a direção do vento efetivo e a linha de costa é cerca de $25^{\circ}$. Embora pequeno, este ângulo é suficiente para que os campos de dunas ativos, com até $2 \mathrm{~km}$ de comprimento, avancem por distância relativamente grande ao interior, favorecendo a criação, à retaguarda, das maiores planícies deflacionárias dentre as quatro áreas, com até $5 \mathrm{~km}$.

A área de Guajiru, com arcos praiais alongados segundo WNW, apresenta associação praia-duna com até $300 \mathrm{~m}$ de comprimento na direção do vento e ângulo de cerca de $22^{\circ}$ entre o vento efetivo e a linha de costa. Em virtude deste ângulo mais baixo, a areia eólica passa consequentemente a distribuir-se numa distância menor (cerca de $2 \mathrm{~km}$ ) no rumo do vento e as feições francamente deposicionais tornam-se mais importantes em relação às mais deflacionárias em comparação com a área de Três Irmãos. Assim, o campo de dunas atinge maior extensão $(4,5 \mathrm{~km})$, em comparação com as outras três áreas estudadas.

A terceira área, Enxu Queimado, formada por um único arco praial extenso orientado segundo WNW, apresenta ângulo ainda menor $\left(16^{\circ}\right)$ entre a direção do vento efetivo e a praia, o que restringe a zona deflacionária para menos de 1,5 km. Em vista disso, a associação praiaduna, cuja extensão é de até $100 \mathrm{~m}$, chega localmente a passar diretamente para a associação campo de dunas, esta com até 3,6 km de comprimento. Continua, desse modo, o domínio das feições mais deposicionais sobre mais feições deflacionárias, já observado em Guajiru.

A praia do Marco apresenta linha de costa em forma de " $u$ " suave, aberto para N, com ruínas de construções que sugerem erosão atual, a qual no entanto é pouco perceptível nas imagens de satélite disponíveis no Google Earth; na análise do sistema eólico ativo, observase que a praia que atua como fonte se encontra a aproximadamente $2 \mathrm{~km}$ a $\mathrm{E}$, formando um ângulo de $30^{\circ}$ com a direção do vento efetivo, o que favorece planície deflacionária relativamente extensa, de até $4 \mathrm{~km}$; já as feições deposicionais apresentam extensões de $200 \mathrm{~m}$ na associação praia-duna e de menos de $3 \mathrm{~km}$ no campo de dunas transgressivos, o que demonstra o retorno do domínio das feições deflacionárias observado em Três Irmãos (Fig. $5.3)$. 


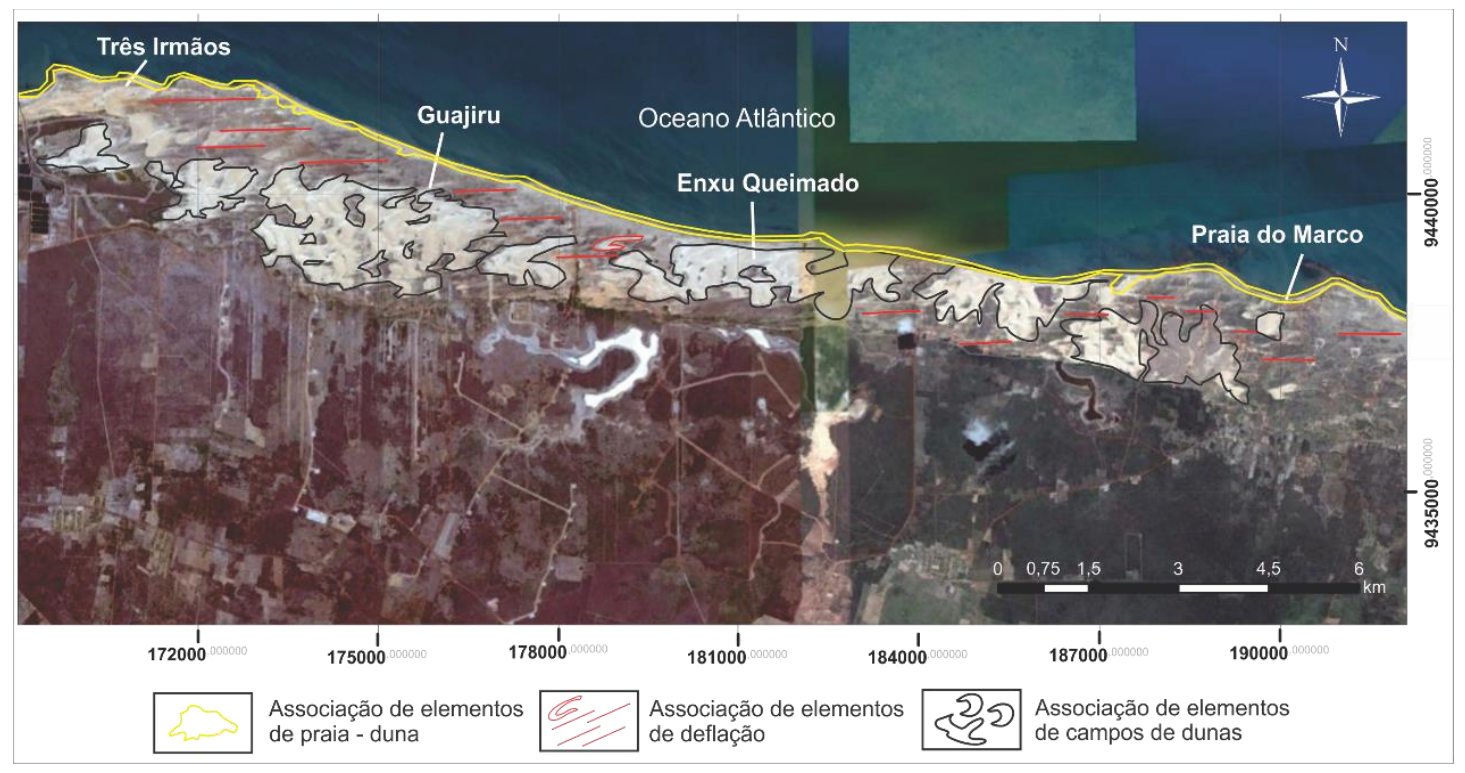

Fig. 5.3. Áreas de estudo no RN, com destaque para o sistema eólico ativo e suas associações de elementos morfológicos.

Os corpos de eolianitos afloram de diferentes formas e em distintas posições em relação ao sistema eólico ativo. Em Três Irmãos, eles ocorrem principalmente junto à praia, na forma de quatro falésias subverticais (Fig. 5.4a) de até $10 \mathrm{~m}$ de altura por mais de $100 \mathrm{~m}$ de extensão cada uma. As três falésias mais proeminentes dão nome à área. Em Guajiru e Enxu Queimado, e também ao interior das falésias em Três Irmãos, os eolianitos foram encontrados em meio às zonas deflacionárias, na forma de cordões com cristas descontínuas, com 0,4 a 3 m de altura, cuja orientação é paralela à direção do vento efetivo (ESE-WNW) e aos rastros lineares residuais dos campos de dunas ativos, pelas quais são parcialmente cobertos (Fig.5.4b). A orientação dos corpos de eolianito encobertos pode ser rastreada, ao longo da zona de deflação, pela distribuição de rizoconcreções in situ, aflorantes em meio à areia do sistema ativo. Mais resistentes à erosão que a rocha onde se encontram, estas rizoconcreções concentram-se ao longo de faixas estreitas de areia (menos de 100m de largura) orientadas grosso modo segundo E-W. Já na Praia do Marco, o eolianito, menos consolidado que nas demais áreas, aflora analogamente em falésias costeiras de cerca de $4 \mathrm{~m}$ de altura, as quais se encontram parcialmente cobertas pela duna frontal atual em rampa ou cordão (Fig. 5.4c). 


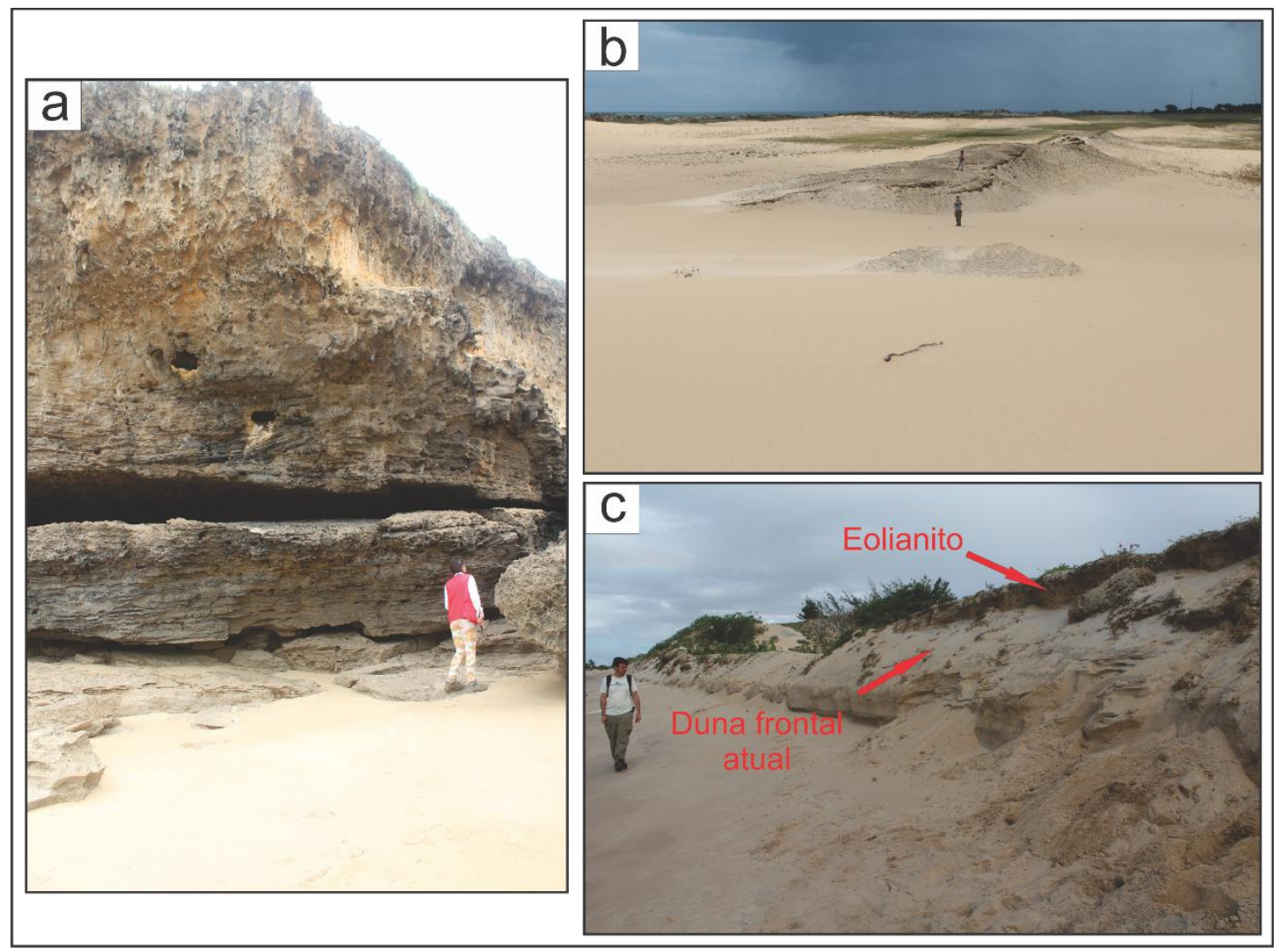

Fig. 5.4. Tipos de afloramentos de eolianitos na costa do RN: a. formando falésia costeira, em Três Irmãos; b. em corpo alongado com orientação E-W, em Enxu Queimado; e c. em falésia costeira, sob dunas frontais em rampa e cordão, na Praia do Marco.

\subsubsection{Morfologia dos eolianitos e os sistemas eólicos de Fernando de Noronha}

A morfologia do AFN é condicionada pelo próprio edifício vulcânico, e feições de erosão superpostas, e pelos recifes e/ou bancos bioclásticos de corais e algas vermelhas que se desenvolvem na orla costeira. Depósitos sedimentares eólicos, consolidados (eolianitos) ou não, ocorrem sobre estes dois tipos de rochas e alcançam altitudes de até $30 \mathrm{~m}$. Maior parte deles encontra-se embutida em reentrâncias restritas (menos de $0,5 \mathrm{~km}^{2}$ ) dos corpos ígneos, junto à costa.

Basicamente, o arquipélago apresenta dois tipos de exposições de eolianitos, aqui designados baixos e altos. Os baixos (Figs. 5.5 e 5.6), encontrados nas ilhas localizadas no norte do arquipélago, correspondem a afloramentos próximos (menos de $10 \mathrm{~m}$ acima) do nível do mar atual, dois deles com acesso possível, mas somente um, localizado na Ilha Rasa, com estratificações cruzadas aptas para tomada de medidas de atitude. As exposições deste tipo observam-se como relictos sedimentares (e.g. Pedra da Bigorna), que possivelmente resistiram ao intemperismo e à abrasão marinha associada às ultimas transgressões (Fig. 5.6). 


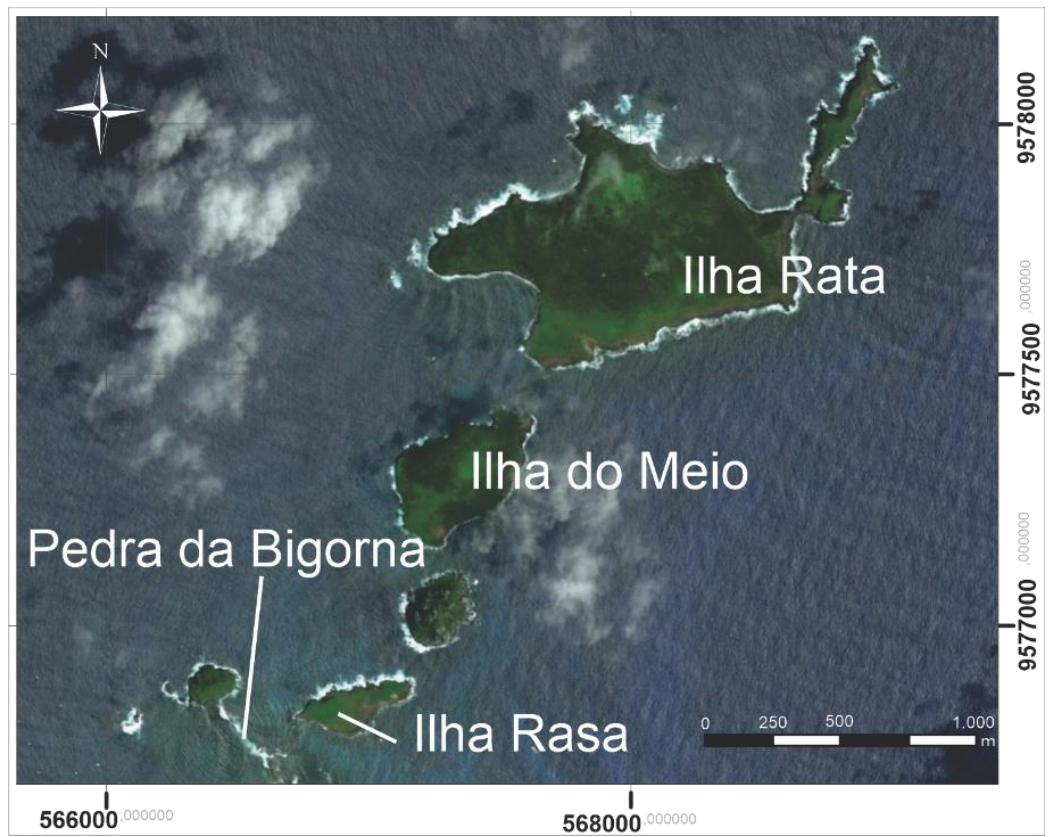

Fig. 5.5. Localização dos afloramentos baixos de eolianitos no AFN, concentrados nas ilhas da parte norte do arquipélago.

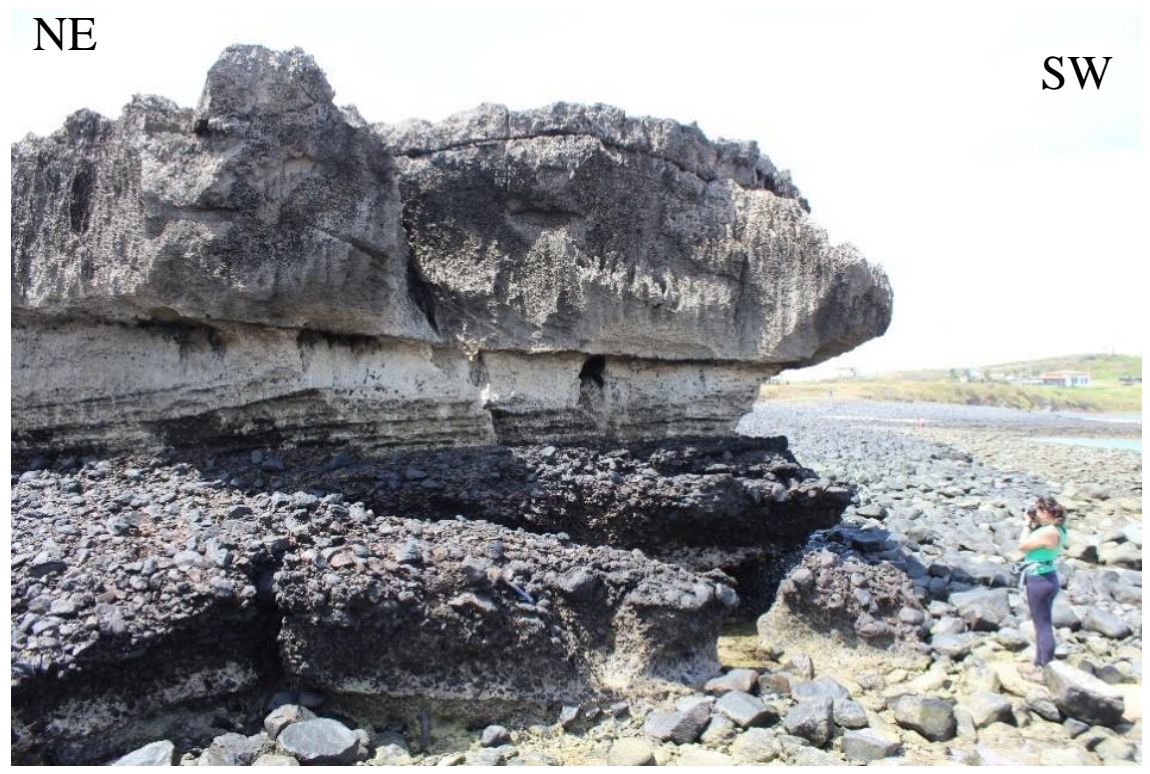

Fig. 5.6. Afloramento baixo de eolianito, na Pedra da Bigorna, AFN, na forma de relicto sedimentar de abrasão marinha, menos de $10 \mathrm{~m}$ acima do nível do mar atual.

A exposição dos eolianitos altos (Figs. 5.7 e 5.8) ocorre em quatro pontos da porção leste-sudeste da ilha principal: Ponta das Caracas, Forte de São Joaquim, Saco de Atalaia e Enseada da Caieira, onde os depósitos eólicos cavalgaram o embasamento vulcânico a cotas de até $30 \mathrm{~m}$ acima do nível do mar atual, com afloramentos cuja espessura varia de $7 \mathrm{~m}$, no setor nordeste da região de Enseada da Caieira, a até 30 m, na região de Saco de Atalaia (Fig. 5.8). 
Correspondem portanto, no que se refere às relações com o embasamento, a paleodunas cavalgantes (climbing dunes) e empoleiradas ou de topo de escarpa (perched dunes ou cliff top dunes) (sensu Semeniuk \& Johnson, 1985; Short 1988), como já reconhecido por Angulo et al. (2013a).

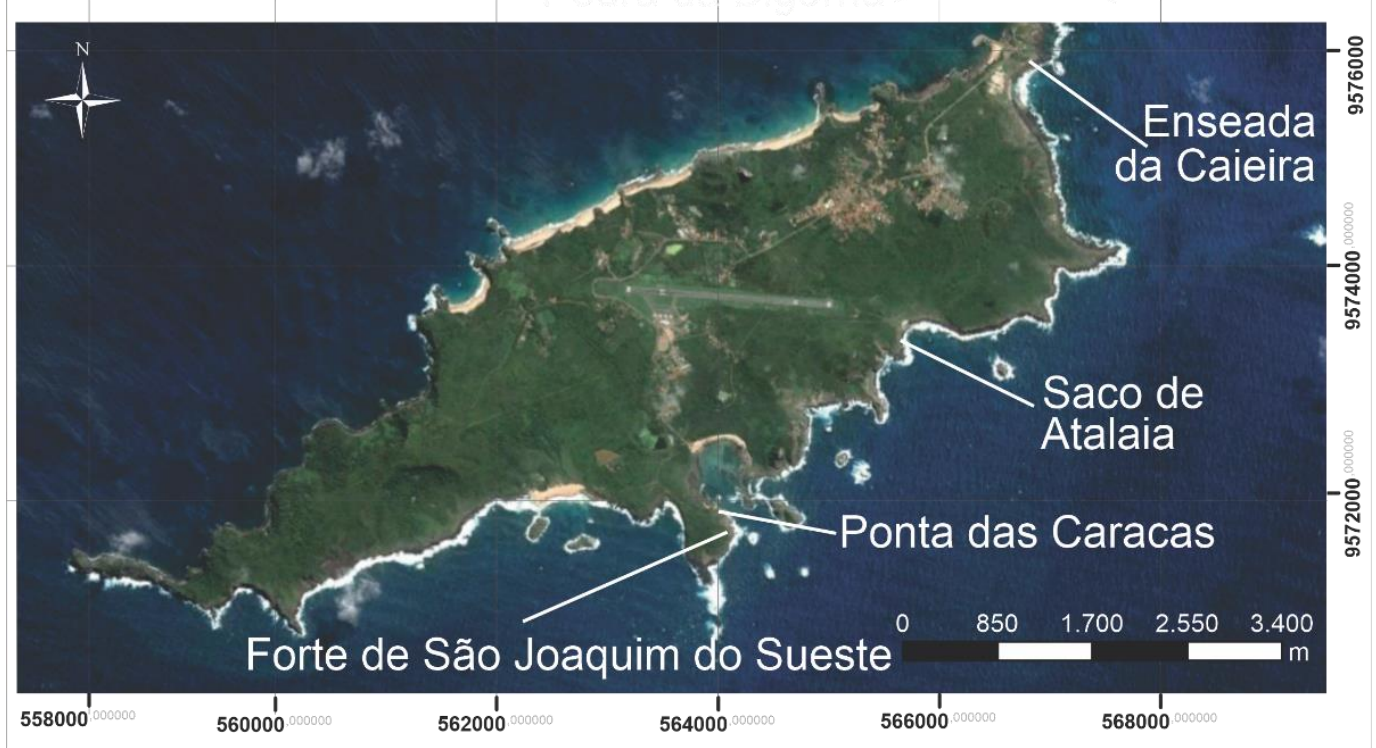

Fig. 5.7. Localização dos afloramentos altos de eolianitos, presentes na região leste-sudeste da ilha principal.

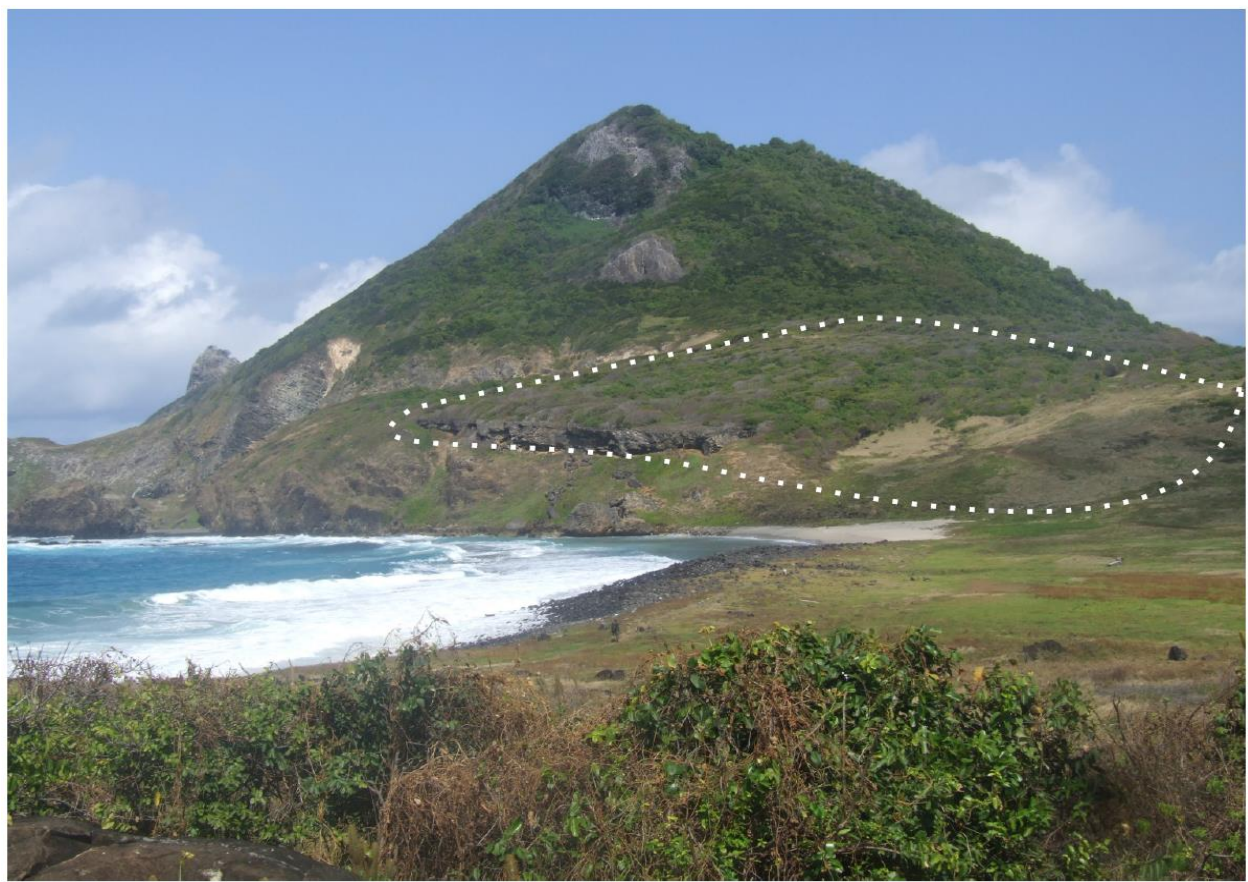

Fig. 5.8. Exemplo de afloramento alto de eolianito em Atalaia, AFN, delimitado, em pontilhado branco, sobre o embasamento de rocha piroclástico-vulcânica. Ele atinge altitude da ordem de $30 \mathrm{~m}$. 
Depósitos eólicos inconsolidados encontram-se junto às praias da Enseada da Caieira e do Saco de Atalaia. A praia da Enseada da Caieira (Figs. 5.9a, b) é intermediária, contendo cascalho (seixo a matacão) de rocha ígnea na berma e pós-praia, com discreta seleção transversal (concentração de grossos na parte mais alta da pós-praia), e areia na antepraia (Fig.5.9c). A berma é nítida na extremidade nordeste da praia; rumo SW, porém, onde areias médias a finas com minerais pesados escuros passam a ocorrer no pós-praia inferior (Fig.5.9c), a berma é substituída por depósitos eólicos com cerca de $1500 \mathrm{~m}^{2}$ de área total. Estes depósitos chegavam aparentemente a formar um pequeno campo de dunas voltado para NW (Fig. 5.9a), ativo no meio do século passado (Almeida 1955), mas hoje em avançado processo de estabilização pela vegetação. De acordo com Almeida (1955), o transporte eólico de areia por sobre a península rumo à praia arenosa de Santo Antônio, hoje conhecida como Praia do Porto, foi interrompido pela urbanização (Angulo et al. 2013a). A atividade atual do sistema eólico permanece na porção barlavento do antigo campo de dunas (ponto EFN 08), onde cavalga o terreno que tem mergulho para o mar (Fig. 5.9d); ali, o sistema é formado por nebkhas, passando a blowouts (Fig. 5.9e) e pequenas dunas parabólicas coalescidos.

A praia de Saco de Atalaia (Fig. 5.10) apresenta uma piscina natural em sua porção sudoeste, devido a existência de recife na zona submersa a aproximadamente $20 \mathrm{~m}$ da linha de maré média. Esta praia é constituída por cascalho (blocos e seixos de rocha vulcânica) na fácies de espraiamento e por areia carbonática média a grossa na fácies da berma (Figs. 5.10 b e c); seguindo para o interior (W), observam-se prováveis dunas fixadas por vegetação, aparentemente orientadas com rumo NW, com presença de rastro linear residual segundo essa direção (Fig. 5.10d). 

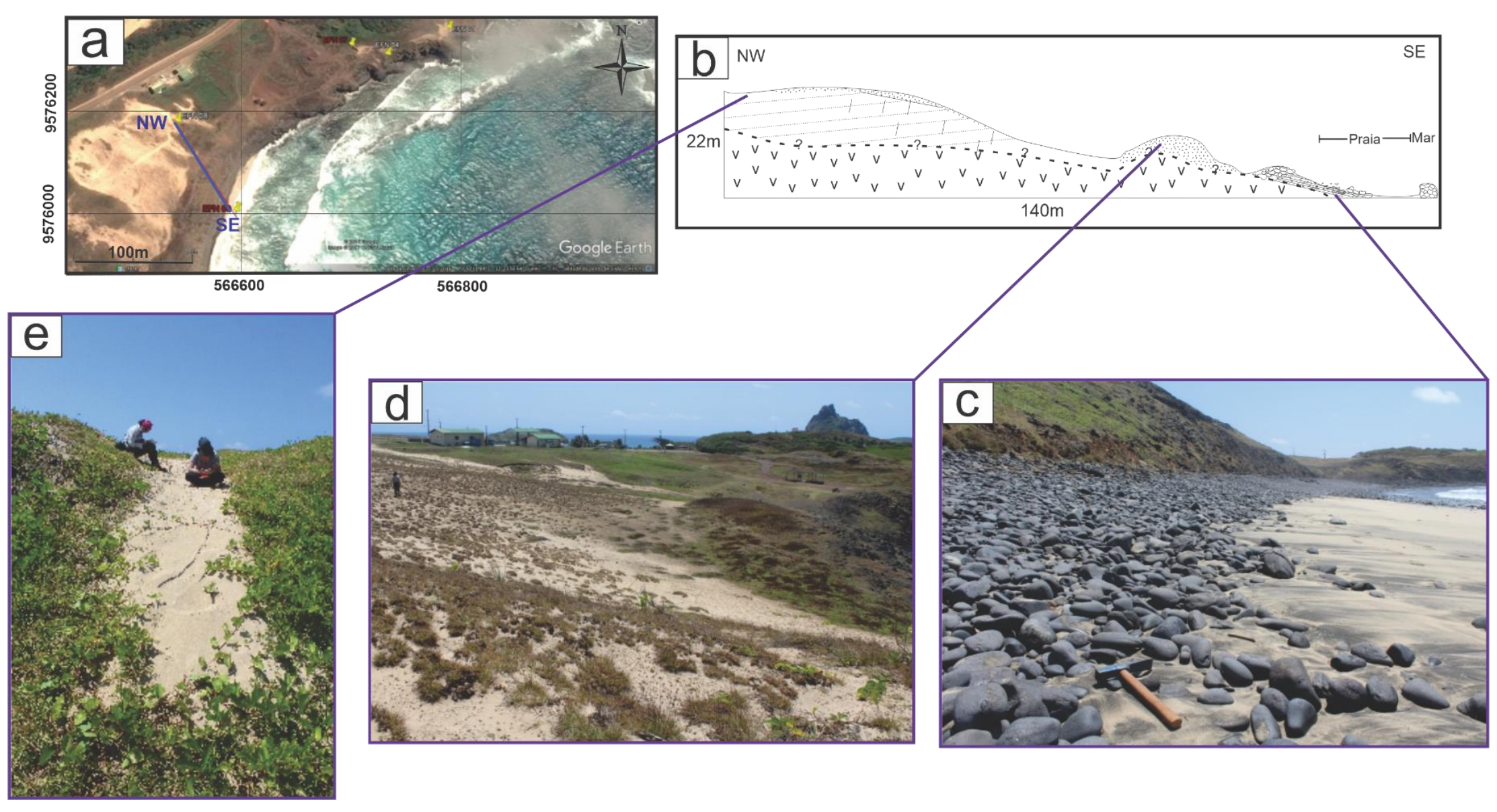

Fig. 5.9. Praia da Caieira, AFN, e dunas eólicas associadas: a. localização da praia; b. corte NW-SE; c. porção central da praia, com segregação granulométrica entre face praial superior, composta de cascalho, e inferior, dominada por areia rica em minerais pesados escuros; $\mathbf{d}$. sistema eólico em processo de estabilização, adjacente à porção central da praia; e. detalhe do sistema eólico, a cerca de $100 \mathrm{~m}$ da praia: blowout, visto a partir de seu lobo deposicional ativo. 


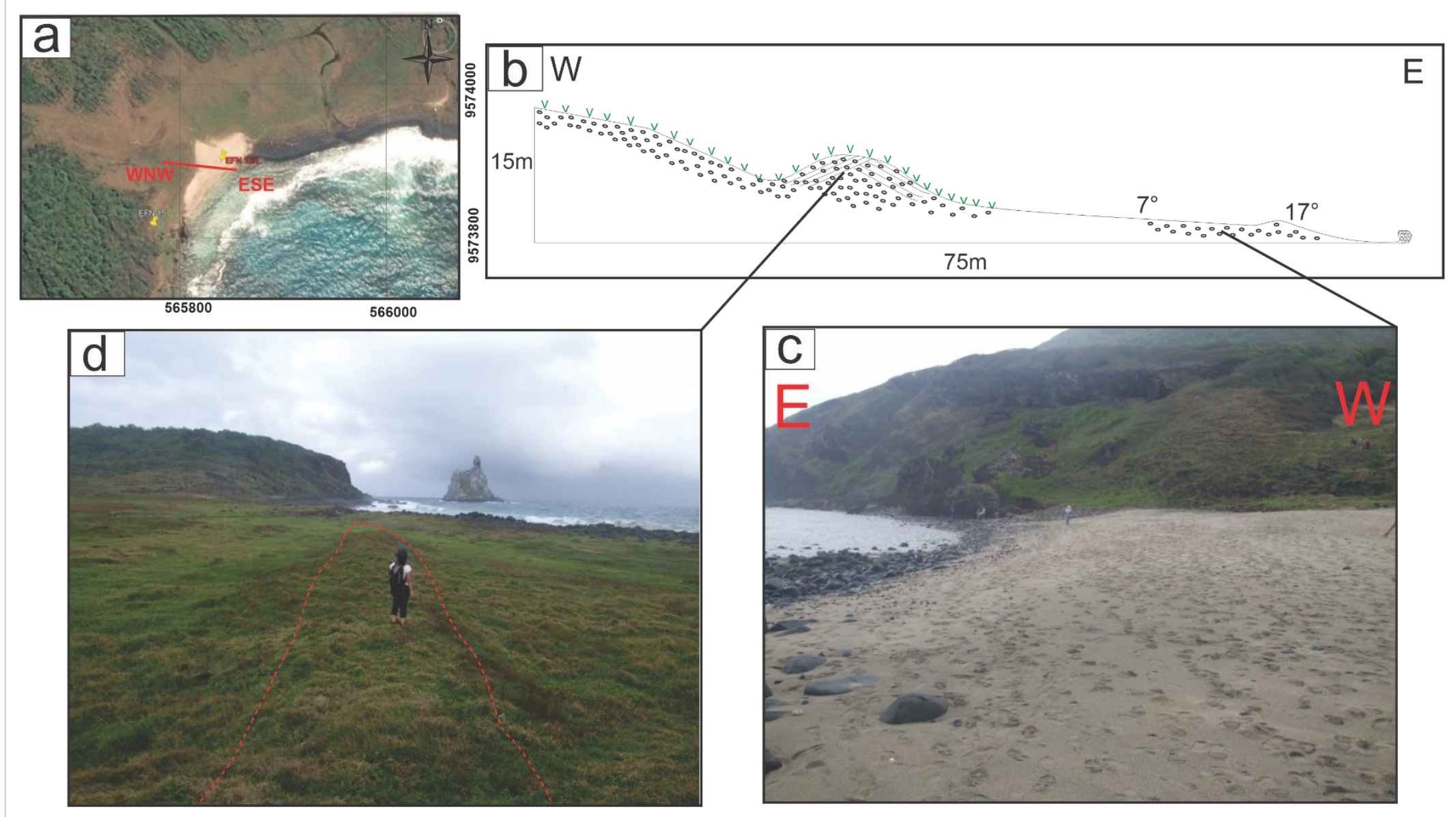

Fig. 5.10. Praia do Atalaia, AFN, e feições eólicas associadas: a. localização da praia; b. corte W-E; c. vista transversal da praia, com cascalho na face praial inferior e areia na face praial superior e na berma; d. rastro linear residual estabilizado. 


\subsection{Descrição de Fácies Deposicionais}

Na classificação de fácies, agruparam-se em separado as de eolianito (item 5.2.1) e as de depósitos não eólicos e/ou não carbonáticos associados aos eolianitos (5.2.2). O sumário descritivos das fácies é apresentada neste item e o seu contexto de ocorrência em cada afloramento, inclusive associações de fácies, no item 5.3.

\subsubsection{Eolianitos}

Dez fácies deposicionais foram reconhecidas nos eolianitos (Quadro 6 e Figs. 5.11, 5.12 e 5.13), todas de arenito (A), sendo uma maciça $(\mathbf{m})$ e as outras nove com estratificações cruzadas (c), estas distintas entre si quanto a três critérios principais: I. ângulo de mergulho dominante destas estratificações, se alto (a), acima de 10 (Aca), ou baixo (Acb); II. geometria aparente destas estratificações, se plano-paralela (Apa), cruzada plana (Acb ou Aca), cruzada acanalada/festonada (isto é, tangencial a côncava-subconcordante na base: Acf, Acbf) ou cruzada sigmoide (tangencial na base e no topo: Acs); e III. presença de rizoconcreções, que podem ser sempre abundantes na fácies (Acbra, Apbra e Amra) ou não (Acar). 
Quadro 6. Sumário de descrição de fácies deposicionais em eolianitos

\begin{tabular}{|c|c|c|c|c|}
\hline \multirow[b]{2}{*}{$\begin{array}{l}\text { Código } \\
\text { de } \\
\text { fácies }\end{array}$} & \multirow[b]{2}{*}{ Descrição } & \multicolumn{2}{|c|}{ Espessura visível $(\mathrm{m})$} & \multirow[b]{2}{*}{$\begin{array}{c}\text { Área de } \\
\text { ocorrência }\end{array}$} \\
\hline & & $\begin{array}{c}\text { Séries de } \\
\text { estratifica- } \\
\text { ções } \\
\end{array}$ & Fácies & \\
\hline $\mathrm{Ac}_{\mathbf{a}}$ & $\begin{array}{l}\text { Arenito fino a médio com estratificação cruzada } \\
\text { plana de ângulo alto }\left(>10^{\circ}\right)\end{array}$ & $0,4-1$ & $0,5-1$ & $\begin{array}{l}\text { Ilha Rasa, Pedra } \\
\text { da Bigorna, Ponta } \\
\text { das Caracas, } \\
\text { Atalaia }\end{array}$ \\
\hline $\mathbf{A p a}$ & $\begin{array}{l}\text { Arenito com estratificação plano-paralela com } \\
\text { ângulo alto para barlavento }\end{array}$ & $0,2-0,4$ & $0,2-0,8$ & $\begin{array}{l}\text { Enseada da } \\
\text { Caieira }\end{array}$ \\
\hline $\mathbf{A p}_{\mathbf{b}} \mathbf{r}_{\mathbf{a}}$ & $\begin{array}{l}\text { Arenito com estratificação plano-paralela com } \\
\text { ângulo baixo para barlavento e rizoconcreções } \\
\text { abundantes }\end{array}$ & $0,2-0,4$ & $0,2-0,8$ & $\begin{array}{l}\text { Enseada da } \\
\text { Caieira }\end{array}$ \\
\hline$A c_{b}$ & $\begin{array}{l}\text { Areia ou arenito com estratificação cruzada plana de } \\
\text { ângulo baixo }\end{array}$ & $0,5-1,0$ & $0,5-1,5$ & $\begin{array}{l}\text { Guajiru, Três } \\
\text { Irmãos }\end{array}$ \\
\hline$A_{\mathrm{f}}$ & $\begin{array}{l}\text { Arenito médio a fino com estratificação cruzada } \\
\text { acanalada/festonada, algumas vezes com } \\
\text { rizoconcreções, escassas ou abundantes }\end{array}$ & $0,5-1,5$ & $1-2$ & $\begin{array}{l}\text { Ponta das Caracas, } \\
\text { Forte de São } \\
\text { Joaquim } \\
\end{array}$ \\
\hline$A c_{b f}$ & $\begin{array}{l}\text { Areia com estratificação cruzada acanalada / } \\
\text { festonada de ângulo baixo }\end{array}$ & $0,2-0,4$ & $0,2-0,6$ & Guajiru \\
\hline Acs & $\begin{array}{l}\text { Arenito médio a fino com estratificação sigmoide, } \\
\text { às vezes similar a hummocky, ocasionalmente com } \\
\text { rizoconcreções, escassas ou abundantes }\end{array}$ & $0,5-2$ & $1-5$ & $\begin{array}{l}\text { Enseada da } \\
\text { Caieira, Atalaia, } \\
\text { Forte de São } \\
\text { Joaquim }\end{array}$ \\
\hline Acbra & $\begin{array}{l}\text { Areia ou arenito fino a grosso com estratificação } \\
\text { plano-paralela ou cruzada de ângulo baixo }\left(\leq 10^{\circ}\right) \text { e } \\
\text { rizoconcreções abundantes }(>10 \% \text { em volume })\end{array}$ & $0,5-1,5$ & $0,5-2$ & $\begin{array}{l}\text { Enxu Queimado, } \\
\text { Guajiru, Três } \\
\text { Irmãos } \\
\end{array}$ \\
\hline $\mathbf{A c}_{\mathbf{a}} \mathbf{r}$ & $\begin{array}{l}\text { Arenito fino a médio com estratificação cruzada } \\
\text { plana de ângulo alto }\left(>10^{\circ}\right) \text { com rizoconcreções } \\
\text { abundantes ou escassas }\end{array}$ & $1-2$ & $2-3$ & Ilha Rasa, Atalaia \\
\hline $\mathbf{A m r}_{\mathbf{a}}$ & $\begin{array}{l}\text { Areia fina a grossa maciça com rizoconcreções } \\
\text { abundantes (>10\% em volume) }\end{array}$ & - & $1-2$ & $\begin{array}{l}\text { Enseada da } \\
\text { Caieira }\end{array}$ \\
\hline
\end{tabular}



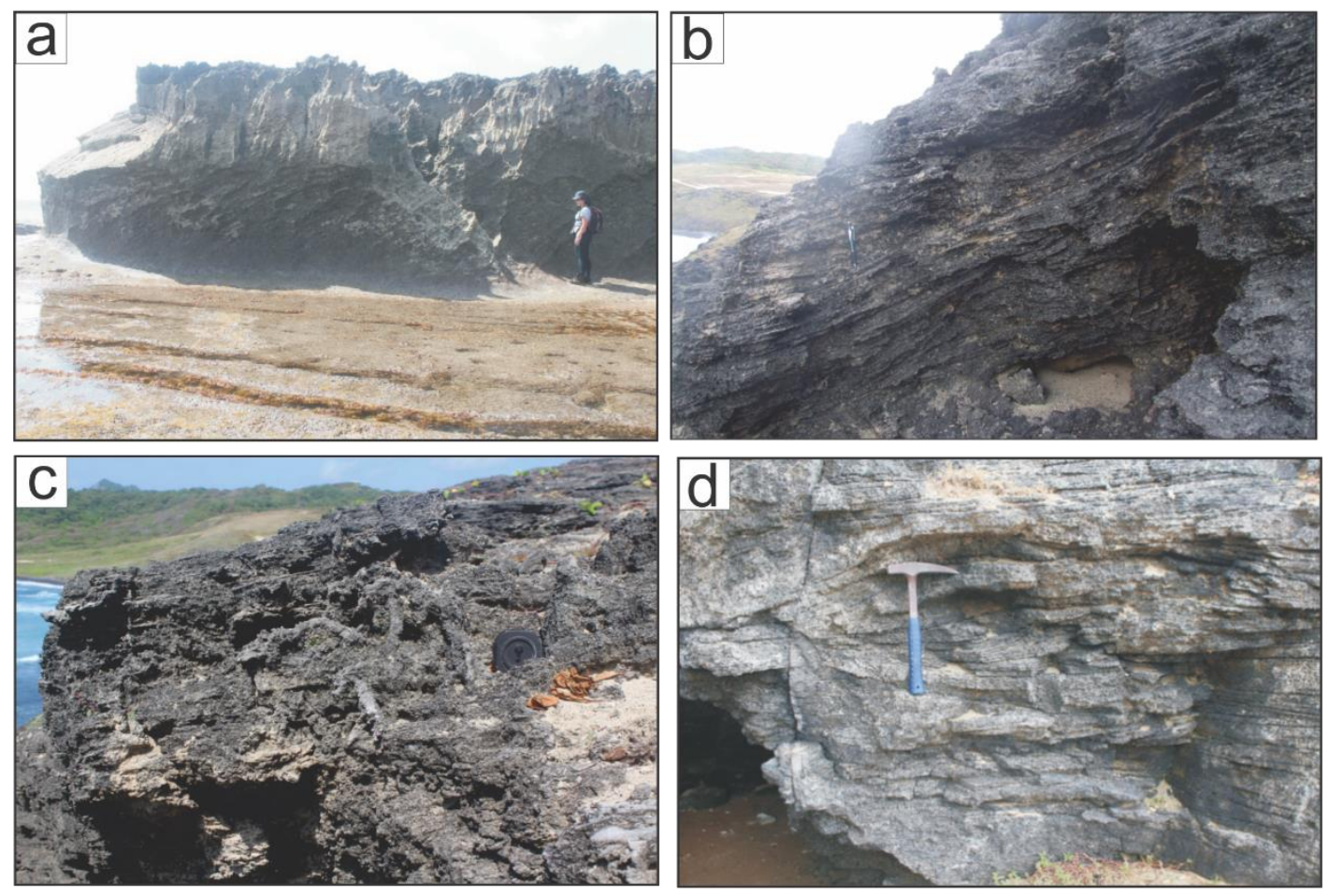

Fig. 5.11. Fácies deposicionais de ângulos altos observadas nos eolianitos: a. Aca, na Ilha Rasa (AFN); b. Apa; c. Apbra, na Enseada da Caieira (AFN); d. Acs em Ponta das Caracas (AFN)
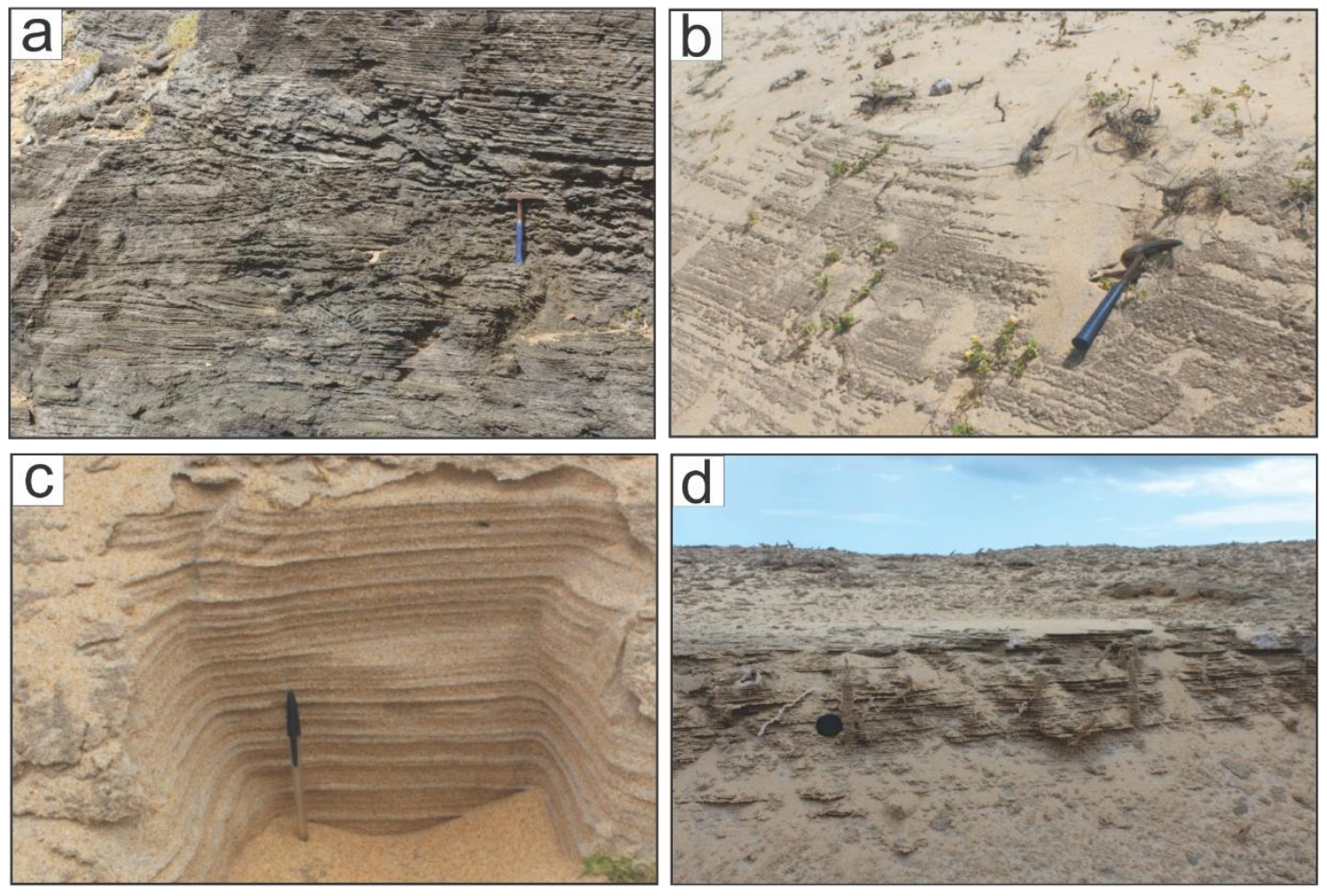

Fig. 5.12. Fácies deposicionais com estratificações de baixo ângulo observadas nos eolianitos: a. Acf, em Ponta das Caracas (AFN); b. Acbf, em Guajiru (RN); c. Acb, em Guajiru (RN).; e d. Acbra em Enxu Queimado (RN). 


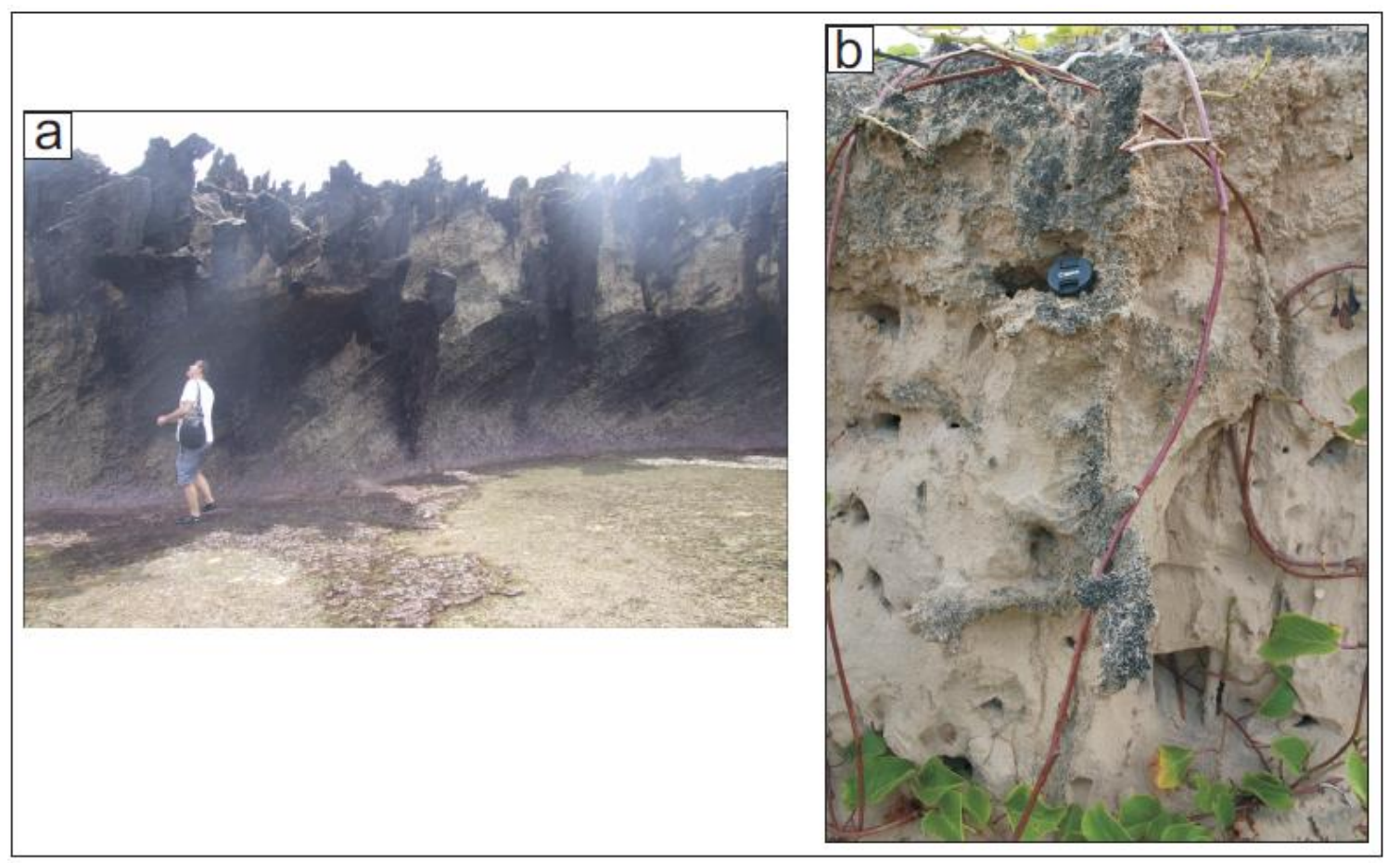

Fig. 5.13. Fácies deposicionais em eolianitos insulares: a. Acr, em Ilha Rasa (AFN); b. Amra em Enseada da Caieira (AFN).

\subsubsection{Fácies associadas}

Seis fácies associadas a eolianitos foram identificadas (Quadro 7 e Fig. 5.14). O aspecto maciço (ausência de estruturas sindeposicionais aparentes) é a característica mais comum, aparecendo em três delas (Rgn, Am e Amg). Destaca-se também, em duas das fácies associadas (Amg e Apb), a presença marcante de carapaças de moluscos, principalmente na granulação cascalho. Na fácies Apb (variedade de beach-rock), que ocorre tanto subjacente aos eolianitos continentais (Enxu Queimado e Três Irmãos) quanto adjacente a SE aos insulares (praia de Enseada da Caieira), os moluscos ocorrem como bioclastos; já a fácies $\mathbf{A m g}$, encontrada no afloramento alto da Enseada da Caieira, próximo à praia de Tamandaré, contém gastrópodes inteiros, em meio ao sedimento arenoso, aparentemente como vestígios de vida in situ; destacam-se carapaças milimétricas da espécie Zonitoides nitidus e centimétricas dos gêneros Gastrocopta, Rhinus, Cyclodontina e Pleuroploca.

No AFN, além da fácies Apb da Enseada da Caieira, três fácies associadas ( $\mathbf{R g n}, \mathbf{A p}$ e Am) ocorrem em sucessão subjacente aos eolianitos no afloramento baixo da Pedra da Bigorna (Fig. 5.14a,b,c). Enquanto isso, no RN as principais fácies associadas são os beach rocks (Apb e Apbz) de Enxu Queimado e Três Irmãos (Fig. 5.14d, e). A fácies Apbz, identificada apenas em 
Três Irmãos, diferencia-se da $\mathbf{A} \mathbf{p}_{\mathbf{b}}$ pela presença de zooturbações na forma de cilindros de paredes lisas, verticais ou inclinados (shafts), com diâmetro centimétrico, comprimento de até pelo menos 20 cm e ramificações em T ou em Y (Fig. 5.14e); em vista destas características, estas zooturbações foram atribuídas ao icnogênero Thalassinoides ( $c f$. elementos diagnósticos descritos em Fernández \& Pazos 2012). Estruturas de sobrecarga (flame) podem ocorrer no topo.

Quadro 7. Sumário de descrição de fácies nos depósitos sedimentares associados aos eolianitos.

\begin{tabular}{|c|c|c|c|c|}
\hline \multirow{2}{*}{$\begin{array}{l}\text { Código de } \\
\text { fácies }\end{array}$} & \multirow{2}{*}{ Descrição } & \multicolumn{2}{|c|}{ Espessura visível (m) } & \multirow{2}{*}{$\begin{array}{l}\text { Área de } \\
\text { ocorrência }\end{array}$} \\
\hline & & $\begin{array}{l}\text { Séries ou } \\
\text { camadas }\end{array}$ & Fácies & \\
\hline Rgn & $\begin{array}{l}\text { Rudito clasto-suportado, com blocos, seixos e grânulos } \\
\text { possivelmente imbricados, de matriz e/ou cimento } \\
\text { carbonático, formando sucessões com gradação normal } \\
\text { mal definida }\end{array}$ & $0,5-1,0$ & $0,5-2$ & $\begin{array}{l}\text { Pedra da Bigorna } \\
\text { (AFN) }\end{array}$ \\
\hline Ap & $\begin{array}{l}\text { Calciarenito rico (>20\% em volume) em clastos rudáceos } \\
\text { de líticos ígneos (até } 8 \mathrm{~cm} \text { de eixo maior) frequentemente } \\
\text { oblatos sub-horizontais, com estratificação plano-paralela } \\
\text { de leve caimento para SW }\end{array}$ & $0,4-1,0$ & $0,4-1,0$ & $\begin{array}{l}\text { Pedra da Bigorna } \\
\text { (AFN) }\end{array}$ \\
\hline Am & $\begin{array}{l}\text { Calciarenito, arenito ou areia, médios a finos, maciços, às } \\
\text { vezes com clastos imbricados ou concreções }\end{array}$ & $0,1-0,6$ & $0,1-1,0$ & $\begin{array}{l}\text { Pedra da Bigorna } \\
(\mathrm{AFN}), \text { Santa } \\
\text { Isabel }(\mathrm{RN})\end{array}$ \\
\hline Amg & $\begin{array}{l}\text { Arenito ou areia, médios a finos, maciços, com } \\
\text { gastrópodes inteiros }\end{array}$ & $0,1-0,7$ & $0,1-2$ & Caieira (AFN) \\
\hline Apb & $\begin{array}{l}\text { Arenito muito grosso a médio com séries cuneiformes } \\
\text { decimétricas de laminação plano-paralela e tendência } \\
\text { granodecrescente ascendente, contendo bioclastos, } \\
\text { rudáceos (beach rock) e, às vezes, estruturas } \\
\text { eodiagenéticas deformacionais e brechas intraclásticas }\end{array}$ & $0,1-0,6$ & $0,1-2$ & $\begin{array}{l}\text { Caieira (AFN), } \\
\text { Enxu Queimado } \\
\text { e Três Irmãos } \\
\text { (RN) }\end{array}$ \\
\hline Apbz & $\begin{array}{l}\text { Arenito muito grosso a médio com séries cuneiformes } \\
\text { decimétricas de laminação plano-paralela e tendência } \\
\text { granodecrescente ascendente, contendo bioclastos e } \\
\text { rudáceos (beach rock), com presença de zooturbações } \\
\text { abundantes e, às vezes, estruturas eodiagenéticas } \\
\text { deformacionais no topo }\end{array}$ & $0,1-1,0$ & $0,6-1,0$ & Três Irmãos (RN) \\
\hline
\end{tabular}




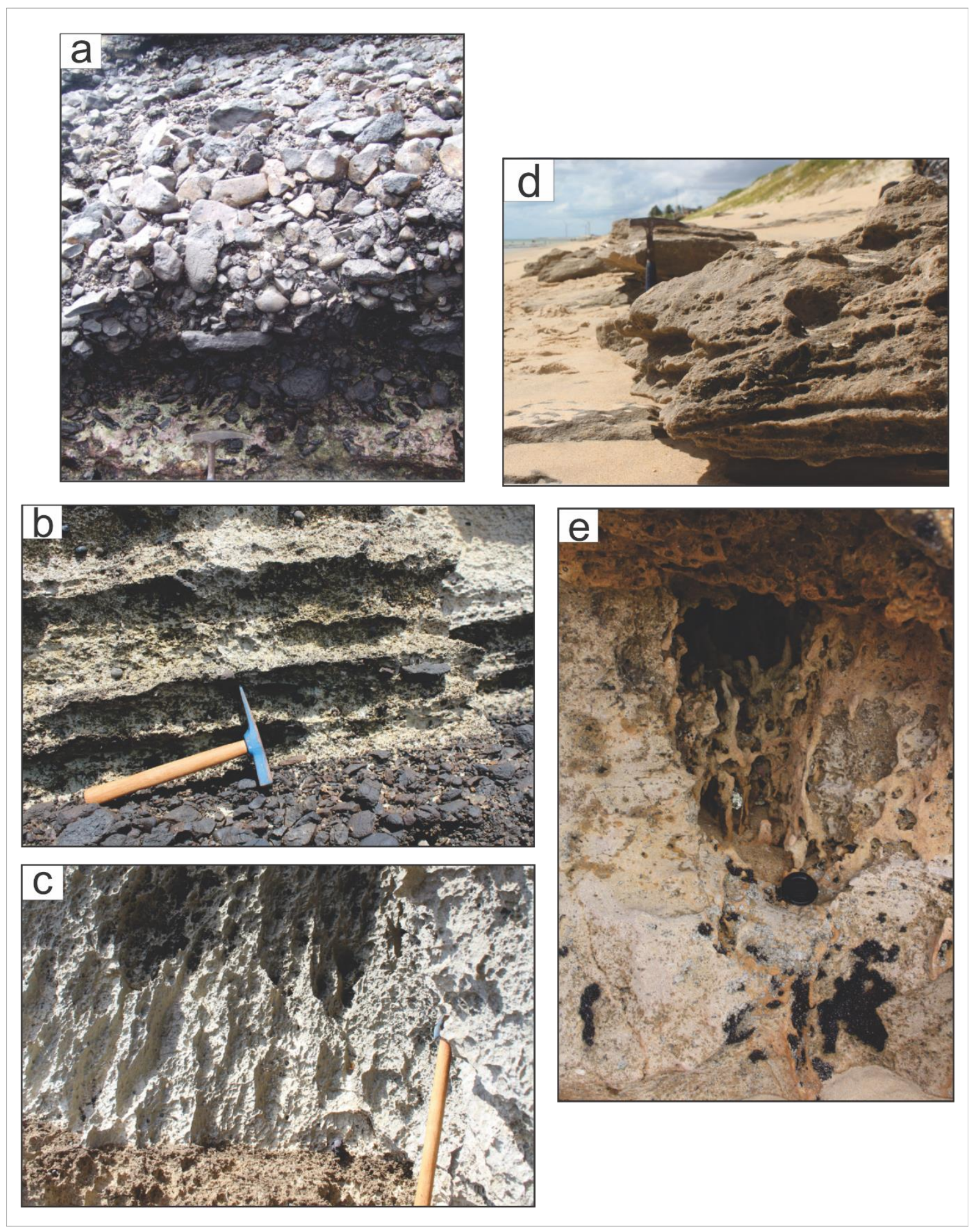

Fig. 5.14. Fácies deposicionais associadas aos eolianitos: a. Rgn, b. Ap e c. Am, na área da Pedra da Bigorna (AFN); d. Apb, na praia de Enxu Queimado; e. Apbz, na região de Três Irmãos (RN). 


\subsection{Distribuição Espacial dos Eolianitos e Associações de Fácies Deposicionais}

\subsubsection{Rio Grande do Norte}

\subsubsection{Três Irmãos}

Os eolianitos aflorantes nas falésias de Três Irmãos (Figs. 5.15 a 5.18) apresentam duas fácies, Acb e Acbra, com espessuras decimétricas. A espessura total de eolianitos varia entre 60 cm, na falésia mais a W (ERN 18; Figs. 5.15c,d), e 2,5m, na meio-leste (ERN 19; Fig. 5.17c), sempre em contato basal concordante com o topo das fácies relacionadas a beach rocks, Apb e Apbz. A fácies Apb, na parte inferior da sucessão e com base encoberta pela areia de praia atual, é areno-conglomerática, brechoide intraclástica, com estruturas eodiagenéticas deformacionais sugestivas de fluidificação (Fig. 5.17g); o topo da fácies Apbz, que faz contato com os eolianitos, encontra-se entre 3,8 e 4,3 m acima do nível de espraiamento de maré média atual.

As rizoconcreções, com diâmetros de até $8 \mathrm{~cm}$ e comprimentos que variam entre 5 e 60 cm (Fig. 5.18d), foram observadas principalmente no topo dos afloramentos (fácies Acbra) e, localmente, têm continuidade nas porções inferiores, chegando a alcançar as fácies associadas sotopostas, Apb e Apbz.

Em ERN 18, o contato dos eolianitos com as fácies de beach rock é mais nítido e plano, e mergulha para o mar $(\mathrm{N})$ cerca de $15^{\circ}$, enquanto o contato entre as duas fácies de beach rocks sotopostas e as estratificações plano-paralelas nelas contidas apresentam mergulho em ângulo baixo para SW (Fig. 5.15g). Nesse mesmo afloramento, o contato entre as duas fácies de beach rock, Apbz sobre Apb, é irregular quando examinado de perto, com estruturas eodiagenéticas deformacionais de sobrecarga em chama (flame), de porte decimétrico (fig 5.15h). 


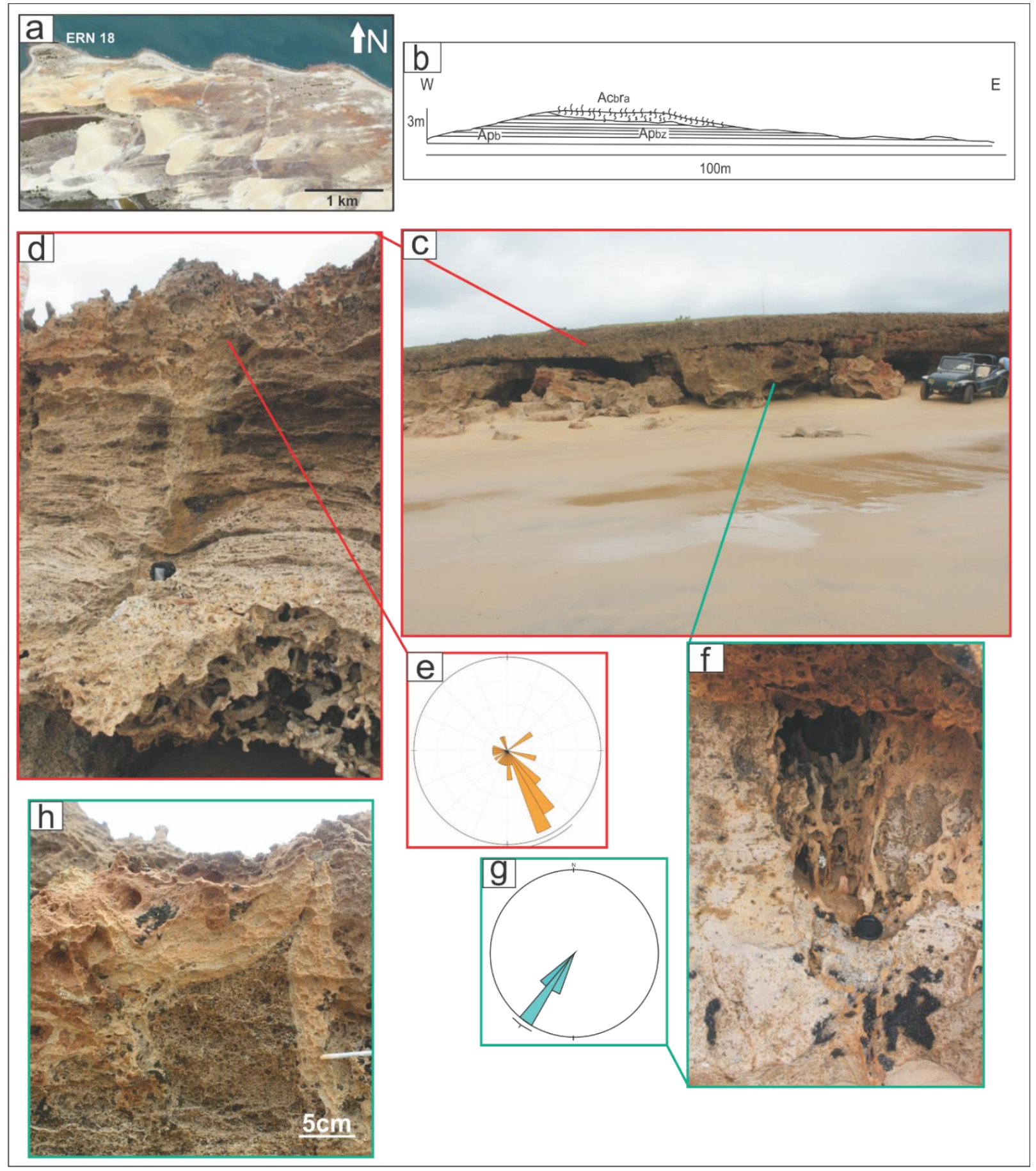

Fig. 5.15. Associação de fácies na falésia ERN 18, pertencente aos Três Irmãos: a. localização; b. corte W-E, com as principais fácies deposicionais; c. foto panorâmica; d. fácies de eolianito Acbra, com tubos atribuídos a rizoconcreções, sobreposta a fácies Apbz; e. histograma circular de azimutes de mergulho de estratificações cruzadas em eolianitos (azimute médio: 164, $6^{\circ}$; intervalo de confiança de 95\%: 25, $9^{\circ} ; \mathrm{n}=32$ ); f. fácies associada a eolianito $\mathbf{A p b z}$, com presença de tubos de Thalassinoides; g. histograma circular de azimutes de mergulho de estratificações cruzadas na fácies associada Apbz (azimute médio: 216,5 ; intervalo de confiança de 95\%: 7,4 ; $=4$ ).h. Estrutura flame observada na fáies $\mathbf{A p b}$. 


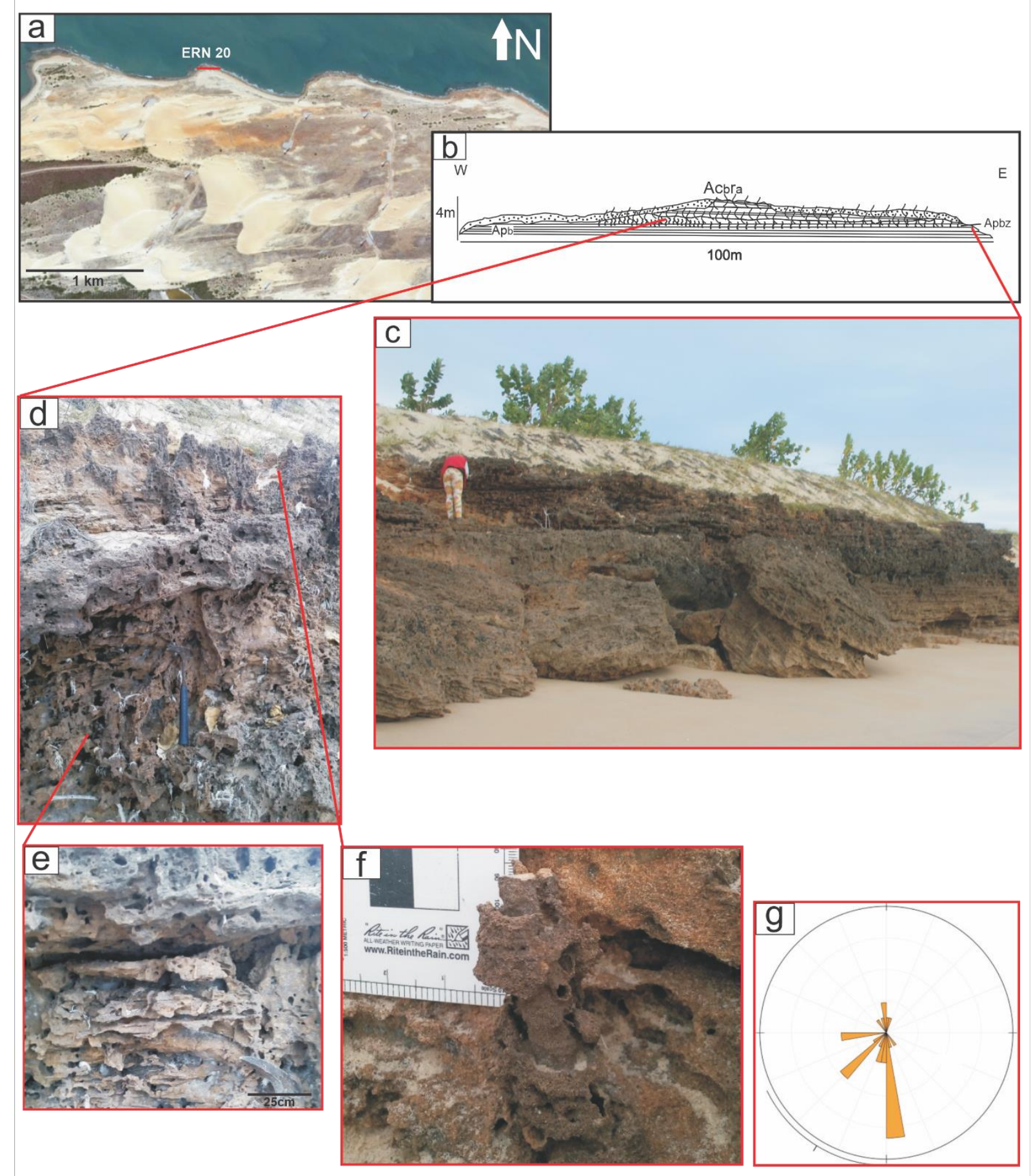

Fig. 5.16. Associação de fácies na falésia ERN 20, pertencente a Três Irmãos: a. localização; b. corte W-E, com as principais fácies observadas; c. imagem panorâmica; d. contato das fácies Apbz, abaixo, com Acbra; e. fácies associada Apbz; f. detalhe de rizoconcreção da fácies Acbra; g. histograma circular de azimutes de mergulho de estratificações cruzadas em eolianitos (azimute médio: $211,6^{\circ}$; intervalo de confiança de $95 \%$ : 32, $5^{\circ}$; $n=28$ ). 


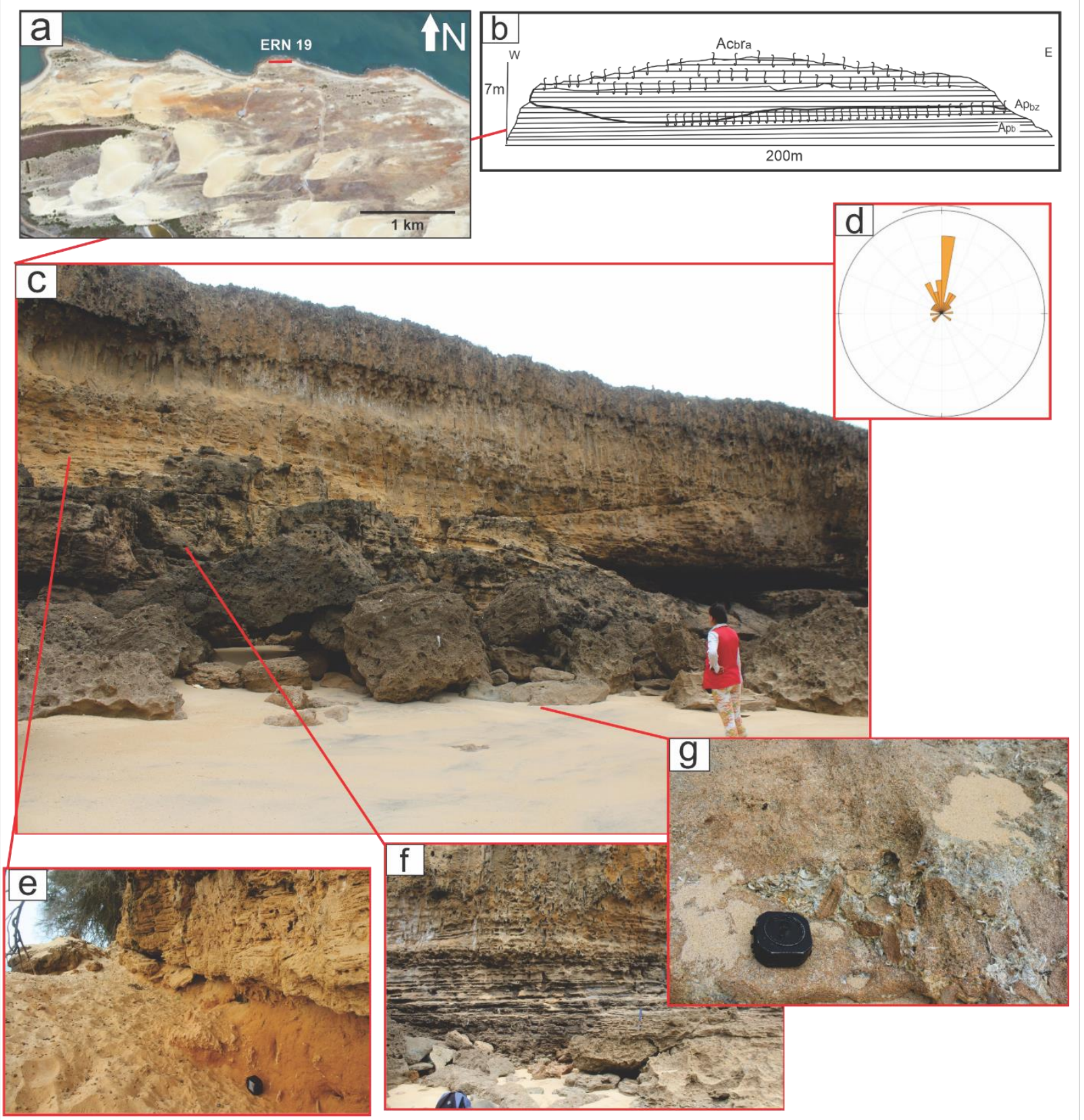

Fig. 5.17. Associação de fácies na falésia ERN 19, pertencente aos Três Irmãos: a.

localização; b. corte W-E, com as principais fácies observadas; c. imagem panorâmica da falésia; d. histograma circular de azimutes de mergulho de estratificações cruzadas em eolianitos (azimute médio: $357,1^{\circ}$; intervalo de confiança de 95\%: 18,3 $;$ n=31); e. fácies Acbra; f. fácies associada sotoposta Apbz; $\mathbf{g}$. fácies associada sotoposta $\mathbf{A p b}$, aqui representada por brecha intraclástica com arcabouço de calcário róseo e matriz de arenito a conglomerado bioclástico cinza. 


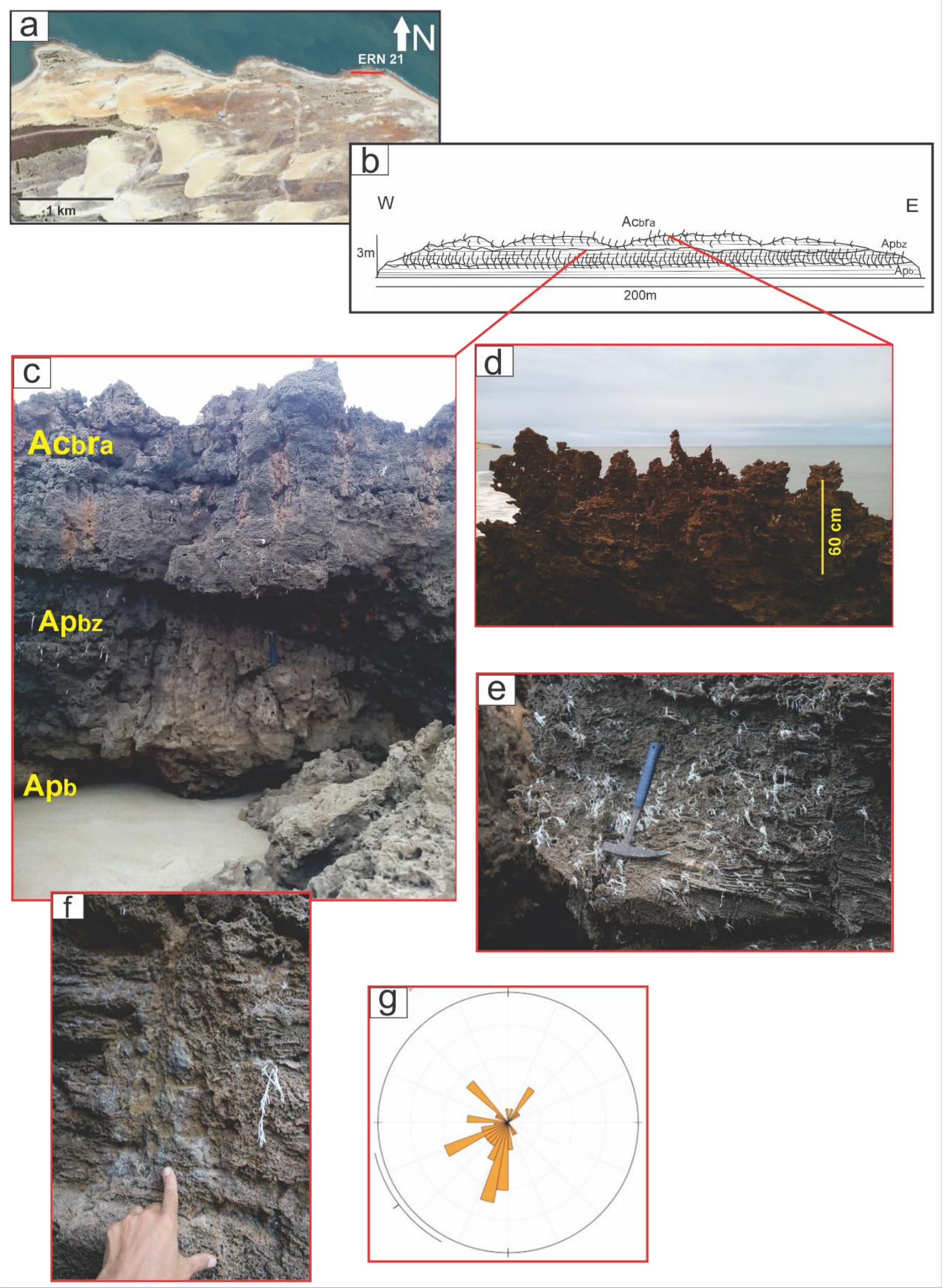

Fig. 5.18. Associação de fácies na falésia ERN 21, pertencente a Três Irmãos: a. localização; b. corte W-E, com as principais fácies observadas; c. imagem parcial da falésia, com empilhamento de fácies; $\mathbf{d}$. detalhe da fácies Acbra, com rizoconcreções ressaltadas por intemperismo diferencial; $\mathbf{e}, \mathbf{f}$. detalhes da fácies Acb, com rizoconcreção em f; $\mathbf{g}$. histograma circular de azimutes de mergulho de estratificações cruzadas em eolianitos (azimute médio: 233, $1^{\circ}$; intervalo de confiança de $95 \%$ : 23, $9^{\circ}$; $n=48$ ). 
O histograma de azimutes de mergulho de eolianitos referente ao conjunto de falésias de Três Irmãos apresenta padrão grosseiramente bipolar assimétrico, com moda principal em torno de S e moda secundária para N (Fig. 5.19). Já quando as falésias são consideradas individualmente, dominam os padrões unimodais para SE a SW nos afloramentos ERN 18, ERN 20 e ERN 21, este com maior dispersão de dados, e para N no ERN 19 (Figs. 5.15e, 5.16g, $5.17 \mathrm{~d}$ e. $5.18 \mathrm{~g})$.

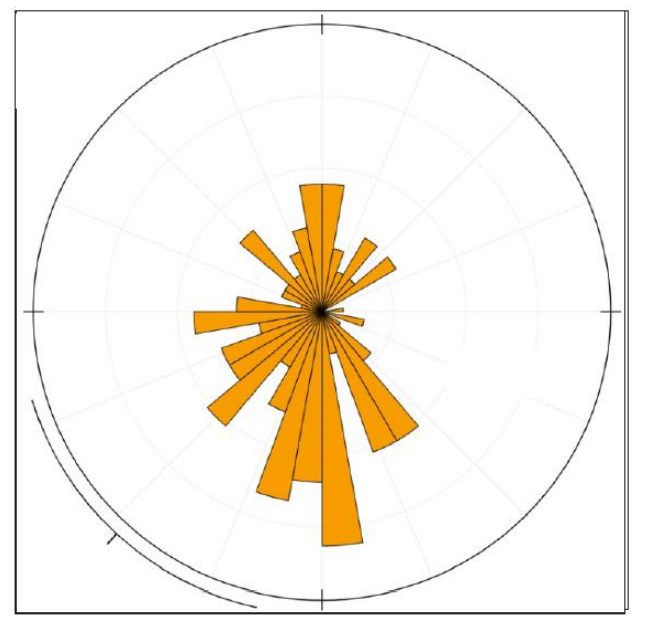

Fig. 5.19. Histograma circular de azimutes de mergulho de estratificações cruzadas nos eolianitos de Três Irmãos, RN, com padrão grosso modo bipolar, com moda principal S (azimute médio: $241,6^{\circ}$; intervalo de confiança de $95 \%: 30,3^{\circ} ; \mathrm{n}=135$ ).

\subsubsection{Guajiru}

Ao longo do perfil realizado no sistema eólico ativo de Guajiru, desde a associação praia-duna a ENE (ERN 10), até o campo de dunas (ERN 17) (Figs. 5.20a e b), as ocorrências dos eolianitos apresentam-se sob três formas diferentes. A primeira forma de ocorrência observou-se quase no topo do que parece ser uma feição morfológica de planície deflacionária (possível retrocordão) de aproximadamente 1,5 m de altura, heterogeneamente cimentada (ERN 08; Fig. 5.20d), onde as fácies Acb e Acbf ocorrem pouco consolidadas, com frágeis rizoconcreções de diâmetro subcentimétrico. A segunda corresponde a corpos aplainados em meio a planície deflacionária, restritos em área aflorante (menos de $\left.10 \mathrm{~m}^{2}\right)$, contendo a fácies Acbra (ERN 09; Fig. 5.20e); no rumo do vento efetivo (WSW), estes corpos tornam-se cada vez mais cobertos por areia recente do campo de dunas ativo, passando a ser rastreados através de faixas alongadas, com até cerca de $10 \mathrm{~m}$ de largura e orientadas grosso modo W-E, de 
rizoconcreções in situ (Fig. 5.20f). A terceira forma de ocorrência corresponde a cordão alongado de aproximadamente $50 \mathrm{~m}$ de extensão $\mathrm{W}$-E, parcialmente coberto por depósitos eólicos recentes (ERN 07). Neste cordão, identificam-se duas fácies (Acb e Acbf) (Figs. 5.21a e b). Apesar de ocorrer adjacente à área de afloramento de rizoconcreções in situ, parcialmente cobertas por rastros lineares residuais ativos, o cordão de eolianito não apresenta rizoconcreções.

A pouca consolidação e/ou a pequena espessura aflorante das duas primeiras formas de ocorrência dos eolianitos de Guajiru não permitiram medição, em número estatisticamente significativo, de atitudes de estratificações. Já na última forma de ocorrência (Figs. 5.21b, c e d), encontrou-se padrão de azimutes de mergulho unimodal para NW, na fácies Acb (Fig. 5.21d), e bimodal, com moda principal rumo S, na fácies Acbf (Fig. 5.21f). Nesta fácies, a bissetriz do ângulo entre as duas modas coincide aproximadamente com a orientação da crista do cordão de eolianito. 


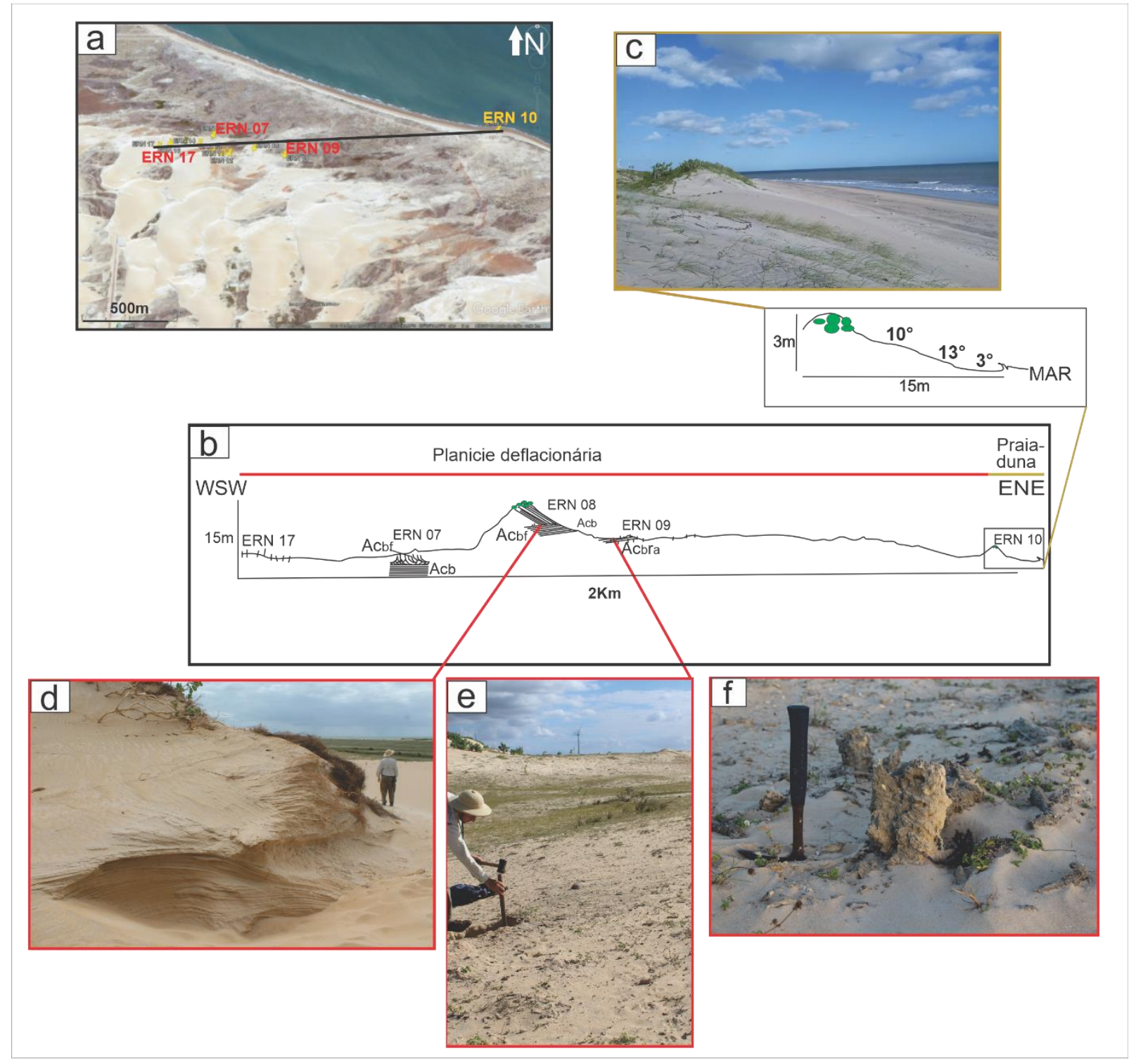

Fig. 5.20. Associação de fácies de eolianito encontrada em Guajiru, RN: a. localização, com destaque para o perfil de caminhamento WSW-ENE; b. corte WSW-ENE com as principais fácies observadas; c. panorâmica da duna frontal da praia de Guajiru; d. eolianito pouco consolidado, com as fácies Acbf e Acb; e. corpo de eolianito aplainado, no substrato da planície de deflação, com fácies Acbra; f. rizoconcreção do eolianito observado em e. 


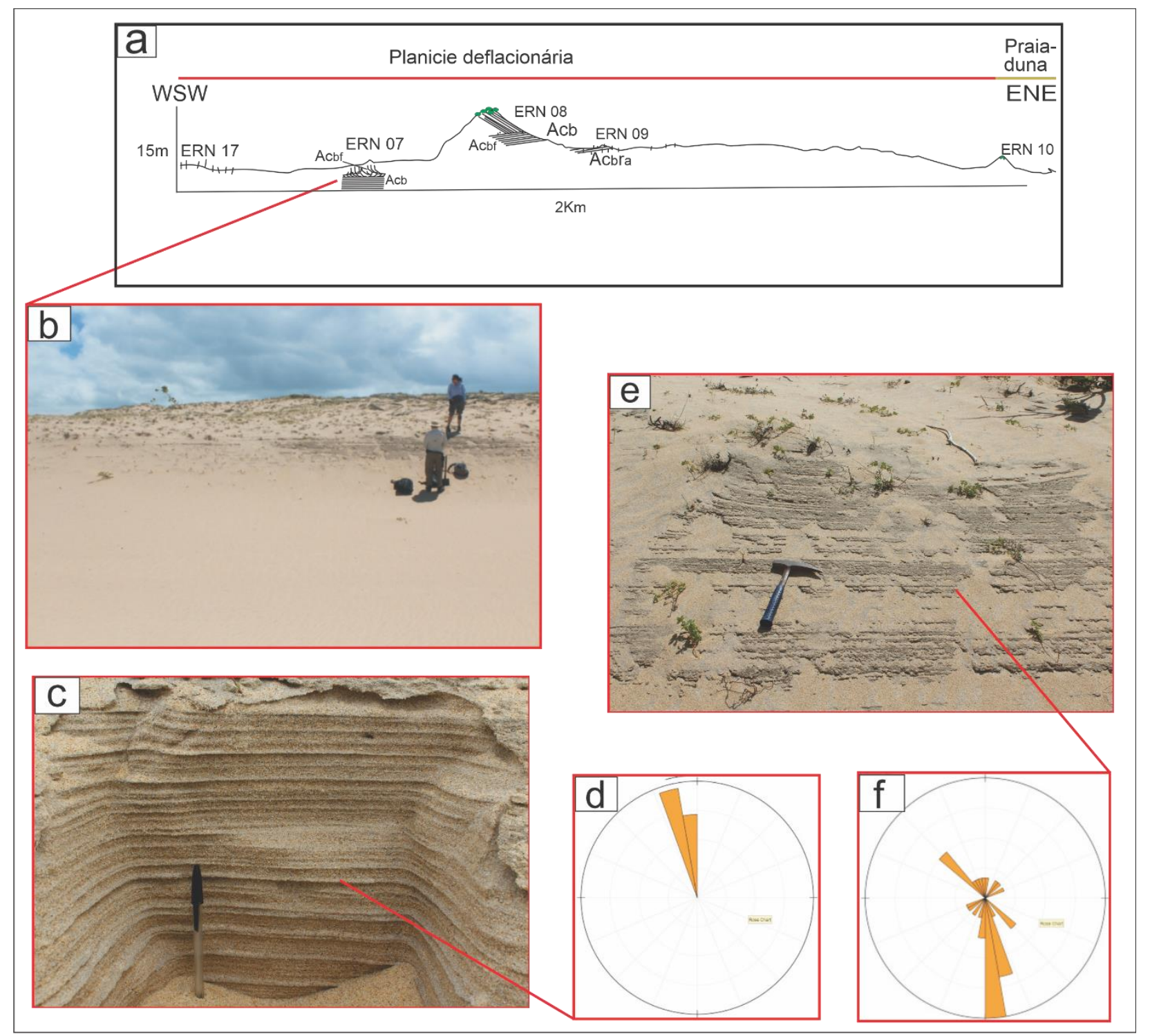

Fig. 5.21. Detalhes de afloramento e rosas de areia dos eolianitos encontrados em Guajiru, RN: a. corte WSW-ENE com as principais fácies observadas; b. panorâmica do cordão de eolianito com fácies Acb e Acbf; c. detalhe da fácies Acb; d. histograma circular de azimutes de mergulho da fácies Acb (azimute médio: $350^{\circ}$; intervalo de confiança de $95 \%: 5,1^{\circ} ; \mathrm{n}=7$ ); e. detalhe da fácies Acf;

f. histograma circular de azimutes de mergulho da fácies Acf (azimute médio: 184 $; n=30$ ).

\subsubsection{Enxu Queimado}

No perfil levantado em Enxu Queimado (Figs. 5.22a e b), foram observados afloramentos de beach rocks, em meio à associação praia-duna do sistema ativo (ERN 01; Figs. $5.22 \mathrm{c}$ e d), e de eolianitos, estes em meio tanto à planície deflacionária (ERN 02) quanto ao campo de dunas ativos (ERN 03). Os beach rocks ocorrem como lajes ao pé da duna frontal e 
são representados pela fácies Apb, paraconglomerática, de até $25 \mathrm{~cm}$ de espessura exposta, com duas camadas cujas estratificações plano-paralelas mostram azimutes de mergulho opostos (Fig. 5.22d): a inferior tem inclinação para o mar $\left(5 / 10^{\circ}\right)$, enquanto a superior mostra caimento para o continente (159/13 $)$; o contato entre estas duas camadas da fácies Apb encontra-se 2,4 $\mathrm{m}$ acima da zona de espraiamento de preamar atual. O afloramento de eolianito na planície deflacionária ocorre como cordão alongado NNE-SSW, de aproximadamente 300m de extensão (Fig. 5.22e), aparentemente formado por uma única fácies (Acbra); e o afloramento da porção barlavento do campo de dunas livres sobressai em meio a planícies interdunas como um montículo de aproximadamente $5 \mathrm{~m}$ de comprimento por $2 \mathrm{~m}$ de altura, contendo a mesma fácies; rizoconcreções são mais aparentes na superfície do cordão, tanto in situ quanto caídas (Figs. $5.22 \mathrm{f} \mathrm{e} \mathrm{g).} \mathrm{Sobre} \mathrm{o} \mathrm{cordão} \mathrm{de} \mathrm{ERN} \mathrm{02,} \mathrm{foram} \mathrm{observados} \mathrm{dois} \mathrm{possíveis} \mathrm{sambaquis} \mathrm{com} \mathrm{menos}$ de 20m de comprimento máximo e espessura aparentemente decimétrica (Fig. 5.23a, b), constituídos por carapaças de bivalves (Anomalocardia brasiliana e Ostrea sp.; Fig. 5.23e) e gastrópodes (Strombus goliath).

O histograma circular de azimutes de mergulho de estratificações cruzadas, na fácies Acbra apresenta padrão unimodal, para NNW (Fig. 5.23 e). 

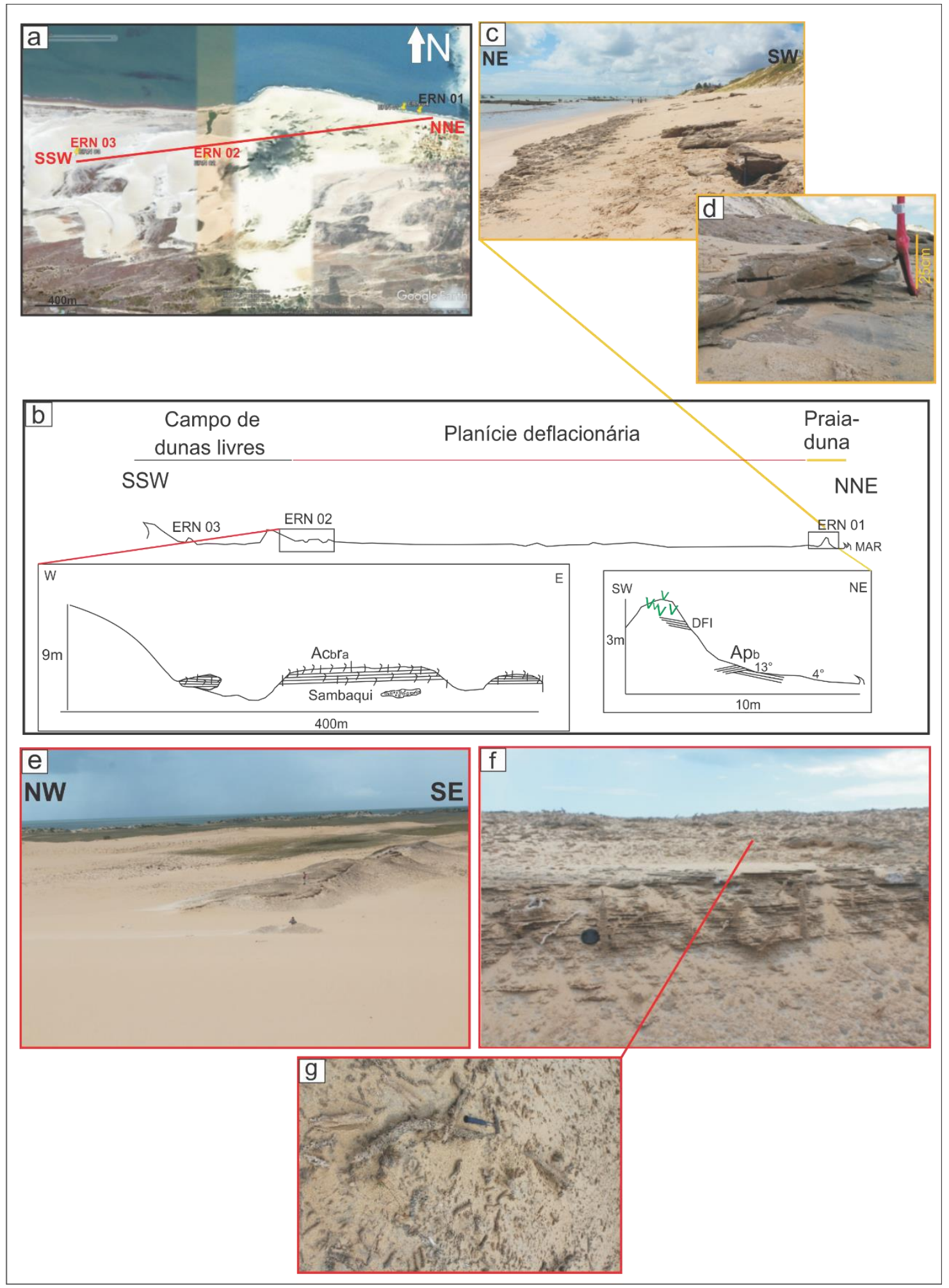

Fig. 5.22. Associação de fácies encontrada em Enxu Queimado, RN: a. localização; b. corte SSW-NNE, com as principais fácies observadas; c. panorâmica da associação praia - duna frontal incipiente (DFI), com destaque para a presença de afloramentos de beach rock no pé da duna frontal; d. beach rock, fácies $\mathbf{A p b}$, com duas séries de estratificação plano-paralela superpostas: mergulhando para o interior (acima) e para o mar (abaixo); e. panorâmica do cordão de eolianito; f. fácies Acbra, com zoom in em g; g. rizoconcreções caídas no topo do cordão de eolianito. 


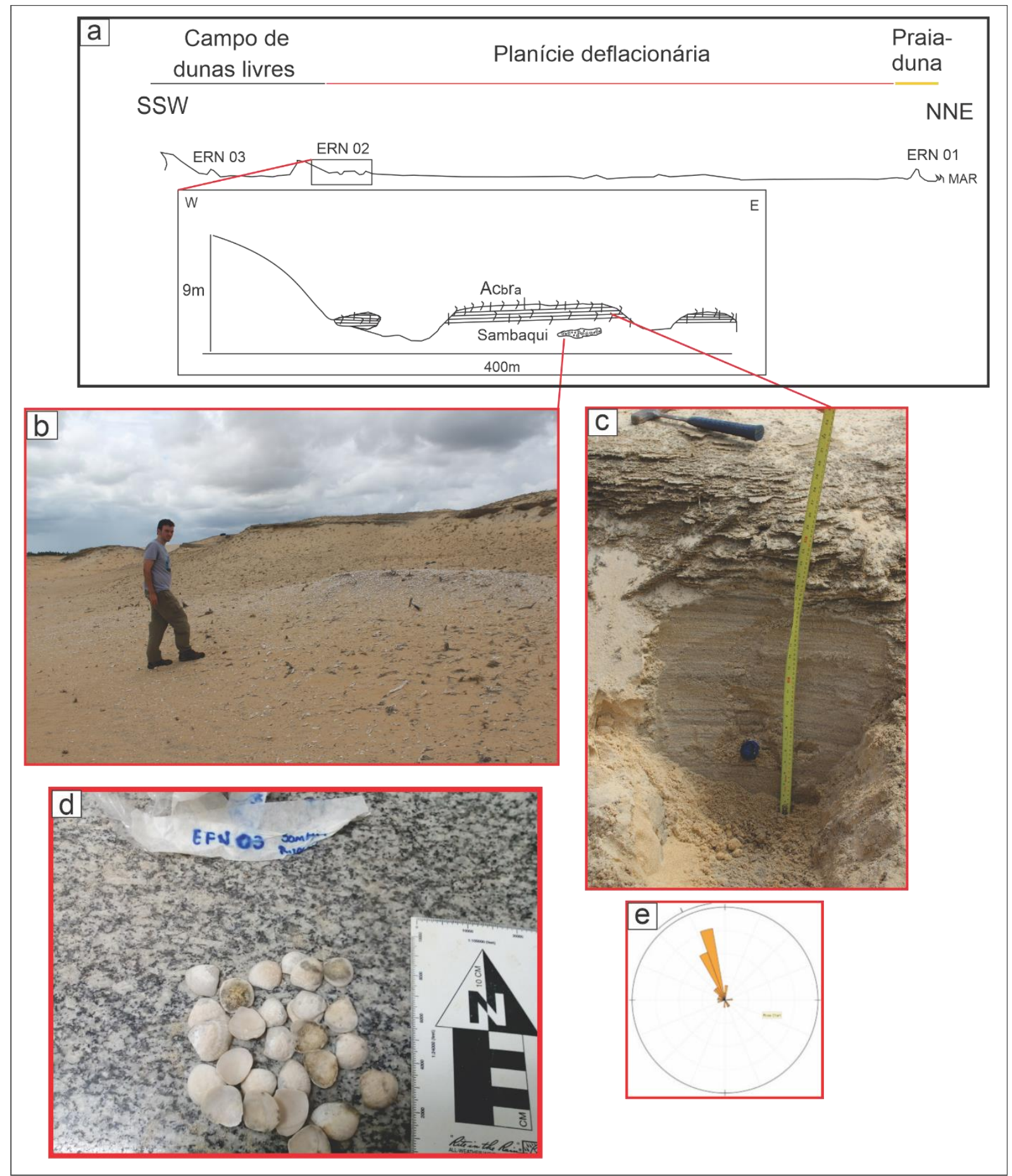

Fig. 5.23. Detalhes de campo e rosa de areia dos eolianitos de Enxu Queimado, RN: a. corte

W-E; b. sambaqui sobre eolianito; c. amostragem da fácies Acbra; d. carapaças de bivalves (Anomalocardia brasiliana); e. histograma circular de azimutes de mergulho da fácies Acbra (azimute médio: $334,2^{\circ}$; intervalo de confiança de $95 \%: 17,7^{\circ} ; \mathrm{n}=32$ ). 


\subsubsection{Praia do Marco}

Os eolianitos da praia do Marco ocorrem em falésia de cerca de $4 \mathrm{~m}$ de altura, parcialmente coberta por dunas frontais incipientes em rampa (Fig. 5.24d). São subconsolidados, com estratificação cruzada de ângulo baixo (fácies Acb, Fig. 5.24e) rica em minerais pesados escuros; em virtude do baixo grau de consolidação, não foi possível tomar medidas de estratificação.

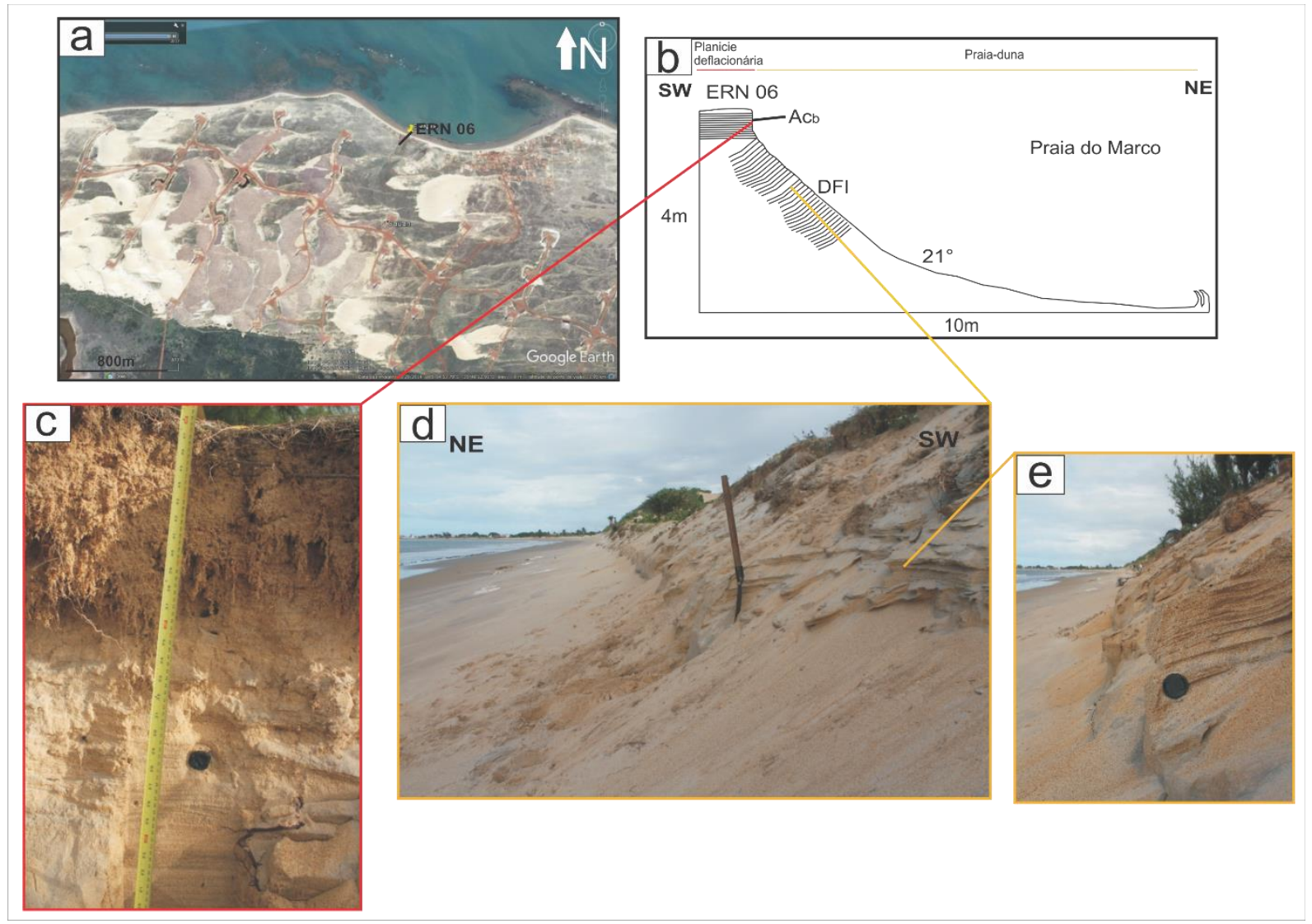

Fig. 5.24. Eolianitos na Praia do Marco, RN: a. localização; b. corte SW-NE, com as fácies observadas; c. fácies Acb, com tubo de coleta da amostra ERN 06B; d. panorâmica do eolianito coberto por duna frontal em rampa; e. fácies Acb, parcialmente encoberta na base. 


\subsubsection{Arquipélago de Fernando de Noronha}

\subsubsection{Ilha Rasa}

A Ilha Rasa é a área de estudo localizada mais ao norte do arquipélago e foi analisada ao longo da extensa escarpa SE-NW da porção sul da ilha e da falésia da extremidade oeste, perpendicular à primeira (Fig. 5.25a). Seus eolianitos apresentam estratificações cruzadas com mergulhos divergentes na seção SW-NE (Fig. 5.25b, c) e com mergulho aparente para NW, na seção NW-SE (Fig. 5.25d, e, f); em ambas as seções, repousam concordantemente sobre o que em campo aparenta ser um recife e subdividem-se em duas fácies: Aca, de aproximadamente 2,5 m de espessura (Fig. 5.25e), na parte inferior, e Acar, com aproximadamente 1,5 m de espessura, na parte superior; as rizoconcreções desta fácies aparentemente alcançam seu máximo desenvolvimento vertical a SE (Fig. 5.25f). Só foi possível tomar medidas de estratificação cruzada na fácies Acar; o histograma circular destas medidas evidencia duas modas próximas entre si para quadrantes de norte (NNW e NW) e outras duas modas próximas, para quadrantes de sul (SW e S). 

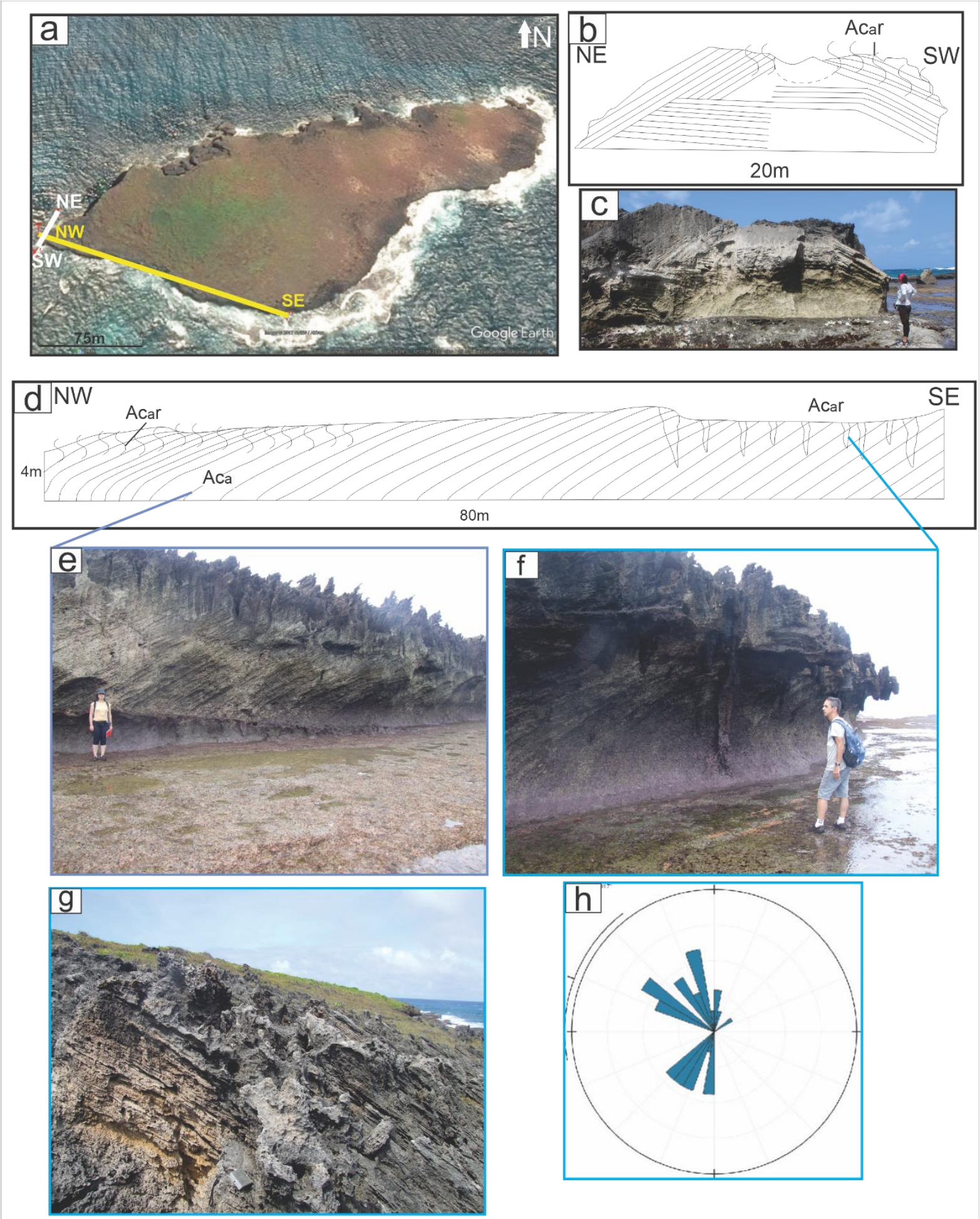

Fig. 5.25. Eolianitos da Ilha Rasa, AFN: a. localização dos cortes NW-SE e NE-SW; b. seção NE-SW com fácies Acar, evidenciando padrão de estratificações cruzadas divergentes (NE e SW) e rumo observador (NW); c. panorâmica do corte NE-SW; d. corte NW-SE, com as fácies Aca e Acar; notar mergulho aparente para NW; e. panorâmica da porção mais a NW do corte d, com fácies Acar; f. panorâmica da porção mais a SE do corte d, onde as rizoconcreções apresentam comprimento métrico; g. fácies Acar, no topo do extremo oeste da ilha; h. histograma circular de azimutes de mergulho de

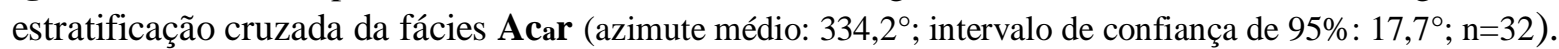




\subsubsection{Pedra da Bigorna}

A Pedra da Bigorna é um remanescente tabular de abrasão marinha situado entre a ponta norte da ilha principal e a Ilha Rasa (Fig.5.26a). Os eolianitos ocorrem na forma das fácies Aca e Acar, no topo da seguinte sucessão concordante de fácies sedimentares costeiras (Fig. 5.26b): I. ortoconglomerado com gradação normal, dominado por blocos de rocha ígnea afanítica escura (basalto?) com ligeiro mergulho para SW, e com matriz e/ou cimento carbonáticos (fácies Rgn; Fig 5.26c); II. calciarenito com laminação plano-paralela com leve caimento aparente para NE, contendo clastos rudáceos da mesma rocha ígnea escura, frequentemente achatados, orientados paralelamente à estratificação ou imbricados com mergulho NE (fácies Ap); o padrão de azimutes de mergulho encontrado nesta fácies, única em que foi possível tomar atitudes de estratificações cruzadas, é polimodal, porém, pouco confiável em vista do número reduzido de medidas ( $\mathrm{n}=9$ ) e do ângulo baixo de mergulho (Fig. 5.26d); III. calciarenito maciço com clastos rudáceos dispersos e levemente orientados paralelamente entre si (fácies Am) em passagem transicional com a fácies sotoposta; IV. calciarenito com estratificação cruzada de ângulo alto com mergulho aparente para SW (fácies Aca; Fig. 5.26e), a qual se torna gradualmente menos nítida em direção a fácies sobrejacente; V. calciarenito com estratificação cruzada de ângulo alto, com abundantes rizoconcreções carbonáticas (fácies Acar; Fig. 5.26f) ou, ocasionalmente, ferruginosas (Fig. 5.26g). 


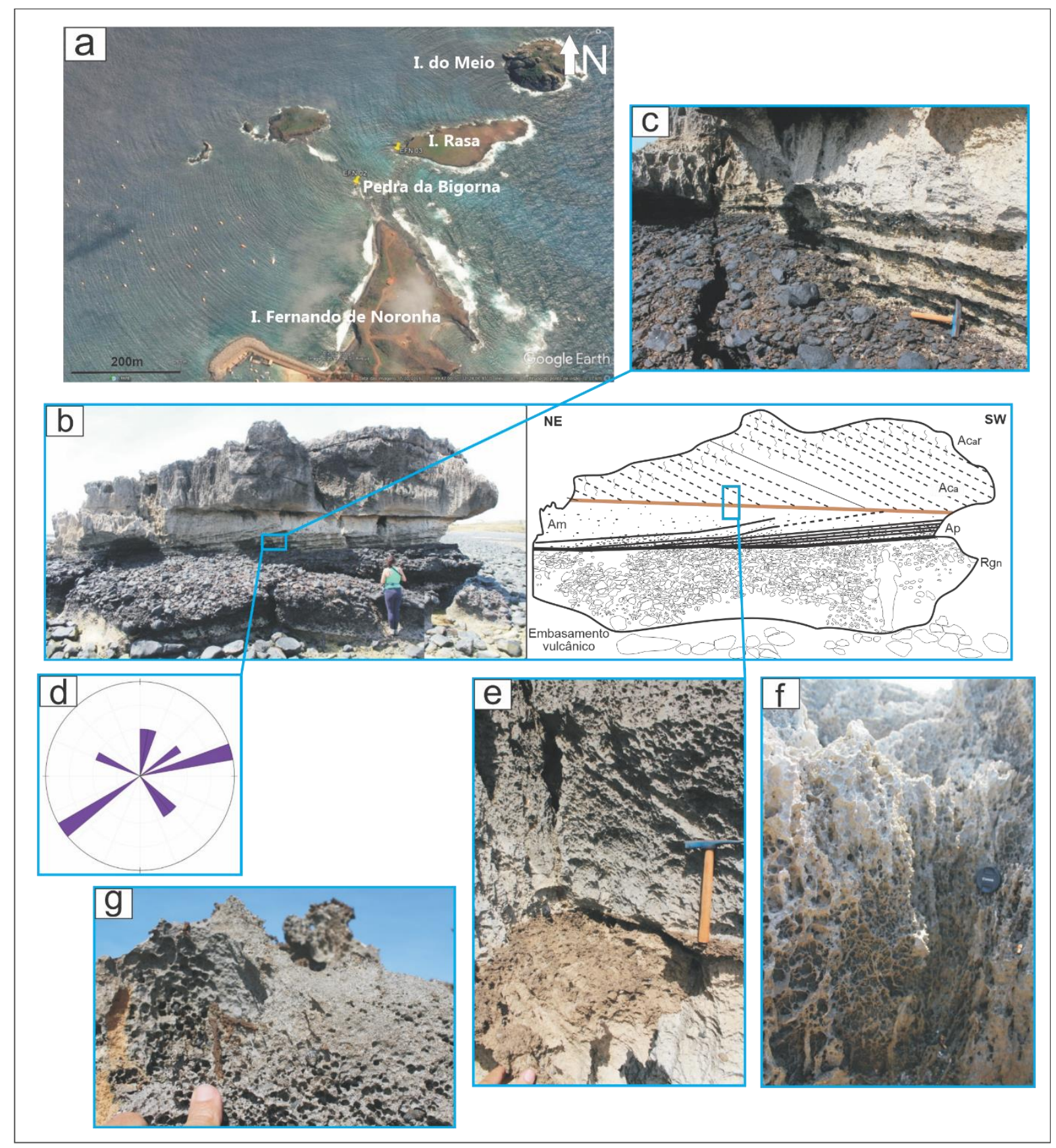

Fig. 5.26. Sucessão de fácies do afloramento EFN 02, na Pedra da Bigorna, em que os eolianitos ocorrem no topo (Aca e Acar): a. localização; b. corte NE-SW, com as fácies observadas; c. fácies Ap, em contato concordante abrupto com a fácies Rgn; d. histograma circular de azimutes de mergulho de estratificação cruzada da fácies $\mathbf{A p}$ (azimute médio: $73^{\circ} ; \mathbf{n}=9$ ); e. fácies $\mathbf{A} \mathbf{c a}$ em contato concordante abrupto com a fácies Am; f. fácies Acar; g. zoom in das rizoconcreções ferruginosas da fácies Acar. 


\subsubsection{Enseada da Caieira}

$\mathrm{Na}$ Enseada da Caieira, encontram-se quatro afloramentos de eolianito (EFN 01, EFN 04, EFN 07 e EFN 08, de ENE para WSW; Fig. 5.27a) nas altitudes entre 11m e 22m, os quais possivelmente se correlacionam entre si na lateral (Fig. 5.27b). O afloramento mais diversificado faciologicamente é o EFN 04, com três fácies em contatos transicionais. Da base para o topo, são elas: Apa, de aproximadamente $1,7 \mathrm{~m}$ de espessura; Acs, espessa aproximadamente 2m, com escassas rizoconcreções (Fig. 5.27c); e Apbra, de pouco mais de $1 \mathrm{~m}$ de espessura (Fig. 5.26d). Esta última fácies encontra-se também nos afloramentos EFN 01 e EFN 08 (Fig. 5.28a), onde aparece em contato com o embasamento piroclástico-vulcânico (Fig. 5.27e); nestes dois pontos, as rizoconcreções possuem dominantemente comprimento subdecimétrico e diâmetro subcentimétrico; no ponto EFN 08, os eolianitos encontram-se pouco consolidados (Figs.5.27b e c), e ocorrem sob depósitos subconsolidados da fácies associada Amg, ricos em gastrópodes terrestres inteiros da espécie Rydleya quinquelinata; já o ponto EFN 07, caracteriza-se pela fácies Amra, com espessura de até 2m, cujas rizoconcreções exibem comprimento de até mais de $1 \mathrm{~m}$ e diâmetro de até $1 \mathrm{dm}$ (Figs. 5.28d, e e f). Esta fácies encontra-se consolidada por cimento apenas nos 30 a $60 \mathrm{~cm}$ superiores e associa-se, localmente, sobretudo nas zonas topograficamente deprimidas, a depósitos subconsolidados da fácies $\mathbf{A m g}$, contendo carapaças inteiras de gastrópodes terrestres das espécies Rydleya quinquelinata, Hyperaulax ridleyi e Hysperaulax ramagei, bem como patas de caranguejos, também terrestres (Gecarcinus lagostoma, segundo Angulo et al. 2013a). Na praia da Enseada da Caieira, adjacente a SE, e que em tese atuou como fonte para os depósitos eólicos, afloram beach rocks de espessura aparente decimétrica, conglomeráticos (contendo seixos, inclusive fragmentos de conchas, e blocos), e com estratificação plano-paralela mergulhando para o mar (fácies Apb; Fig. 5.27a).

Para cada fácies, foi construído o histograma circular de azimutes de mergulho das estratificações cruzadas, observando-se que as três apresentam vetor médio e modas para SE (Fig.5.29a, b e c), com importantes modas adicionais para SSW, na fácies Acs (Fig. 5.29b), e para S e NE, na fácies Acbra (Fig. 5.29c). 


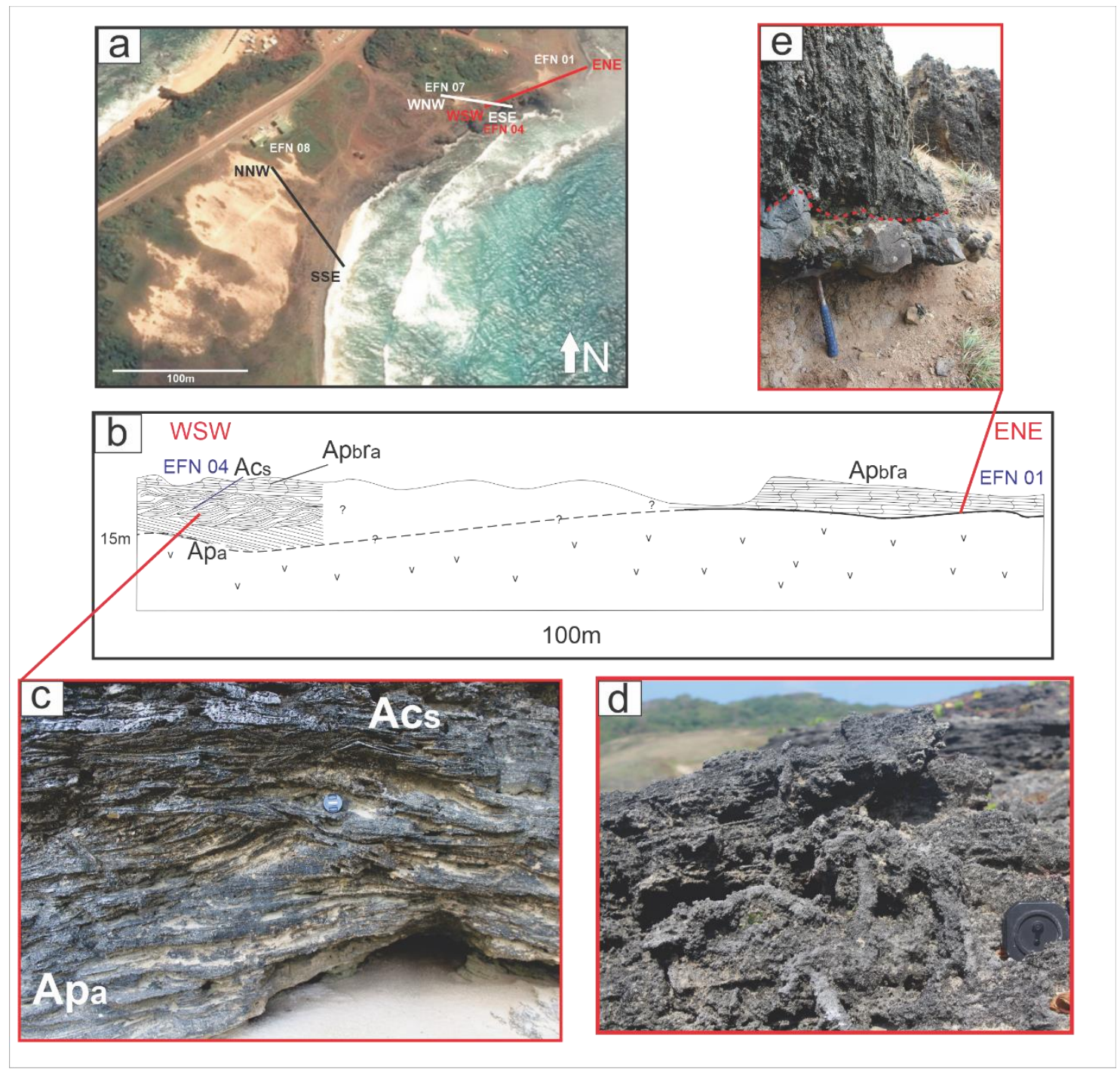

Fig. 5.27. Associações de fácies de eolianitos, em Enseada da Caieira, AFN, com ênfase na seção WSW-ENE: a. localização dos cortes WSW-ENE, WNW-ESE e NNW-SSE; b. corte WSWENE, com as fácies presentes nos pontos EFN 04 e EFN 01; c. contato transicional entre a fácies Apa e $\mathbf{A c s}$; d. fácies $\mathbf{A} \mathbf{p}_{\mathbf{b}} \mathbf{r}_{\mathbf{a}}$ no ponto EFN 04; e. contato da fácies $\mathbf{A} \mathbf{p}_{\mathbf{b}} \mathbf{r}_{\mathbf{a}}$ com a rocha piroclástico-vulcânica no ponto EFN 01. 


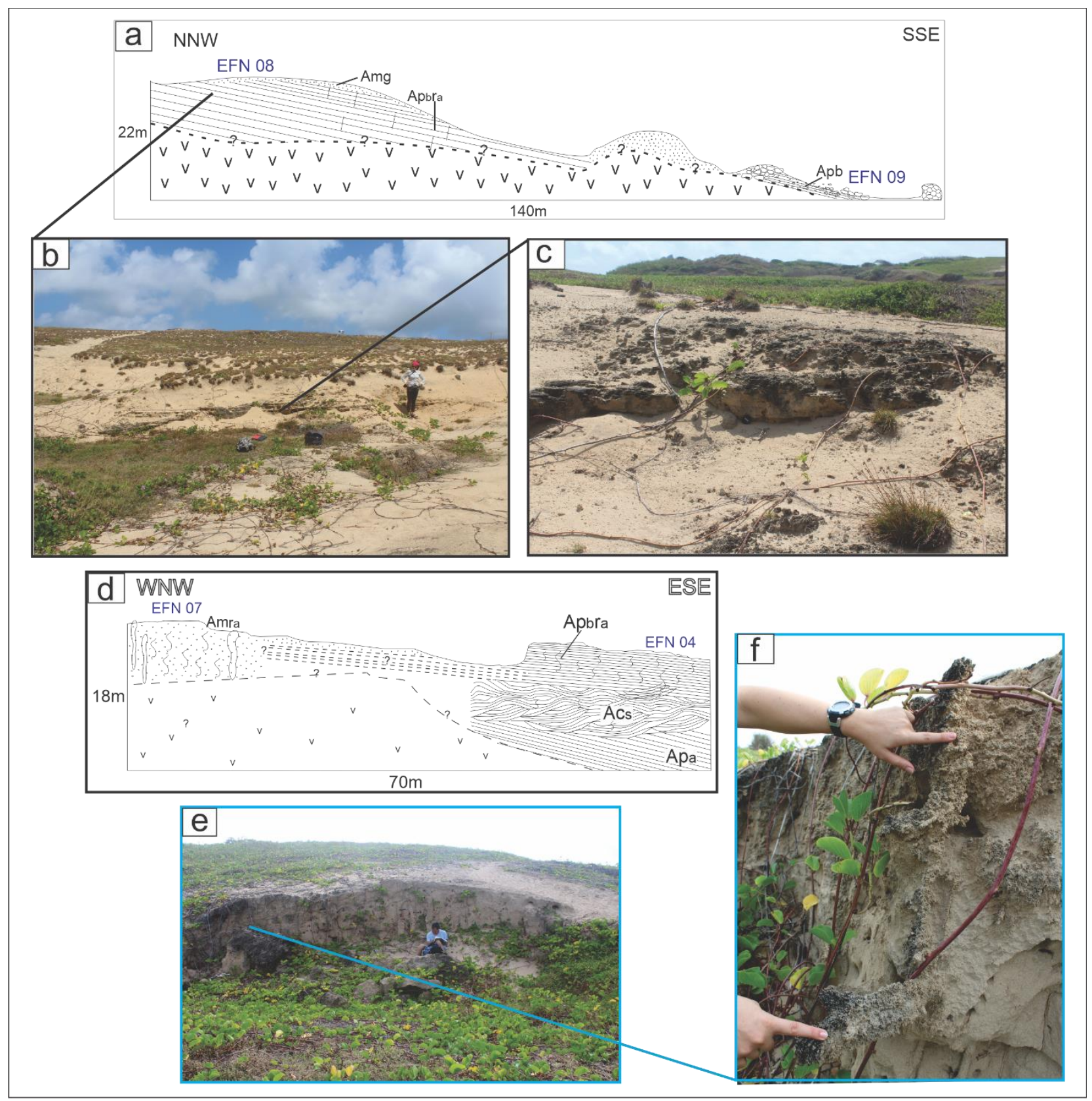

Fig. 5.28. Associações de fácies de eolianitos, em Enseada da Caieira, AFN, seções NNWSSE e WNW-ESSE: a. corte NNW-SSE, com as fácies presentes no ponto EFN 08; b. panorâmica do ponto EFN 08; c. zoom-in da fácies $\mathbf{A p}_{\mathbf{b}} \mathbf{r}_{\mathbf{a}}$; d. corte WNW-ESE, com as fácies representativas dos pontos EFN 07 e EFN 04; e. panorâmica do ponto EFN 07; f. zoom-in na fácies $\mathbf{A m r}_{\mathbf{a}}$. 

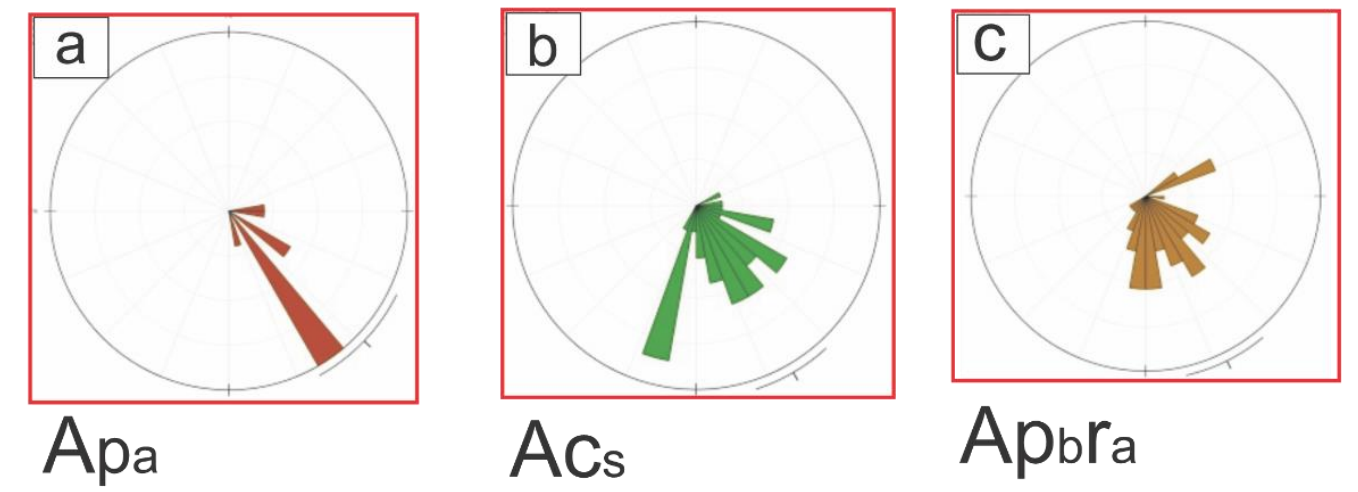

Fig. 5.29. Histogramas circulares de azimutes de mergulho para os eolianitos de Enseada da

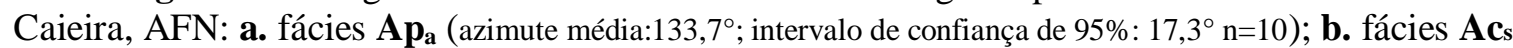
(azimute médio: $149,8^{\circ} ; 95 \%$ confiabilidade: $12,2^{\circ} \mathrm{n}=35$ ); $\mathbf{c}$. fácies $\mathbf{A p}_{\mathbf{b}} \mathbf{r}_{\mathbf{a}}$ (azimute média: $153,7^{\circ} ; 95 \%$ confiabilidade: $\left.13,5^{\circ} ; n=47\right)$.

\subsubsection{Saco de Atalaia}

Localizada na porção sudeste da ilha principal, Atalaia apresenta um paredão de eolianitos, com orientação aproximada S-N (Figs. 5.30a e b). Os depósitos eólicos aparentemente cavalgaram a encosta da rocha vulcânica, cujo caimento é para S. Neste afloramento, observam-se três fácies de espessuras métricas, que fazem entre si contatos laterais ou verticais transicionais (Fig. 5.30c). Da base para o topo, estas fácies são: Aca (Fig. 5.30d), com até cerca de $5 \mathrm{~m}$ de espessura; Acar, com aproximadamente $10 \mathrm{~m}$ de espessura máxima e em que as abundantes rizoconcreções apresentam comprimento centimétrico (Figs. 5.30e e f); e Acs, com até aproximadamente 12m de espessura (Fig. 5.30g). As fácies Aca e Acs foram observadas em contato basal discordante com a rocha piroclástico-vulcânica, enquanto a fácies Acar ocorre preferencialmente sobre Aca (Fig. 5.30d).

Os histogramas circulares de azimutes de cada fácies apresentam padrão unimodal, com tendência em comum para W, mas com variações para SW, na fácies Aca (Figs. 5.31a e b), NW, na fácies Acar (Figs. 5.31c,d e e), e de SW a NW, na fácies Acs (Fig. 31f). 


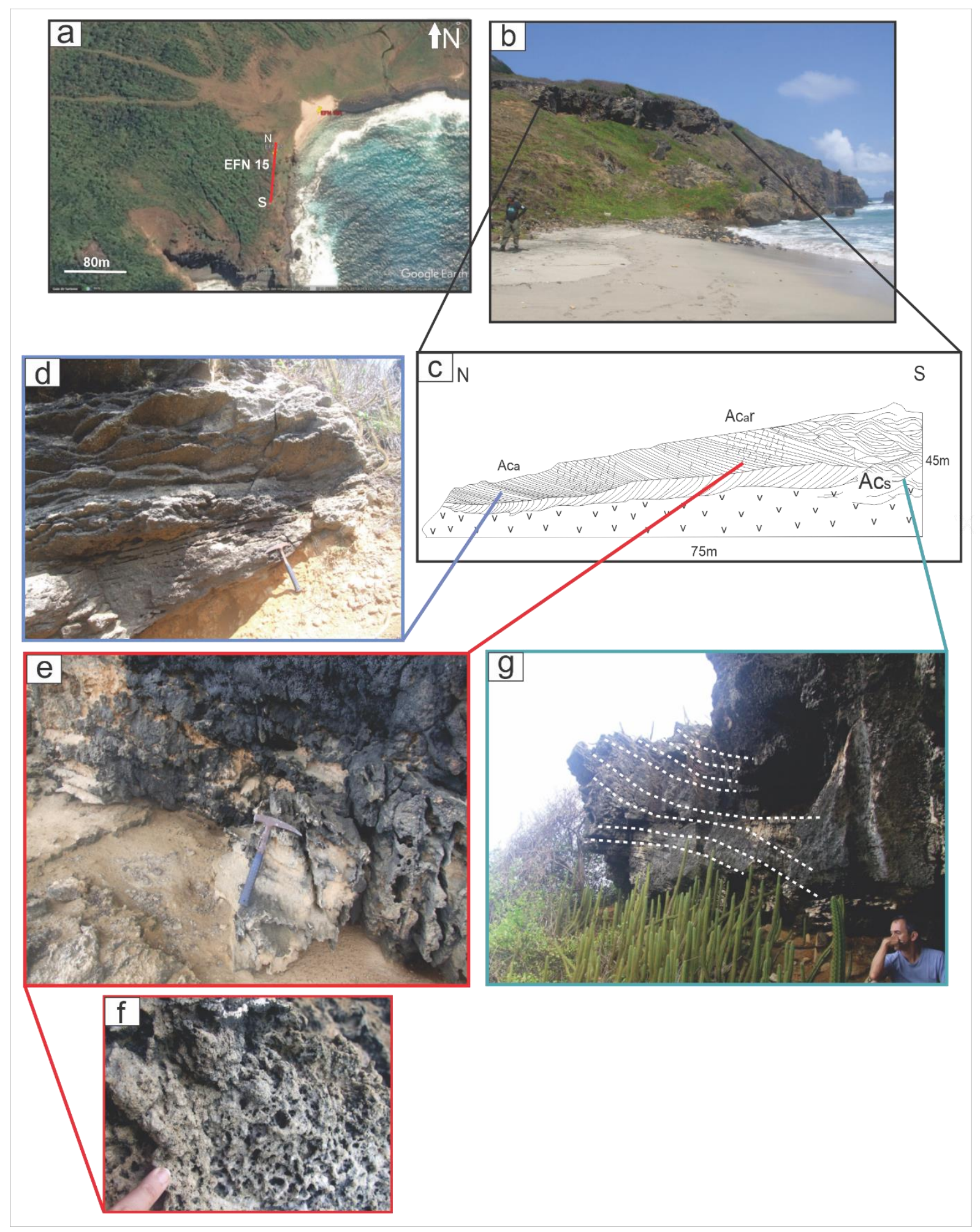

Fig. 5.30. Associação de fácies deposicionais em Atalaia, AFN: a. localização do corte $S-N$; b. panorâmica do afloramento; c. seção esquemática S-N, com as três fácies observadas; d. fácies Aca em contato com a rocha vulcânica; e. fácies Acar; f. detalhe da fácies Acar; g. fácies Acs. 


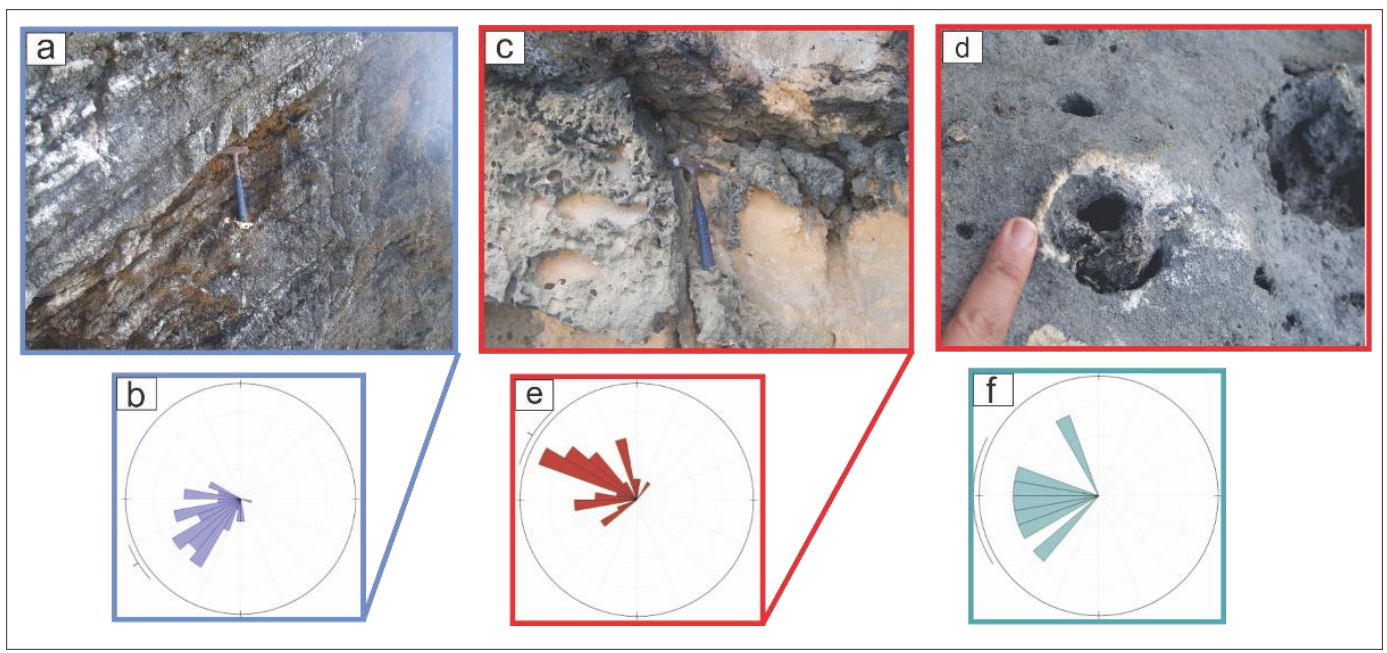

Fig. 5.31. Detalhes de afloramento e histogramas circulares para as fácies de eolianito de Atalaia, AFN: a. fácies Aca; b. histograma circular de azimutes de mergulho da fácies Aca (direção médio: 267,5 ; $95 \%$ confiabilidade: 30,3; n=7); c. fácies Acar; d. zoom-in de rizoconcreções da fácies Acar; e. histograma circular de azimutes de mergulho da fácies Acar (azimute médio: 301,7; intervalo de confiança de 95\%: 15; $\mathrm{n}=28$ ); f. histograma circular de azimutes de mergulho da fácies Acs (azimute médio: 238; $95 \%$ confiabilidade: $9,8^{\circ} ; \mathrm{n}=51$ ).

\subsubsection{Ponta das Caracas}

$\mathrm{Na}$ Ponta das Caracas, encontra-se possivelmente a maior exposição de eolianitos da ilha principal do AFN, com dois afloramentos (NE-SW e NW-SE, conforme Figs. 5.32a e b, 5.33a e b) e três fácies deposicionais: Aca, Acf e Acs. No afloramento NE-SW (Fig. 5.32b) identifica-se a fácies Aca, cujas estratificações cruzadas apresentam geometria piramidal (Fig. 5.32c). Medidas de estratificações cruzadas somente foram possíveis no setor sudoeste do afloramento, onde resultou padrão unimodal rumo W (Fig. 5.32d). A fácies associada sotoposta à Aca é a Rgn. No outro afloramento, SE-NW (Figs. 5.33a e b), a sucessão de fácies transicional observada é Acf, com aproximadamente $12 \mathrm{~m}$ de espessura, na base (Figs. 5.33c e d), seguida acima de Acs, com aproximadamente $8 \mathrm{~m}$ de espessura (Figs. 5.33e e f), esta contendo abundantes rizoconcreções e um sistema de fraturas $\left(285^{\circ} / 57^{\circ} \mathrm{W}\right)$, algumas vezes com cimento sobressalente, indício aparente de percolação preferencial de fluidos (Fig. 5.33g).

O histograma circular de azimutes de mergulho de estratificações obtido na fácies Acf (Fig. 5.33h) apresenta padrão bimodal, com moda principal para SW; já na fácies Acs, a presença ostensiva de rizoconcreções não permitiu tomar medidas de atitude das estratificações. 


\subsubsection{Forte São Joaquim do Sueste}

Em Forte São Joaquim do Sueste, apresenta-se um paredão de eolianitos de aproximadamente $20 \mathrm{~m}$ de altura, aparentemente mais meteorizados do que na Ponta das Caracas, da qual se avizinha $250 \mathrm{~m}$ a SE (Fig. 5.34a). As evidências de intemperismo e erosão intensos, inclusive ao longo de fraturas, são a presença de feições de alteração em torres e ruineformes, no topo do afloramento, e de matacões e blocos angulosos de eolianitos, ao pé do paredão (Figs. 5.34b e c). As fácies observadas são Acs, na base, com séries de estratificações de espessura decimétrica (Fig. 5.34d), e Acf, no topo, com abundantes rizoconcreções, que se observam principalmente na parte superior do afloramento (Figs. 5.34e e f). O histograma circular de azimutes de mergulho de estratos cruzados obtido para a fácies Acs mostra dispersão elevada (intervalo de confiança de 183 graus), com moda principal para NE (Fig.5.34g); já a fácies Acf apresenta histograma circular de azimutes com padrão bimodal, tendo modas para NW e SSE (Fig. 5.34h).
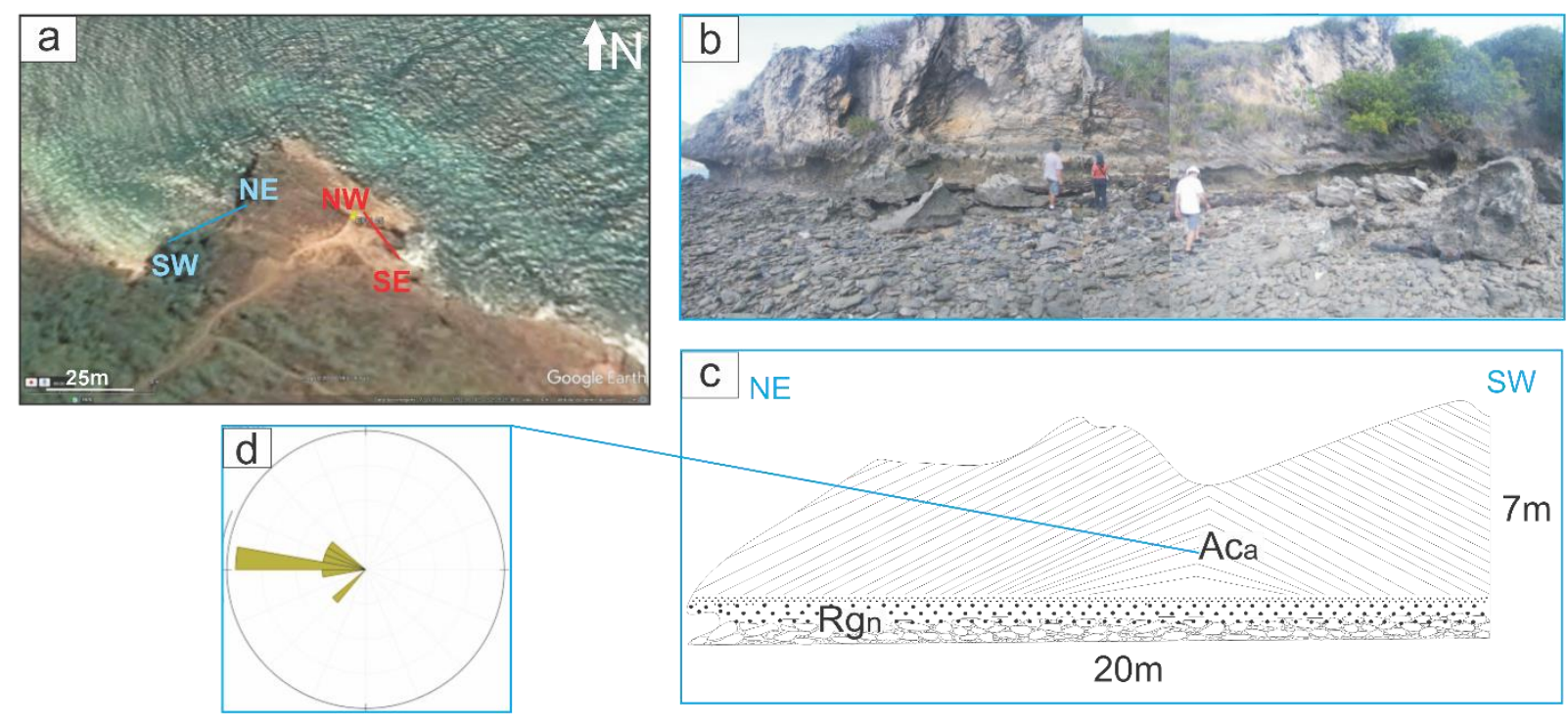

C ${ }_{\mathrm{NE}}$

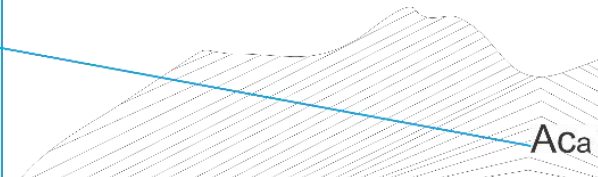

$7 \mathrm{~m}$

Rgn

$20 \mathrm{~m}$

Fig. 5.32. Associação de fácies na Ponta das Caracas, com ênfase na seção NE-SW: a. localização dos dois paredões de afloramento, orientados NE-SW e SE-NW; b. panorâmica do corte NE-SW; c. seção esquemática NE-SW, com a fácies de eolianito Aca sobre a fácies $\mathbf{R g}$; $\mathbf{d}$. histograma circular de azimutes de mergulho da fácies Aca na porção sudoeste do afloramento NE-SW (azimute médio: $275^{\circ}$; intervalo de confiança de $95 \%: 183^{\circ} ; \mathrm{n}=8$ ). 


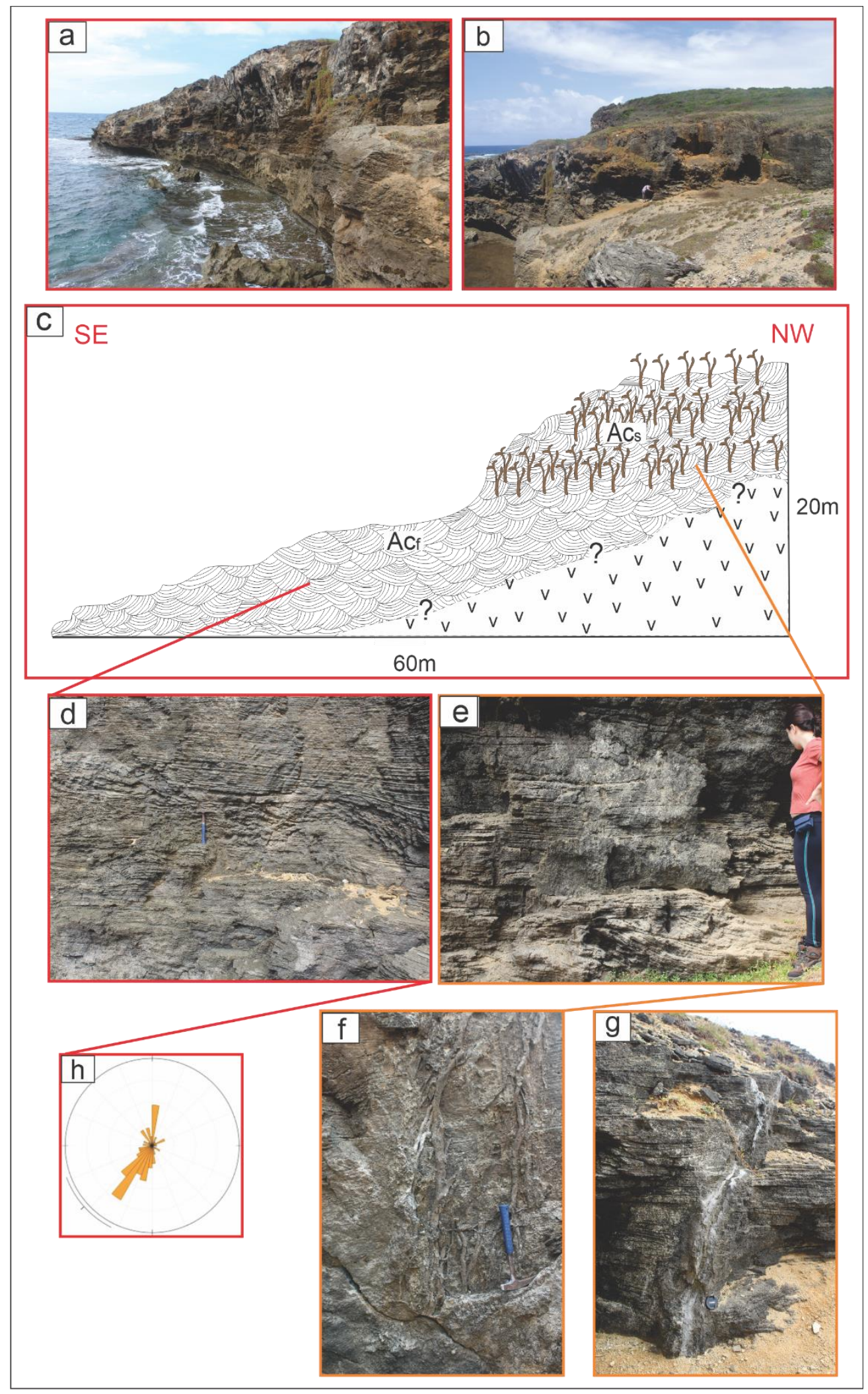

Fig. 5.33. Associação de fácies na Ponta das Caracas, com ênfase na seção SE-NW: a. fotografia panorâmica da base do afloramento SE-NW; b. panorâmica do topo do corte SE-NW; c. corte SE-NW, com as fácies Acf e Acs; d. zoom-in da fácies Acr; e. zoom-in da fácies Acs; f. zoom-in de rizoconcreções na fácies Acs; $\mathbf{g}$. detalhe da fratura com indícios de percolação de fluidos na fácies

Acs; h. histograma circular de azimutes de mergulho da fácies Acr (azimute médio: 228,2; intervalo de confiança de $95 \%: 21,5^{\circ} ; \mathrm{n}=97$ ) 

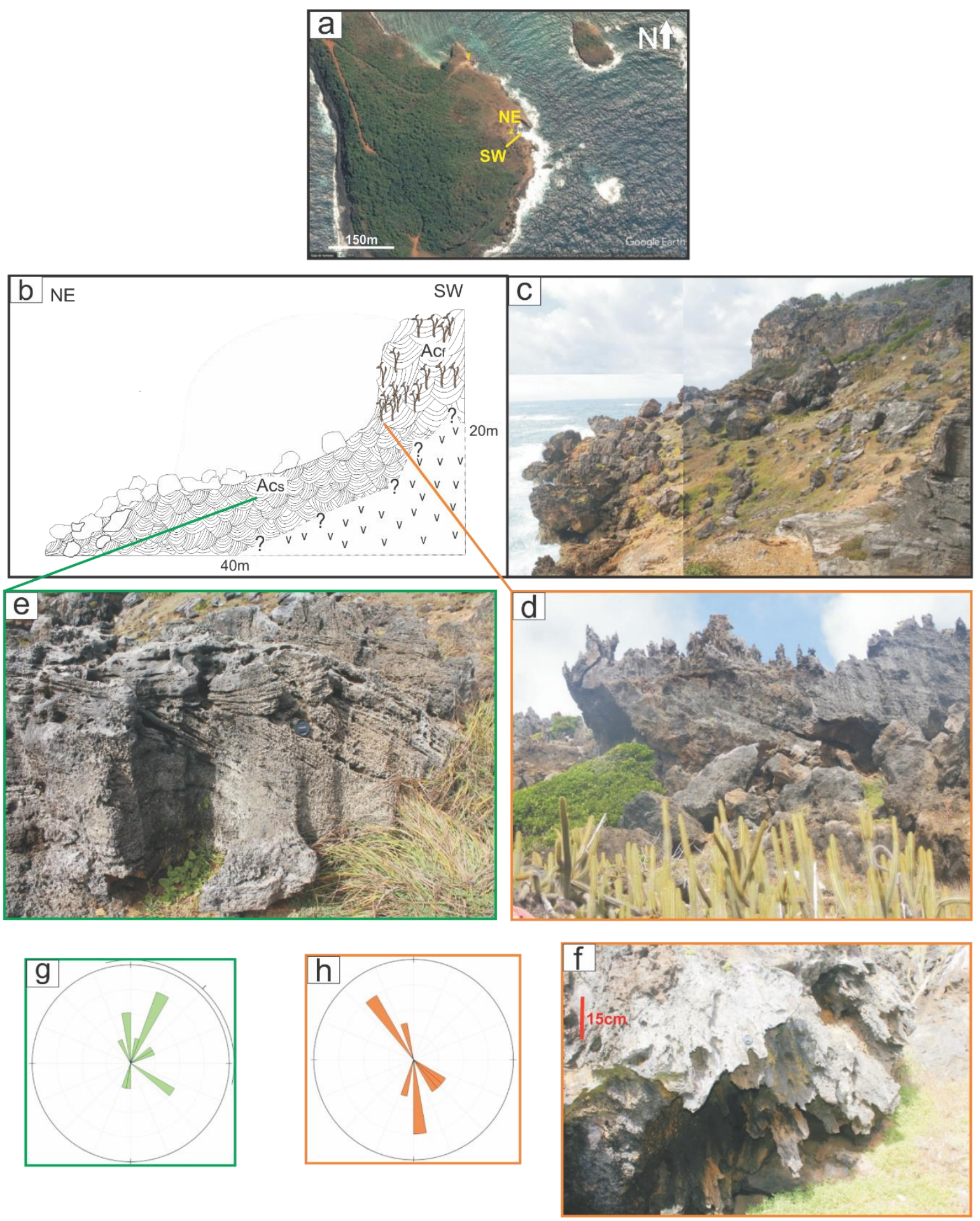

Fig. 5.34. Associação de fácies em Forte de São Joaquim do Sueste: a. localização do corte NE-SW; b. seção esquemática NE-SW, com as fácies presentes; c. panorâmica da área; d. fácies Acs na base do afloramento; e. fácies Acf, no topo do afloramento; f. zoom-in na base da fácies Acf; $\mathbf{g}$. histograma circular de azimutes de mergulho da fácies Acs (azimute médio: $44^{\circ}$; intervalo de confiança de 95\%: 58, $1^{\circ} ; \mathrm{n}=13$ ); h. histograma circular de azimutes de mergulho da fácies Acf (azimute médio:174,1; n=9). 


\subsection{Granulometria}

Analisou-se quanto à granulometria um total de 60 amostras de eolianitos (Apêndice 1), tanto das ocorrências do $\mathrm{RN}$ e do $\mathrm{AFN}$ descritas no item 5.3, quanto das áreas do PI e CE estudadas por Espinel-Arias (2015). Já para a análise gráfica e estatística dos resultados (Figs. 5.35 a 5.39), dessas 59 amostras foram selecionadas 26 de eolianitos continentais correspondentes às quatro áreas geográficas com maior número de coletas em eolianitos da associação de elementos morfológicos planície deflacionária (Macapá - PI, Três Irmãos, Guajiru e Enxu Queimado - RN); e 13 dos eolianitos insulares altos, correspondentes às áreas de Enseada da Caieira, Ponta das Caracas e Atalaia. Os resultados de distribuição granulométrica em massa da fração areia, correspondentes ao material retido nas peneiras em intervalos de 0,5 $\phi$, foram representados em gráficos de linhas, reunidos por área geográfica (Figs. 5.35 a 5.38), e analisados estatisticamente em gráfico de caixa (boxplot), neste caso para o conjunto das 26 amostras de eolianitos continentais (Fig. 5.39) e 12 amostras dos insulares.

\subsubsection{Eolianitos continentais}

As 12 amostras de eolianitos de Macapá apresentam distribuição bimodal nas frações (retidas) 1,0 $\phi$ e 2,5 a 3,0 $\phi$ (Fig. 5.35); as seis amostras de Três Irmãos possuem moda principal em 1,0 $\phi$ e moda subordinada entre 2,0 $\phi$ e 2,5 $\phi$, com tendência para decréscimo nas frações mais finas (Fig. 5.36); as quatro amostras de Guajiru mostram padrão bimodal similar ao de Macapá, porém com modas de 1,0 $\phi$ muito mais pronunciada que a de 2,5 $\phi$ (Fig. 5.37); finalmente, das quatro amostras de Enxu Queimado, três apresentam moda na classe 2,5 $\phi$ e uma na 1,0 $\phi$ (Fig. 5.38). Já o gráfico boxplot para todo o conjunto de amostras de planície deflacionária (Fig. 5.39) reforça a tendência para domínio das frações $1,0 \phi$ e 2,5 $\phi$, que são também as que apresentam maior variabilidade, expressa tanto na amplitude de variação total (bigodes) quanto na extensão do intervalo interquartis (caixa). 


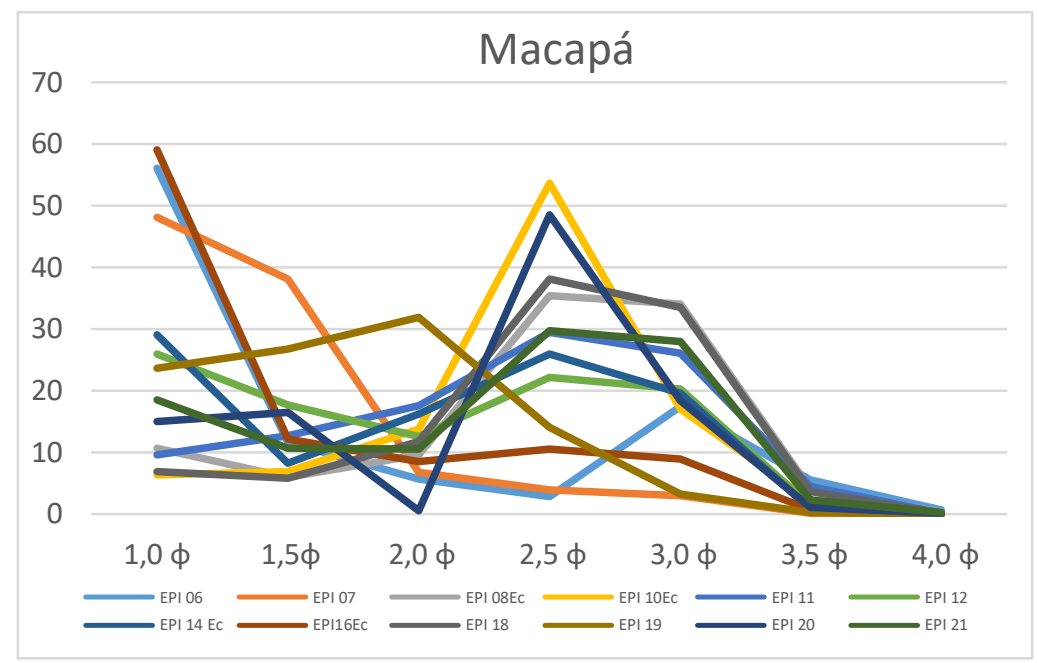

Fig. 5.35. Gráficos de densidade de distribuição granulométrica retida da fração areia para as amostras de eolianito de Macapá, PI.

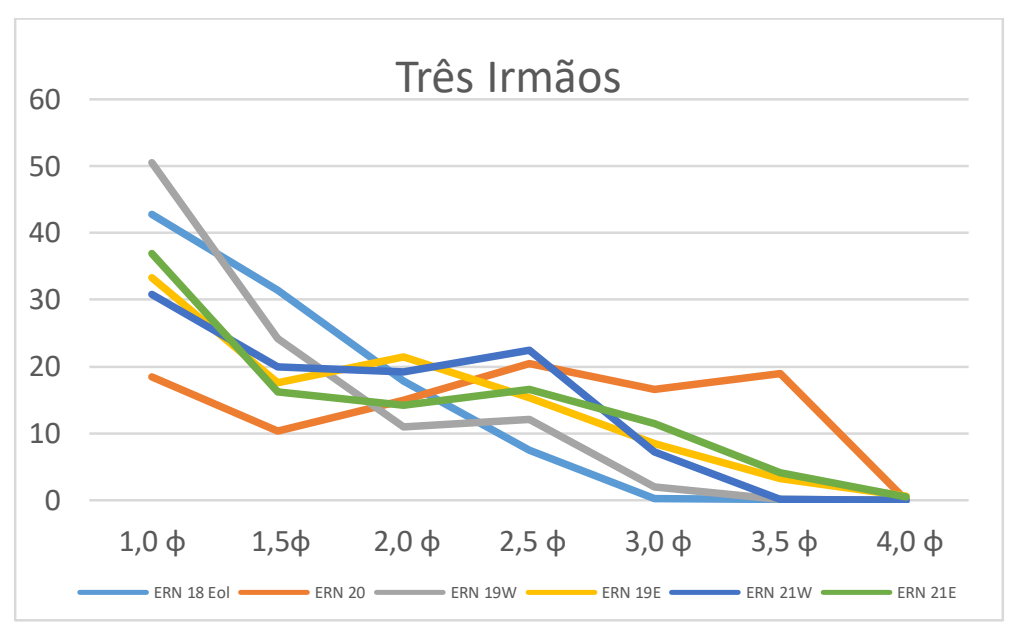

Fig. 5.36. Gráficos de densidade de distribuição granulométrica retida da fração areia para as amostras de eolianito de Três Irmãos, RN.

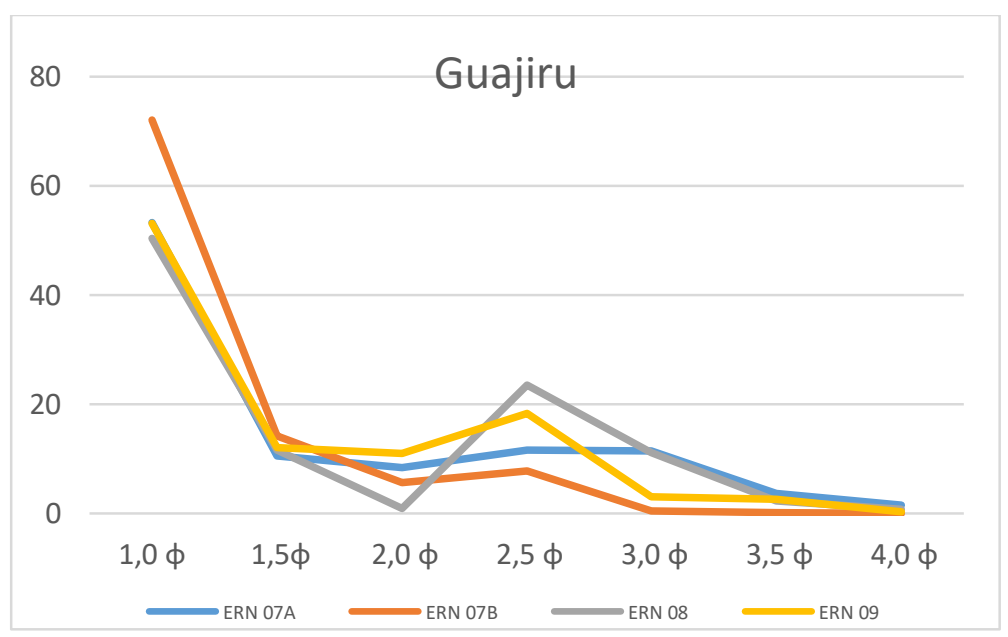

Fig. 5.37. Gráficos de densidade de distribuição granulométrica retida da fração areia para as amostras de eolianito de Guajiru, RN. 


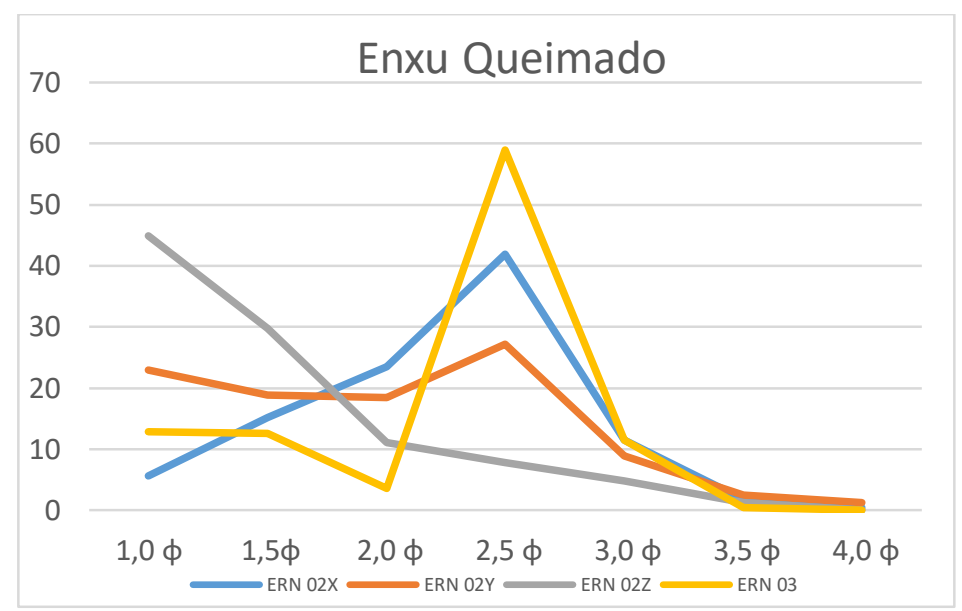

Fig. 5.38. Gráficos de densidade de distribuição granulométrica retida da fração areia para as amostras de eolianito de Enxu Queimado, RN.

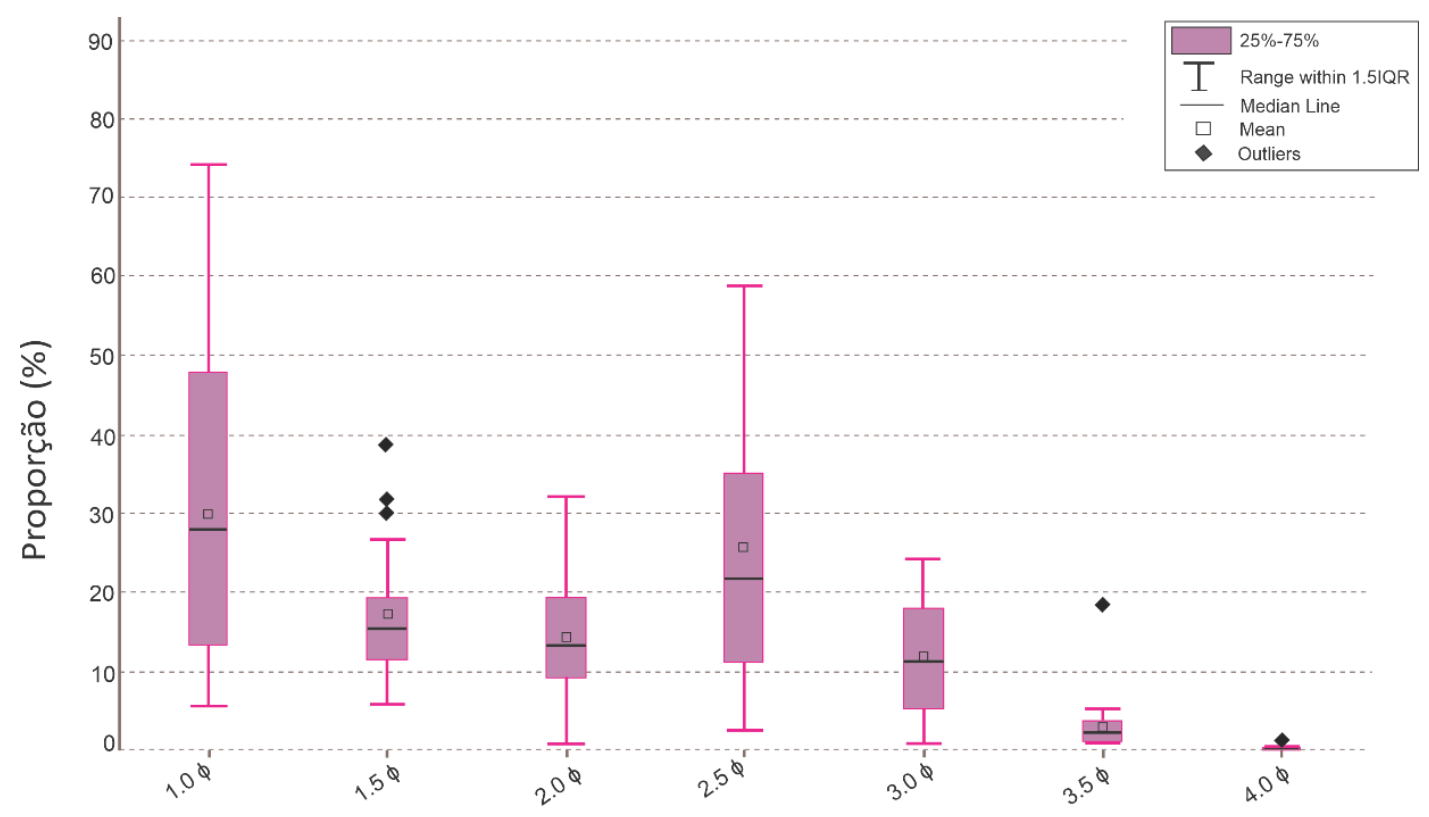

Fig. 5.39. Variação das proporções das frações granulométricas retidas de areia, para o conjunto de amostras de planície deflacionária das quatro áreas selecionadas para análise (Macapá, Guajiru, Três Irmãos e Enxu Queimado: Figs. 5.35 a 5.38). Nota-se tendência para domínio das frações $1,0 \phi$ e $2,5 \phi$.

\subsubsection{Eolianitos insulares}

As cinco amostras de eolianito de Enseada da Caieira apresentam uma moda principal, na fração 2,5 $\phi$ (Fig. 5.40), enquanto as de Ponta das Caracas e Atalaia, com quatro amostras cada, possuem padrão bimodal em 1,0 $\phi$ e 2,5 $\phi$, com tendência para decréscimo nas frações mais finas (Figs. 5.41 e 5.42), sendo que, em Atalaia, a moda de 1,0 $\phi$ é muito mais acentuada 
que a de 2,5 ф. Já o gráfico boxplot para todo o conjunto de amostras de eolianitos altos (Fig. 5.43) reforça a tendência para domínio das frações $1,0 \phi$ e 2,5 $\phi$, com grande amplitude tanto na variação total (bigodes) quanto na extensão do intervalo interquartis (caixa).

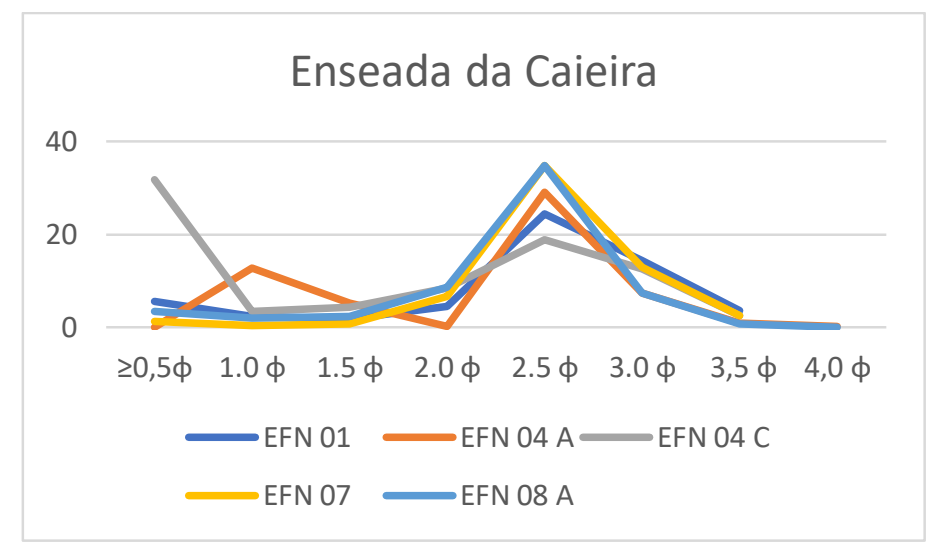

Fig. 5.40. Gráficos de densidade de distribuição granulométrica retida da fração areia para as amostras de eolianito de Enseada da Caieira, AFN

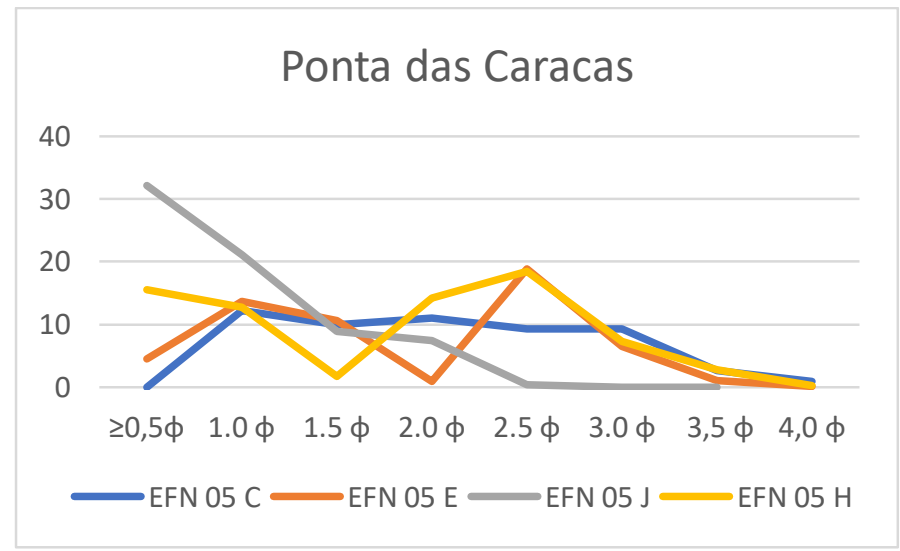

Fig. 5.41. Gráficos de densidade de distribuição granulométrica retida da fração areia para as amostras de eoloanito de Ponta das Caracas, AFN.

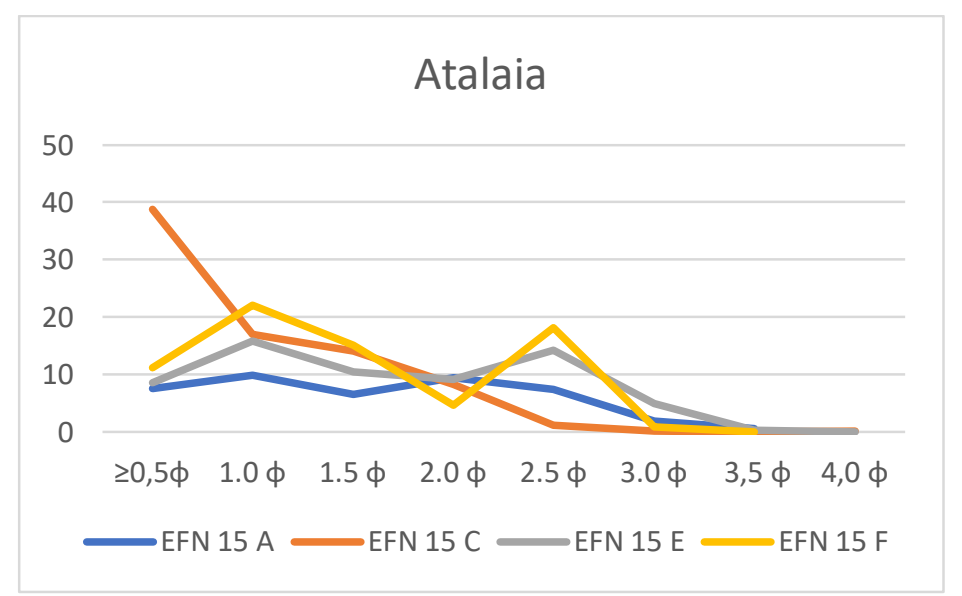

Fig. 5.42. Gráficos de densidade de distribuição granulométrica retida da fração areia para as amostras de eolianito de Atalaia, AFN. 


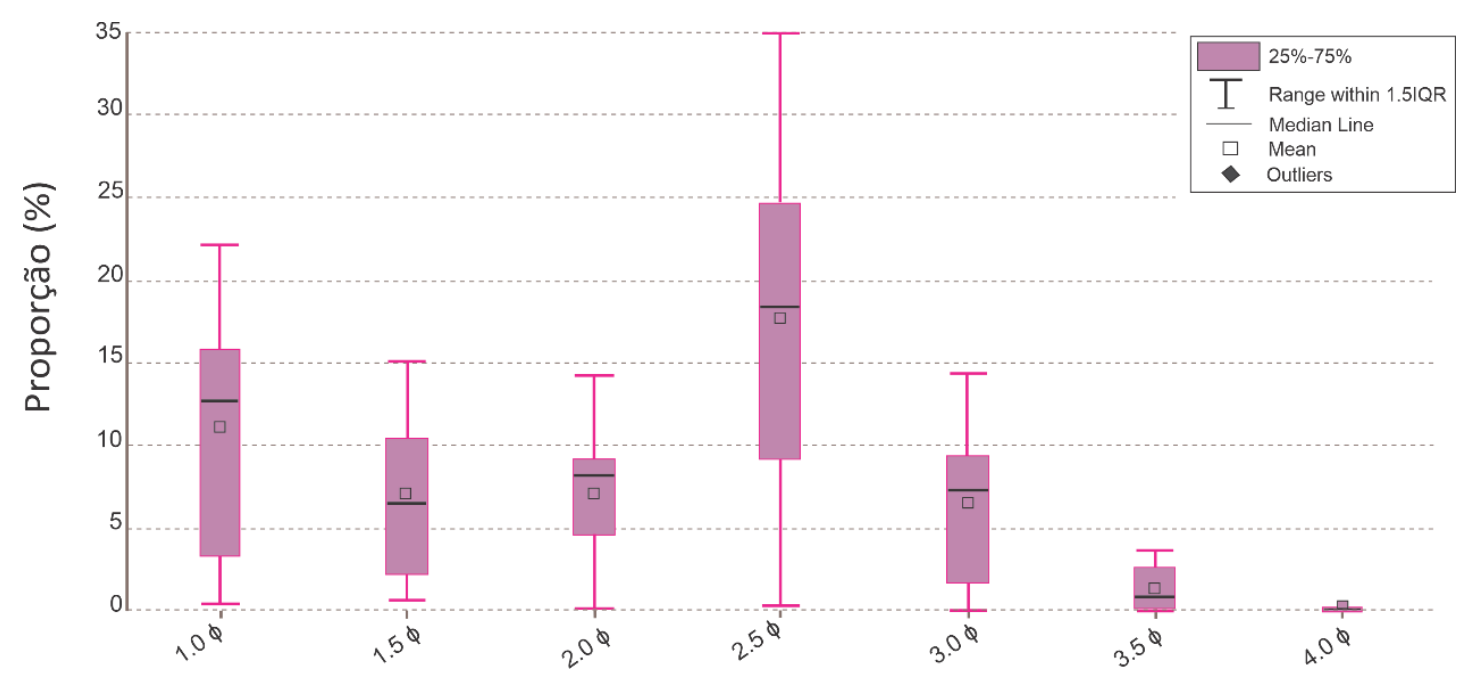

Fig. 5.43. Variação das proporções das frações granulométricas retidas de areia, para o conjunto de amostras de eolianitos altos, das áreas selecionadas para análise (Enseada da Caieira, Ponta das Caracas, e Atalaia: Figs. 5.34 a 5.37). Nota-se tendência para domínio das frações 1,0 $\phi$ e, principalmente, $2,5 \Phi$.

\subsection{Proporção de Bioclastos por Casse Granulométrica}

Cada uma das classes de areia de 0,5 $\phi$, no intervalo entre 1,0 $\phi$ e 3,0 $\phi$, obtidas por peneiramento das 26 amostras de eolianitos continentais de planície deflacionária referidas no subitem anterior, foi submetida, na lupa estereoscópica, à estimativa visual da proporção de bioclastos. A finalidade foi verificar se eventuais concentrações preferenciais de bioclastos carbonáticos em frações granulométricas majoritárias na planície de deflação (normalmente mais grossas que o restante do sistema eólico) ajudam a explicar a formação de eolianitos nessa associação de elementos morfológicos dos sistemas continentais.

Os eolianitos de Macapá apresentam tendência para maiores proporções de bioclastos na fração 2,0 $\phi$, variando de 10 a 35\% (Fig. 5.44); já em Três Irmãos, das seis amostras analisadas apenas as duas mais ricas em bioclastos (ERN18 e ERN21W) mostram tendência para concentração nas frações 1,5 $\phi$ e 2,0 $\phi$ (Fig. 5.45); em Guajiru, as frações com maior concentração de bioclastos variam entre 2,0 ф e 3,0 ф (Fig. 5.46); e em Enxu Queimado, os eolianitos não apresentam tendências bem definidas de concentração de bioclastos por classe granulométrica (Fig. 5.47). 


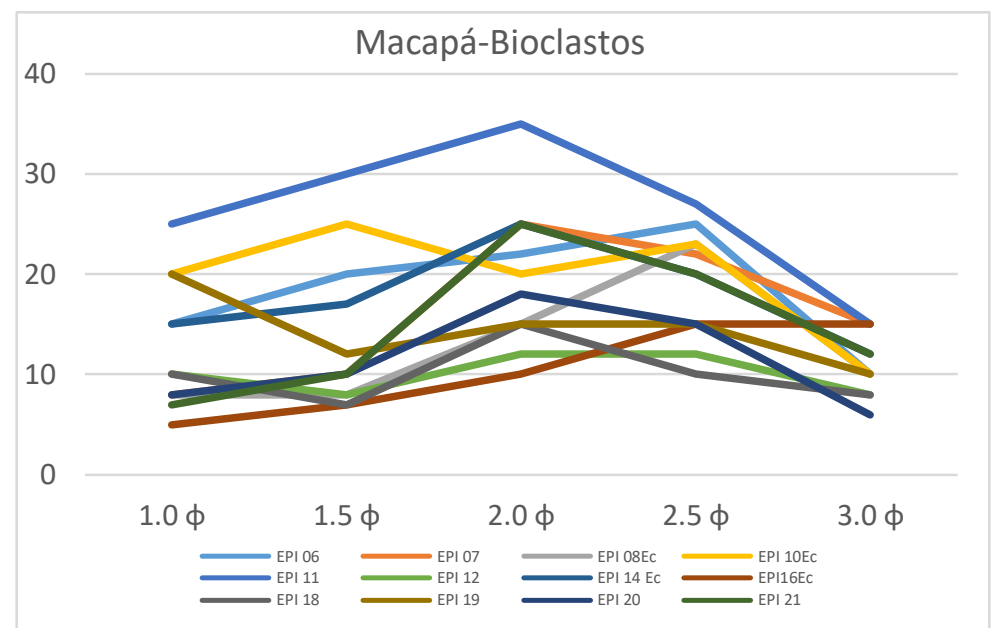

Fig. 5.44. Variação do teor estimado de bioclastos por fração granulométrica das amostras de eolianito de Macapá, PI.

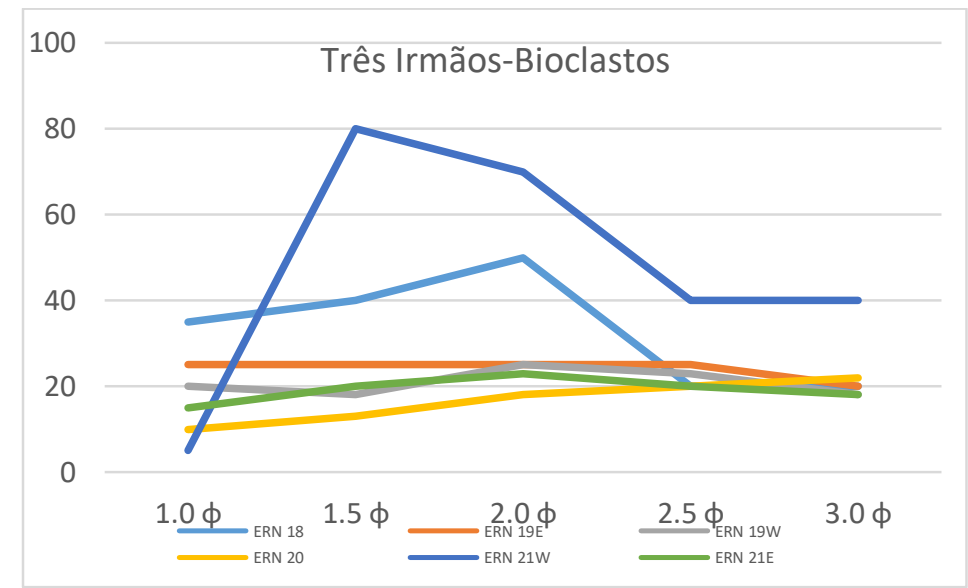

Fig. 5.45. Variação do teor estimado de bioclastos por fração granulométrica retida das amostras de eolianito de Três Irmãos, RN.

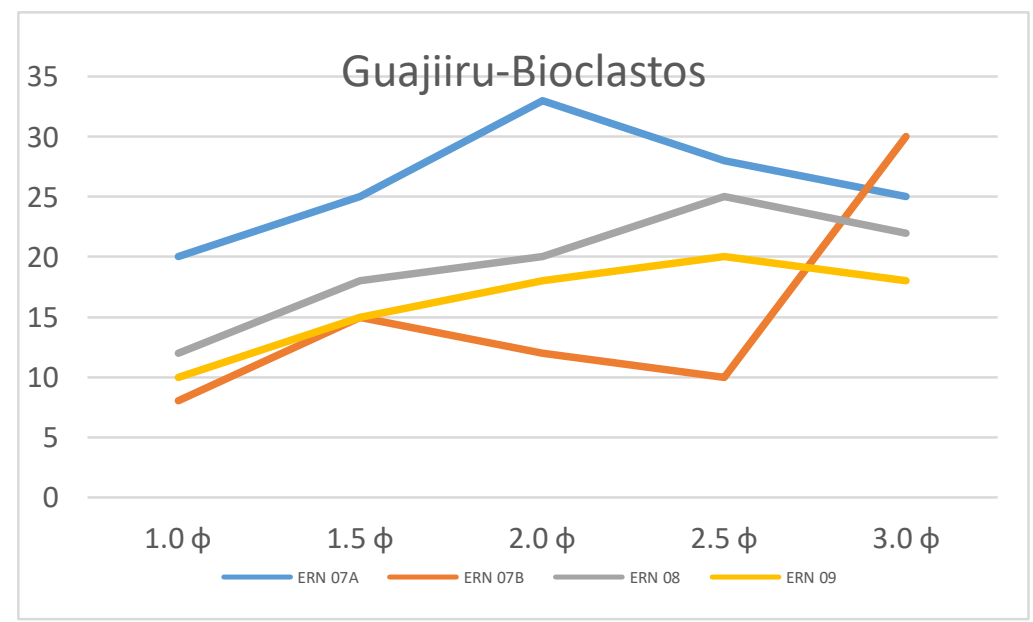

Fig. 5.46. Variação do teor estimado de bioclastos por fração granulométrica retida das amostras de eolianito de Guajiru, RN. 


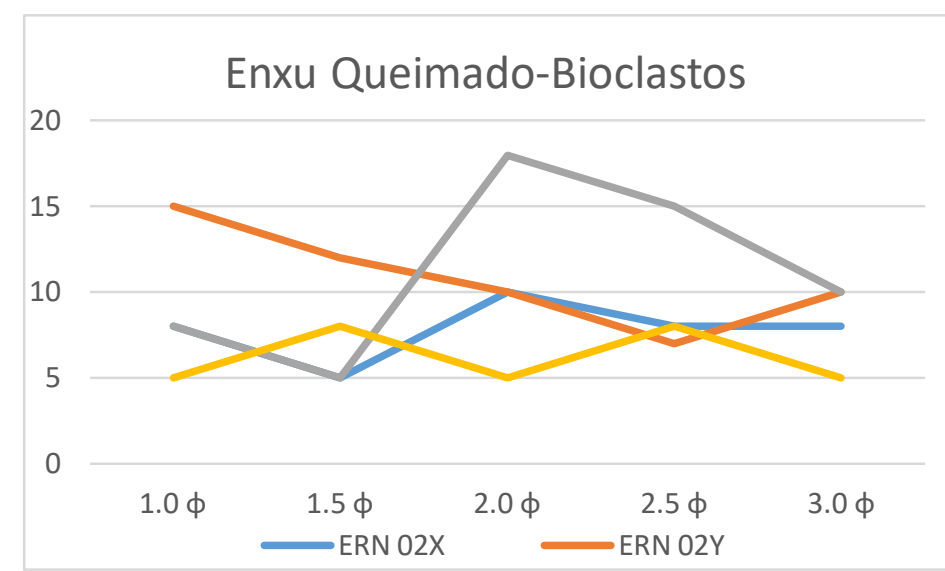

Fig. 5.47. Variação do teor estimado de bioclastos por fração granulométrica retida das amostras de eolianito de Enxu Queimado, RN.

Quando se comparam os gráficos de distribuição granulométrica de bioclastos carbonáticos nos eolianitos continentais de planície deflacionária (Figs. 5.44 a 5.47) com os gráficos de distribuição granulométrica total nos mesmos eolianitos (Figs. 5.35 a 5.38), observa-se que as modas granulométrica da distribuição total, correspondentes ao material retido em 1,0 $\phi$ (areia muito grossa) e em 2,5 $\phi$ (areia fina), não são, na maioria dos casos, bem representadas em carbonato bioclástico. Observa-se também que a moda de bioclastos mais comum é o retido em $2,0 \phi$ (areia média).

\subsection{Datações}

Neste item, apresentam-se resultados de 71 datações, das quais 56 foram feitas por ${ }^{14} \mathrm{C}$ AMS (Apêndice 6) e 15 por LOE-SAR (Apêndice 7). Das datações por ${ }^{14} \mathrm{C}, 38$ referem-se a amostras coletadas no $\mathrm{AFN}$, enquanto as outras 18 pertencem às quatro diferentes áreas do $\mathrm{RN}$; já as datações por luminescência são todas de amostras do RN.

\subsubsection{Rio Grande do Norte}

As 15 datações por luminescência no RN (Tabela 3) permitem reconhecer três grupos de idades; o primeiro, entre 86,3 ka e 40,5 ka, é observado em Três Irmãos (amostras ERN 18 até ERN 21E, na Fig. 5.48), com uma amostra saturada (ERN 21W, com idade mínima de 119.6ka); o segundo, de 3,1 até 1,3 ka, foi encontrado nas regiões de Enxu Queimado e Guajiru 
(Tabela 3); e o terceiro, que com idades entre 92 e 9 anos pode ser considerado subatual, foi observado em afloramentos de Guajiru e Praia do Marco (Tabela 3, Fig. 5.49).

As 18 datações por ${ }^{14} \mathrm{C}$ também se agrupam em três intervalos de idades, só que com limites diferentes: entre 30,8 e 19,3 ka cal AP, em Três Irmãos (Tabela 3, Fig. 5.48); entre 7,0 e 0,9 ka cal AP (Fig. 5.49), em afloramentos de Enxu Queimado, Guajiru e Praia do Marco; e entre 0,6 e 0,1 ka cal AP, em Guajiru (Fig. 5.49). Destas 18 datações, uma (ERN 19E) referese à rocha total, outra (ERN 06B) a bioclastos e as 16 restantes provêm de oito amostras pareadas bioclasto - cimento, observando-se em duas delas (ERN 03 e ERN 21E) inversão de idades, isto é, bioclasto mais novo que cimento (Tabela 3).

Na área de Três Irmãos (amostras ERN 18, ERN 19E e ERN 21E), as idades obtidas por ${ }^{14} \mathrm{C}$ são entre 28 e 49 mil anos mais novas que as obtidas por LOE nos mesmos afloramentos (Tabela 3, Fig.5.48); já nas demais áreas do RN, em que as datações incidem todas no Holoceno, as idades LOE são na maioria dos casos mais novas que a idade ${ }^{14} \mathrm{C}$ do bioclasto e/ou mais velhas que a idade ${ }^{14} \mathrm{C}$ do cimento (Tabela 3, Fig. 5.49). Observam-se, no conjunto de idades holocenas, dois agrupamentos: de 7,0 a 4,7 ka; e inferiores a 3,1 ka. Nota-se também que, dentre estas amostras holocenas, as idades de cimento são iguais ou mais novas que 2,1 ka (Fig. 5.48). 
Tabela 3. Datações por LOE-SAR e ${ }^{14} \mathrm{C}$ AMS obtidas para as áreas do Rio Grande do Norte. Amostras listadas por área geográfica, de acordo com a numeração de campo.

\begin{tabular}{|c|c|c|c|c|c|}
\hline Amostra & $\begin{array}{c}\text { Fácies } \\
\text { deposicio } \\
\text { nal / } \\
\text { área }\end{array}$ & $\begin{array}{c}\begin{array}{c}\text { Idade } \\
\text { de }\end{array} \\
\text { cimento } \\
\text { (anos cal } \\
\text { AP) } \\
\end{array}$ & $\begin{array}{c}\text { Idade }^{14} \mathrm{C} \\
\text { de } \\
\text { bioclasto } \\
\text { (anos cal } \\
\text { AP) } \\
\end{array}$ & $\begin{array}{c}\text { Idade } \\
\text { LOE } \\
\text { (anos) }\end{array}$ & $\begin{array}{l}\text { Erro LOE } \\
\quad \text { (anos) }\end{array}$ \\
\hline ERN 02E & \multirow{4}{*}{$\begin{array}{c}\text { Acbra/ } \\
\text { Enxu } \\
\text { Queimad } \\
\text { o }\end{array}$} & & & 1479 & 160 \\
\hline ERN 02C & & $1718-1950$ & $6907-7034$ & 2224 & 236 \\
\hline ERN 02W & & & & 2877 & 272 \\
\hline ERN 03 & & $2002-2158$ & $494-540$ & & \\
\hline ERN 06A & \multirow{2}{*}{$\begin{array}{c}\text { Acb / } \\
\text { Praia do } \\
\text { Marco } \\
\end{array}$} & & & 82 & 10 \\
\hline ERN 06B & & & $2309-2384$ & 80 & 11 \\
\hline ERN 07A & $\begin{array}{c}\text { Acb / } \\
\text { Guajiru }\end{array}$ & & & 67 & 7 \\
\hline ERN 07B & $\begin{array}{c}\text { Acbf / } \\
\text { Guajiru }\end{array}$ & & & 47 & 5 \\
\hline ERN 08 & $\begin{array}{c}\text { Acbf/ } \\
\text { Guajiru }\end{array}$ & $113-136$ & $2953-3083$ & 14 & 5 \\
\hline ERN 09 & \multirow{3}{*}{$\begin{array}{l}\text { Acbra / } \\
\text { Guajiru }\end{array}$} & $1287-1364$ & $6173-6279$ & 2594 & 296 \\
\hline ERN 14 & & $578-652$ & $4612-4767$ & & \\
\hline ERN 17 & & $932-1013$ & $5851-5939$ & & \\
\hline ERN 18 & \multirow{7}{*}{$\begin{array}{c}\text { Acbra / } \\
\text { Três } \\
\text { Irmãos }\end{array}$} & $19256-19716$ & $25694-26085$ & 65215 & 10327 \\
\hline ERN 19E & & \multicolumn{2}{|c|}{$26610-27442$ (rocha total) } & 76825 & 9463 \\
\hline ERN 19W & & & & 54674 & 5746 \\
\hline ERN 20 & & & & 49702 & 9234 \\
\hline ERN 21E & & $30825-31265$ & $26802-27440$ & 59429 & 6519 \\
\hline ERN 21W & & & & 57836 & 6140 \\
\hline ERN 21Wsat & & & & 119626 & 10040 \\
\hline
\end{tabular}




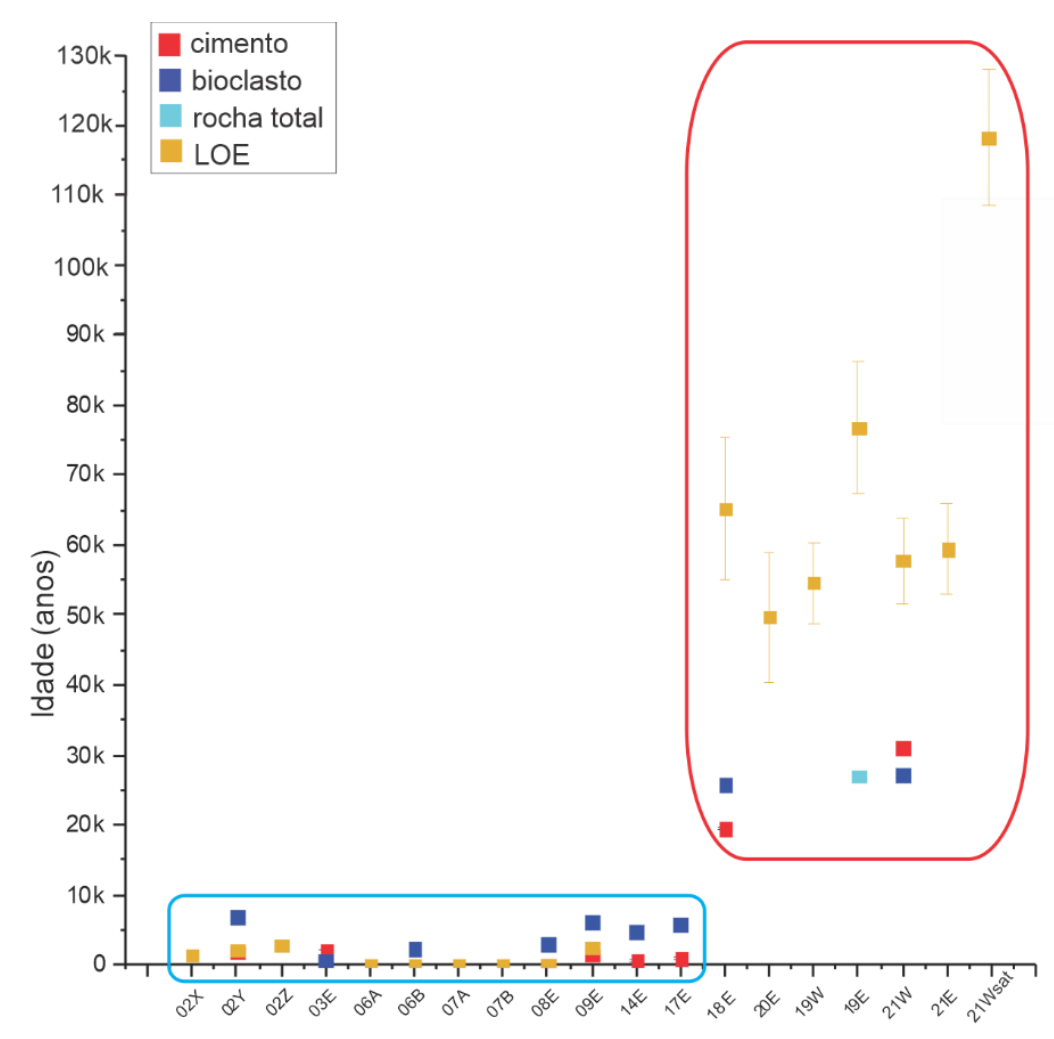

Fig. 5.48. Distribuição por amostra das idades em eolianitos do Rio Grande do Norte. Notar dois grupos principais de idades, destacados pelos retângulos. O grupo mais novo, por sua vez, pode ser subdividido em pelo menos dois conjuntos de idades (mostrados na Fig. 5.44).

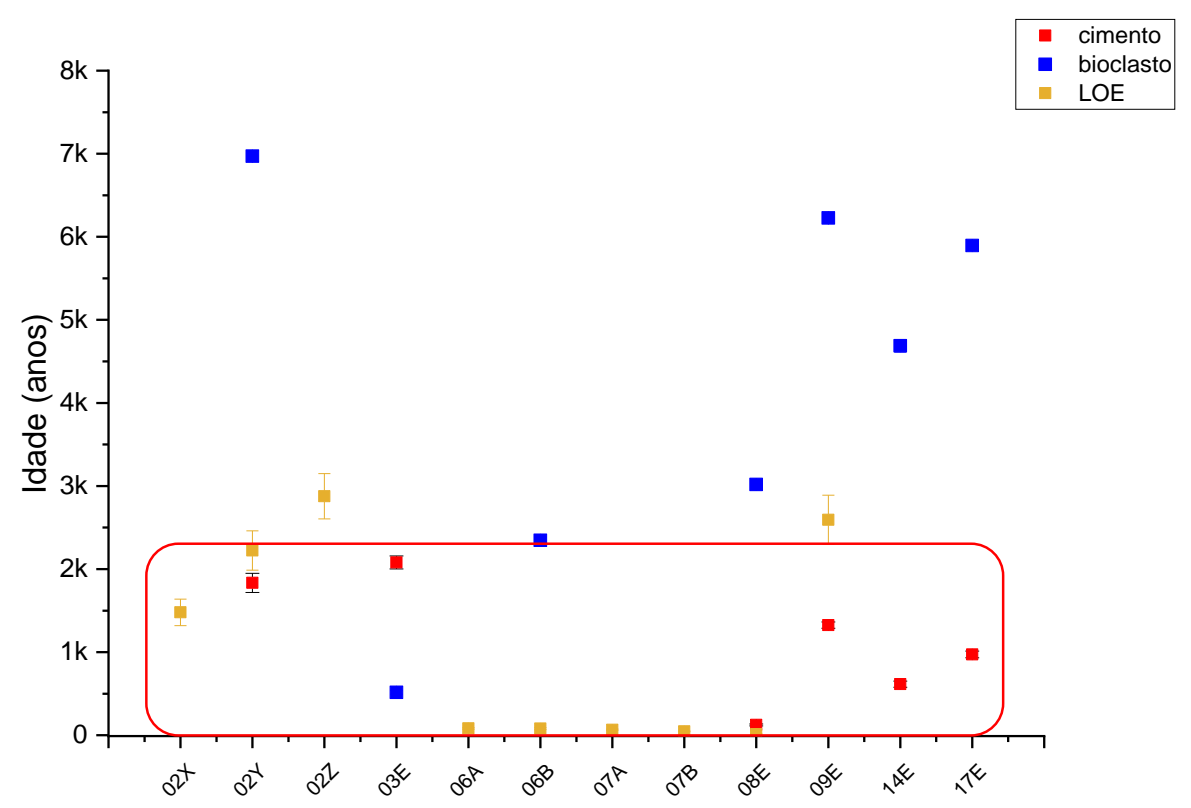

Fig. 5.49. Distribuição por amostra das idades medianas mais novas que $7,0 \mathrm{ka}$ em eolianitos do Rio Grande do Norte. Notem-se dois grupos de idades, separados por intervalo sem datações entre 4,7 e 3,1 ka. Note-se também que as datações de cimentos estão contidas no intervalo entre 2,1 e 0 ka, ressaltado pelo retângulo. 
A comparação estatística, via boxplot, mostra diferença significativa entre as distribuições de idades obtidas em fácies deposicionais com e sem rizoconcreções (Fig. 5.50). Enquanto o intervalo interquartis dos eolianitos com rizoconcreções estende-se amplamente, de $\sim 32 \mathrm{ka} \mathrm{a} \sim 2 \mathrm{ka}$, o dos eolianitos sem rizoconcreções restringe-se aos últimos 1000 anos.

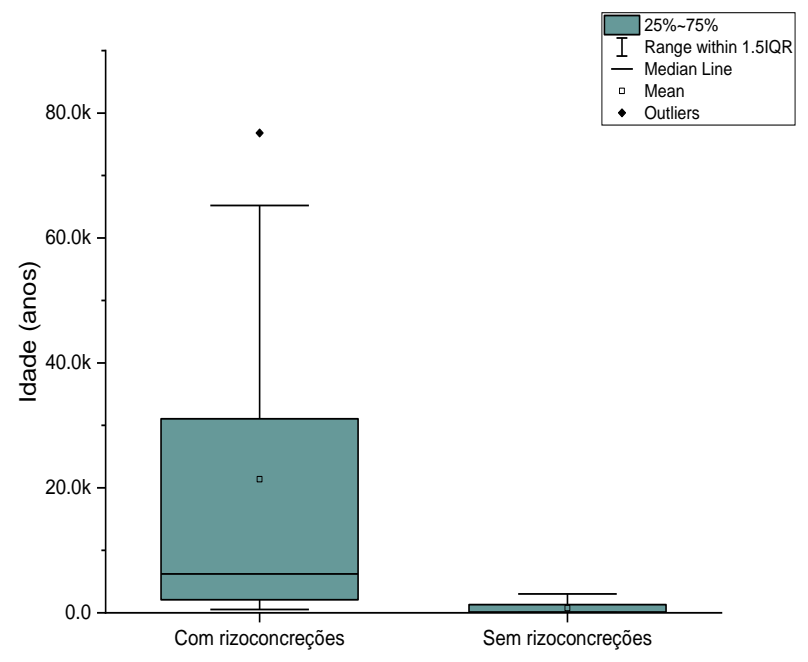

Fig. 5.50. Gráfico boxplot das datações por fácies com rizoconcreções $(n=13)$ e sem rizoconcreções $(\mathrm{n}=5)$, em eolianitos do Rio Grande do Norte.

Histogramas de distribuição de frequências de idades em eolianitos do RN, agrupadas em intervalos de classe de 5 mil anos (Fig. 5.46), evidenciam maior concentração de idades entre 5 e 0 ka, com mais de $50 \%$ do total de ocorrências; $67 \%$ das idades obtidas incidem no Holoceno. Intervalos mais antigos reúnem, cada um, menos de $10 \%$ das ocorrências e são representados exclusivamente nos afloramentos de Três Irmãos.
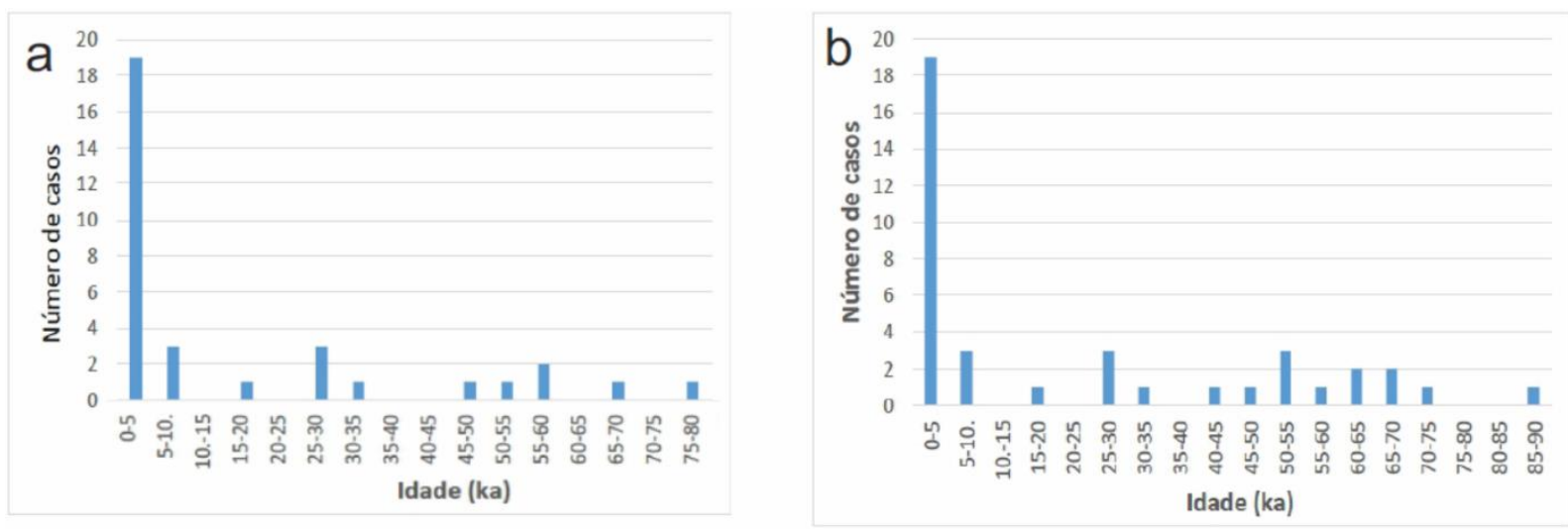

Fig. 5.51. Histogramas de distribuição de frequências de idades em eolianitos do Rio Grande do Norte, agrupadas em intervalos de classe de 5 mil anos: a. sem considerar a margem de erro da datação; b. considerando a margem de erro da datação. 


\subsubsection{Arquipélago de Fernando de Noronha}

As 38 datações ${ }^{14} \mathrm{C}$ realizadas nas 22 amostras de eolianitos do AFN selecionadas apresentam duas modas de idades: de 46,1 a 22,1 ka e entre 18,2 e 5,3 ka cal AP (Tabela 4). Estas 38 idades disponíveis correspondem a oito amostras datadas em rocha total e mais 15 amostras pareadas em cimentos e bioclastos.

Das amostras pareadas, duas (EFN 06B e EFN 15A) exibiram relação esperada de idades entre bioclastos e cimentos, isto é, bioclasto mais antigo que cimento, e as outras 13 $(87 \%)$ mostraram aparente inversão nesta relação, à semelhança do verificado em Três Irmãos (amostra ERN 21E: Tabela 3).

Tabela 4. Datações por ${ }^{14} \mathrm{C}$-AMS obtidas para as áreas de Fernando de Noronha.

\begin{tabular}{|c|c|c|c|c|}
\hline Amostra & $\begin{array}{c}\text { Fácies } \\
\text { deposicional / área }\end{array}$ & $\begin{array}{c}\text { Idade }{ }^{14} \mathrm{C} \text { de } \\
\text { cimento (anos } \\
\text { cal } \mathrm{AP} \text { ) } \\
\end{array}$ & $\begin{array}{c}\text { Idade }{ }^{14} \mathrm{C} \text { de } \\
\text { bioclasto } \\
(\text { anos cal } \mathbf{A P}) \\
\end{array}$ & $\begin{array}{c}\text { Idade }{ }^{14} \mathrm{C} \mathrm{de} \\
\text { rocha total } \\
(\text { anos cal AP) } \\
\end{array}$ \\
\hline EFN $02 \mathrm{~F}$ & Acar / Bigorna & & & $11182-11351$ \\
\hline EFN $03 \mathrm{C}$ & Acar / I. Rasa & $15279-15716$ & $13918-14250$ & \\
\hline EFN 04 B & Apa / Caieira & $18295-18663$ & $8152-8318$ & \\
\hline EFN 05 B & \multirow{2}{*}{ Aca / Caracas } & & & $14202-14961$ \\
\hline EFN $05 \mathrm{C}$ & & $24253-25061$ & $23640-24286$ & \\
\hline EFN $05 \mathrm{E}$ & \multirow{2}{*}{ Acf / Caracas } & $34132-34697$ & $28697-29224$ & $28183-29020$ \\
\hline EFN $05 \mathrm{~F}$ & & & & $30793-31406$ \\
\hline EFN $05 \mathrm{H}$ & Acs / Caracas & $40162-42255$ & $38333-40483$ & \\
\hline EFN $05 \mathrm{~J}$ & Acf / Caracas & $40879-42732$ & $32266-33705$ & \\
\hline EFN $06 \mathrm{~B}$ & Acs / Forte S.J. & $31316-32734$ & 34710 - 36929 & \\
\hline EFN 07 & Amra / Caieira & $17104-17559$ & $9262-9469$ & \\
\hline EFN $08 \mathrm{~A}$ & Acpra / Caieira & $7574-7675$ & $5343-5466$ & \\
\hline EFN $15 \mathrm{~A}$ & Acar / Atalaia & $32050-33612$ & $34700-35948$ & \\
\hline EFN $15 \mathrm{~B}$ & \multirow{2}{*}{ Aca / Atalaia } & & & $28798-29828$ \\
\hline EFN $15 \mathrm{C}$ & & $42115-43982$ & 38223 - 39781 & \\
\hline EFN 15 D & \multirow{2}{*}{ Acar / Atalaia } & & & $34721-36272$ \\
\hline EFN $15 \mathrm{E}$ & & $42840-46143$ & $42185-44073$ & \\
\hline I. do MEIO 1 & \multirow{5}{*}{ Não especificada } & $25150-25554$ & 21709-22125 & \\
\hline I. RATA 3 & & $33282-33813$ & 29947 - 30696 & \\
\hline I. RATA 5 & & 44104-45078 & 29082-29613 & \\
\hline CHAPÉU 05 & & & & $16292-16737$ \\
\hline CHAPÉU 02 & & & & $11196-11251$ \\
\hline
\end{tabular}


O gráfico de distribuição de idades, com amostras organizadas espacialmente de NE para SW (Fig. 5.52), evidencia quatro conjuntos de amostras (destacados pelos retângulos na figura), sendo três associados à moda de idades mais antiga e um à moda mais nova; estes conjuntos possuem significado geográfico; os conjuntos geográficos dentro da moda mais antiga correspondem às Ilhas do Meio e Rata, no extremo nordeste do arquipélago, e a Atalaia e Ponta das Caracas - Forte de São Joaquim, na porção sudoeste; uma única amostra com idade estatisticamente anômala ou outlier (EFN 05B, cerca de 15 ka AP) ocorre em Atalaia; já o conjunto com as idades mais novas corresponde à área geográfica, no nordeste do arquipélago, que abrange Chapéu, Pedra da Bigorna, Ilha Rasa e Enseada da Caieira.

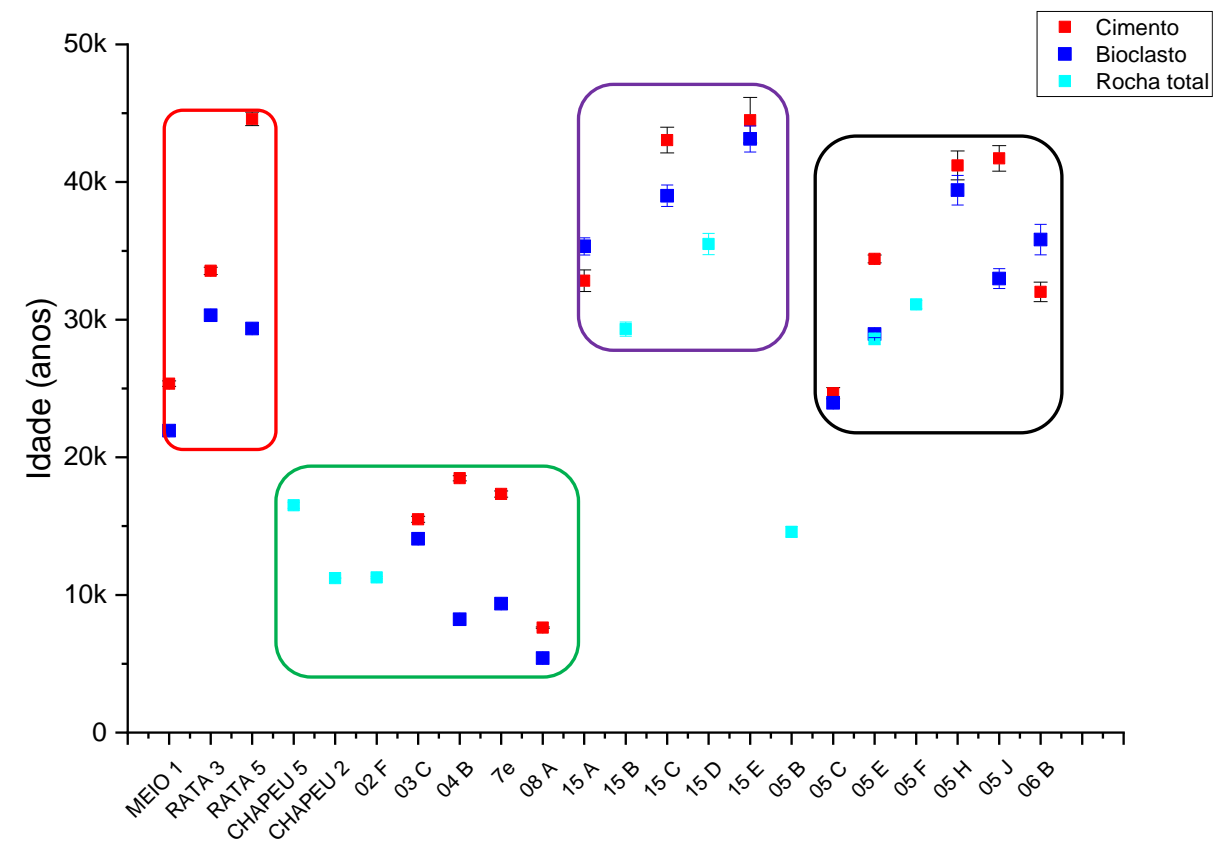

Fig. 5.52. Datações obtidas nos eolianitos de Fernando de Noronha, listados de NE para SW, com destaque para agrupamentos de idades ou áreas geográficas: retângulo vermelho - ilhas do Meio

e Rata; retângulo verde - ilhas do Chapéu, Pedra da Bigorna e Rasa, mais Enseada da Caieira; retângulo lilás - Atalaia; retângulo preto - Caracas e Forte de São Joaquim.

Tendo em vista o grande número de inversões aparentes de idade entre bioclasto e cimento (Tabela 4, Fig. 5.52), foi feito um gráfico de caixa para comparar estatisticamente as idades de cimento, bioclasto I (com idade mais antiga que o cimento da mesma amostra), bioclasto II (com idade mais nova que o cimento da mesma amostra) e rocha total (Fig. 5.53). O gráfico mostra que as idades de bioclasto I são compreendidas no intervalo interquartis das idades de cimento e pouco mais antigas que a média e mediana destas idades. Já o intervalo interquartis de rocha total é muito mais próximo do intervalo interquartis de bioclasto II que de 
cimento, o que pode sugerir que, em termos de datação, a rocha total é mais influenciada pelo seu arcabouço de que pelo cimento.

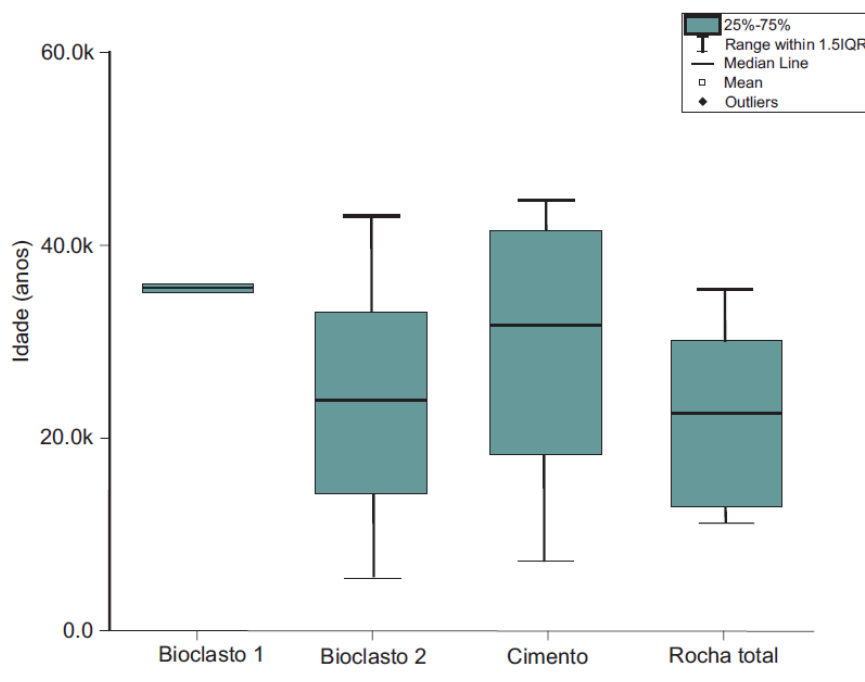

Fig. 5.53 Gráfico de caixa comparando as idades obtidas quanto a tipo de material datado e relação de idade bioclasto versus cimento: bioclasto $\mathrm{I}$, com idade mais velha que cimento $(\mathrm{n}=2)$; bioclasto II, com idade mais nova que cimento $(n=13)$; cimento $(n=15)$; e rocha total $(n=8)$.

Os gráficos de dispersão entre idade e altura estimada de cada amostra datada para os afloramentos de Saco de Atalaia (Fig. 5.54) e Ponta das Caracas - Forte de São Joaquim (Fig. 5.55) apresentam, ambos, a mesma tendência, estatisticamente significativa ( $p=0,02$ e 0,002, respectivamente), de amostras coletadas no topo do afloramento mais velhas que as coletadas na base.

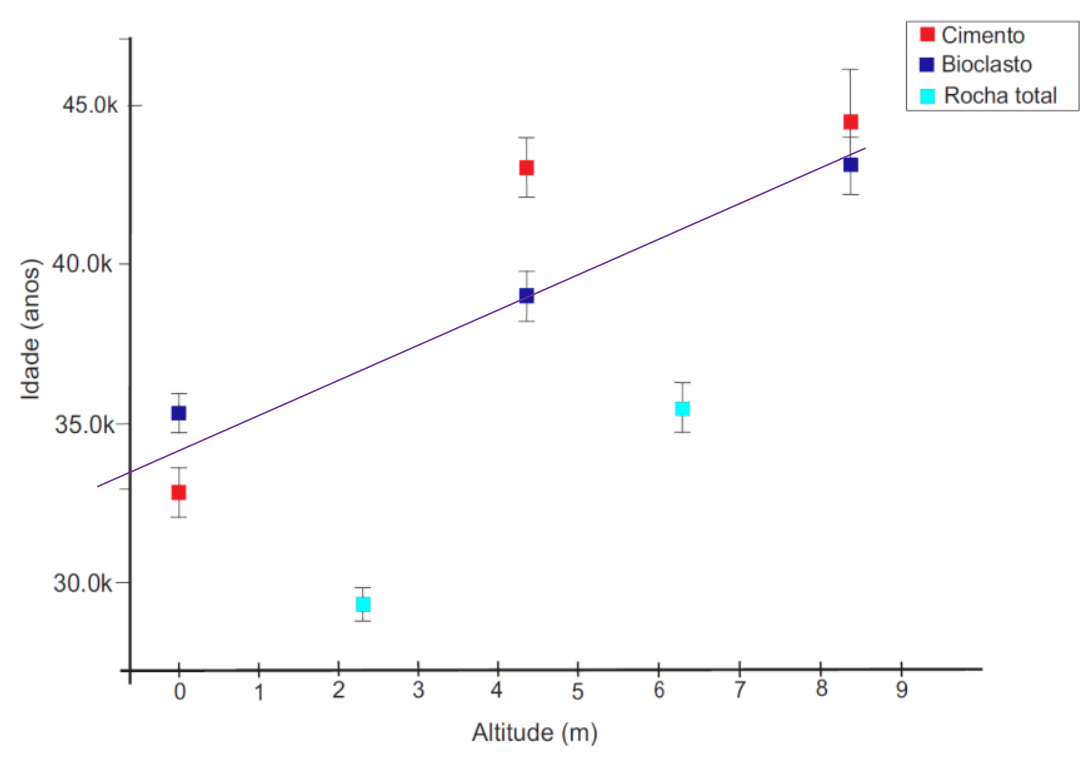

Fig. 5.54. Variação da idade em função da altura no afloramento, em Atalaia (coeficiente de correlação $r=0,704$; valor $\mathrm{p}=0,02$ ). 


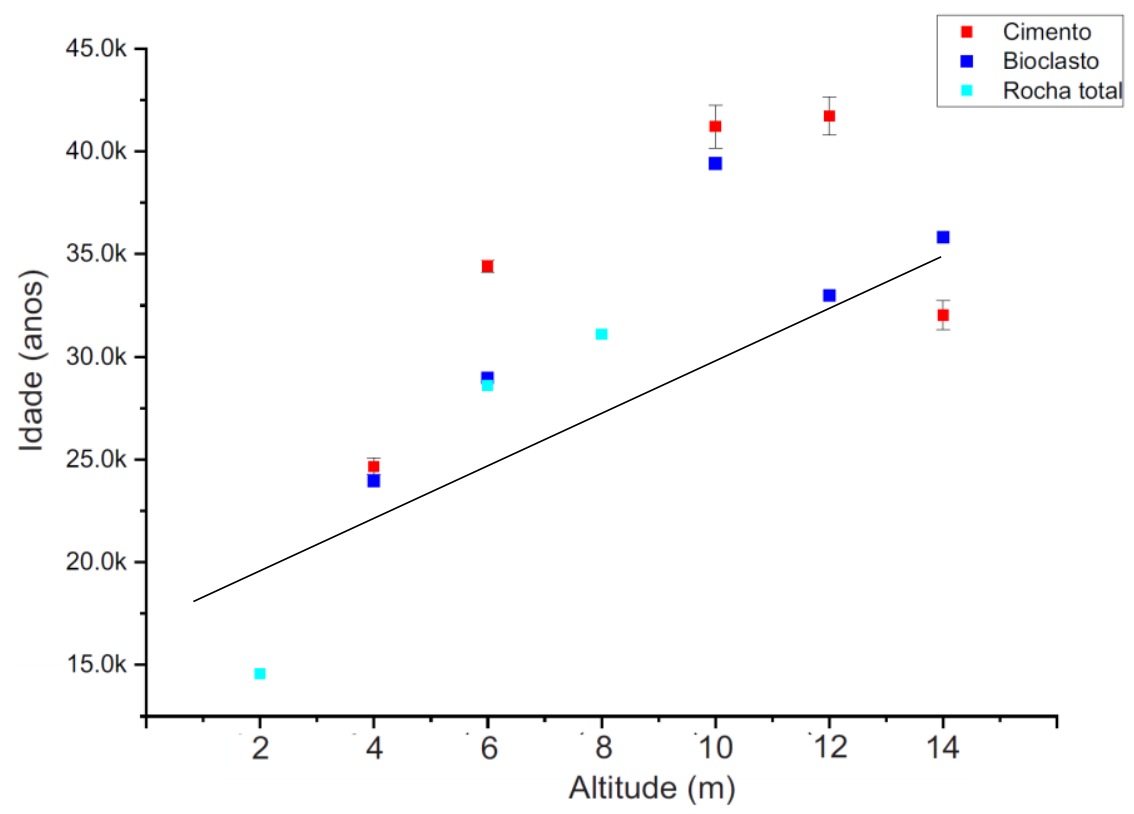

Fig. 5.55. Variação da idade em função da altura no afloramento, em Ponta das Caracas e Forte de São Joaquim (coeficiente de correlação r = 0,719; valor $\mathrm{p}=0,002$ ).

Os histogramas de número de amostras por intervalos de cada 5 mil anos (Fig. 5.56), construídos com base na idade mediana do intervalo (Fig. 5.56a) e em todo o intervalo (Fig.5.56b), mostram, em comum, o destaque dos intervalos de 45 a 40 ka AP e de 35 a 30 ka AP, apesar da boa homogeneidade das distribuições ao longo dos últimos 45 ka em geral; além disso, os histogramas realçam as duas modas maiores de idades, antes e depois de 25-20 ka, já descritas com base em outras análises (e.g. Fig. 5.52).
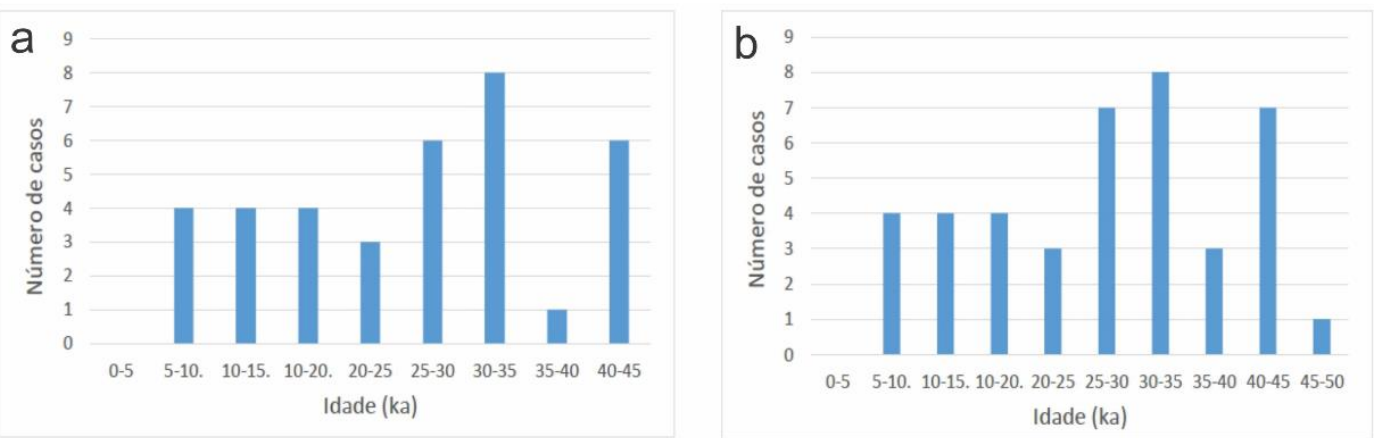

Fig. 5.56. Histogramas de distribuição de frequências de idades em eolianitos do Arquipélago de Fernando de Noronha, agrupadas em intervalos de classe de 5 mil anos: a. considerando apenas a idade mediana do intervalo de datação calibrada; b. considerando o intervalo inteiro de datação calibrada. 


\subsection{Análise Petrográfica}

Das 66 seções delgadas analisadas ao microscópio de luz polarizada, 55 são de eolianitos (Apêndice 3) e 11 pertencem a diferentes fácies a eles associadas, tanto do RN quanto do AFN.

\subsubsection{Rio Grande do Norte}

\subsubsection{Eolianitos}

Nas 14 seções delgadas de eolianitos do RN, a rocha é clasto-suportada, em alguns casos com granulometria modal na classe areia média, em outros com granulometria bimodal dentro do intervalo entre as classes areia grossa e areia fina; a seleção granulométrica visualmente estimada varia entre pobre e muito pobre, e em poucos casos, moderada, quando considerado todo o conjunto de grãos; porém, nos eolianitos com segregação quanto à granulometria, a seleção por lâmina segregada chega a muito boa (Fig. 5.57). Quanto à forma, os grãos terrígenos variam entre angulares e subarredondados; e a esfericidade é principalmente baixa (Fig. 5.57).

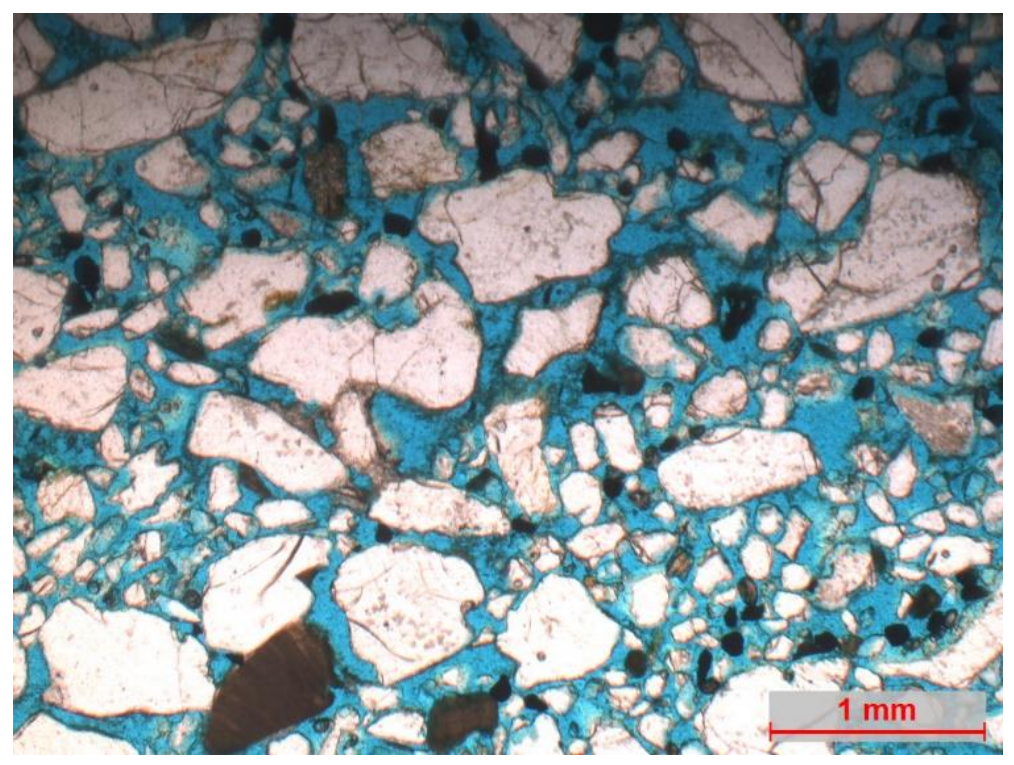

Fig. 5.57. Seção delgada da amostra ERN 09, com destaque para a segregação granular do arcabouço, por lâmina, quanto a tamanho (areia fina a muito fina versus areia grossa a muito grossa) e mineralogia (maior concentração de minerais pesados nas lâminas de grãos menores). A seleção granulométrica, muito pobre se considerado o conjunto de grãos, passa a boa, se considerada cada lâmina segregada. Notar ainda o predomínio de grãos de quartzo de esfericidade baixa e subangulosos a subarredondados. 
$\mathrm{Na}$ estimativa dos componentes texturais dos eolianitos (Fig. 5.58), predomina o arcabouço (até 60\%), seguido de poros (até pouco menos de 50\%) e cimento (até cerca de 30\%); matriz infiltrada (até 20\%) está presente em amostras com rizoconcreções.

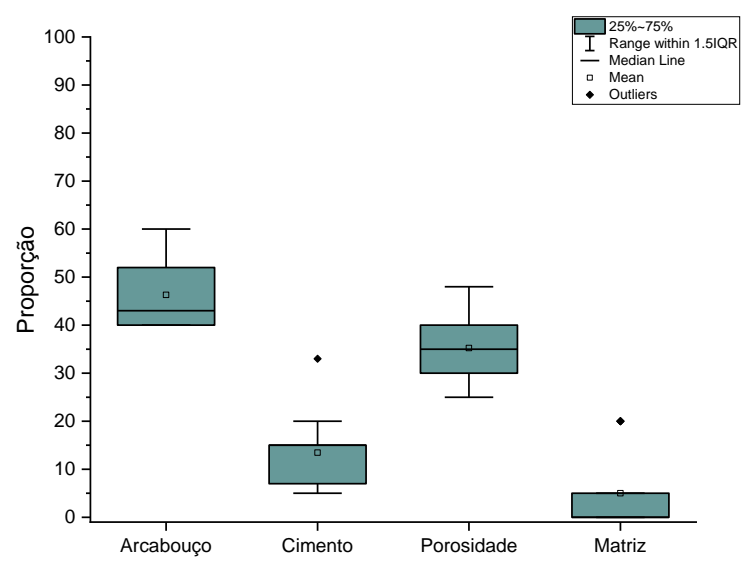

Fig. 5.58. Variação das proporções dos componentes texturais nos eolianitos do RN. $n=13$, com matriz presente apenas em quatro amostras, todas com rizoconcreções.

No que se refere às propriedades de petrotrama, na maioria das seções delgadas observase segregação granular quanto a tamanho e mineralogia (Figs. 5.57, 5.59a e 5.62g) e/ou orientação subparalela de clastos e bioclastos. O empacotamento dos eolianitos é aberto (IP $\mathrm{KP}_{\mathrm{K}}$

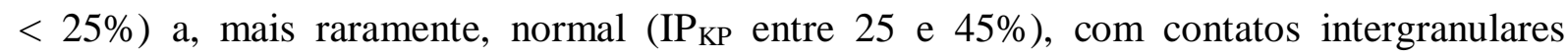
dominantemente pontuais (tangenciais), planos ou mesmo ausentes (grãos flutuantes; Fig. 5.59a e b).

A porosidade estimada varia de 25 a $48 \%$ no conjunto de amostras analisadas, e, segundo a classificação de Schmidt et al. (1972), é seletiva, principalmente intergranular, sendo os tipos mais comuns: heterogeneidade de empacotamento, poros alongados, dissolução parcial (Fig. 5.60a) e móldica (Fig. 5.60b). 


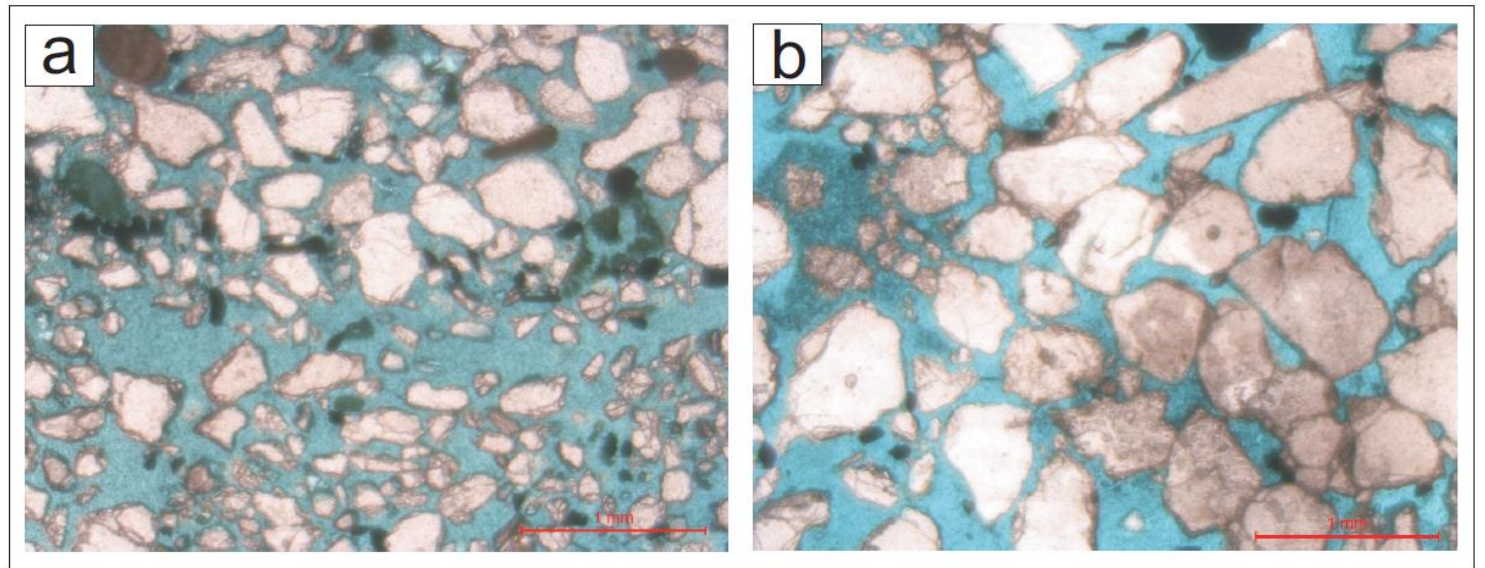

Fig. 5.59. Feições principais da petrotrama dos eolianitos do RN: a. segregação granular quanto a tamanho e mineralogia, com concentração preferencial de minerais pesados (escuros) nas faixas de granulação mais fina (ERN 02E); notar ainda sub-paralelismo de grãos alongados; $\mathbf{b}$. empacotamento aberto a normal, com contatos intergranulares pontuais e planos (ERN 02C). Fotomicrografias a polarizadores paralelos.

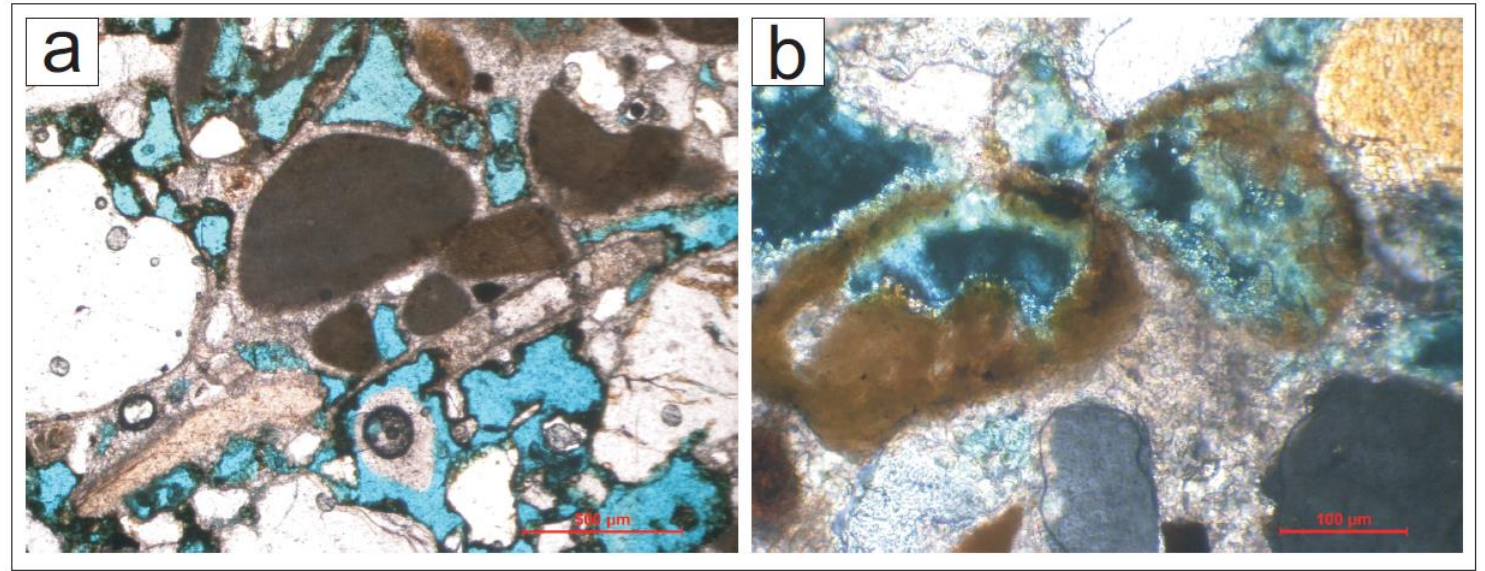

Fig. 5.60. Exemplos de tipos de porosidade observados nos eolianitos do RN: a. por dissolução parcial (ERN 21E); b. móldica, total ou parcial (ERN 21W). Fotomicrografias a polarizadores paralelos (a) e cruzados (b).

Quanto aos componentes do arcabouço diferenciados em termos de origem (extra versus intrabacinal), predominam os grãos terrígenos, com teores de até 79\% e média de 63\% (Fig. 5.61); o principal componente é o quartzo, com teores de até $75 \%$ e média de $54 \%$, seguido de minerais pesados opacos, fragmentos líticos e outros minerais transparentes, inclusive feldspatos (Fig. 5.63); os grãos intrabacinais, com teores de até $58 \%$ e média de $37 \%$ (Fig. 5.61), são dominantemente de composição carbonática; abrangem peloides, bioclastos diversos, como algas vermelhas, moluscos, foraminíferos bentônicos (Miliolina, Peneroplídeo e Nummulites) e cracas, pellets fosfáticos (Figs. 5.62) e lito-intraclastos (Fig. 5.62f). 


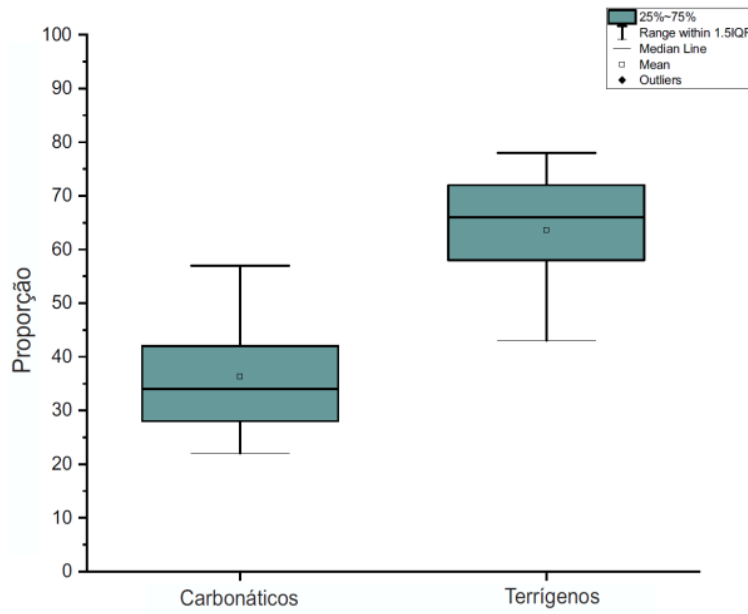

Fig. 5.61. Variação das proporções dos tipos genéticos de grãos do arcabouço nos eolianitos do Rio Grande do Norte. $n=13$. 

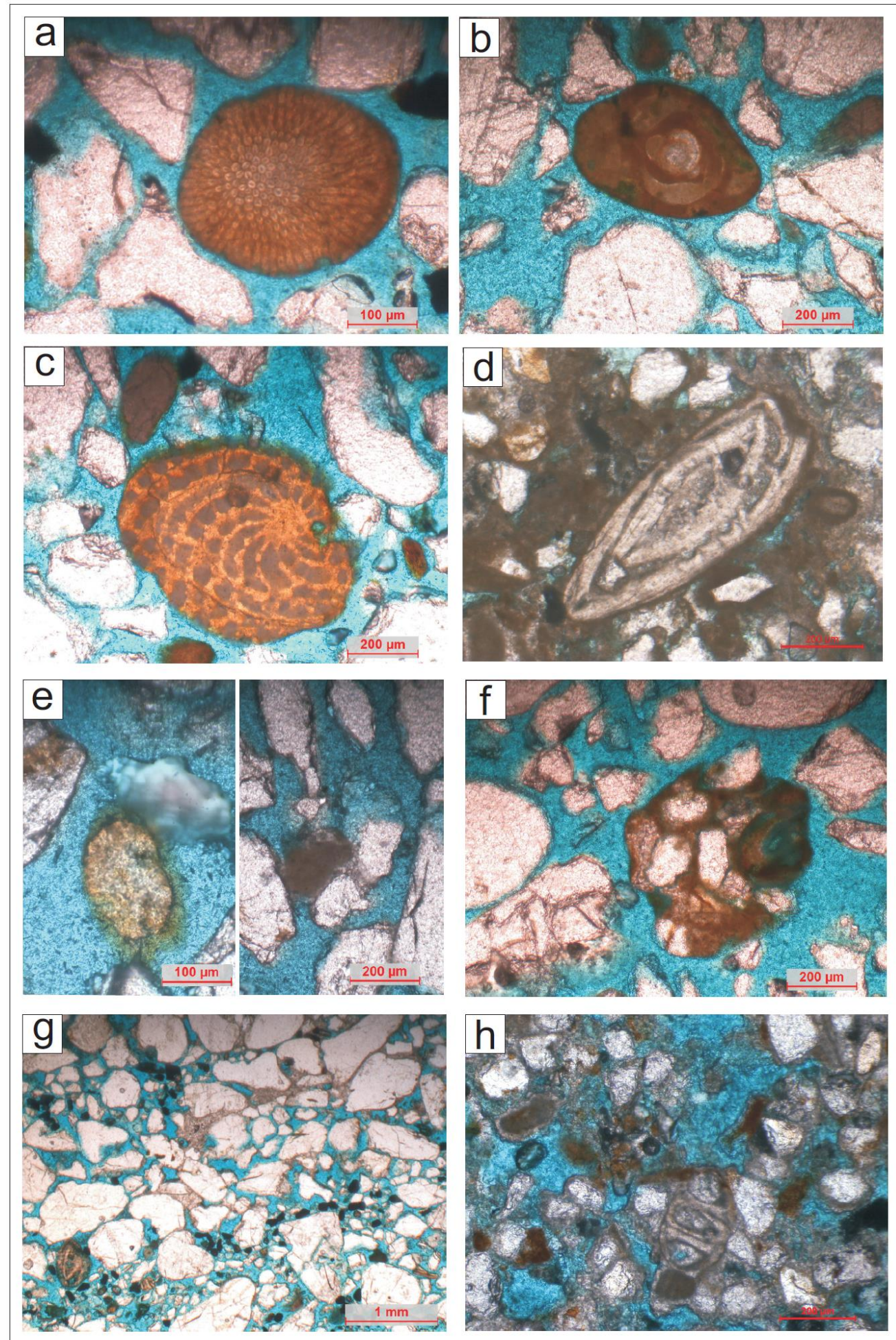

Fig. 5.62. Principais componentes do arcabouço dos eolianitos do Rio Grande do Norte: $\mathbf{a}$ a h. grãos de quartzo subangulares; a: alga vermelha (ERN 08); b a d: foraminíferos bentônicos: Miliolina (b), Peneroplídeo (c) (ERN 08) e Nummulites (d) (ERN 18); e: pellet fosfático e peloide (ERN 15); f: lito-intraclasto (ERN 08); g: minerais pesados (sobretudo opacos), concentrados na fração mais fina (ERN 09); h: craca (ERN 20). Fotomicrografias a polarizadores paralelos. 


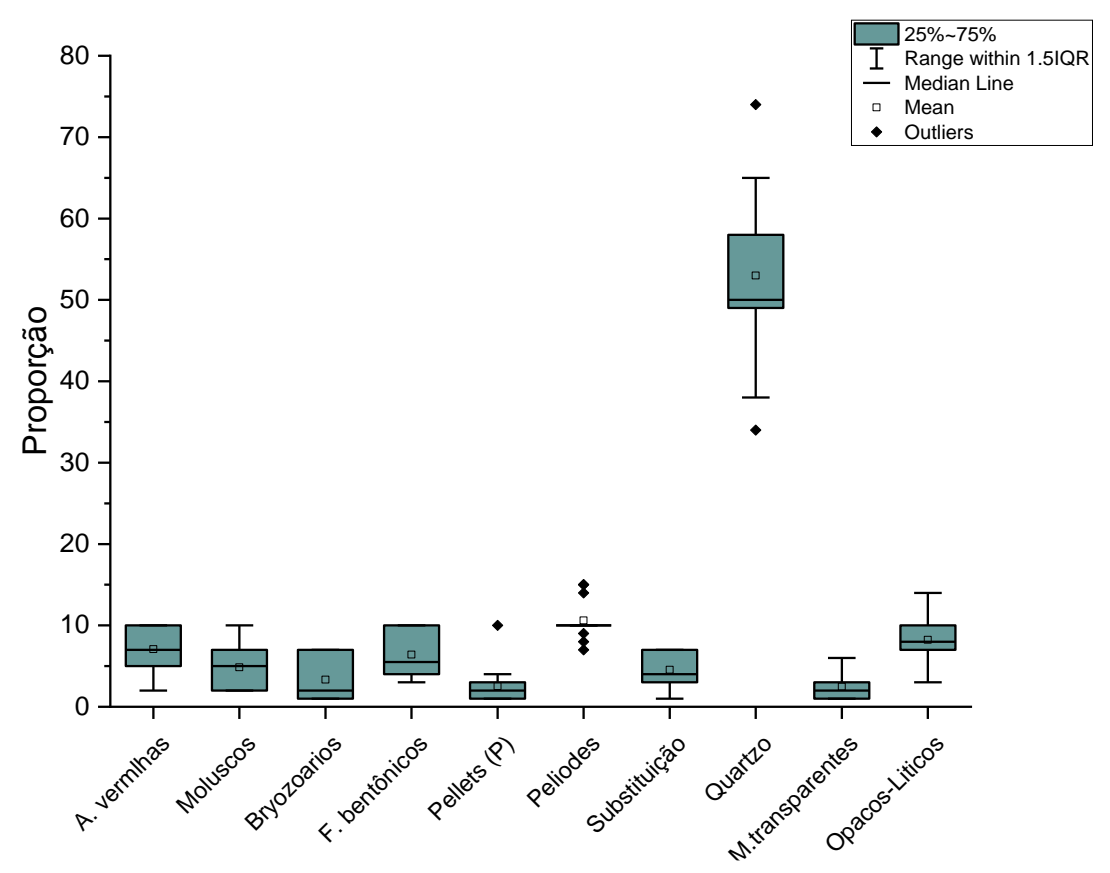

Fig. 5.63. Variação das proporções dos principais componentes do arcabouço nos eolianitos do RN. $n=13$; briozoários observados somente em três amostras. Abreviaturas utilizadas: a. vermelhas: algas vermelhas; f. bentônicos: foraminíferos bentônicos; pellets (P): pellets fosfáticos; substituição: bioclastos parcial ou totalmente substituídos por cimento; $\mathrm{m}$. transparentes: minerais transparentes, fora quartzo.

As proporções dos diferentes tipos de grãos intrabacinais variam expressivamente dentre áreas, pelo que foram feitos gráficos de caixa individuais destes tipos de grãos para Enxu Queimado, Guajiru e Três Irmãos. Nos gráficos dos componentes intrabacinais do arcabouço por área, observa-se que em Enxu Queimado (Fig. 5.64) e em Guajiru (Fig. 5.65) predominam os peloides, enquanto em Três Irmãos, este predomínio é dividido entre algas vermelhas, foraminíferos e peloides, com teores em torno de $10 \%$ (Fig. 5.66). 


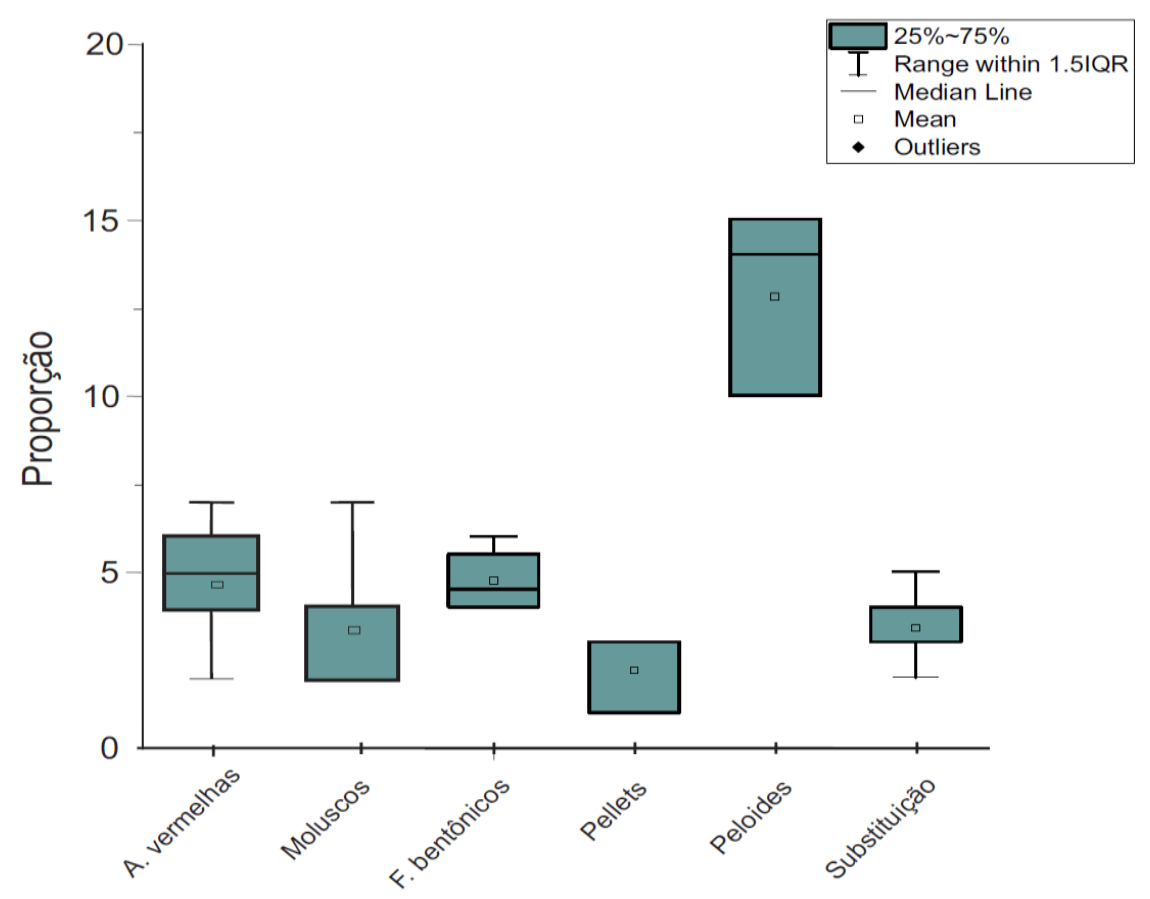

Fig. 5.64. Variação das proporções dos tipos de grãos intrabacinais no arcabouço dos eolianitos de Enxu Queimado, RN. n=4. Abreviaturas utilizadas: a. vermelhas: algas vermelhas; f. bentônicos: foraminíferos bentônicos; substituição: bioclastos parcial ou totalmente substituídos por cimento.

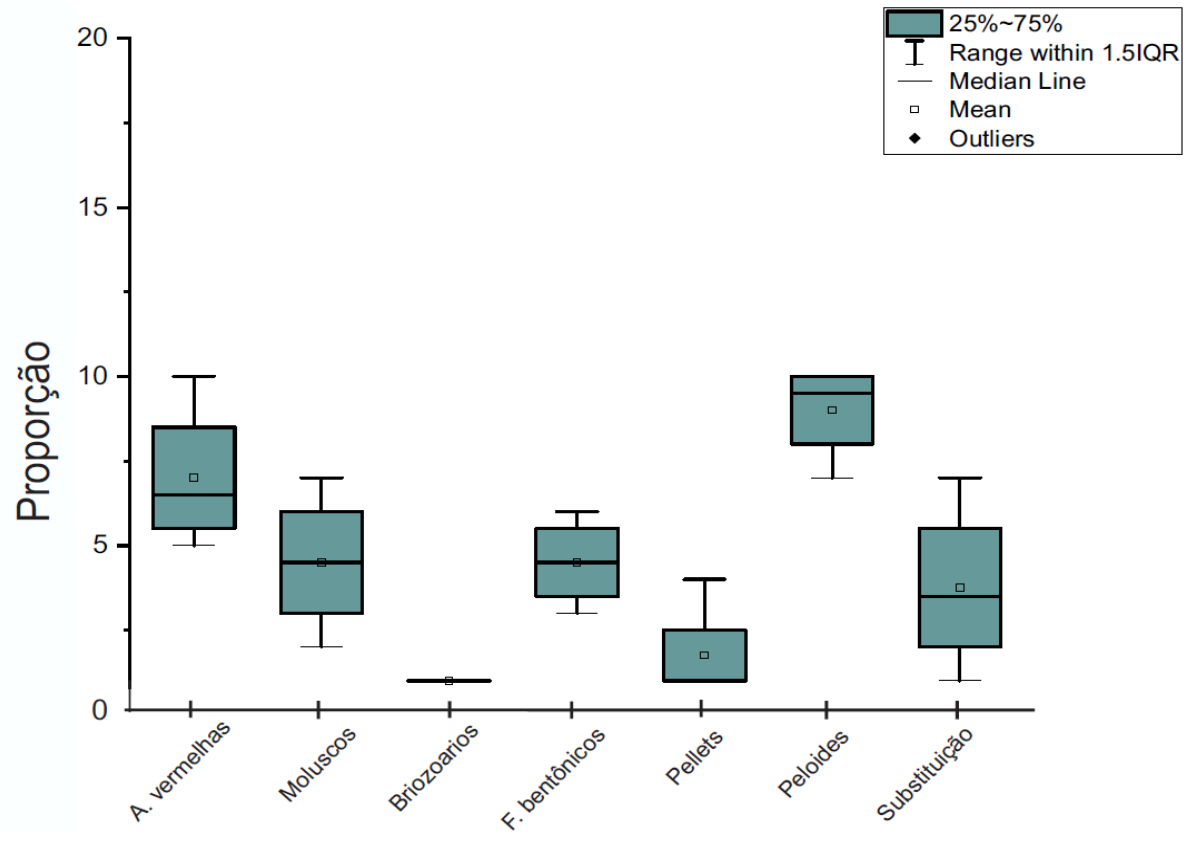

Fig. 5.65. Diagrama de caixa dos tipos de grãos intrabacinais no arcabouço dos eolianitos de Guajiru, RN. n=4; apenas uma amostra apresentou briozoários. Abreviaturas utilizadas: a. vermelhas: algas vermelhas; f. bentônicos: foraminíferos bentônicos; substituição: bioclastos parcial ou totalmente substituídos por cimento. 


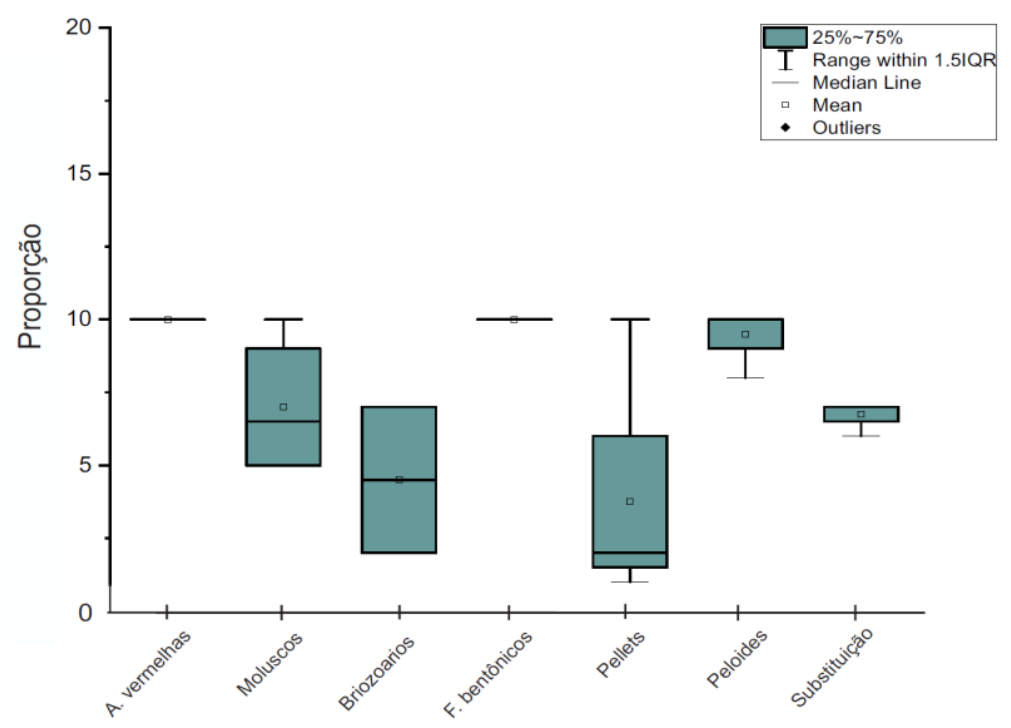

Fig. 5.66. Variação das proporções dos tipos de grãos intrabacinais no arcabouço dos eolianitos de Três Irmãos, RN. n=4; somente duas amostras apresentaram briozoários. Abreviaturas utilizadas: a. vermelhas: algas vermelhas; f. bentônicos: foraminíferos bentônicos; substituição: bioclastos parcial ou totalmente substituídos por cimento.

Visto que o arcabouço é caraterizado pelo domínio de peloides em todas as amostras, seguido pela presença de algas vermelhas, calculou-se a razão peloides / algas vermelhas (Pe/Al) por área do RN, resultado com o qual foi construído o gráfico boxplot da Fig. 5.67. Observa-se, nesse gráfico, que a razão Pe/Al apresenta maior dispersão de dados e valores mais elevados de intervalo interquartis em Enxu Queimado que nas outras áreas (mediana de 73\% contra 55\% Guajiru e 50\% em Três Irmãos). 


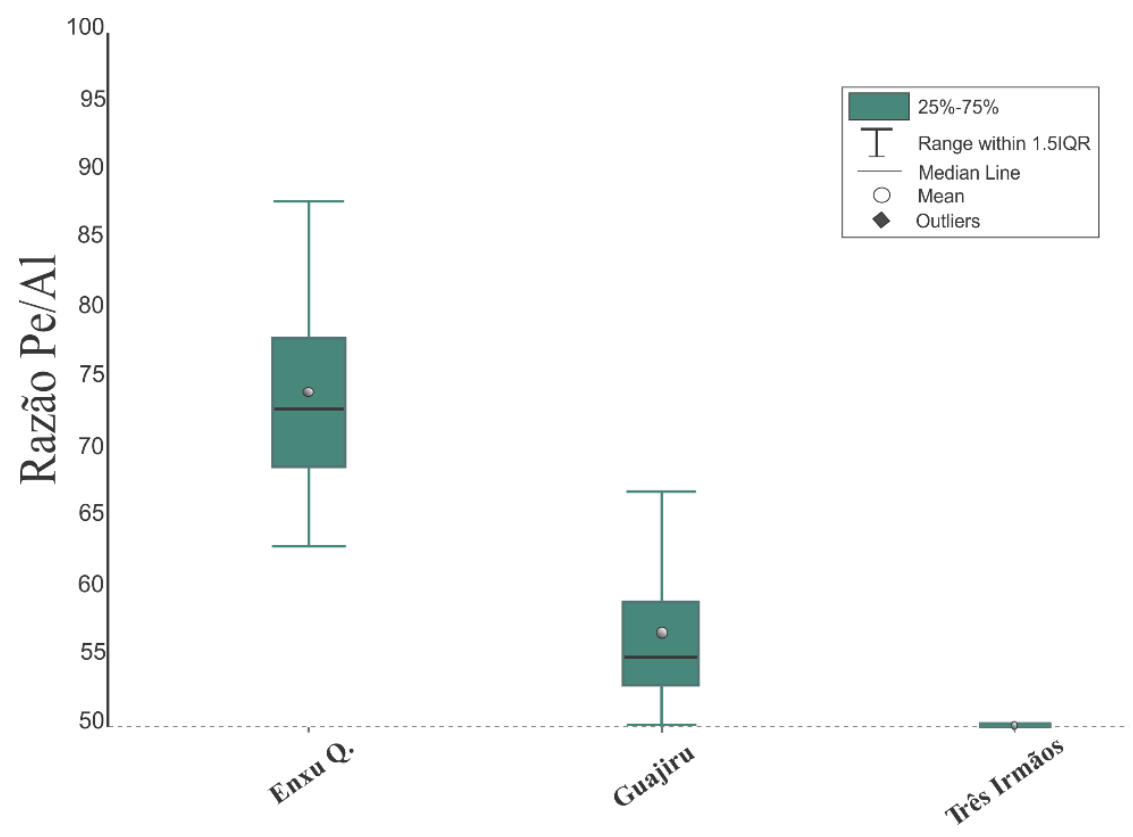

Fig. 5.67 Razão Pe/Al (peloides / algas vermelhas) nas áreas de Enxu Queimado, Guajiru e Três Irmãos, RN.

O cimento de carbonato de cálcio alcança até 33\% de proporção em volume e encontrase nas dimensões microespática (Fig. 5.68) e, em menor abundância, espática (Fig. 5.69) e micrítica. Sua distribuição espacial é frequentemente heterogênea, com concentração em porções de empacotamento menos aberto e/ou junto a grãos carbonáticos. A ocorrência mais comum é como franja envolvente isópaca ou anisópaca nas bordas dos grãos (Fig. 5.68a e b, $5.69 \mathrm{c}$ e d); as franjas envolventes de grãos adjacentes podem chegar a se juntar formando feições similares a meniscos e/ou linhas medianas ligeiramente suturadas (Fig. 5.68a, 5.69c); ou ainda constituir trama drusiforme, isto é, crescimento de tamanho dos cristais da borda para o interior do poro (Fig. 5.68b), inclusive associada a cimentos mais tardios de revestimento de poro (Fig. 5.69d); outras formas de ocorrência do cimento são em microespato ou espato equidimensional em menisco (Fig. 5.68c), concentrado (micronodular) ao longo de zonas subverticais (Fig. 5.68d) ou junto a aglomerações de grãos mais finos, sobretudo bioclastos, inclusive ao longo de zonas sub-horizontais associadas a segregação granular (Fig. 5.68e e f).

Outros tipos de tramas, observadas sobretudo com cimento espático, são: geopetal em pêndulo (Fig. 5.69a), preenchimento inter e intragranular em mosaico (Fig. 5.69b) e revestimento ou preenchimento parcial dos espaços intergranulares (Fig.5.69c e d). Nos casos em que as gerações de cimento evidenciam sucessão entre franja envolvente isópaca ou 
anisópaca e preenchimento ou revestimento de poro, linhas medianas ligeiramente suturadas podem estar presentes entre diferentes gerações de cimento (Fig. 5.69 c e d).

Outro tipo de textura observada eventualmente é o preenchimento de porosidade móldica (Fig.5.69c).

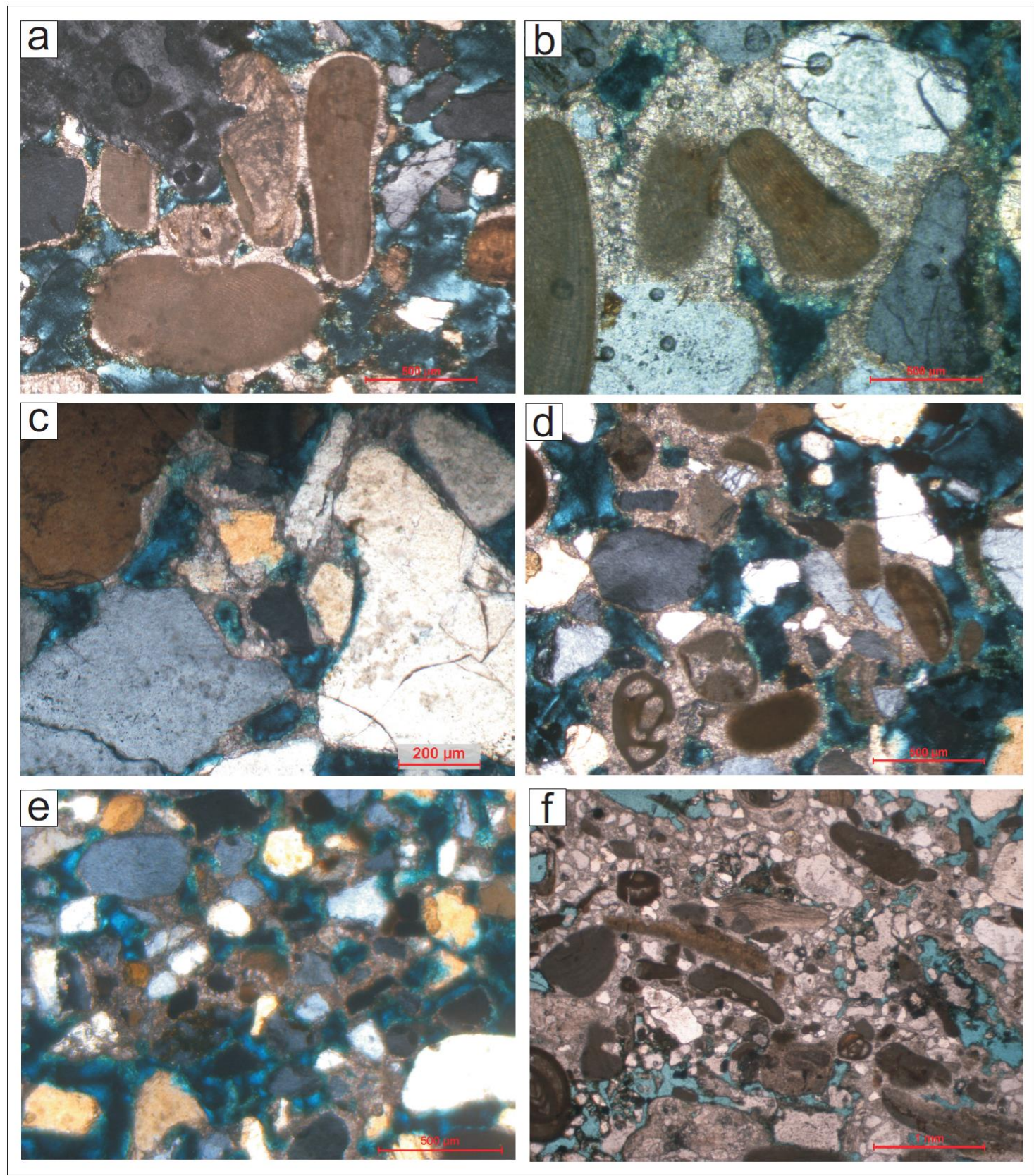

Fig. 5.68. Tipos de trama de cimento microespático presentes nos eolianitos do Rio Grande do Norte: a. franjas anisópacas, com formação local de meniscos e linhas medianas suturadas (ERN 09); b. franjas (principalmente anisópacas) com arranjo drusiforme (ERN 19W); c. em menisco (ERN 09); d. concentrado ao longo de zonas subverticais (ERN 19W); e, f. concentrado preferencialmente junto a grãos mais finos, ao longo de zonas sub-horizontais (ERN 21W, ERN 21E). Notar também subparalelismo de grãos alongados, em f. Fotomicrografias a polarizadores cruzados $(\mathbf{a}$ a e $)$, e paralelos (f). 


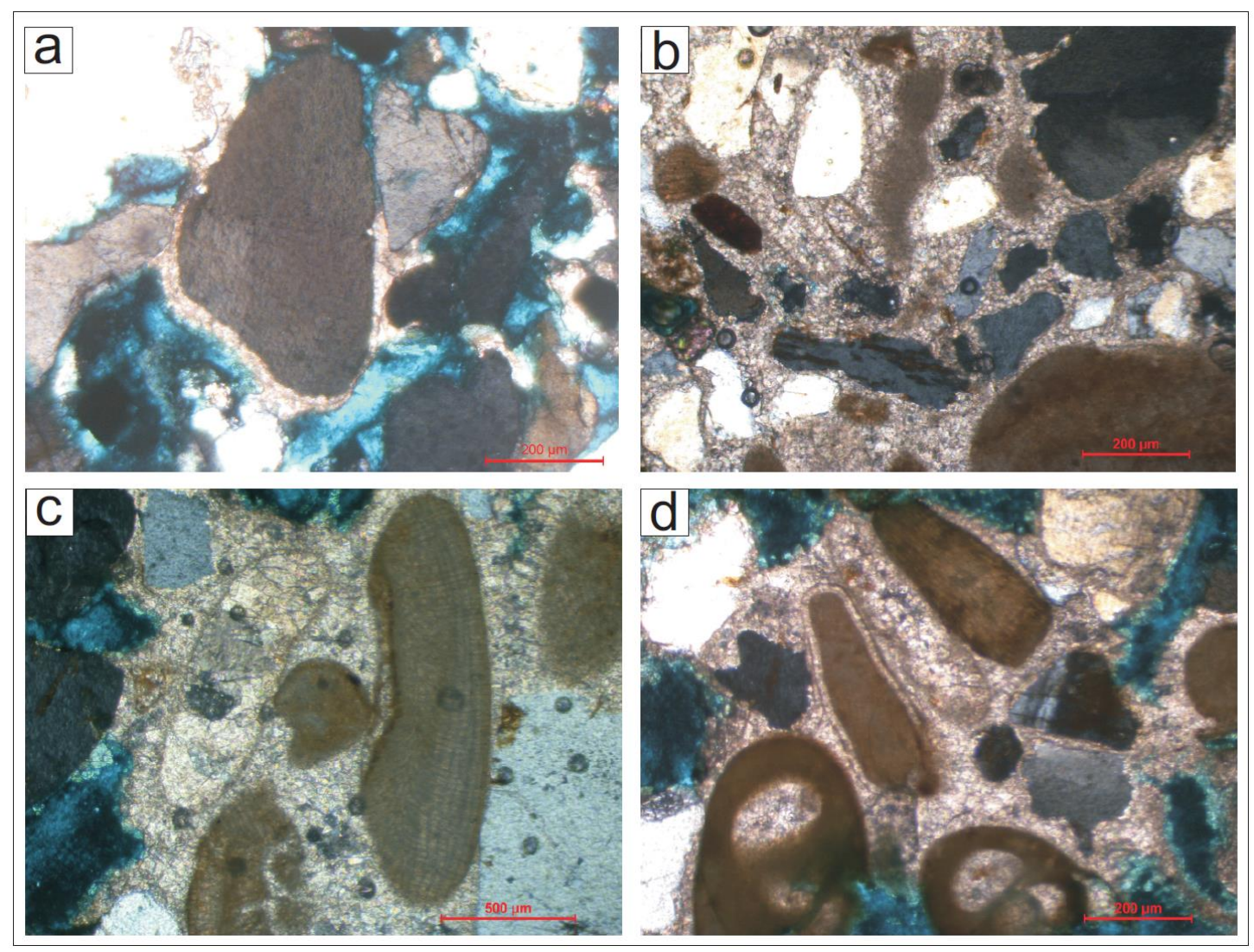

Fig. 5.69. Tipos de trama de cimento espático em eolianitos do RN: a. duas gerações separadas por linha mediana, a primeira grão-envolvente, anisópaca, e a segunda de revestimento em menisco e geopetal em pêndulo (ERN 02X); b. em mosaico, tanto intergranular quanto intragranular móldica (ERN 21E); c. em franja envolvente anisópoca, seguida de revestimento de poro e preenchimento móldico, indicando pelo menos duas gerações (ERN19W); e d. em franja envolvente isópaca e posterior revestimento de poro e preenchimento móldico (ERN 19W). Fotomicrografias a polarizadores cruzados.

Quando as tramas de cimento carbonático são analisadas por área (Fig. 5.70 a 5.72), em Enxu Queimado (Fig. 5.70) predominam as franjas envolventes anisópacas e as concentrações segunda zonas sub-verticais e sub-horizontais; já em Guajiru (Fig. 5.71), dominam franja envolvente anisópaca, e, em menores proporções, revestimento de poros e menisco; e nos afloramentos de Três Irmãos, predominam franja envolvente anisópaca, preenchimento em mosaico e revestimento de poros (Fig. 5.72). 


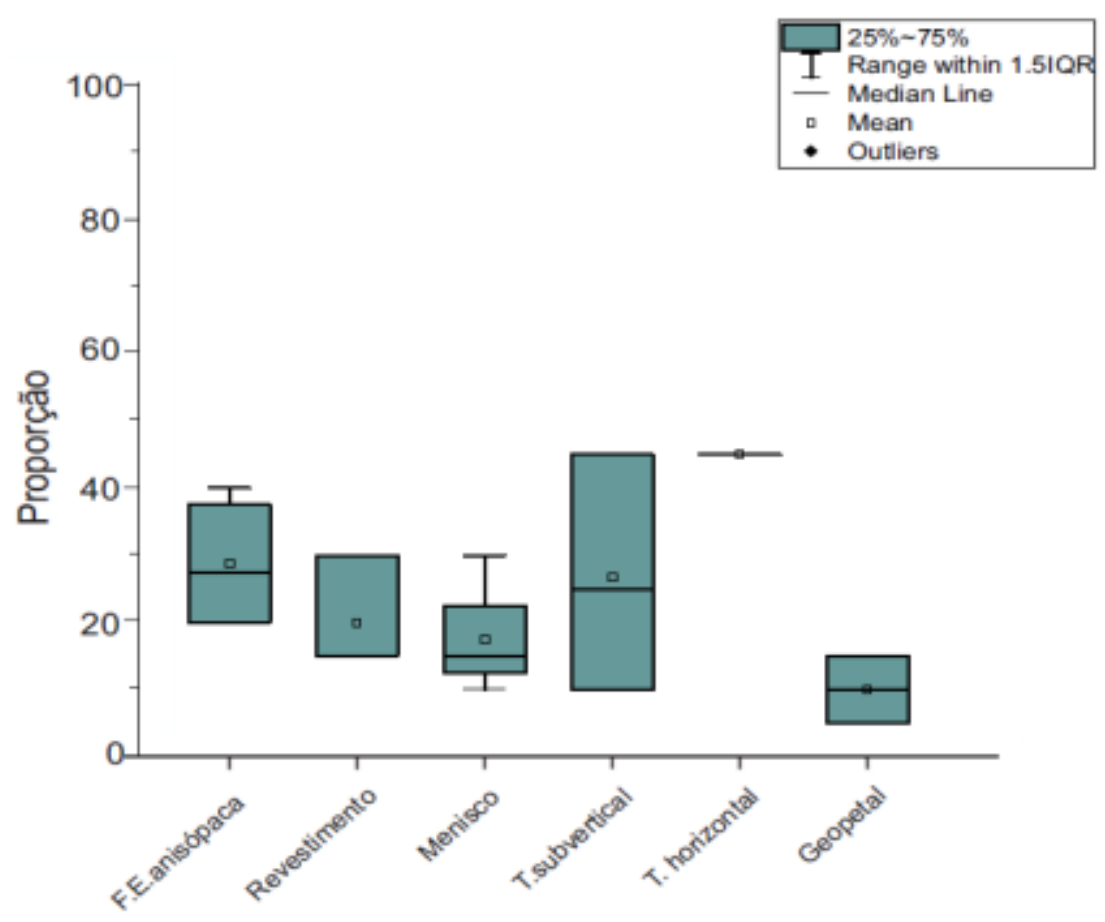

Fig. 5.70. Variação das proporções das tramas de cimento nos eolianitos de Enxu Queimado, Rio Grande do Norte. $n=4$; revestimento e tendência à concentração subvertical e geopetal foram observados em três amostras; tendência à concentração horizontal, em uma amostra. Abreviatura utilizada: f.e. anisópaca: franja envolvente anisópaca, revestimento: revestimento de poros, t: tendência à concentração

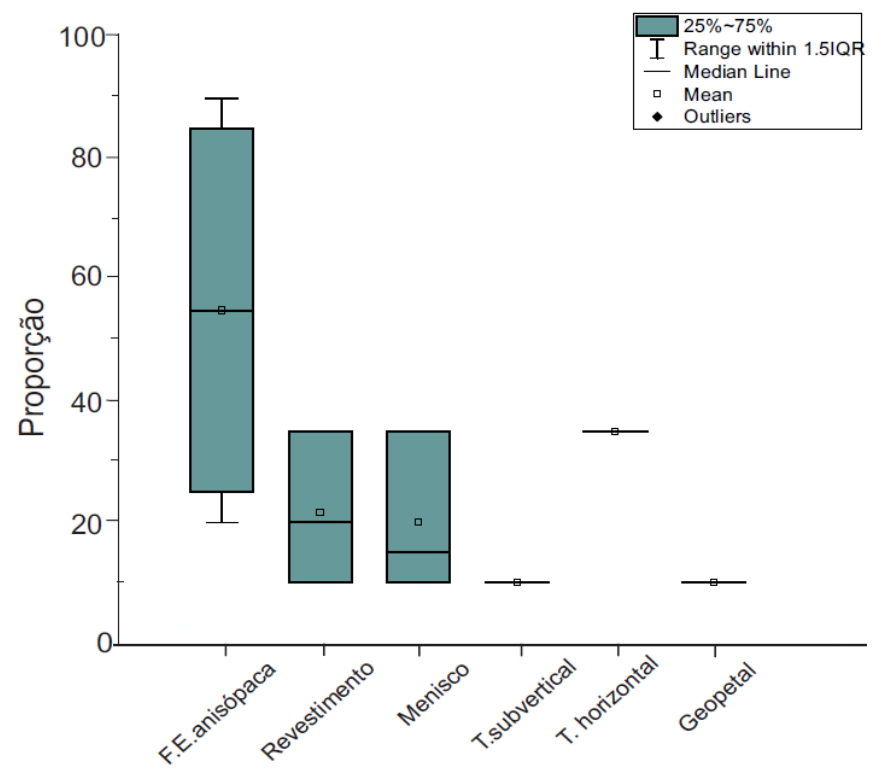

Fig. 5.71. Variação das proporções das tramas de cimento nos eolianitos de Guajiru, RN. $n=4$; tramas em revestimento de poro e em menisco foram observados em três amostras; tramas com tendência à concentração subvertical, horizontal e geopetal foram observadas em uma amostra. Abreviatura utilizada: f.e. anisópaca: franja envolvente anisópaca, revestimento: revestimento de poros, t: tendência à concentração 


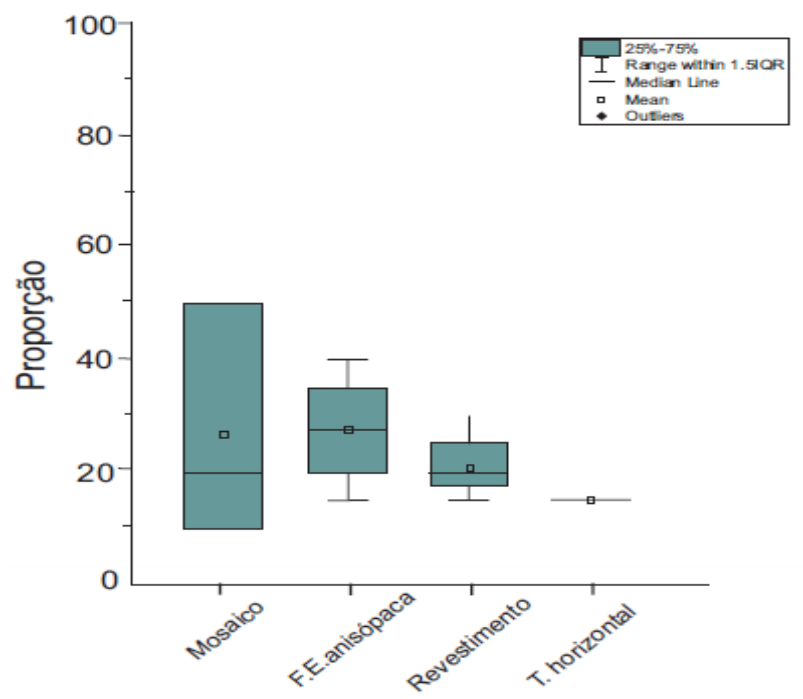

Fig. 5.72. Variação das proporções das tramas de cimento nos eolianitos de Três Irmãos, RN. $\mathrm{n}=4$. Tendência à concentração horizontal só foi observada em uma amostra. Abreviatura utilizada: f.e. anisópaca: franja envolvente anisópaca, revestimento: revestimento de poros, t: tendência à concentração.

Seguindo uma combinação, adotada nesta tese, das classificações petrográficas de Dunham (1962) e de Folk (1959, 1962), os eolianitos do RN correspondem a quartzo arenitos biopelmicroespatitos. A confirmação do prefixo do termo referente à minoritária fração carbonática (biopel) depende, porém, da interpretação da origem dos peloides, o que será feito adiante, no item de discussão.

\subsubsection{Fácies associadas}

Duas amostras pertencentes a fácies associadas aos eolianitos, e interpretadas como beach rocks (Apb, em Enxu Queimado; e Apbz, em Três Irmãos), apresentam, ao exame petrográfico, trama clasto-suportada, com arcabouço de granulometria bimodal e uma das modas na classe areia grossa a muita grossa. A seleção granulométrica é moderada a boa, e a forma dos grãos terrígenos caracteriza-se por esfericidade baixa a mediana e por subangulosidade, exceto na moda mais grossa, que é subarredondada a arredondada (Figs. 5.73 e 5.74). O arcabouço é composto principalmente por quartzo monocristalino, feldspatos, minerais pesados e bioclastos, estes dominados por algas vermelhas, foraminíferos bentônicos e moluscos. 
A petrotrama destas duas lâminas apresenta empacotamento aberto e contatos intergranulares pontuais, com orientação de grãos alongados em algumas porções (Fig. 5.73).

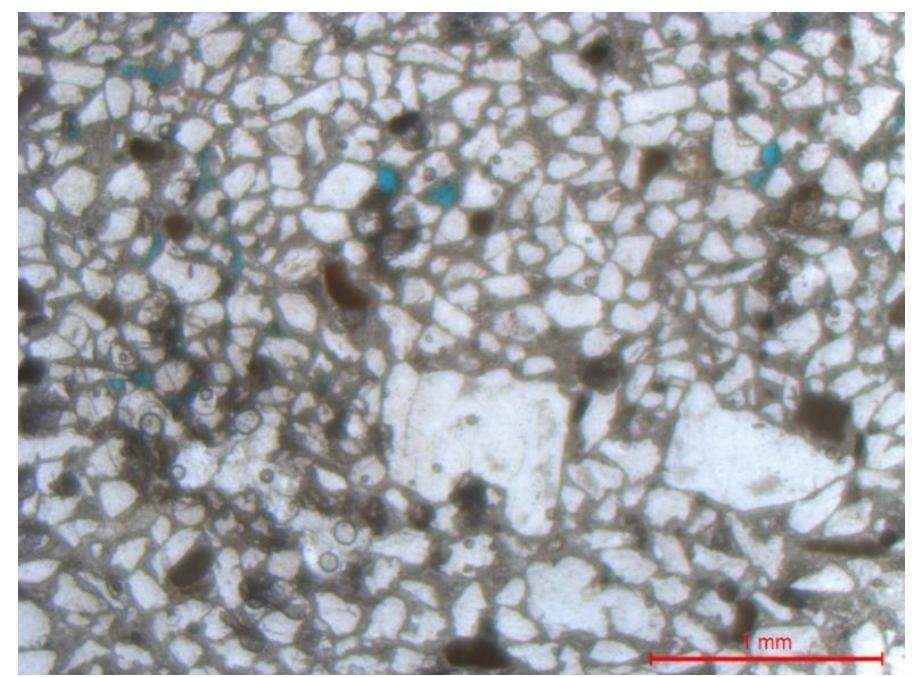

Fig. 5.73. Seção delgada do beach rock da área de Enxu Queimado (fácies APbz, amostra ERN 01br), apresentando granulometria bimodal, arcabouço dominado por quartzo, com presença subordinada de bioclastos, e contatos intergranulares pontuais.

A porosidade varia entre 6 e $10 \%$ e é principalmente seletiva intergranular. O cimento apresenta textura espática ou microespátca e as tramas mais comuns são em mosaico, em franjas envolventes isópacas com linhas de sutura medianas, em preenchimento de porosidade móldica e em revestimento de poros (Fig.5.74).

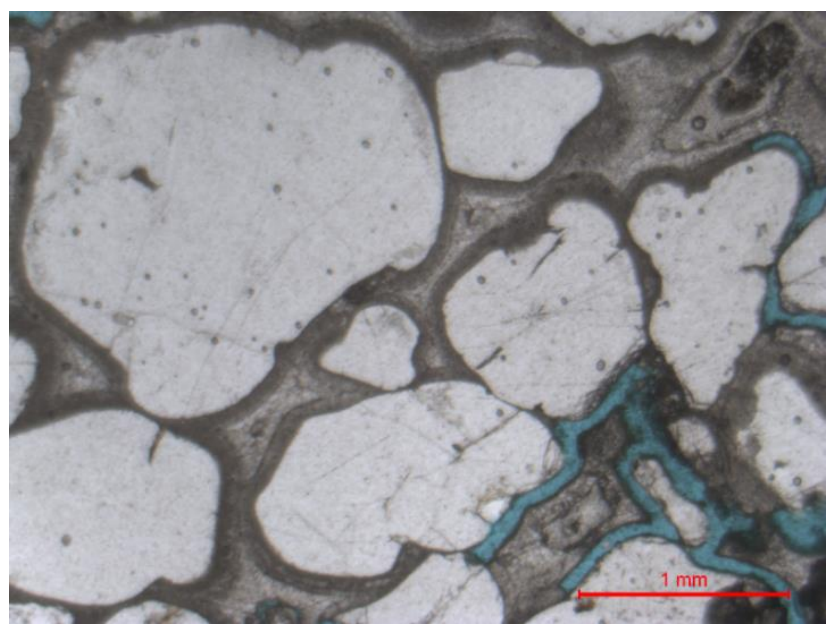

Fig. 5.74. Seção delgada do beach rock de Três Irmãos (fácies Apbz, amostra ERN 18br). Notar areia quartzosa fina a muito grossa, com cimentos em duas gerações, sendo a primeira na forma de franja isópaca microespática, e a segunda, espática, intersticial em mosaico.

Nas classificações de Dunham (1962) e Folk $(1959,1962)$, combinadas, as amostras das fácies Apb e Apbz correspondem a quartzo arenito bioespatito. 


\subsubsection{Arquipélago de Fernando de Noronha}

\subsubsection{Eolianitos}

As 42 amostras de eolianitos do AFN examinadas em seção delgada são todas clastosuportadas, algumas com granulometria modal na classe areia média, e outras com segregação granular, ou com granulometria bimodal, dentro do intervalo entre as classes areia grossa e areia fina; a seleção granulométrica visualmente estimada varia entre boa e moderada e, em poucos casos, pobre; os grãos são predominantemente subangulosos a subarredondados, com esfericidade média a baixa, explicada pelo domínio de bioclastos, principalmente algas vermelhas, e de peloides, ambos com formato tabular ou cilíndrico (Fig. 5.75).
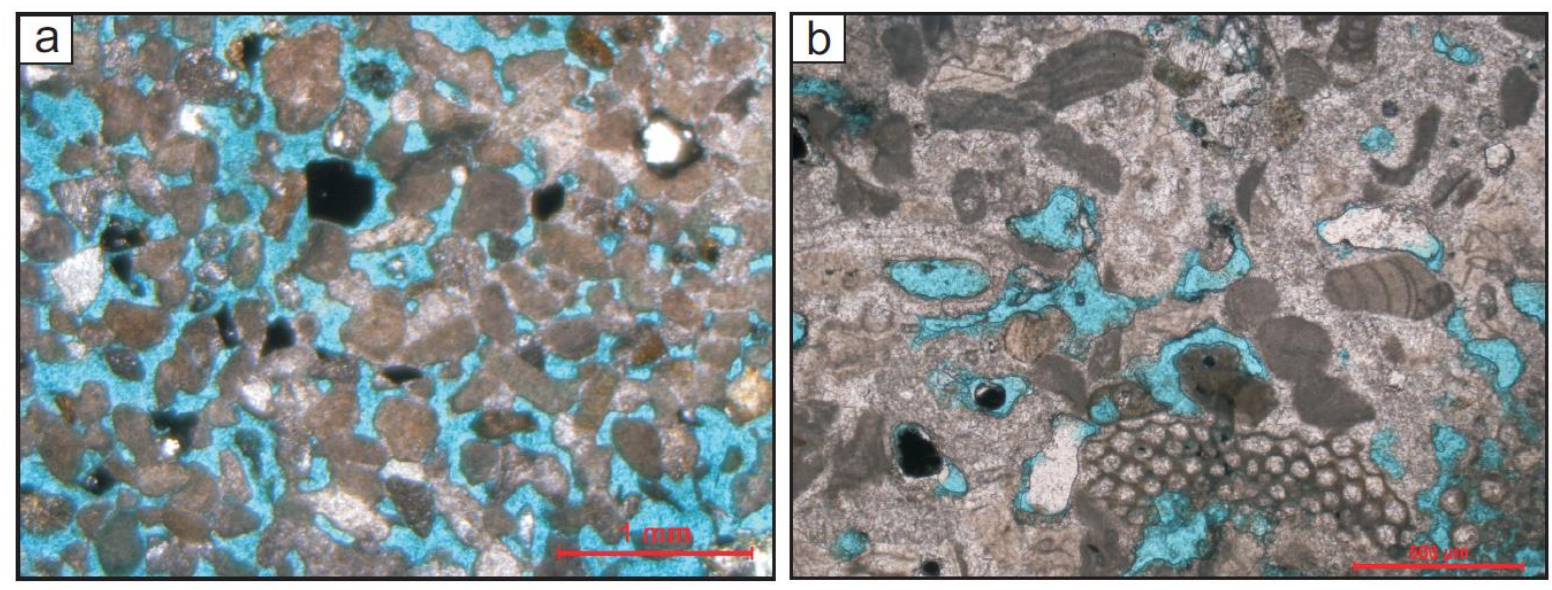

Fig. 5.75. Aspecto geral do arcabouço dos eolianitos do AFN: predomínio de bioclastos, principalmente de rodofíceas e peloides, com esfericidade média a baixa supostamente condicionada pela forma original do próprio organismo ou grão: a. amostra EFN 07, com granulometria unimodal areia fina, formada por peloides e opacos (inclusive líticos vulcânicos?); b. amostra EFN 05H, com granulometria bimodal de areia fina a grossa, cimentada por calcita espática. Fotomicrografias a polarizadores paralelos. Em b, notar fragmento de briozoário na parte inferior da imagem.

No que se refere às propriedades de petrotrama, observa-se, em algumas amostras, orientação subparalela de grãos alongados, principalmente de algas vermelhas (Fig. 5.76a). O empacotamento dos eolianitos é aberto a, mais raramente, normal, com contatos intergranulares dominantemente pontuais (tangenciais), ou mesmo ausentes (Fig. 5.76b). 

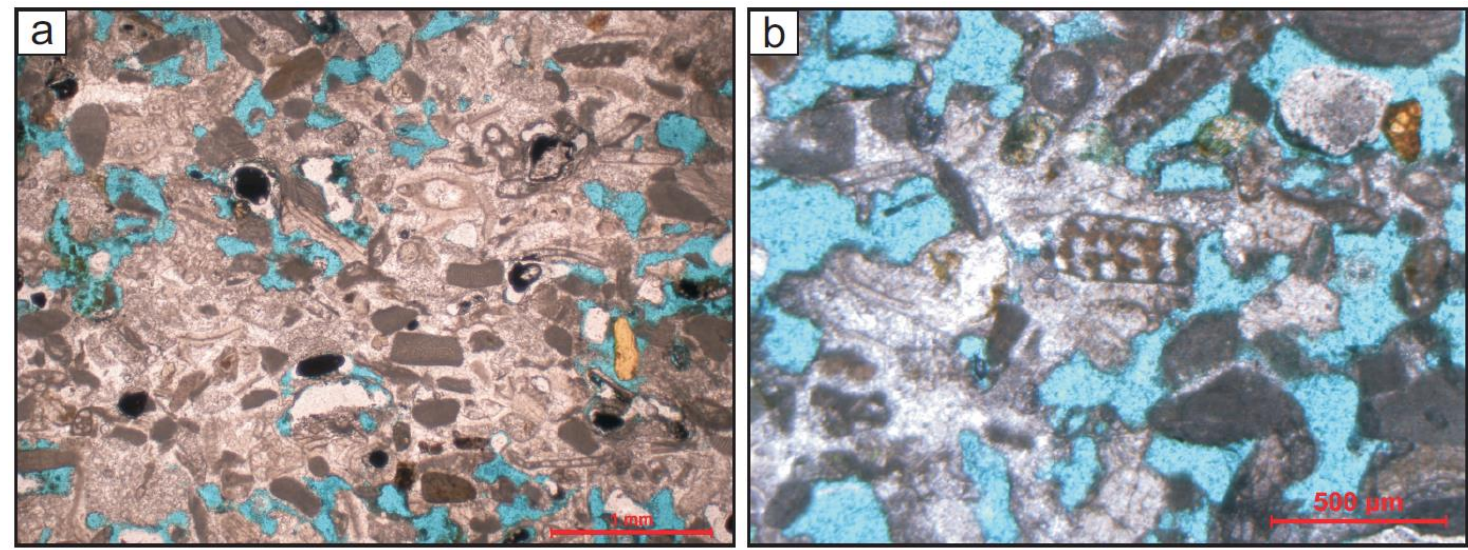

Fig. 5.76. Aspectos da petrotrama dos eolianitos do AFN: a. orientação subparalela de bioclastos alongados $(\mathrm{EFN} \mathrm{05H);} \mathrm{b.} \mathrm{empacotamento} \mathrm{aberto,} \mathrm{com} \mathrm{predomínio} \mathrm{de} \mathrm{contatos} \mathrm{pontuais}$ (EFN 05B). Em a, notar grão fosfático (amarelo). Fotomicrografias a polarizadores paralelos.

A porosidade estimada varia de 1 a $45 \%$ no conjunto de amostras analisadas, e, segundo a classificação de Schmidt et al. (1972), é seletiva, principalmente intergranular (Fig. 5.77), e, em proporções subordinadas, de heterogeneidade de empacotamento (Fig. 5.77a), em poros alongados (Fig. 5.77b) e intragranular, esta última presente em bioclastos como gastrópodes e foraminíferos. Porosidade móldica, raramente percebida nas seções delgadas, foi confirmada nas análises ao MEV (ver item 5.8).

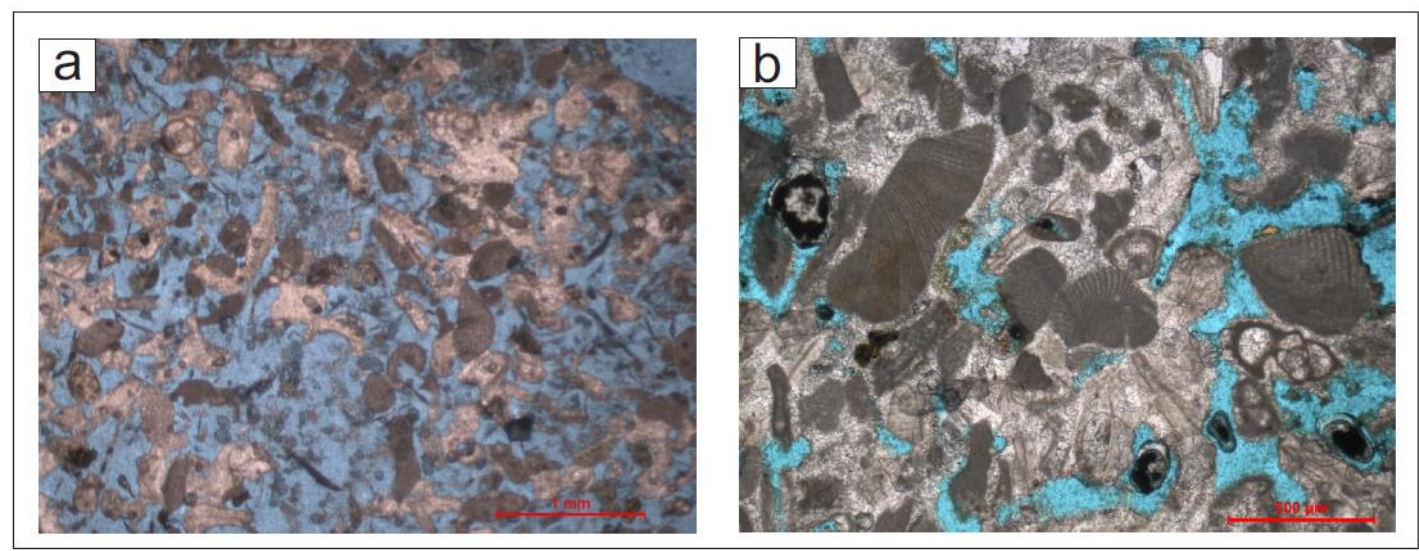

Fig. 5.77. Tipos de porosidade intergranular observados nos eolianitos do AFN: a. heterogeneidade de empacotamento (EFN 05D); b. alongada subvertical (EFN 05H). Fotomicrografias a polarizadores cruzados.

As proporções em volume de arcabouço, cimento e poros são semelhantes entre si, apesar da ligeira tendência para domínio de arcabouço e da maior variabilidade dos poros, representada pelo seu amplo intervalo interquartis (Fig. 5.78). A matriz micrítica, quando 
presente (nove casos dentre $42=21 \%$ ) é considerada infiltrada, já que se associa ao preenchimento de poros no interior de rizoconcreções, e apresenta valores sempre menores que $15 \%$.

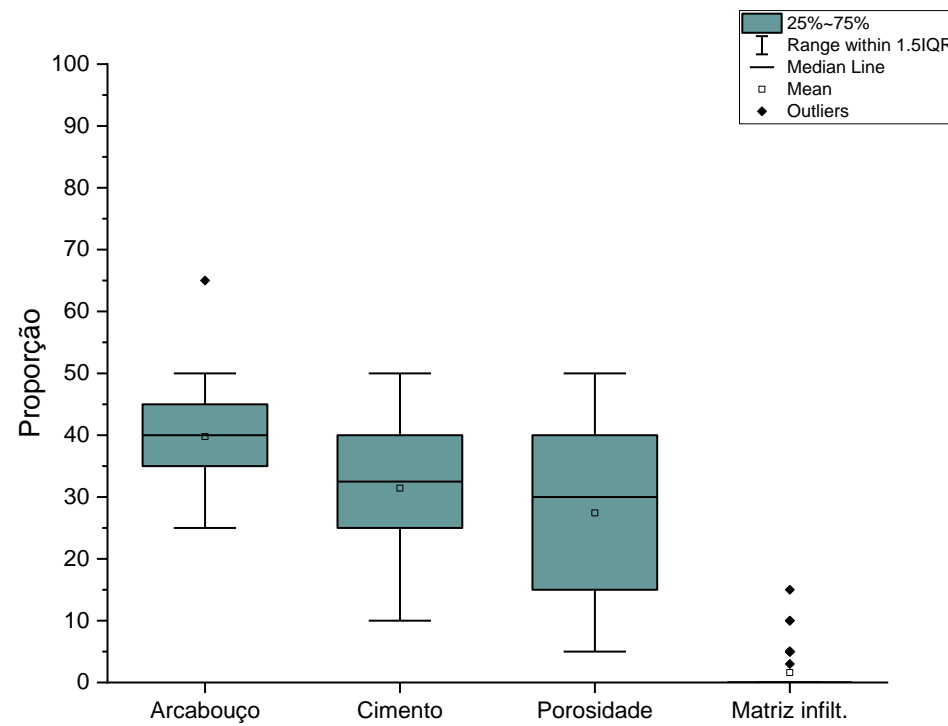

Fig. 5.78. Variação das proporções dos componentes texturais dos eolianitos do $\operatorname{AFN}(n=42$; somente nove amostras apresentam matriz infiltrada).

Quando se analisa a variação dos componentes texturais por área geográfica (Figs. 5.79 a 5.82), observa se que em Enseada da Caieira (Fig. 5.79) predominam o arcabouço e a porosidade, com proporções em volume em torno de 35 e $50 \%$, respectivamente; enquanto isso, em Atalaia (Fig. 5.80) os teores de arcabouço e cimento predominam, com médias de $40 \%$ e 35\%, respectivamente. Já nos eolianitos de Ponta das Caracas (Fig.5.81), arcabouço, cimento e poros apresentam proporções similares (entre 25 e 40\%); e no Forte de São Joaquim, predomina o cimento com proporções em volume entre 40 e $45 \%$, enquanto as quantidades de arcabouço e poros são semelhantes entre si (Fig. 5.82). 


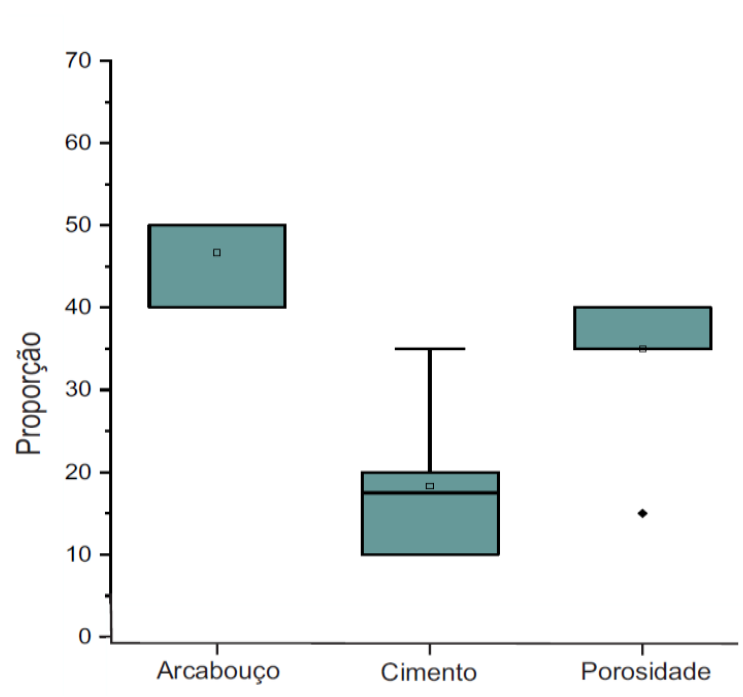

Fig. 5.79. Variação das proporções dos componentes texturais dos eolianitos de Enseada da Caieira, AFN. $n=6$.

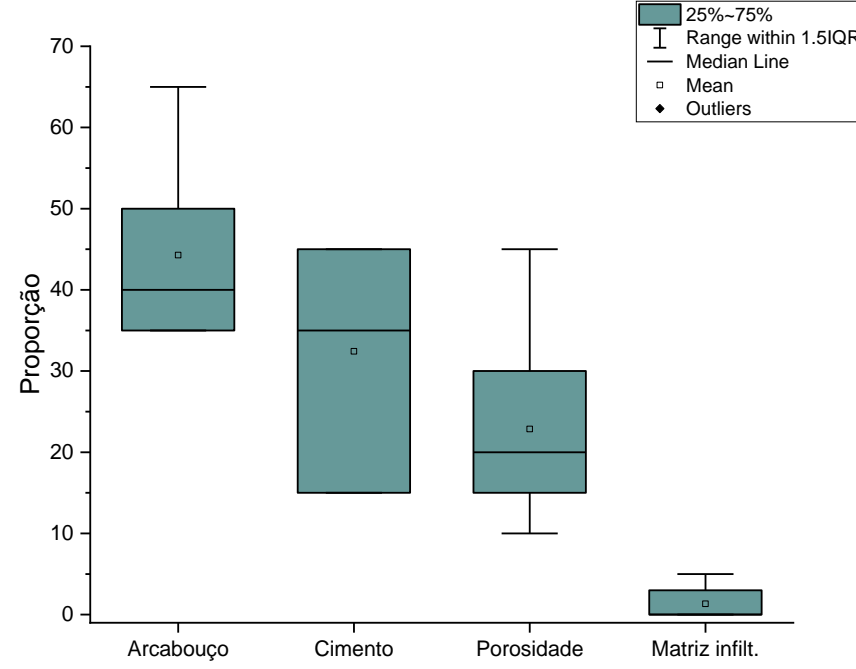

Fig. 5.80. Variação das proporções dos componentes texturais dos eolianitos de Atalaia, AFN. $\mathrm{n}=7$; somente duas amostras apresentaram matriz infiltrada, a qual ocorre em condutos subverticais atribuídos a rizoconcreções. 


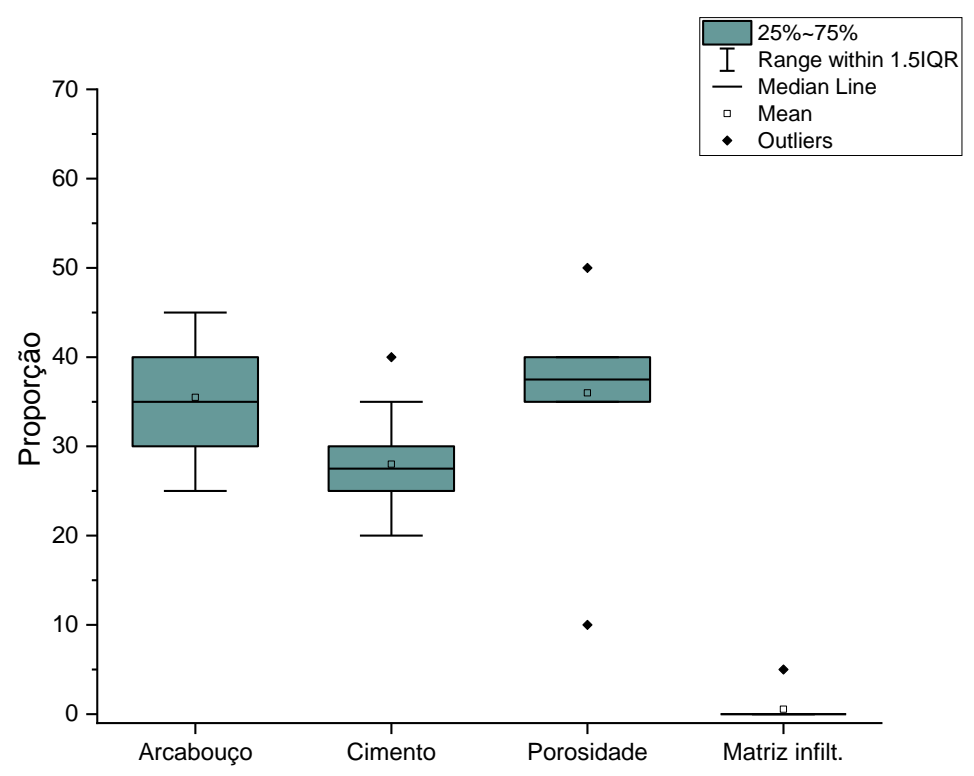

Fig. 5.81. Variação das proporções dos componentes texturais dos eolianitos de Ponta das Caracas, AFN. n=10; somente uma amostra apresentou matriz infiltrada, associada ao preenchimento de rizoconcreções.

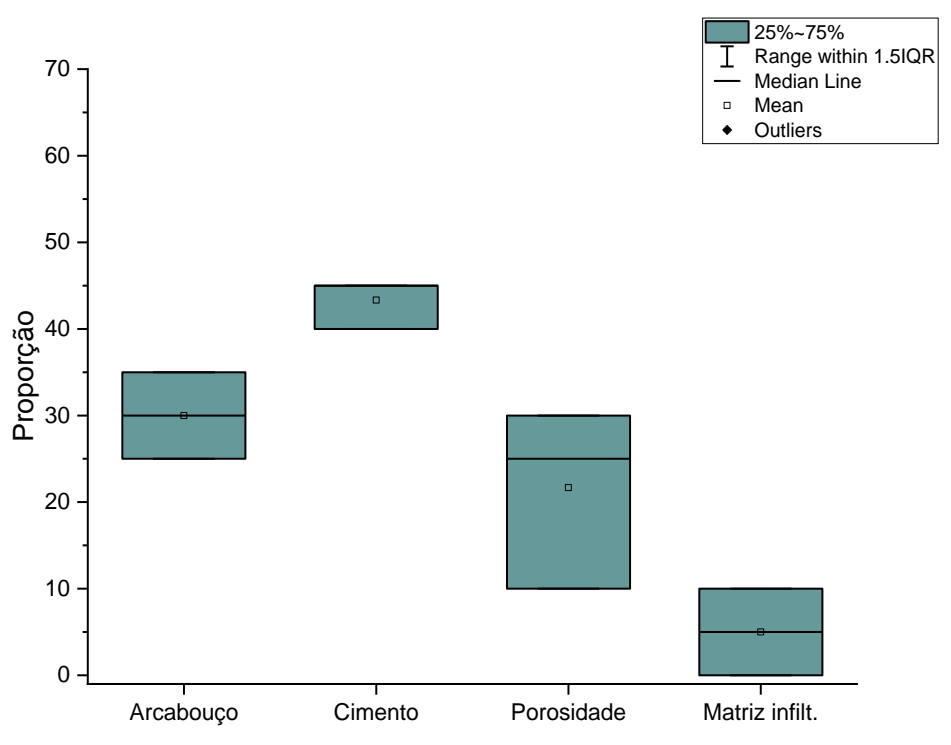

Fig. 5.82. Variação das proporções dos componentes texturais dos eolianitos de Forte de São Joaquim; $n=3$; somente duas amostras apresentaram matriz infiltrada, associada ao preenchimento de rizoconcreções.

Em relação à constituição do arcabouço (Figs. 5.83, 5.84 e 5.85), os eolianitos do AFN apresentam domínio, em volume, de grãos intrabacinais (70-90\%), com destaque, em ordem decrescente de concentração, para: peloides, algas vermelhas, foraminíferos bentônicos (dos taxa Miliolina, Peneroplidae e Nummulites, além de formas incrustante junto a algas vermelhas), pellets fosfáticos e glauconíticos, e em menores proporções $(<5 \%)$, fragmentos de 
esponjas, corais, equinodermas, briozoários, cracas, intraclastos, minerais pesados transparentes e líticos vulcânicos (estes últimos particularmente abundantes nas amostras coletadas em Enseada da Caieira). O domínio de peloides na constituição do arcabouço ocorre em todas as amostras, com valores de até $75 \%$ e média de $45 \%$. As algas vermelhas apresentam concentrações média de 15\%, e os demais componentes, médias menores que $10 \%$ cada um (Fig. 5.85).
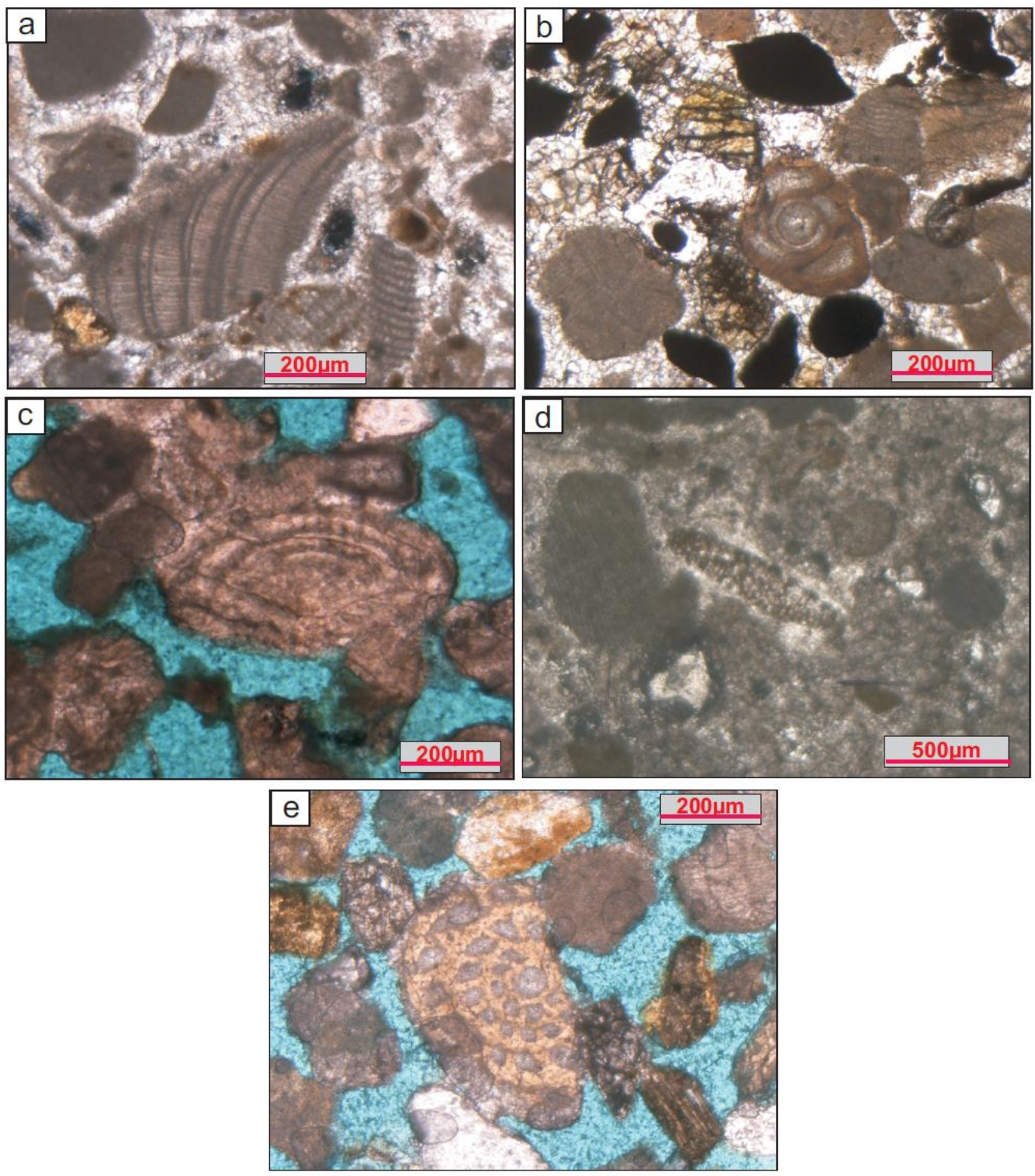

Fig. 5.83 Principais componentes do arcabouço dos eolianitos do AFN: a. peloides, algas vermelhas e possível pellet fosfático, amarelo (EFN 02E); b a f. foraminíferos bentônicos: b. Miliolina (EFN 04C); c. Nummulites (EFN 02F); d. Rotalina (I. do Meio 3); e. Peneroplidae (EFN 04A); notar possíveis pellets fosfáticos também em $\mathbf{b}$ e peloides em todas as imagens. Fotomicrografias a polarizadores paralelos. 

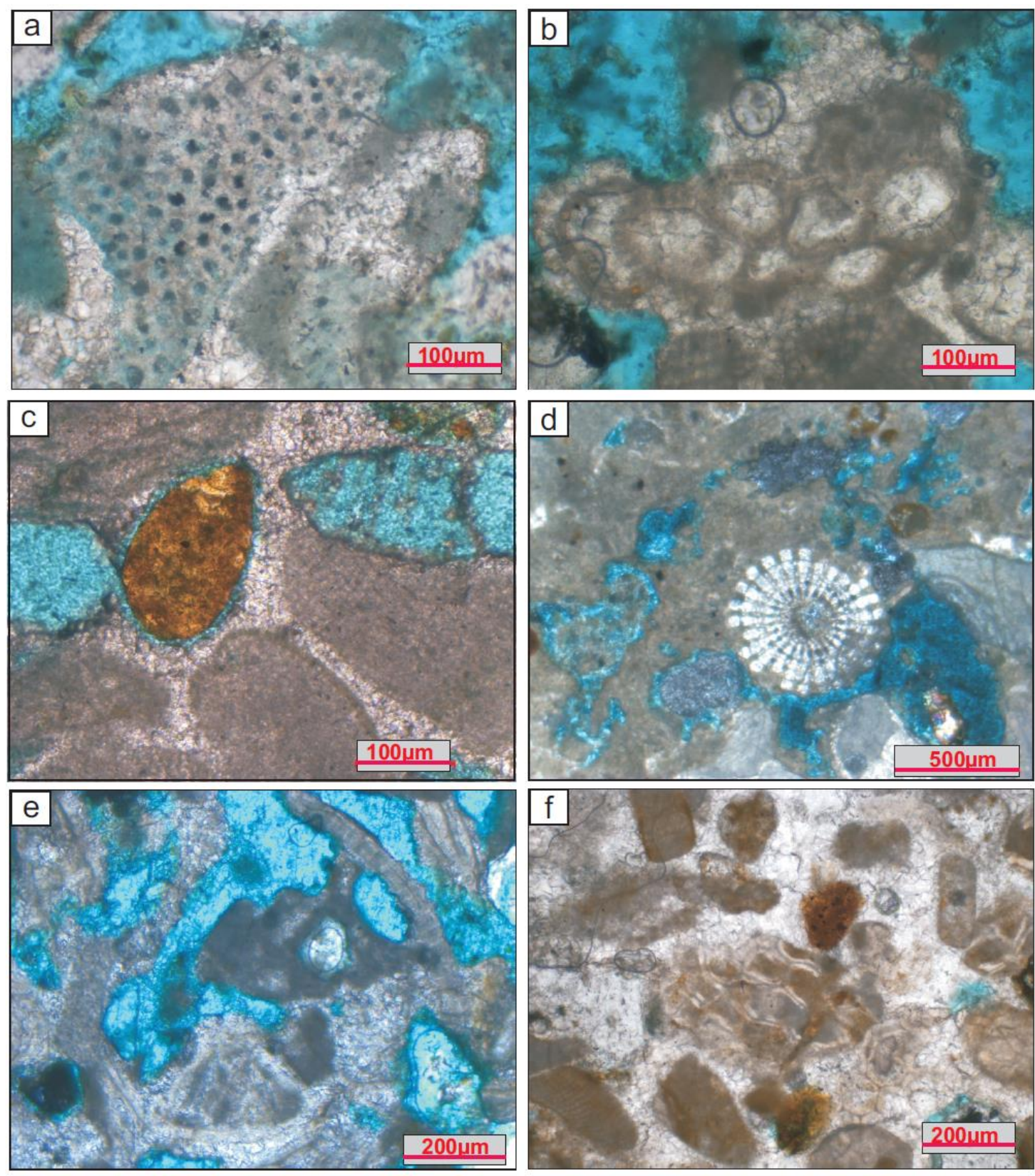

Fig. 5.84. Outros componentes do arcabouço dos eolianitos do AFN: a. fragmento de esponja (EFN 05I); b. fragmento de briozoário (EFN 05Da); c. pellet fosfático (EFN 04B); d. espinho de equinoderma, em seção transversal (I. Rata 1); e. fragmento de coral (EFN 05Da); f. provável foraminífero incrustante (I. do Meio 1). Fotomicrografia d a polarizadores cruzados, e as outras, a paralelos. 


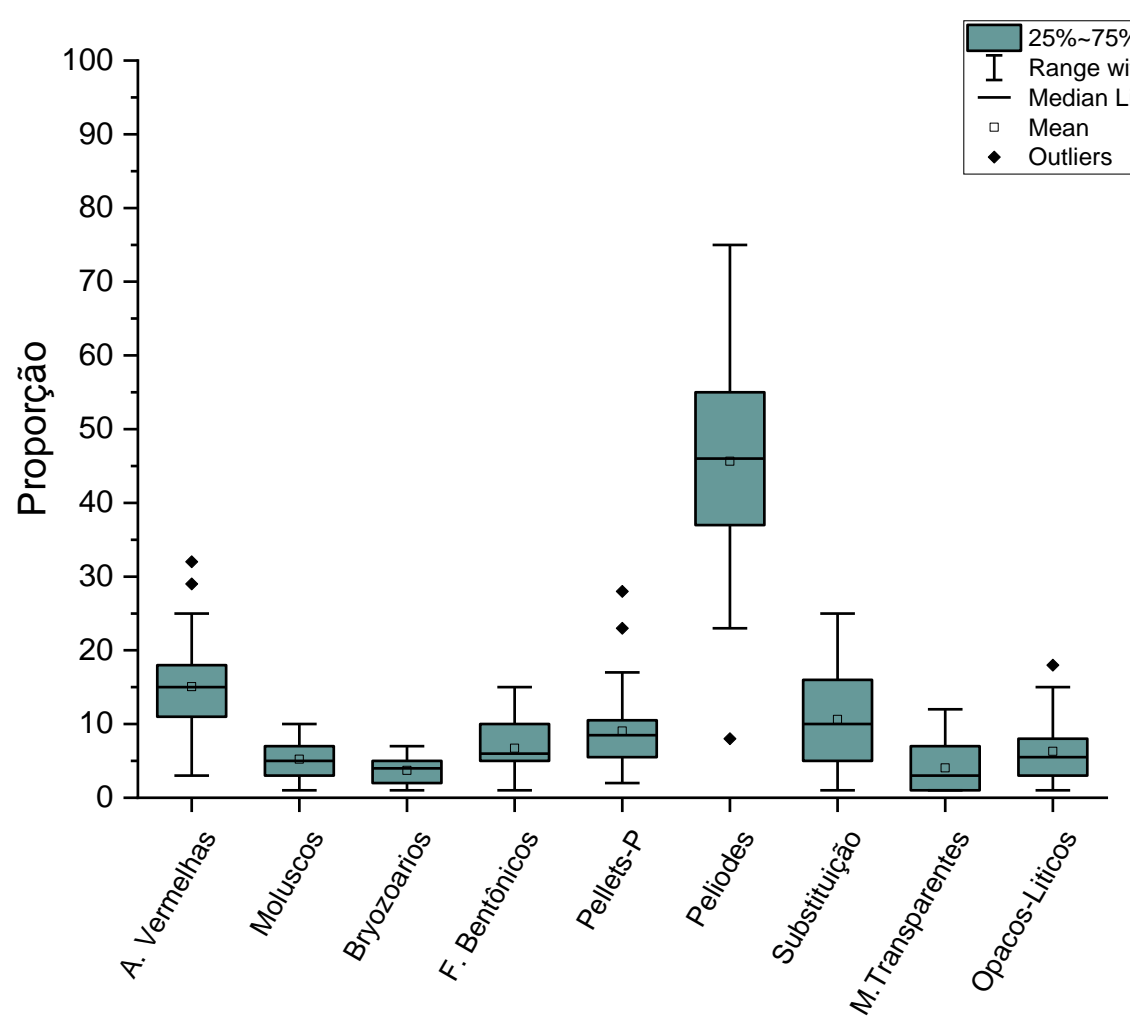

Fig. 5.85. Variação das proporções dos componentes do arcabouço dos eolianitos do AFN. $\mathrm{n}=42$; número de ocorrências: pellets, 40; moluscos, f. bentônicos e opacos e líticos, 38; m.

transparentes, 33; substituição, 31; briozoários, 25. Abreviaturas utilizadas: a. vermelhas: algas vermelhas; f. bentônicos: foraminíferos bentônicos; pellets (P): pellets fosfáticos; substituição: bioclastos parcial ou totalmente substituídos por cimento; m. transparentes: minerais transparentes, fora quartzo.

Um gráfico boxplot (Fig. 5.86) foi construído para comparar a variação da razão peloides / algas vermelhas (Pe/Al) nos afloramentos baixos (Pedra da Bigorna, Chapéu, Ilhas Rata, do Meio e Rasa), reunidos, e altos (Enseada da Caieira, Atalaia, Ponta das Caracas e Forte de São Joaquim), estes analisados cada um em separado. Os resultados mostram medianas e intervalos interquartis de Pe/Al mais elevados para os afloramentos altos de que para os baixos, com exceção do afloramento alto de Ponta das Caracas, que é também o que apresenta maior dispersão de valores, isto é, maior amplitude de intervalo interquartis. 


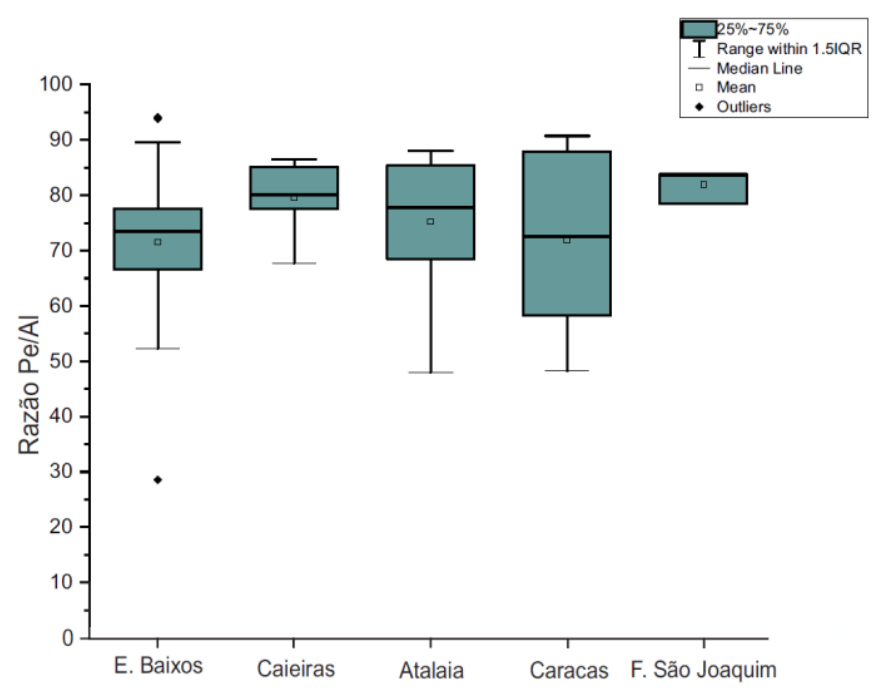

Fig. 5.86. Variação da razão peloides / algas vermelhas (Pe/Al), por área, no AFN. Eolianitos baixos: $n=16$; Caieiras: $n=6$; Atalaia: $n=7$; Caracas: $n=10$; Forte São Joaquim: $n=3$.

O cimento de carbonato de cálcio alcança até $50 \%$ de proporção em volume e encontrase, principalmente, nas dimensões microespática e, em menor presença, micrítica e espática. Ocorre como película ou franja, principalmente nas bordas dos bioclastos, e, em menor proporção, como revestimento ou preenchimento parcial a completo dos espaços intergranulares. A franja envolvente apresenta-se isópaca (Fig. 5.87a) ou, mais comumente anisópaca (Fig. 5.87b); em alguns casos, podem estar evidentes diferentes gerações de cimento.
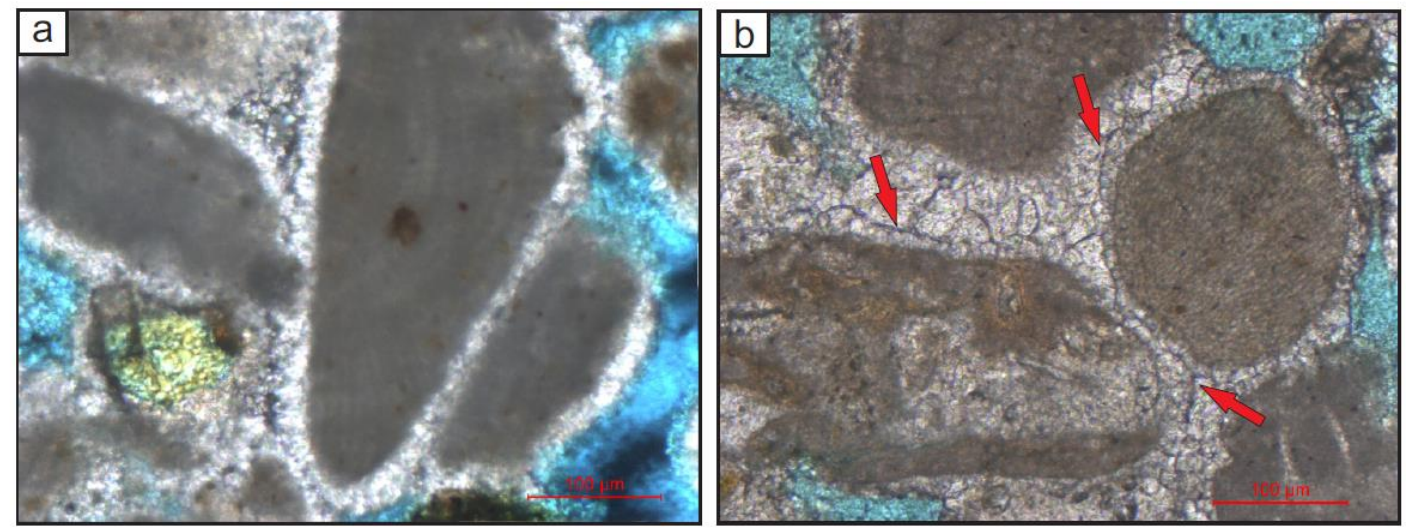

Fig. 5.87. Principais tramas de cimento carbonático em eolianitos do AFN: a. franjas isópacas e anisópacas (EFN 02E); b. franjas anisópacas e preenchimento em mosaico, com linhas de sutura mediana indicadas pelas setas (EFN 04B). Fotomicrografias a polarizadores paralelos.

Outras tramas de cimento carbonático comuns são: em menisco (Fig. 5.88a); e micronodular, concentrada ao longo de zonas oblíquas ou junto a agrupamentos de grãos mais finos e/ou mais próximos, sobretudo bioclastos (Fig. 5.88b). 
Tipos de textura e trama de cimento carbonático observados em menor proporção são: preenchimento intergranular espático em mosaico e substituição espática parcial ou total de bioclastos (Fig. 5.89).
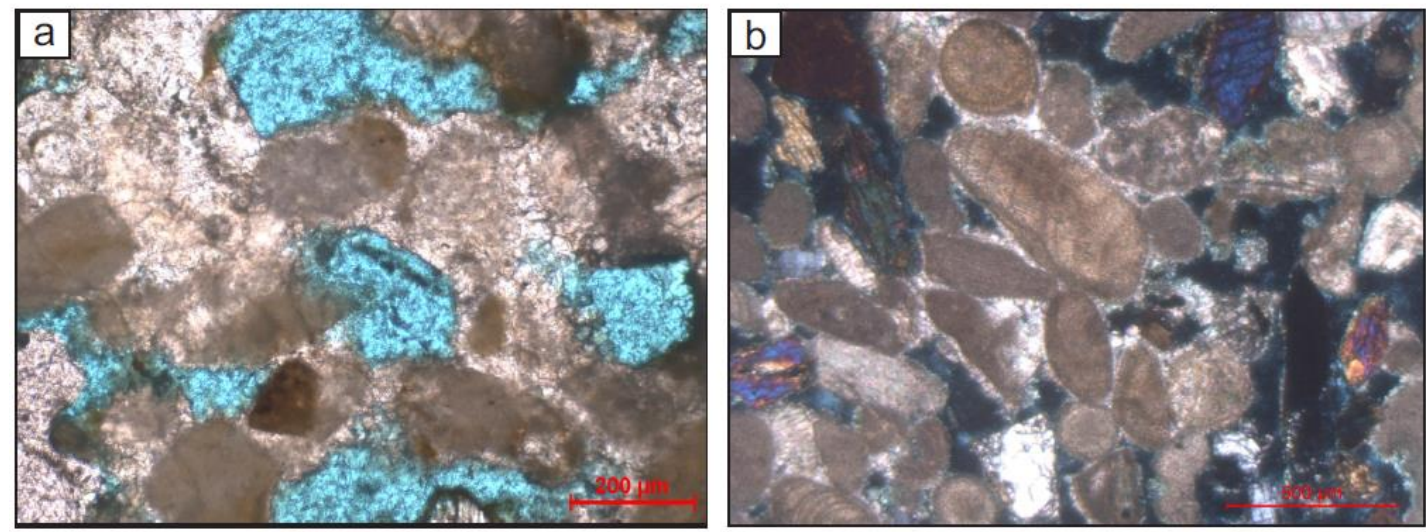

Fig. 5.88. Outras tramas de cimento em eolianitos do AFN: a. em menisco (EFN 05B); b. concentrado junto a bioclastos, ao longo de zonas oblíquas (EFN 04B). Fotomicrografias a polarizadores cruzados.
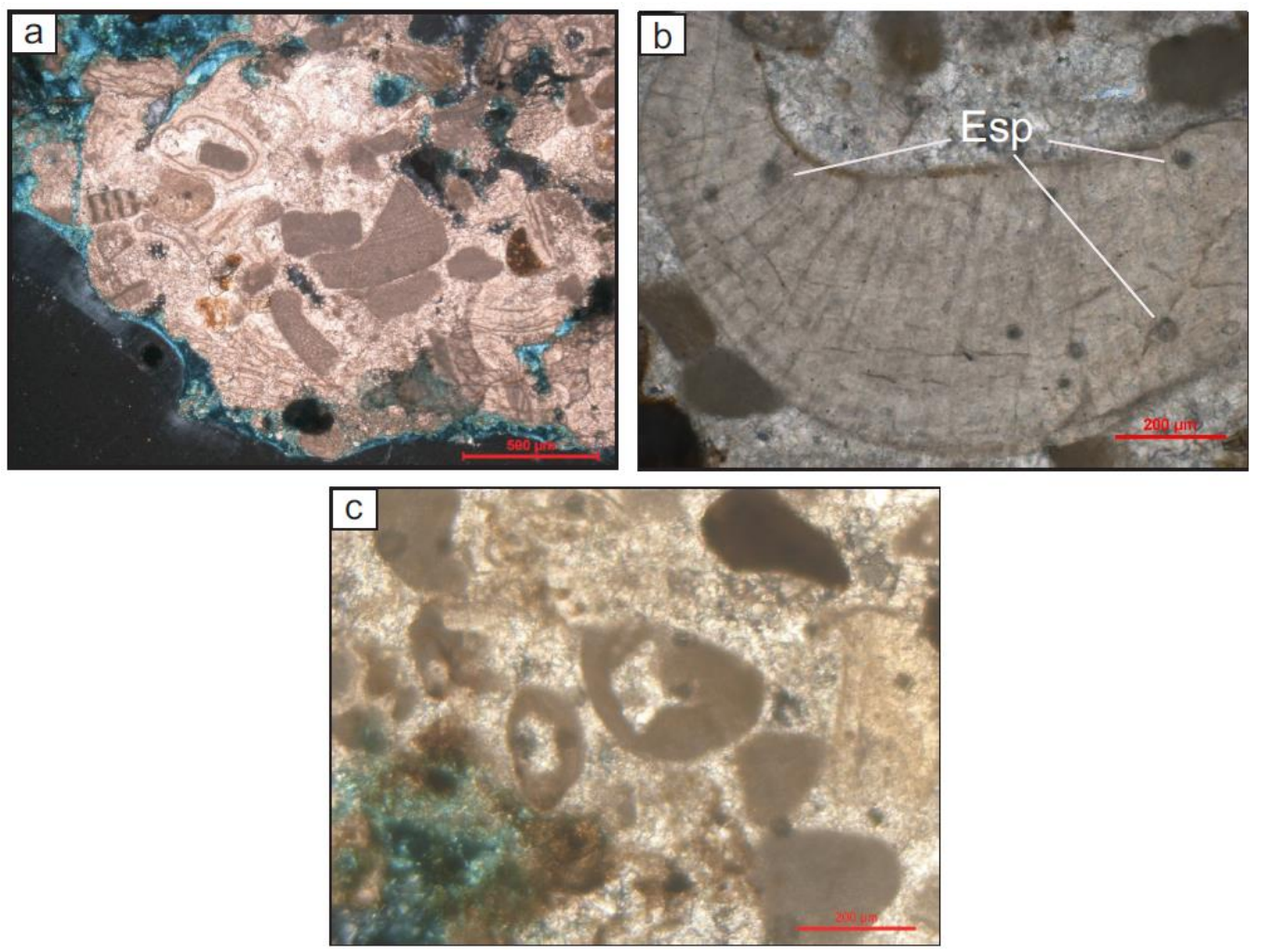

Fig. 5.89. Tramas de cimentos espáticos em eolianitos do AFN: a. em mosaico (EFN 05H); b. de neomorfismo de alga vermelha (com presença de esporângios - Esp) (Ilha do Meio 1); e c. como substituição parcial de bioclastos com envelope micrítico (Ilha do Meio 1). Fotomicrografias a polarizadores cruzados. 
Os boxplots das Figs. 5.90 e 5.91 apresentam resultados de quantificação de tramas de cimento para afloramentos baixos e altos, respectivamente. Nos afloramentos baixos (Fig. 5.90), destaca-se a presença de franjas envolventes anisópacas, isópacas e em mosaico; enquanto isso, nos afloramentos altos, o cimento em mosaico tem maior destaque, seguido pela franja envolvente anisópaca, com total ausência da isópaca (Fig. 5.91).

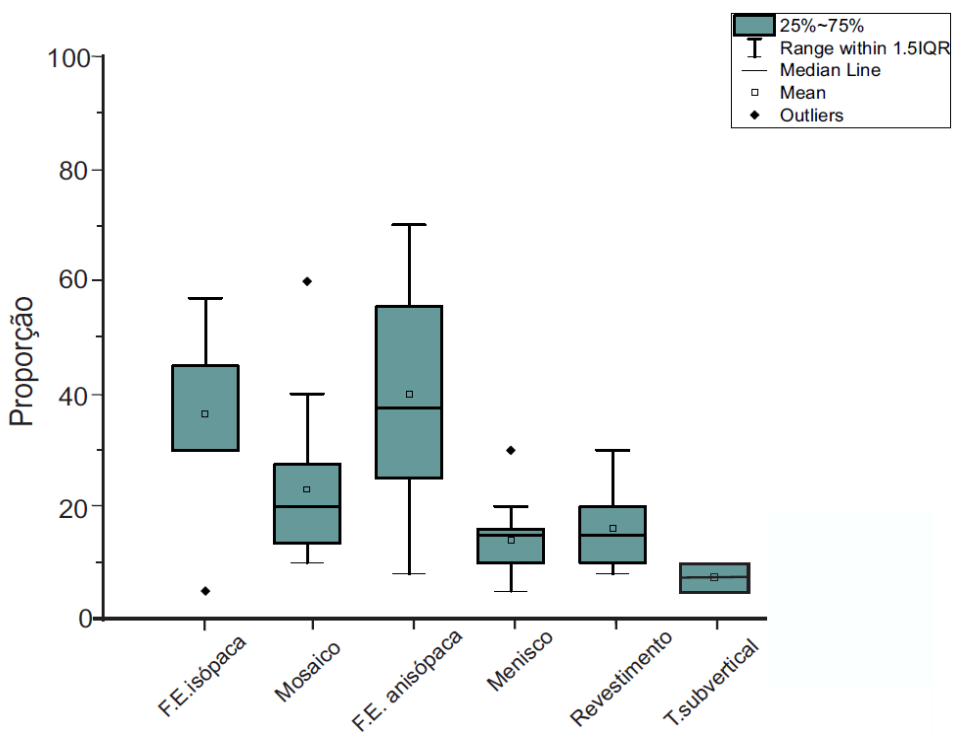

Fig. 5.90. Variação das proporções das tramas de cimento nos afloramentos baixos do AFN. Números de ocorrências: f.e. isópaca, 5; mosaico e f.e. anisópaca, 16; menisco, 12; revestimento, 15; T. subvertical, 2. Abreviaturas utilizadas: f.e. isópaca/ anisopaca: franja envolvente isópaca/ anisopaca, revestimento: revestimento de poros, t: tendência à concentração.

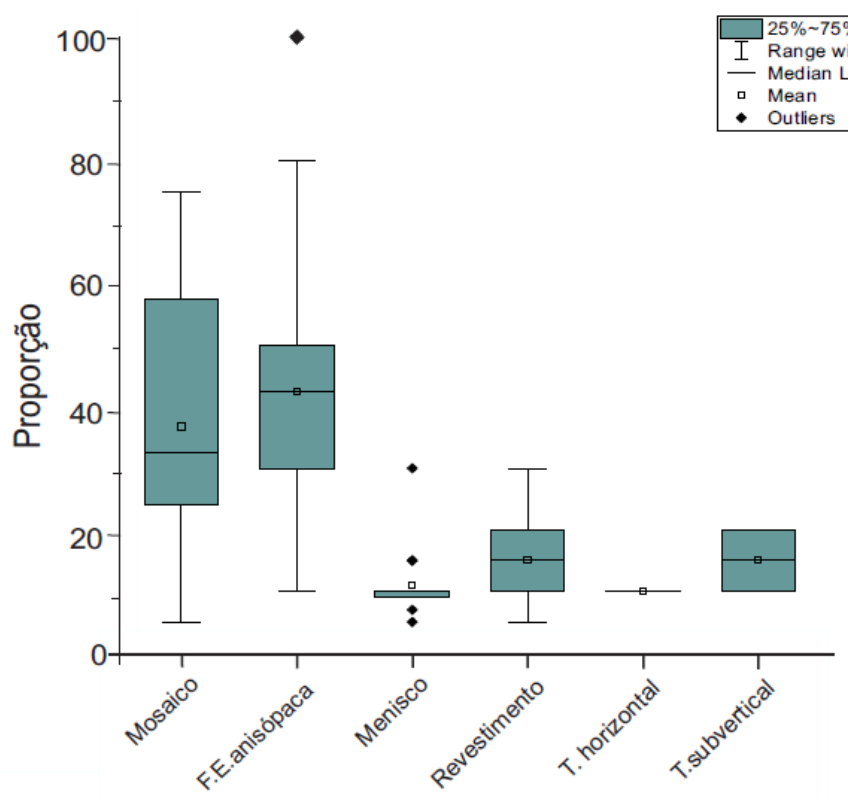

Fig. 5.91. Variação das proporções de tramas de cimentos nos afloramentos altos do AFN. Números de ocorrências: mosaico, 24; f. e. anisópaca, 26; menisco,13; revestimento, 23; t. horizontal, 6; t. subvertical, 2. Abreviaturas utilizadas: f.e. anisopaca: franja envolvente anisopaca, revestimento: revestimento de poros, t: tendência à concentração. 
Os boxplots das Figs. 5.92 e 5.95 apresentam resultados de quantificação de tramas de cimento para as diferentes áreas geográficas com afloramentos altos. Quando são comparadas individualmente estas áreas, a Enseada da Caieira distingue-se por ter as proporções de franja envolvente anisópaca mais elevadas, com intervalo interquartis entre 45 e $80 \%$, sem sobreposição com os intervalos de outros tipos de trama (Fig. 5.92); em Atalaia (Fig. 5.93) e em Ponta das Caracas (Fig. 5.94), as tramas dominantes são franja anisópaca e mosaico, com sobreposição parcial de intervalo interquartis entre estes dois tipos de trama; já nos eolianitos de Forte de São Joaquim, a trama em mosaico é fortemente dominante, com intervalo interquartis, entre 70 e 74\%, muito mais elevado que demais tipos de tramas (Fig. 5. 95).

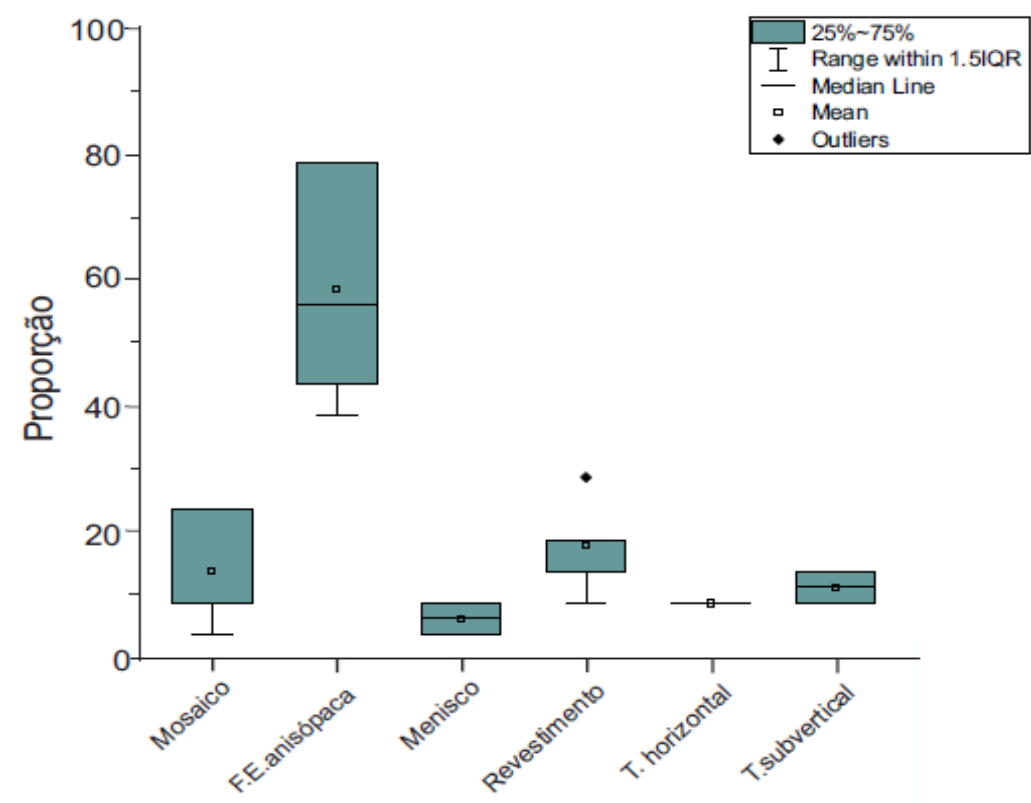

Fig. 5.92. Variação das proporções dos tipos de tramas de cimento nos eolianitos de Enseada da Caieira, AFN. Números de ocorrências: mosaico, 5; f. e. anisópaca, 6; menisco, 2; revestimento, 6; t. horizontal, $1 ;$ t. subvertical, 2 . Abreviaturas utilizadas: f.e. anisópaca: franja envolvente anisópaca, revestimento: revestimento de poros, t: tendência à concentração. 


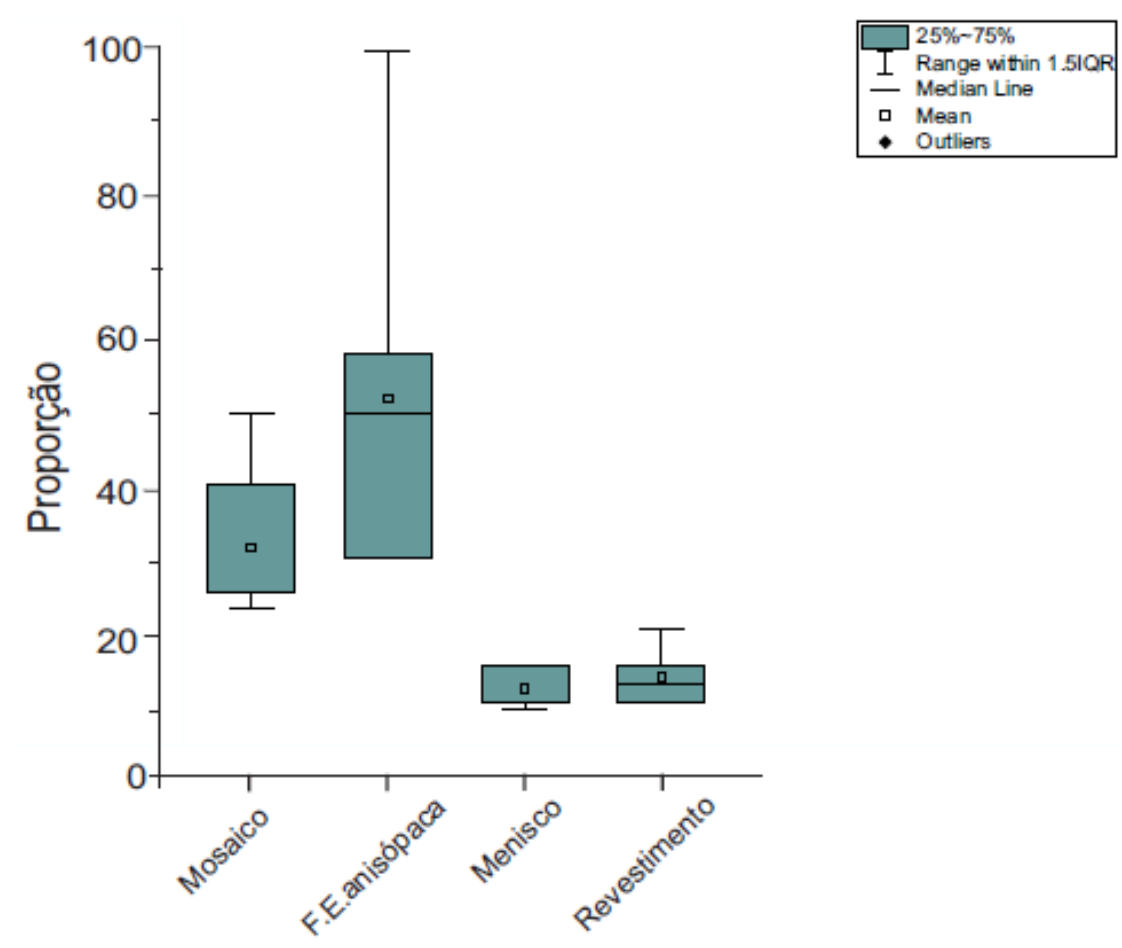

Fig. 5.93. Variação das proporções dos tipos de tramas de cimento nos eolianitos de Atalaia, AFN. Números de ocorrências: mosaico, 6; f. e. anisópaca, 7; menisco, 5; revestimento, 6. Abreviaturas utilizadas: f.anisópaca: franja envolvente anisópaca, revestimento: revestimento de poros.

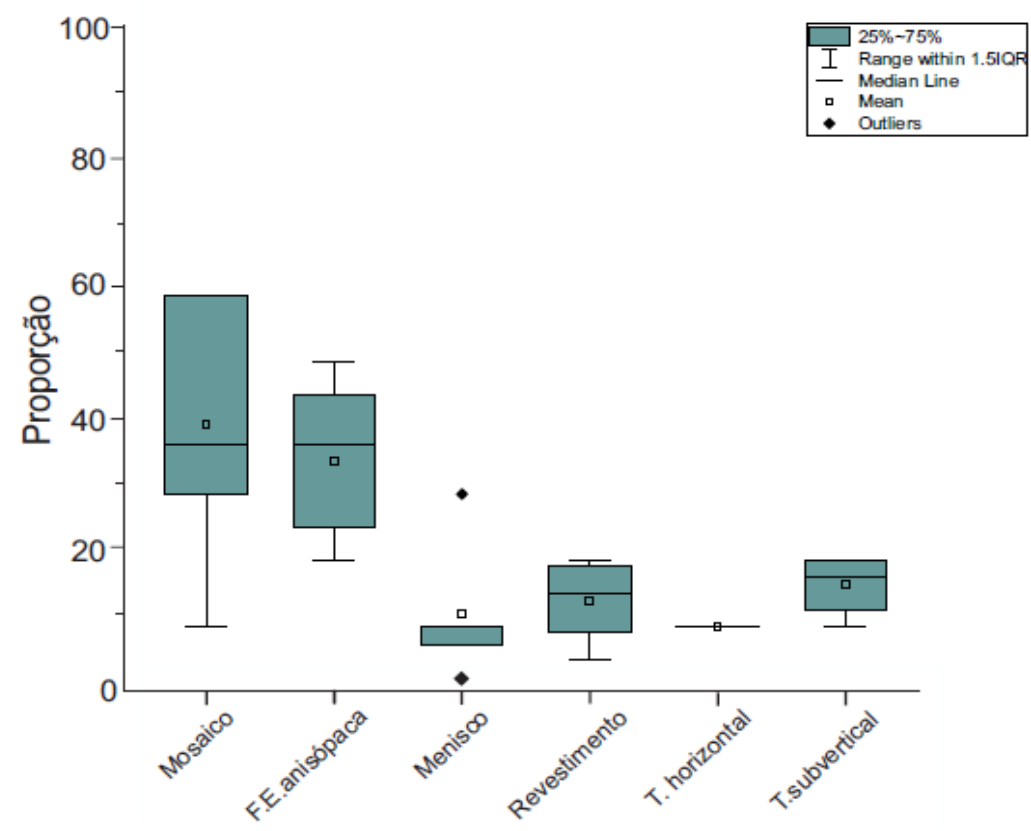

Fig. 5.94. Variação das proporções dos tipos de tramas de cimento nos eolianitos de Ponta das Caracas, AFN. Números de ocorrências: mosaico, 10; f. e., 10; menisco, 5; revestimento, 8; t. horizontal, 1 ; t. subvertical, 4. Abreviaturas utilizadas: f.e. isópaca/anisópaca: franja envolvente isópaca/ anisópaca, revestimento: revestimento de poros, t: tendência à concentração. 


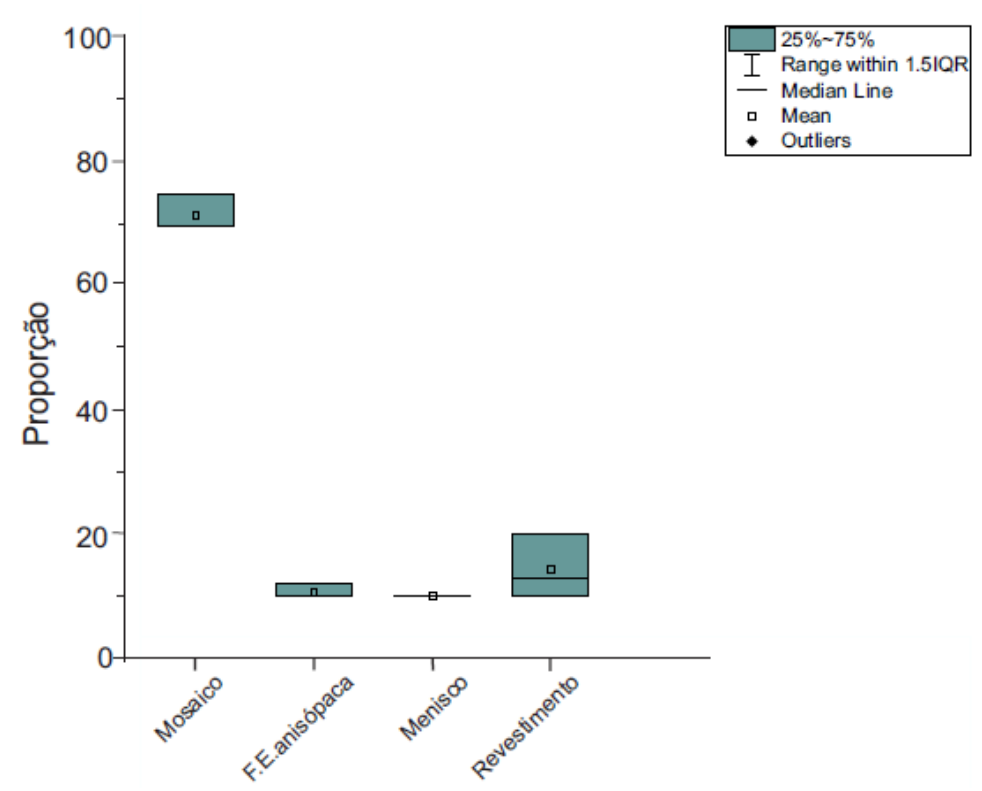

Fig. 5.95. Variação das proporções dos tipos de tramas de cimentos nos eolianitos de Forte de São Joaquim, AFN. Números de ocorrências: mosaico, 3; f.e. anisópaca, 3; menisco, 1; revestimento, 3. Abreviaturas utilizadas: f.e. anisópaca: franja envolvente anisópaca, revestimento: revestimento de poros.

Nas classificações de Folk (1959, 1962), os eolianitos de AFN foram considerados como calciarenitos biopelmicroespatitos. A confirmação do prefixo do segundo termo (biopel) depende da interpretação da origem dos peloides, a ser feita no item de discussão da tese. 


\subsubsection{Fácies associadas}

Quanto às fácies associadas aos eolianitos, foram analisadas duas lâminas de amostras pertencentes ao afloramento baixo de Pedra da Bigorna. A primeira, referente à fácies Ap (EFN 02C), é clasto-suportada, com arcabouço de moda granulométrica na classe areia fina, bem selecionado, composto principalmente por bioclastos de algas vermelhas (com suas estruturas internas parcialmente apagadas), foraminíferos bentônicos, moluscos, líticos vulcânicos e minerais pesados opacos e transparentes (Fig. 5.96a). A segunda amostra, da fácies Am (EFN 02D), é clasto-suportada, com arcabouço de moda granulométrica na classe areia fina, moderadamente selecionado, cujos principais componentes são fragmentos de moluscos, peloides e equinodermas (Fig. 5.96b).

A petrotrama destas duas lâminas apresenta empacotamento aberto e contatos pontuais, com orientação de grãos visível em algumas porções. As porosidades são principalmente seletiva intergranular, e em menor proporção, intragranular.

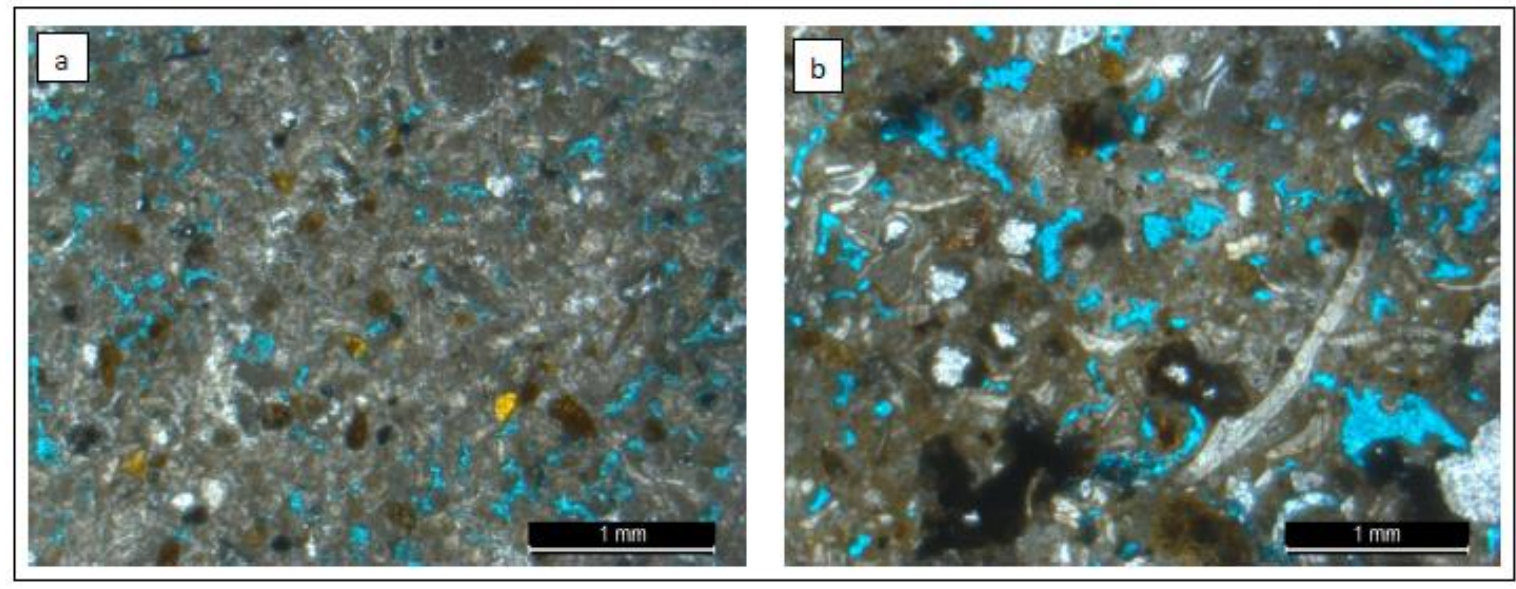

Fig. 5.96 Fotomicrografias a polarizadores paralelos de fácies associadas a eolianitos na área da Pedra da Bigorna: a. lâmina EFN 02C (fácies Ap); b. EFN 02D (fácies Am). Em a, notar os peloides e grãos fosfáticos (amarelos) e em $\mathbf{b}$, notar valvas de moluscos, e peloides aglutinados, suspeitos como de algas vermelhas micritizadas.

Já os cimentos observados são carbonáticos, principalmente em franja isópaca com linhas de sutura e recristalização de bioclastos (apagando as estruturas internas, lâmina EFN 02C) (Fig. 5.97a), e como preenchimento de porosidade móldica por espato na lâmina EFN 02D (Fig. 5.97b). 


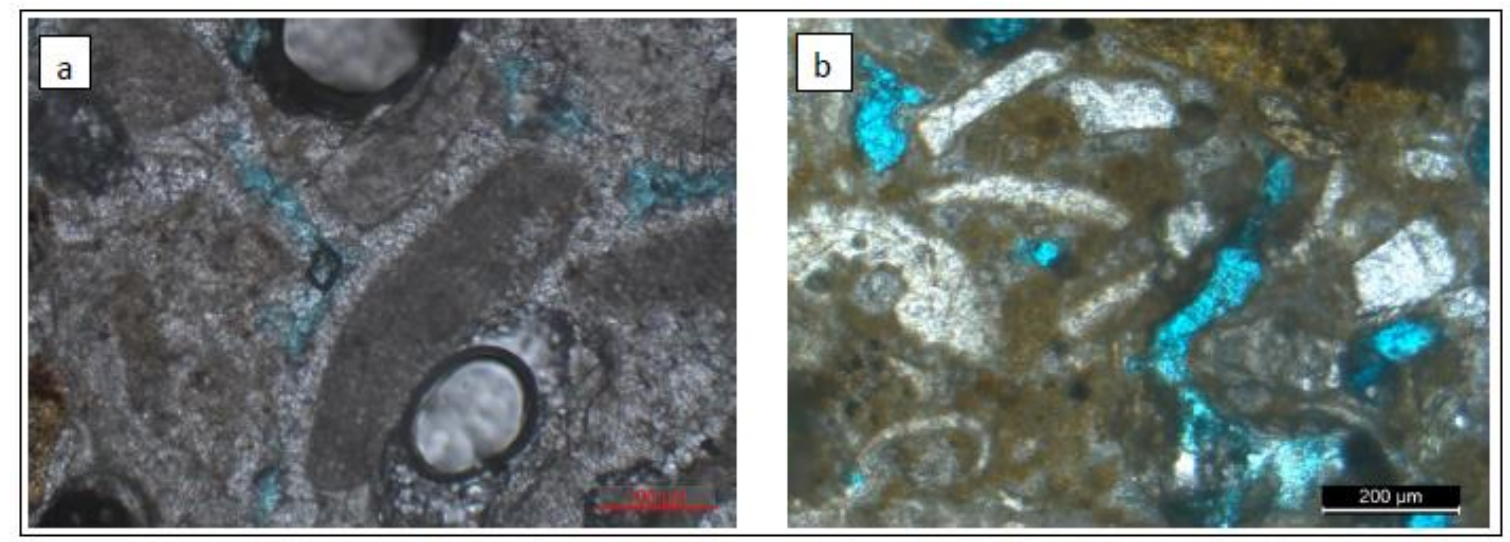

Fig. 5.97 Cimentos carbonáticos presentes nas fácies associadas a eolianitos do AFN: a. franja isópaca espática, em torno de bioclastos de algas vermelhas com estrutura interna parcialmente apagada, na lâmina EFN 02C - fácies Ap; b. preenchimento de porosidade móldica por cimento

espático, na lâmina EFN 02D - fácies Am. Fotomicrografias a polarizadores paralelos.

Nas classificações de Folk (1959, 1962), as amostras tanto da fácies Ap como da Am correspondem a calciarenito biopelespatito. A exemplo das classificações petrográficas anteriores, o prefixo do segundo termo (biopel) depende da discussão sobre a origem dos peloides.

\subsection{Microscopia Eletrônica de Varredura}

Sete amostras foram analisadas ao sistema MEV-EED, sendo: três de rocha bruta in natura (fratura fresca) previamente datadas por ${ }^{14} \mathrm{C}$, duas delas do AFN (I. Rata 3 e EFN 05E) (Fig. 5.98) e uma do RN (ERN 21E); duas de bioclastos previamente separados (Fig. 5.99), a partir das mesmas amostras do AFN, para a datação pareada (cimento versus bioclasto); e duas na forma de seções delgadas (Ilha do Meio 1 e EFN 04A; Tabela 5 e Fig. 5.100), com foco na análise química quantitativa por EED. A finalidade principal deste estudo ao MEV-EED foi buscar feições de trama, textura e composição química dos bioclastos ou do cimento, que pudessem explicar a inversão sistemática de idades ${ }^{14} \mathrm{C}$ entre bioclasto e cimento (isto é, bioclasto mais novo que cimento, $c f$. item 5.6).

Nas análises feitas em rocha íntegra, observaram-se feições indicativas de dissolução parcial ou total de bioclastos de algas vermelhas: estes bioclastos são frequentemente ocos e envolvidos por cimentos em franja e menisco (Fig. 5.93), o que aponta para porosidade alveolar 
(Fig. 5.98a) a móldica (Fig. 5.98 b, c e f), gerada por dissolução da calcita magnesiana da alga, ocorrida após a cimentação grão-envolvente. Também com frequência, calcita espática ou microespática, mais bem cristalizada que a do cimento envolvente, é encontrada como preenchimento parcial desta porosidade alveolar ou móldica (Fig. 5.98c e d). Com base nestes resultados, elaborou-se a hipótese de trabalho de que o que foi datado nas alíquotas de bioclastos, sobretudo naquela maioria dos casos em que houve inversão de idade, corresponde sobretudo ao cimento de calcita, mais tardio, que preencheu a porosidade alveolar-móldica, e não à calcita magnesiana original da alga vermelha, tampouco ao cimento mais precoce que envolve os bioclastos. Desse modo, os grãos com idades ${ }^{14} \mathrm{C}$ mais novas que o cimento seriam, na verdade, pseudomorfos de algas vermelhas.

Para testar esta hipótese de trabalho, foram tomadas ao MEV imagens, com maior detalhe (aumentos de 10 mil vezes ou mais), de bioclastos que ainda exibiam a trama celular característica da alga vermelha. Nestas imagens, as células mostram-se formadas por agregados hemisferoides, de cerca de $10 \mu \mathrm{m}$, de calcita tabular com frequente terminação em ponta (Fig. 5.99). A análise química semiquantitativa por EED destes agregados apontou para a presença, em alto conteúdo, de Ca (acima de 40\%) e de O (25-50\%); e em menor proporção (0,4 a 6,1\%), de Fe, P, Si e Mg (o C não foi contabilizado na análise, por coincidir com a composição do revestimento utilizado na preparação da amostra). 


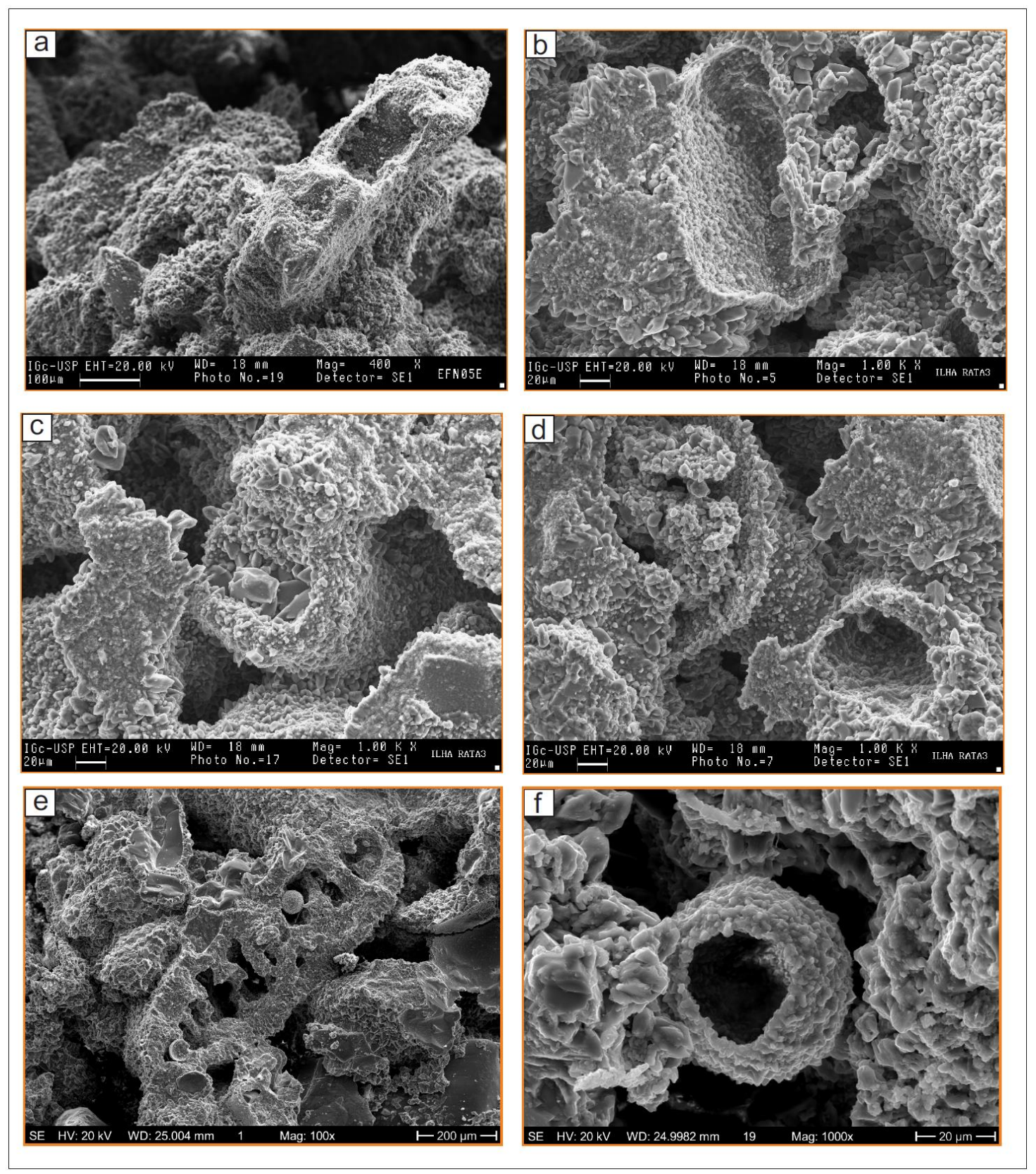

Fig. 5.98. Feições de dissolução e cimentação em bioclastos de alga vermelha de amostras in natura: a. dissolução parcial de bioclasto, gerando porosidade alveolar; b. dissolução total de bioclasto, gerando porosidade móldica; c. cimento microespático grosso, preenchendo porosidade móldica de alga vermelha previamente revestida por microespato isópaco fino; $\mathbf{d}$. poros móldicos, inclusive parcialmente preenchidos (esquerda superior), em bioclastos previamente cimentados em menisco e em franja anisópaca; e. pseudomorfo de alga vermelha, com restos de esporângios; f. detalhe de um esporângio, evidenciando porosidade móldica. Amostras EFN 05E em a; I Rata3 em b, c e d; e ERN 21E em e e f. Eletromicrografias obtidas com detector de elétrons secundários. 
O tamanho reduzido do pico de $\mathrm{Mg}$ e o baixo teor em massa deste elemento (menor que 1\%) nas análises semiquantitativas (Fig. 5.99) reforçam a hipótese de dissolução da calcita magnesiana original da alga vermelha. $\mathrm{O}$ teor calculado de $\mathrm{Mg}$ na calcita magnesiana da alga vermelha de águas tropicais (19\% de proporção molar de $\mathrm{MgCO}_{3}$ para $81 \%$ de $\mathrm{CaCO}_{3}$; Morse \& Mackenzie 1990, Ries 2010, Mackenzie et al. 2018), sem contabilizar o carbono, seria de $5,4 \%$, e a relação de proporção em massa entre $\mathrm{Mg}$ e Ca, de cerca de 0,14 , enquanto nas análises semiquantitativas realizadas esta relação se mostrou sempre inferior a 0,02. Além disso, considerando que se trate de cimento pseudomorfo, este baixo teor de $\mathrm{Mg}$ é pouco compatível com calcita precipitada a partir de água do mar (em áreas tropicais, 14 a 19\% de proporção molar de $\mathrm{MgCO}_{3}$ : Folk 1974, Mackenzie et al. 2018), o que sugere que a substituição da alga se deu sob influência de água meteórica (Fig. 5.99).

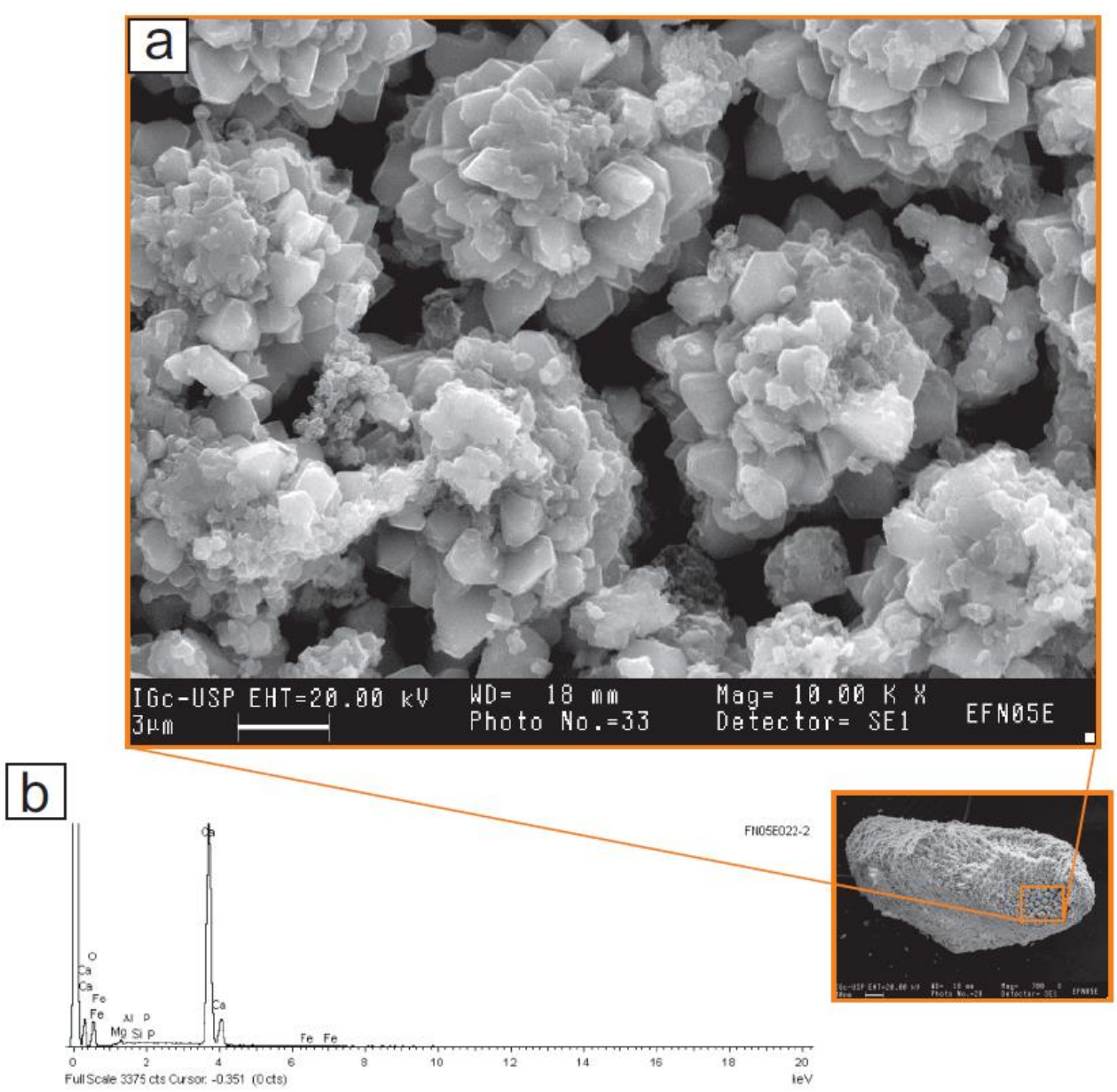

Fig. 5.99 Pseudomorfismo ou neomorfismo (substituição de calcita $\mathrm{Mg}$ por calcita) de bioclasto de alga vermelha: a. zoom-in nos agregados de cristais de calcita; b. gráfico de EED da calcita, com pico de $\mathrm{Mg}$ reduzido, o que evidencia substituição da calcita $\mathrm{Mg}$ original da alga vermelha. Notar que, apesar do pseudomorfismo, a trama celular original da alga permanece, o que dificulta a identificação do neomorfismo ao microscópio óptico. Amostra EFN 05E, eletromicrografias obtidas com detector de elétrons secundários. 
Visando comparar com maior precisão as composições de bioclastos versus cimento, análise química por EED foi realizada também em seção delgada (Fig. 5.100), agora com resultados quantitativos (Tabela 5). A eletromicrografia a elétrons retroespalhados mostrou parte dos grãos (por exemplo, pontos 5 e 13 na Fig. 5.100) com coloração mais escura que a do cimento, o que se associa a teor ligeiramente mais alto de $\mathrm{Mg}$ (Tabela 5).

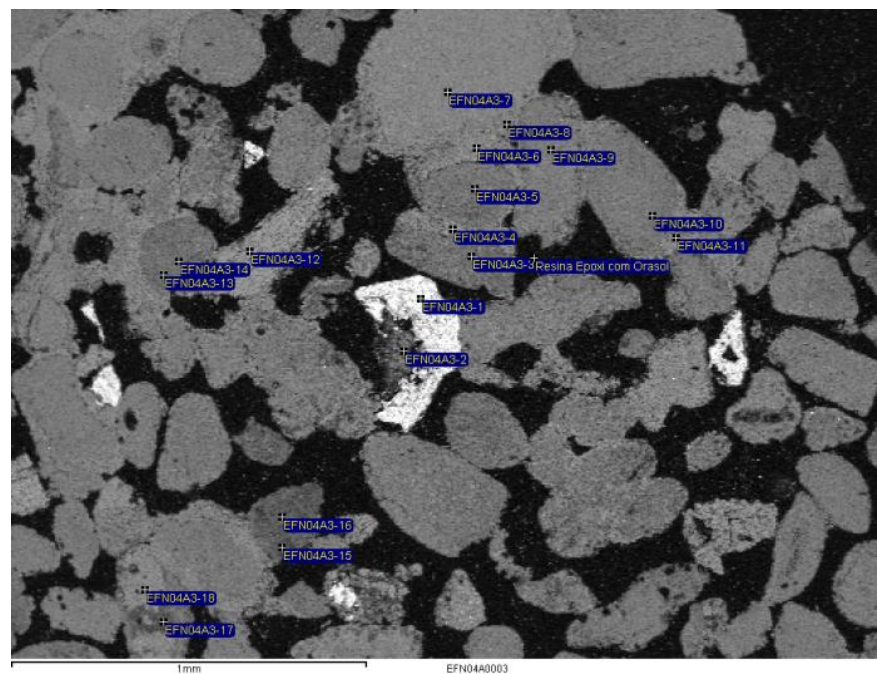

Fig. 5.100. Eletromicrografia de retroespalhados da lâmina EFN 04A, indicando os pontos analisados (grãos-bioclastos e cimentos), cuja composição é listada na Tabela 5.

Tabela 5. Análise química semiquantitativa por EED na seção delgada da amostra EFN 04A. ND indica não detectado. * Proporções em massa calculadas em relação aos elementos químicos da calcita magnesiana, sem o carbono.

\begin{tabular}{|c|c|c|c|c|c|c|}
\hline $\begin{array}{c}\text { Ponto da } \\
\text { eletromicrografia } \\
\text { (Fig. 5.95) }\end{array}$ & $\begin{array}{c}\text { Material } \\
\text { analisado }\end{array}$ & $\begin{array}{c}\text { Mg } \\
\text { (\% em } \\
\text { átomos) }\end{array}$ & $\begin{array}{c}\text { Ca } \\
\text { (\% em } \\
\text { átomos) }\end{array}$ & $\begin{array}{c}\text { Mg (\% em } \\
\text { massa, } \\
\text { calculada*) }\end{array}$ & $\begin{array}{c}\text { Ca (\% em } \\
\text { massa, } \\
\text { calculada*) }\end{array}$ & $\begin{array}{c}\text { Mg/Ca } \\
\text { (em } \\
\text { massa) }\end{array}$ \\
\hline EFN04A3-3 & Grão & 4,88 & 43,75 & 4,38 & 65,49 & 0,07 \\
\hline EFN04A3-4 & Cimento & 2,40 & 46,36 & 2,12 & 68,31 & 0,03 \\
\hline EFN04A3-5 & Grão & 4,40 & 45,03 & 3,90 & 66,47 & 0,06 \\
\hline EFN04A3-6 & Cimento & 1,15 & 48,02 & 1,00 & 69,80 & 0,01 \\
\hline EFN04A3-7 & Grão & ND & 49,34 & ND & 71,16 & 0,00 \\
\hline EFN04A3-8 & Cimento & 2,52 & 47,06 & 2,20 & 68,57 & 0,03 \\
\hline EFN04A3-9 & Grão & 7,41 & 41,70 & 6,71 & 62,90 & 0,11 \\
\hline EFN04A3-10 & Grão & 5,65 & 43,35 & 5,07 & 64,84 & 0,08 \\
\hline EFN04A3-11 & Cimento & 0,89 & 48,82 & 0,77 & 70,36 & 0,01 \\
\hline EFN04A3-13 & Grão & 6,09 & 42,74 & 5,50 & 64,30 & 0,09 \\
\hline EFN04A3-15 & Grão & 6,00 & 40,05 & 5,64 & 62,77 & 0,09 \\
\hline EFN04A3-18 & Grão & ND & 48,58 & ND & 70,78 & 0,00 \\
\hline
\end{tabular}

A diferença composicional entre grão e cimento fica bem evidenciada no gráfico boxplot da Fig. 5.101, o qual compara os teores em massa de Mg encontrados nos cimentos e bioclastos analisados não somente entre si (Tabela 5), mas também com os teores em massa mínimo 
(correspondente a 5\% de moléculas de $\mathrm{MgCO}_{3}: 5 \%$ mol) e máximo (30\% mol) registrados na literatura para algas vermelhas em geral e com o teor médio de algas vermelhas de áreas tropicais (19\% mol) (Morse \& Mackenzie 1990, Ries 2010, Mackenzie et al. 2018). Na construção desse gráfico, o teor mínimo adotado é o encontrado exclusivamente em algas de águas frias e todos os teores apresentados referem-se ao total da calcita sem contabilizar o carbono (já que este elemento foi desconsiderado nas análises por EED). O gráfico mostra que, apesar das evidências de ocorrência de neomorfismo dos bioclastos de algas vermelhas (Fig. 5.101), o intervalo interquartis do teor de $\mathrm{Mg}$ nos grãos de algas dos eolianitos é mais elevado que o intervalo interquartis do cimento, com quase nenhuma sobreposição. Por outro lado, o intervalo interquartis desses bioclastos é mais baixo que os teores máximo e médio de $\mathrm{Mg}$ em algas vermelhas de águas tropicais.

Os teores de $\mathrm{Mg}$ mais altos nos bioclastos que no cimento, evidenciados na análise química quantitativa por EED (Tabela 5, Figs. 5.100 e 5.101), permitem sugerir que parte da calcita magnesiana original pode ter-se preservado, o que ajudaria a explicar a boa conservação, observada ao microscópio óptico, da estrutura biogênica em alguns dos bioclastos de algas vermelhas. Outra hipótese, não excludente da primeira, é que, admitido o neomorfismo dos grãos, o seu teor mais alto de $\mathrm{Mg}$ poderia significar que o segundo cimento, de preenchimento pseudomorfo da porosidade móldica, teria se precipitado sob influência de águas mais salinas que o primeiro, envolvente.

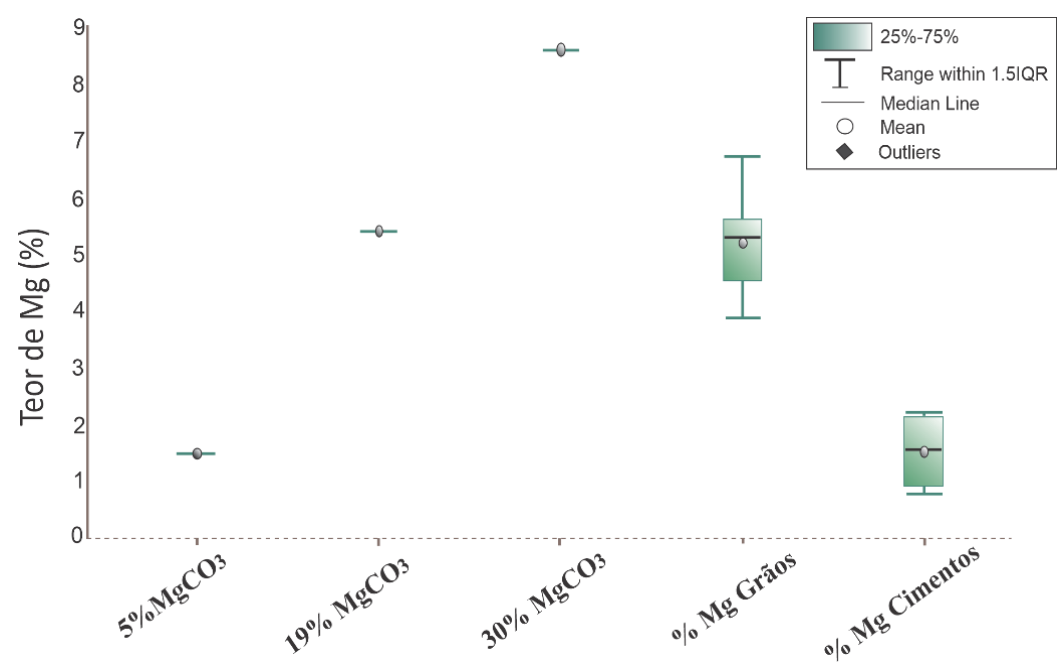

Fig. 5.101. Comparação entre os teores de $\mathrm{Mg}$ em algas vermelhas com diferentes concentrações de $\mathrm{MgCO}_{3}(\mathrm{~N} \% \mathrm{~mol})$ e os resultados da análise quantitativa de $\mathrm{Mg}$ por EED em grãos $(n=6)$ e nos cimentos $(n=5)$ da seção delgada EFN 04A. Os três valores de N\%mol apresentados correspondem às proporções mínima $(5 \% \mathrm{~mol})$, média de águas tropicais $(19 \% \mathrm{~mol})$ e máxima (30\% mol) (Morse \& Mackenzie 1990, Ries 2010, Mackenzie et al. 2018). Todos os teores calculados em relação aos elementos químicos da calcita magnesiana, sem o carbono, conforme Tabela 5. 


\subsection{Teor de Carbonato}

O teor em massa de carbonato foi analisado pelo método do ataque ácido em todas as 85 amostras (75 de eolianitos e 10 de fácies associadas; Tabelas 6, 7 e 8; Figs 5.102 e 5.103).

Os eolianitos do RN apresentam teores entre 6 e $80 \%$, e os do AFN, entre 48 e $98 \%$ (Tabelas 6 e 7). O gráfico boxplot comparando o teor de carbonatos dos eolianitos continentais (RN) com os insulares (Fig. 5.102) mostra valores completamente discrepantes entre estes dois grupos, exceto pelos outliers (valores anomalamente altos) do RN, presentes nas amostras de rizoconcreções. Esta tendência para teores mais altos no AFN já era esperada em vista dos resultados de petrografia (item 5.7), que mostram que o arcabouço dos eolianitos do arquipélago é composto quase na totalidade por clastos carbonáticos, em contraste à frequente presença de terrígenos (sobretudo grãos quartzo-feldspáticos e de minerais opacos) no RN. As fácies associadas mostram a mesma tendência (Tabela 8, Fig. 5.103), com teores de carbonato de cálcio entre 4 e $27 \%$ no RN, e entre 75 e $92 \%$ no AFN.

Tabela 6. Teores de carbonato, determinados por ataque com $\mathrm{HCl}$, nas amostras de eolianitos do RN. N/I indica não identificada.

\begin{tabular}{|c|c|c|c|}
\hline AMOSTRA & Área & $\begin{array}{c}\text { Teor } \\
\text { CaCO3 } \\
(\%) \\
\end{array}$ & $\begin{array}{c}\text { Fácies } \\
\text { deposicional }\end{array}$ \\
\hline ERN 02E & \multirow{4}{*}{$\begin{array}{c}\text { ENXU } \\
\text { QUEIMADO }\end{array}$} & 12.5 & Acbra \\
\hline ERN 02C & & 6.6 & Acbra \\
\hline ERN 02W & & 7.3 & Acbra \\
\hline ERN 03 & & 11.3 & Acbra \\
\hline ERN 06A & \multirow{7}{*}{$\begin{array}{l}\text { PRAIA DO } \\
\text { MARCO }\end{array}$} & 9.8 & Acb \\
\hline ERN 06B & & 6.3 & Acb \\
\hline ERN 19E & & 45.5 & Acbra \\
\hline ERN 19W & & 36.7 & Acbra \\
\hline ERN 20 & & 56 & Acbra \\
\hline ERN 21E & & 47.2 & Acbra \\
\hline ERN $21 \mathrm{~W}$ & & 51.6 & Acbra \\
\hline
\end{tabular}

\begin{tabular}{|c|c|c|c|}
\hline AMOSTRA & Área & $\begin{array}{c}\text { Teor } \\
\text { CaCO3 } \\
(\%)\end{array}$ & $\begin{array}{c}\text { Fácies } \\
\text { deposicional }\end{array}$ \\
\hline ERN 07A & \multirow{12}{*}{ GUAJIRU } & 9 & Acb \\
\hline ERN 07B & & 10.1 & Acbf \\
\hline ERN 08 & & 6.7 & Acb \\
\hline ERN 09 & & 28.1 & Acbra \\
\hline ERN 11r & & 59.0 & Acbra \\
\hline ERN 12 & & 48.4 & Acbra \\
\hline ERN 13r & & 27.7 & Acbra \\
\hline ERN 14r & & 72.3 & Acbra \\
\hline ERN 15r & & 24.9 & Acbra \\
\hline ERN 16r & & 79.8 & Acbra \\
\hline $\begin{array}{c}\text { ERN16- } \\
17\end{array}$ & & 20.3 & $\mathrm{~N} / \mathrm{I}$ \\
\hline ERN 17r & & 32.2 & Acbra \\
\hline
\end{tabular}


Tabela 7. Teores de carbonato, determinados por ataque com $\mathrm{HCl}$, nas amostras de eolianitos do AFN. N/I indica não identificada.

\begin{tabular}{|c|c|c|c|}
\hline \multicolumn{4}{|c|}{ Afloramentos baixos } \\
\hline Amostra & Área & $\begin{array}{c}\text { Teor } \\
\mathrm{CaCO}_{3} \\
(\%)\end{array}$ & $\begin{array}{c}\text { Fácies } \\
\text { deposicional }\end{array}$ \\
\hline $\begin{array}{c}\text { B. } \\
\text { SUESTE } \\
01\end{array}$ & \multirow{2}{*}{$\begin{array}{c}\text { BAÍA } \\
\text { SUESTE }\end{array}$} & 95,9 & N/I \\
\hline $\begin{array}{c}\text { B.SUESTE } \\
02\end{array}$ & & 95,5 & $\mathrm{~N} / \mathrm{I}$ \\
\hline $\begin{array}{c}\text { CHAPEU } \\
01\end{array}$ & \multirow{5}{*}{$\begin{array}{c}\text { CHAPÉU } \\
\text { DE } \\
\text { SUESTE }\end{array}$} & 92,3 & $\mathrm{~N} / \mathrm{I}$ \\
\hline $\begin{array}{c}\text { CHAPEU } \\
02\end{array}$ & & 99,8 & $\mathrm{~N} / \mathrm{I}$ \\
\hline $\begin{array}{c}\text { CHAPEU } \\
03 \\
\end{array}$ & & 88,4 & $\mathrm{~N} / \mathrm{I}$ \\
\hline $\begin{array}{c}\text { CHAPEU } \\
04 \\
\end{array}$ & & 95,8 & $\mathrm{~N} / \mathrm{I}$ \\
\hline $\begin{array}{c}\text { CHAPEU } \\
05 \\
\end{array}$ & & 87,2 & N/I \\
\hline $\begin{array}{c}\text { I. do } \\
\text { MEIO } 1\end{array}$ & \multirow{4}{*}{$\begin{array}{l}\text { ILHA DO } \\
\text { MEIO }\end{array}$} & 89,9 & $\mathrm{~N} / \mathrm{I}$ \\
\hline $\begin{array}{c}\text { I. do } \\
\text { MEIO } 2 \\
\end{array}$ & & 83,1 & $\mathrm{~N} / \mathrm{I}$ \\
\hline $\begin{array}{c}\text { I. do } \\
\text { MEIO } 3\end{array}$ & & 89,2 & N/I \\
\hline $\begin{array}{c}\text { I. do } \\
\text { MEIO } 4\end{array}$ & & 94,1 & $\mathrm{~N} / \mathrm{I}$ \\
\hline I. RATA A & \multirow{7}{*}{$\begin{array}{l}\text { ILHA } \\
\text { RATA }\end{array}$} & 97,9 & $\mathrm{~N} / \mathrm{I}$ \\
\hline I. RATA B & & 88,7 & $\mathrm{~N} / \mathrm{I}$ \\
\hline I. RATA 1 & & 93,5 & $\mathrm{~N} / \mathrm{I}$ \\
\hline I. RATA 2 & & 90,8 & $\mathrm{~N} / \mathrm{I}$ \\
\hline I. RATA 3 & & 87,8 & $\mathrm{~N} / \mathrm{I}$ \\
\hline I. RATA 4 & & 95,1 & $\mathrm{~N} / \mathrm{I}$ \\
\hline I. RATA 5 & & 82,1 & $\mathrm{~N} / \mathrm{I}$ \\
\hline EFN 02E & \multirow{2}{*}{$\begin{array}{c}\text { PEDRA } \\
\text { DA } \\
\text { BIGORNA }\end{array}$} & 91,6 & Aca \\
\hline EFN 02F & & 89,5 & Acara \\
\hline EFN 03 & \multirow{2}{*}{$\begin{array}{l}\text { ILHA } \\
\text { RASA }\end{array}$} & 92,6 & Aca \\
\hline EFN 03C & & 91,2 & Acara \\
\hline
\end{tabular}

\begin{tabular}{|c|c|c|c|}
\hline \multicolumn{4}{|c|}{ Afloramentos altos } \\
\hline Amostra & Área & $\begin{array}{c}\text { Teor } \\
\mathrm{CaCO}_{3} \\
(\%)\end{array}$ & $\begin{array}{c}\text { Fácies } \\
\text { deposicional }\end{array}$ \\
\hline EFN 01 & \multirow{8}{*}{ CAIEIRAS } & 75,9 & Acbra \\
\hline EFN 04A & & 76,1 & Apa \\
\hline EFN 04B & & 72,5 & Acs \\
\hline EFN 04C & & 63,3 & Apbra \\
\hline EFN 07 & & 82.9 & Amra \\
\hline EFN 08A & & 80,0 & Acbra \\
\hline EFN 08B & & 73,3 & Acbra \\
\hline EFN 08C & & 93,4 & Acbra \\
\hline EFN 05B & \multirow{11}{*}{$\begin{array}{c}\text { PONTA } \\
\text { DAS } \\
\text { CARACAS }\end{array}$} & 92,0 & Aca \\
\hline EFN 05C & & 83,3 & Aca \\
\hline EFN 05D & & 67,1 & Aca \\
\hline EFN 05Da & & 82,0 & Aca \\
\hline EFN 05E & & 88,9 & Aca \\
\hline EFN 05F & & 80,3 & Acf \\
\hline EFN 05G & & 88,3 & Acf \\
\hline EFN 05H & & 92,5 & Acf \\
\hline EFN 05I & & 92,0 & Acs \\
\hline EFN 05J & & 88,3 & Acs \\
\hline $\begin{array}{c}\text { PONTA } \\
\text { CARACAS } \\
01\end{array}$ & & 83,3 & N/I \\
\hline EFN 06A & \multirow{3}{*}{$\begin{array}{c}\text { FORTE } \\
\text { DE SÃO } \\
\text { JOAQUIM } \\
\text { DO } \\
\text { SUESTE }\end{array}$} & 94,2 & Acs \\
\hline EFN 06B & & 91,4 & Acf \\
\hline EFN 06C & & 75,3 & Acf \\
\hline EFN 15A & \multirow{6}{*}{ ATALAIA } & & Aca \\
\hline EFN 15B & & 95,4 & Aca \\
\hline EFN 15C & & 97,0 & Aca \\
\hline EFN 15D & & 89,3 & Acar \\
\hline EFN 15E & & 87,3 & Acar \\
\hline EFN 15F & & 82,8 & Acs \\
\hline
\end{tabular}




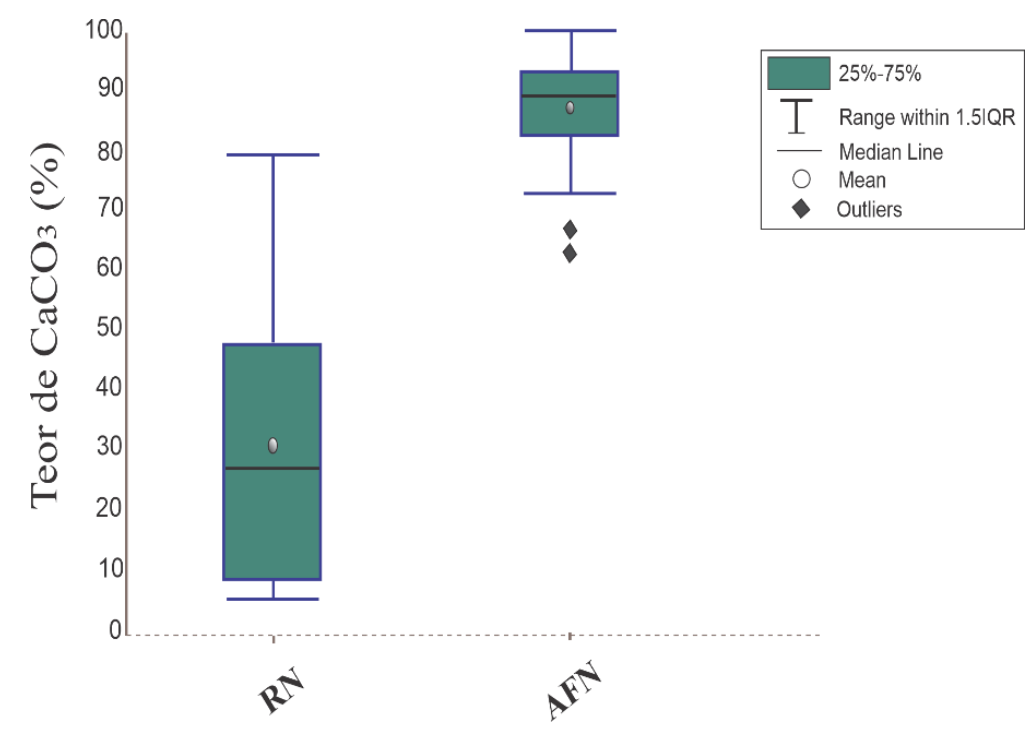

Fig. 5.102. Comparação entre os teores em massa de carbonato, determinados por ataque com $\mathrm{HCl}$, nos eolianitos do $\mathrm{RN}(\mathrm{n}=25)$ e do $\mathrm{AFN}(\mathrm{n}=50)$.

Tabela 8. Teores de carbonato, determinados por ataque com $\mathrm{HCl}$, nas amostras de fácies associadas

\begin{tabular}{|c|c|c|c|}
\hline AMOSTRA & Área & Teor $\mathrm{CaCO}_{3}$ & $\begin{array}{c}\text { Fácies } \\
\text { deposicional }\end{array}$ \\
\hline ERN $01 \mathrm{br}$ & \multirow{3}{*}{$\begin{array}{c}\text { ENXU } \\
\text { QUEIMADO- } \\
\text { RN }\end{array}$} & 19.7 & $\mathrm{Apb}$ \\
\hline ERN 04Df & & 5.1 & $\mathrm{Al}$ \\
\hline ERN 04P & & 6.4 & $\mathrm{Al}$ \\
\hline ERN 10Df & \multirow{2}{*}{$\begin{array}{c}\text { GUAJIRU- } \\
\text { RN }\end{array}$} & 4 & $\mathrm{Al}$ \\
\hline ERN 10P & & 7,6 & $\mathrm{Al}$ \\
\hline ERN 18br & $\begin{array}{c}\text { TRÊES } \\
\text { IRMÃOS-RN }\end{array}$ & 26.6 & Apbz \\
\hline EFN 02B & \multirow{3}{*}{$\begin{array}{c}\text { PEDRA DA } \\
\text { BIGORNA- } \\
\text { AFN }\end{array}$} & 77 & Rgn \\
\hline EFN 02C & & 92,1 & Ap \\
\hline EFN 02D & & 75.2 & $\mathrm{Am}$ \\
\hline EFN 09A & $\begin{array}{l}\text { CAIEIRA- } \\
\text { AFN }\end{array}$ & 81,8 & $\mathrm{Apb}$ \\
\hline
\end{tabular}




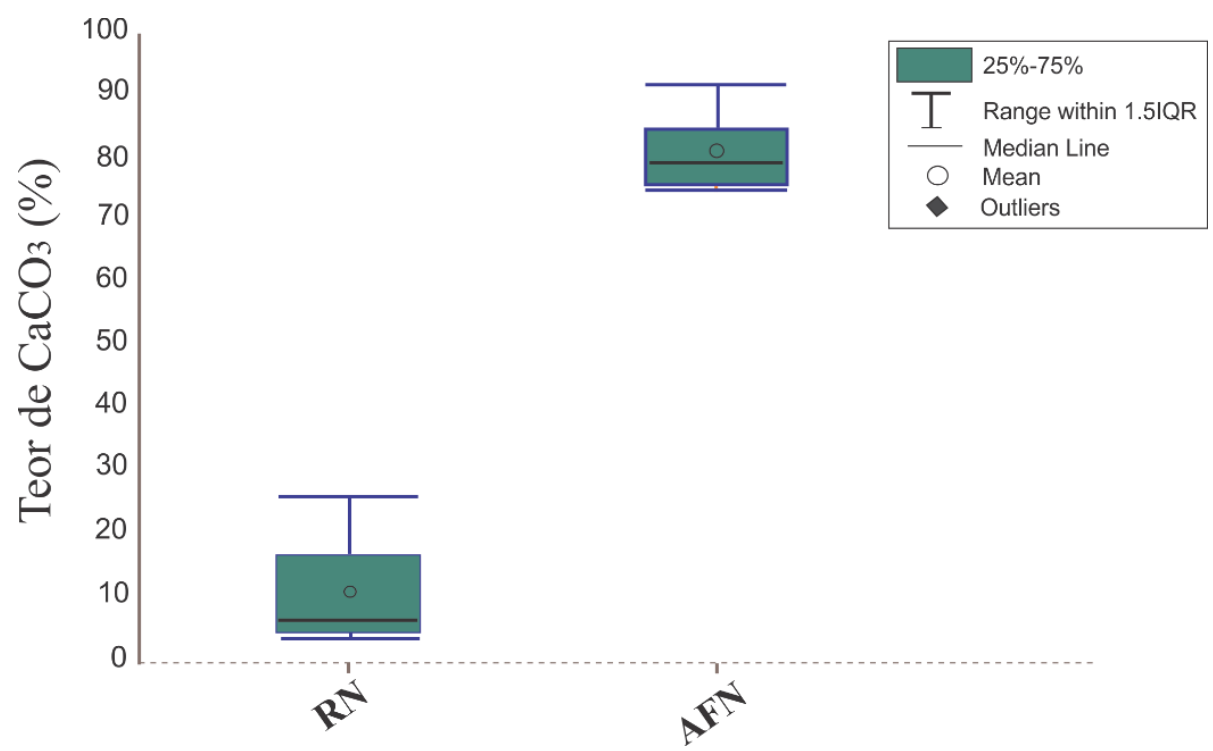

Fig. 5.103. Comparação entre os teores em massa de carbonato nas fácies associadas a eolianitos, no RN (n=2) e no AFN ( $n=4)$

Foram elaborados também gráficos boxplot do teor de carbonatos por área geográfica, tanto do RN como do AFN (Figs. 5.104 e 5.105). Nos gráficos por áreas do RN, observa-se que três das áreas estudadas apresentam teores entre 6 e 28\%, enquanto na quarta, Três Irmãos, os teores são maiores que 37\% (Fig. 5.104); já no AFN, os eolianitos de Enseada da Caieira apresentam tendência para teores mais baixos que os de outras áreas, chegando ao mínimo de 63\% (Fig. 5.105). Seu intervalo interquartis não se sobrepõe com os de demais áreas, exceto com a porção inferior do intervalo interquartis de Forte de São Joaquim. 


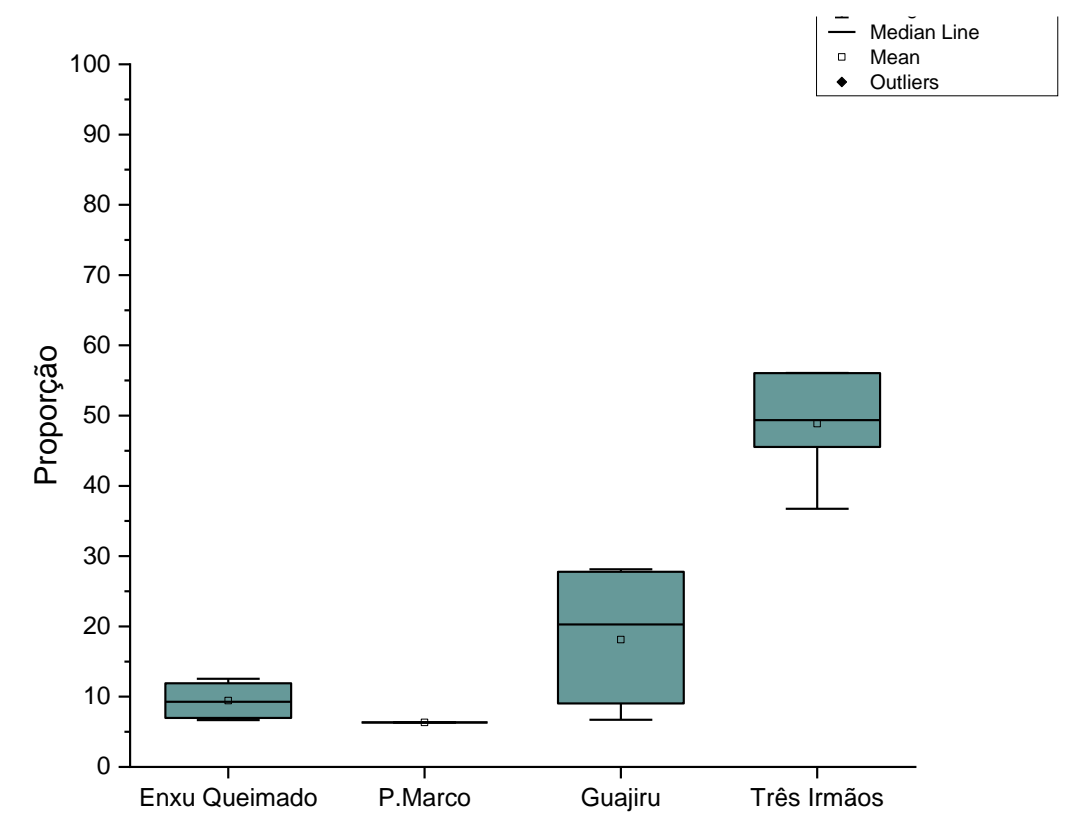

Fig. 5.104. Variação do teor em massa de carbonato nos eolianitos, por área geográfica do RN. Enxu Queimado: n=4; Praia do Marco: n=2; Guajiru: n=7; Três Irmãos: n=6.

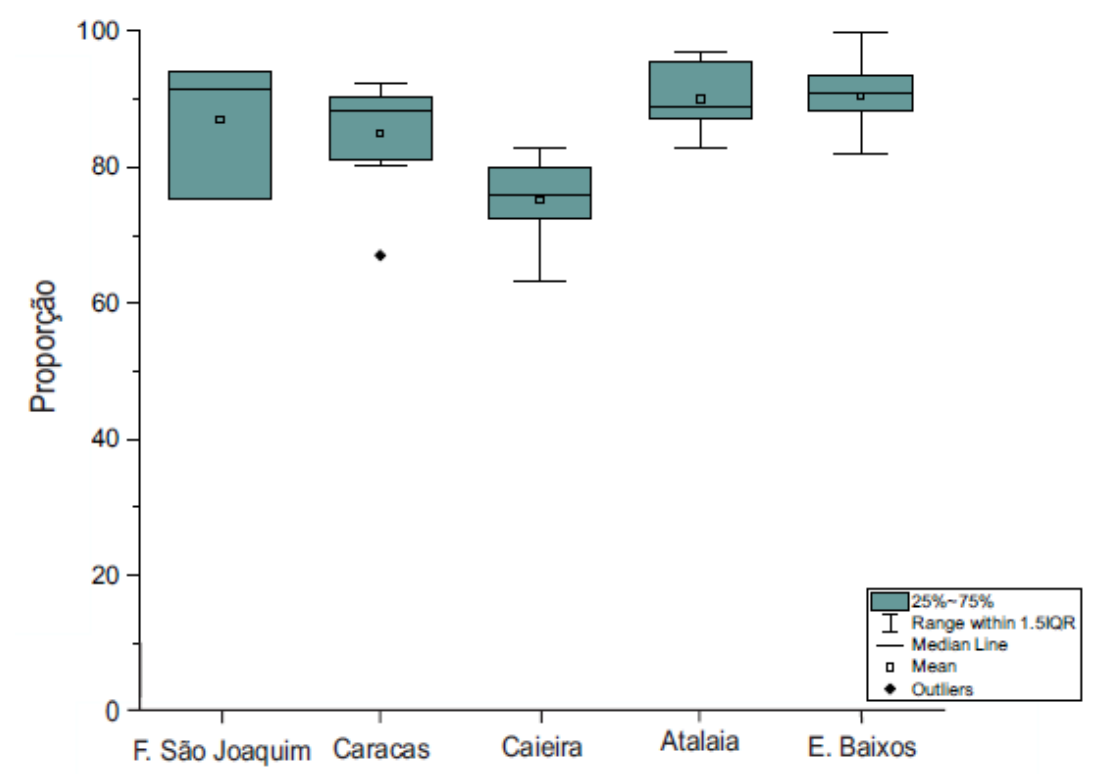

Fig. 5.105. Variação do teor em massa de carbonato nos eolianitos, por área geográfica do AFN. Forte de São Joaquim: n=3; Ponta das Caracas: $n=8$; Enseada da Caieira e Atalaia: $n=6$; afloramentos baixos: $\mathrm{n}=21$.

Os teores de carbonato foram lançados ainda em gráfico de dispersão, em função da distância à praia (Fig. 5.106), o qual mostra duas nuvens de pontos muito distintas, correspondentes às amostras do RN (laranja) e do AFN (azul). Este grande contraste entre as áreas é explicado pela diferença de ordem de grandeza dos teores, maiores no AFN, e de 
distância à praia, maiores no RN. Por esta razão, os dados de AFN foram lançados em um diagrama em separado (Fig. 5.107), de modo a realçar graficamente o efeito sobre eles da variação relativa da distância. No caso de $R N$, pode-se observar tendência linear $(r=0,40, p=$ 0,02) de aumento do teor de carbonato com o incremento de distância da praia (Fig. 5.106), enquanto no AFN não existe tendência estatisticamente consistente (Fig. 5.107).

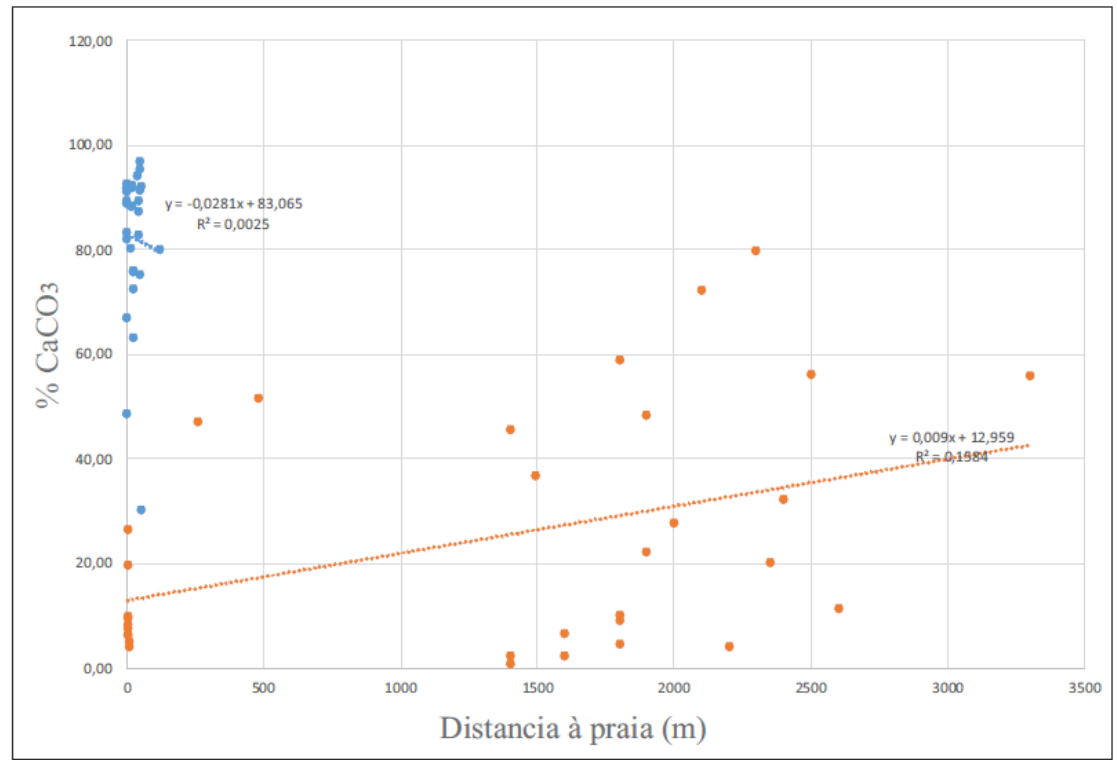

Fig. 5.106. Gráfico de dispersão de teor de carbonato vs distância à praia. Pontos em azul: AFN. Pontos em laranja: costa do RN. Nível de significância p da correlação linear: linha laranja 0,02; linha azul 0,40.

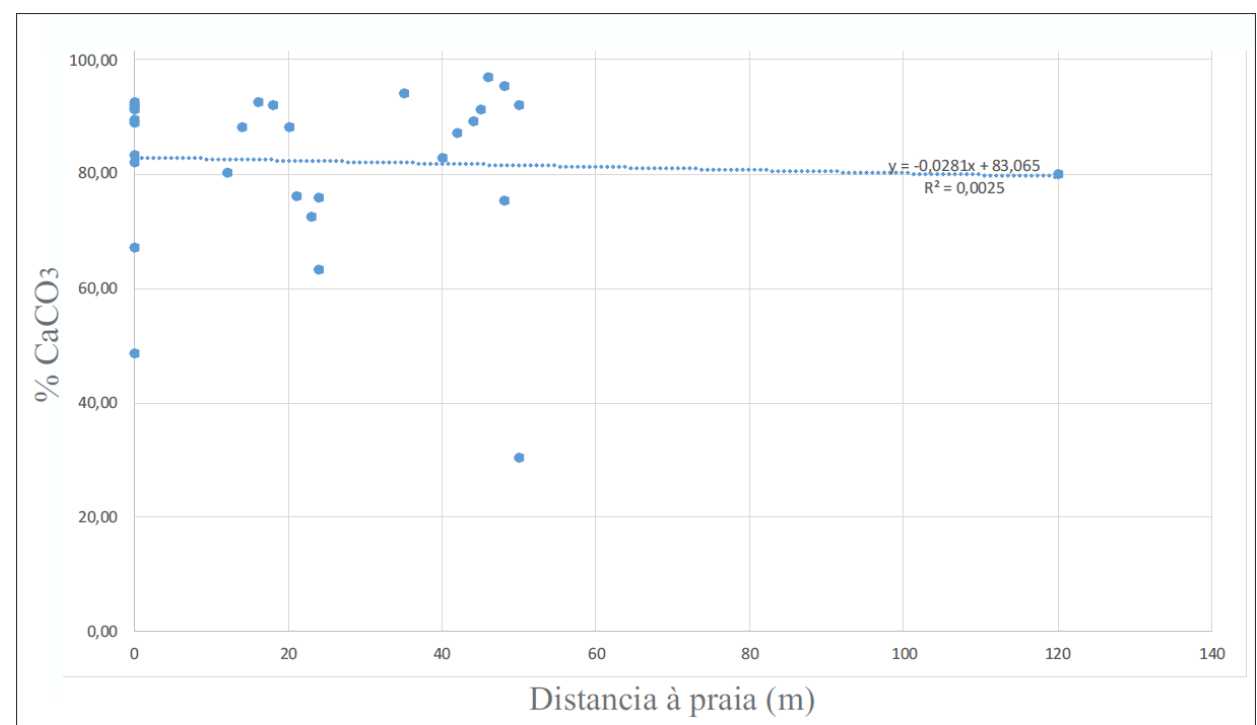

Fig. 5.107. Gráfico de dispersão de teor de carbonato $v s$ a distância à praia dos eolianitos do AFN. 


\subsection{Análise de Minerais Pesados}

Para o estudo de minerais pesados, além das amostras coletadas especificamente para este trabalho, foram incluídas amostras de eolianitos de PI e CE (coletadas no âmbito da dissertação de Espinel-Arias 2015), de modo a compor-se um conjunto amplo de eolianitos continentais, em escala regional, a ser comparado com os insulares; para isto, selecionaram-se, no total, 60 amostras (Apêndice 3), sendo 38 pertencentes a eolianitos continentais (PI, CE e $\mathrm{RN}$ ) e 22 a insulares (AFN). Para cada conjunto de amostras, foram determinadas as assembleias mineralógicas e testados índices ABi ( $c f$. Morton \& Hallsworth 1999) segundo os minerais principais encontrados.

\subsubsection{Caraterização da assembleia de eolianitos continentais}

$\mathrm{Na}$ fração não magnética da classe areia fina, estão presentes os seguintes minerais transparentes não micáceos, em ordem decrescente de abundância média: zircão, hornblenda, epídoto, turmalina, sillimanita, cianita, rutilo, estaurolita, andalusita e granada (Quadros 8 e 9; Figs. 5.108 a 5.111). Outros componentes, com concentração menor que 1\%, são: titanita, allanita, ferrossilita ("hiperstênio"), augita, perovskita, monazita, leucoxênio, anfibólio tremolítico (incolor), cassiterita e coríndon (Fig. 5.112). Dentre os agrupamentos geográficos de amostras analisadas, observam-se domínios de sillimanita e cianita, na área de Carnaubinha (PI), e de epídoto e hornblenda, em Paracuru (CE) e Três Irmãos (RN).

Quadro 8. Classificação nominal para as frequências porcentuais médias de minerais pesados dos eolianitos continentais, segundo a escala de Coutinho \& Coimbra (1974). Classes: predominante: $>50 \%$; abundante: entre 20 e 50\%; comum: entre 5 e 20\%; escasso entre 2 e $5 \%$; e raro entre 1 e $2 \%$. Abreviações: ZIR (zircão), HBL (hornblenda), EPI (epídoto), TUR (turmalina), SIL (sillimanita), CIA (cianita), RUT (rutilo), EST (estaurolita), AND (andalusita) e GRD (granada). Minerais com porcentagem menor que $1 \%$ não foram incluídos no quadro.

\begin{tabular}{|l|c|c|c|c|c|c|c|c|c|c|}
\cline { 2 - 12 } \multicolumn{1}{c|}{} & ZIR & HBL & EPI & TUR & SIL & CIA & RUT & EST & AND & GRD \\
\hline Predominante & $\mathrm{X}$ & & & & & & & & & \\
\hline Abundante & & $\mathrm{X}$ & & & & & & & & \\
\hline Comum & & & $\mathrm{X}$ & $\mathrm{X}$ & $\mathrm{X}$ & $\mathrm{X}$ & & & & \\
\hline Escasso & & & & & & & $\mathrm{X}$ & $\mathrm{X}$ & $\mathrm{X}$ & \\
\hline Raro & & & & & & & & & & $\mathrm{X}$ \\
\hline
\end{tabular}




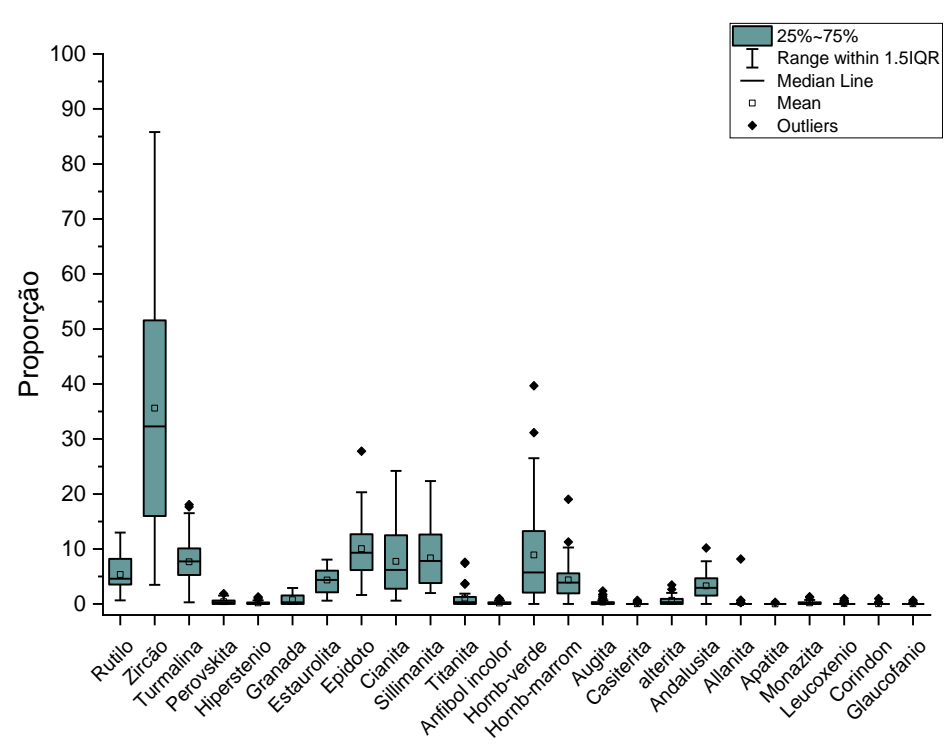

Fig. 5.108. Distribuição da assembleia de minerais pesados dos eolianitos continentais. $n=38$. Números de ocorrências: rutilo, zircão e turmalina, estaurolita, epídoto, cianita e sillimanita, 38; hornblenda verde e marrom e andalusita, 37; granada, 28; titanita, 27; perovskita, 25; alterita, 23; augita, 14; anfibólio incolor, 13; monazita, 13; ferrossilita ("hiperstênio"), 12; allanita, 7; leucoxênio, 5; cassiterita e coríndon, 3; e apatita, 1.

Quadro 9. Principais minerais pesados presentes nos eolianitos continentais e suas características dominantes.

\begin{tabular}{|c|c|c|c|c|}
\hline Mineral & Forma & Arredondamento & Cor e pleocroísmo & Alteração \\
\hline Zircão & $\begin{array}{l}\text { Subédrica a, raramente, } \\
\text { euédrica, bipiramidada }\end{array}$ & $\begin{array}{l}\text { Arredondado a } \\
\text { subanguloso }\end{array}$ & Incolor & $\begin{array}{c}\text { Manchas marrons } \\
\text { eventuais, de } \\
\text { metamictização }\end{array}$ \\
\hline Hornblenda & $\begin{array}{c}\text { Subédrica prismática } \\
\text { alongada }\end{array}$ & $\begin{array}{l}\text { Subarredondado a } \\
\text { subanguloso }\end{array}$ & $\begin{array}{l}\text { Verde e, em menor } \\
\text { proporção, marrom }\end{array}$ & \\
\hline Epídoto & $\begin{array}{c}\text { Subédrica prismática } \\
\text { curta }\end{array}$ & Subarredondado & $\begin{array}{l}\text { Verde amarelado a } \\
\text { incolor }\end{array}$ & $\begin{array}{c}\text { Manchas marrons } \\
\text { eventuais }\end{array}$ \\
\hline Turmalina & $\begin{array}{l}\text { Subédrica prismática, } \\
\text { alongada ou, mais } \\
\text { raramente, curta }\end{array}$ & $\begin{array}{l}\text { Subarredondado a } \\
\text { subanguloso }\end{array}$ & \begin{tabular}{|c|}
$\begin{array}{c}\text { Forte pleocroísmo, } \\
\text { dominantemente em } \\
\text { tons de marrom }\end{array}$ \\
\end{tabular} & \\
\hline Sillimanita & $\begin{array}{c}\text { Em agregados alongados } \\
\text { fibrosos ("fibrolita") e } \\
\text { mais raramente subédrica } \\
\text { prismática }\end{array}$ & Subarredondado & $\begin{array}{c}\text { Incolor, podendo ser } \\
\text { marrom nos } \\
\text { agregados }\end{array}$ & $\begin{array}{l}\text { Aspecto sujo, nos } \\
\text { agregados }\end{array}$ \\
\hline Cianita & $\begin{array}{c}\text { Subédrica prismática, } \\
\text { com planos de clivagem } \\
\text { bem preservados }\end{array}$ & Subanguloso & Incolor & $\begin{array}{l}\text { Ocasionalmente } \\
\text { com manchas } \\
\text { marrons }\end{array}$ \\
\hline Rutilo & Subédrica prismática & $\begin{array}{l}\text { Subarredondado a } \\
\text { subanguloso }\end{array}$ & $\begin{array}{l}\text { Marrom profundo, } \\
\text { avermelhado }\end{array}$ & \\
\hline Estaurolita & Subédrica prismática & $\begin{array}{l}\text { Subarredondado a } \\
\text { subanguloso }\end{array}$ & $\begin{array}{l}\text { Pleocroísmo amarelo } \\
\text { a laranja, diagnóstico }\end{array}$ & \\
\hline Andalusita & Subédrica prismática & Subarredondado & $\begin{array}{l}\text { Incolor a levemente } \\
\text { pleocroico em rosa }\end{array}$ & \\
\hline Granada & Subédrica a anédrica & Subanguloso & \begin{tabular}{|c|} 
Incolor ou, em menor \\
frequência, rosa ou \\
verde claros
\end{tabular} & \\
\hline
\end{tabular}




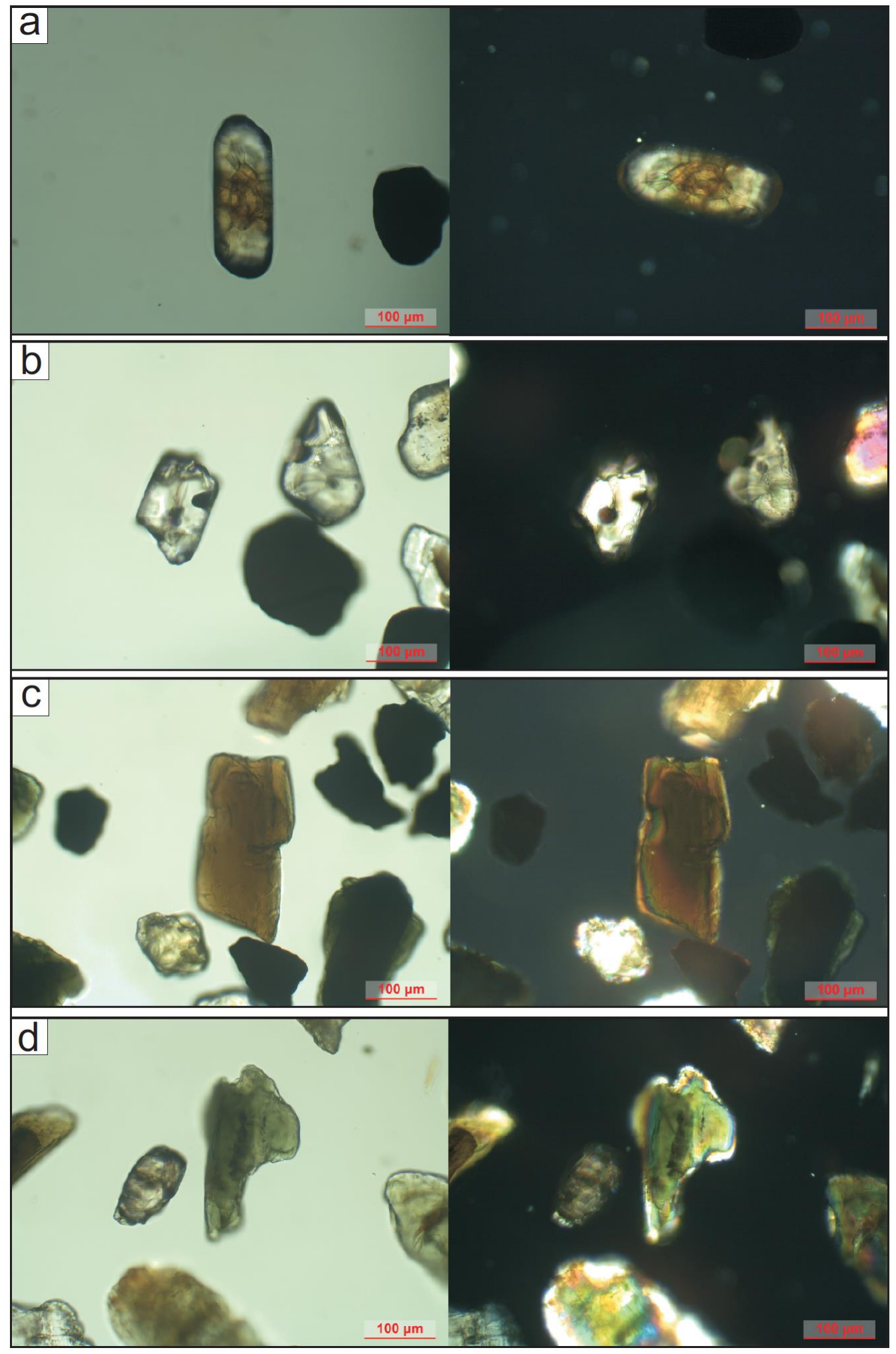

Fig. 5.109. Minerais pesados dominantes ou abundantes nos eolianitos continentais: a. zircão prismático bipiramidal subanguloso, com mancha marrom possivelmente associada à metamictização; b. zircão subequidimensional subarredondado a arredondado; c. hornblenda marrom; d. hornblenda verde. Imagens da esquerda correspondem a polarizadores paralelos e as da direita, a cruzados 

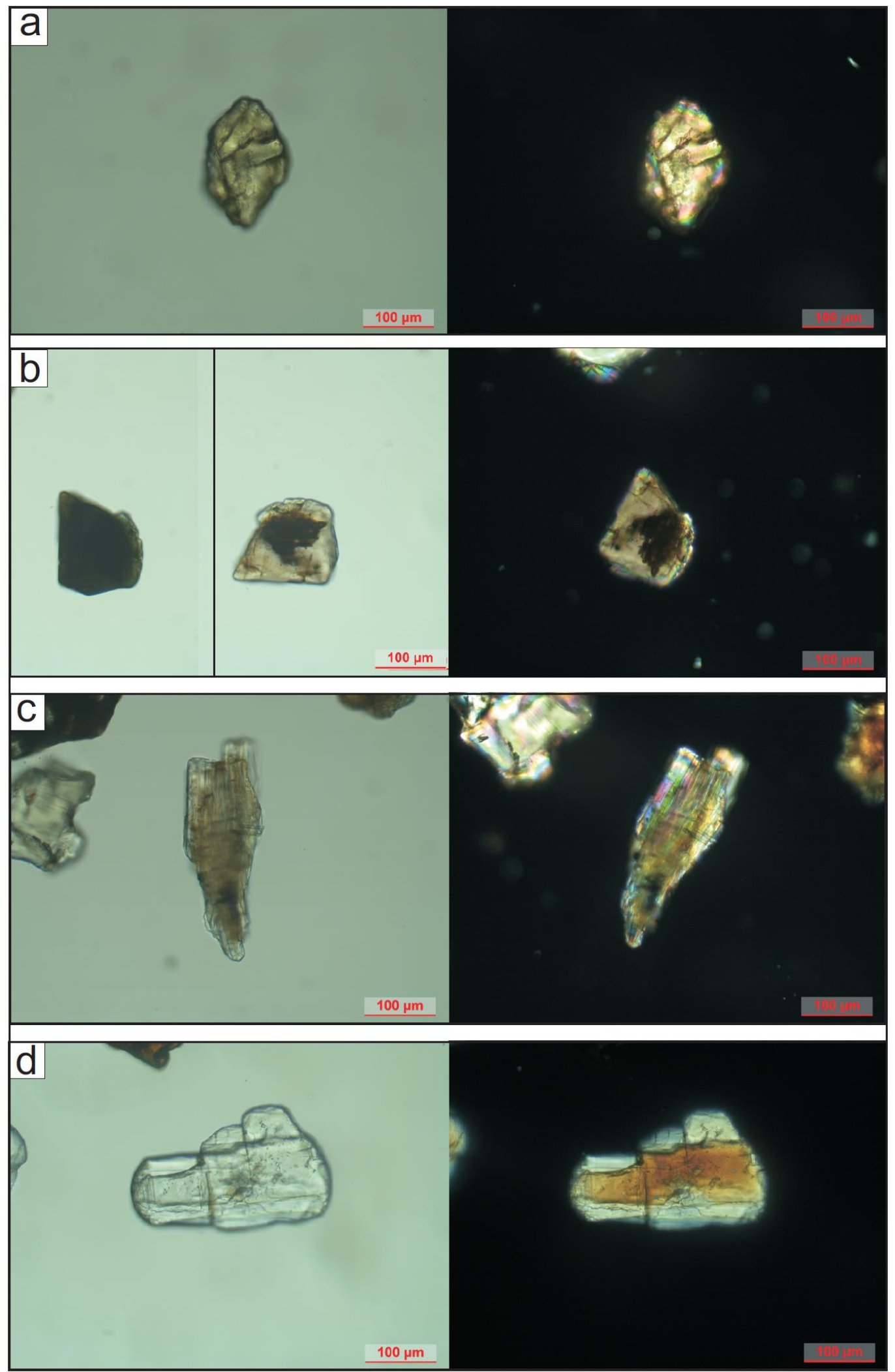

Fig. 5.110. Minerais pesados comuns nos eolianitos continentais: a. epídoto subédrico, em prisma curto; b. turmalina subédrica, em prisma curto (em duas posições de giro da platina, à esquerda, para evidenciar o forte pleocroísmo); c. sillimanita fibrosa, com aspecto sujo; d. cianita subédrica em prisma lamelar. Imagens da esquerda obtidas a polarizadores paralelos, e da direita, a cruzados. 

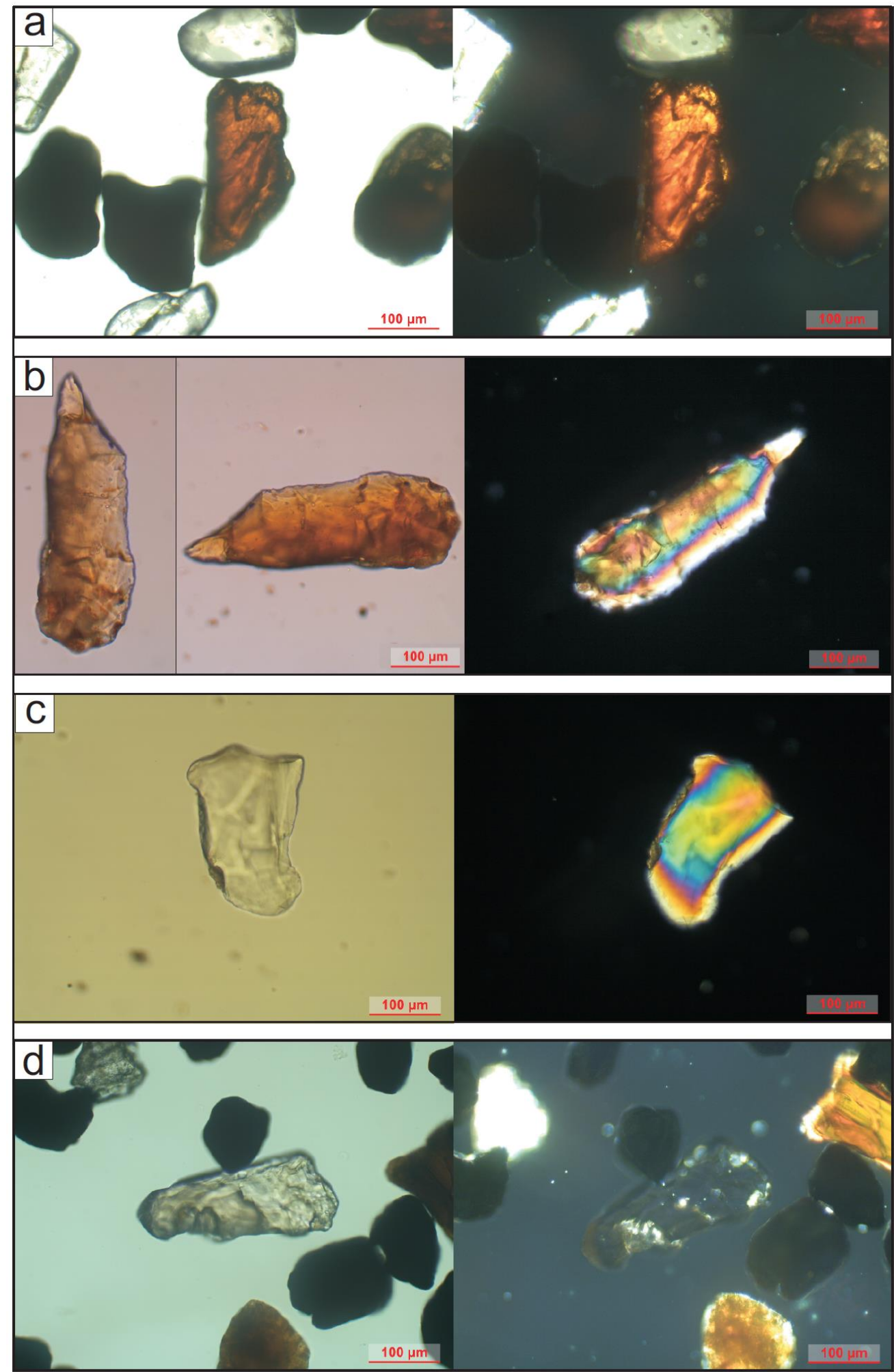

Fig. 5.111. Minerais pesados escassos nos eolianitos continentais: a. rutilo subédrico, priasmático; b. estaurolita subédrica, em prisma longo (em duas posições de giro da platina, à esquerda, para evidenciar o pleocroísmo sutil, porém nítido); c. andalusita, subédrica prismática; d. granada rósea. Imagens da esquerda obtidas a polarizadores paralelos e, da direita, a cruzados. 


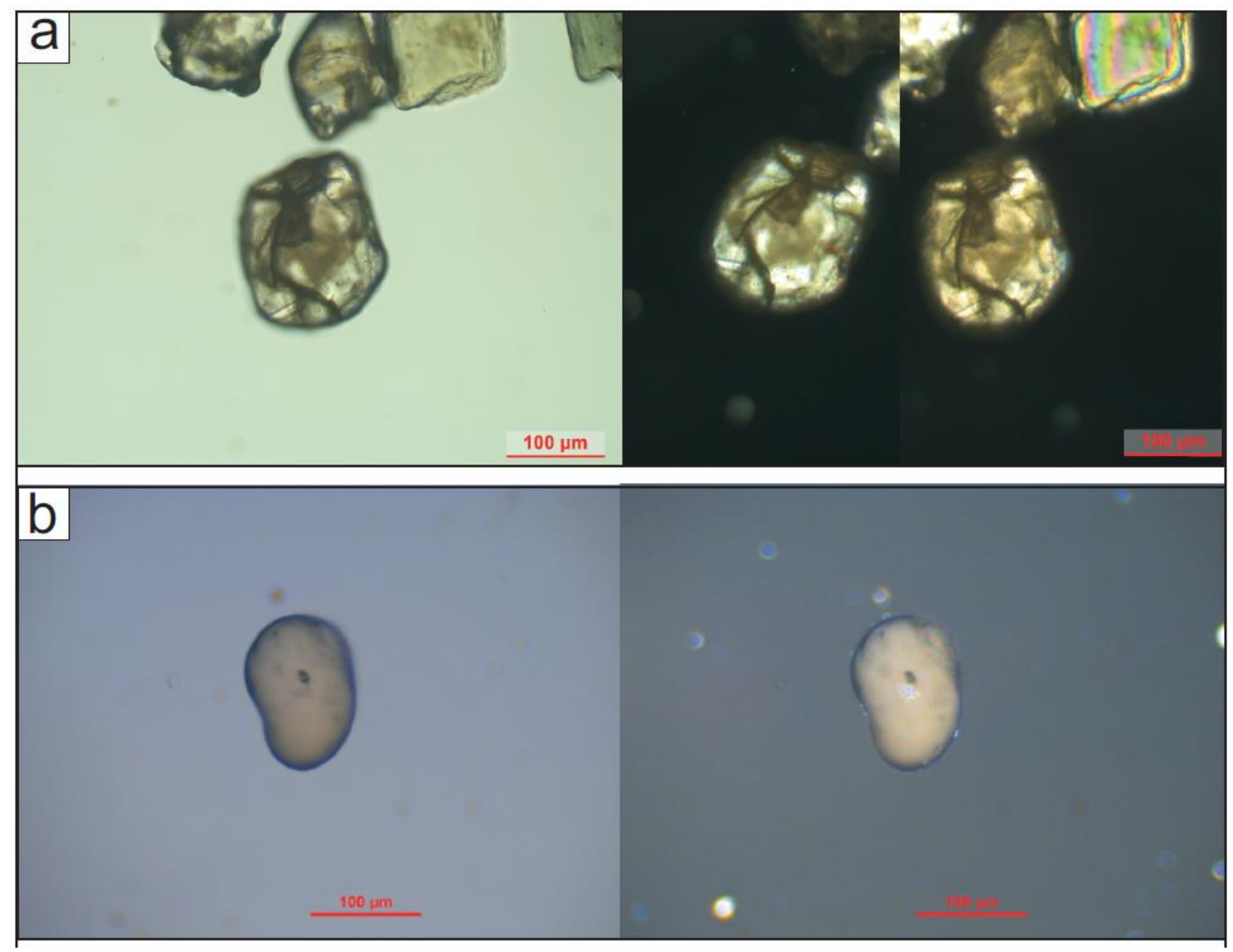

Fig. 5.112. Minerais pesados escassos nos eolianitos continentais: a. titanita (em duas posições de giro da platina, à direita, para evidenciar extinção anômala, devida à forte dispersão da luz); b. monazita. Imagens da esquerda obtidas a polarizadores paralelos, e, da direita, a cruzados.

\subsubsection{Variação espacial dos minerais e índices mineralógicos dos eolianitos} continentais

Cada um dos quatro índices mineralógicos $\mathrm{ABi}$ calculados ( $\mathbf{Z R i}$ como indicador suposto de área fonte, THi e EsEpi, como indicadores supostos de maturidade química, e ZTi como indicador suposto de seleção durante o transporte) foi representado em gráfico boxplot com intuito de comparar entre si as quatro áreas com maior número de amostras (de $\mathrm{W}$ para $\mathrm{E}$ : Macapá, no PI, e Três Irmãos, Guajiru e Enxu Queimado, no RN) (Fig. 5.1113 a 5.116).

O ZRi (Fig. 5.113) apresenta valores menores de intervalo interquartis no PI que nas três áreas do RN; já entre estas três áreas, nota-se neste índice, de W para E, aumento da amplitude e do valor máximo do intervalo interquartis.

Os dois índices supostamente ligados a maturidade, THi e EsEpi (Figs. 5.114 e 5.115) mostram comportamentos $\mathrm{W}$-E aproximadamente invertidos entre si: enquanto o THi possui 
tendência contínua de aumento dos valores de intervalo interquartis para $\mathrm{E}$, com pouca sobreposição de intervalo interquartis entre as quatro áreas (Fig. 5.114), o EsEpi apresenta seus maiores valores a W (Macapá, PI), com sobreposição acentuada de intervalos interquartis entre as demais áreas, a E (Fig. 5.115).

O ZTi (Fig. 5.116) apresenta tendência de aumento de W para E, ainda que com sobreposição dos intervalos interquartis, exceto entre as duas áreas extremas, Macapá, com interquartis de 60 a 84\%, e Enxu Queimado, com interquartis de 85 a 92\%.

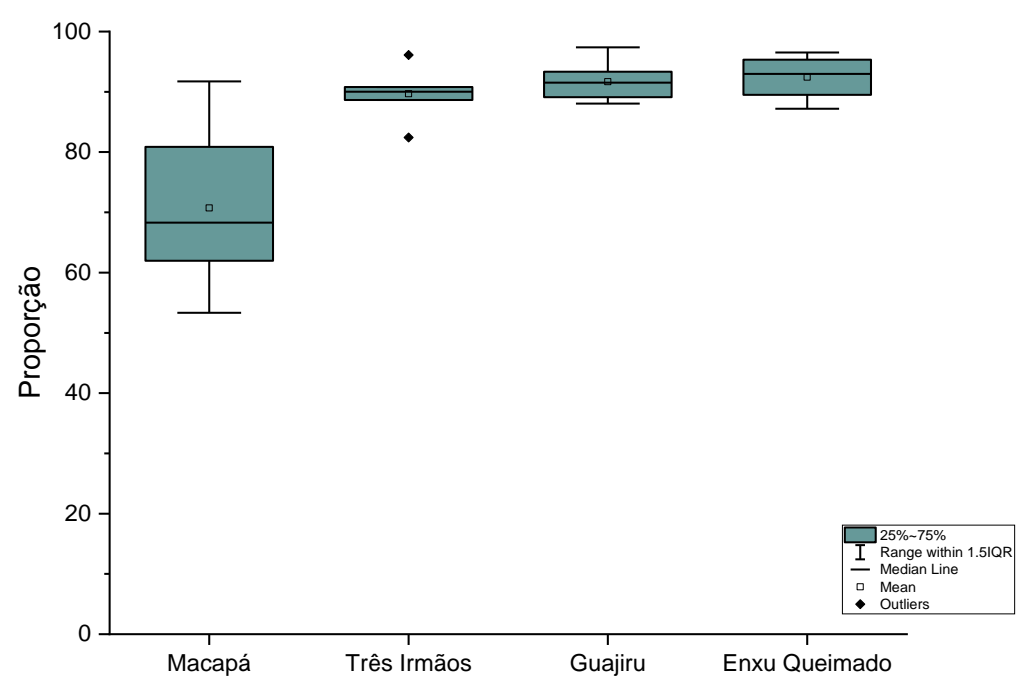

Fig. 5.113. Índice zircão/rutilo (ZRi) das quatro áreas principais de ocorrência de eolianitos continentais, apresentadas de W para E: Macapá $(n=12)$, Três Irmãos $(n=6)$, Guajiru $(n=8)$ e Enxu Queimado ( $n=4)$.

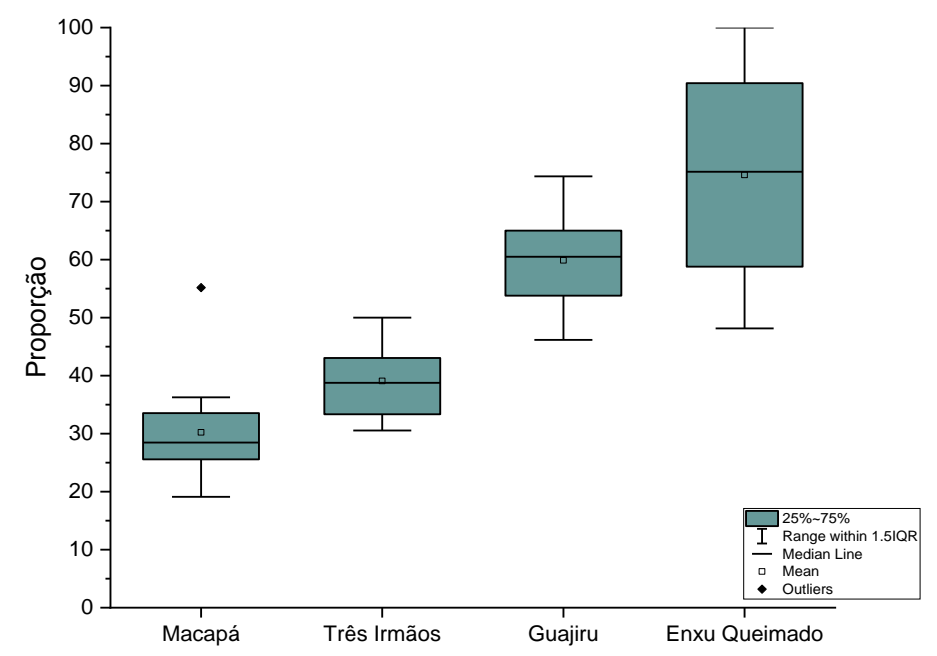

Fig. 5.114. Índice turmalina/hornblenda (THi) das quatro áreas principais de ocorrência de eolianitos continentais, apresentadas de W para E: Macapá $(n=12)$, Três Irmãos $(n=6)$, Guajiru $(n=8)$ e Enxu Queimado $(n=4)$. 


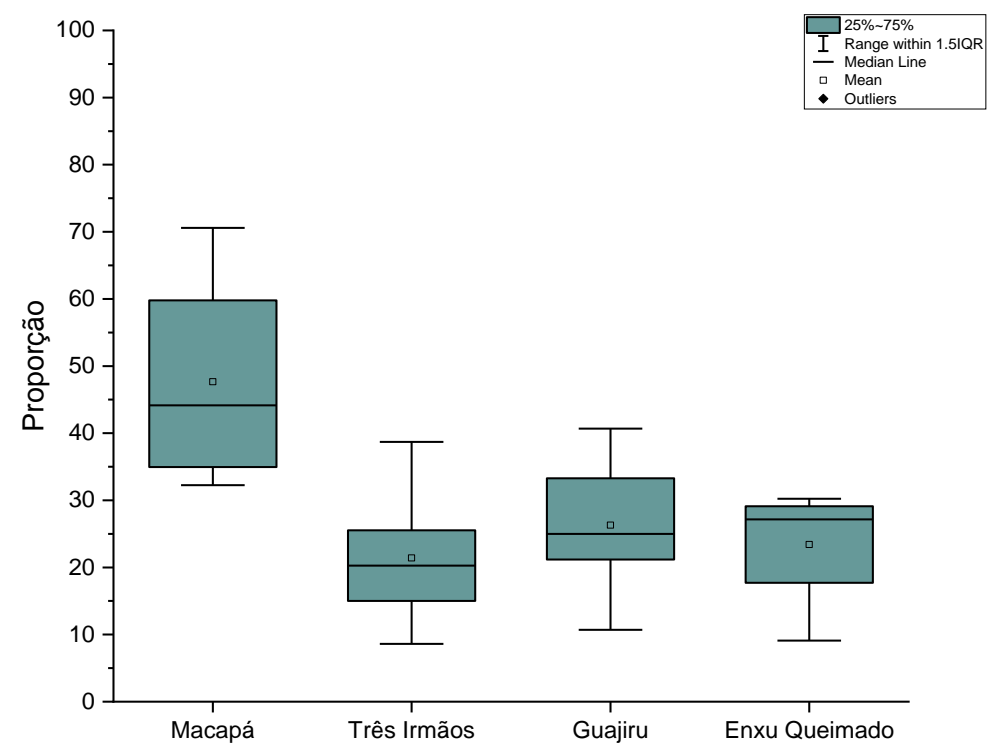

Fig. 5.115. Índice estaurolita/epídoto (EsEpi) das quatro áreas principais de ocorrência de eolianitos continentais, apresentadas de W para E: Macapá $(n=12)$, Três Irmãos $(n=6)$, Guajiru $(n=8)$ e Enxu Queimado $(n=4)$.

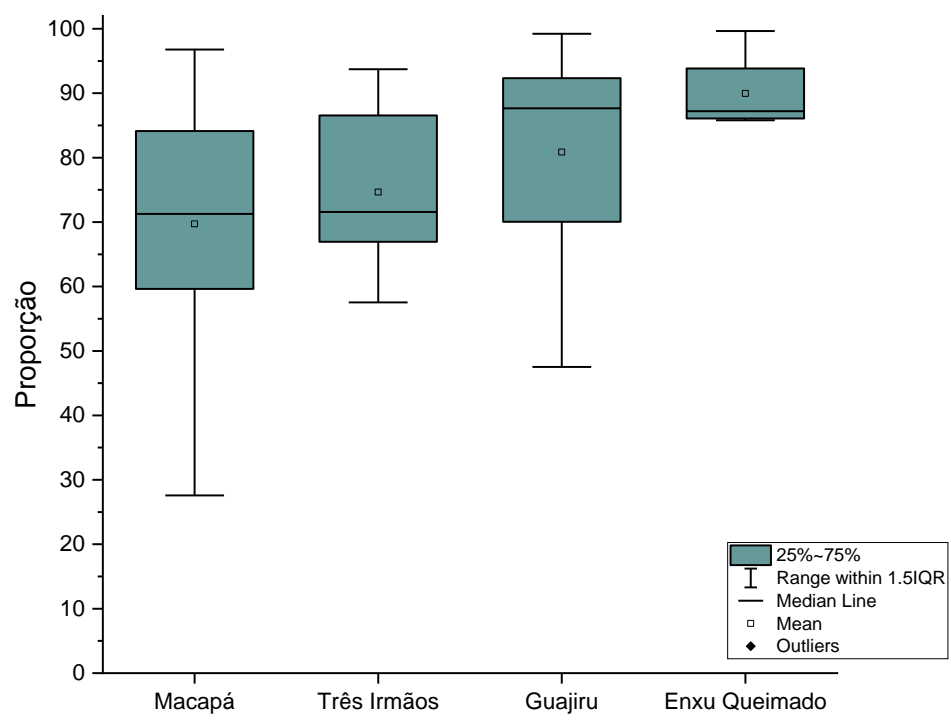

Fig. 5.116. Índice zircão/turmalina (ZTi) das quatro áreas principais de ocorrência de eolianitos continentais, apresentadas de W para E: Macapá $(n=12)$, Três Irmãos $(n=6)$, Guajiru $(n=8)$ e Enxu Queimado $(n=4)$.

\subsubsection{Caraterização da assembleia de eolianitos insulares}

Para a análise de minerais pesados no AFN, foram selecionadas só as áreas dos afloramentos altos, por apresentarem teor médio de terrígenos mais elevado. Na fração não magnética da classe areia fina, encontraram-se os seguintes minerais transparentes não 
micáceos principais, em ordem decrescente de abundância média: augita, hornblenda marrom (provável kaersutita), augita-Ti ("titanoaugita”), titanita, olivina, ferrossilita ("hiperstênio"), diopsídio, allanita e apatita (Fig. 5.117 a 5.120); outros minerais, com concentração menor que 1\%, são: perovskita, enstatita (Fig.120), granada, epídoto, hornblenda verde e monazita. O Quadro 10 apresenta a classificação nominal geral de frequências dos minerais pesados principais segundo a escala de Coutinho \& Coimbra (1974) e o Quadro 11 exibe as principais feições ópticas e texturais dos grãos.

Quadro 10. Classificação nominal para as frequências porcentuais médias de minerais pesados dos eolianitos insulares, segundo a escala de Coutinho \& Coimbra (1974). Classes: predominante: $>50 \%$; abundante: entre 20 e 50\%; comum: entre 5 e $20 \%$; escasso entre 2 e $5 \%$; e raro entre 1 e $2 \%$. Abreviações: AUG (augita), HBL (hornblenda), TAU (augita-Ti), TIT (titanita), OLI (olivina), FER (ferrossilita), DIO (diopsídio), ALL (allanita) e APA (apatita). Minerais com concentração menor que $1 \%$ não foram incluídos.

\begin{tabular}{|l|c|c|c|c|c|c|c|c|c|}
\cline { 2 - 11 } \multicolumn{1}{c|}{} & AUG & HBL & TAU & TIT & OLI & FER & DIO & ALL & APA \\
\hline Predominante & $\mathrm{X}$ & & & & & & & & \\
\hline Abundante & & $\mathrm{X}$ & $\mathrm{X}$ & & & & & & \\
\hline Comum & & & & $\mathrm{X}$ & $\mathrm{X}$ & $\mathrm{X}$ & & & \\
\hline Escasso & & & & & & & $\mathrm{X}$ & $\mathrm{X}$ & \\
\hline Raro & & & & & & & & & $\mathrm{X}$ \\
\hline
\end{tabular}

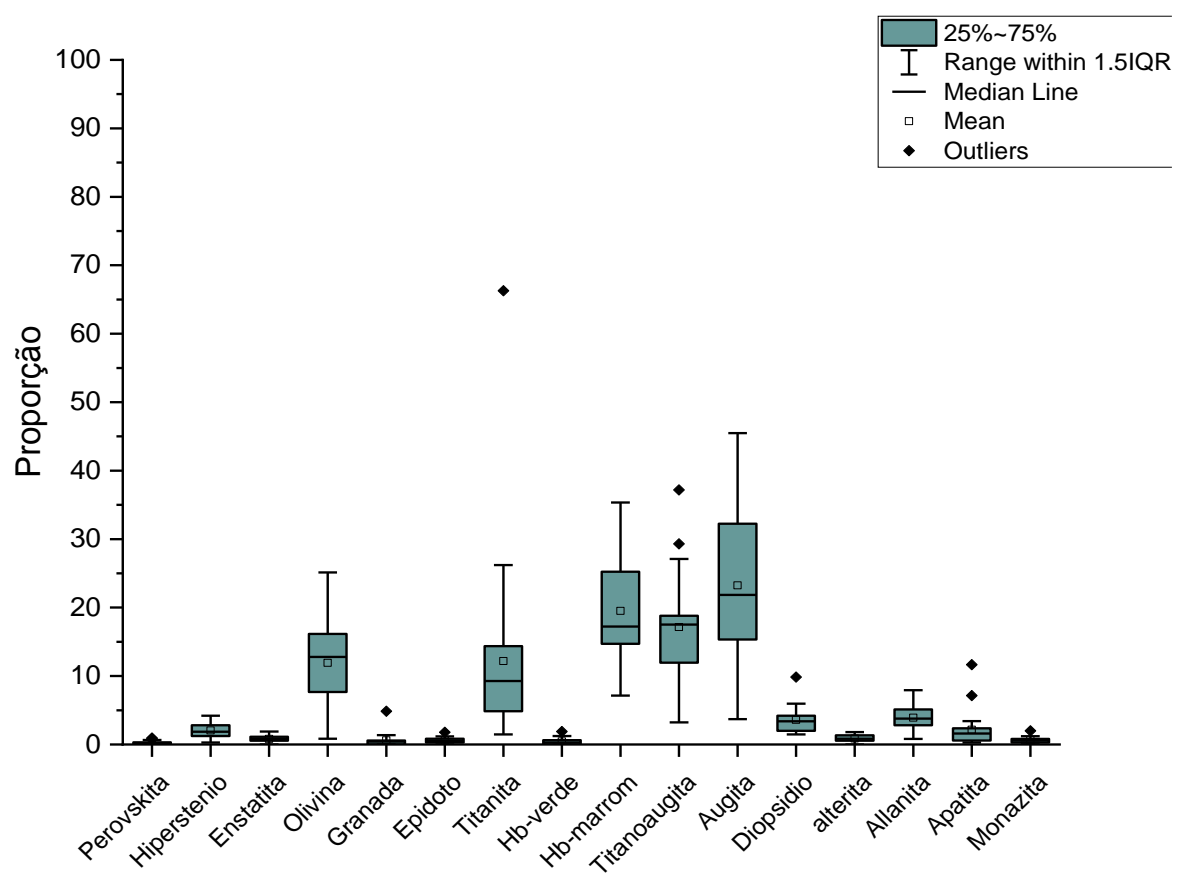

Fig. 5. 117. Assembleia de minerais pesados transparentes não micáceos do $A F N$. $n=22$. Número de ocorrências: ferrossilita ("hiperstênio"), olivina, titanita, hornblenda (hb) marrom, augitaTi, augita, diopsídio, allanita, apatita e monazita, 22; enstatita, 21; epídoto, 21; alterita, 18; hornblenda (hb) verde, 16; granada, 14; perovskita, 11. 
Quadro 11. Principais minerais pesados presentes nos eolianitos insulares e suas características dominantes.

\begin{tabular}{|c|c|c|c|c|}
\hline Mineral & Forma & Arredondamento & Cor & Alteração \\
\hline Augita & $\begin{array}{l}\text { Subédrica } \\
\text { prismática }\end{array}$ & $\begin{array}{c}\text { Subarredondado a } \\
\text { subangular }\end{array}$ & $\begin{array}{l}\text { Verde a verde } \\
\text { pardacento } \\
\text { pálidos }\end{array}$ & $\begin{array}{l}\text { Manchas marrons; } \\
\text { sulcamento de } \\
\text { clivagem e dentes } \\
\text { terminais, atribuídos à } \\
\text { dissolução }\end{array}$ \\
\hline Hornblenda & $\begin{array}{l}\text { Subédrica a } \\
\text { euédrica } \\
\text { prismática }\end{array}$ & Subarredondado & $\begin{array}{l}\text { Principalmente } \\
\text { marrom }\end{array}$ & \\
\hline Augita -Ti & $\begin{array}{l}\text { Subédrica a } \\
\text { euédrica } \\
\text { prismática }\end{array}$ & Subangular & $\begin{array}{l}\text { Marrom a rosa, } \\
\text { pálido }\end{array}$ & \\
\hline Titanita & $\begin{array}{c}\text { Subédrica a } \\
\text { euédrica, em } \\
\text { prisma curto } \\
\text { achatado } \\
\end{array}$ & $\begin{array}{l}\text { Subarredondado a } \\
\text { arredondado }\end{array}$ & Incolor & \\
\hline Olivina & $\begin{array}{c}\text { Subédrica } \\
\text { prismática curta }\end{array}$ & $\begin{array}{l}\text { Subangular a } \\
\text { subarredondado }\end{array}$ & Incolor & $\begin{array}{l}\text { Manchas marrons } \\
\text { comuns }\end{array}$ \\
\hline $\begin{array}{l}\text { Ferrossilita } \\
\text { ("hiperstênio") }\end{array}$ & $\begin{array}{l}\text { Subédrica a } \\
\text { euédrica } \\
\text { prismática }\end{array}$ & Subarredondado & $\begin{array}{l}\text { Marrom claro a } \\
\text { incolor }\end{array}$ & $\begin{array}{c}\text { Sulcamento de } \\
\text { clivagem e dentes } \\
\text { terminais, atribuidos à } \\
\text { dissolução }\end{array}$ \\
\hline Diopsídio & $\begin{array}{l}\text { Subédrica a } \\
\text { euédrica } \\
\text { prismática }\end{array}$ & Subarredondado & Incolor & $\begin{array}{c}\text { Manchas marrons } \\
\text { eventuais }\end{array}$ \\
\hline Allanita & $\begin{array}{l}\text { Subédrica a } \\
\text { euédrica } \\
\text { prismática }\end{array}$ & Subangular & Marrom & \\
\hline Apatita & $\begin{array}{c}\text { Euédrica a } \\
\text { subédrica } \\
\text { prismática, às } \\
\text { vezes } \\
\text { monoterminada }\end{array}$ & Subarredondado & Incolor & $\begin{array}{c}\text { Picoteamento e } \\
\text { sulcamento de } \\
\text { clivagem, atribuidos à } \\
\text { dissolução }\end{array}$ \\
\hline
\end{tabular}



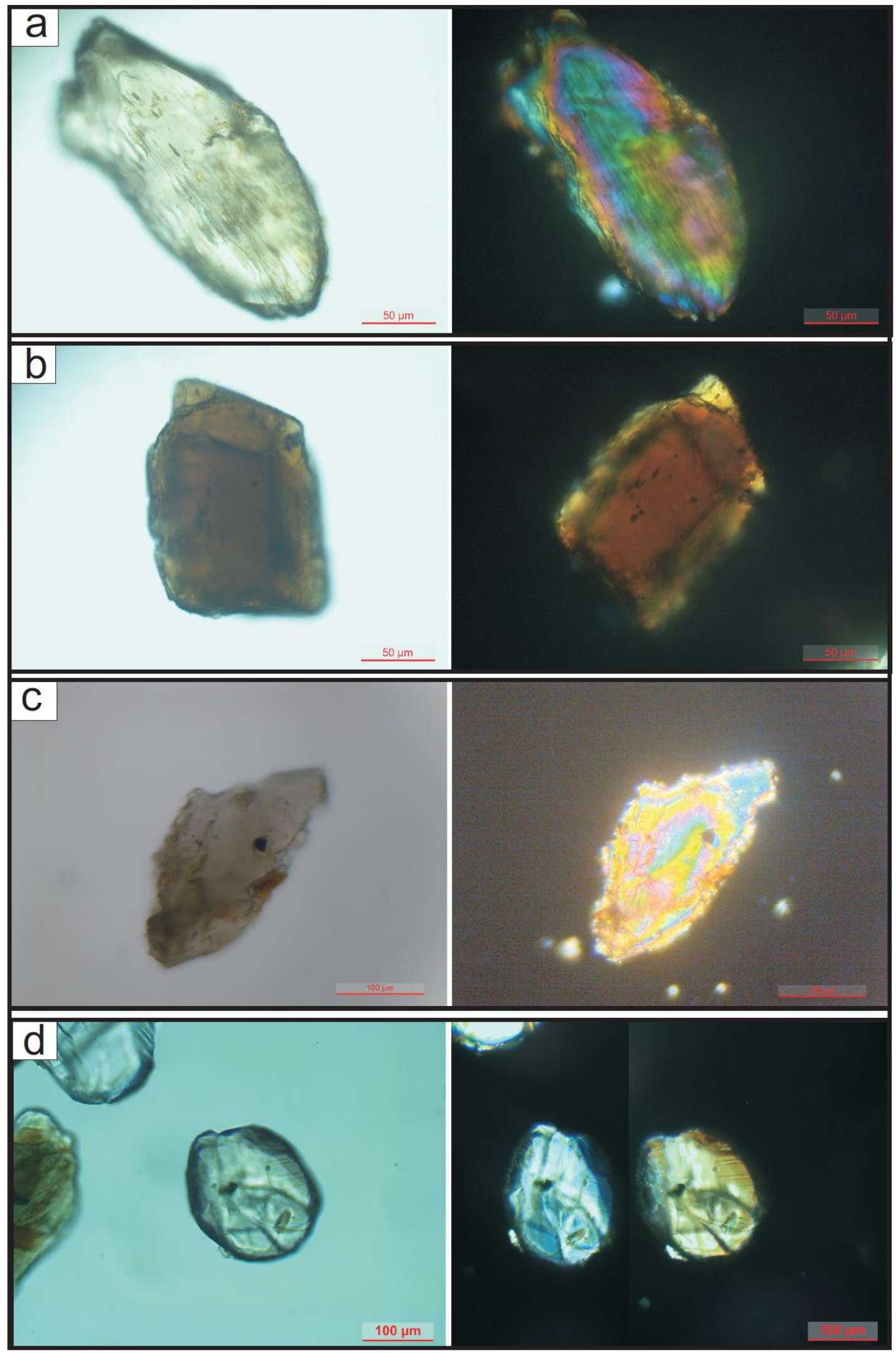

Fig. 5.118. Minerais pesados dominantes ou abundantes nos eolianitos insulares: a. augita; b. hornblenda marrom; c. augita-Ti; e d. titanita. Imagens da esquerda obtidas a polarizadores paralelos, e, da direita, a cruzados. 


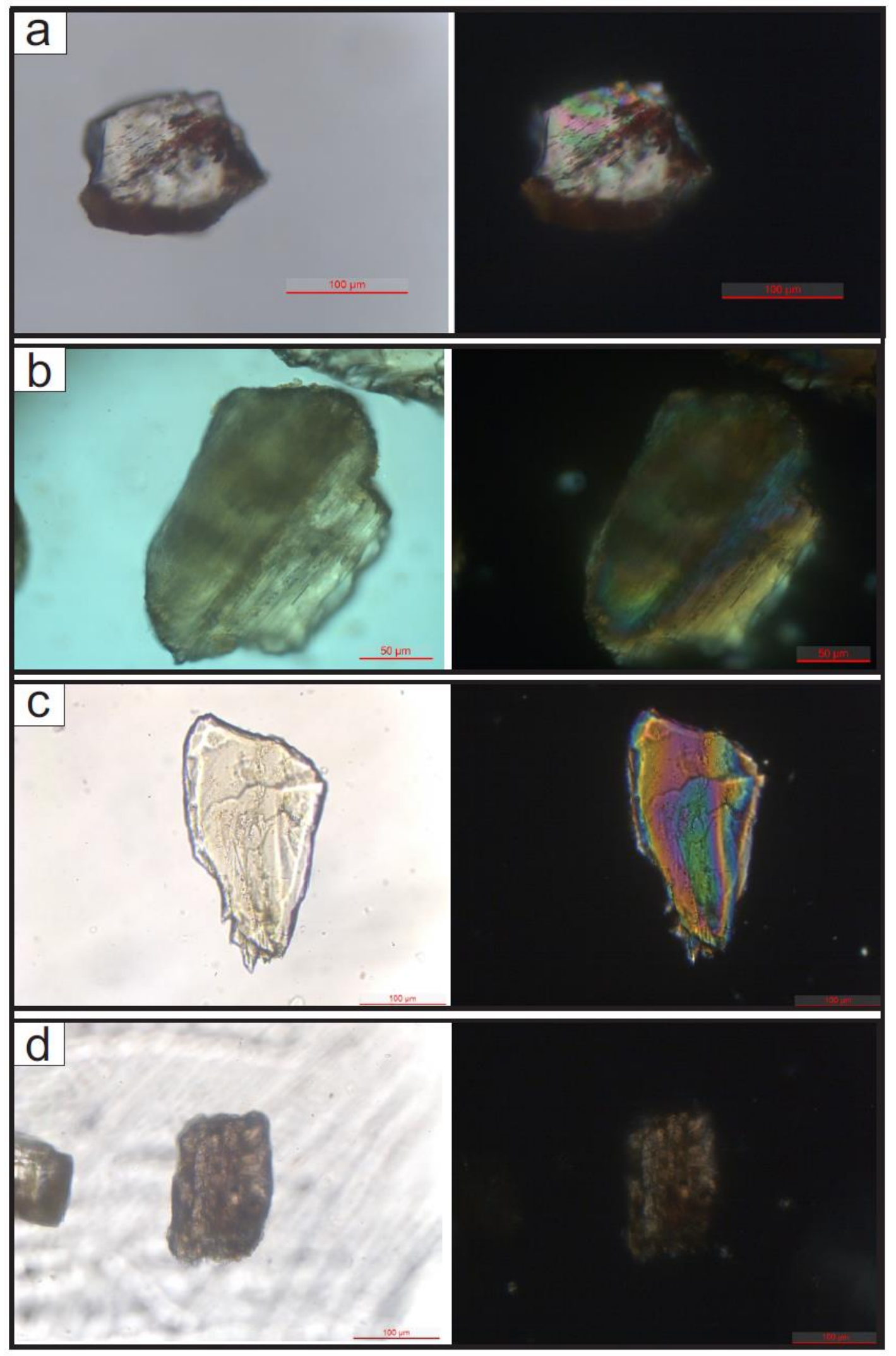

Fig. 5.119. Minerais pesados comuns nos eolianitos insulares: a. olivina; b. ferrossilita; c. diopsídio; e d. allanita. Imagens da esquerda obtidas a polarizadores paralelos, e, da direita, a cruzados. 


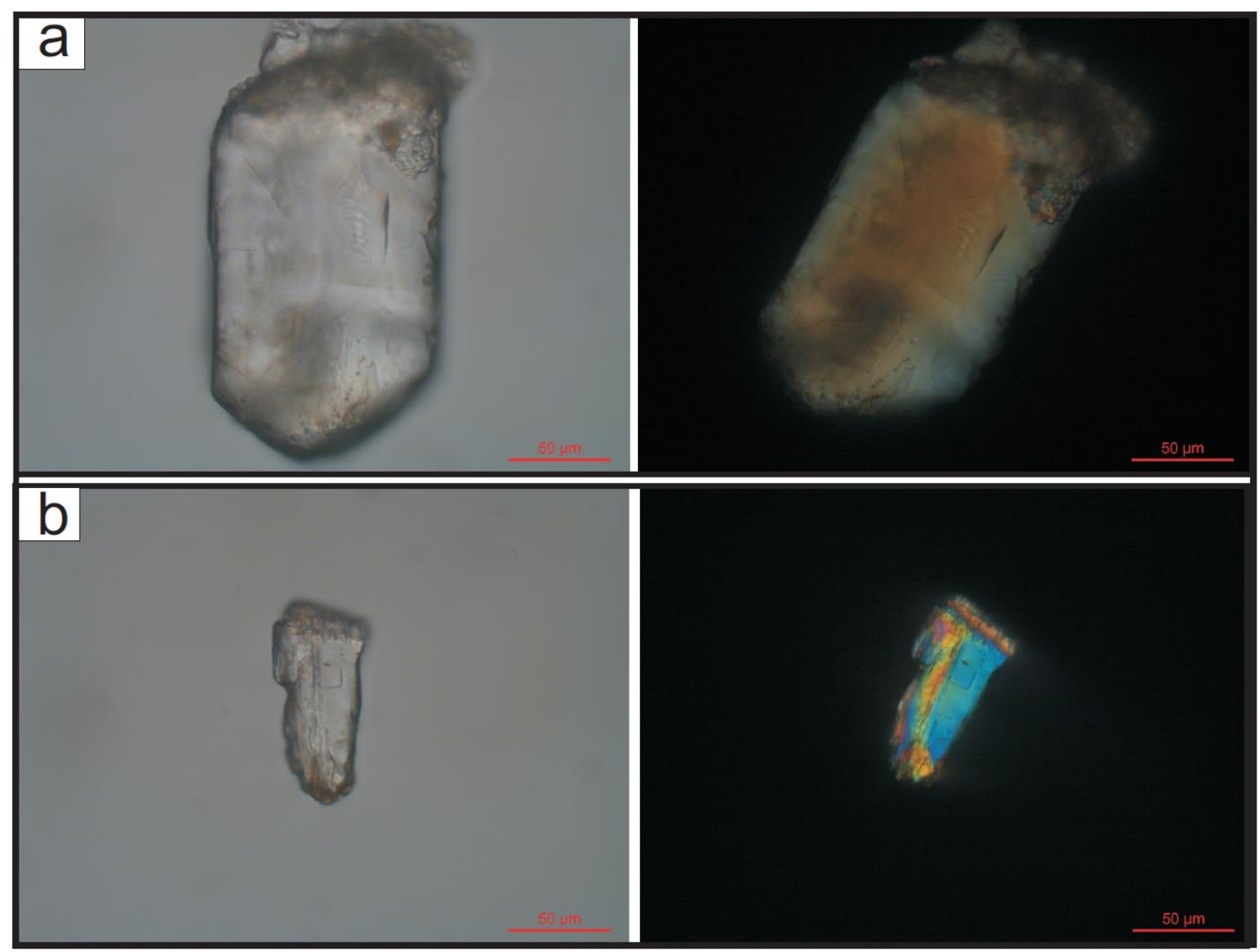

Fig. 5.120. Minerais pesados escassos ou raros nos eolianitos insulares: a. apatita; b. enstatita. Imagens da esquerda obtidas a polarizadores paralelos, e, da direita, a cruzados.

Quando as assembleias de minerais pesados dos eolianitos do arquipélago são analisadas por área de afloramentos (Enseada da Caieira, Ponta das Caracas, Forte de São Joaquim, Atalaia: Fig. 5.121 a 5.124), diferenças se observam, principalmente quanto aos minerais dominantes e suas concentrações; em Enseada da Caieira, os principais minerais são augita e olivina, seguidos de augita-Ti, hornblenda marrom e titanita, todos os cinco com concentrações entre 10 e 30\% (Fig. 5.121); na Ponta das Caracas, a augita é destaque, com intervalo interquartis muito superior aos demais (32 a 37\%), seguida de augita-Ti, hornblenda marrom e olivina (Fig. 5.122); nos eolianitos de Forte de São Joaquim, augita-Ti e hornblenda marrom apresentam os intervalos interquartis a valores mais elevados, com sobreposição entre si (Fig. 5.123). Em contraste, os de Atalaia apresentam domínio de hornblenda marrom (intervalo interquartis de 25 a 32\%), seguida de titanita (13 a 26\%), e de olivina, augita e augita-Ti (5 a $16 \%$ ); apatita, mineral pouco comum nas outras áreas, é o sexto mineral mais importante da assembleia em Atalaia, com intervalo interquartis de 3 a 7\% (Fig. 5.124). 


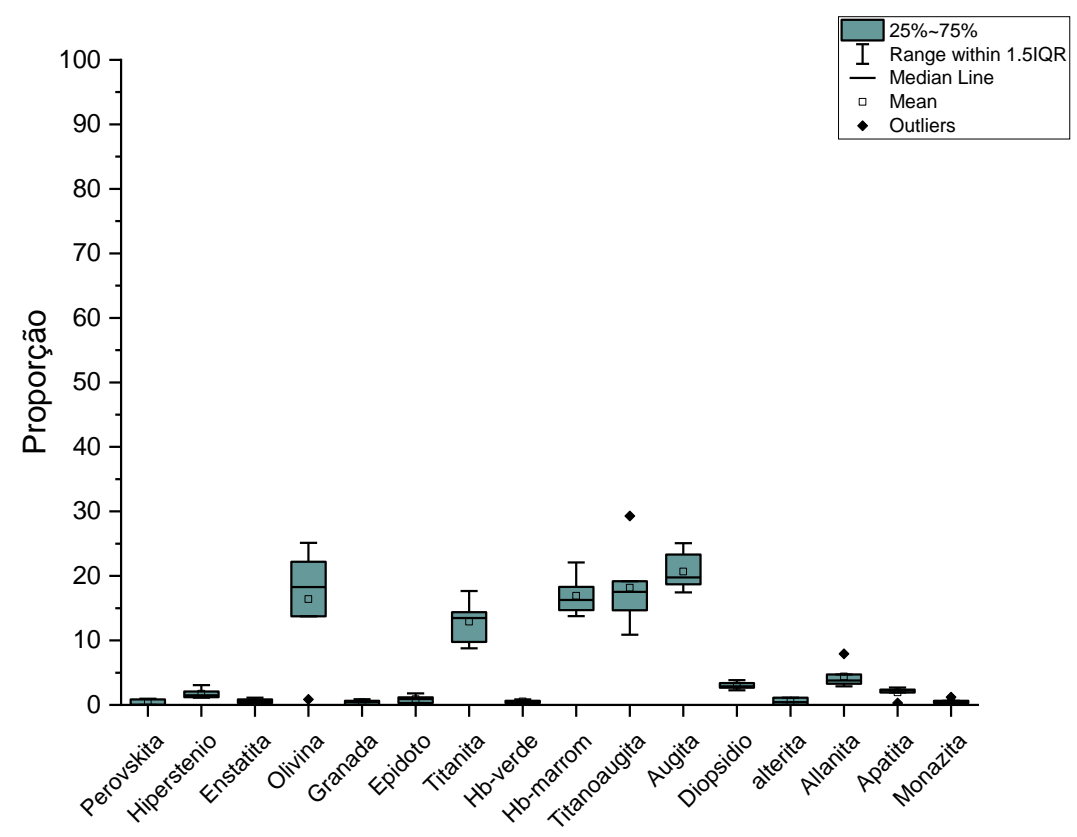

Fig. 5. 121. Assembleia de minerais pesados transparentes não micáceos de Enseada da Caieira, AFN. n= 6. Números de ocorrências: ferrossilita ("hiperstênio"), hornblenda (hb) marrom, augita-Ti, augita e diopsídio, allanita, apatita e monazita, 6; enstatita e olivina, 5; granada, 4; epídoto, titanita, hornblenda (hb) verde, alterita, 3; perovskita, 2.

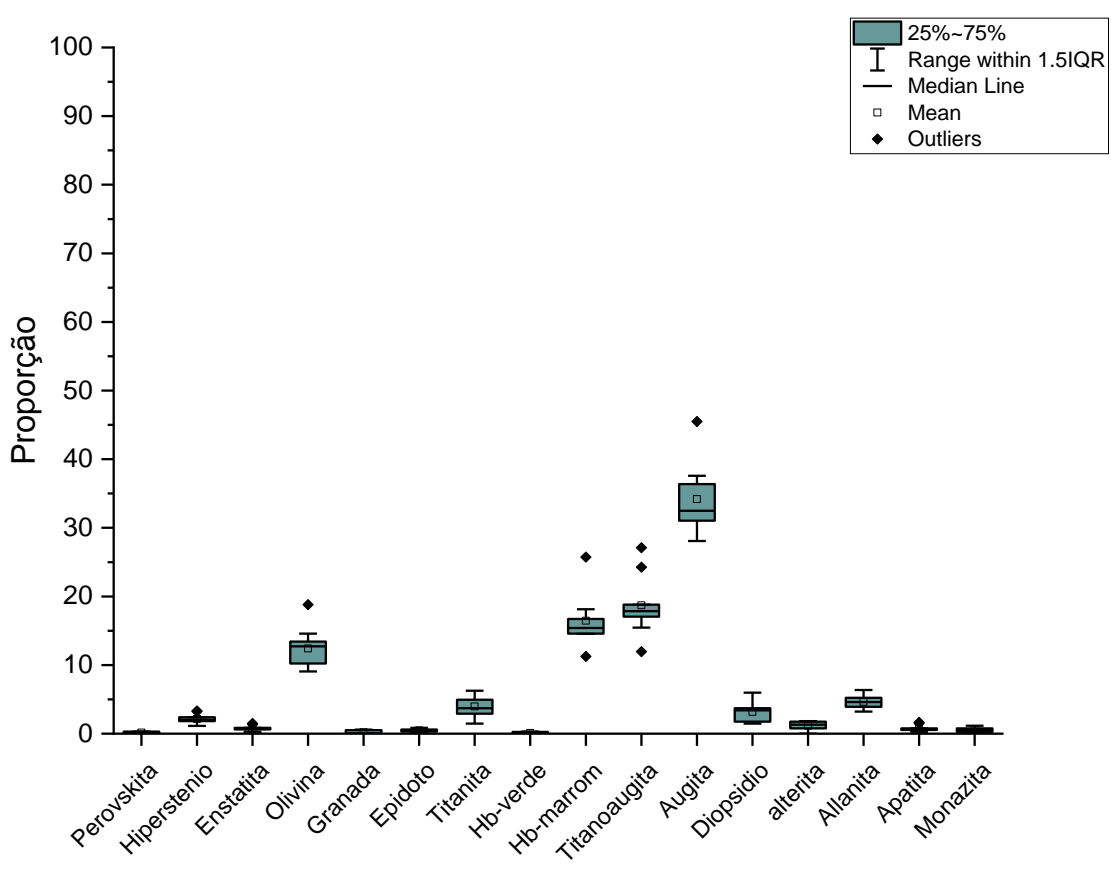

Fig. 5. 122. Assembleia de minerais pesados transparentes não micáceos de Ponta das Caracas, AFN. n=9. Número de ocorrências: ferrossilita ("hiperstênio"), enstatita e olivina, epídoto, titanita, hornblenda (hb) marrom, augita-Ti, augita, diopsídio, allanita, apatita e monazita, 9; alterita, 8; perovskita, 5; granada, 4; hornblenda (hb) verde, 3 . 


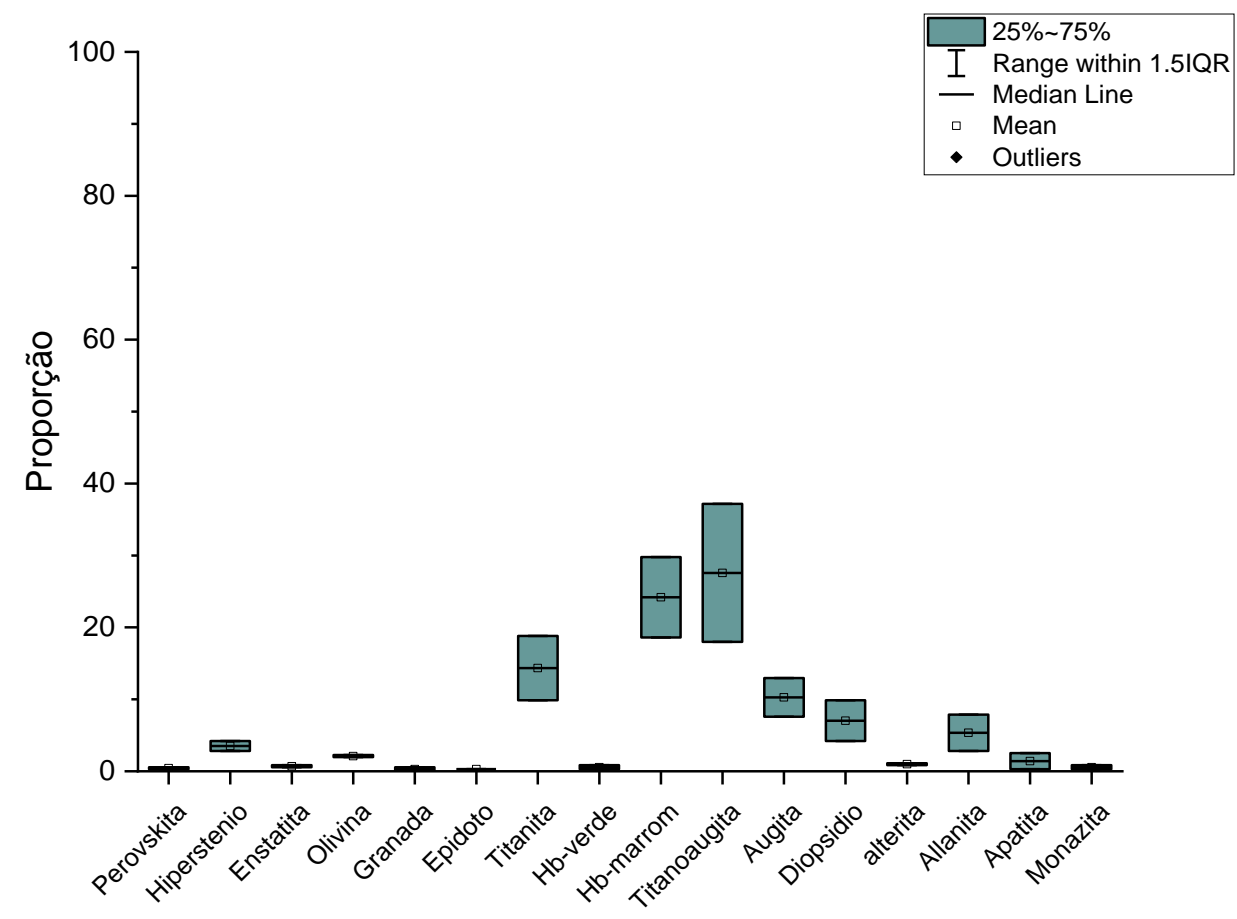

Fig. 5. 123. Assembleia de minerais pesados transparentes não micáceos de Forte de São Joaquim, AFN. $n=2$. Números de ocorrências: uma para granada, duas para os demais.

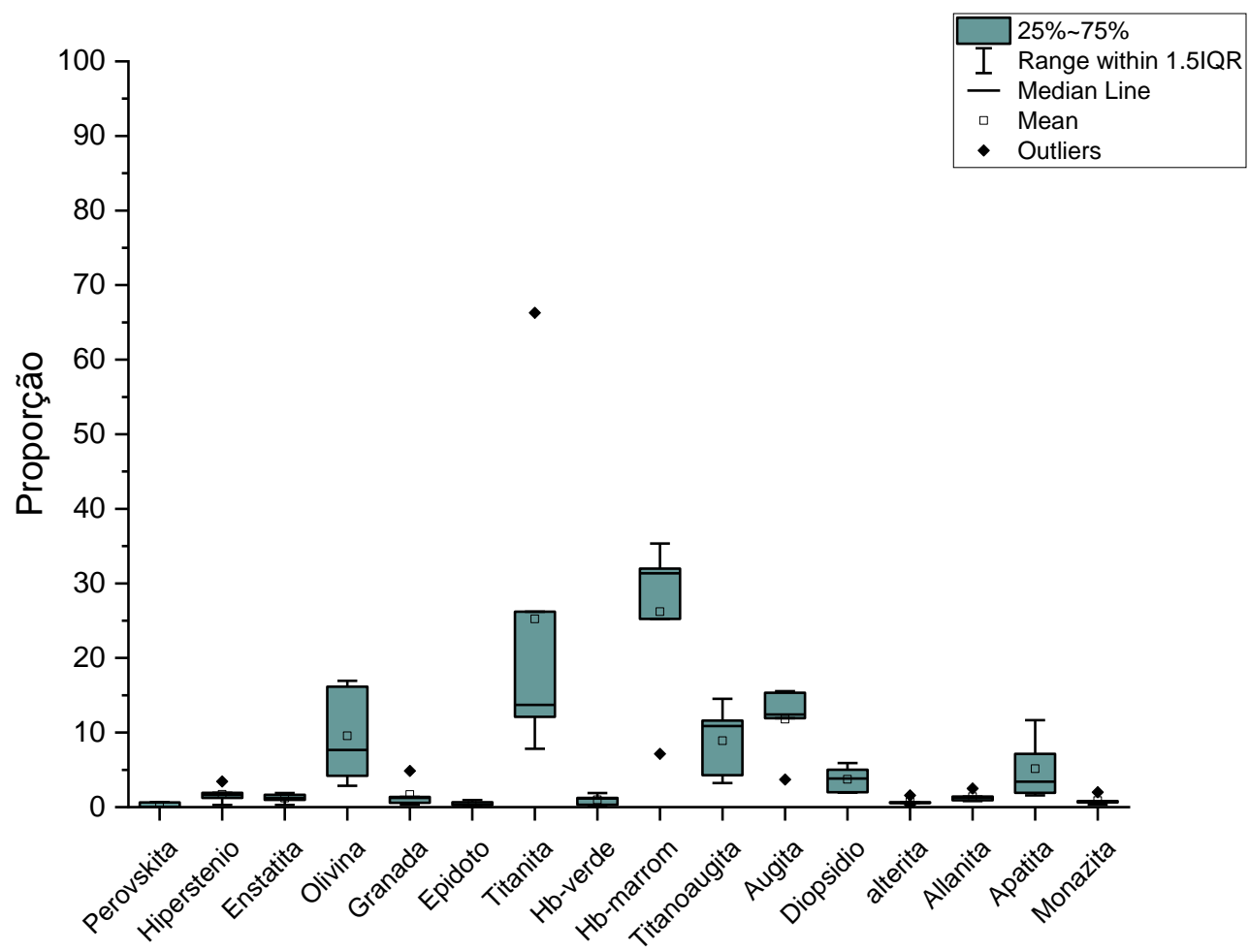

Fig. 5. 124. Assembleia de minerais pesados transparentes não micáceos de Atalaia, AFN. $\mathrm{n}=5$. Números de ocorrências: ferrossilita ("hiperstênio"), enstatita, olivina e granada, titanita, hornblenda (hb) verde, hornblenda (hb) marrom, augita-Ti, augita, diopsídio, alterita, allanita, apatita e monazita, 5; epídoto, 4; perovskita, 2. 
5.10.4 Variação espacial dos minerais e índices mineralógicos dos eolianitos insulares

A exemplo do que foi feito com os eolianitos continentais, quatro índices mineralógicos ABi (TiAli como indicador suposto de área fonte, HbAui como indicador suposto de seleção durante o transporte, e TiOli e TiAui, como indicadores supostos de maturidade química) foram calculados e representados em gráficos boxplot com intuito de comparar entre si as quatro áreas de ocorrência de afloramentos de eolianitos insulares altos (de NE para SW: Caieiras, Atalaia, Caracas e São Joaquim; Figs. 5.125 a 5.128).

O TiOli apresenta intervalo interquartis em valores mais elevados nos afloramentos de Forte de São Joaquim (82 a 90\%), com pequena sobreposição com o intervalo interquartis de Atalaia, e valores mais baixos (17 a 32\%) nos afloramentos vizinhos de Ponta das Caracas, este sem sobreposição com os intervalos de demais áreas. Tendências parecidas se observam com TiAui (Fig. 5.126) e HbAui (Fig. 5.127), nestes casos porém com sobreposição total entre os intervalos interquartis de Forte de São Joaquim e Atalaia. Em ambos os casos, o intervalo interquartis tem maior amplitude e alcança valores mais altos em Forte de São Joaquim.

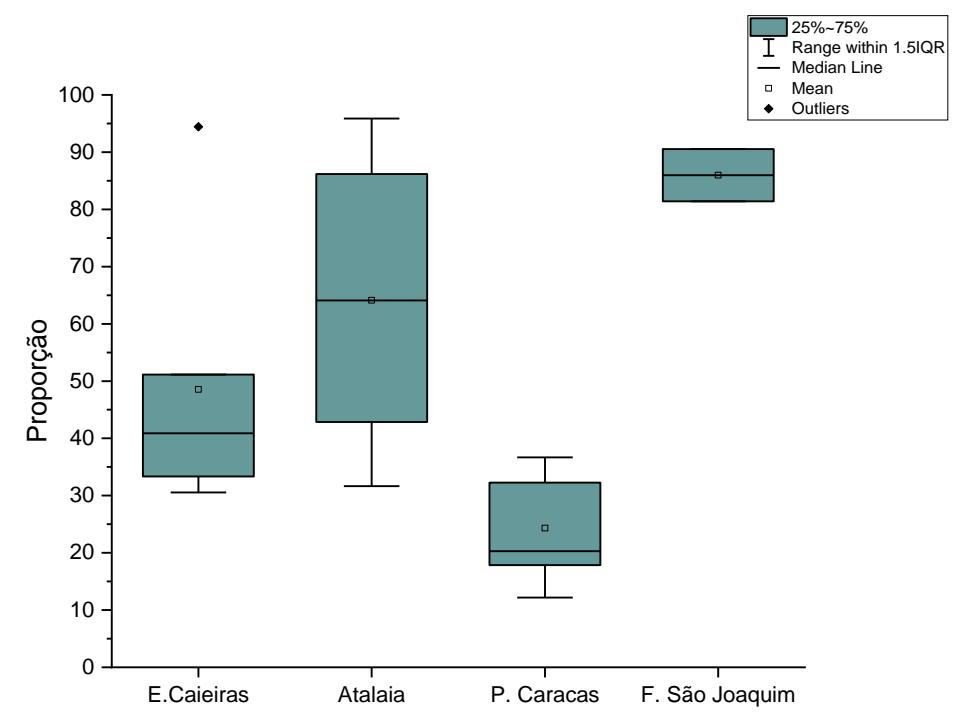

Fig. 5.125. Índice titanita/olivina (TiOli) dos quatro afloramentos altos do AFN, apresentados de NE para SW: Enseada da Caieira $(n=6)$, Atalaia $(n=5)$, Ponta das Caracas $(n=9)$ e Forte de São Joaquim $(n=2)$. 


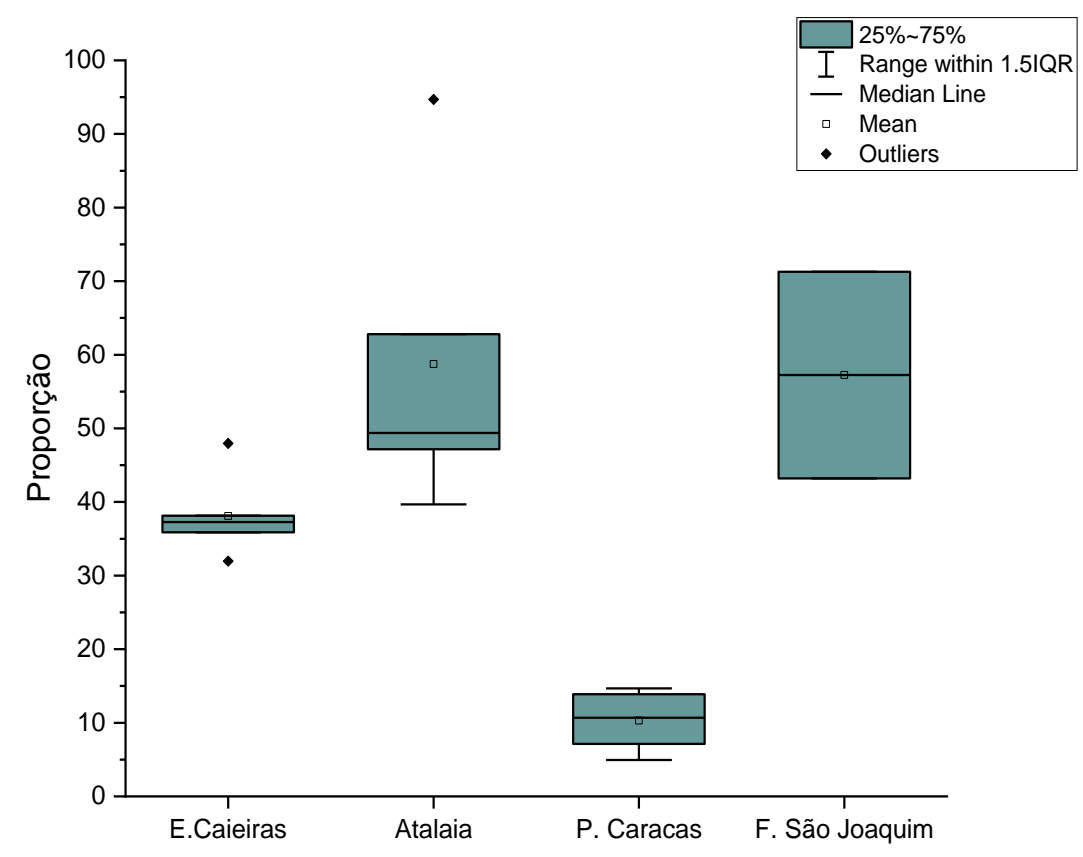

Fig. 5.126. Índice titanita/augita (TiAui) dos quatro afloramentos altos do AFN, apresentados de NE para SW: Enseada da Caieira $(n=6)$, Atalaia $(n=5)$, Ponta das Caracas $(n=9)$ e Forte de São Joaquim $(n=2)$.

Com respeito à razão supostamente indicadora de transporte (HbAui; Fig.5.127), os afloramentos de Atalaia e Forte de São Joaquim apresentam valores mais elevados (59 a 79), e o de Ponta das Caracas, valores mais baixos (24 a 38).

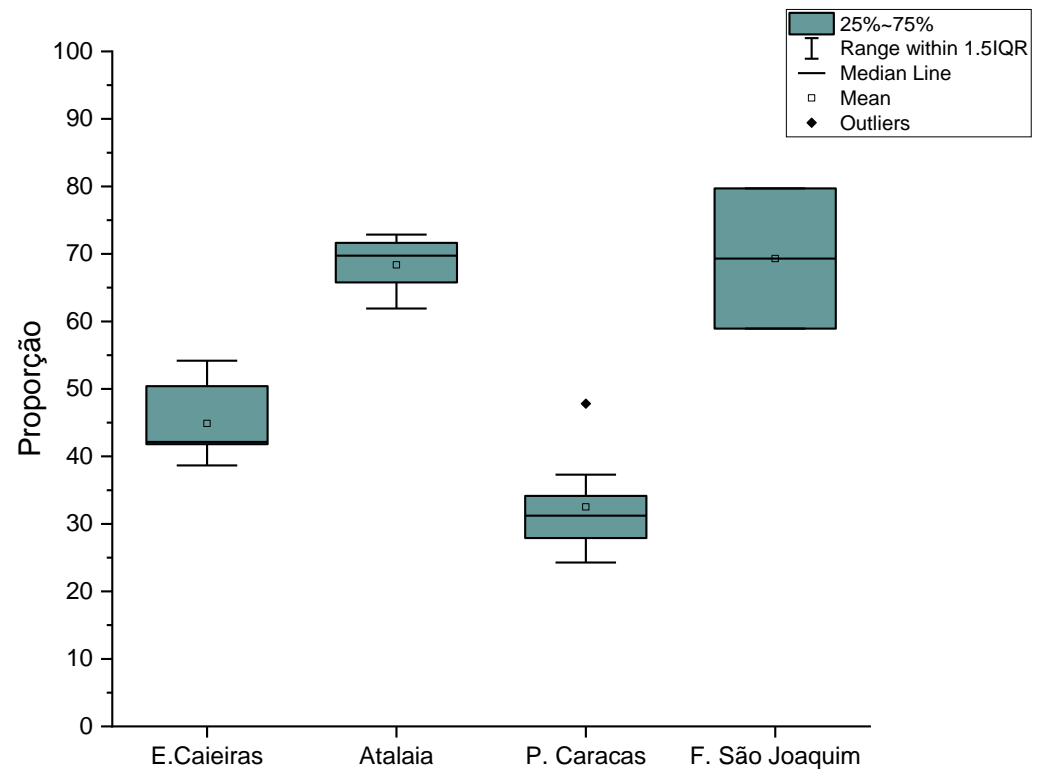

Fig. 5.127. Índice hornblenda/augita (HbAui) dos quatro afloramentos altos do AFN, apresentados de NE para SW: Enseada da Caieira $(n=6)$, Atalaia $(n=5)$, Ponta das Caracas $(n=9)$ e Forte de São Joaquim $(n=2)$. 
O intervalo interquartis da razão TiAli (Fig. 5.128), suposto indicador de fonte, possui menor amplitude e atinge maiores valores (93 a 95\%) nos eolianitos de Atalaia; os valores mais baixos de intervalo interquartis deste índice (42 a 51\%) encontram-se na Ponta das Caracas; os intervalos interquartis a valores intermediários, em Caieiras e Forte São Joaquim, mostram sobreposição entre si.

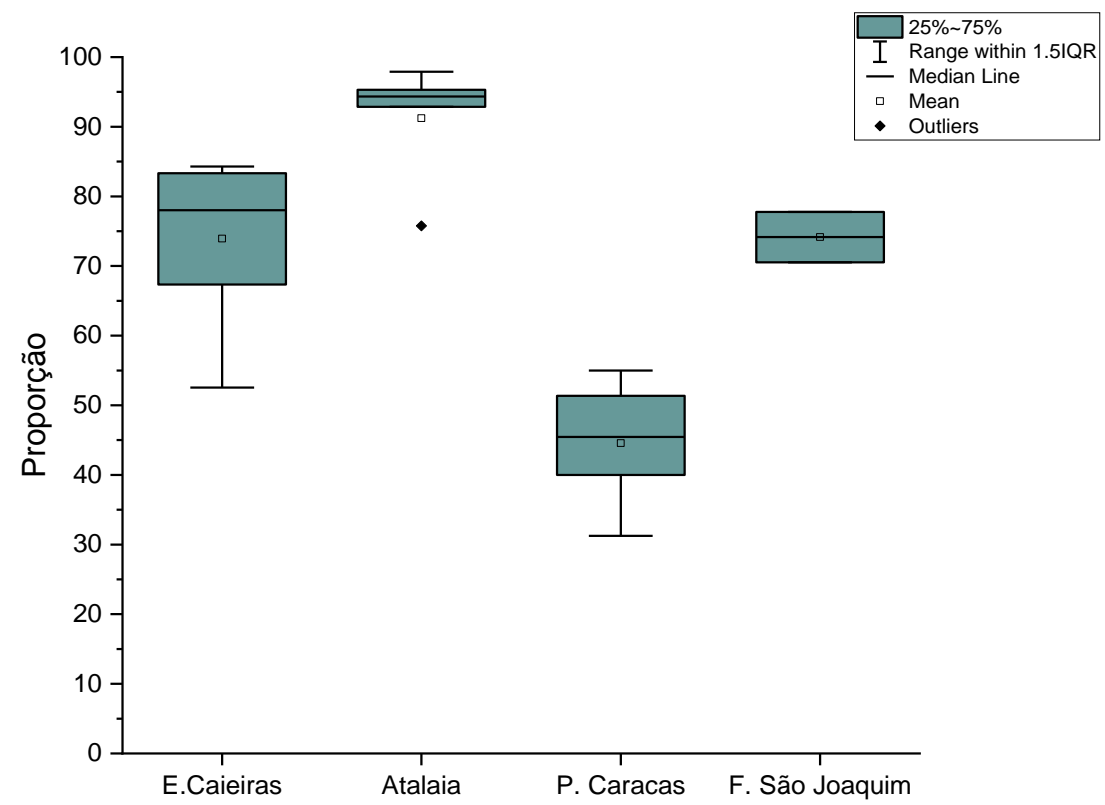

Fig. 5.128. Índice titanita/allanita (TiAli) dos quatro afloramentos altos do AFN, apresentados de NE para SW: Enseada da Caieira $(n=6)$, Atalaia $(n=5)$, Ponta das Caracas $(n=9)$ e Forte de São Joaquim $(n=2)$. 


\section{DISCUSSÕES}

A formação de sistemas eólicos costeiros pressupõe a existência de sedimentos disponíveis para o transporte pelo vento, a partir de uma área fonte em algum momento submersa, e de espaço para a acumulação eólica, onde o depósito passa a sofrer modificações por diagênese. Desta perspectiva, as características sedimentológicas do depósito eólico costeiro em geral, e de eolianitos em particular, dependem de três fatores: fonte imediata marinha, acumulação e diagênese; estes três fatores, em conjunto, controlam a formação e preservação de eolianitos, e, portanto, sua distribuição no espaço e no tempo.

A estrutura adotada para os primeiros três itens deste capítulo de discussão de resultados segue essa ordem lógica, da fonte à acumulação e daí à diagênese. O primeiro item do capítulo é dedicado à questão da proveniência dos sedimentos contidos nos eolianitos, seja quanto aos seus componentes intrabacinais, seja quanto aos terrígenos. O segundo item é dedicado à influência da área de acumulação nas características morfológicas e faciológicas do sistema eólico. O terceiro item trata dos efeitos da diagênese sobre os depósitos e suas implicações petrográficas e composicionais. Finalmente, o quarto item é dedicado à distribuição dos eolianitos no espaço, e, sobretudo, no tempo, com base nas datações realizadas. O motivo central em todos os itens é a comparação entre eolianitos de costas continentais e insulares.

\section{1. Áreas Fontes}

Tendo em vista que o primeiro fator para a formação de eolianitos é a bacia carbonática submersa adjacente, deve-se considerar os contrastes, nesse quesito, entre a plataforma continental do Nordeste do Brasil, desde PI até RN, e os bancos e recifes carbonáticos que circundam o AFN (Fig. 6.1).
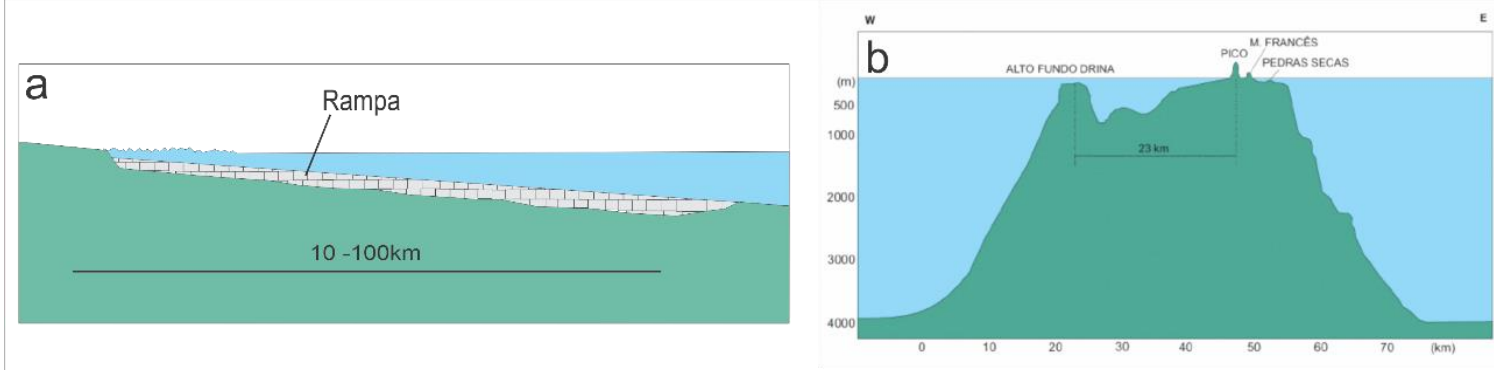

Fig. 6.1. Diferenças morfológicas entre as plataformas carbonáticas que atuaram como fontes de sedimentos para os eolianitos: a. continentais e b. insulares; $\mathbf{b}$, baseado no caso do AFN, extraído de Teixeira et al. (2003). 
O primeiro aspecto que controla o desenvolvimento e a composição dessa bacia carbonática submersa é o volume relativo de aporte terrígeno. Nas áreas de ocorrência dos eolianitos continentais brasileiros, a ampla área fonte emersa formada por rochas de composição silicática, com destaque para ígneas e metamórficas granitoides e para a Formação Barreiras, litologias ricas em quartzo e feldspato, implica composição mista (i.e. extraintrabacinal) na cobertura da plataforma continental. No caso insular, em contraste, a área de captação hidrográfica restrita reduz o aporte terrígeno e favorece a limpidez das águas, a maior proliferação de comunidades bentônicas e o desenvolvimento de recifes algálicos, com sedimentos carbonáticos bioclásticos associados, na plataforma submersa; a rocha fonte de composição básica a ultrabásica alcalina, a qual se intemperiza facilmente, também contribui para a escassez de suprimento terrígeno.

O segundo aspecto a controlar as características sedimentares da bacia carbonática que atua como fonte para a areia bioclástica do eolianito é o morfológico. Sob este ponto de vista, a plataforma continental nordestina pode ser classificada como uma "rampa sem bordas" (Read 1982), isto é, uma superfície de fundo com caimento suave (tipicamente menor que $1^{\circ}$ ) e pouco variável em que barreiras recifais estão ausentes, o que impossibilita a identificação de uma estrutura (borda) protetora em relação à ação das ondas (Fig. 6.1a). Esta plataforma chega a ser dominada por sedimentos carbonáticos (Kowsmann e Costa 1979), mas que estão sobretudo na granulação cascalho, de difícil remobilização pelas ondas e pelo vento; a fração carbonática varia, em termos de constituição majoritária, de moluscos, foraminíferos bentônicos e algas recifais, no trecho entre Macau e São Miguel do Gostoso (RN), para algas coralináceas ramificantes (rodólitos) e recifais, na região do PI e CE (Kowsmann e Costa 1979; Fig. 3.8).

Já a plataforma carbonática do AFN pode ser considerada "isolada", na classificação de Read (1982), com depósitos carbonáticos de águas rasas (“altos fundos”) rodeados por águas profundas em todas as direções e com estruturas recifais dominantemente algálicas (Almeida 1955, Ottmann 1959) nas suas bordas, ladeadas por taludes acentuados.

O contraste acentuado na taxa de aporte terrígeno, em vista da extensão e litologia da área fonte emersa e da morfologia da plataforma carbonática, é um dos aspectos que melhor diferenciam os eolianitos brasileiros continentais dos insulares em termos composicionais; este contraste se expressa por exemplo no teor de carbonato (item 5.9; Fig. 5.97), com valores médios de $25 \%$ nos eolianitos continentais, contra $87 \%$ nos insulares, na proporção de clastos carbonáticos $(54 \%$, nos continentais contra $>77 \%$, no AFN; item 5.9, Tabelas 6,7 e 8) e na 
classificação petrográfica (quartzo arenitos versus calciarenitos, respectivamente). Franco domínio de grãos carbonáticos também é evidente em vários outros eolianitos insulares como os de Bahamas (Kindler e Mazzolini, 2001, Kindler \& Hearty 1995, Aalto \& Drill 1996, Mylroie 2008, Deely et al. 2011), Havaí (Fletcher III et al. 2005), Chipre (Erginal et al. 2011), Madeira (Silva \& Gomes 2016), Menorca (Pomar et al. 2017), Canárias (Mangas et al. 2008), Cabo Verde (Dabrio et al. 2006) e Ilhas do Canal, na Califórnia (Muhs et al. 2018). Analogamente, o domínio de grãos terrígenos é relatado em muitos outros eolianitos de margem continental como os da Austrália (Lipar \& Webb 2014, Brooke et al. 2014, Lipar et al. 2017), México (Loucks \& Ward 2001), Turquia (Erginal et al. 2013) e Tunísia (Fréboug et al. 2010).

No que se refere especificamente ao tipo de grão carbonático, nos eolianitos do RN, foi possível identificar microfácies dominadas por peloides (10\% em média), algas vermelhas (7\%), foraminíferos bentônicos (6\%) e moluscos (6\%), entre outros tipos de grãos (Fig. 5.57), procedentes da plataforma mista adjacente (Kowsmann e Costa 1979; Fig. 3.8). O único componente intraclástico desses eolianitos não destacado previamente na constituição dessa plataforma corresponde aos peloides, que, portanto, muito provavelmente não são um tipo de grão primariamente existente na bacia, mas sim o resultado de modificações pós-deposicionais atuantes sobre bioclastos (como será melhor discutido no item 6.3). Já nos eolianitos insulares, as microfácies encontradas nos eolianitos têm franco domínio de peloides (46\% em média) e algas vermelhas (15\%), ainda que com registro significativo $(8 \%)$ de foraminíferos bentônicos (Figs. 5.78, 5.80). Mais uma vez, não há relato de presença importante de peloides nos altos fundos e, portanto, este tipo de grão pode resultar da modificação diagenética de bioclastos, sobretudo algas.

Como se pode ver, não há diferenças expressivas quanto aos tipos de grãos carbonáticos nos eolianitos continentais e insulares: a diferença no teor de peloides, se considerada como de origem pós-deposicional, não tem implicações em termos de composição da plataforma; e a diferença na proporção de moluscos $(6 \%$ em média no caso continental contra $4 \%$ no AFN, nos eolianitos), é pouco expressiva. Esta semelhança no tipo de grão reflete similaridades de microfácies, ou seja, no regime de temperatura e salinidade e na produtividade biológica das águas que envolvem as áreas fontes submersas. O domínio de peloides e algas vermelhas, nos eolianitos de ambos os casos, permite enquadrar estas áreas na Associação Photozoa, na classificação de James (1997), ou Photozoa-T (definida, conforme item 3.5, como de zonas tropicais, com SST constante e alta durante todo o ano), no modelo de distribuição global de 
fábricas de carbonatos de água rasa de Laugie et al. 2019 (Fig. 6.2); este fato contraria a hipótese de Brooke (2001), comentada na síntese bibliográfica do item 3.5 (Tabelas 1 e 2), segundo o qual a distribuição geográfica de eolianitos se correlaciona preferencialmente com a distribuição da Associação Heterozoa; uma possibilidade é que a correlação traçada por este último autor tenha validade restrita aos eolianitos de latitude média (acima de aproximadamente $30^{\circ}$ ), como é o caso dos da Austrália (1 na Fig. 6.2; Hearty 2003, Hearty \& Leavy 2008, Lipar \& Webb 2014, Brooke et al. 2014, James \& Bone 2015, Lipar \& Webb 2015, Lipar et al. 2017), África do Sul (2 na Fig.6.2; Cooper \& Green 2016) e das ilhas Shidao, na China (3 na Fig. 6.2; Li et al. 2018), e Canárias (4 na Fig. 6.2; Mangas et al. 2008); por outro lado, os eolianitos de latitudes menores, com domínio de bioclastos como algas vermelhas, peloides e foraminíferos, os quais se encontram sub-representados no mapa-múndi de ocorrências de eolianitos de Brooke 2001 (Fig.3.4), podem associar-se ao que foi referido por Laugie et al. (2019) como fábricas de Photozoa-T; entre eles, incluem-se os eolianitos de Bahamas (5 em Fig.6.2; Kindler \& Hearty 1995, Aalto \& Drill 1996, Mylroie 2008, Deely et al. 2011), Havaí (6 em Fig.6.2; Fletcher III et al. 2005), Cabo Verde (7 em Fig. 6.2; Dabrio et al. 2006), sul do Golfo Arábico (8 em Fig.6.2; El-Asmar \& Wood 2000, William \& Walkden 2002), sul da Califórnia (9 em Fig.6.2; Muhs et al. 2018), Índia (10 em Fig.6.2; Dasgupta \& Bandyopadhyay 2008), México (11 em Fig.6.2; Loucks \& Ward 2001) e Brasil (12 em Fig.6.2; Angulo et al. 2013a, Espinel Arias et al. 2015); já as áreas com eolianitos no Mar Mediterrâneo, como costa do Egito (13 em Fig.6.2; El-Asmar 1994) e ilhas de Menorca (14 em Fig.6.2; Pomar et al. 2017) e Chipre (15 em Fig.6.2; Erginal et al. 2011), antes atribuídos por James (1997) à Associação Heterozoa, foram realocadas por Laugie et al. (2019) na fábrica Photozoa-C; esta associação caracterizase pela presença de algas vermelhas, foraminíferos e, às vezes, algas verdes, ooides, moluscos e briozoários, e relaciona-se a SST com forte sazonalidade e produtividade oceânica moderada. 


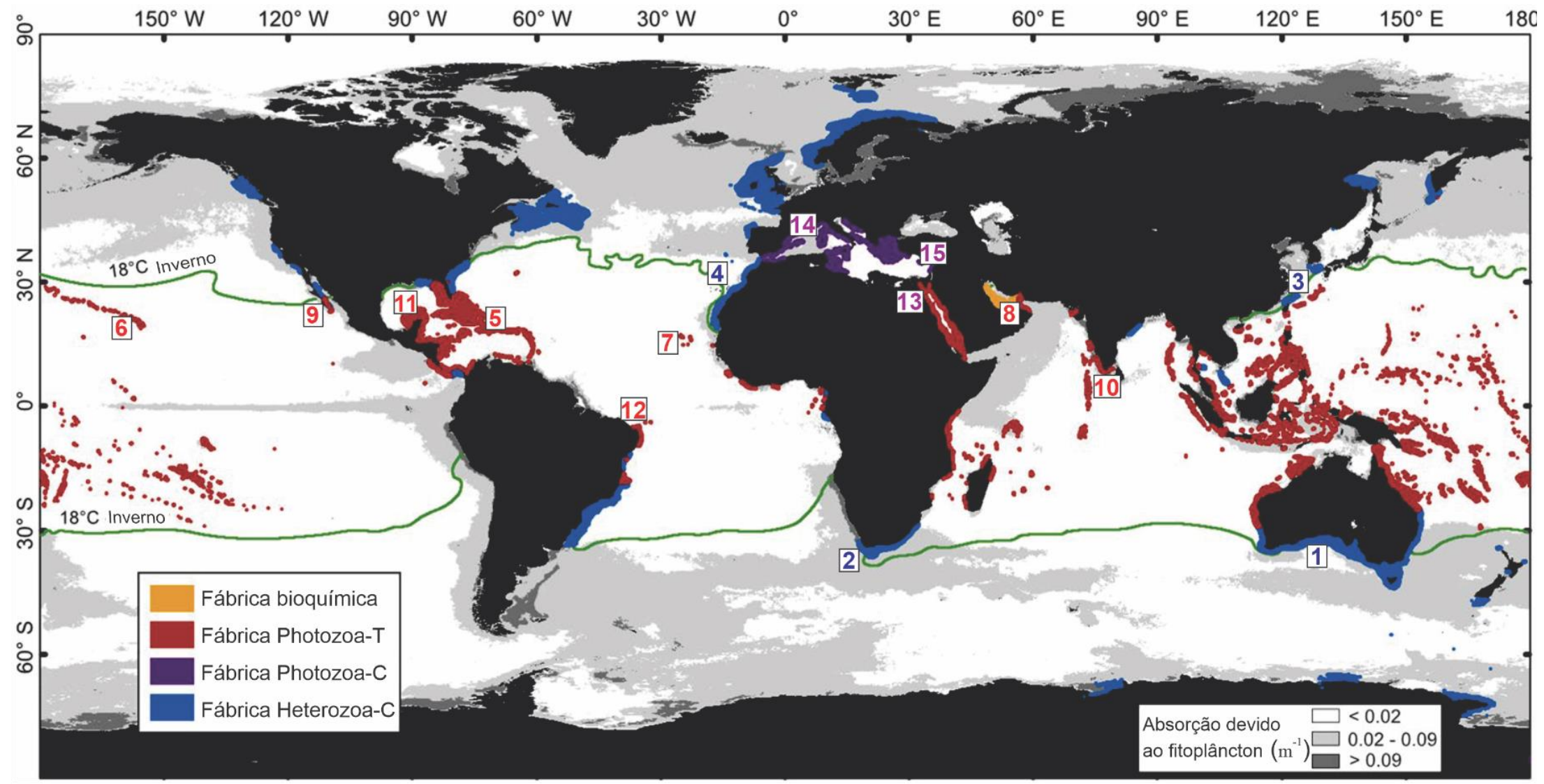

Fig 6.2 Distribuição mundial de fábricas modernas de carbonato marinho em águas rasas. Extensão da fábrica de carbonato é exagerada para fins de visualização. Mapa oceanográfico de fundo corresponde a dados de sensoriamento remoto de produtividade primária marinha (absorção devido ao fitoplâncton). Distribuição da plataforma de carbonato provém de dados bibliográficos. As quatro fábricas são definidas segundo Michel et al. (2018, 2019), dividindo a as fábricas de Schlager (2005, 2000, 2003) em "Bioquímicas", "Photozoa-T", "Photozoa-C" e "Heterozoa-C". Extraído de Laugie et al. (2019), e modificado com as áreas de eolianitos, enumeradas de $1 \mathrm{a} 15$, referidas no texto. 
Quanto aos minerais terrígenos, as diferenças composicionais entre eolianitos continentais e insulares também se explicam antes de mais nada pela questão da proveniência ligada ao contexto geológico maior: como foi referido anteriormente, os eolianitos continentais são formados a partir de sedimentos provenientes de rochas ígneas ácidas, metamórficas e sedimentares siliciclásticas, que apresentam domínio de terrígenos leves no tamanho areia fina a areia grossa e proporções menores $(<5 \%$ em massa na classe areia fina) de minerais pesados como zircão, hornblenda, epídoto, turmalina, sillimanita, cianita e estaurolita (Figs. 5.108 a 5.111). Em contraste, os eolianitos insulares, ao associarem-se a um atol de substrato piroclástico-vulcânico de composição básica-ultrabásica, apresentam assembleia mineralógica fortemente distinta, mais rica em minerais pesados, dentre os quais se destacam augita, hornblenda, augita-Ti, titanita, olivina, diopsídio e ferrossilita (Figs. 5.117 a 5.119). O grupo da hornblenda é o único componente mineralógico que ocorre em quantidades significativas (isto é, como comum a predominante, $c f$. Quadros 8 e 10) em ambos os contextos, mas, ainda assim, em minerais provavelmente distintos, já que nos eolianitos continentais predomina francamente a hornblenda verde, enquanto nos insulares a hornblenda marrom é mais abundante (Fig. 6.3).
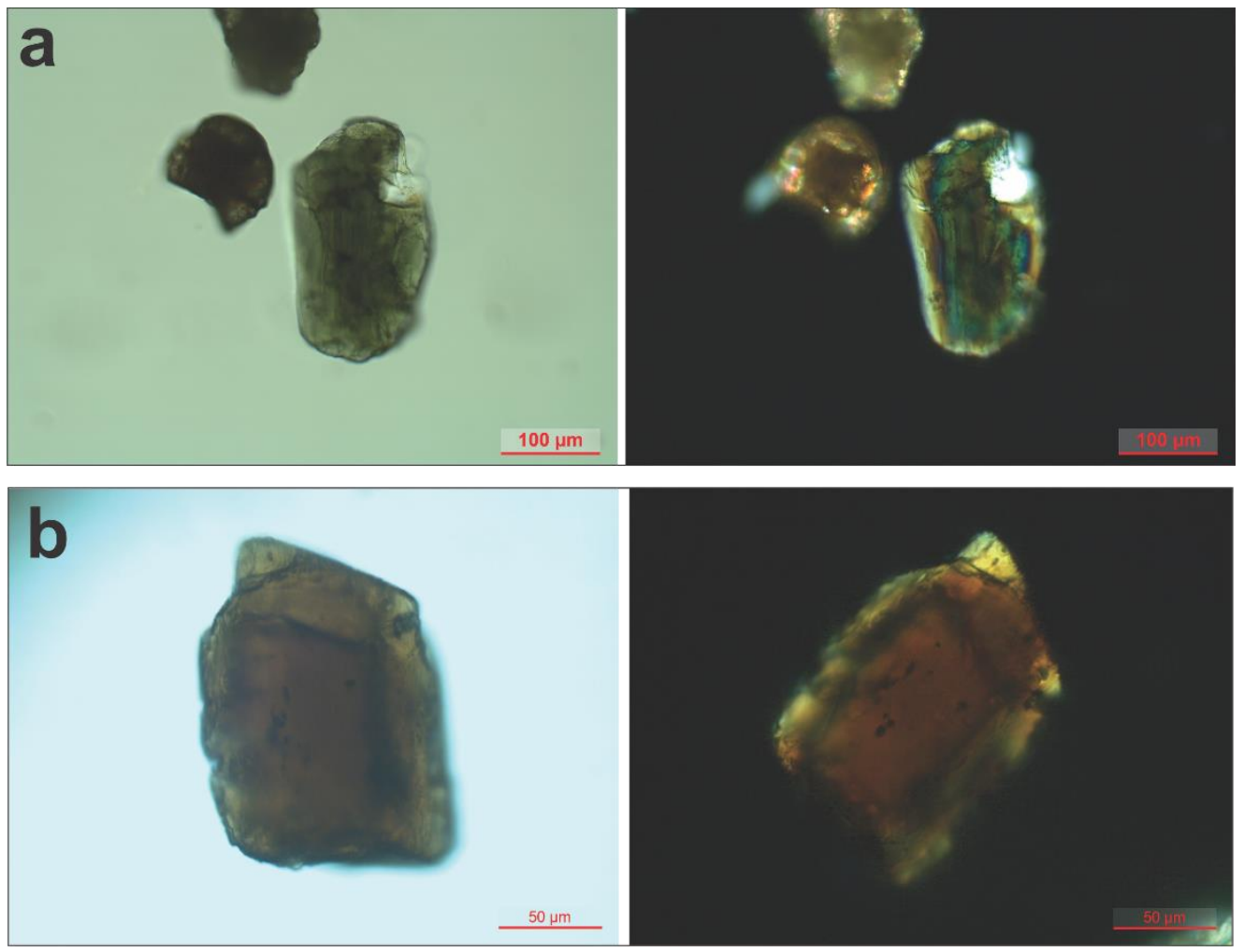

Fig. 6.3 Tipo óptico de hornblenda dominante nos eolianitos: $\mathbf{a}$. continentais; $\mathbf{b}$. insulares. Fotomicrografias em polarizadores paralelos (esquerda) e cruzados (direita). 
Outra diferença composicional entre eolianitos continentais e insulares reside na variabilidade das razões mineralógicas supostamente indicadoras de fonte. Nos eoliantos continentais, a razão ZRi, considerada índice de proveniência por Morton \& Hallsworth (1994, 1999), varia relativamente pouco: em termos de valores médios, entre cerca de $70 \%$, na região de Macapá, PI, e 90\% em Enxu Queimado, RN (Fig. 5.113). Já nos eolianitos insulares, o índice TiAli mostra variações significativas (40 a 98\%) de um afloramento para outro, o que parece surpreendente para um arquipélago tão restrito em área; isto reflete a complexa variabilidade composicional, típica dos magmatismos básico-ultrabásicos e alcalinos. Esta razão mineralógica (Fig. 5.128) apresentou seus maiores valores (98\%) nos eolianitos de Saco de Atalaia, o que se explica pela proximidade de diques e domos de fonolitos afíricos, litologia que exibe altos teores de hornblenda e titanita (Lopes \& Ulbrich 2015); os eolianitos de Enseada da Caieira e Forte de São Joaquim também apresentam valores relativamente elevados de TiAli (entre 52 e 95\%), devido a associação de ambas as áreas com ocorrências de ankaratritos (Ulbrich 1993), melanofelinitos e basanitos (Perlingueiro et al. 2013), litologias estas ricas em titanita (Lopes \& Ulbrich 2015).

\section{2. Área de Acumulação e Elementos Morfológicos}

\subsubsection{Morfologia do sistema eólico e dos corpos de eolianito}

A geomorfologia continental ou insular exerce forte influência sobre a área de acumulação eólica e, por decorrência, sobre a forma, a espessura e a extensão dos depósitos e seus afloramentos. A morfologia em rampa da plataforma continental ( $c f$. item 6.1) tem certa continuidade na área emersa, onde cria cenário possível para o grande desenvolvimento em área de sistemas eólicos costeiros, cujos remanescentes ativos no PI, CE e RN podem ser considerados do tipo 6 ou 7 (Fig. 3.3) na classificação de Giannini et al. (2014). Nestes sistemas ativos, as amplas áreas de acumulação dos sedimentos eólicos favorecem sua livre migração e espalhamento. Desse modo, os depósitos, sobretudo os da planície de deflação, resultam relativamente extensos e delgados (Fig. 6.4), muitas vezes alongados na direção do vento na forma de rastros lineares residuais (Giannini et al. 2014). Esta condição favorece corpos de eolianitos igualmente extensos (até $400 \mathrm{~m}$ ) e pouco espessos (a maioria com menos de $5 \mathrm{~m}$ ), com frequência na forma de cordões alongados na direção do vento em meio à planície deflacionária ativa. A hipótese, por analogia, de que estes corpos alongados correspondam a 
antigos rastros lineares residuais (Espinel-Arias et al. 2015) parece parcimoniosa. No RN, o alongamento desta planície, do sistema como todo e dos corpos de eolianito tem relação com a orientação do vento em relação à linha de costa, conforme já observado nos sistemas eólicos costeiros associados aos eolianitos do PI e CE (Espinel-Arias 2015, Espinel-Arias et al. 2015); o ângulo entre o vento efetivo e a linha de costa determina, em proporcionalidade direta, o desenvolvimento e as dimensões do sistema eólico e de suas feições morfológicas constituintes; assim, em Três Irmãos, onde o ângulo entre vento efetivo e linha de costa é de $30^{\circ}$, a planície deflacionária possui até $3 \mathrm{~km}$ de extensão; em Guajiru, onde este ângulo é de $25^{\circ}$, o comprimento da planície não passa de 2,3 km; e em Enxu Queimado, onde o ângulo é de apenas $12^{\circ}$, o comprimento da planície deflacionária é de até somente $1,5 \mathrm{~km}$ (Fig. 6.5). A Praia do Marco, com ângulo de $30^{\circ}$ e comprimento da planície deflacionária de somente $1,2 \mathrm{~km}$, foge desta regra, provavelmente por se encontrar em erosão atual, o que estaria, em curto prazo, acentuando o ângulo entre a linha de costa e a direção do vento efetivo.
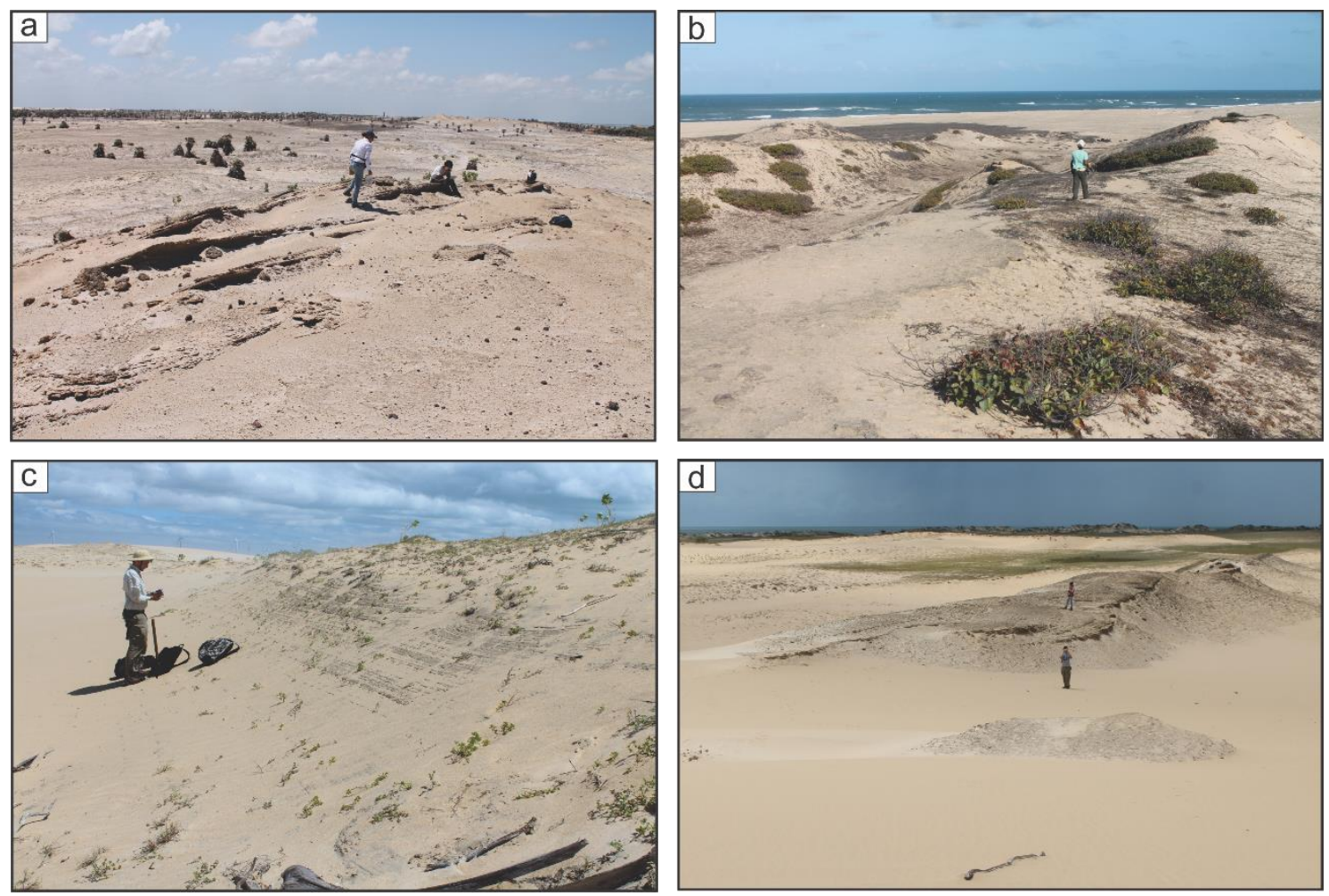

Fig. 6.4. Afloramentos dos eolianitos continentais extensos e pouco espessos nas áreas de: a. Macapá-PI; b. Paracuru-CE (Espinel-Arias 2015); c. Guajiru e d. Enxu Queimado-RN. Em a, b e c, notar a forma de cristas alongadas na direção do vento, indicativas de origem a partir de rastros lineares residuais. 

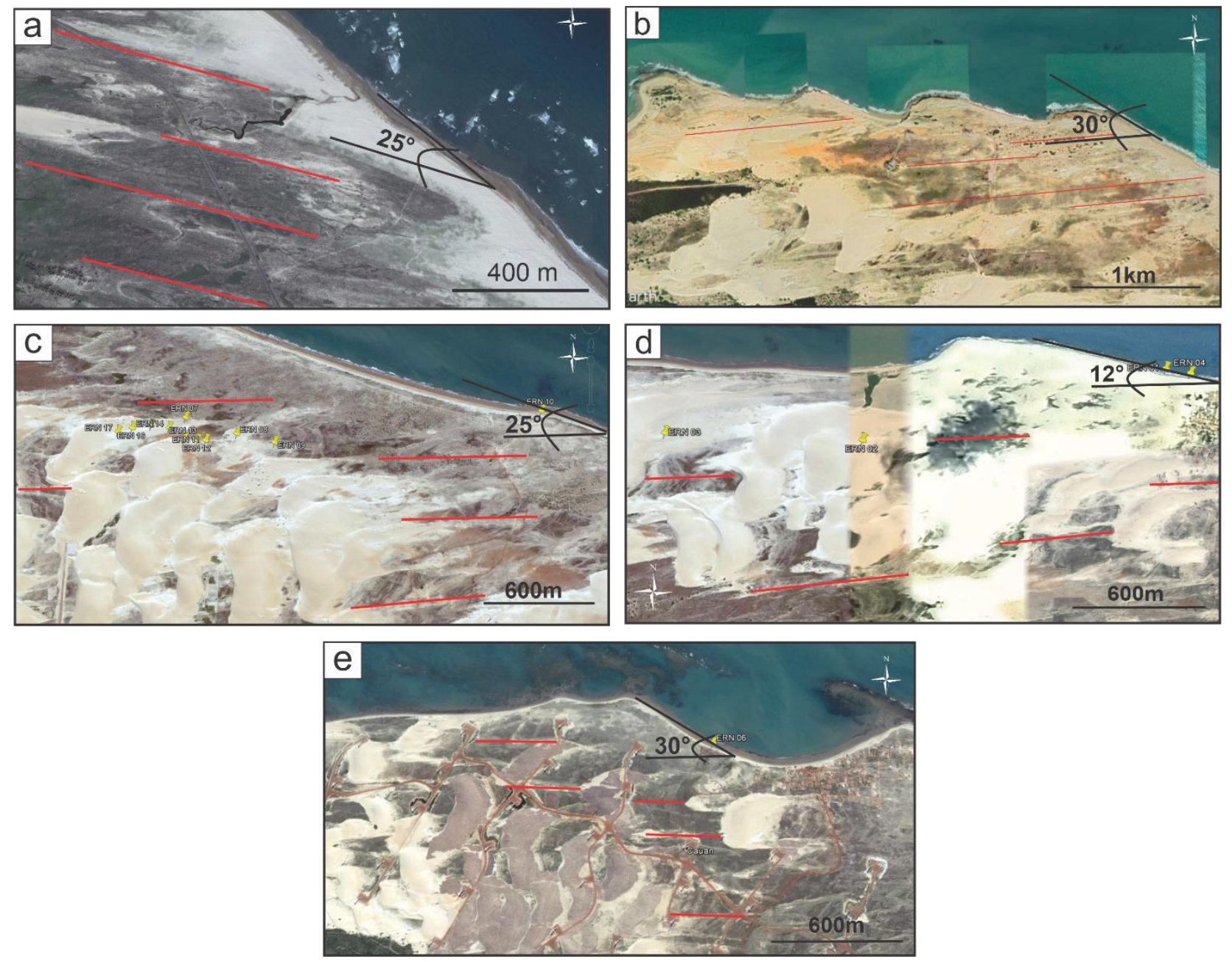

Fig 6.5. Mapa apresentando os ângulos e comprimento das planícies deflacionárias das áreas de: a. Paracuru-CE (Espinel-Arias 2015); b. Três Irmãos - RN; c. Guajiru-RN; d. Enxu Queimado - RN; e. Praia do Marco - RN. 
No AFN, o desenvolvimento limitado de sistemas eólicos ativos faz com que não se disponha, como nas áreas continentais, de bons análogos modernos para os elementos morfológicos que geraram os corpos de eolianitos. Apesar disso, a morfologia do sistema pode ser deduzida a partir das relações espaciais dos depósitos eólicos com o embasamento e da atitude e dimensões de suas estratificações. A irregularidade da morfologia insular, determinada pela topografia acidentada da rocha piroclásticovulcânica, restringiu a extensão das praias e a área de acumulação eólica e dificultou o desenvolvimento de planícies deflacionárias, já que estas foram facilmente entulhadas de areia; não há, portanto, corpos de eolianitos alongados, comparáveis aos dos sistemas eólicos continentais, e a influência do ângulo entre a linha de costa e a direção do vento efetivo no desenvolvimento do sistema não fica evidente; a topografia irregular das rochas piroclástico-vulcânicas devem ter impedido a migração da areia eólica por longa distância, sobretudo nos afloramentos altos, cujo substrato é mais acidentado; isto favoreceu o empilhamento desta areia e, supostamente, a formação de sistemas eólicos de mais elevada razão aporte sedimentar / área de acumulação (tipo 7 ou 8 na classificação de Giannini et al. 2014, Fig 3.3.), portanto com forte presença de elementos morfológicos de campo de dunas (e.g. barcanas e lobos deposicionais) cuja migração gerou as séries métricas de estratificações cruzadas comuns nos eolianitos do arquipélago. Porém, os elementos morfológicos dos sistemas eólicos do AFN são tipicamente pouco definidos ou preservados em superfície, exatamente pela falta de espaço para o seu desenvolvimento, sobretudo nos afloramentos altos. Elementos morfológicos deflacionários como dunas parabólicas e rastros lineares, se existentes (tipo 7), podem ter sido em parte afogados, nos afloramentos baixos, ou estar em zonas acidentadas e com aclives, nos altos, o que dificulta sua preservação ou seu reconhecimento. Nos afloramentos altos, a escalação da areia nos aclives acentuados de barlavento favoreceu a formação de rampas eólicas íngremes, extensas por dezenas de metros, como bem representado nos eolianitos com estratificação mergulhando para SE na Enseada da Caieira. Uma vez alcançado o topo das encostas vulcânicas, formas de leito eólicas migraram por poucas dezenas de metros até colidir com obstáculos, como paredões subverticais de rocha piroclástico-vulcânica. Os afloramentos altos de eolianito resultam assim espessos (até 25m), mas pouco contínuos lateralmente (até 75m) (Fig. 6.6). 

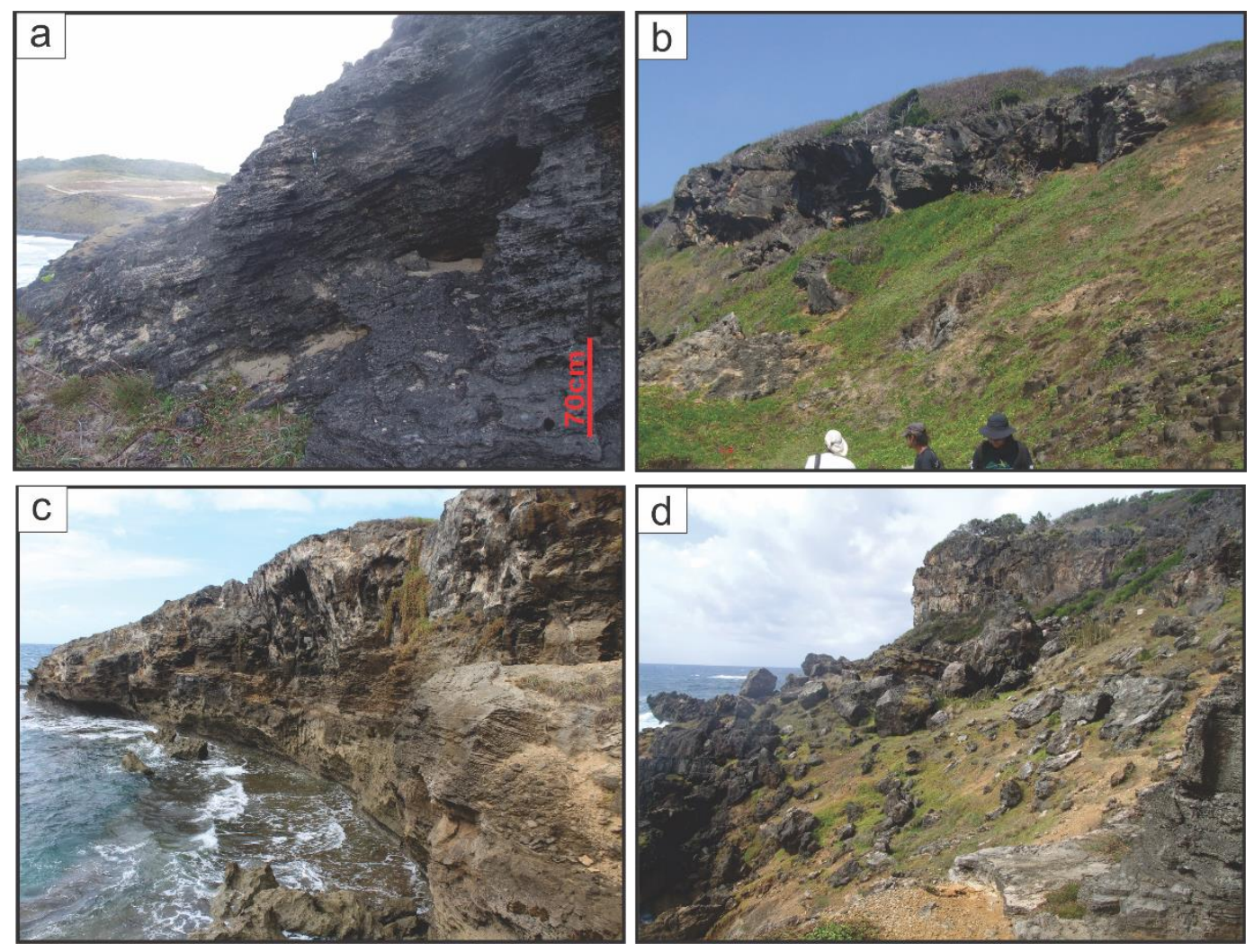

Fig. 6.6. Morfologia e afloramentos dos eolianitos insulares: a. Enseada da Caieira; b. Atalaia; c. Ponta das Caracas; d. Forte de São Joaquim.

\subsubsection{Fácies e associações de fácies nos eolianitos}

As fácies sedimentares dos eolianitos são a materialização de seus processos deposicionais, os quais, porém, dependem da morfologia e extensão dos sistemas eólicos e, por extensão, do espaço de acumulação eólica disponível (Giannini et al. 2014); assim, nos sistemas continentais, com suas amplas planícies de deflação e corpos extensos de eolianitos, a tendência é de predomínio de fácies de estratificação de ângulo baixo, sejam planas (Acb) sejam acanaladas-festonadas (Acbf); enquanto isso, nos insulares, as fácies sedimentares de planície deflacionária, se presentes, estão em zonas acidentadas, e evoluem para fácies de campo de dunas à medida que a areia eólica cavalga as encostas e se empoleira nos nichos do embasamento, levando a um consequente domínio de fácies com estratificações cruzadas de ângulo alto (Aca); o turbilhonamento e desaceleração brusca do fluxo eólico ao encontrar os paredões de rocha ígnea favorece a elevada taxa de decantação de grãos e, consequentemente, a preservação parcial da crista das formas de leito. Este fator explica a frequente presença de fácies com estratificação cruzada sigmoide (Fig. 6.7b), ou mesmo em aparente padrão hummocky (truncamento convexo 
sobre côncavo) nas porções superiores dos eolianitos formados junto a obstáculos de relevo, como é o caso dos afloramentos altos de Ponta das Caracas, Forte de São Joaquim, Atalaia e Enseada da Caieira. Migração contínua de formas de leito eólicas, expressas em séries de cruzadas extensas por dezenas de metros, foi possível apenas nos afloramentos baixos, menos acidentados. A exceção, dentre os afloramentos considerados altos, é Atalaia, onde as séries de cruzadas extensas mergulham contra o caimento de uma rampa suave do embasamento (Fig. 5.30d).

Tanto nos eolianitos continentais como nos insulares, as rizoconcreções observam-se na maioria das fácies, mas em menor abundância naquelas com cruzadas de ângulo alto e/ou sigmoide. Nos eolianitos do AFN, as rizoconcreções são em média mais abundantes no topo dos afloramentos altos, onde, possivelmente, marcam a estabilização do sistema eólico por vegetação. Já nos baixos, elas aparecem também como feição integrante de paleossolos nos eolianitos, como na Ilha Rasa (Fig. 5.25f e g), ou nas fácies associadas, como na Pedra da Bigorna (Fig. 5.26f).
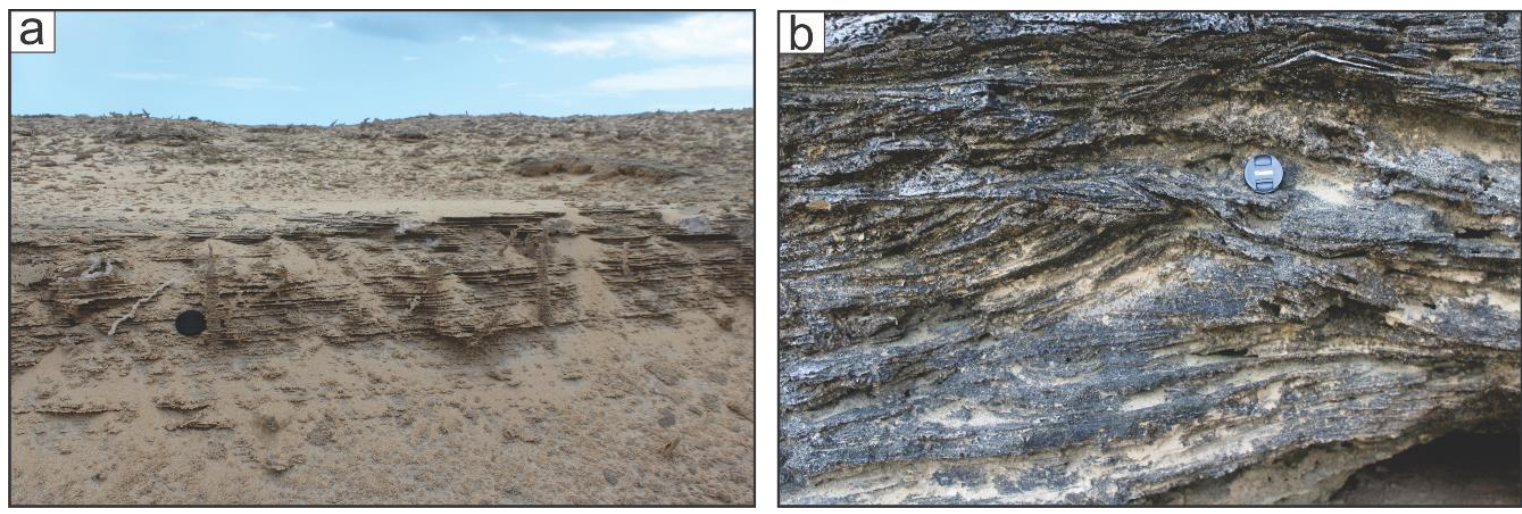

Fig. 6.7. Fácies deposicionais preferencialmente representadas nos eolianitos: a. continentais (Acb em Enxu Queimado - RN); e b. insulares (Acs em Enseada da Caieira - AFN). Em a, notar presença de rizoconcreções.

Quanto à distribuição de azimutes de mergulho de estratificações cruzadas, os eolianitos do RN exibem padrão de dispersão predominantemente bimodal, tendo a direção do vento efetivo como bissetriz entre as duas modas; este mesmo tipo de padrão já fora previamente observado nos eolianitos do PI e CE (Espinel-Arias 2015; EspinelArias et al. 2015; Fig. 6.8). Ele é bem evidenciado, por exemplo, nos histogramas circulares de Três Irmãos e Guajiru (Figs. 5.15, 5.21f, 6.8e, 6.8f), ambos com tendências principais para SE e W; já em Enxu Queimado, o histograma circular obtido, unimodal 
(Figs. $5.23 \mathrm{e}$ e $6.8 \mathrm{~g}$ ) com tendência para $\mathrm{NW}$, pode ser atribuído à pouca representatividade dos dados, isto é, à limitada extensão do afloramento, que contemplaria apenas uma parte do elemento morfológico; o conjunto destes histogramas circulares (Fig. 6.8), as fácies deposicionais dominantemente de baixo ângulo (Acb e Acbf; Quadro 12) e as observações de campo de morfologias de cordões alongados (Fig. 6.4) favorecem a hipótese (enunciada em 6.1) de que a formação dos eolianitos continentais possa ser atribuída à migração de dunas parabólicas, ou aos rastros lineares residuais deixados por essa migração, ao longo de planícies deflacionárias com quilômetros de extensão (Fig. 6.9)

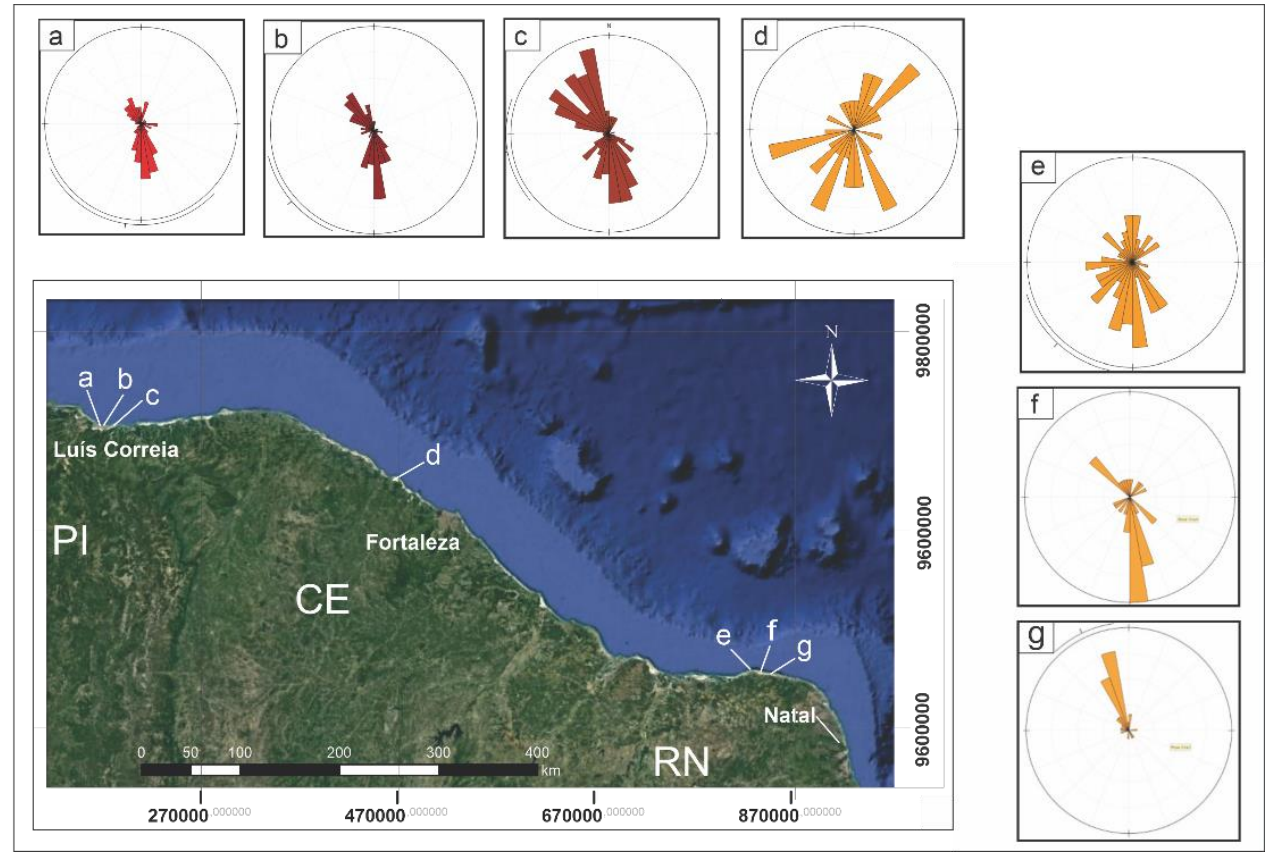

Fig. 6.8. Histogramas circulares de azimutes de mergulho de estratificações cruzadas em eolianitos continentais: a. Itaqui-PI (azimute médio: $188.9^{\circ}$; intervalo de confiança de $95 \%$ : $55^{\circ}$; $\mathrm{n}=87$ );

b. Carnaubinha-PI (azimute médio: $229.2^{\circ}$; intervalo de confiança de $95 \%: 26,8^{\circ} ; \mathrm{n}=120$ ); c. Macapá-PI (azimute médio: $259.9^{\circ}$; intervalo de confiança de $95 \%: 29.9^{\circ}$; n=170); d. Paracuru-CE (azimute médio: $203.7^{\circ}$; intervalo de confiança de $95 \%: 23.9^{\circ} ; \mathrm{n}=36$ ); e. Três Irmãos - RN (azimute médio: $241,6^{\circ}$; intervalo de confiança de $95 \%: 30,3^{\circ} ; \mathrm{n}=135$ ); f. Guajiru-RN (azimute médio: 184º $; \mathrm{n}=30$ ); g. Enxu Queimado-RN (azimute médio: $334,2^{\circ}$; intervalo de confiança de $95 \%: 17,7^{\circ} ; \mathrm{n}=32$ ). 

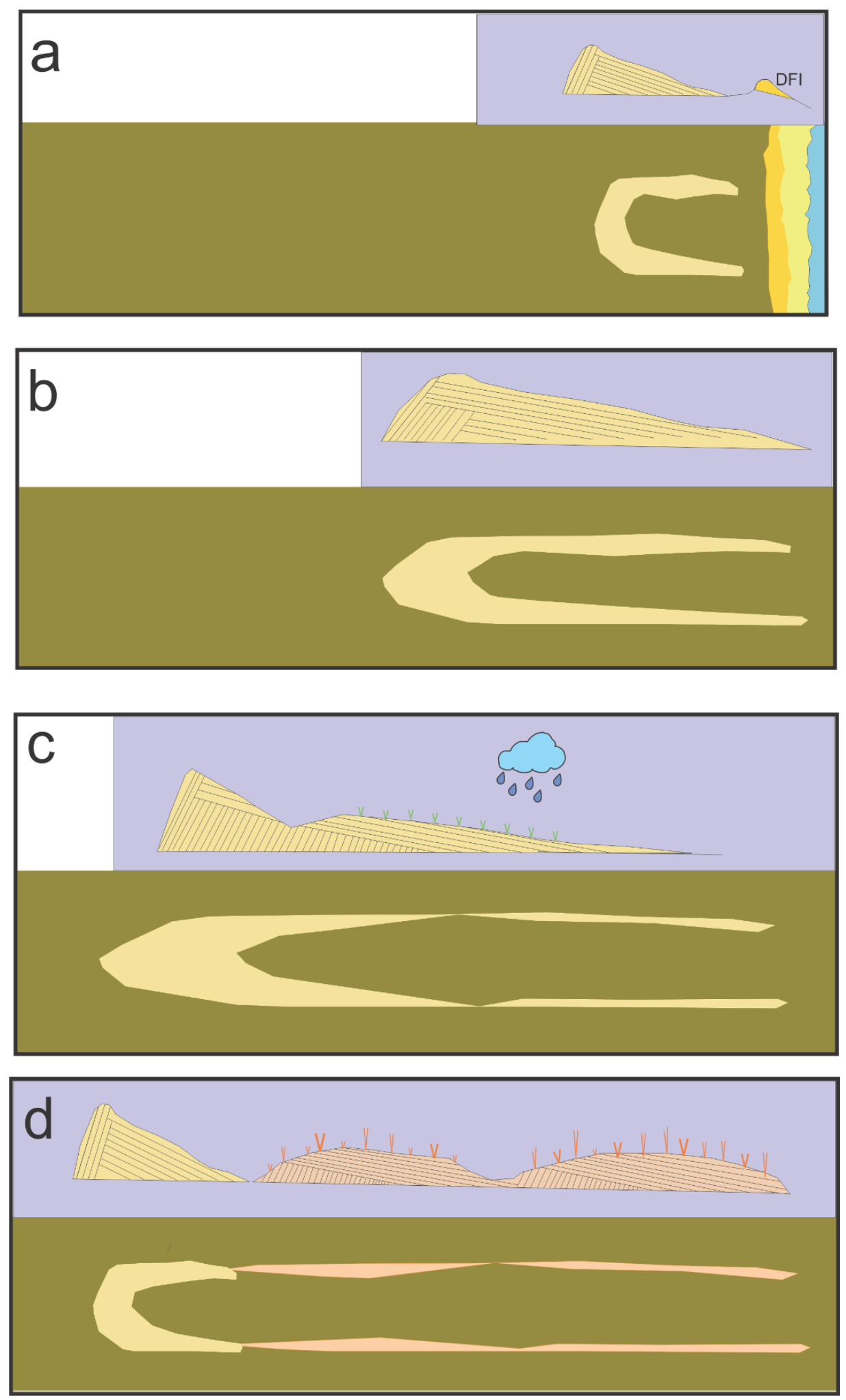

Fig. 6.9. Hipotese da formação de eolianitos associados a migração de dunas parabólicas apresentando no retângulo lilás a imagem de perfil e em marrom a imagen de planta, a. início da deposição eólica na planície deflacionaria formando a duna parabólica, b. migração de dita duna evidenciada nos rastros residuais, c. migração da duna acompanhada de momentos de unidade que favoreceram a estabilização por vegetação e d. a cimentação dos rastros residuais lineares. 
A interpretação dos eolianitos continentais como cordões alongados de braços de parabólicas e rastros lineares é reforçada pelos dados das análises granulométricas (itens 5.4 e 5.5), que indicam elevada concentração de grãos, tanto bioclásticos quanto, principalmente, terrígenos, nas classes mais grossas da distribuição areia, característica coerente com a acentuação dos processos deflacionários durante a estabilização com vegetação destes cordões, evidenciada pelas rizoconcreções (Acbra).

O fato de a moda granulométrica mais comum dos bioclastos dos eolianitos continentais de planície deflacionária (retido em 2,0 , areia média: Figs. 5.44 a 5.47) ser muito mais fina que a moda granulométrica principal da distribuição total (retido em 1,0 $\phi$, areia grossa: Figs. 5.35 a 5.39) é sugestivo de baixa disponibilidade de bioclastos nas classes mais grossas de areia $(<1,5 \phi)$ na área fonte. Sendo a densidade da calcita/aragonita dos bioclastos $\left(2,80\right.$ a $\left.2,95 \mathrm{~g} / \mathrm{cm}^{3}\right)$ ligeiramente mais elevada que a do quartzo e feldspato $\left(2,62\right.$ a 2,70 g/ $\left.\mathrm{cm}^{3}\right)$, esperava-se que os bioclastos cilíndricos de algas vermelhas tivessem equivalente hidráulico 0,1 a $0,2 \phi$ mais fino, à semelhança de minerais pesados com densidade semelhante e hábito alongado, como apatita e turmalina (Rubey, 1933, Rittenhouse et al 1943), e, portanto, que apresentassem moda entre 1,0 e 1,5 ф. Nas lâminas petrográficas dos eolianitos, observa-se de fato que os bioclastos carbonáticos ocorrem em média mais finos que o quartzo, apesar de sua forma alongada (no caso das algas) ou placoide (no caso de moluscos) favorecer a facilidade de transporte (pivotabilidade). Além disso, nos eolianitos do RN, o teor de carbonatos aumenta com a distância à praia (Fig. 5.106), reforçando que o carbonato não se concentra nos sedimentos mais grossos das porções mais proximais. Este resultado permite interpretar que a granulometria relativamente grossa (isto é, frequentemente dominada por areia muito grossa) dos eolianitos de planície de deflação não é determinada pela disponibilidade preferencial de bioclastos nessa fração granulométrica, ainda que estes contribuam, de modo expressivo, na constituição da classe areia média. É pouco provável, portanto, que o domínio de feições deflacionárias nos eolianitos continentais esteja ligado à maior riqueza destas feições em sedimento grosso de composição carbonática. Esse domínio estaria ligado antes a uma questão de facilidade de formação, cimentação e preservação dos elementos morfológicos de planície de deflação que de disponibilidade de sedimento calcário mais grosso. Entre os fatores que favorecem a formação e preservação de eolianitos continentais na planície de deflação pode-se destacar a variação sazonal do freático e da cobertura vegetal nesta porção do sistema (Tsoar et al. 2009), e, 
por decorrência, a constante dissolução e reprecipitação dos bioclastos (Espinel-Árias 2015).

Os dois tipos de afloramentos de eolianitos insulares (baixos versus altos) apresentam associações de fácies distintas, o que lhes permite atribuir diferentes elementos morfológicos. Os afloramentos baixos, localizados em áreas mais próximas ao nível do mar atual, como Ilha Rasa, caracterizam-se pelo domínio de fácies de estratificação cruzada de ângulo alto divergentes, em padrão bimodal (Fig. 5.25h), que, pela grande espessura (métrica), podem ser atribuídas às paredes externas de blowouts, dunas parabólicas ou lobos deposicionais parabólicos (neste caso, de frente de campo de dunas); a ausência de afloramentos piroclástico-vulcânicos próximos é compatível com a disponibilidade de espaço para livre migração dessas formas de leito eólicas, com deposição ao longo de áreas extensas. Os afloramentos altos, que alcançam até $30 \mathrm{~m}$ acima do nível do mar atual e ocorrem junto e/ou sobre rochas piroclástico-vulcânicas de topografia acidentada, subdividem-se em duas associações de fácies distintas, cada qual com um padrão azimutal de estratificações mais característico; a primeira associação de fácies, Apa, Apbra, Acs e Amra, encontra-se na área de Enseada da Caieira; nesta associação, a fácies deposicional Apa representa o cavalgamento do flanco barlavento (lado sudeste) do afloramento piroclástico-vulcânico por rampas de areias eólicas, e as fácies Apbra e Amra, a estabilização por vegetação destas areias cavalgantes, empilhadas em áreas de menor declive ou armadilhadas em reentrâncias; já a fácies Acs sugere o cavalgamento e soterramento rápido das formas de leito eólicas onduladas, junto a obstáculos, como paredes de rocha (Quadro 12); as três fácies estratificadas desta associação mostram padrões azimutais similares (Fig. 5.29), que, integrados (Fig. 6.10), evidenciam tendência unimodal para SE-S; este resultado reforça a hipótese de rampa eólica no flanco barlavento das elevações de rocha ígnea, intensamente exposto aos ventos alísios. A segunda associação de fácies, encontrada nos afloramentos altos de Atalaia, Ponta das Caracas e Forte de São Joaquim, caracteriza-se por séries de espessuras métricas de estratificações cruzadas planas e acanaladas, dominantemente de alto ângulo (Aca, Acf), ou sigmoides (Acs) (Fig. 6.11), com padrão azimutal ora unimodal, com predominância de rumo W (Figs. 5.32d e 6.11b), ora bimodal SW e NE (fácies Acf: Figs. 5.33h, 6.11c, 6.11d). Esta associação é atribuída ao cavalgamento dos morros de rocha ígnea por campos de dunas (Quadro 12), com formação de lobos deposicionais parabólicos (Aca, Acs) ou mesmo de barcanas e barcanoides (Acf). 

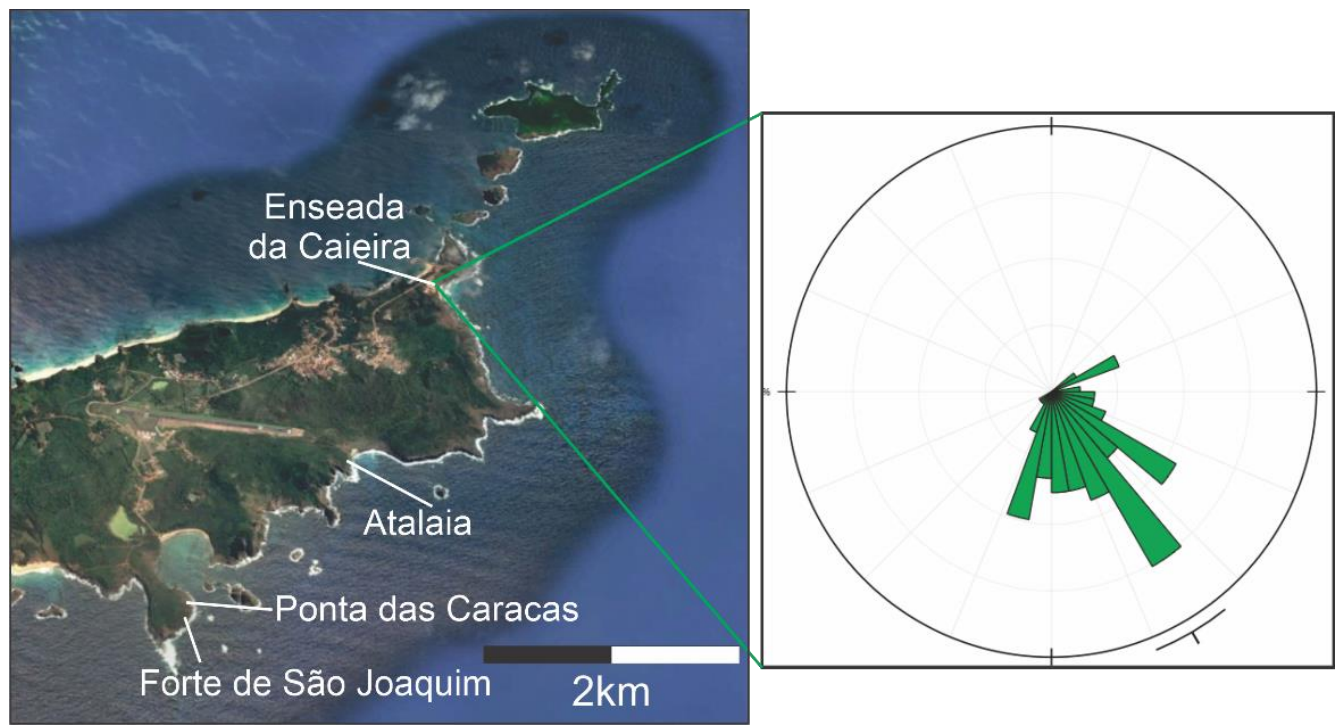

Fig 6.10. Histograma circular de azimutes de mergulho geral das estratificações cruzadas nos eolianitos da região de Enseada da Caieira-AFN, com padrão grosso modo unimodal, com moda principal SE (azimute médio: $149.6^{\circ}$; intervalo de confiança de $95 \%: 8,3^{\circ} ; \mathrm{n}=92$ ).
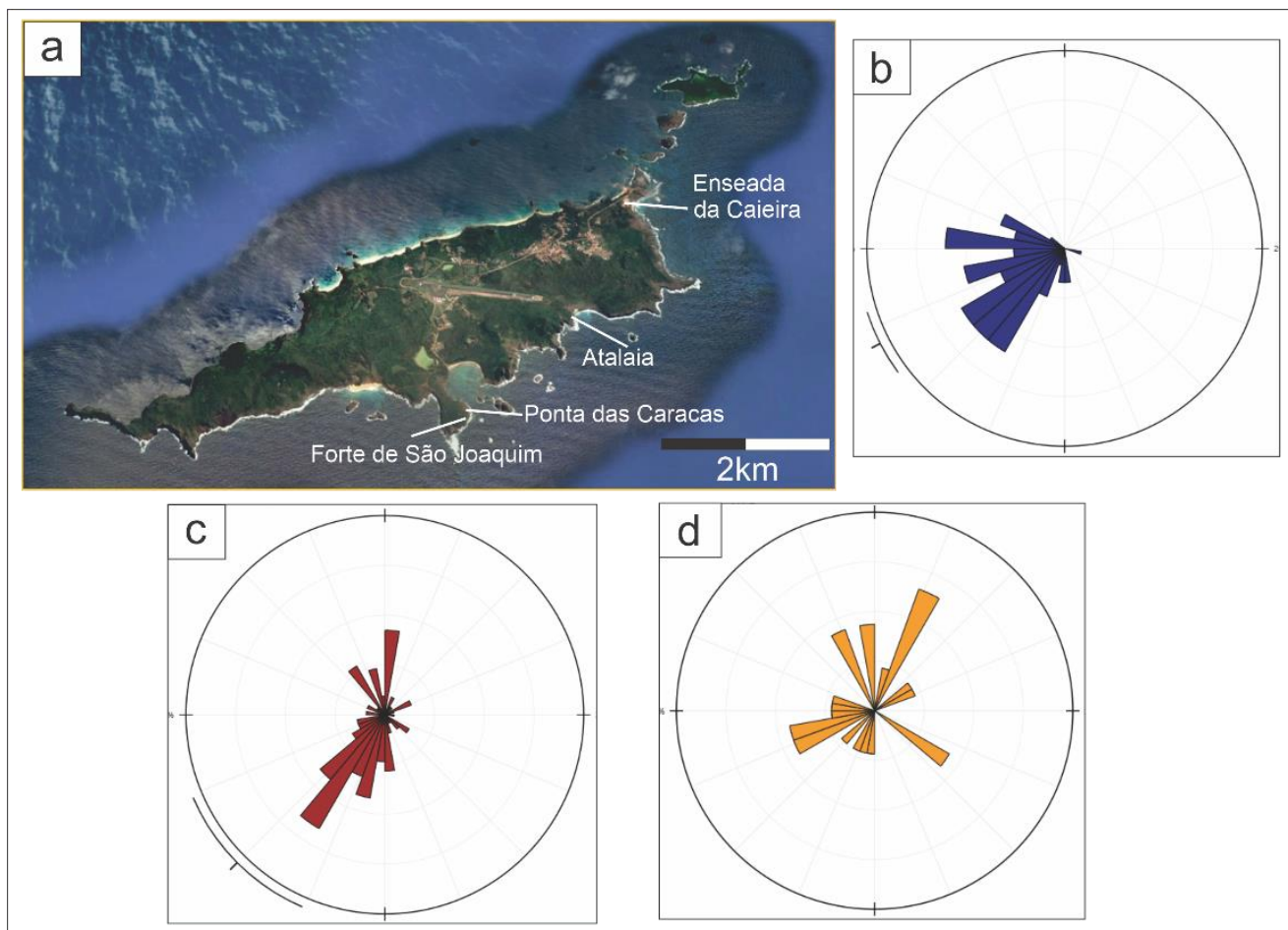

Fig 6.11. Histogramas circulares e rumos de estratificação das fácies presentes nos eolianitos altos; a. mapa de localização; b. fácies Aca (azimute médio: $242.7^{\circ}$; intervalo de confiança de 95\%: 9.4ㅜ $\mathrm{n}=58$ ), presente nas áreas de Atalaia e Ponta das Caracas; c. fácies Acr (azimute médio: $225^{\circ}$; intervalo de confiança de $95 \%: 21.7^{\circ}$; $\mathrm{n}=106$ ), presente nas áreas de Ponta das Caracas e Forte de São Joaquim; d. fácies Acs (azimute médio: $300.2^{\circ}$; n=23), presente nas áreas de Atalaia, Ponta das Caracas e Forte de São Joaquim. 
Quadro 12. Interpretação das fácies deposicionais dos eolianitos

\begin{tabular}{|c|c|c|c|}
\hline $\begin{array}{c}\text { Código } \\
\text { de fácies }\end{array}$ & $\begin{array}{l}\text { Descrição } \\
\text { resumida da } \\
\text { fácies }\end{array}$ & $\begin{array}{l}\text { Associação de } \\
\text { elementos } \\
\text { morfológicos }\end{array}$ & Processos deposicionais e elementos morfológicos \\
\hline $\mathbf{A c}_{\mathbf{a}}$ & $\begin{array}{l}\text { Arenito com } \\
\text { estratificação } \\
\text { cruzada plana de } \\
\text { ângulo alto }\end{array}$ & $\begin{array}{l}\text { Planície } \\
\text { deflacionária } \\
\text { ou campo de } \\
\quad \text { dunas }\end{array}$ & $\begin{array}{l}\text { Queda e fluxo de grãos nos flancos externos e/ou na frente } \\
\text { de blowout, duna parabólica ou lobo deposicional } \\
\text { parabólico }\end{array}$ \\
\hline $\mathbf{A p}_{\mathbf{a}}$ & $\begin{array}{c}\text { Arenito com } \\
\text { estratificação } \\
\text { plana-paralela com } \\
\text { ângulo de } \\
\text { caimento alto para } \\
\text { barlavento } \\
\end{array}$ & Rampa eólica & $\begin{array}{l}\text { Cavalgamento do flanco barlavento de obstáculo do } \\
\text { embasamento por areia eólica }\end{array}$ \\
\hline $\mathbf{A p} \mathbf{p}_{\mathbf{b}} \mathbf{r}_{\mathbf{a}}$ & $\begin{array}{c}\text { Arenito com } \\
\text { estratificação } \\
\text { plano-paralela com } \\
\text { ângulo baixo para } \\
\text { barlavento e } \\
\text { rizoconcreções } \\
\text { abundantes }\end{array}$ & Rampa eólica & $\begin{array}{l}\text { Estabilização por vegetação de areia eólica cavalgando o } \\
\text { flanco barlavento de obstáculo do embasamento }\end{array}$ \\
\hline $\mathbf{A c}_{\mathbf{b}}$ & $\begin{array}{l}\text { Areia ou arenito } \\
\text { com estratificação } \\
\text { cruzada plana de } \\
\text { ângulo baixo }\end{array}$ & $\begin{array}{l}\text { Praia-duna ou } \\
\text { planície } \\
\text { deflacionária }\end{array}$ & $\begin{array}{c}\text { Aprisionamento de grãos alternado com deflação no topo } \\
\text { aplainado de duna frontal, rastro linear residual ou } \\
\text { retrocordão }\end{array}$ \\
\hline Acbf & $\begin{array}{c}\text { Areia com } \\
\text { estratificação } \\
\text { cruzada acanalada } \\
\text { / festonada de } \\
\text { ângulo baixo }\end{array}$ & $\begin{array}{l}\text { Planície } \\
\text { deflacionária }\end{array}$ & $\begin{array}{c}\text { Formação de blowouts sobre retrocordões e rastros lineares } \\
\text { residuais }\end{array}$ \\
\hline $\mathrm{Ac}_{\mathrm{f}}$ & $\begin{array}{l}\text { Arenito com } \\
\text { estratificação } \\
\text { cruzada acanalada } \\
\text { / festonada de } \\
\text { ângulo alto }\end{array}$ & $\begin{array}{l}\text { Campo de } \\
\text { dunas } \\
\text { empoleiradas }\end{array}$ & $\begin{array}{c}\text { Avanço de barcanas, barcanoides e lobos deposicionais } \\
\text { parabólicos por sobre elevações }\end{array}$ \\
\hline Acs & $\begin{array}{c}\text { Arenito com } \\
\text { estratificação } \\
\text { sigmoide, às vezes } \\
\text { similar a } \\
\text { hummocky }\end{array}$ & $\begin{array}{l}\text { Campo de } \\
\text { dunas } \\
\text { empoleiradas }\end{array}$ & $\begin{array}{c}\text { Avanço de lobos deposicionais cavalgantes, interrompido } \\
\text { pela presença de paredões do embasamento, com } \\
\text { soterramento rápido de formas onduladas }\end{array}$ \\
\hline $\mathbf{A c}_{\mathbf{b}} \mathbf{r}_{\mathbf{a}}$ & $\begin{array}{c}\text { Areia ou arenito } \\
\text { com estratificação } \\
\text { plano-paralela ou } \\
\text { cruzada de ângulo } \\
\text { baixo e } \\
\text { rizoconcreções } \\
\text { abundantes }\end{array}$ & $\begin{array}{c}\text { Planície } \\
\text { deflacionária }\end{array}$ & $\begin{array}{c}\text { Estabilização por vegetação do topo aplainado de rastro } \\
\text { linear residual }\end{array}$ \\
\hline $\mathrm{Ac}_{\mathrm{a}} \mathbf{r}$ & $\begin{array}{c}\text { Arenito com } \\
\text { estratificação } \\
\text { cruzada plana de } \\
\text { ângulo alto com } \\
\text { rizoconcreções }\end{array}$ & $\begin{array}{l}\text { Campo de } \\
\text { dunas }\end{array}$ & $\begin{array}{c}\text { Queda e fluxo de grãos no flanco externo de lobo } \\
\text { deposicional parabólico, seguidos pela estabilização por } \\
\text { vegetação }\end{array}$ \\
\hline $\mathbf{A m r}_{\mathbf{a}}$ & $\begin{array}{l}\text { Areia maciça com } \\
\text { rizoconcreções } \\
\text { abundantes }\end{array}$ & $\begin{array}{l}\text { Campo de } \\
\text { dunas } \\
\text { empoleiradas }\end{array}$ & Estabilização por vegetação de areia eólica cavalgante \\
\hline
\end{tabular}


Outra diferença entre eolianitos continentais e insulares está relacionada com os minerais pesados e refere-se à variabilidade dos índices $\mathrm{ABi}$ com suposto significado de seleção hidro-aerodinâmica pelo transporte sedimentar, como ZTi e HbAui; os eolianitos continentais, por se distribuírem por áreas mais amplas, apresentam variações mais representativas que os insulares nesses índices mineralógicos (e.g. Fig. 5.116, 5.127). Neles, a razão ZTi (indicadora inversa de seleção por transporte) apresentou valores menores nos afloramentos de Macapá (PI), e maiores nos de Enxu Queimado (RN), o que sugere transporte mais curto nesta última área (Fig. 5.116); este resultado é coerente com a maior extensão no rumo do vento do sistema eólico costeiro no Piauí $(7,5 \mathrm{~km}$ em Macapá contra 1,5 km em Enxu Queimado).

Nos eolianitos insulares, a razão HbAui (indicadora direta de seleção por transporte sedimentar) apresentou seus valores mais elevados (entre 40 e 80\%) nos afloramentos de Saco de Atalaia e Forte de São Joaquim (Fig. 5.127), com fácies de estratificação cruzada sigmoide (Acs) e localizados em cotas mais altas, o que indica que seus sedimentos sofreram intensa seleção aerodinâmica no processo de cavalgamento das rochas vulcânico-piroclásticas. Efeito semelhante, enriquecimento em minerais pesados mais leves nas porções mais elevadas de paleodunas cavalgantes, já havia sido registrado no Cabo de Santa Maria (SC), por Martinho et al. (2001).

\subsubsection{Fácies e associações de fácies nos depósitos associados aos eolianitos}

As fácies deposicionais associadas auxiliam na interpretação geral do contexto ambiental e de NRM, bem como da variação de linha de costa, durante a formação das dunas mistas ou carbonáticas que deram origem aos eolianitos.

As principais fácies associadas aos eolianitos continentais são os beach rocks de Enxu Queimado e Três Irmãos. Em Enxu Queimado, as séries superpostas de estratificações plano-paralelas da fácies Apb exibem azimutes de mergulho opostos (Fig. 5.22d); a inferior, com inclinação para o mar, corresponde aparentemente ao leito plano da zona de espraiamento, enquanto a superior, com mergulho para o continente, representa a berma. Tem-se, assim, o que parece ser um empilhamento regressivo, com fácies de antepraia sob fácies de berma e esta sob eolianitos. O contato entre essas duas 
séries da fácies Apb encontra-se 2,4 m acima da zona de espraiamento de preamar atual, a qual pode ser considerada sua zona homóloga. Desse modo, esta diferença de $2,4 \mathrm{~m}$ é uma estimativa do paleonível marinho na época de deposição dos sedimentos do beach rock.

Os beach rocks de Três Irmãos apresentam duas fácies: a Apb, com estruturas deformacionais sugestivas de fluidificação (Figs. 5.15h e 5.17g; Quadro 13); e a Apbz, contendo o fóssil-traço Thalassinoides. Embora considerado "facies-crossing", este icnogênero, produzido sobretudo por crustáceos, é mais típico de águas marinhas rasas (e.g. Frey et al. 1984, Monaco et al. 2007), formando-se especialmente em sedimentos saturados em água, sob condições energéticas oxidantes (Ekdale 1992, Monaco et al. 2007). Segundo Buatois \& Mángano (2011), os mesmos crustáceos (e.g. Callichirus) que constroem os tubos de Ophiomorpha em substrato arenoso móvel são capazes de produzir Thalassinoides em fundo arenoso mais estável. A presença de Callichirus major é comum em fundos arenosos dominados por areia fina da zona de espraiamento de baixamar, na costa brasileira entre Pernambuco e centro-sul de Santa Catarina (Rodrigues et al. 1983, Borzone \& Souza 1996, Botter-Carvalho et al. 2002); e o icnogênero Ophiomorpha, como provável produto da ação desta espécie, tem sido identificado no registro quaternário desta região em depósitos com essa granulometria (e.g. Lessa et al. 2000, Angulo et al. 2009, Giannini et al. 2009; Guedes et al. 2011, 2017); sendo assim, não pode ser descartada a hipótese de que, em areias mais grossas e, portanto, menos móveis, Ophiomorpha seja substituído em fácies similares por Thalassinoides. Desse modo, a fácies Apbz de Três Irmãos é aqui interpretada como depósito de antepraia, coberto concordantemente, também em sucessão regressiva, pelos depósitos eólicos bioclásticos que vieram depois a se consolidar como eolianitos. Os depósitos brechoides intraclásticos da fácies Apb sob Apbz podem indicar retrabalhamento rápido de superfícies submetidas à litificação precoce (Quadro 13). O topo da fácies Apbz encontra-se entre 3,8 e 4,3 m acima do nível de espraiamento de maré média atual, o que pode ser considerado uma estimativa grosseira do paleonível marinho, mais alto que o atual, em que esta fácies se formou.

Já nos eolianitos insulares, as principais fácies associadas encontram-se no afloramento baixo da Pedra da Bigorna e no afloramento alto da Enseada da Caieira, próximo à praia de Tamandaré. Na Pedra da Bigorna, a sucessão de fácies Rgn, Ap e Am 
ocorre sob os eolianitos; na fácies Rgn, os clastos rudáceos imbricados e a presença de sucessões com gradação apontam para a sua deposição em meio a cascalheiras praiais, as quais teriam sido recobertas por areias com seixos de zona de espraiamento, correspondentes à fácies Ap; esta sucessão, bem como as gradações verticais observadas na fácies Rgn, devem ter sido decorrentes de mudanças graduais na distribuição das granulações, longitudinais e transversais à linha de costa, as quais são comuns em praias com cascalho em geral (Buscombe \& Masselink 2006) e podem ser observadas atualmente em várias praias da ilha principal (Figs. 5.9 e 5.10); o desaparecimento gradual das estratificações plano-paralelas na passagem da fácies Ap para a Am e a presença de concreções permitem interpretar Am como um paleossolo formado pela exposição subaérea das fácies praiais, e sobre o qual se depositaram os sedimentos bioclásticos eólicos da fácies de eolianito Aca. A interpretação dada aqui para a sucessão de fácies associadas Ap-Am é compatível com deposição em estágio de nível do mar pouco mais alto que o atual, seguido por abandono da sedimentação subaquosa e formação do solo; a idade ${ }^{14} \mathrm{C}$ de rocha total do eolianito sobre o paleossolo $(11,4-11,2 \mathrm{ka}$ AP) pode ser representativa da cimentação ( $c f$. item 5.6.2, Fig. 5.53) e, desse modo, informa apenas a idade mínima de deposição; a sucessão Ap-Am deve pertencer a um NRM alto anterior a essa idade, por exemplo o do MIS 3 ou o do MIS 5; considerando que se trata de NRM alto similar ou superior ao atual, uma idade MIS 5 para Ap-Am é mais provável.

$\mathrm{Na}$ Enseada da Caieira, a fácies associada, de arenito maciço com gastrópodes inteiros (Amg), contém também fósseis de caranguejo e gastrópodes das espécies Hyperaulax ramagei e Hyperaulax ridleyi (Smith, 1890), os quais são endêmicos do arquipélago (Salgado e Coelho 2003; Gomes et al. 2006; Simone 2006; Serafini et al. 2010; Angulo et al. 2013a; Freitas et al. 2020) e indicam ambientes terrestres. O aspecto maciço dos depósitos, associado à presença abundante destes gastrópodes, apontam para taxa de deposição eólica baixa, com obliteração das estratificações por pedogênese e/ou bioturbação. Em vista destas indicações, pode-se interpretar esta fácies como lençóis de areia; as idades entre 17,6 e 9,3 cal AP (Tabela 4, amostra EFN 07) obtidas nesses depósitos são de cimentação. A idade máxima do intervalo coincide com época de NRM muito mais baixo que o atual e com linha de costa mais distante. Na costa de Santa Catarina, Rodrigues et al. (2020) demonstram a formação de lençóis de areia eólica desde o UMG até a época da máxima inundação marinha do Holoceno, condicionada pela menor umidade devido ao distanciamento da costa e pelo consequente desenvolvimento 
de vegetação mais esparsa, o que favorece o trânsito (by-pass) de sedimentos eólicos, típico de lençóis de areia (Schwan 1988).

Quadro 13. Interpretação das fácies deposicionais associadas aos eolianitos.

\begin{tabular}{|c|c|c|c|c|}
\hline $\begin{array}{l}\text { Código } \\
\text { de } \\
\text { fácies }\end{array}$ & Descrição resumida da fácies & $\begin{array}{l}\text { Elementos } \\
\text { morfológicos }\end{array}$ & $\begin{array}{c}\text { Processos } \\
\text { deposicionais }\end{array}$ & $\begin{array}{l}\text { Área de } \\
\text { ocorrência }\end{array}$ \\
\hline Rgn & $\begin{array}{l}\text { Rudito clasto-suportado, } \\
\text { possivelmente imbricado, de matriz } \\
\text { e/ou cimento carbonático, } \\
\text { formando sucessões com gradação } \\
\text { normal mal definida (Fig. 5.14a) }\end{array}$ & $\begin{array}{l}\text { Antepraia de } \\
\text { cascalho }\end{array}$ & $\begin{array}{l}\text { Corrente pulsátil (saca } \\
\text { e ressaca das ondas) }\end{array}$ & $\begin{array}{l}\text { Pedra da } \\
\text { Bigorna } \\
(\mathrm{AFN})\end{array}$ \\
\hline Ap & $\begin{array}{c}\text { Calciarenito rico }(>20 \% \text { em } \\
\text { volume) em clastos rudáceos de } \\
\text { líticos ígneos (até } 8 \mathrm{~cm} \text { de eixo } \\
\text { maior) frequentemente oblatos sub- } \\
\text { horizontais, com estratificação } \\
\text { plano-paralela de leve caimento } \\
\text { para SW (Fig. } 5.14 \mathrm{~b} \text { ) }\end{array}$ & $\begin{array}{l}\text { Antepraia de } \\
\text { areia e } \\
\text { cascalho }\end{array}$ & $\begin{array}{l}\text { Corrente pulsátil } \\
\text { atuante sobre leito } \\
\text { plano de regime de } \\
\text { fluxo superior, com } \\
\text { mudanças graduais na } \\
\text { distribuição espacial } \\
\text { das granulações }\end{array}$ & $\begin{array}{l}\text { Pedra da } \\
\text { Bigorna } \\
(\text { AFN })\end{array}$ \\
\hline Am & $\begin{array}{l}\text { Calciarenito, arenito ou areia, } \\
\text { médios a finos, maciços, às vezes } \\
\text { com clastos imbricados ou } \\
\text { concreções (Fig. } 5.14 \mathrm{c} \text { ) }\end{array}$ & $\begin{array}{l}\text { Paleossolo } \\
\text { sobre praia } \\
\text { abandonada }\end{array}$ & $\begin{array}{l}\text { Exposição subaérea } \\
\text { com hiato sedimentar }\end{array}$ & $\begin{array}{c}\text { Pedra da } \\
\text { Bigorna } \\
\text { (AFN), Santa } \\
\text { Isabel (RN) }\end{array}$ \\
\hline Amg & $\begin{array}{l}\text { Arenito ou areia, médios a finos, } \\
\text { maciços, com gastrópodes inteiros }\end{array}$ & $\begin{array}{l}\text { Lençol de } \\
\text { areia eólica }\end{array}$ & $\begin{array}{l}\text { Transporte eólico sob } \\
\text { elevado by-pass, com } \\
\text { colonização por } \\
\text { gastrópodes }\end{array}$ & Caieira (AFN) \\
\hline Apb & $\begin{array}{l}\text { Arenito muito grosso a médio com } \\
\text { séries cuneiformes decimétricas de } \\
\text { laminação plano-paralela e } \\
\text { tendência granodecrescente } \\
\text { ascendente, contendo bioclastos, } \\
\text { rudáceos (beach-rock; Fig. } 5.14 \mathrm{~d} \text { ) e } \\
\text { estruturas deformacionais eventuais }\end{array}$ & $\begin{array}{l}\text { Berma e/ou } \\
\text { antepraia }\end{array}$ & $\begin{array}{l}\text { Corrente pulsátil } \\
\text { atuante sobre leito } \\
\text { plano de regime de } \\
\text { fluxo superior, } \\
\text { inclusive spillover }\end{array}$ & $\begin{array}{c}\text { Caieira } \\
\text { (AFN), Enxu } \\
\text { Queimado } \\
\text { (RN) e Três } \\
\text { Irmãos (RN) }\end{array}$ \\
\hline Apbz & $\begin{array}{l}\text { Arenito muito grosso a médio com } \\
\text { séries cuneiformes decimétricas de } \\
\text { laminação plano-paralela e } \\
\text { tendência granodecrescente } \\
\text { ascendente, contendo bioclastos e } \\
\text { rudáceos (beach-rock), com } \\
\text { presença de zooturbações } \\
\text { abundantes (Fig. 5.14e) e estruturas } \\
\text { de sobrecarga na base }\end{array}$ & Antepraia & $\begin{array}{l}\text { Corrente pulsátil } \\
\text { atuante sobre leito } \\
\text { plano de regime de } \\
\text { fluxo superior na zona } \\
\text { de espraiamento de } \\
\text { baixamar, com } \\
\text { colonização por } \\
\text { crustáceos } \\
\text { (Callichirus?) }\end{array}$ & $\begin{array}{l}\text { Três Irmãos } \\
\text { (RN) }\end{array}$ \\
\hline
\end{tabular}

\subsection{Petrografia e Efeitos da Diagênese nos Eolianitos}

Ao microscópio, um dos pontos em comum entre eolianitos continentais e insulares é o domínio de peloides e algas vermelhas dentre os componentes clásticos intrabacinais ( $c f$. item 6.1). Como os peloides apresentam formas e dimensões similares às das algas vermelhas, a razão Pe/Al foi, analisada, no item 5.7, para testar a hipótese de origem pós-deposicional para a estrutura interna maciça característica dos peloides. Esta 
razão apresenta valores médios por área geográfica mais elevados nos eolianitos insulares (74 e $82 \%$ ) de que nos continentais (50 e 75\%) (Fig. 6.12). Considerando que os eolianitos continentais são dominados por idades holocenas e os insulares por idades pleistocenas e admitido que a história diagenética mais longa dos eolianitos pleistocenos favoreça o neomorfismo do carbonato, a maior incidência de peloides no AFN (Fig. 6.13), robustece a suspeita de que esses peloides correspondam, na verdade, a algas vermelhas que tiveram suas estruturas internas diagnósticas apagadas por recristalização (neomorfismo) ou substituição por cimentos móldicos; uma hipótese alternativa é a de que os peloides sejam algas intensamente micritizadas, isto é, com envelope micrítico muito espesso; visto que o envelope micrítico é uma feição eodiagenética desenvolvida por bactérias endolíticas na zona fótica (Tucker \& Wright 1990, Scholle \& Ulmer-Scholle 2003, Flügel 2004), neste caso a maior incidência de peloides no AFN estaria ligada à zona fótica mais extensa e espessa devido à maior limpidez das águas.

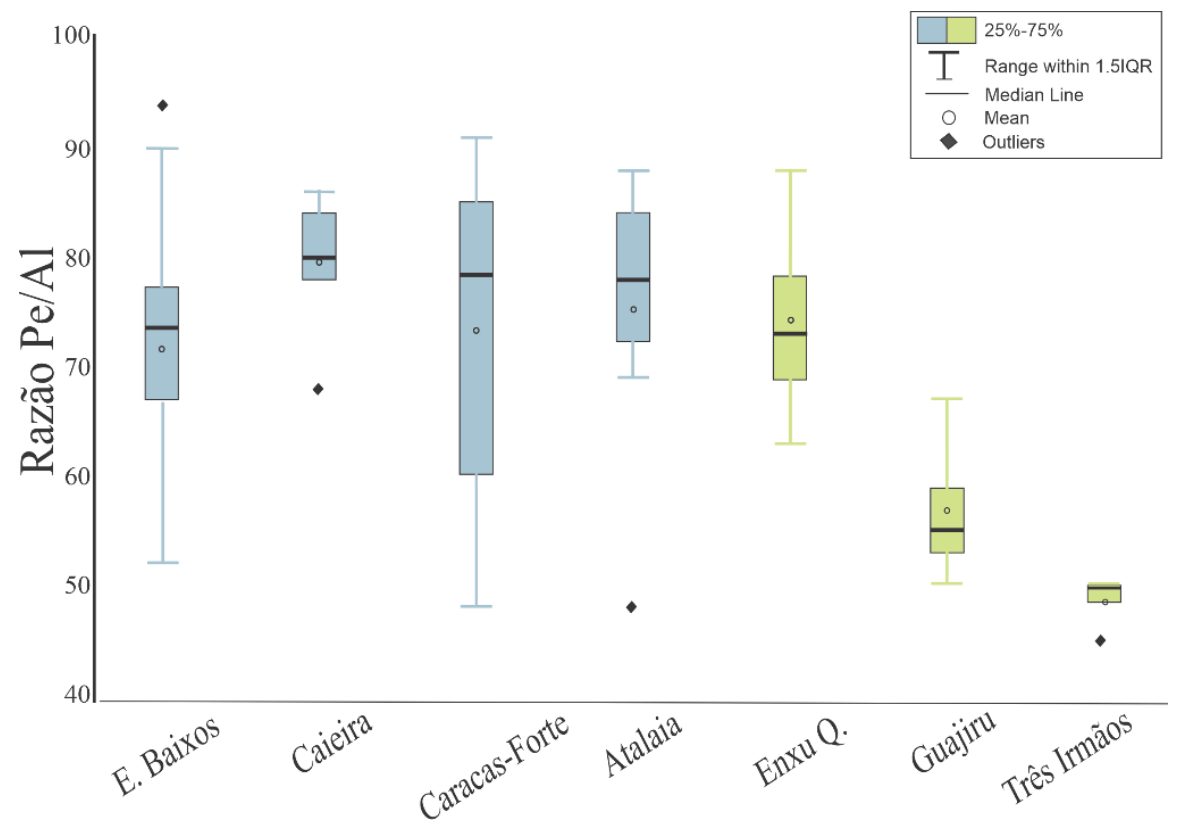

Fig 6.12. Boxplot da razão Pe/Al nos eolianitos insulares (azul) e continentais (verde). 


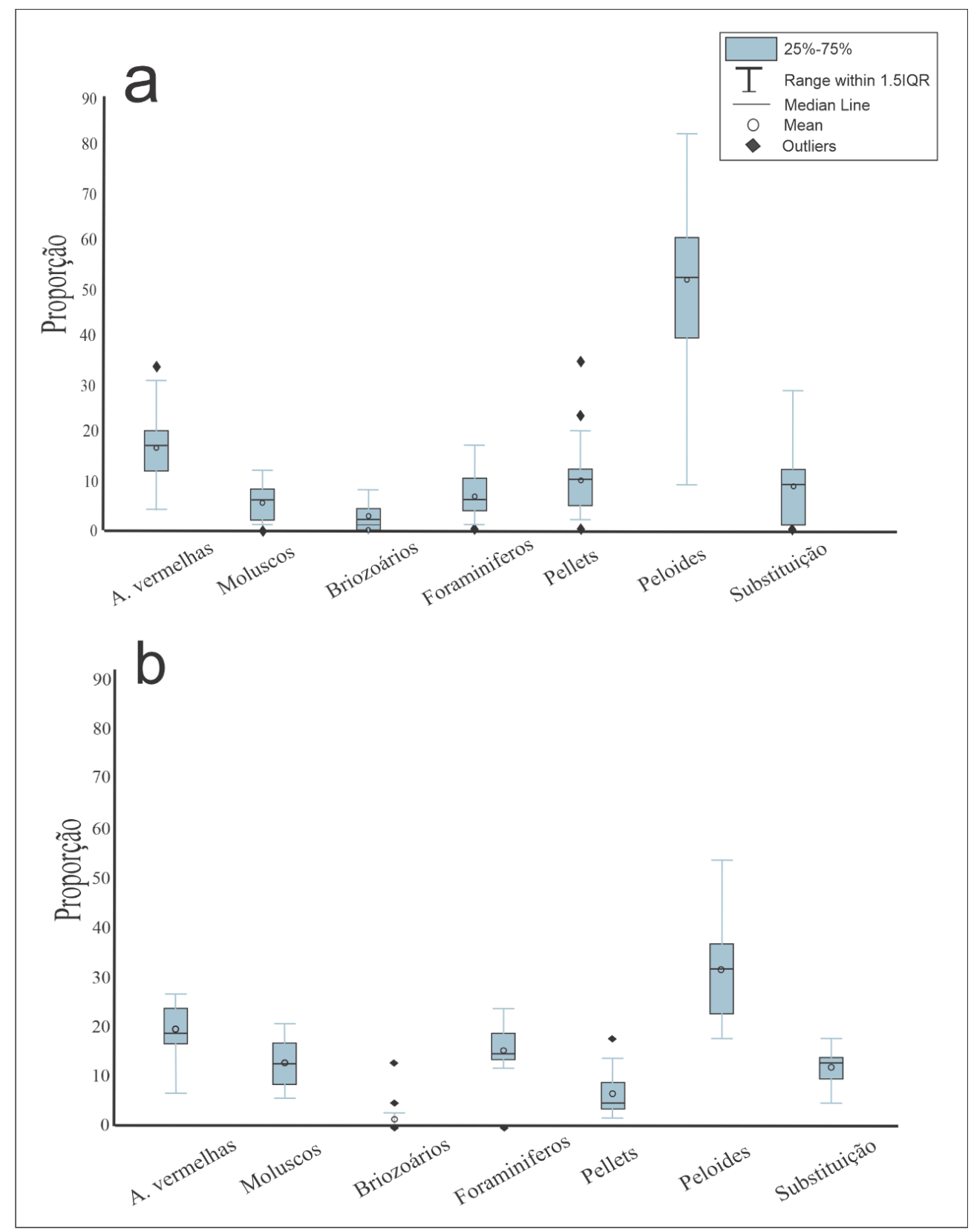

Fig. 6.13. Graficos boxplot dos clastos intrabacinais dos eolianitos: a. insulares; b. continentais.

Ao microscópio, os eolianitos continentais e insulares apresentam também diferenças, tanto de trama e textura do arcabouço quanto de porosidade e cimentação. No aspecto da trama e textura, os eolianitos continentais exibem, em muitas amostras, segregação granular, com grãos terrígenos, principalmente quartzo monocristalino, nas granulações mais grossas, e grãos carbonáticos nas mais finas (Fig. 6.14a); a forte bimodalidade da granulometria reforça a hipótese de estes eolianitos terem sido formados na planície deflacionária, onde se alternam grãos maiores, de caráter residual, e grãos 
menores aprisionados na sombra aerodinâmica dos maiores ou relacionados às porções mais deposicionais de elementos morfológicos de deflação. Já nos eolianitos insulares, a maior parte dos grãos são bioclastos com granulometria mais homogênea e unimodal (Fig 6.14b), o que pode estar relacionado com a menor distância de transporte eólico e com a composição mais uniforme dos clastos, haja vista o franco predomínio de carbonáticos.
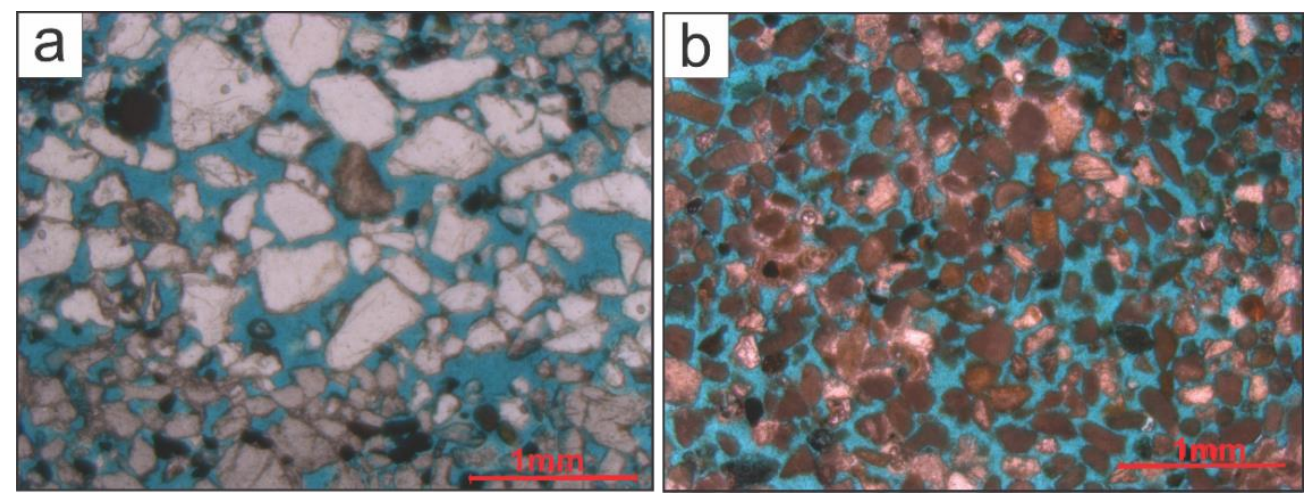

Fig. 6.14. Diferenças granulométricas entre os eolianitos: a. continentais (lâmina ERN 02E); e b. insulares (lâmina EFN 01). Fotomicrografias a polarizadores paralelos.

Quanto aos poros e cimentos, os eolianitos continentais apresentam geralmente porosidade seletiva intergranular e eventualmente móldica, e cimentação principalmente por microespato, com predominância de texturas em franja anisópaca, menisco, geopetal, revestimento de poros e em concentrações sub-horizontais acompanhando a granulometria mais fina da segregação granular (Fig. 6.15a), as quais apontam para condições de insaturação em água (vadosas); no caso dos afloramentos de Três Irmãos, em particular, a presença de cimentos indicativos de ambientes meteóricos tanto freáticos quanto vadosos aponta para dois ou mais eventos de diagênese, com condições distintas de saturação em água.

Nos eolianitos insulares, a porosidade também é intergranular e eventualmente móldica ou por aparente dissolução da rocha, e os cimentos são de composição microespática, também em franja, tanto anisópaca quanto isópaca, em mosaico e em menisco, alguns deles evidenciando pelo menos duas gerações; esta ampla gama de tipos de trama de cimento implica que as condições de cimentação podem ter sido ora vadosas, ora freáticas (Fig 6.15b). 


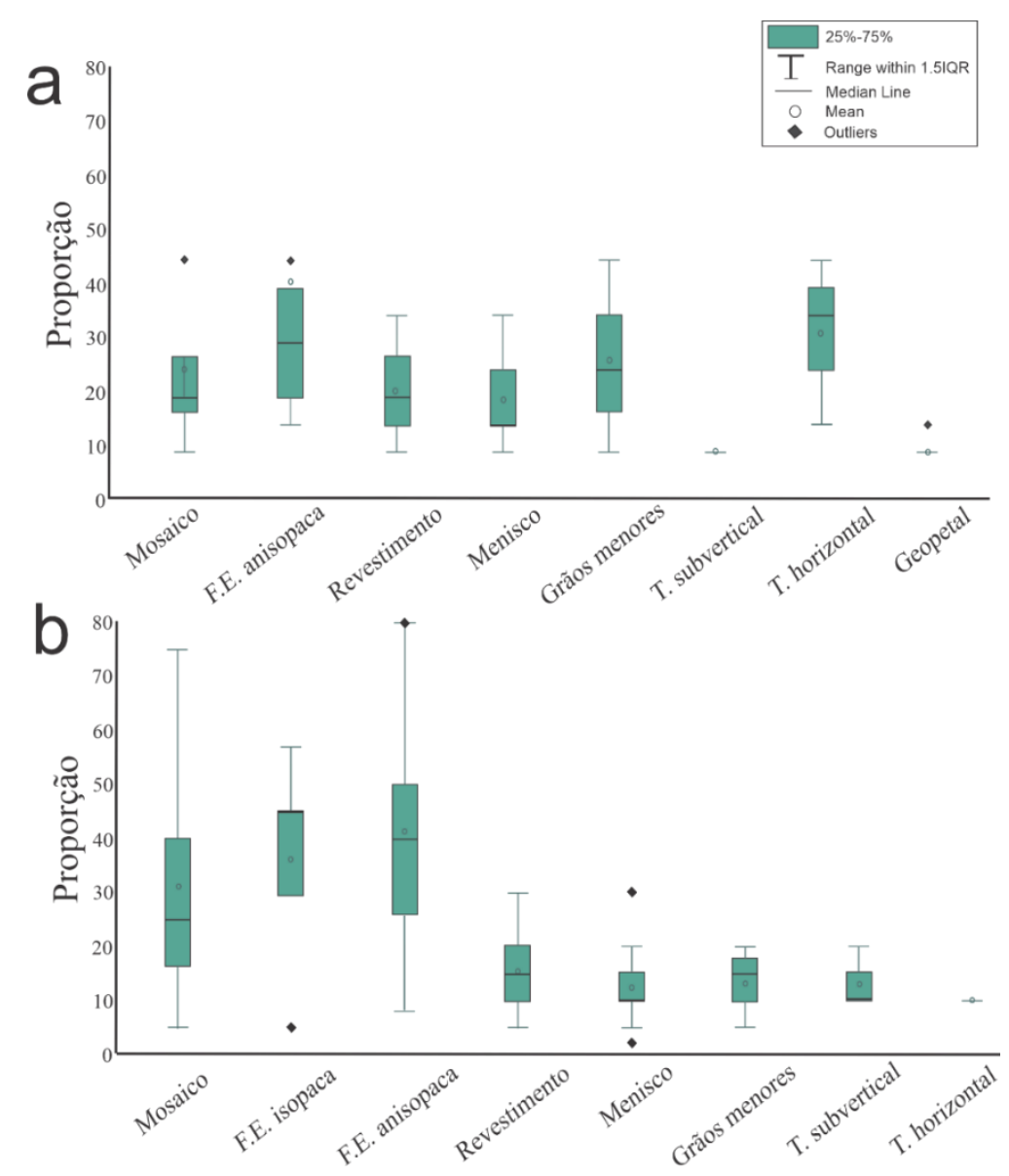

Fig. 6.15. Boxplot das diferenças dos arranjos de cimentos carbonáticos dos eolianitos: a. continentais; $\mathbf{b}$. insulares.

Para a distinção das petrofácies dos eolianitos, tomaram-se como critérios a mineralogia dominante, a proporção de poros e o tipo de ambiente diagenético, se vadoso ou freático, conforme apresentado no Quadro 14.

Quadro 14. Critérios e classificação das petrofácies dos eolianitos.

\begin{tabular}{|c|c|c|c|c|}
\hline Critério & \multicolumn{4}{|c|}{ Classificação } \\
\hline $\begin{array}{l}\text { Mineralogia } \\
\text { dominante }\end{array}$ & $\begin{array}{c}\text { Q } \\
\text { Quartzosa }\end{array}$ & $\begin{array}{c}\text { C } \\
\text { Calcária }\end{array}$ & & \\
\hline $\begin{array}{l}\text { Proporção de } \\
\text { porosidade, } \\
\text { em volume }\end{array}$ & $\begin{array}{c}\text { ma } \\
\text { Muito alta } \\
(50-40 \%)\end{array}$ & $\begin{array}{c}\text { a } \\
\text { Alta } \\
(40-30 \%)\end{array}$ & $\begin{array}{c}\text { m } \\
\text { Média } \\
(30-20 \%)\end{array}$ & $\begin{array}{c}\mathbf{b} \\
\text { Baixa } \\
(20-10 \%)\end{array}$ \\
\hline $\begin{array}{c}\text { Tipo de } \\
\text { ambiente } \\
\text { diagenético }\end{array}$ & $\begin{array}{c}\mathbf{v} \\
\text { Vadoso }\end{array}$ & $\begin{array}{c}\mathbf{f} \\
\text { Freático }\end{array}$ & \begin{tabular}{c}
\multicolumn{1}{c}{$\mathbf{f}$} \\
Vadoso e \\
freático
\end{tabular} & \\
\hline
\end{tabular}

Entre as feições sugestivas de ambientes vadosos, foram consideradas: I. franja envolvente anisópaca em torno de bioclasto ou grão de quartzo (este somente em 
eolianitos continentais), frequentemente acompanhada de linha de sutura mediana no contato com franjas de grãos adjacentes (Figs. 5.68b e 5.87b); II. menisco entre grãos adjacentes (Figs 5.68c e 5.88a); III. cimento pendular ou estalactítico, portanto de caráter geopetal ou gravitacional, indicador de topo e base (Fig. 5.69a); e IV. revestimento anisópaco de poros (Fig. 5.69c). Os cimentos concentrados ao longo de zonas subverticais foram atribuídos ao fluxo de fluidos, seja descendente gravitacional seja ascendente por capilaridade, ambos mais característicos de zona vadosa ou da interface vadoso-freático. Já entre as microfeições indicativas de ambientes freáticos, foram consideradas: I. franja envolvente isópaca, frequentemente acompanhada de linha de sutura mediana (Fig. 5.87a); III. revestimento de poro isópaco; e III. preenchimento uniforme em mosaico (Fig. 5.89a).

No total, foram reconhecidas seis petrofácies, as quais se encontram resumidas no Quadro 15.

Quadro 15. Sumário das petrofácies atribuídas aos eolianitos, com sua distribuição geográfica e cronológica

\begin{tabular}{|c|c|c|c|}
\hline Petrofácies & Descrição & Área & Idade (ka) \\
\hline Qmav & $\begin{array}{c}\text { Quartzo arenito com peloides e bioclastos de } \\
\text { algas vermelhas, com porosidade média a muito } \\
\text { alta ( } 25 \text { e } 48 \%) \text { e cimentos em franja anisópaca e } \\
\text { em concentração subvertical }\end{array}$ & $\begin{array}{l}\text { Enxu } \\
\text { Queimado, } \\
\text { Guajiru } \\
\text { (RN) }\end{array}$ & 0,014 a 6,0 \\
\hline Qmvf & $\begin{array}{l}\text { Quartzo arenito com peloides e grãos } \\
\text { substituídos por calcita microespática, com } \\
\text { porosidade média a alta ( } 25 \text { a } 40 \%) \text { e cimentos } \\
\text { em franja anisópaca e mosaico }\end{array}$ & $\begin{array}{l}\text { Três Irmãos } \\
\text { (RN) }\end{array}$ & 19,2 a 76,8 \\
\hline Cmavf & $\begin{array}{c}\text { Calciarenito com peloides, algas vermelhas e } \\
\text { foraminíferos, com porosidade média a muito } \\
\text { alta }(25 \text { a } 50 \%) \text { e cimentos em franja anisópaca e } \\
\text { mosaico }\end{array}$ & $\begin{array}{l}\text { Ilha Rasa, } \\
\text { Ilha Rata, } \\
\text { Pedra da } \\
\text { Bigorna, } \\
\text { Ponta das } \\
\text { Caracas } \\
\text { (AFN) }\end{array}$ & 11,3 a 45,0 \\
\hline Cav & $\begin{array}{l}\text { Calciarenito com peloides, algas vermelhas e } \\
\text { foraminíferos, com porosidade alta (30 a 40\%) e } \\
\text { cimento em franja anisópaca }\end{array}$ & $\begin{array}{c}\text { Enseada da } \\
\text { Caieira } \\
(\mathrm{AFN}) \\
\end{array}$ & 5,4 a 18,6 \\
\hline Cbf & $\begin{array}{c}\text { Calciarenito com peloides, algas vermelhas e } \\
\text { foraminíferos, com porosidade baixa a média ( } 10 \\
\text { a } 30 \% \text { ) e cimento em mosaico }\end{array}$ & $\begin{array}{l}\text { Forte de } \\
\text { São } \\
\text { Joaquim } \\
\text { (AFN) }\end{array}$ & 34,7 a 31,3 \\
\hline Cmvf & $\begin{array}{l}\text { Calciarenito com peloides, algas vermelhas e } \\
\text { foraminíferos, com porosidade variável (10 a } \\
45 \% \text { ), dominando a média, e cimento em franja } \\
\text { anisópaca e mosaico }\end{array}$ & $\begin{array}{l}\text { Saco de } \\
\text { Atalaia } \\
(\mathrm{AFN})\end{array}$ & 28,8 a 46,1 \\
\hline
\end{tabular}


Ao analisar-se a distribuição das petrofácies por área geográfica e idade (Quadro 15), nota-se que, nos eolianitos continentais holocenos, a porosidade varia de média a muito alta, com tendência de redução para o topo do afloramento, e as tramas de cimento sugerem precipitação a partir de águas vadosas. A redução da porosidade para o topo é compatível com a presença de crostas superficiais de cimentação preferencial, com espessura desde centimétrica até métrica, observada em campo tanto nesta tese, no RN, quanto por Espinel-Arias (2015) e Espinel-Arias et al. (2015), no PI e CE. Estas crostas podem ser atribuídas ao próprio processo de cimentação vadosa, portanto superficial, dos eolianitos.

Os eolianitos continentais pleistocenos (Três Irmãos) apresentam porosidade média a alta e cimentos tanto vadosos quanto freáticos. A porosidade em média menor e a história de cimentação mais complexa dos eolianitos em relação aos holocenos pode ser atribuída a alterações nas condições de saturação de poros, as quais podem ter relação com o maior tempo de sujeição a mudanças de clima e, especialmente, de NRM e linha de costa; isto porque os afloramentos pleistocenos ocorrem na forma de falésias costeiras, as quais devem ter sido parcialmente afogadas durante o nível do mar mais alto que o atual do Holoceno e cuja parte basal se encontra, ainda hoje, ao alcance das ondas de preamar e sob forte influência do aerossol marinho. Desse modo, condições de afogamento e de emersão, implicando influência de águas com diferentes salinidades, devem ter-se alternado.

Já entre os eolianitos insulares, os afloramentos baixos e os de Ponta das Caracas caracterizam-se por apresentar porosidade dominantemente muito alta e cimentação tanto vadosa quanto freática; a exemplo de Três Irmãos (continentais), os afloramentos baixos e a seção NE-SW de Ponta das Caracas encontram-se inteiramente a menos de $10 \mathrm{~m}$ de altitude, com influência maior ou mais direta, em comparação com afloramentos mais altos, das oscilações de NRM e/ou do aerossol marinho, e por consequência, de oscilações também na saturação dos poros em água. Também sob forte influência do aerossol marinho ficaram os afloramentos altos de Enseada da Caieira, em grande parte voltados diretamente para os ventos de SE e caracterizados pelo domínio de porosidade alta e cimento vadoso e freático (mosaico). Em contraposição, os eolianitos altos de Forte de São Joaquim e Saco de Atalaia, localizados em cotas mais elevadas, apresentam porosidades mais baixas e maior presença de tramas de cimentação freáticas. Em vista da 
distribuição de idades nestes afloramentos, mais antigas no topo (Figs.5.54 e 5.55), e do fato de essas idades representarem majoritariamente eventos de cimentação intergranular ou preenchimento pseudomorfo de grãos dissolvidos, pode-se interpretar que, a exemplo dos eolianitos continentais holocenos, a cimentação deu-se a partir da superfície, com formação de crostas de baixa permeabilidade; esta condição teria criado uma espécie de freático suspenso no topo destes afloramentos, isto é, zonas menos porosas, propensas à saturação em água, onde condições dominantemente freáticas teriam se estabelecido.

A litificação mais intensa no topo que na base, visível em muitos afloramentos do Holoceno, e as inversões de idade entre base e topo em afloramentos do Pleistoceno evidenciam cimentação restrita ou preferencial, e/ou mais precoce, nas porções superiores do depósito (Fig. 6.16), em contato mais direto com o ambiente de sedimentação eólica; além disso, a petrografia mostra que a compactação mecânica ou química foram fracas ou pouco efetivas, conforme evidenciado pela porosidade intergranular frequentemente elevada, pelo empacotamento aberto do arcabouço, pela escassez de contatos entre grãos que, quando observados, são dominantemente pontuais, e pela frequente presença de cimentos envolventes, os quais preveniram a aproximação dos grãos por eventual compactação posterior. A textura dominantemente micrítica a microespática dos cimentos carbonáticos sugere precipitação rápida a partir de soluções supersaturadas, com pouco tempo e/ou profundidade para recristalização espática. Desse modo, o conjunto de resultados de campo e petrográficos permite inferir que os eolianitos foram litificados na eodiagênese, caracterizada por alterações do depósito em condições de soterramento progressivo raso e precoce, ou seja em intervalo de tempo e profundidade compatíveis com a manutenção da influência das condições geoquímicas da própria sedimentação (Choquette \& Pray 1970, Tucker \& Wright 1990). 

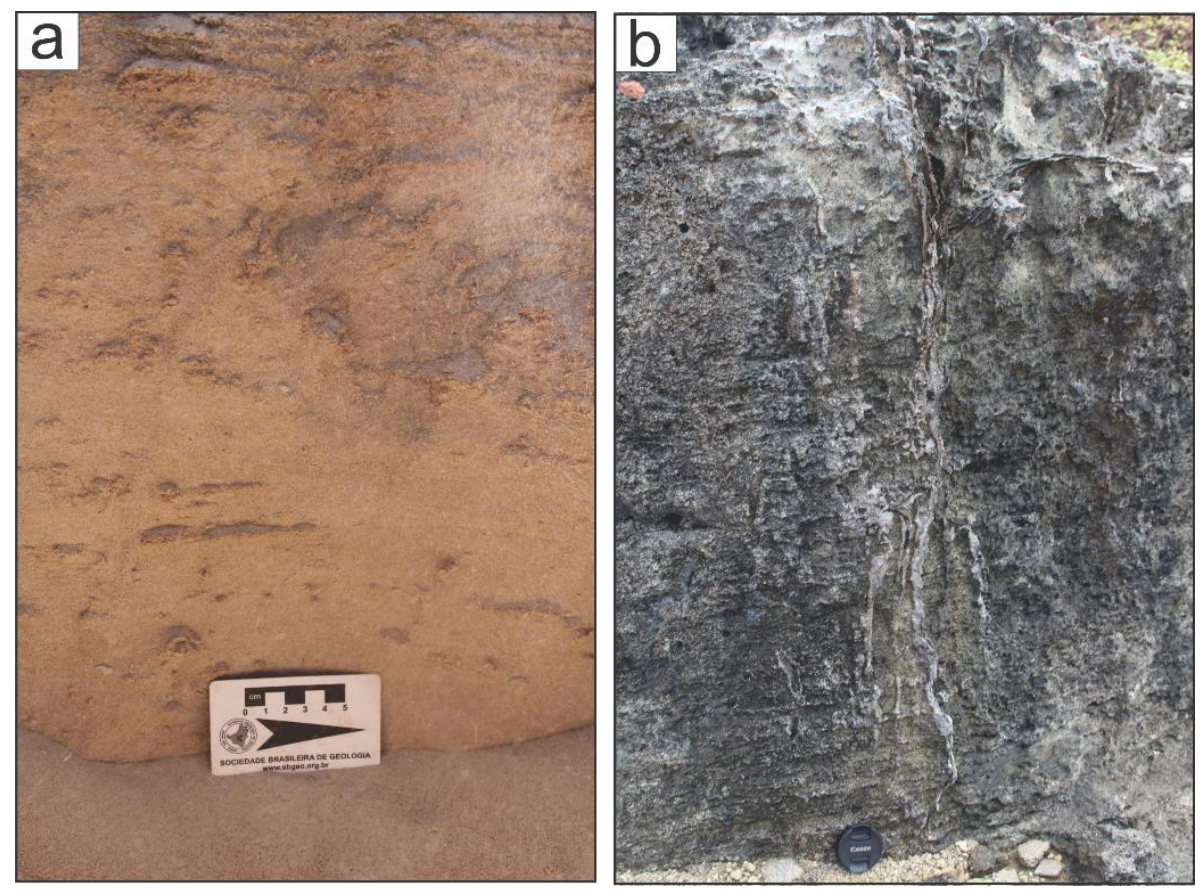

Fig. 6.16 Eolianitos com diferentes idades e graus de consolidação: a. primeiro estágio de cimentação em eolianito holoceno, com formação de crostas, mais concentradas na superfície

(Carnaubinha-PI); b. eolianito pleistoceno, com alto grau de litificação (Ponta das Caracas AFN).

As análises realizadas por MEV-EED em eolianitos que apresentaram inversão nas idades ${ }^{14} \mathrm{C}$ (cimentos mais velhos que os bioclastos, item 5.6) evidenciam estágio de cimentação intergranular, seguida de dissolução de grãos carbonáticos com produção de porosidade móldica, esta depois em parte preenchida por calcita espática ou microespática, pseudomorfa do grão dissolvido (Fig. 6.17). A composição pobre em Mg da calcita do cimento envolvente $(\leq 2,2 \%$ sem contabilizar o carbono, contra 3,9 a $5,4 \%$ esperados para cimento de calcita magnesiana marinha) favorece a hipótese de precipitação a partir de água doce meteórica. Já os bioclastos de algas vermelhas apresentam teor de $\mathrm{Mg}$ variável (até 6,7\% sem contabilizar o carbono), o que significa que parte deles não foi inteiramente neomorfizada e/ou que o cimento pseudomorfo (Figs. 5.99 a 5.101) pode ter-se formado sob alguma influência de águas salinas, como aerossol ou inundações marinhos.

A alternância entre momentos de dissolução e momentos de reprecipitação pode abranger pelo menos dois tipos de controle: variações de pluviosidade, ligado seja à sazonalidade anual, a qual é bem marcante na Região Nordeste, seja a períodos mais longos (subdecadais a seculares) de umidificação ou aridificação; e flutuações do NRM e de proximidade da costa, implicando mudanças na frequência e intensidade de ação de 
inundações e aerossóis salinos. Em relação à sazonalidade ou oscilações climáticas, por exemplo, períodos de maior pluviosidade podem ter favorecido a dissolução de bioclastos carbonáticos e a criação de poros secundários móldicos, enquanto temporadas mais secas teriam favorecido a precipitação de cimentos intergranulares ou de preenchimento móldico; em relação ao NRM, períodos de NRM mais baixo em tese favoreceriam a dissolução de bioclastos e a consequente formação de porosidade móldica, enquanto períodos de NRM mais altos favoreceriam a precipitação de cimentos.

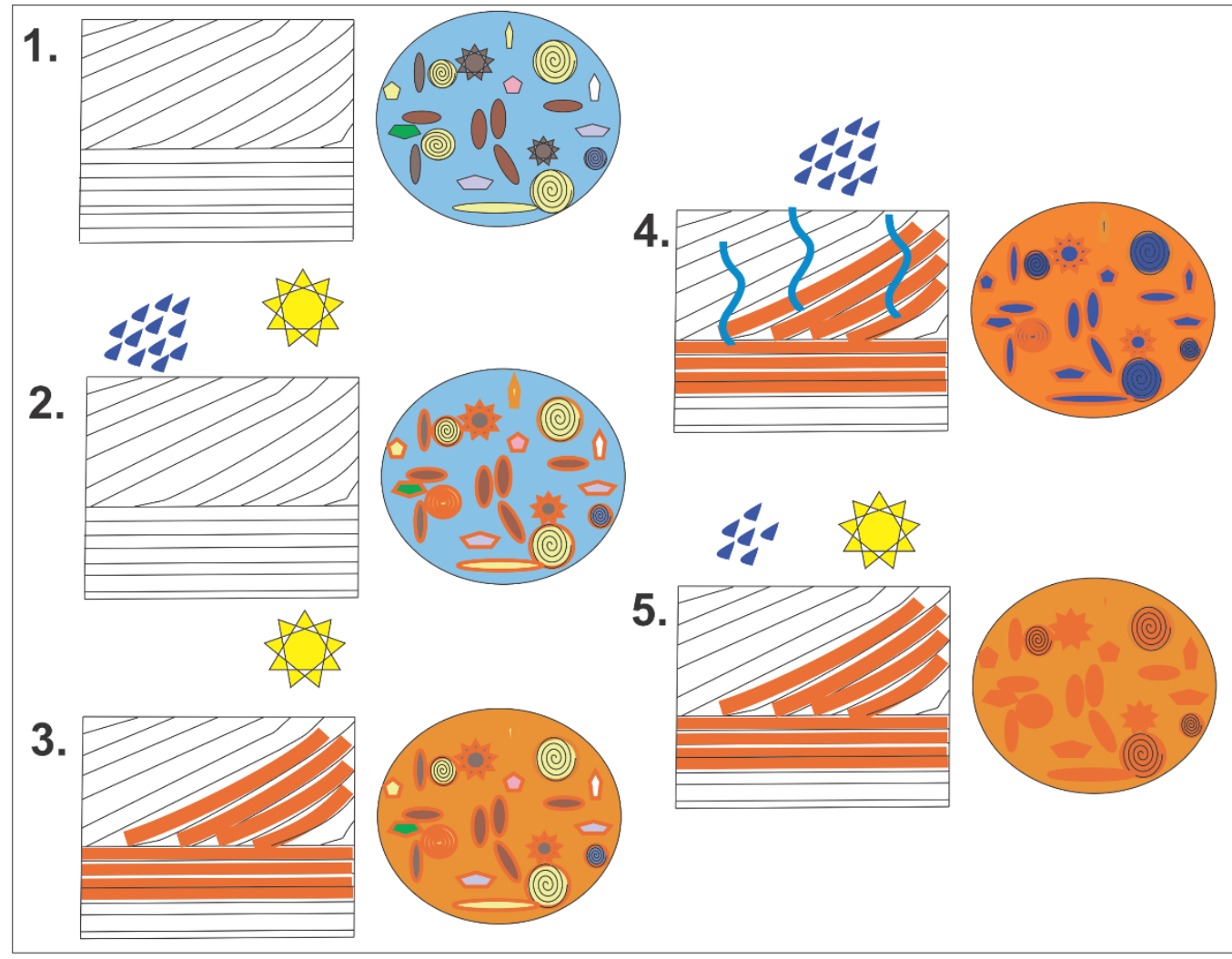

Fig. 6.17. Hipótese de estágios de diagênese dos eolianitos pleistocenos, representados em escala de afloramento (quadrado) e de microscopia ótica (círculo): 1: deposição do sedimento eólico; 2 início da cimentação (laranja) nas bordas dos grãos; 3 : cimentação avançada da rocha, ou de partes dela; 4: dissolução dos grãos bioclásticos, restando o cimento intersticial prévio e a porosidades móldica (azul); 5: preenchimento da porosidade móldica por nova geração de cimento.

As análises de minerais pesados também podem auxiliar na interpretação diagenética dos eolianitos, através das razões mineralógicas testadas como indicadoras de maturidade química, obtidas no item 5.10; nos eolianitos continentais, porém, esta indicação não ficou clara, já que os dois índices testados, THi (Fig. 5.114) e EsEpi (Fig. 5.115), apresentaram mais correlação com a distribuição geográfica de que com o tempo de diagênese (idade) e, além disso, tiveram tendências geográficas opostas, o que sugere 
controle destes minerais pela área-fonte. Já nos insulares, os índices mineralógicos de maturidade, TiOli e TiAui (Figs.5.125 e 5.126), alcançam seus maiores valores nos afloramentos de Atalaia e, principalmente, Forte de São Joaquim, e menores em Ponta das Caracas; por serem estas duas últimas áreas muito próximas, pode-se concluir, neste caso, que a fonte não influenciou na diferença de razão mineralógica entre elas; desse modo, é provável que a dissolução pós-deposicional de minerais instáveis (olivina e augita) tenha sido mais efetiva nos eolianitos de Forte de São Joaquim, o que condiz com o aspecto ruineforme de seus afloramentos.

\subsection{Distribuição dos Eolianitos no Tempo}

Seja na escala global seja na local, a formação de eolianitos é determinada por um controle passivo e por vários controles ativos. O controle passivo é associado à existência de fonte sedimentar (plataforma) carbonática, isto é, terraços que estejam ou tenham sido previamente inundados por elevações do NRM, e com baixo aporte terrígeno. Frequentemente, a própria inundação marinha é um fator de redução deste aporte, uma vez que contribui para afogar os rios e reter os terrígenos junto à costa (James 1997, James \& Bone 2015, James \& Jones 2016, Tucker \& Wright 1990).

Os controles ativos são essencialmente ligados ao clima, para além dos aspectos inerentes à glácio-eustasia. Abrangem assim a ação das ondas, capazes de transportar clastos carbonáticos desde a fonte até a costa, e a atuação do vento a partir daí, rumo ao continente. Esta, por sua vez, está ligada a fatores globais, como, no Nordeste do Brasil, a posição da ZCIT e das faixas subtropicais de alta pressão, controladoras das direções dominantes e intensidade dos alísios; porém, para estes sedimentos serem transportados pelo vento, é necessário ainda que eles se encontrem incoesos e, portanto, secos, o que adiciona mais um fator de ordem climática, a umidade regional ou local. Desse modo, a formação de eolianitos é favorecida por clima quente e seco em três momentos da história sedimentar: 1. na constituição da plataforma calcária, já que a baixa precipitação reduz o aporte terrígeno e a turbidez das águas, e assim amplia a comunidade bentônica geradora de carbonatos; 2 . na efetividade do vento como agente de transporte, necessária para a formação das dunas eólicas; e 3. na precipitação química do carbonato por evaporação durante a diagênese precoce, necessária para a consolidação do eolianito. Dentro do 
momento 1, e especialmente em sistemas eólicos de constituição terrígena ou mista, o baixo aporte terrígeno contribui ainda para a redução da taxa de progradação subaquosa, o que ajuda a fixar a linha de costa e o espaço de acumulação e aumenta a disponibilidade de sedimentos ao retrabalhamento eólico (Giannini et al. 2014).

\subsubsection{Limitações e significados dos resultados geocronológicos}

Os resultados de datação LOE e ${ }^{14} \mathrm{C}$ nas diferentes áreas de eolianitos brasileiros estudadas nesta Tese (e por Espinel-Arias 2015, Espinel-Arias et al, 2015, Santos 2012 e Angulo et al 2013a) encontram-se representados no gráfico boxplot da Fig. 6.18. Eles mostram o nítido domínio de idades pleistocenas nos eolianitos insulares e holocenas nos continentais, independentemente do método de datação.

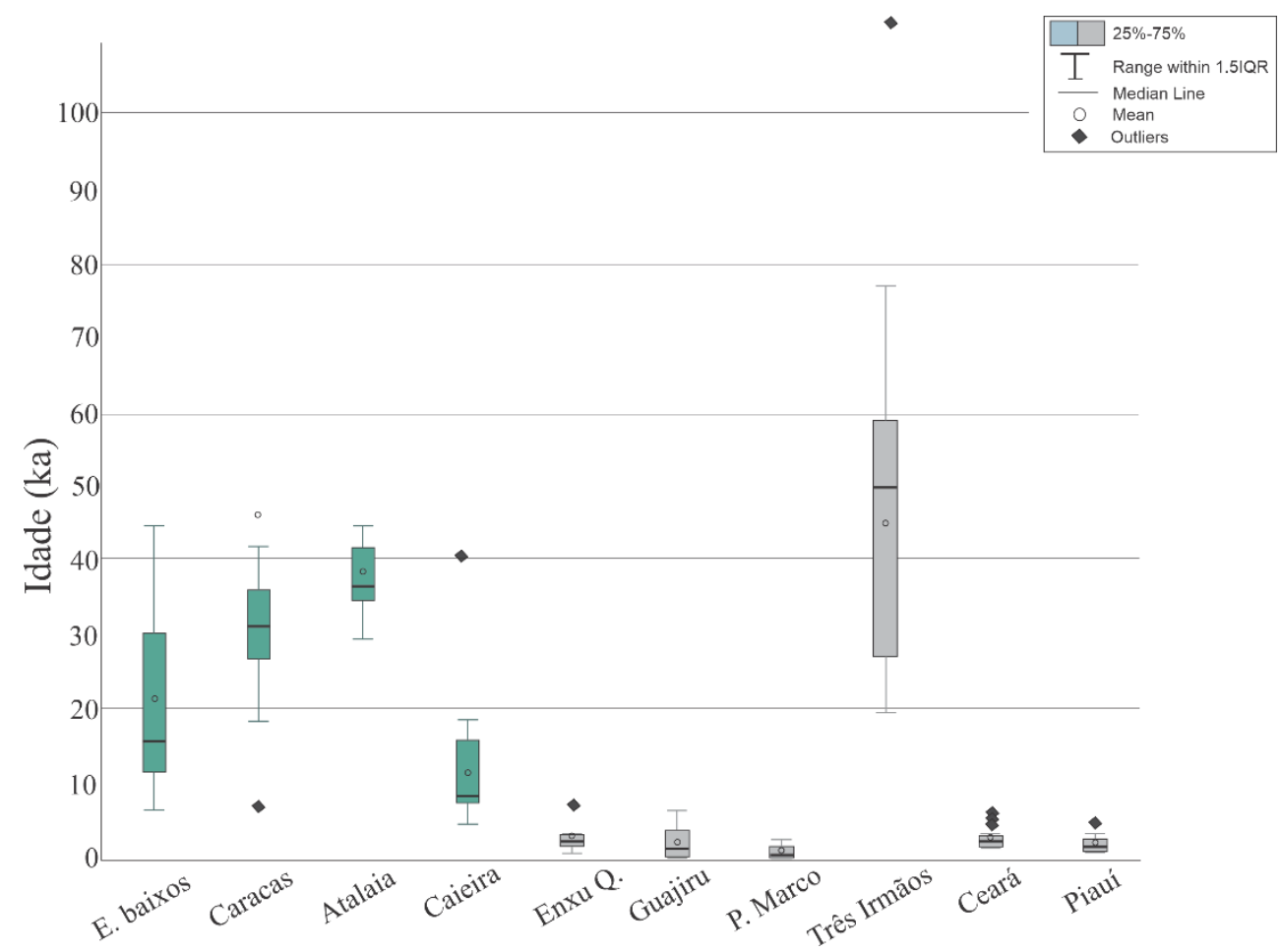

Fig. 6.18 Gráfico de caixa de idades ${ }^{14} \mathrm{C}$ e LOE dos eolianitos insulares (cor verde) e continentais (cor cinza). Idades de eolianitos insulares incluem datações obtidas por Santos (2012) e Angulo et al. (2013) e as dos continentais, idades do Ceará e Piauí obtidas por EspinelArias (2015). Valores de n são: E. baixos: 13; Caracas: 22; Atalaia: 11; Caieira: 9; Enxu Q.: 7; Guajiru: 12; Praia do Marco: 3; Três Irmãos:12; Ceará: 17 e Piauí: 16.

Resultados de datação obtidos por LOE indicam a época de deposição, enquanto os obtidos por ${ }^{14} \mathrm{C}$, quando em bioclastos, sugerem uma possível idade máxima de erosão da plataforma carbonática rasa pelo vento, e, quando em cimento, a idade da diagênese. 
No que se refere às idades holocenas, estes diferentes tipos de resultados mostraram-se coerentes entre si, isto é, cimento contemporâneo ou mais novo que bioclasto e idade LOE igual ou mais nova que ${ }^{14} \mathrm{C}$ de bioclasto, dentro da margem de erro dos métodos, o que aponta para uma reconstrução cronológica confiável. As exceções são duas únicas amostras (ERN 03, na porção continental, e EFN 08A, na insular; Tabelas 3 e 4) cujas idades ${ }^{14} \mathrm{C}$ apresentaram um padrão de resultados inesperado, com inversão em relação à lógica de que a idade mais antiga deve ser a do bioclasto e a mais nova a do cimento. Espinel-Arias (2015) já observara duas amostras com esse tipo de inversão, em um universo de dezenas de datações pareadas nos eolianitos de CE e PI, o que atribuiu a possíveis erros na coleta das alíquotas pareadas à lupa.

Já nos eolianitos pleistocenos, tanto continentais (Três Irmãos) quanto insulares, este mesmo tipo de inversão de idades ${ }^{14} \mathrm{C}$ foi observado de modo sistemático ( $83 \%$ dos casos), o que permite descartar a hipótese de erros na coleta e preparação das alíquotas datadas e reforça a hipótese, mencionada no item anterior e evidenciada pelas análises de MEV-EED, de existência de pseudomorfismo de bioclastos, ligada a eventos de dissolução e preenchimento de porosidades móldicas.

Quando os resultados cronológicos por ${ }^{14} \mathrm{C}$ nos eolianitos pleistocenos do $\mathrm{RN}$ e AFN são analisados em gráfico de caixa segundo o tipo de material datado (Fig. 6.19), observa se que a caixa das idades de bioclastos I (sem inversão de idade com o cimento intergranular) pertence à metade superior (mais antiga) da caixa de idades de cimento intergranular; isto pode indicar a contemporaneidade entre os primeiros estágios de deposição dos eolianitos e a cimentação intergranular precoce, os quais teriam acontecido portanto entre 44 e 32 ka atrás; já nas datações com aparente inversão de idades, os resultados de datação ${ }^{14} \mathrm{C}$ dos pseudomorfos dos grãos (bioclasto II) são similares às da rocha total, o que indica que estas refletem mais a idade do bioclasto neomorfizado do que a do cimento intergranular, e contemplam preferencialmente, assim, os últimos estágios de diagênese. Isso significa que idades obtidas em rocha-total, inclusive em estudos anteriores, muito provavelmente estão subestimadas em relação à idade de deposição. 


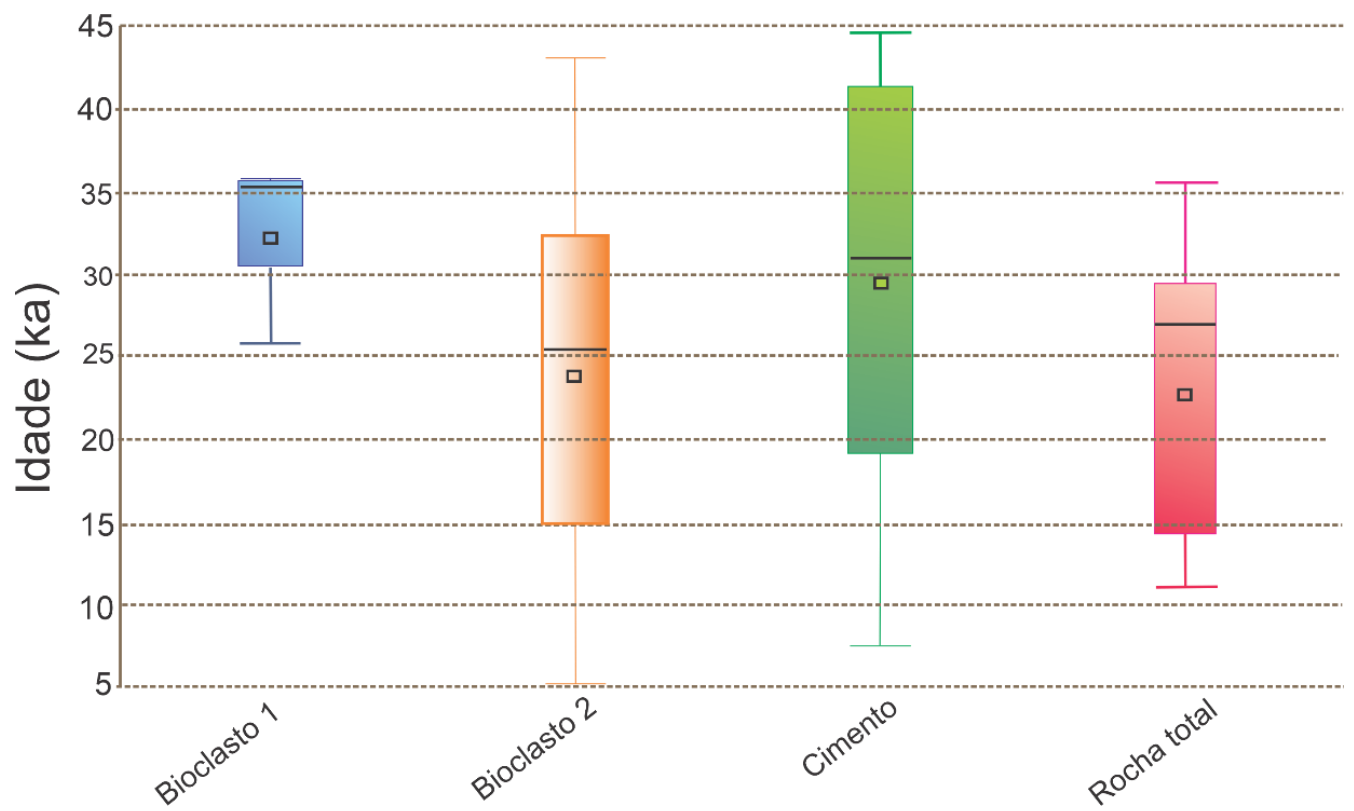

Fig. 6.19. Gráfico de caixa comparando as idades obtidas nos eolianitos pleistocenos do AFN e RN quanto ao tipo de material datado e relação de idade bioclasto versus cimento: bioclasto I, com idade mais velha que cimento $(n=3)$; bioclasto II, com idade mais nova que cimento $(n=14)$; cimento $(n=17)$; e rocha total $(n=9)$.

Nos eolianitos insulares, o padrão de inversão de idades entre bioclasto e cimento foi observado em todas as amostras pareadas datadas, exceto duas: EFN 06B (Forte São Joaquim), com idade de bioclasto I de 36,9-34,7 ka cal AP e idade de cimento de 32,731,3 ka cal AP; e EFN 15A (Atalaia), com idade de bioclasto I de 35,9-34,7 ka cal AP e cimento com 33,6-32,0 ka cal AP. Estas duas únicas amostras sem inversão cronológica no AFN apresentam entre si grande semelhança de idades, tanto na alíquota bioclasto quanto na alíquota cimento. É possível, portanto, que as idades de bioclastos nelas obtidas representem de fato um evento deposicional eólico importante no arquipélago; nesse caso, as idades pouco mais novas de cimento intergranular seriam compatíveis com um evento de diagênese precoce, como também fartamente evidenciado na análise petrográfica.

As duas modas de idades encontradas nos eolianitos insulares, de 46 a $22 \mathrm{ka} \mathrm{cal}$ AP e de 18 a 7,7 ka cal AP (Fig. 5.52), apresentam controle geográfico, altimétrico e/ou faciológico. A moda mais antiga encontra-se dominantemente nos eolianitos altos da porção sudeste da ilha principal (Atalaia e Ponta das Caracas-Forte de São Joaquim; quadrados amarelo e verde em Fig. 6.20), enquanto a mais nova encontra-se na parte nordeste do arquipélago: nos eolianitos baixos de ilha do Chapéu e nas fácies de rampa de barlavento de Enseada da Caieira (Ponta de Santo Antônio; quadrado vermelho em 
Fig. 6.20). Ambas as modas mostram coincidências com resultados de datações prévias nos eolianitos do AFN: no que se refere à moda mais antiga, Menor et al. (2001) encontraram idades ${ }^{14} \mathrm{C}$ entre $42 \mathrm{ka} \mathrm{e} 20 \mathrm{ka}$ cal AP; Santos (2012), estudando os maiores afloramentos do arquipélago, obteve idades entre 48 ka e $26 \mathrm{ka}$ cal AP; e Angulo et al. (2013a) apontaram o intervalo entre 46 ka e 27 ka cal AP. Já com relação à moda de idades mais novas, Angulo et al. (2013a) obtiveram datações entre 10,7 ka e 5,7 ka cal AP, e Menor et al. (2001), entre 10,5 e 9,5 ka cal AP.

Dentro da moda de idades mais novas de eolianitos do AFN encontradas nesta Tese, distinguem-se dois subgrupos: os eolianitos baixos do Chapéu, Pedra da Bigorna e Ilha Rasa são todos pleistocenos (idades em rocha total), enquanto os altos com fácies de barlavento de Enseada da Caieira são os únicos que apresentaram idades ${ }^{14} \mathrm{C}$ tanto pleistocenas (cimentos entre 18,6 e $15 \mathrm{ka}$ cal AP) quanto holocenas, mas todas com inversão entre bioclasto e cimento. Este resultado permite sugerir que as idades holocenas presentes correspondam a eventos diagenéticos (de cimentação intergranular e, sobretudo, de pseudomorfismo de bioclastos), o que levaria a concluir que não há evidência segura de deposição eólica holocena no AFN. Assim, é possível que todos os eolianitos insulares aqui estudados tenham sido formados no Pleistoceno. 


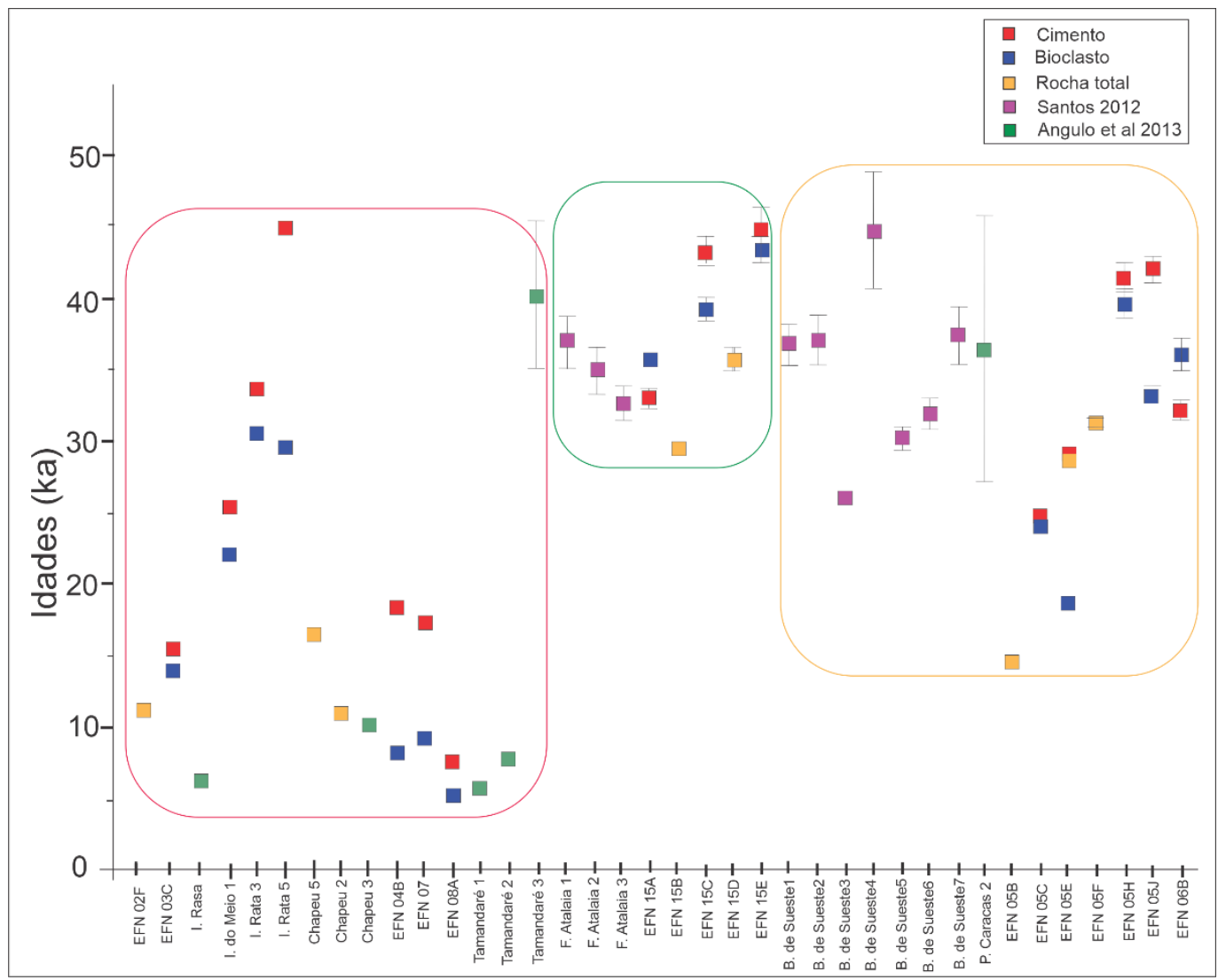

Fig. 6.20. Comparação dos resultados de datação de eolianitos insulares obtidos nesta pesquisa e em trabalhos anteriores (Santos 2012 e Angulo et al. 2013). Amostras estão ordenadas de NE para SW, com os afloramentos de eolianitos baixos (incluindo a ilha do Chapéu) primeiro. Notar tendência para eolianitos mais novos na parte nordeste do arquipélago e mais antigos na sudoeste (eolianitos altos).

Os afloramentos altos de Saco de Atalaia, Ponta das Caracas e Forte de São Joaquim (Figs. 5.54 e 5.55) apresentaram padrão recorrente de aparente inversão de idades ${ }^{14} \mathrm{C}$ com a estratigrafia, isto é, idades (pleistocenas) mais novas na base que no topo do afloramento, pelo que surgem duas hipóteses, não excludentes: 1. que a cimentação precoce se dá preferencialmente na superfície, como bem evidenciado em campo nos afloramentos do Holoceno; ou 2. que eventos de dissolução e cimentação mais tardios ocorreram através da infiltração ao longo de raízes e rizoconcreções presentes nestas áreas (Fig. 6.21). 


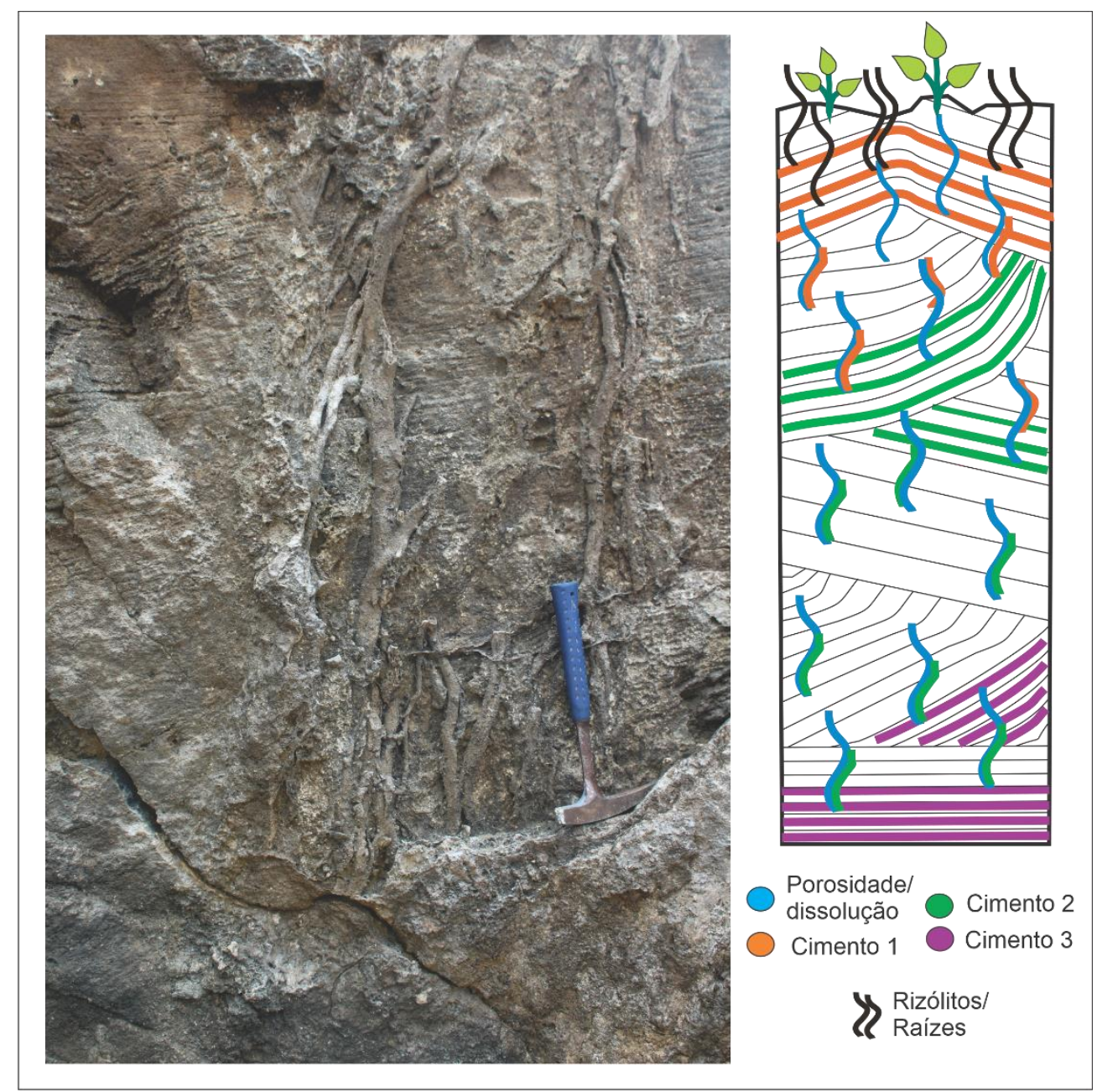

Fig. 6.21. Hipótese do desenvolvimento dos eolianitos pleistocenos que apresentam inversão estratigráfica de idades. Fotografia é de afloramento na Ponta das Caracas; cimentos 1, 2 e 3 são de gerações sucessivas, nessa ordem.

Os eolianitos da porção continental apresentam idades holocenas e pleistocenas, estas últimas na área de Três Irmãos (RN), onde os resultados de datações LOE variaram de 86,2 a 40,7 ka e os de ${ }^{14} \mathrm{C}$ de bioclastos, de 27,4 a 25,6 ka cal AP (Tabela 3; Fig. 6.22); as idades LOE muito mais antigas que as dos bioclastos reforçam a hipótese, já sugerida com base em outras evidências, de que as idades ${ }^{14} \mathrm{C}$ são todas de cimentação e de que houve dois ou mais eventos de cimentação carbonática. Nesta mesma área, a amostra ERN 21W apresentou saturação de dose LOE em cinco alíquotas, com idade de 119,6ka, o que é interpretado aqui como a idade de areias com película de cimento carbonático, portanto não fotoesvaziadas, retrabalhadas dos beach rocks próximos aos depósitos eólicos (como será discutido no item 6.4.2). Já nas amostras continentais holocenas, só uma apresentou inversão de idades entre bioclasto e cimento (ERN 03, com idade de 
cimento de 2160 anos), porém sem deixar de pertencer à moda principal de idades obtidas nesses eolianitos, tanto nesta pesquisa como por Espinel-Arias (2015), nos quais 86\% das amostras datadas caem dentro do intervalo dos últimos 3,3ka (Fig. 6.23).

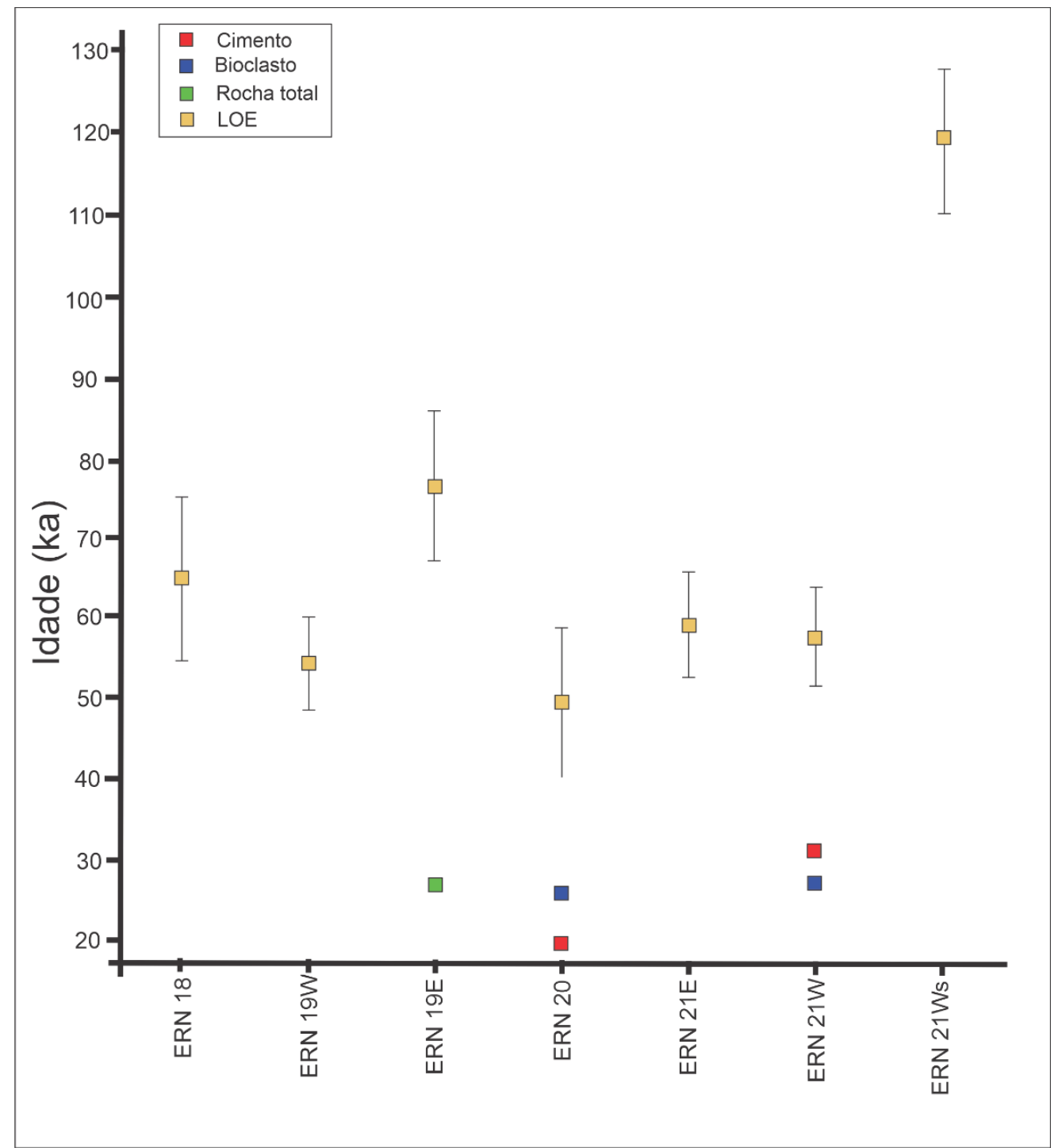

Fig. 6.22. Distribuição de idades ${ }^{14} \mathrm{C}$ e LOE nos afloramentos de Três Irmãos. Notar que as idades LOE (amarelo) são mais antigas que $40 \mathrm{ka}$ e as idades ${ }^{14} \mathrm{C}$ são mais novas que $35 \mathrm{ka}$ cal AP. 


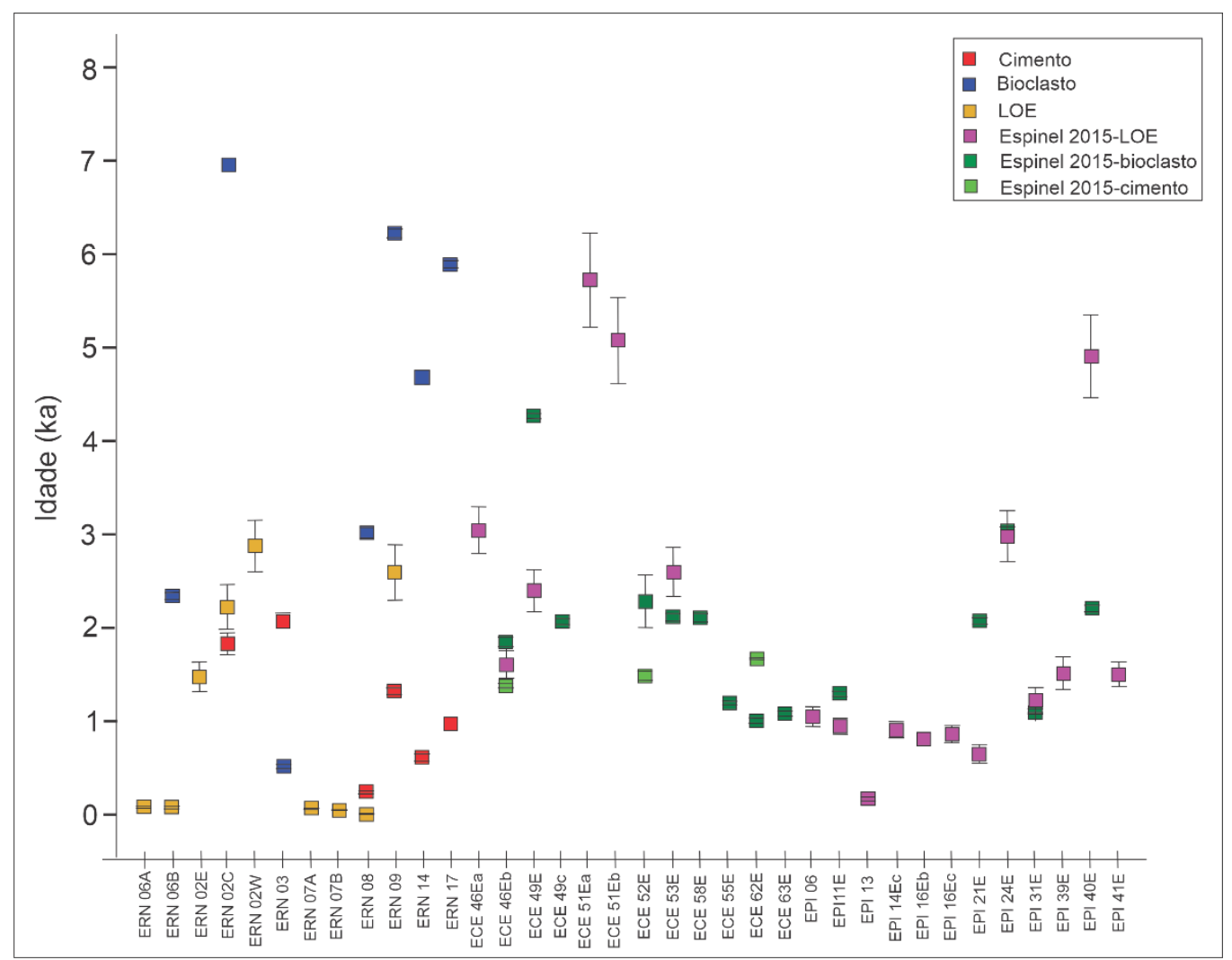

Fig. 6.23. Distribuição das idades LOE e ${ }^{14} \mathrm{C}$ de eolianitos continentais do Nordeste obtidas nesta pesquisa e por Espinel-Arias (2015). Notar que a maioria de amostras apresentam idades dos últimos $3 \mathrm{ka}$.

\subsubsection{Idades versus NRM}

As variações de NRM e linha de costa possuem papel essencial na formação de eolianitos. Momentos de final de transgressão ou de NRM alto têm sido apontados como favoráveis ao desenvolvimento de sistemas eólicos costeiros carbonáticos por pelo menos três razões distintas: a grande quantidade de sedimentos em circulação no prisma costeiro, com pouca progradação subaquosa (como defendido, no caso terrígeno, por Lees 2006 e Giannini et al. 2007, 2014); a redução do aporte terrígeno pela elevação do nível de base, em paralelo com a retenção desse aporte pelo afogamento das drenagens; e o desenvolvimento de amplas plataformas inundadas, com proliferação de organismos carbonáticos que, nos momentos de estabilização ou declínio do NRM em trato de mar alto, são em seguida erodidos e transportados à costa (Brooke 2001, Hearty \& O'Leary 2008, James \& Bone 2015, James \& Jones 2016).

Os eolianitos de Três Irmãos apresentam os resultados de datação mais antigos desta pesquisa, com idades de deposição (LOE) entre 76,8+/-9,5 ka e 49,7+/-9,2 ka, e 
com uma amostra saturada (ERN 21Ws) cuja idade mínima é de 119,6 ka (Tabela 3). Lançadas junto à curva-envelope de variação do NRM de Waelbroeck et al. (2002) (Fig. 6.24), as idades de amostras não saturadas, com suas respectivas margens de erro, distribuem-se entre o MIS 5b e o MIS 3 e abrangem, portanto, dois momentos de NRM alto e, entre eles, um de NRM baixo. O fato de os eolianitos de Três Irmãos encontraremse acima de fácies marinha rasa (beach rock, Fig. 5.18g), à qual corresponde um paleonível do mar de 2,4 m (cf. item 6.2.3), compatível com o aceito para o MIS 5, inclusive no Nordeste do Brasil, sugere que estes eolianitos de fato se depositaram após o nível do mar máximo desse interestádio (MIS 5e); a idade mínima de 119,6 ka da amostra saturada, por sua vez, coincide aproximadamente com a época desse máximo nível do mar e permite interpretar que os eolianitos tenham-se formado, em parte, a partir do retrabalhamento pelo vento de sedimentos correlatos ao beach rock, de estágio de nível do mar mais alto que o atual (mais provavelmente o próprio MIS 5e); sendo a diagênese dos beach rocks tipicamente precoce, é possível que a película de cimento carbonático eodiagenético já existisse e tenha impedido o fotoesvaziamento completo dos grãos. Deposição eólica na época do MIS 5 no Nordeste do Brasil foi encontrada por Guedes (2012) na geração G0/G1 do Maranhão, terrígena, cujas idades vão de 238 ka a 88 ka.

As amostras de eolianitos não saturadas de Três Irmãos são em parte cronocorrelatas a sistemas eólicos terrígenos previamente datados por LOE e/ou TL no RN (Fig. 6.25). Elas se sobrepõem com o início da geração de dunas designadas "tênues ou dissipadas", identificada por Barreto et al. (2004), e interpretada por esses autores como parabólicas alongadas com rastros lineares residuais, formadas em momentos de nível do mar mais baixo que o atual; esta unidade teria importante contribuição da Formação Barreiras como fonte, indicada pelo ajuste estatístico entre as assembleias de minerais pesados (Giannini et al. 2001) e pela herança da coloração avermelhada devida à impregnação dos grãos vindos daquela formação (Barreto et al. 2004); a cor avermelhada é uma característica também dos eolianitos de Três Irmãos (Fig. 5.18). O range de idades dos eolianitos de Três Irmãos sobrepõe-se também, e em grande parte, com a geração de depósitos eólicos mais antiga encontrada por Zular (2016) e Zular et al. (2018) no RN por datação de sedimentos sub-superficiais, o que reforça a ideia de deposição eólica na região nesse período (Fig. 6.25); as datações ${ }^{14} \mathrm{C}$ de Três Irmãos apresentam idades $40 \mathrm{ka}$ a $30 \mathrm{ka}$ mais novas que as idades LOE (Tabela 3), o que permite 
inferir tratar-se de idade de eventos de diagênese, os quais teriam acontecido na passagem do MIS 3 para o MIS 2, antes do pico do último máximo glacial (UMG, 20 ka BP).

Do ponto de vista da geomorfologia do arquipélago, o platô capaz de sustentar a plataforma carbonática que serviu de fonte para os bioclastos dos eoliantos possui largura máxima de apenas $7 \mathrm{~km}$ e profundidade variável entre $50 \mathrm{~m}$, a W, e 20m, a E. Combinando-se esses dados com a curva-envelope global de variações do NRM de Waelbroeck et al. (2002) (Fig. 6.24), pode-se inferir que, ao longo do período em que se distribuem as idades obtidas, esse platô pode ter estado pelo menos em parte submerso em dois momentos: antes de cerca de 25 ka e após $11 \mathrm{ka}$. Esses dois períodos foram portanto mais favoráveis para o desenvolvimento da plataforma carbonática que serviu de fonte para os eolianitos.

Conforme indicado no item 6.4.1, as idades obtidas nos eolianitos do AFN provavelmente correspondem em grande parte a eventos de cimentação. Apesar disso, na moda de idades mais antiga (entre 46,1 e 22,1 ka cal AP), as duas amostras pareadas sem inversão (EFN 06B e EFN 15A; Tabela 4), permitem interpretar que houve de fato, deposição eólica nessa época, mais precisamente entre 36,9 ka e 34,7 ka, período que coincide com a época do patamar de NRM alto do MIS 3 (Fig 6.24). Já as inversões de idade nas demais amostras da mesma moda, com evidências de pseudomorfismo dos bioclastos, indicam ter havido eventos diagenéticos de cimentação interpartícula, seguida de dissolução dos bioclastos de alga vermelha e, por fim, de cimentação de preenchimento móldico. A hipótese de deposição eólica no AFN na época do MIS 3, baseada nas idades de bioclastos não neomorfizados, é compatível com a formação preferencial de eolianitos em períodos interglaciais (Hearty \& O'Leary 2008, James \& Bone 2015, James and Jones 2016, Brooke 2001), quando plataformas carbonáticas rasas se desenvolvem e permitem criar o necessário suprimento bioclástico costeiro. Seguindo este mesmo raciocínio, podese considerar que os eolianitos insulares com inversão de idade se formaram em tratos de mar alto anteriores ou contemporâneos às idades de diagênese neles encontradas, como os dos MIS 5 e MIS 3, respectivamente. Eolianitos pleistocenos formados principalmente nesses estágios são de fato amplamente relatados na literatura; aos estágios 5a, 5c e 5e, correlacionam-se os de Bahamas (Kindler \& Hearty 1995 e Deely et al. 2011), Havaí (Fletcher III et al. 2005), Turquia (Erginal et al. 2012), Golfo Arábico (El-Asmar \& Wood 2000, William \& Walkden 2002) e Austrália (Brooke et al. 2014; James \& Bones 
2015; Lipar \& Webb 2015 e Lipar \& Webb 2014); e ao MIS 3, várias ocorrências insulares, como Ilha Shidao, no sul da China (Li et al. 2018), Menorca, no Mediterrâneo (Pomar et al. 2017) e Tufia-Canárias (Mangas et al. 2008) e Madeira (Silva \& Gomes 2016), no Atlântico.

Petrograficamente, os afloramentos altos, onde se concentram as idades mais antigas, apresentam cimentos de ambiente diagenético tanto vadoso quanto freático. $\mathrm{O}$ cimento vadoso, por exemplo na forma de franja anisópaca (item 5.7.2, Fig 5.87b), teria sido favorecido pelo fato de estes depósitos estarem elevados vários metros acima do nível do mar, onde estariam sujeitos à infiltração e circulação das águas pluviais e à dissolução móldica da calcita magnesiana das algas. A influência de água doce na diagênese confere com os valores relativamente baixos tanto dos teores em massa de $\mathrm{Mg}$ detectados por MEV-EED ( $<6,7$ sem contabilizar o C), sobretudo no cimento mais antigo (intersticial), quanto nos dados de $\delta^{13} \mathrm{C}(<-3,0 \%$ ov-PDB) obtidos por Valença et al. (2005) em amostras de rocha bruta de mesma faixa de idade (pré-UMG).

O hiato entre as duas modas de idades, que vai de 22,1 a 18,2 ka cal AP, coincide com o UMG, época em que o baixo NRM deve ter favorecido a percolação dos depósitos carbonáticos por água doce e, portanto, a ocorrência preferencial de dissolução; nesse hiato, pode ter sido gerado, por dissolução de material carbonático, o bicarbonato de cálcio intersticial que propiciou, em seguida, a fase de precipitação de cimentos materializada na segunda moda de idades (entre 18,2 e 5,3 ka cal AP), mais efetiva nos afloramentos baixos e/ou de rampa de barlavento; a manutenção sistemática e sem exceções do padrão de inversões de idade na moda mais nova (Enseada da Caieira) indica que a dissolução e reprecipitação móldica de bioclastos continuou a ocorrer ao longo desta segunda fase e que as idades obtidas são de cimentação; esta fase abrange a subida do nível do mar até o máximo holoceno do MIS 1 que, no arquipélago, seria o mesmo ao longo dos últimos 6 ka, segundo Angulo et al. (2013a); formou-se, portanto, em parte, com nível do mar alto e linha de costa próxima, sob maior influência de água ou spray marinhos. Os valores isotópicos positivos (até 1,0\%ov-PDB) de $\delta^{13} \mathrm{C}$ registrados nesta segunda moda de idades por Valença et al. (2005) indicam maior influência marinha na diagênese (item 5.8, Tabela 5; Figs. 5.99 e 5.101), o que é compatível, em situação de NRM relativamente alto, com afloramentos baixos (e.g. Ilha do Chapéu) ou voltados para barlavento (e.g. Enseada da Caieira), assim mais expostos a inundações pela maré e a 
aerossol marinho. Feições petrográficas, como franjas isópacas (item 5.7.2, Fig. 5.87a), são sugestivas de domínio de cimentação freática, aqui atribuída à saturação progressiva em águas de forte influência marinha, relacionada com o final do trato transgressivo e início do trato de mar alto.

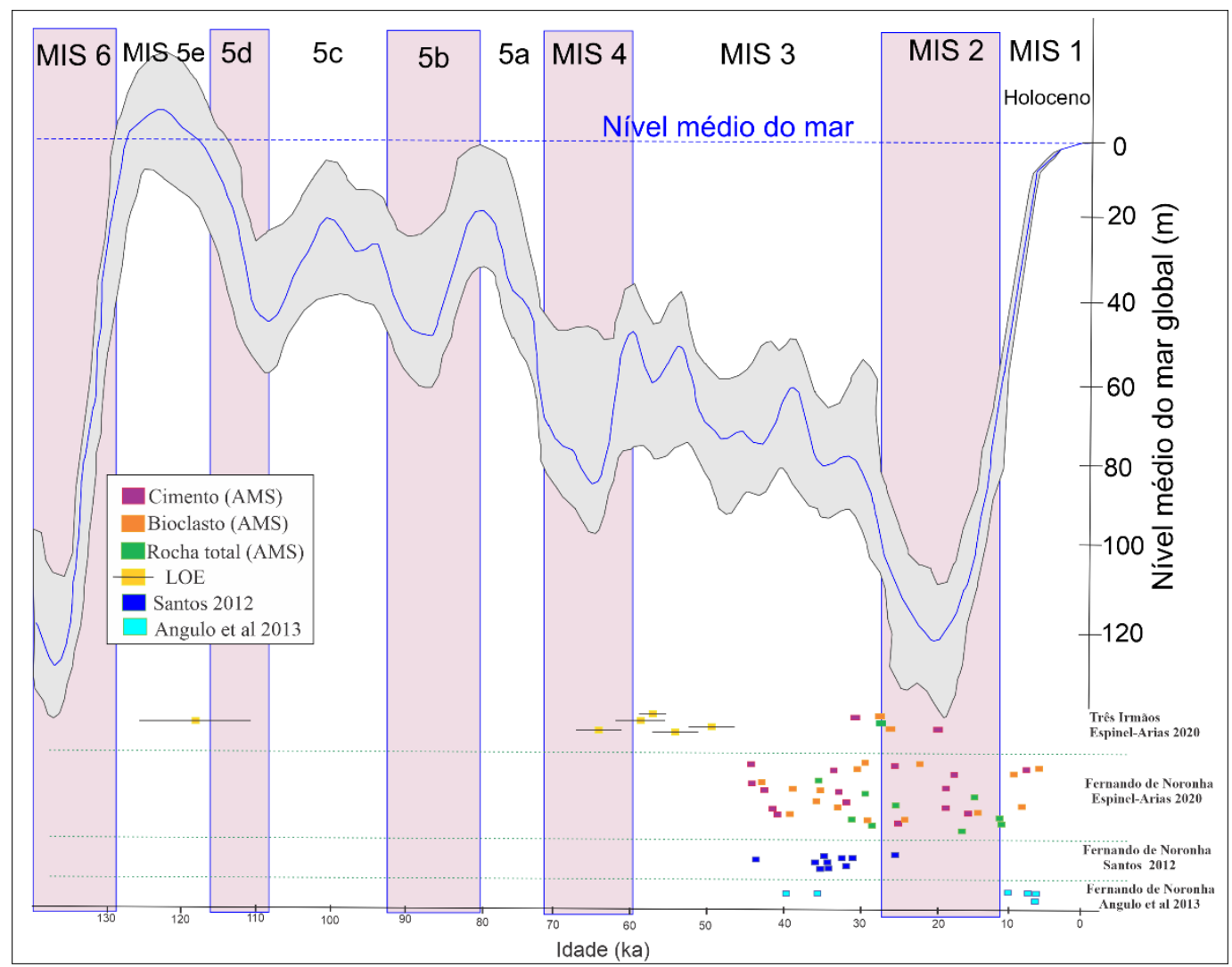

Fig. 6.24. Curva-envelope global da variação do NRM de Waelbroeck et al. (2002), com todas as idades, e respectivas margens de erro, dos eolianitos pleistocenos obtidas nesta pesquisa, tanto continentais (Três Irmãos) como insulares (AFN), mais as idades obtidas no AFN por Santos (2012) e Angulo et al. (2013).

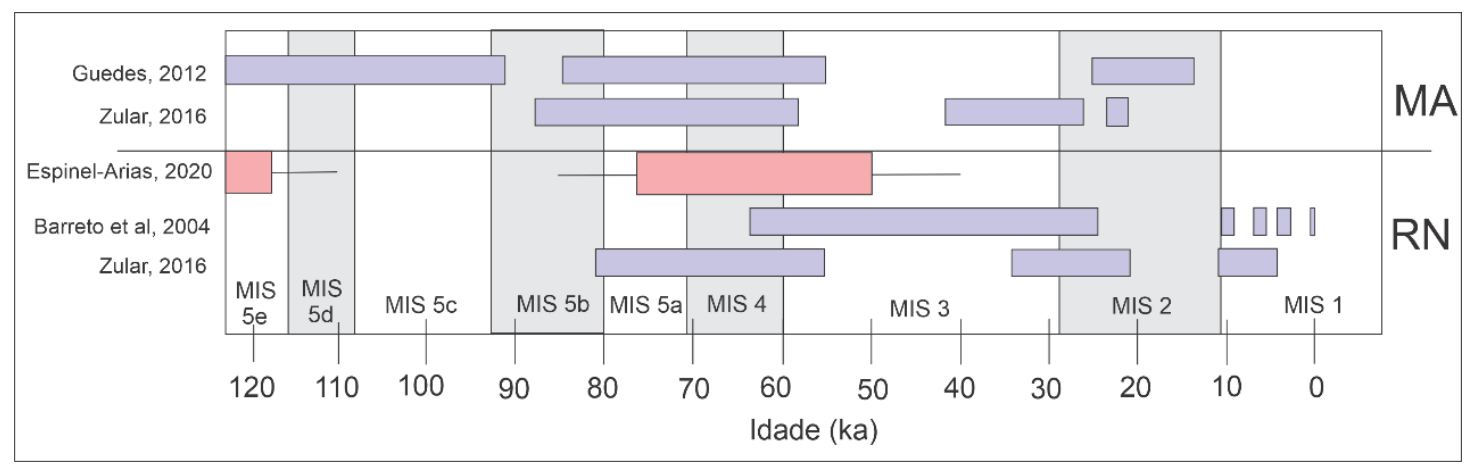

Fig. 6.25. Esquema cronológico comparando as idades LOE/TL de gerações de paleodunas eólicas costeiras terrígenas de idades pleistocenas de Maranhão e Rio Grande do Norte (Barreto et al. 2004, Guedes 2012, Zular 2016), na cor lilás, e as paleodunas carbonáticas (eolianitos) de Três Irmãos (RN), na cor rosa (com a linha preta que marca a margem de erro). 
Os eolianitos holocenos da costa continental nordeste brasileira apresentam idades entre 7,1 ka e 14 anos, com maior concentração ( $86 \%$ das idades) nos últimos 3,3 ka (Fig. 6.26). No RN, notam-se duas modas de idades LOE, entre 3,0 e 1,5 ka e entre 82 e 14 anos, esta segunda porém representada por eolianitos menos consolidados (Tabela 3, Fig. 6.26). Moda semelhante à mais antiga (entre 3,2 e 0,8 ka) já fora detectada no PI e CE (Espinel-Arias et al. 2015). Assim, o período principal de formação dos eolianitos melhor consolidados no Nordeste incide em época de NRM até $3 \mathrm{~m}$ mais alto que o atual no Ceará (Caldas et al. 2006, Vasconcelos et al. 2014) e na costa brasileira entre Pernambuco e a latitude $28^{\circ} \mathrm{S}$ (Angulo et al. 2006). Os sedimentos eólicos foram portanto depositados em trato de mar alto, com NRM em declínio suave (Fig. 6.26). Depósitos eólicos siliciclásticos cronocorrelatos aos eolianitos de PI, CE e RN incluem as gerações de dunas D3, D2 e D1 definidas por Claudino Sales (2002) no CE, as "formas nítidas", interpretadas como dunas parabólicas compostas antigas e ativas por Barreto et al. (2004) no RN, e os depósitos "recentes" identificados por Guedes (2012) e Guedes et al. (2011a,b, 2013, 2017) no MA, com atividade contínua desde pelo menos 6,5 ka até hoje (Fig. 6.27); as idades ${ }^{14} \mathrm{C}$ de até $7 \mathrm{ka} \mathrm{AP}$, obtidas em bioclastos, sugerem a erosão da plataforma carbonática a partir desta data, que marca aproximadamente o alcance do nível do mar similar ao atual, reforçando a hipótese de formação de sistemas eólicos terrígenos e carbonáticos em condição de NRM estável ou caindo suavemente; esta suposição contraria as interpretações de Maia et al. (1997) e Carvalho et al. (2008) segundo as quais os eolianitos do Nordeste brasileiro se formam em condições transgressivas, sob nível do mar mais baixo que o atual, e que sua fonte imediata é a plataforma continental hoje submersa. Em contraposição a esta interpretação, Espinel-Arias et al. (2015) evidenciam que as porcentagens de carbonato nos eolianitos de PI e CE são mais parecidas com as das praias atuais (com teores de até $26 \%$ ) de que com a plataforma carbonática submersa (50\%, segundo Kowsmann \& Costa 1979); mesma relação se observa no RN, onde os teores de carbonatos são de até $28 \%$ nos eolianitos e de até $21 \%$ nas fácies associadas (Tabelas 6 e 8).

Desse modo, a distribuição de idades dos eolianitos holocenos do Brasil não é diferente dos de outras partes do mundo, tais como Bahamas, com idades de formação entre 5ka e 0,5ka (Kindler 1992; Mylroie 2008 e Deely et al. 2011), Chipre, com idades LOE em torno de 1,5 ka (Erginal et al. 2011), Austrália, com idades LOE de 4,1 ka a 0,5 ka (Lipar et al. 2017; Lipar \& Webb 2014) e Tunísia, com idades ${ }^{14} \mathrm{C}$ de até 8 ka (Fréboug 
et al. 2010). Este conjunto de dados sugere que a deposição global dos eolianitos durante o Holoceno deu-se a partir de 8-7ka, quando o NRM teve sua taxa de subida desacelerada.

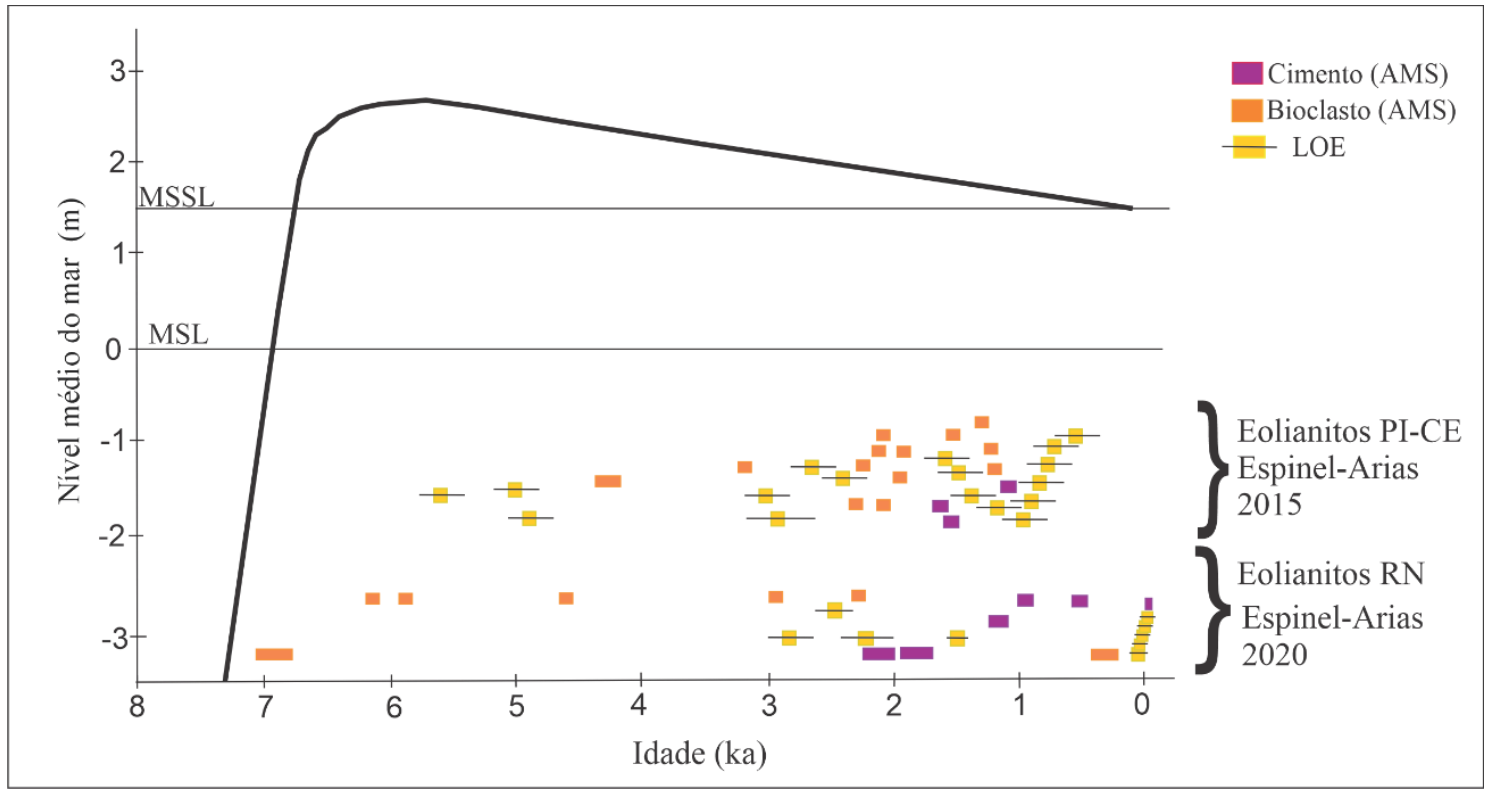

Fig. 6.26. Idades dos eolianitos continentais holocenos do Nordeste, incluindo dados de Espinel-Arias (2015), lançadas junto à curva do NRM de Caldas et al. (2006), para o Rio Grande do Norte. Notar maior concentração entre 3000 anos e 600 anos

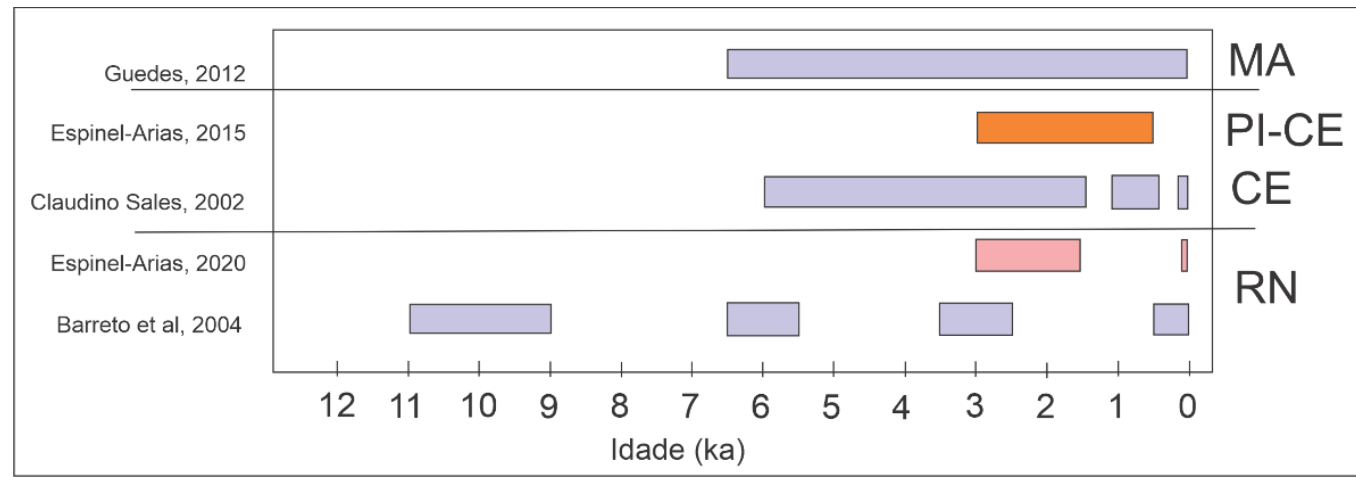

Fig. 6.27. Esquema cronológico comparando as idades LOE/TL de gerações de paleodunas eólicas costeiras terrígenas de idades holocenas de Maranhão, Piauí, Ceará e Rio Grande do Norte (Barreto et al. 2004, Claudino Sales 2002, Guedes 2012, Guedes et al. 2013) na cor lilás, com os eolianitos do Piauí e Ceará (Espinel-Arias 2015) na cor laranja, e do Rio Grande do Norte, na cor rosa.

\subsubsection{Idades vs clima}

O fator climático é um dos principais controles ativos na formação de eolianitos. Isto se dá em escala regional, através da ação das ondas que transportam os clastos carbonáticos e do clima pouco úmido e ventoso que permite seu transporte eólico; e se dá 
também em escala global, ligada à posição e mudanças da ZCIT e das faixas subtropicais de alta pressão, controladoras dos ventos alísios que formam eolianitos em baixas latitudes, como os do Nordeste brasileiro. No Quaternário tardio, a posição da ZCIT é controlada por pelo menos dois fatores: o primeiro é a curva de insolação no hemisfério Sul, ligada ao ciclo astronômico de precessão; quando a insolação aumenta, a ZCIT desloca-se para sul, o que gera aumento de umidade em grande parte do continente sulamericano; em parte do Nordeste do Brasil, porém, por influência do fenômeno do Cavado do Nordeste, o deslocamento da ZCIT para sul em escala continental é acompanhado de um ligeiro deslocamento para norte em escala regional, o que significa afastamento da faixa de baixa pressão e alta umidade e, portanto, redução da precipitação pluviométrica; isto resulta em antifase de umidade entre Sul-Sudeste e Nordeste do Brasil, bem demonstrada no Holoceno (Cruz et al. 2009). Outro fator que controla a posição da ZCIT é a AMOC, cuja redução parcial ou total de atividade afetaria a distribuição do calor no oceano Atlântico, com esfriamento das águas do Atlântico norte e expansão para sul das águas superficiais frias; com a propagação para a atmosfera da baixa temperatura das águas superficiais, a ZCIT desloca-se para o sul nesses momentos de AMOC enfraquecida (Peterson et al. 2000, Chiang \& Koutavos 2004); momentos de AMOC enfraquecida no Pleistoceno são correlacionados aos eventos estadiais Heinrich, ou HS (Clement \& Peterson 2008), os quais, em grande parte do hemisfério Sul, correspondem a períodos mais quentes e chuvosos.

Com base nas idades LOE e suas margens de erro, a formação dos eolianitos continentais de Três Irmãos estende-se no período entre 86 ka e 40 ka, o qual abarca até quatro eventos Heinrich (HS7b, HS7a, HS6 e HS5) e termina por volta de um quinto, o HS4 (Fig. 6.28); admitindo que a antifase entre variação cíclica de insolação e a precipitação no Nordeste do país, descrita por Cruz et al. (2009) para o Holoceno do RN, seja válida também para o Pleistoceno Tardio, o Nordeste brasileiro teria experimentado nesse intervalo de tempo dois picos de queda de precipitação, em tese favoráveis à formação de dunas eólicas, um bem no início do intervalo e outro no meio, por volta de $67 \mathrm{ka}$; inversamente, picos de umidade, fora os relacionados aos eventos HS, teriam ocorrido aproximadamente em 80 e $55 \mathrm{ka}$; desse modo, é possível supor que grande parte das dunas carbonáticas tenha-se formado no período de aridez crescente do meio do intervalo, com auge em $67 \mathrm{ka}$, e sido estabilizada com o aumento de umidade de $55 \mathrm{ka}$ e/ou com os dois eventos Heinrich (HS5 e HS4) que o sucederam. Deve-se lembrar 
também que o aumento de precipitação pode implicar aumento de aporte sedimentar continental e da taxa de progradação e isto pode ter efeito desfavorável adicional à acumulação eólica costeira (Giannini et al. 2014, Rodrigues et al. 2020), ainda que este raciocínio seja mais aplicável a dunas terrígenas que carbonáticas. Os depósitos eólicos terrígenos cronocorrelatos a estes eolianitos no RN correspondem a G1 de Zular (2016) (Quadro 3, Fig. 6.25), que é a de maior taxa de acumulação eólica segundo dados do autor. Esta correlação confirma a favorabilidade à formação de dunas em escala regional nessa época, independentemente da constituição, se terrígena ou carbonática. Se a deposição eólica pode ser ajudada pela aridez, a acumulação e preservação eólicas seriam favorecidas pela incidência de eventos de estabilização, sob umidade elevada, a qual ajudaria também no desenvolvimento de vegetação capaz de bloquear o avanço das dunas e empilhar seus sedimentos (Rodrigues et al. 2020). A presença abundante de rizoconcreções nos eolianitos reforça a hipótese de que a estabilização se deu em períodos de aumento de precipitação e, portanto, de cobertura vegetal, sem descartar-se a possibilidade de contribuição da vegetação na própria estabilização (Fig 6.29). Os resultados de datação ${ }^{14} \mathrm{C}$ dos eolianitos de Três Irmãos, representativos de idade de cimentação, apresentam-se concentrados num período (entre 30ka e 20ka; Tabela 3) de umidade relativamente baixa na Região Nordeste (Liu et al. 2009, Zhang et al. 2015, Mendes et al. 2019), mas que abrange dois episódios curtos de aumento de umidade, o HS3 e o HS2. Isso permite defender a hipótese de que a precipitação dos cimentos se deu em período de umidade relativamente baixa e que os episódios curtos de aumento de precipitação teriam permitido a dissolução de carbonato, principalmente no início do período. 


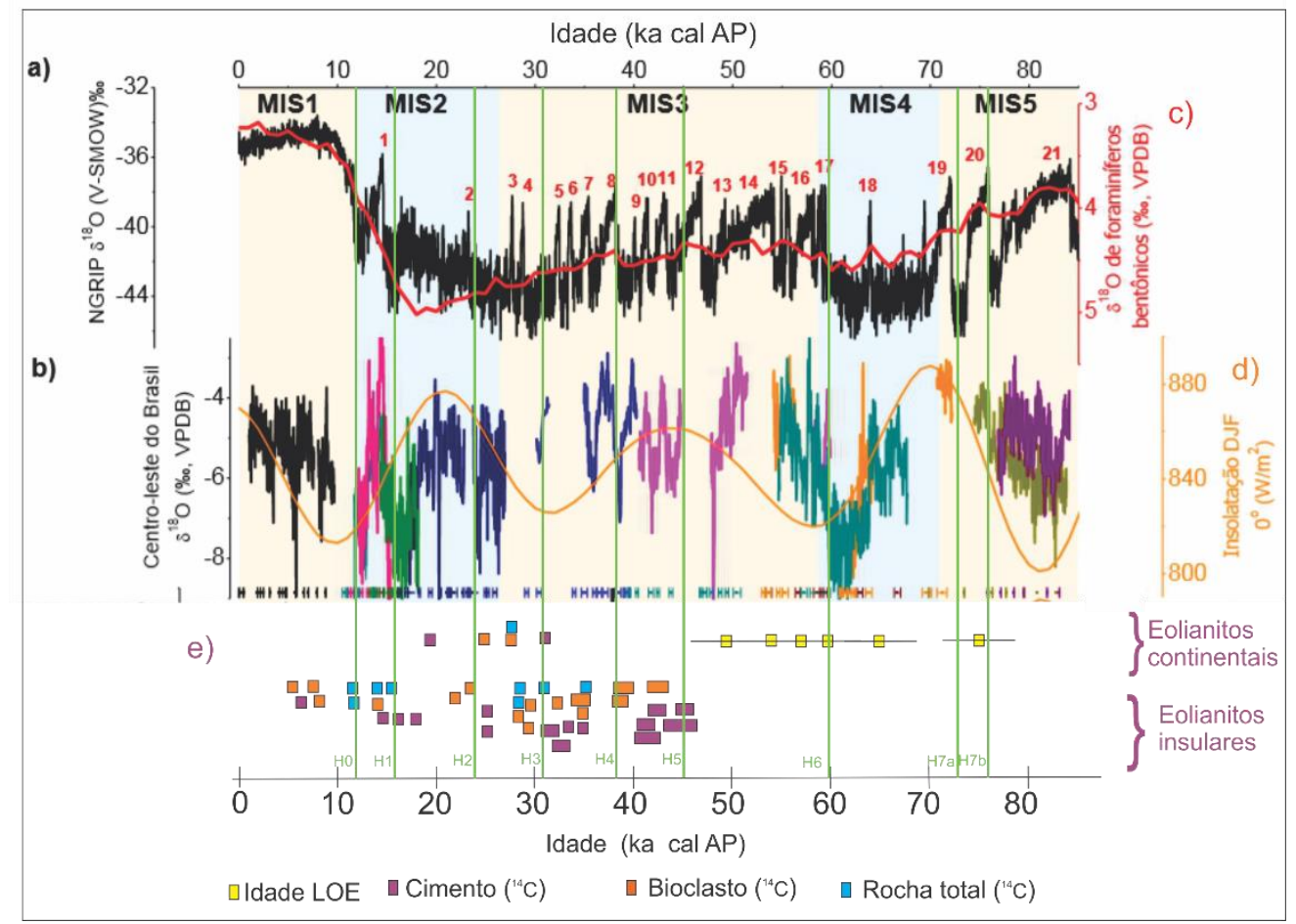

Fig. 6.28. Comparação entre idades de eolianitos e indicadores paleoclimáticos para os últimos $85 \mathrm{ka}$ : a) registro de $\delta^{18} \mathrm{O}$ do testemunho de gelo NGRIP (North Greenland Ice Core Project Members, 2004); b) registro de $\delta^{18} \mathrm{O}$ em espeleotemas das cavernas Lapa Grande e Lapa Sem Fim, centro-leste do Brasil (Strikis 2015); c) curva dos estágios marinhos isotópicos (MIS) baseada em $\delta^{18} \mathrm{O}$ em foraminiferos bentônicos (Lisiecki \& Raymo 2005); d) curva de insolação média de dezembro a fevereiro para a latitude $10^{\circ} \mathrm{S}$ (Berger \& Loutre 1991); e) idades dos eolianitos continentais e insulares brasileiros (presente estudo). Os números em vermelho referem-se aos eventos Greenland Interestadial (GI) de acordo com a revisão estratigráfica de Rasmmussen et al. (2004). Modificado de Strikis (2015). 

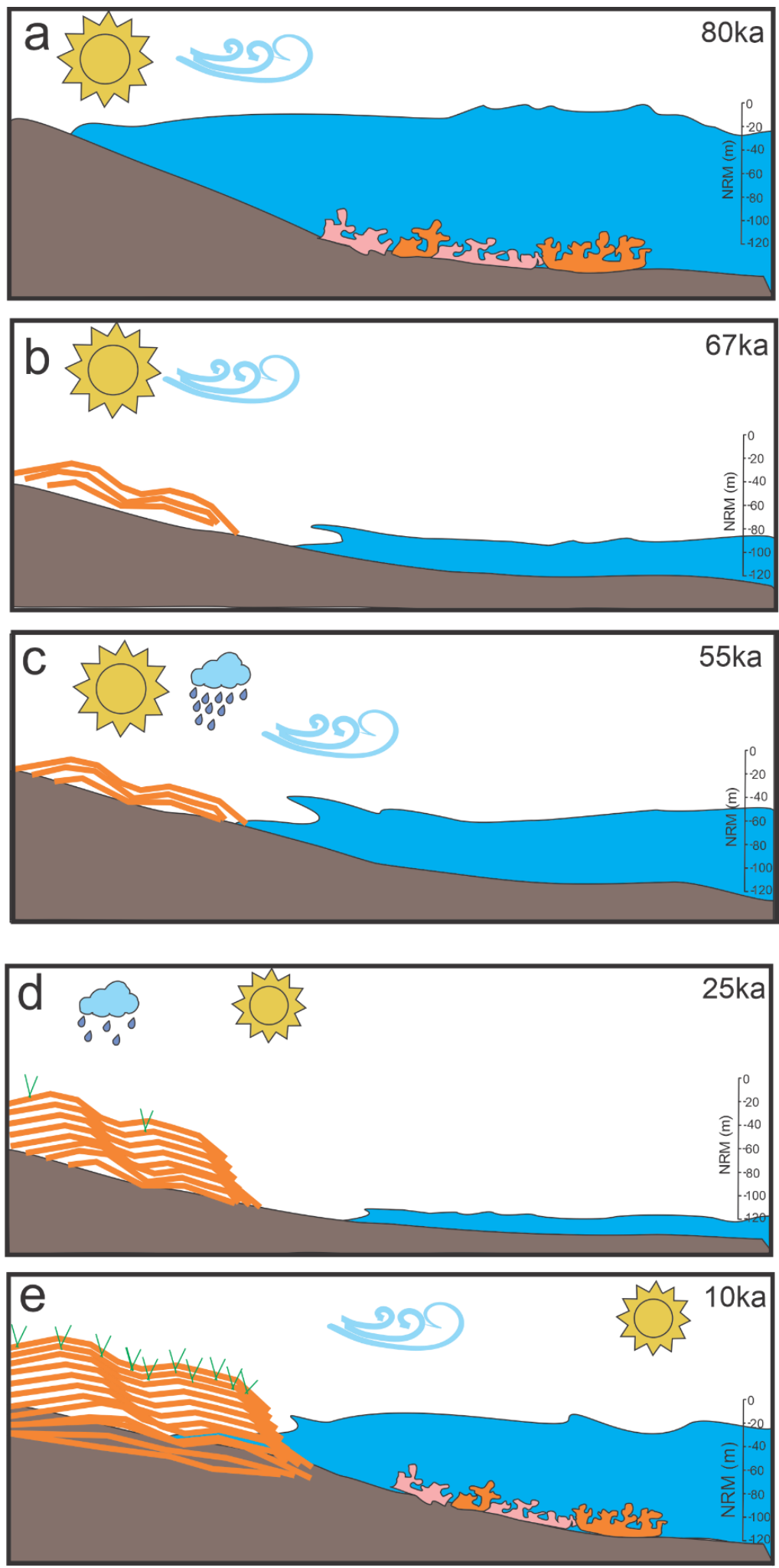

Fig. 6.29. Estágios de formação dos eolianitos de Três Irmãos, Rio Grande do Norte: a. proliferação de organismos de carapaça calcária e possível início da deposição eólica, por volta do MIS 5a; b. NRM em descenso e continuação da deposição eólica; c. aumento do NRM no período interglacial MIS 3; d. período glacial (MIS 2), com queda de temperatura e aumento de precipitação, favorecendo dissolução de carbonatos e estabilização por vegetação; e. transgressão holocena no período interglacial com climas mais cálidos favorecendo a formação de cimento de calcita. 
Dos eolianitos insulares, pode-se dizer, que, mesmo também apresentando idades pleistocenas, a exemplo dos eolianitos continentais de Três Irmãos, climaticamente podem não se correlacionar com eles de modo tão direto; isto porque o $\mathrm{AFN}$, apesar de também localizado sob influência da ZCIT, encontra-se mais afastado do desvio desta zona para norte pelo Cavado do Nordeste; e, além disso, em regime climático mais oceânico; é possível que estes dois fatores contribuam para uma maior estabilidade na precipitação no AFN (Fig. 3.11). Conforme já discutido no item anterior, os eolianitos de AFN apresentam principalmente idades de cimentação e duas possíveis idades de deposição (EFN 06B e EFN 15A, Tabela 4), as quais incidem no trato de mar alto do MIS 3, em consonância com a ideia de maior favorabilidade de formação de eolianitos nos interglaciais (Brooke 2001). A moda de idades mais antiga (entre 46 e $22 \mathrm{ka} \mathrm{cal} \mathrm{AP),}$ melhor representada nos afloramentos altos, e na qual se incluem as duas possíveis idades de deposição, começa próximo a um pico de elevada insolação no hemisfério Sul e, presumivelmente, de baixa umidade no Nordeste do Brasil, pelo menos na sua porção mais influencada pelo cavado, e termina pouco depois de um pico de insolação oposto (Fig. 6.31b). A segunda moda (entre 18,7 ka cal AP e 5,3 ka cal AP), melhor representada em afloramentos baixos e em rampas de barlavento, começa analogamente num momento de insolação alta e presumível umidade baixa e termina pouco depois do máximo subsequente de umidade do ciclo de insolação de precessão (Liu et al. 2009, Zhang et al. 2015, Mendes et al. 2019; Fig. 6.31c). A presença de feições petrográficas sugestivas de condições freáticas nesses afloramentos (item 5.7.2, Fig. 5.89a) é compatível com o aumento de saturação dos poros sob precipitação crescente, ainda que com indícios também de influência marinha (e.g. valores mas altos de $\delta^{13} \mathrm{C}$ ). Uma vez que se trata sobretudo de idades de cimentação, o que o padrão encontrado em ambas as modas aponta é que o início da formação dos cimentos se dá em condições de maior aridez, mas a precipitação pode ter prosseguido sob umidade crescente, talvez envolvendo dissolução e reprecipitação, o que ajuda a explicar a formação e preenchimento de porosidades moldicas. Um bom modelo para a primeira moda é o de que o cimento intergranular se forma de modo precoce sob clima menos úmido, provavelmente ainda durante a sedimentação eólica; a dissolução móldica ocorreria em seguida, na fase de aumento e de auge de umidade; e o preenchimento móldico ao final, já no início do novo ciclo de queda de umidade. O mesmo modelo se aplica à segunda moda, só que nesse caso sem evidências conclusivas até agora de deposição eólica. Neste caso, o inicio da cimentação 
poderia estar ligado ao pico de aridez e o final à saturação por águas salinas, ligadas ao aumento do NRM rumo ao MIS 1 e à trangressão da costa, o que ajuda a explicar a ocorrência preferencial desta moda nos afloramentos baixos. As rizoconcreções presentes principalmente no topo de todos os afloramentos demonstram o favorecimento da colonização vegetal com o estabelecimento de condições mais úmidas ao final da sedimentação e no decorrer da diagênese (Fig 6.30).
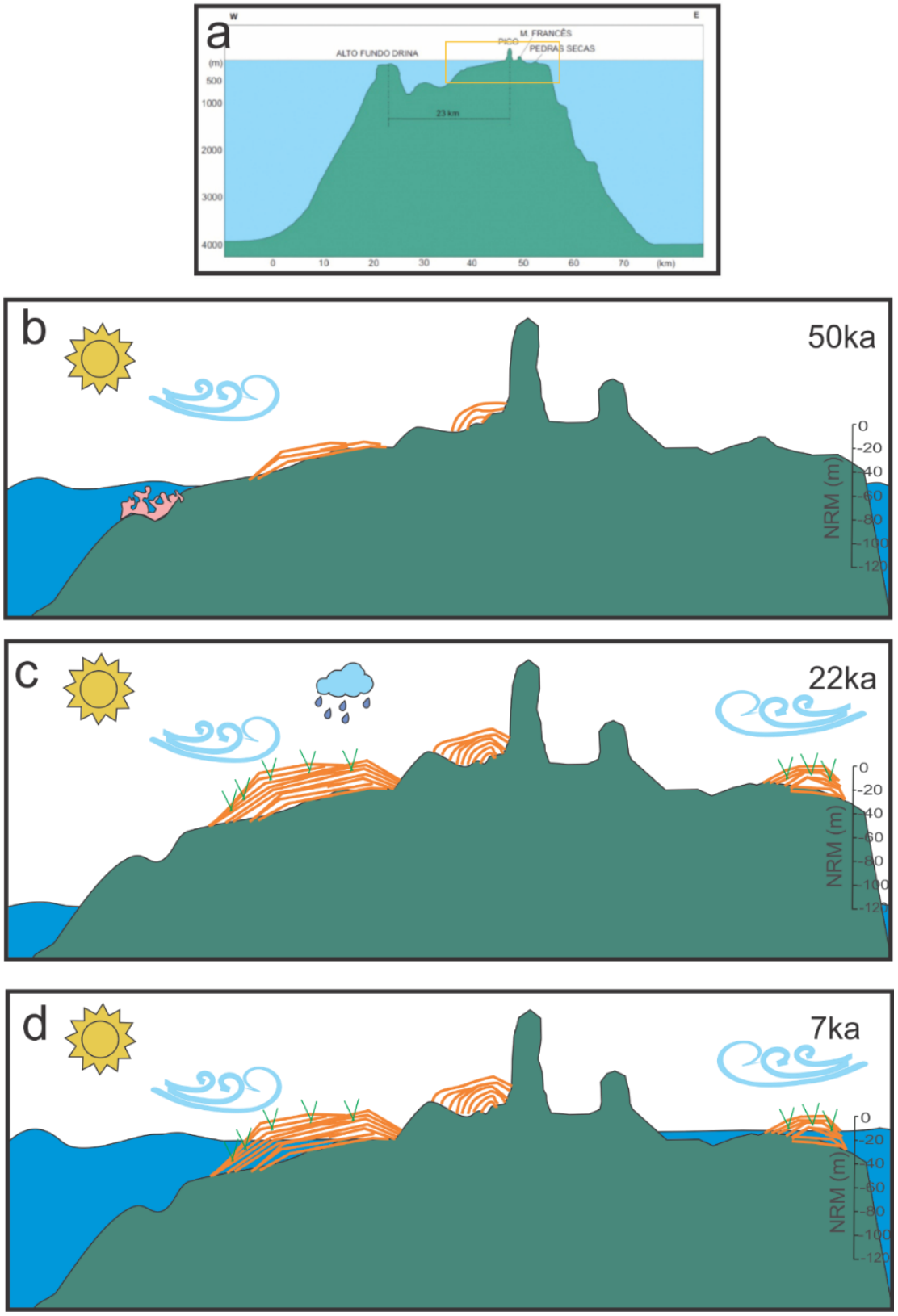

Fig. 6.30. Estágios de formação de eolianitos insulares: a. desenho esquemático da plataforma carbonatica de AFN (Teixeira et al. 2003), com destaque para a área de estudo (retângulo laranja); b. inicio da proliferação de organismos e deposicao dos eolianitos durante o MIS 3; c. descida do NRM e aumento de unidade, favorecendo a estabilização por vegetação;e

d. estabilização do NRM e processos de cimentação em periodos mais áridos. 
Os eolianitos continentais holocenos concentram-se nos intervalos de idades entre 3,0 ka e 1,5 ka, e, os menos consolidados, entre 82 e 14 anos; pelo menos a primeira moda de idades enquadra-se na fase de umidade mais baixa no Holoceno do Nordeste brasileiro (Liu et al. 2009, Zhang et al. 2015, Mendes et al. 2019), ligada ao deslocamento da ZCIT rumo sul por aumento de insolação no hemisfério Sul (Peterson et al. 2000) e registrada inclusive nos dados de $\delta^{18} \mathrm{O}$ em espeleotemas do RN (Cruz et al. 2009). Neste contexto de relativa aridificação, a ação eólica e a precipitação de cimentos carbonáticos por evaporação teriam sido ambas favorecidas, levando ao principal estágio de formação de eolianitos continentais holocenos. A moda de 3,0 ka a 1,5 ka atrás situa-se também entre os picos de umidade correlatos aos eventos Bond 2 e Bond 1 (Fig.6.31), ainda que este último não tenha sido detectado nos espeleotemas do centro-leste do Brasil por Strikis et al. (2011). Nos eventos Heinrich (HS) e Bond (BS), diferentemente do que ocorre nos ciclos de precessão, o aumento de umidade no hemisfério Sul gerado pelo deslocamento da ZCIT para sul, por ser controlado por outros tipos de mecanismos, tais como enfraquecimento da AMOC (HS) e queda da atividade solar (BS), geram não somente intensificação da SMAS como também elevação da umidade em grande parte do continente sul-americano, inclusive no Nordeste do Brasil (Cruz et al. 2009, Stríkis et al. 2011, Mulitza et al. 2017). O aumento de precipitação e a queda de ventosidade durante esses eventos favorecem, em tese, a redução do transporte eólico e o aumento da cobertura vegetal e, com isso, podem afetar a morfodinâmica de sistemas eólicos e levar à sua estabilização, como evidenciado na região dos Lençóis Maranhenses no HS1 (Guedes et al. 2017); o desenvolvimento de elementos morfológicos vegetados seria favorecido nesta condição, e sua expansão, além de certos limites, pode levar à estabilização dos campos de dunas. Em vista deste mecanismo, períodos de estabilização têm sido associados ao aumento de vegetação em períodos úmidos (Kocurek 1998, Young \& Young 2002, Fitzsimmons et al. 2009), e, segundo alguns autores (Ashkenazy et al. 2012, Chase 2009, Tsoar e Blumberg 2002, Tsoar 1990, 2005, 2008), a perda de força do vento pode ser o principal controle da estabilização de dunas por vegetação, sobretudo em condições de pluviosidade abaixo de $50 \mathrm{~mm}$ ano $^{-1}$. Nestas condições, a estabilização das dunas através de vegetação pode ocorrer (Ashkenazy et al. 2012, Yizhag et al. 2009) desde que o aporte eólico caia por enfraquecimento dos ventos e/ou baixa disponibilidade de sedimentos na área fonte (Fig 6.31). 
Além disso, no caso especifico dos eolianitos, o aumento de precipitação nos eventos Bond pode facilitar a dissolução de carbonatos; o bicarbonato então colocado em solução na água intersticial levaria à precipitação de cimentos nos estágios mais áridos subsequentes. Os cimentos carbonáticos nos eolianitos continentais apresentam idades ${ }^{14} \mathrm{C}$ mais novas que $2,1 \mathrm{ka}$ cal $\mathrm{AP}$, o que está dentro do período mais seco da Região Nordeste relacionado ao ciclo de insolação de alta precessão de insolação e, ao mesmo tempo, dentro do pós-Bond 2. Outro período de menos umidade ocorreria pós-Bond 0, até o presente, evidenciado no eolianitos sem rizoconcreções formados nos últimos 100 anos (Fig. 6.32).

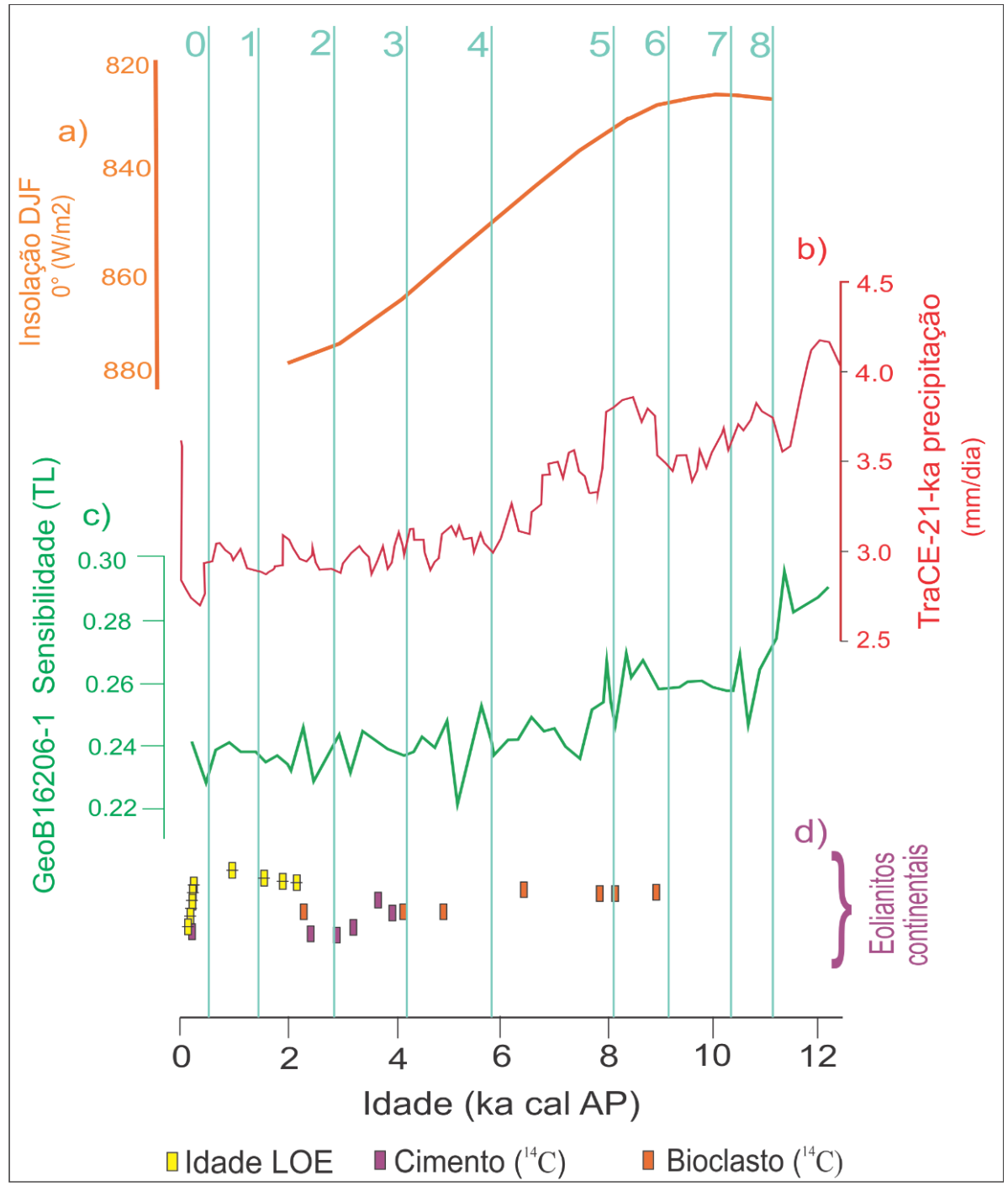

Fig. 6.31. Comparação entre idades de eolianitos e indicadores paleoclimáticos para o Holoceno: a. curva de insolação média de dezembro a fevereiro para a latitude $10^{\circ} \mathrm{S}$ (Berger \& Loutre 1991)b. precipitação modelada sobre o Nordeste do Brasil (TraCE-21ka, Liu et al., 2009), c Sensibilidade à termoluminescência (TL) do núcleo de sedimento marinho (GeoB16206-1, Mendes et al. 2019); d. idades dos eolianitos continentais do Rio Grande do Norte. As linhas azuis representam os eventos Bond (Bond et al. 1997), numerados de 0 a 8. 

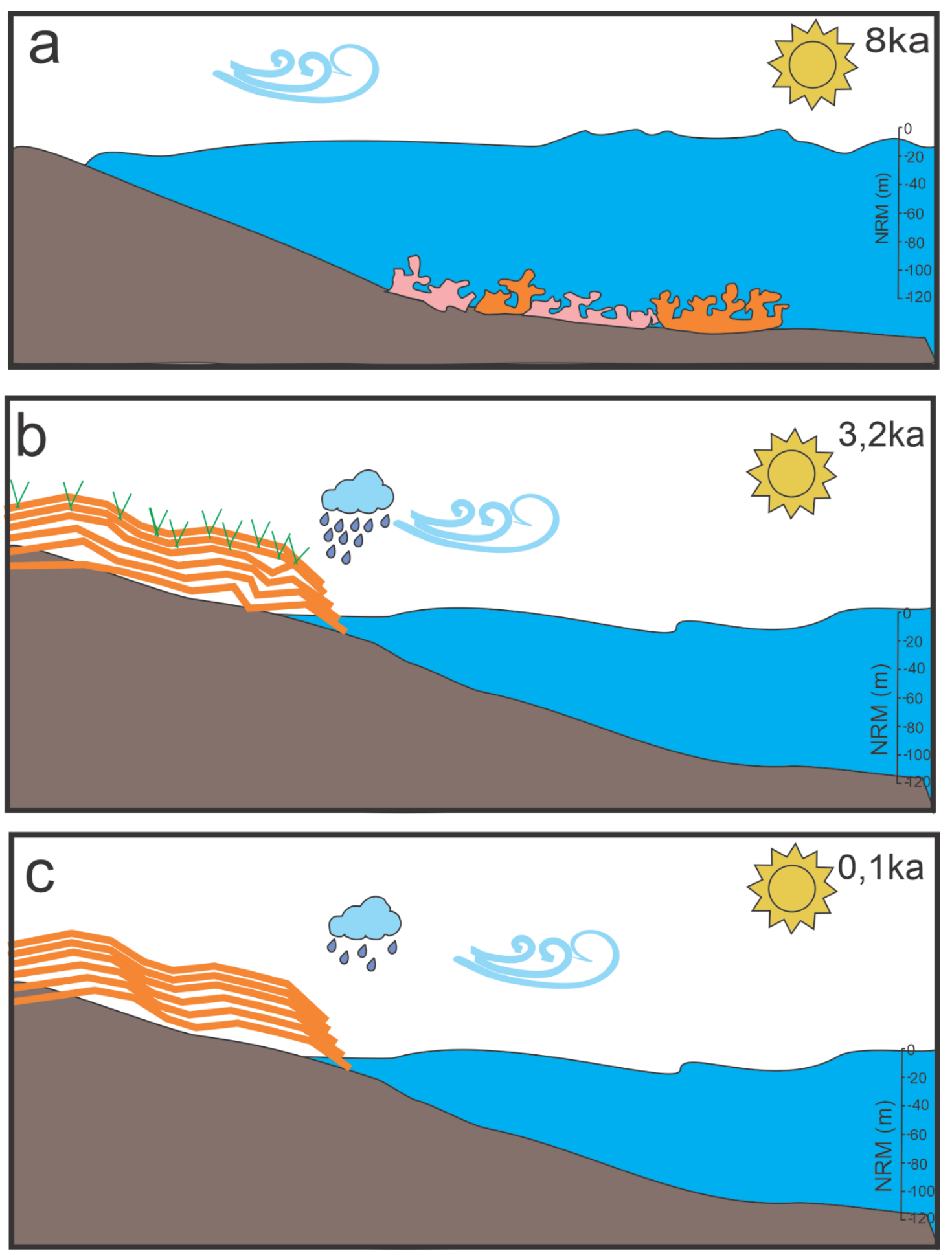

Fig. 6.32. Estágios de formação dos eolianitos continentais holocenos: a. transgressão holocena, que favoreceu a proliferação de organismos de carapaça carbonática; $\mathbf{b}$. leve descenso do NRM, com aumento de umidade, o que favoreceu a colonização vegetal e a estabilização das dunas; $\mathbf{c}$. formação dos eolianitos mais recentes. 


\section{CONCLUSÕES}

Com base nos resultados obtidos e discutidos nesta pesquisa de doutorado, e tendo em vista responder às questões colocadas na introdução da tese, podem-se listar as seguintes conclusões:

- O Nordeste brasileiro apresenta eolianitos quaternários em dois cenários diferentes, continental (PI, CE e RN) e insular (AFN), o que determina contrastes quanto a área fonte, espaço de acumulação, morfologia, fácies deposicionais e composição.

- Quanto à área fonte, os eolianitos continentais estão associados a plataforma carbonática em rampa, de margem passiva, enquanto os insulares do AFN associam-se a plataforma isolada esculpida, em sucessivos níveis do mar altos correspondentes a interglaciais quaternários, pela ação de abrasão marinha sobre rochas piroclásticovulcânicas.

- O espaço de acumulação eólica amplo nos sistemas eólicos da costa continental favorece o espalhamento das areias, com desenvolvimento de planícies de deflação extensas, enquanto o espaço restrito e acidentado nos sistemas insulares favorece a desaceleração rápida do vento e o bloqueio do transporte sedimentar, com a colmatação de irregularidades topográficas por areia eólica.

- Por decorrência, a associação de fácies de planície deflacionária é tão bem ou melhor representada que a de campo de dunas nos sistemas de costa continental, e sobretudo nos eolianitos, ao contrário do que acontece nos insulares. As fácies de barlavento, como rampas de areia eólica, e as de dunas empoleiradas, são muito mais presentes nos eolianitos insulares que nos continentais.

- Quanto à composição, os eolianitos continentais são mistos (extra e intrabacinas), com quartzo como mineral principal, enquanto os insulares são dominantemente carbonáticos, com boa presença de minerais pesados dentre os extrabacinais.

- O comprimento da planície deflacionária dos sistemas eólicos costeiros ativos nas áreas de ocorrência de eolianitos continentais aumenta com o ângulo entre a linha de costa e a direção do vento efetivo; a exceção, encontrada na Praia do Marco, pode estar 
relacionada com a mudança local de direção da costa, esta talvez ligada à erosão recente observada em imagens de satélite e confirmada em campo.

- Os corpos de eolianitos continentais encontram-se em meio às planícies deflacionárias ativas, principalmente na forma de rastros lineares residuais, os quais são paralelos à direção do vento efetivo atual; os eolianitos são dominados por fácies deposicionais com estratificação cruzada de ângulo baixo, atribuídas à deposição concordante com a crista aplainada do rastro linear, às vezes com rizoconcreções que indicam a estabilização por vegetação.

- Razões de minerais pesados indicadoras de transporte (ZTi) são menores nos eolianitos continentais do RN de que nos do PI, o que pode ser atribuído a maior proximidade da área fonte praial.

- A ocorrência preferencial de eolianitos continentais em fácies de planície deflacionária não tem relação com a concentração de bioclastos carbonáticos nos sedimentos dessa associação de fácies ou nas porções mais proximais do sistema eólico. Pelo contrário, nos eolianitos do RN, o teor de carbonatos aumenta com a distância à praia. A variação sazonal do freático e da cobertura vegetal na planície de deflação deve ser um dos fatores favoráveis à formação e preservação dos eolianitos nessas porções do sistema.

- Os eolianitos insulares localizam-se a até poucas centenas de metros da linha de costa atual, em afloramentos de até 30m de espessura, com predomínio de fácies deposicionais com estratificação cruzada de ângulo alto e/ou sigmoide, atribuídas ao cavalgamento dos sedimentos sobre o embasamento piroclástico-vulcânico, em condição de escassa área de acumulação eólica.

- Os afloramentos insulares baixos tendem a apresentar espessuras menores e séries de estratificações cruzadas mais extensas, em vista do maior espaço para livre migração das formas de leito eólicas por sobre plataformas de abrasão.

- O conjunto de idades LOE e ${ }^{14} \mathrm{C}$ obtidas nos eolianitos insulares e continentais abrange, em ambos, o Pleistoceno Tardio e o Holoceno. Inversão sistemática de idades ${ }^{14} \mathrm{C}$ entre bioclastos e cimentos de cada amostra, nos depósitos continentais com datações do Pleistoceno e nos insulares em geral, sugere história diagenética complexa, com precipitação de cimento intergranular, seguida de dissolução móldica, principalmente da 
calcita-Mg das algas vermelhas, e de nova fase de cimentação, agora preenchendo a porosidade móldica.

- Fácies de beach rocks, associadas como substrato à parte dos eolianitos continentais holocenos do $\mathrm{RN}$, foram atribuídas a antepraia superior e berma e permitiram interpretar paleonível marinho 2,4 $\pm 1,5 \mathrm{~m}$ acima do atual; no caso do eolianito pleistoceno de Três Irmãos, os beach rocks apresentam fácies inferior intraclástica e fácies superior intensamente zooturbada por Thalassinoides, atribuídos a ação de crustáceos marinhos em fundo raso, estável e oxigenado; o contato desta fácies sob o eolianito encontra-se 3,8 a 4,3 m acima do nível médio do mar atual.

- As idades obtidas nos eolianitos continentais (PI, CE e RN) são dominantemente holocenas, entre 3,0 ka e 0,6 ka, com resultados de LOE indicativos também de eolianitos mais recentes (entre 82 e 14 anos, em RN), porém muito fracamente consolidados; idades pleistocenas foram obtidas somente no conjunto de afloramentos de Três Irmãos (resultado de datação LOE em amostras não saturadas de até $80 \mathrm{ka}$ ), que se distingue dos demais pelo maior grau de consolidação e pela ocorrência na forma de falésias costeiras.

- As idades dos eolianitos continentais pleistocenos e o paleonível marinho das fácies de água rasa a eles sotopostas permitem interpretar sua formação após o nível do mar mais alto do MIS 5.

- As idades dos eolianitos continentais holocenos indicam deposição em trato de mar alto, isto é, na fase de relativa estabilização posterior ao nível máximo, atingido por volta de $6 \mathrm{ka}$.

- Os eolianitos continentais são cronocorrelatos a gerações de depósitos eólicos terrígenos da Região Nordeste, principalmente durante momentos do nível relativo do mar mais baixo que o atual, e sua estabilização pode ser atribuída a ciclos ou episódios de aumento de precipitação e enfraquecimento dos ventos, com incremento de vegetação associada sugerido pela presença de rizoconcreções.

- O período de formação dos eolianitos continentais holocenos coincide com momento de deslocamento da ZCIT para o sul, controlado pelo ciclo de insolação de precessão, cuja resposta na Região Nordeste é a redução de umidade, favorecendo tanto o transporte e deposição pelo vento quanto a formação precoce de cimentos carbonáticos. A cimentação carbonática teria se dado essencialmente nos últimos 2,1 ka cal AP, o que 
está dentro do período de mais insolação na Região Nordeste no Holoceno e, ao mesmo tempo, dentro do pós-Bond 2.

- A presença frequente de rizoconcreções nos eolianitos continentais, indicando a presença de vegetação, pode ter um controle antes faciológico que climático, já que esses eolianitos se associam a planícies de deflação, que são as porções mais úmidas e vegetadas do sistema eólico. Por outro lado, a aparente redução de rizoconcreções nos eolianitos mais recentes (últimos 1000 anos) pode ter relação com a redução da cobertura vegetal por aridificação do clima.

- As idades ${ }^{14} \mathrm{C}$ dos eolianitos insulares variam do Pleistoceno Tardio ao Holoceno Médio, com duas modas cuja distribuição espacial sugere controle altimétrico e geográfico e indica eventos diagenéticos de cimentação-dissolução-reprecipitação, os quais ocorreram em diferentes épocas em porções distintas do arquipélago.

- Os eolianitos insulares mais antigos, pré-UMG, mais concentrados nos afloramentos altos, foram formados provavelmente durante o MIS 3, sem descartar a possiblidade de deposição em tratos de mar alto anteriores, como o MIS 5, enquanto os mais novos, que ocorrem em afloramentos baixos e em fácies de barlavento, têm idades de cimentação e pseudomorfismo correlatas à época de subida do NRM que levou ao MIS 1; não se encontraram evidências conclusivas de deposição eólica nesta segunda moda de idades.

- Os resultados de datação ${ }^{14} \mathrm{C}$ que apontam para idades holocenas nos eolianitos insulares abarcam não só o começo do trato de mar alto mas também o final do transgressivo; elas são anteriores à época de estabilização de NRM que caracteriza os últimos 6 ka no arquipélago e coincidentes com período de aumento de insolação e de aridez na Região Nordeste.

- Em termos de microfácies carbonática, tanto os eolianitos continentais quanto os insulares apresentam domínio de peloides e algas vermelhas, sendo os peloides possivelmente resultantes da alteração diagenética de bioclastos de algas vermelhas; esta composição permite enquadrá-los na Associação Photozoa ou Photozoa-T, como também ocorre em outros eolianitos de baixa latitude, por exemplo Bahamas, Havaí, Califórnia, Índia e México 
- Os eolianitos continentais apresentam granulometria entre areia média e areia fina, segregação granular, porosidade seletiva, eventualmente móldica, e tramas sugestivas de cimentação precoce, principalmente vadosa, ainda que com presença também de feições freáticas nos de idade pleistocena.

- Os eolianitos insulares apresentam porosidade seletiva frequentemente móldica e pelo menos duas gerações de cimento, formadas em condições meteóricas tanto vadosas como freáticas.

- A distribuição por idade das seis petrofácies identificadas indica que os eolianitos holocenos apresentam porosidades médias a muito altas (25-50\%) e cimentos geopetal, franjas anisópacas e menisco, o que sugere ambiente eodiagenético vadoso, enquanto nos pleistocenos as porosidades são principalmente médias (10-30\%) e os cimentos são mosaico, em franjas isópacas e anisópacas e em duas gerações, o que sugere ambientes freáticos intercalados com ambientes vadosos.

- Nos eolianitos continentais holocenos, a eodiagênese é restrita às porções superiores do depósito, em contato mais direto com os agentes da sedimentação e intemperismo, conforme evidenciado pela litificação mais intensa do topo dos afloramentos. Nos eolianitos continentais pleistocenos e nos insulares, a ocorrência de uma fase inicial de cimentação superficial, embora não evidenciada em afloramento, não pode ser descartada, haja visto o registro de idades ${ }^{14} \mathrm{C}$ mais antigas no topo que na base de uma mesma seção e a existência de pelo menos duas gerações de cimento.

- Estes resultados indicam que a cimentação precoce se dá inicialmente na superfície, onde provavelmente reduz a permeabilidade, avançando para baixo em seguida, de modo mais lento, via escoamento superficial das águas de chuva e/ou percolação através de raízes ou fraturas.

- O predomínio de textura micrítica a microespática na primeira geração de cimento indica precipitação rápida de carbonato, portanto em condições de elevada concentração de bicarbonato de cálcio na água intersticial, o que é favorecido por insaturação aquosa de poro; já a presença de espato em mosaico nos cimentos mais tardios aponta para precipitação lenta e baixa concentração de bicarbonato na água intersticial, o que pode estar ligado tanto a condição climática mais úmida quanto à circulação mais 
limitada da água de chuva nas porções cimentadas superiores do afloramento, sem tempo suficiente para o contato com os grãos e a colocação de bicarbonato em solução.

- Em afloramentos altos do AFN, os cimentos pseudomorfos de bioclastos de algas vermelhas, formados por preenchimento de poros móldicos, e os cimentos envolventes anteriores à dissolução móldica das algas apresentam baixos teores de $\mathrm{Mg}$, compatíveis com a hipótese de precipitação química a partir de água doce.

- Um modelo geral para a história diagenética dos eolianitos continentais pleistocenos e insulares é: cimentação intergranular precoce, dominantemente micrítica, sob clima relativamente pouco úmido, provavelmente ainda durante a sedimentação eólica; dissolução móldica em fase de aumento e/ou de auge de umidade; preenchimento móldico espático a microespático, no início do novo ciclo de queda de umidade. 


\section{REFERENCIAS BIBLIOGRÁFICAS}

Aalto, K.R., and Dill, R.F.1996. Late Pleistocene stratigraphy of a carbonate platform margin, Exumas, Bahamas: Sedimentary Geology, 103: 129-143

Aguiar, R.B. \& Gomes, J.R.C. 2004. Projeto cadastro de fontes de abastecimento por água subterránea. Diagnóstico do município de Luís Correia. Serviço Geológico do Brasil - CPRM.

Almeida, F. F. M. de. 1951. A propósito dos relêvos policiclicos na tectônica do escudo brasileiro. Boletim Paulista de Geografia, São Paulo, 9:3-18.

Almeida, F. F. M. De, 1955 Geologia e Petrologia do Arquipélago de Fernando de Noronha. DNPM, monografia XIII. 181p

Amado-Filho, G.A.; Moura, R.L., Bastos, A.C.; Salgado, L.T.; Sumida, P.Y.; Guth, A.Z., et al, 2012. Rhodolith beds are major $\mathrm{CaCO} 3$ Bio-factories in the tropical South West Atlantic. PLoS ONE 7(4): e35171.

Amarante, O.A.C.; Brower, M.; Zack, J.; Leite De Sa, A. 2002. Atlas do potencial eolico brasileiro, Brasilia, 44p

Ambrosio, B.G. 2019. Modelagem hidrodinâmica da porção setentrional do Arquipélago de Fernando de Noronha (PE): A influência da sazonalidade do clima de ondas. 289p Exame de Qualificação de Doutorado (inéd.): São Paulo, Instituto Oceanográfico-Universidade de São Paulo. 54p

Anderton, R. 1985. Clasticfacies models and facies analysis. In: Brenchley, P.J. \& Williams, B.P.J. eds. Recent Developments and Applied Aspects. Oxford, The Geological Society. - Blackwell Scientific Publishers.p.31-47.

Andrade, H.A.A. 2012. As Paleodunas e a Evolução Sedimentar da Planície Costeira da Pinheira, Palhoça - SC. Trabalho de Formatura São Paulo, Universidade de São Paulo, Instituto de Geociências, 50 p.

Andrews, J.T. 1998. Abrupt changes (Heinrich events) in late Quaternary North Atlantic marine environments: a history and review of data and concepts. Journal of Quaternary Science.13: 3-16

Angulo, R.J; Lessa, G.C; Souza, M.C. 2006.A critical review of mid- to late-Holocene sea-level fluctuations on the eastern Brazilian coastline.Quaternary Science Reviews, 25: 486-506.

Angulo, R.J.; Lessa, G.C.; Souza, M.C. 2009. The Holocene barrier systems of Paranaguá and northern Santa Catarina coasts, Southern Brazil. In: Sergio R. Dillenburg; Patrick A. Hesp. (Org.). Geology and Geomorphology of Holocene Coastal Barriers of Brazil. Lecture Notes in Earth Sciences. Berlin, Springer-Verlag, 2009, 107: 135176. 
Angulo, R.J; Souza, M.C; Fernandes L.A; Disaró, S.T. 2013A. quaternary sea-level changes and aeolianites in the fernando de noronha archipelago, northeastern brazil. Quaternary International 305: 15-30

Angulo, R. J; Souza, M. C; Campos, T.F.C. ; Bezerra, F.H.R. ; Fernandes, L.A; Giannini, P.C.F; Pitombo, F.B; Veiga, F.A. 2013B. Evidence for late Quaternary episodic uplift of the São Pedro and São Paulo Archipelago, Equatorial Atlantic. Quaternary International, p.102-111,

Angulo, R.J; Souza, M.C. 2015. Revisão conceitual de indicadores costeiros de paleoníveis marinho quaternários no Brasil. Quaternary and Environmental Geosciences 05(02) p.01-32.

Araujo, M.V. 2011. Modelo batimétrico da plataforma continental interna de AcaraúCeará-Brasil. Anais XV Simpósio Brasileiro de Sensoriamento Remoto - SBSR, Curitiba, PR, Brasil. INPE p.76-82

Arz, H.W., Patzold, J., Wefer, G. 1999. The deglacial history of the western tropical Atlantic as inferred from high resolution stable isotope records off northeastern Brazil. Earth and planetary Sciencie Letters, 167: 105-117.

Ashkenazy, Y. Yizhaq, H. Tsoar, H.. 2012 Sand dune mobility under climate change in the Kalahari and Australian deserts. Climatic Change. 112: 901-923

Bagnold, R.A. 1941. The physics of blown sand and desert dunes. London: Methuen. Progress in Physical geography: Earth and Environment. 18: 91-96

Baker, S., Diz, P., Vautravers, M.J., Pike, J., Knorr, G., Hall, I.R., Broecker, W.S. 2009. Interhemispheric Atlantic seesaw response during the last deglaciation. Nature, 457 (26): 1097-1103

Baptista, E.M.C. 2010. Estudo Morfosedimentar dos Recifes de Arenito da Zona Litorânea do Estado do Piauí, Brasil. Tese de Doutorado Universidade Federal de Santa Catarina, Centro de Filosofia e Ciências Humanas. Programa de PósGraduação em Geografia - Florianópolis, SC, 2010.

Barbosa, L.M. 1997. Campos de Dunas Costeiras Associados à Desembocadura do Rio São Francisco (SE/AL). Tese de Doutoramento (inéd.), Salvador, Instituto de Geociências da Universidade Federal da Bahia, 202 p.

Barreto, A.M.F, Suguio, K., Bezerra, F.H.R., Tatumi, S.H.. Yee, M., Giannini, P.C.F. 2004. Geologia e geomorfologia do Quaternário costeiro do Estado do Rio Grande do Norte. São Paulo, Geologia-Universidade de São Paulo, 4(2), 1-12.

Berger, A.; Loutre, M-F. 1991. Insolation values for the climate of the last 10 million years. Quaternary Science Reviews 10(4):297-317 
Bernat M; Martini L; Bittencourt,A.C.S.P.; Vilasboas G.S.1983. Datation Io/U du plus haut niveau marin interglaciairesur le côte du Brésil: Utilization $d u$ $229^{\mathrm{Th}}$ commetraceur. Comptes Rendus de L'Académie de Sciences de Paris, 296: 197-200.

Bezerra, F.H.R., Barreto, A.M.F., Suguio, K., 2003. Holocene sea level history on the Rio Grande do Norte State Coast, Brazil. Marine Geology 196: 73-89.

Bittencourt, A.C.S.P.; Martin, L.; Dominguez, J.M.L.; Ferreira, Y.A. 1982. Dados preliminares sobre a evolução paleogeográfica do Rio São Francisco - SE/AL, durante o Quaternário: influência das variações do nível do mar. In: Simpósio do Quaternário No Brasil, 4, Rio de Janeiro, RJ, 1981. Atas... Rio de Janeiro. p. 49-68.

Bond, G.C; Showers, W.; Cheseby, M.; Lotti, R.;Almasi, P.; Demenocal, P.; Priore, P.; Cullen, H.; Hajdas, I.; Bonani, G. 1997. A Pervasive Millennial-scale cycle in North Atlantic Holocene and glacial climates. Science $\mathbf{2 7 8}$

Bond, G.C; Showers, W.; Elliot, M.; Evans, M.; Lotti, R.; Hajdas, I.; Bonani, G.; Johnsen, S. 1999. The North Atlantic's 1-2 kyr climate rhythm: Relation to Heinrich events, Dansgaard/Oeschger cycles and the Little Ice Age, in mechanisms of Global Climate Change Milennial Time Scales, Geophysical Monograph 112 edited by P.U.Clarck, R.S. Webb and L.D.Keigwin, p 35-68, Washington D.C.

Borzone, C.A. \& J.R.B. Souza. 1996. A extração de corrupto, Callichirus major (Decapoda: Callianassidae) para uso como isca em praias do litoral do Paraná: Características da pesca. Nerítica, Curitiba, 10: 69-79.

Boski, T.; Angulo R.J.Souza, M.C.; Barboza, E.G.; Knicker, H.; González-Pérez, J.A.; González-Vila F.J. 2015. Progradation rates of coastal barriers estimated from the 14C age of soil organic matter. Journal of Quaternary Science, 30(1): 9-18

Botter-Carvalho M.L, Santos P.J.P \& Carvalho P.V.V.C. 2002. Spatial distribution of Callichirus major (Say, 1818) (Decapoda, Callianassidae) on a sandy beach, Piedade, Pernambuco, Brazil. Nauplius 10(2): 97-109

Broecker, W. S.; Peteet, D..M.; Rind, D. 1985. Does ocean-atmosphere system have more tan once stable mode of operation? Nature, 315: 21-26

Brooke, B. P.2001.The distribution of carbonate eolianites. Earth Science Reviews 55: $135-164$

Brooke, B.P., Olley, J.M., Pietsch, T., Payford, P.E., Haines, P.W., $\quad$ Murray-Wallace, C.V., Woodroffe, C.D., 2014. Chronology of Quaternary coastal aeolianite deposition and the drowned shorelines of southwestern Western Australia - a reappraisal. Quaternary Science Reviews. 93, 106-124.

Buatois, L. \& Mangano, M.G. 2011. Ichnology: Organism-substrate interactions in space and time. Geological Magazine, 149 (4): 750 
Buscombe, D. \& Masselink, G. 2006. Concepts in gravel beach dynamics. Earth-Science Reviews 79:33-52

Caetano-Filho, Sergio ; Dias-Brito, Dimas ; Rodrigues, René ; Azevedo, Ricardo Latgé Milward De . 2017. Carbonate microfacies and chemostratigraphy of a late Aptianearly Albian marine distal section from the primitive South Atlantic (SE \& nbsp; Brazilian continental margin): Record of global ocean-climate changes?. Cretaceous Research, 74: 23-44

Cagliarani, R. ; Giannini, P. C. F. ; Espinel-Arias, V. ; Mendes, V.R. 2015. Eolianitos holocênicos de Luís Correia (PI) e Trairi (CE): Caracterização petrográfica e evolução eodiagenética em depósitos mistos terrígeno-carbonáticos.. In: XV Congresso da Associação Brasileira de Estudos do Quaternário, Abequa, Tramandaí, Imbe, RS. 15(2):381-382.

Caldas, L.H.O.; Stattegger, K.; Vital, H. 2006. Holocene sea-level history: evidence from coastal sediments of Rio Grande do Norte coast, NE Brazil. Marine Geology, 228: $39-53$

Carter. R.W.G. 1988. Coastal Environments. London, Academic Press, 617p.

Carvalho, A.M., Claudino Sales, V., Maia, L.P., Castro, J.W.A. 2008. Eolianitos de Flecheiras-Mundaú, Costa Noroeste do Estado do Ceará, Brasil. Sitios Geologicos e Paleontologicos do Brasil. 118

Castro, J.W.A; Gonçalves, A. R. \& Gurgel Jr.,J.B., 1998. Os eolianitos da costa oeste do Estado do Ceará. In: Congresso Brasileiro de Geologia 40, Belo Horizonte - MG. Anais SBG, Vol. único, 259p.

Cavalcanti, I.F.A.; Ferreira, N.J.; da Silva, M.G.A.J.; Dias, M.A.F.S. 2009 Tempo e Clima no Brasil. São Paulo: Oficina de Textos, 463 p.

Chase, B. 2009. Evaluating the use of dune sediments as a proxy for paleoaridity: A Southern African case study. Earth-Science Reviews 93: 31-45

Cheng, H.; Edwards, R.L.; Shen, C-C. Polyak, J.V. , Asmerom, Y., Woodhead, J., Hellstrom, J., Wang, Y., Kong, X., Spotl, C., Wang, X., Alexander, E.C. 2013a. Improvements in 230Th dating, 230Th and 234U half-life values, and U-Th isotopic measurements by multi-collector inductively coupled plasma mass spectrometry.Earth and Planetary Science Letters 371-372, 82-91

Chiang, J. CH \& Koutavos, A. 2004. Tropical flip-flop connections. Nature, 432: 684685

Choquette, P.W.\& Pray, L.1970. Geologic nomenclature and classifications of porosity In:sedimentary carbonates. AAPG Bulletin., 54:207-205

Claudino Sales, V. 2002. Les littoraux du Ceará: Evolution Géomorfophologique de la Zone Côtière de l'Etat du Ceará, du Long Terme au Court Terme. Thèse de Doctorat, Université Paris-Sorbonne, 523p. 
Clement, A.C.; Peterson, L.C. 2008. Mechanisms of abrupt climate change of the last glacial period. Reviews of Geophisics 46 RG4002

Cogliatti-Carvalho, L.C.; Pessoa, T.C.R.; Freitas, A.F.N.; Rocha, C.F.D. 2008. Bromeliaceae species from coastal restinga habitats, Brazilian states of Rio de Janeiro, Espírito Santo and Bahia. The Journal of Biodiversity data, 4 (3): 234-239

Cooper, W.S. 1958. The Coastal Sand Dunes of Oregon and Washington..Tulsa, Okla, Geological Society America (Memoir, 72),169p

Cooper, J.A.G.\& Green, A.N. 2016. Geomorphology and preservation potential of coastal and submerged aeolianite: Examples from KwaZulu - Natal, South Africa. Geomorphology, 271: 1-12.

Costa, M.B.S.F. 2014. Processos Induzidos por Ondas e Marés no Atol das Rocas: Implicações Geomorfológicas e projeções futuras. Exame de Qualificação (inéd),São Paulo, SP, Instituto Oceanográfico, Universidade de São Paulo, 40 p..

Coutinho, J.M.V \& Coimbra, A.M. 1974. Os pesados do Barreiras na costa oriental brasileira: Estudo de áreas fonte. In: Congresso Brasileiro de Geologia, 28, Porto Alegre. Anais. Porto Alegre SBG. 5: 27-41

Coutinho, P. N.; França, A. M. C. \& Summerhayes, C. P. 1976. Sedimentos superficiais da margem continental nordeste brasileira. In: Revista Brasileira de Geociências. Rio de Janeiro 6(2): $71-88$.

Cruz Jr., F.W.; Burns, S.J., Karmann, I., Sharp, W.D., Vuille, M., Cardoso, A.O., Ferrari,J.A., Dias, P.L.S., Viana Jr, O. 2005. Insolation-driven changes in atmospheric circulation over the past 116,000 years in subtropical Brazil. Nature 434: $63-66$

Cruz Jr., F.W.; Vuille, M.; Burns, S.J.; Wang, X.; Cheng, H.; Werner, M.; Edwards, R.L.; Karmann, I.; Auler, A.S.; Nguyen, H. 2009. Orbitally driven east-west antiphasing of South American precipitation. Nature Geoscience, 2: 210-214.

Dabrio, C.J.; Gonzales-Delgado, J.A.; Zazo, C.;Goy, J.L.; Cabero, A.; Hillaire-Marcel, Cl; Ortlieb, L.; Civis, J.; Bardaji, T. 2006. Oscilaciones eustáticas e implicaciones climáticas en el tránsito Neógeno-Cuaternario en la isla de Sal (archipiélago de Cabo Verde). Geo-Temas 9

Dansgaard, W.; Clausen, H.B.; Gundestrup, N.; Hammer, C.U.; Johsen, S.J.; Kristindottir, P.M.; Reeh, N. 1982. A new Greenland ice cores. Geophysical Monograph Series, 33: 71-76

Dasgupta, P.; Bandyopadhyay, S. 2008. Carbonate aeolianites of western Saurashtra, India: Experimental decipherment of the depositional mechanisms. Sedimentology 55(5):1361-1374 
Deely, A. E., Blackwell, B. A. B., Mylroie, J. E., Carew, J.L.; Blickstein, J.I.B.; Skinner, A.R. 2011.Testing cosmic dose rate models for ESR: Dating corals and molluscs on San Salvador, Bahamas. Radiation Measurements, 46 (9): 853-859

Deely, A. E., Blackwell, B. A. B., Mylroie, J. E., Blickstein, J. I. B., Carew, J. L., Davis, R. L., Skinner, A. R. 2012. Tracking sea levels with cortals and mollusks: ESR dating MIS 5 highstsands on San Salvador Island, Bahamas: Studia Universitatis Babeşs-Bolyai, Geology, Special Issue,:11-12

De Mio, E. \& Giannini, P.C.F. 1997. Variação de minerais pesados transversal a planície litorânea de Peruíbe-Itanhaém, SP. In: Congresso da Associação Brasileira de Estudos do Quaternário, Resumos Expandidos. Curitiba. 7: 63-67.

Dias-Brito, D. 2017. Guia Petrográfico dos Carbonatos do Brasil. 244p

Dominguez, J.M.L.; Leão, Z.M.A.N.; Lyrio, R.S. 1996. Litoral norte do Estado da Bahia: roteiro da excursão E4. In: Congresso Brasileiro De Geologia, 37, Salvador, BA. Salvador, SBG, 32p.

Dott, R.H., Jr. 1964. Wacke, graywacke and matrix - what approach to immature sandstone classification? Journal of Sedimentary Petrology. 34 (3): 625-632

Dunham, R. J., 1962. Classification of carbonate rocks according to depositional texture. In: W. E. Ham Ed. Classification of Carbonate Rocks. AAPG 1: 108-121

Ekdale, A.A.1992. Muckraking and mudslinging: the joys of deposit-feeding. Short courses in Paleontology, 5:145-171

El-Asmar, H.M., 1994. Aeolianite sedimentation along the northwestern coast of Egypt: evidence for Middle to Late Quaternary aridity. Quaternary Science Reviews 13: 699-708.

El-Asmar, H.M, Wood, P., 2000. Quaternary shoreline development: the northwestern coast of Egypt. Quaternary Science Reviews 19: 1137-1149.

Emiliani, C. 1955. Pleistocene temperatures. Journal of Geology 63: 538-578

Erginal, A.E., Kivak, N.G., €Ozturk, B., 2010. Investigation of beachrock using microanalyses and OSL dating: a case study from bozcaada island, Turkey. Journal Coastal Research. 26 (2): 350-358.

Erginal, A.E., Kivak, N.G.; Ertek. T.A.2011. A New Late Holocene eolianite record from Altınkum Beach, North Cyprus. Turkish Journal of Earth Sciences 21: 407-414.

Erginal, A.E., Kivak, N.G., Ekinci, Y.L., Demirci, A., Ertek, A., Canel, T., 2013. Age, composition and paleoenvironmental significance of a Late Pleistocene eolianite 
from the western Black Sea coast of Turkey. Quaternary International. 296: 168175.

Espinel-Arias, V. 2015. Fatores Controladores de Sistemas Eólicos Costeiros Carbonáticos: dos Eolianitos Quaternários do Piauí e Oeste do Ceará. Dissertação de Mestrado. São Paulo. Instituto de Geociências da Universidade de São Paulo. $145 \mathrm{p}$

Espinel-Arias, V.; Giannini, P. C. F. ; Cagliarani, R. ; Mendes, V.R. 2015. Morfologia, fácies deposicionais e cronologia dos eolianitos quaternários do litoral do Piauí e oeste do Ceará. In: XV Congresso da Associação Brasileira de Estudos do Quaternario, Abequa. Tramandaí, Imbe, RS., 2.: 377-378

Ewing, R. C., \& G. Kocurek 2010. Aeolian dune field pattern boundary conditions, Geomorphology, 114:175-187.

Fairbridge, R.W. \& Johnson, D.L. 1978. Eolianite. In: Fairbridge, R.W. \& Bourgeois, J. eds. The Encyclopedia of Sedimentology. Dowden, Hutchinson and Ross, Stroudsburg.

Fernández, D. E., Pazos, P. J. 2012. Ichnology of marginal marine facies of the Agrio Formation (Lower Cretaceous, Neuquén Basin, Argentina) at its Type Locality. Ameghiniana, 49(4): 505-524.

Fletcher III, C.H., Murray-Wallace, C.V., Glenn, C.R., Sherman, C.E., Popp, B., Hessler, A. 2005. Age and origin of Late Quaternary eolianite, Kaiehu Point (Moomomi), Molokai, Hawaii. Journal of Coastal Research: an international forum for the littoral sciences, 42: 97-112.

Flugel, E. 2004. Microfacies of Carbonate Rocks. Analysis, Interpretation and Application.: Berlin, Heidelberg, New York Springer-Verlag 976 p

Frebourg, G.; Hasler, C-A.; Davaud, E. 2010 Catastrophic event recorded among Holocene eolianites (Sidi Salem Formation, SE Tunisia). Sedimentary Geology 224 (1-4):38-48

Freitas, A.V.L.; Miranda, M.; Passos,F.D. 2020. Land Snails of the Fernando de Noronha Archipelago, Brazil. American Malacological Bulletin 37(2):66-69

Frey, R.W.; Pemberton, S.G.; Saunders, T.D.A.. 1984. Ichnofacies and Bathymetry: A Passive relationship. Journal of Paleontology 64(1): 155-158

Fitzsimmons, K. E.; Magee, J. W.; Amos, K. J. 2009. Characterisation of aeolian sediments from the Stezelecki and Tirari Deserts, Australia: implications for reconstructing paleoenvironmental conditions. Sedimentary Geology 218: 61-73

Folk, R.L. 1959. Practical petrographic classification of limestones. AAPG Bulletin 43:138. 
Folk, R.L. 1962. Spectral subdivision of limestone types. In: Classification of Carbonate Rocks - A Symposium (Ed. W.E. Ham), AAPG Memories. 1 : 62- 84

Folk, R.L., 1974. The natural history of crystalline calcium carbonate; effect of magnesium content and salinity. Journal of Sedimentary Petrology 44: 40-53.

Fryberger, S.G. \& Dean, G. 1979. Dune forms and wind regime. In: McKee, E.D. (Ed.), A Study of Global Sand Seas. U.S. Geological Survey Professional Paper 1052:137-169.

Fryberger, S.G. \& Schenk, C. 1988. Pin stripe lamination: a distinctive feature of modern and ancient eolian sediments. Sedimentary Geology, 55: 1-15

Galbraith, R.F.; Roberts, R.G.; Laslett, G.M.; Yoshida, H.; Olley, J.M. 1999. Optical dating of single and multiple grains of quartz from Jinmium rock shelter, Northern Australia: Part I, Experimetal design and statistical models. Archaeometry 41: 339364.

Gardner, D.E. 1955. Beach-sand heavy-mineral deposits of Eastern Austrália. BMR Bulletin, 28:103p

Garreaud, R.D.; Vuille, M.; Compagnucci, R.H.; Marengo, J.A. 2009. Present-day South American climate. Palaeogeography Palaeoclimatology Palaeoecology 281: 3-4

Gesicki, A.L.D., 2007. Evolução diagenética das formações Pirambóia e Botucatu (Sistema Aqüífero Guarani) no Estado de São Paulo. São Paulo, DSc Thesis.University of São Paulo.

Giannini, P.C.F. 1993. Sistemas Deposicionais no Quaternário Costeiro entre Jaguaruna e Imbituba, SC. Tese de Doutoramento (inéd.) São Paulo, Instituto de Geociências, Universidade de São Paulo.. 2 v., 2 mapas, 439 p.

Giannini, P.C.F. 1993. Sistemas deposicionais no Quaternário costeiro entre Jaguaruna e Imbituba, SC. Tese de Doutoramento (inéd.) São Paulo, Instituto de Geociências, Universidade de São Paulo.. 2 mapas, 439 p.

Giannini, P.C.F. \& Santos, E.R. 1994.Padrões de variação espacial e temporal na morfologia de dunas de orla costeira no centro-sul catarinense. Boletim Paranaense de Geociências, 42: 73-96.

Giannini, P.C.F.; Sawakuchi, A.O.; Martinho, C.T. 2001. A estratigrafia de seqüências na evolução das dunas costeiras de Santa Catarina, sul do Brasil. In: Congresso do Quaternário dos Países de Língua Ibérica, Lisboa, Portugal. Actas...p.117-120.

Giannini, P.C.F.; Assine, M.L.; Barbosa, L.; Barreto, A.M.F.; Carvalho, A.M.; ClaudinoSales, V.; Maia, L.P.; Martinho, C.T.; Peulvast, J.P.; Sawakuchi, A.O.; Tomazelli, L.J. 2005. Dunas e paleodunas eólicas costeiras e interiores. In: Souza, C.R.G.; 
Suguio, K.; Oliveira, P.E.; Oliveira. A.M. Ed. Quaternário do Brasil (capítulo 11). Abequa, ANP, FAPESP, IG, UnG. RibeirãoPreto, SP, HolosEditora, p.235-257.

Giannini, P.C.F.; Sawakuchi, A.O.; Martinho, C.T.; Tatumi, S.H. 2007.Eolian depositional episodes controlled by Late Quaternary relative sea level changes on the Imbituba-Laguna coastal zone (southern Brazil). Marine Geology,237: 143168.

Giannini, P.C.F. 2007. Sistemas Deposicionais Eólicos no Quaternário Costeiro do Brasil. Tese de Livre Docência, São Paulo, Instituto de Geociências, Universidade de São Paulo 200p.

Giannini, P.C.F.; Guedes, C.C.F.; Nascimento, D.R., Jr.; Tanaka, A.P.B.; Angulo, R.J.; Assine, M.L.; Souza, M.C. 2009. Morphology and sedimentology of Ilha Comprida, southern São Paulo coast. In: DILLENBURG, S.R. \& HESP, P.A. ed. Geology and Geomorphology of Holocene Coastal Barriers of Brazil. Berlin Heidelberg, Springer, p.177-224.

Giannini, P.C.F.; Sawakuchi, A.O.; Martinho, C.T.; Guedes, C.C.F.; Nascimento, D.R., Jr.; Tanaka, A.P.B.; Mendes, C.C.F.; Zular, A.; Andrade, H.A.A.; Fornari, M. 2011. Classificação e dinâmica de feições eólicas costeiras: um modelo sistêmico baseado em exemplos brasileiros. In: Congresso Da Associação Brasileira De Estudos Do Quaternário (Abequa), 13, Armação de Búzios, RJ. Anais...meio digital. Armação de Búzios.

Giannini P. C. F., Sawakuchi, A.O., Mendes, V.R. Zular, A. Andrade, H.A.A., Martinho, C.T., Guedes, C.C.F. Nascimento, Jr. D.R.Tanaka, A.P.B., Fornar, M. 2014. Morfodinâmica de sistemas eólicos costeiros: um modelo baseado em exemplos do Holocénico brasileiro e seu potencial interpretativo. Comunicações Geológicas, 101,Especial II, p 681-685

Goldsmith, V.1978. Coastal dunes. In: Davis, R.A. (Editor). In: Coastal sedimentary environments. New York: Springer- Verlag,. p 171-235

Gomes, R. dos S., Costa, P.M.S., Monteiro, J.C., Coelho, A.C. dos S., Salgado, N.C., 2006. Moluscos das ilhas oceânicas brasileiras, in: Alves, R.J.V., Castro, J.W. de A. (orgs.). Ilhas oceânicas brasileiras: da pesquisa ao manejo. MMA. Secretaria de Biodiversidade e Florestas, pp. 179-198.

Google Earth (acessado Julho 2020)

Guedes, C.C.F.; Giannini, P.C.F.; Dewitt, R.; Sawakuchi, A.O.; Aguiar, V.A.P.; Angulo, R.J. 2011. O sistema de paleodunas eólicas do nordeste maranhense: datações por LOE-SAR e relações com paleoclima. In: Congresso Da Associação Brasileira De Estudos Do Quaternário (Abequa), 13, Armação de Búzios, RJ. Anais... meio digital Armação de Búzios. 
Guedes, C.C.F. 2012. Cronologia e sedimentologia dos depósitos eólicos quaternários da costa Leste maranhense. Tese de Dourorado. São Paulo, Instituto de Geociências, Universidade de São Paulo.

Guedes, C.C.F. ,Sawakuchi, A.O. ,Giannini, P.C.F., Dewitt, R., Aguiar, V.A.P. 2013 . Luminescence characteristics of quartz from Brazilian sediments and constraints for OSL dating. Anais da Academia Brasileira de Ciências. 85: 1303-1316

Guedes, C.C.F.; Giannini, P.C.F. ; Sawakuchi, A.O. ; Dewitt, Regina ; Aguiar, V.A.P. 2017. Weakening of northeast trade winds during the Heinrich stadial 1 event recorded by dune field stabilization in tropical Brazil. Quaternary Research. 88: 369-381.

Guérin, G.; Mercier, N.; Adamiec, G. 2011. Dose-rate conversion factors: update. Ancient TL 29: 5-8.

Hearty, P.J., 2003. Stratigraphy and timing of eolianite deposition on Rottnest Island, Western Australia. Quaternary Research. 60: 211-222.

Hearty,P.J\& O'leary, M.J. 2008. Carbonate and eolianites, quartz, sands, and Quaternary sea level cycle, western Australia: a chronoestratigraphyc approach, QuaternaryGeochronology, 3(1-2): 26-55

Heinrich, H. 1988. Origin and consequences of cyclic ice rafting in the northeast Atlantic Ocean during the past 130.000 years, Quaternary Research 29: 142-152

Hesp, P.A. 2000. Coastal Sand Dunes. Form and Function. Massey, Massey University, (CDNV Technical Bulletin, 4)28 p.

Hilbert, N.N.; Guedes, C.C.F.; Giannini, P.C.F. 2016. Morphologic and sedimentologic patterns of active aeolian dune-fields on the east coast of Maranhão, Northeast Brazil. Earth Surface Processes and Landforms 41: 87-97

Irion, G., De Morais, J.O., Bungenstock, F. 2012. Holocene and Pleistocene sea-level indicators at the coast of Jericoacoara, Ceará, NE Brazil. Quaternay Reasearch 77: $251-257$

James, N.P. 1997. The cool-water carbonate depositional realm. In: James, N. P. Y Clarke, A. D. eds. Cool-water Carbonates. Society of Economic Paleontologists and Mineralogists, SpecialPublication 56: 1-120.

James, N.P., Bone, Y., 2015. Pleistocene aeolianites at Cape Spencer, South Australia; record of a vanished inner neritic cool-water carbonate factory. Sedimentology 62 (7):2038-2059.

James, N. P.; Jones, B. 2016. Origin of Carbonate Sedimentary Rocks. John Wiley \& Sons, Ltd., Chicester 446 pp.

Junior, A.V.F.; Paes, B.C.E.; Vieira, M.M.; Sial, A.N.; Neumann, V.H.M.L. 2018. Diagenesis of Holocene Beach rock in Northeastern Brazil: petrology, isotopic evidence and age. Quaternary and Environmental Geoscience 09(2):26-35 
Kahn, J.S. 1956. The analysis and distribution of the properties of packing in sand-size sediments. 1. On the measurement of packing in sandstone. Journal of Geology, 64: 385-395.

Kindler, P. 1992. Coastal response to the Holocene transgression in the Bahamas: episodic sedimentation versus continuous sea-level rise: Sedimentary Geology, 80: 319-329

Kindler, P., Hearty, P.J. 1995. PreSangamonian eolianites in the Bahamas? New evidence from Eleuthera Island: Marine Geology, 128:73-86.

Kindler, P.; Mazzolini, D. 2001. Sedimentology and petrography of dredged carbonate sands from Stocking Island (Bahamas). Implications for meteoric diagenesis and aeolianite formation. Palaeogeography Palaeoclimatology Palaeoecology 175(1):369-379

Kocurek, G. \& Nielson, J. 1986. Conditions fovourable for the fomation of warm climate aeolian sand sheets. Sedimentology, 33 (6): 795-816.

Kocurek, G.; Townsley, M.; Yeh, E.; Havholm, K.G.; Sweet, M.L. 1992. Dune and dunefield development on Padre Island, Texas, with implications for interdune deposition and water-table-controlled accumulation. Journal of Sedimentary Research, 62: 622-635.

Kocurek, G. \& Havholm, K.G. 1993 .Eolian Sequence Stratigraphy - A Conceptual Framework. In: Siliciclastic Sequence Stratigraphy, p.393-409. AAPG (Memoir, 58).

Kocurek, G.1998. Aeolian system response to external forcing factors-a sequence stratigraphic view of the Saharan region. In: Alsharhan, A.S., Glennie, K. W., Whittle, G. L., Kendall, C.G.S.C. (eds), Quaternary Deserts and Climate Change. Balkema, Rotterdam, 327-337

Kowsmann, R.O. \& Costa, M.D.A. 1979. Sedimentação quaternária da margem continental brasileira e das áreas oceânicas adjacentes. Rio de Janeiro: Petrobrás, 1979. 55 p. (SérieProjetoRemac, 8).

Krumbein, W.C.; Pettijohn, F.J.1938. Manual of sedimentary petrography: I. sampling, preparation for analysis, mechanical analysis and statistical analysis. D. AppletonCentury Company, incorporated, 1938. University of California. 549p

Lancaster, N. 1995. The Geomorphology of Desert Dunes. London, Routledge, 312p

Laugie, M.; Michel, J.; Poli, E.; Borgomano, J. 2019. Global distribution of modern shallow-water marine carbonate factories: a spatial model based on environmental parameters. Scientific Reports 9:16432

Lees, B. 2006.Timing and formation of coastal dunes in northern and eastern Australia.Journal of Coastal Research, 22(1): 78-89. 
Lessa, G.C.; Angulo, R.J.; Giannini, P.C.; Araujo, A.D. 2000. Stratigraphy and Holocene evolution of a regressive barrier in south Brazil. Marine Geology 165: 87-108

Li, T., Horton, R.M.; Bader, D.A.; Liu, F.; Sun, Q.; Kinney, P.L. 2018: Long-term projections of temperature-related mortality risks for ischemic stroke, hemorrhagic stroke, and acute ischemic heart disease under changing climate in Beijing, China. Environment. International., 112: 1-9.

Lipar, M., Webb, J.A., 2014. Middle - Late Pleistocene and Holocene chronostratigraphy and depositional history of the Tamala Limestone, Cooloongup and Safety Bay sands, Nambung National Park, southwestern Western Australia. Australian. Journal. Earth Science. 61, 1023-1039.

Lipar, M., Webb, J.A., 2015. The formation of the pinnacle karst in Pleistocene aeolian calcarenites (Tamala limestone) in southwestern Australia. Earth Science. Reviews. 140, 182-202.

Lipar,M.; Webb,J.A.; Cupper, M.L.; Wang, N. 2017. Aeolianite, calcrete/microbialite and karst in southwestern Australia as indicators of Middle to Late Quaternary palaeoclimates. Palaeogeography, Palaeoclimatology, Palaeoecology 470 11-29

Lisiecki, L. E.; Raymo, M. E. 2005. A Pliocene-Pleistocene stack of 57 globally distributed benthic $18 \mathrm{O}$ records: Paleoceanograpny, 20, PA1103, doi:1029/2004PA00-1071.

Liu, Z., Otto-Bliesner, B. L., He, F., Brady, E. C., Tomas, R., Clark, P. U., et al. 2009. Transient simulation of last deglaciation with a new mechanism for bolling-allerod warming. Science, 325(5938): 310-314. https://doi.org/10.1126/science.1171041

Lopes, R.P.; Ulbrich, M.N.C. 2015. Geochemistry of the alkaline volcanicsubvolcanic rocks of the Fernando de Noronha Archipelago, southern Atlantic Ocean. Brazilian Journal of Geology 45(2):307-333

Loucks, R.G.; Ward, W. 2001. Eolian Stratification and Beach-to-dune transition in a Holocene Carbonate eolianite complex, Isla Cancún, Quintana Roo, Mexico. In: Modern and Ancient Carbonate Eolianites: Sedimentology, Sequence Stratigraphy, and Diagenesis ed. F. E. (Rick) Abegg; David B. Loope; Paul M. (Mitch) Harris

Mackenzie,C.H.; Martin,J.L. 2018. Canadian HABS cientists hold workshop to establish national priorities and develop research network. Harmful Algae News 60:19. http://www.ioc-unesco.org/ha

Maia, L.P.1998. Procesos Costeros y Balance Sedimentario al o Largo de Fortaleza (NEBrasil): Implicaciones para una Gestión Adecuada de la Zona Litoral. Tesis Doctoral, Universitat de Barcelona, Facultat de Geologia, Departementd'Estratigrafia i Paleontologia, 269p

Maia,L.P.; Sabadia, J.A; Freire, J.S.S; Serra, J. 1997: Caracterização geoquimica e diagenetica da cimentaçao carbonatica dos beachrocks e eolianitos da região costeira do Ceará. Bol. XVII Simpósio.Geologia do.Nordeste. 177-181 
Maia, L.P.; Gastão, F.G.C.; Tatumi, S.H.; Lacerda, L.D. 2011. A Utilização do método de Luminescência Opticamente Estimulada para a datação de sedimentos de dunas costeiras do nordeste setentrional do Brasil. Revista Virtual de Quimica, 3(2): 103115.

Mangas, J. Menendez, I.; Ortiz, J.E.; Torres, T. 2008. Coastal aeolianites of upper Pleistocene in the "Sitio de Interés Científico de Tufia" (Gran Canaria Island): sedimentology, petrography and aminochronology. Geo-Temas 10: 1405-1408

Mange, M.A.; Maurer, H.F.W. 1992. Heavy Minerals in Coiour. Chapman and Hall, London, $147 \mathrm{p}$

Martin, 1998

Martinez, R.; Pourret, O.; Faucon, M-P.;Dian, C. 2018. Effect of rare earth elements on rice plant growth. Chemical Geology 489: 28-37

Martinho, C.T.; Giannini, P.C.F. 2001. Petrografia e Microscopia Eletrônica de Varredura de diferentes gerações de paleodunas eólicas quaternárias do Morro de Santa Maria, município de Laguna, SC. Pesquisas em Geociências, 28 (2): 53-66

Martinho, C.T.; Giannini, P.C.F.; Sawakuchi, A.O.; Hesp, P.A. 2006. Morphological and depositional facies of transgressive dunefields in the Imbituba-Jaguaruna region, Santa Catarina State, Southern Brazil.Journal of Coastal Research, SI39: 673-677.

Mauz, B. \& Hoffmann, D. 2014. What to do when carbonate replaced water: Carb, the model for estimating the dose rate of carbonate-rich samples. Ancient TL 32 (2): 2014

McKee, E.D. \& Gutschick, R.C. 1969. History of the Redwall Limestone of Northern Arizona. Geological Society of America Memoir 114: 1-726.

Mckee, E.D., And Ward, W.C. 1983. Eolian environment. In SCHOLLE, P. A., BEBOUT, D. G. AND MOORE, C. H. eds. Carbonate Depositional Environments. AAPG Memoir 33:131-170.

Melo, M.S.; Sinfrônio, E.A.S.; Giannini, P.C.F.; Fachini, M.; Victorino, M.C. 2004. Manual de Procedimentos Analíticos. São Paulo, Laboratório de Sedimentologia, Instituto de Geociências da USP, Manual Interno (inéd.), 44pp.

Melo, A.B.C.; Cavalcanti, I.F.A.; Souza, P.P. 2009. Zona de convergência Intertropical do Atlântico. In:Cavalcanti, I.F.A.; Ferreira, N.J.; Silva, M.G.A.J. \& Silva Dias, M.A.F. 2009. eds. Tempo e Clima no Brasil. São Paulo, Oficina de Textos, p. 2539.

Mendes, V.R. 2012. Cronologia e Sedimentologia dos Depósitos Eólicos Quaternários da Costa Catarinense, entre Ouvidor e Florianópolis. Dissertação de Mestrado (inéd.), São Paulo, Instituto de Geociências, Universidade de São Paulo 97 p. 
Mendes, V.R., Giannini, P.C.F., Guedes, C.C.F., Dewitt, R., Andrade, H.A.A. 2015. Central Santa Catarina coastal dunefields chronology and their relation with relative sea level and climatic changes. Brazilian Journal of Geology (online).

Mendes, V.R., Giannini, P.C.F. 2015. Coastal dunefields of south Brazil as a record of climatic changes in the South American Monsoon System. Geomorphology 246: 22-34.

Mendes, V.R.; Sawakuchi, A.O.; Chiessi, C.M.; Giannini, P.C.F.; Rehfeld, K.; Mulitza, S. 2019. Thermoluminescence and optically stimulated luminescence measured in marine Sediments indicate precipitation changes over Northeastern Brazil. Paleoceanography and Paleoclimatology 34 https://doi.org/ 10.1029/2019PA003691

Menezes, P.M.L. 2009. Análise de fácies e proveniência sedimentar em sambaquis do litoral centro-sul de Santa Catarina. Dissertacao de Mestrado, Instituto de Geociencias-Universidade de São Paulo. 261p

Menor, E.; Neumann, V. Valenca, L.M.M.; Boujo, A. 2001. The aeolian calcarenites of the Fernando de Noronha Island, Northeastern Brazil - a new approach. Anais da Academia Brasileira de Ciências 73(3)

Miall, E.D. 1985. Architectural-element analysis: a new method of facies analysis applied to fluvial deposits. Earth Science Review, 22: 261-308.

Miall, E.D. 1999. Principles of Sedimentary Basin Analysis.New York, Springer-Verlag, $668 \mathrm{p}$.

Milne, G.A.; Long, A.J.; Bassett, S.E. 2005. Modelling Holocene relative sea-level observations from the Caribean and South America.Quaternary Science Reviews, Oxford, 24: 1183-1202.

Monaco, P.; Caracuel, J. E., Giannetti, A., Soria, J. M.; Yébenes, A. 2007. Thalassinoides and Ophiomorpha as cross-facies trace fossils of crustaceans from shallow-to-deepwater environments: Mesozoic and Tertiary examples from Italy and Spain.

Morse, J.W.; Mackenzie, F.T. 1990. Geochemistry of Sedimentary Carbonates. eBook ISBN: $9780080869629706 p$

Morton, A.C \& Hallsworth, C. 1994. Identifying provenance-specific features of detrital heavy mineral assemblages in sandstones. Sedimentary Geology 90: 241-256

Morton, A.C \& Hallsworth, C. 1999. processes controlling the composition of detrital heavy mineral assemblages in sandstones. Sedimentary Geology, 124: 3-29.

Muhs, D. R..; Pigati, J. S.; Schumann, R. R.; Skipp, G.L.; Porat, N. Devogel, S. B. 2018. Quaternary sea-level history and the origin of the northernmost coastal aeolianites in the Americas: Channel Islands National Park, California, USA. Palaeogeography Palaeoclimatology Palaeoecology 491: 38-76 
Mulitza, S.; Chiessi.C.M; Schefub, E. Lippold, J. Wichmann, D.; et al. 2017. Synchronous and proportional deglacial changes in Atlantic meridional overturning and northeast Brazilian precipitation. Paleoceanography 32: 622-633

Murray, A.S., Wintle, A.G., 2000. Luminescence dating of quartz using an improved single-aliquot regenerative-dose protocol. Radiation Measurement, 32: 57-73.

Mylroie, J.E., 2008. Late Quaternary sea-level position: evidence from Bahamian carbonate

deposition and dissolution cycles. Quaternary. International. 183: 61-75.

Neto, I.C.; Cordoba, V.C.; Vital, H. 2010. Petrografia de beachrock em zona costa afora adjacente ao litoral norte do Rio Grande do Norte, Brasil. Quaternary and Environmental Geosciences 02(2):12-18

Ottmann, F. 1959. Estudo das amostras do fundo recolhidas pelo N. E. "Almirante Saldanha" na regiao da embocadura do Rio Amazonas. Trabalho Instituto de Biologia Marinha e Oceanografia. Universidade Recife 1: 77-106

Ottmann, F. 1960. A propos des crues du Capibaribe. Trab. Inst. Biol. Mar. Oceanogr. Recife, 2 (1):261-266.

Perlingueiro, G.; Vasconcelos, P.M.; Knesel,K.M.; Thiede, D.S.; Cordani, U.G.. 2013. 40Ar/39Ar geochronology of the Fernando de Noronha Archipelago and implications for the origin of alkaline volcanism in the NE Brazil. Journal of Volcanology and Geothermal Research 249 : 140-154

Peterson, L. C.; Haug, G. H.; Hughen, K. A. Rohl, U. 2000. Rapid changes in the hydrologic cycle of the tropical Atlantic during the last glacial. Science 290: 19471951

Pettijohn, F.J.; Potter, P.E.; Siever, R. 1972. Sand and sandstone. Heidenlberg, Springer - Verlag, 618p.

Pianca C., Mazzini P. L. F., Siegle E. 2010. Brazilian offshore wave climate based on NWW3 reanalysis.Brazilian Journal of Oceanography, 58(1): 53-70.

Pomar, F.; Fornós, J.J.; Pujol, L-G.; Valle, L. 2017. Las eolianitas cuaternarias de Menorca y los depósitos asociados, In book: Geomorfología Litoral De Menorca (pp.111-136) Edition: Monografies de la Societat d'Història Natural de les Balears, 25 Publisher: Societat d'Història Natural de Balears

Powers, M.C.1953. Comparison chart for visual estimation of roundness. J. Sedimentology. Petrology. 23:117-119

Prescott, J.R. \& Hutton, J.T. 1994. Cosmic ray contributions to dose rates for luminescence and ESR dating: Large depths and long-term time variations. Radiation Measurements, 23: 497-500. 
Pye, K. 1983. Formation and history of Queensland coastal dunes.Z. Geomorphology., suppl-bd.45: 175-204.

Pye, K. \& Bowman, G.M. 1984.The Holocene marine transgression as a forcing function on episodic dune activity on the eastern australian coast. In: Thom, B.G. (ed.), Coastal Geomorphology in Australia. Sydney, Academic Press, 115-127.

Pye, K. \& Tsoar, H. 1990. Aeolian Sand and Sand Dunes. London, Unwin, 396p.

Rasmussen, T.L.; Thomsen, E. 2004. The role of the North Atlantic Drift in the millennial timescale glacial climate fluctuations. Palaeogeography, Palaeoclimatology, Palaeoecology 210: $101-116$

Rasmussen, S.O.; Svensson, A. ; Winstrup, M. 2014b. State of the art of ice core anual layer dating, Pages Magazine 22: 26-27

Raymo, M.E.; Ruddiman, W.F.; Backman, J.; Clement, B.M.; Martinson, D.G. 1989. Late Pliocene variation in northern hemisphere ice sheets and North Atlantic deep water circulation. Paleoceanography and Palaeoclimatology,4(4): 413-446

Read, J.F. 1982. Carbonate plataforms of passive (extensional) continental margins: types, characteristics and Evolution. Tectonophysics 81: 195-212

Reimer Pj, Baillie Mgl, Bard E, Bayliss A, Beck Jw, Blackwell Pg, Bronk Ramsey C, Buck Ce, Burr Gs, Edwards R1, et al 2009. IntCa109 and Marine09 radiocarbon age calibration curves, 0-50,000 years cal BP, Radiocarbon, 51(4): 1111-1150.

Ries, J.B.; Cohen, A.L.; Mccorkle, D.C. 2010. Seawater carbonate chemistry and biological processes during experiments with coral Oculina arbuscula, 2010. Pangaea. Supplement to: Ries, JB et al. (2010): A nonlinear calcification response to $\mathrm{CO} 2$-induced ocean acidification by the coral Oculina arbuscula. Coral Reefs, 29(3):661-674

Rittenhouse, G.; Thorp, E.M. 1943. Heavy minerals in sediment-transportation studies. Eos, Transactions American Geophysical Union 24(2): 524-530

Roberts, R.G.; Galbraith, R.F.; Yoshida, H.; Laslett, G.M.; Olley, J.M. 2000. Distinguishing dose populations in sediment mixtures: A test of single-grain optical dating procedures using mixtures of laboratory-dosed quartz. Radiation Measaruments, 32: 459-465.

Rodrigues S.A. 1983. Aspectos da biologia de Thalassinidea do Atlântico Tropical Americano. Tese de Livre Docência, Instituto de Biociências da Universidade de São Paulo, 174 p.

Rodrigues, F. C. G. 2017. Evolução dos sistemas eólicos costeiros quaternários entre Campo Bom e a foz do rio Araraguá, SC. Dissertação de Mestrado (inéd.),São Paulo, Instituto de Geociencias, Universidade de São Paulo.: 155 p 
Rodrigues, F. C.G. ; Giannini, P.C.F. ; Fornari, M.; Sawakuchi, A.O. 2020. Deglacial climate and relative sea level changes forced the shift from eolian sandsheets to dunefields in southern Brazilian coast. Geomorphology 365: 107252

Rossetti, D. F.; Dominguez, J. M. L. 2011. Evidencia marinha na Formação Barreiras do litoral do estado da Bahia. XIII Congresso da Associação Brasileira de Estudos do Quaternário Abequa

Roy, P.S.; Cowell, P.J.; Ferland, M.A.; Thom, B.G., 1994. Wave-Dominated Coasts.In: Carter, R.W.G. \& Woodroffe, C.D. eds., Coastal Evolution, Late Quaternary Shoreline Morphodynamics. Cambridge, Cambridge University Press, p.121-186.

Roy, P.S. \& Thom, B.G. 1981. Late Quaternary marine deposition in New South Wales and southern Queensland: and evolutionary model. Journal of Geology Society of Australia, 28: 471-89.

Rubey, W.W. 1933. Equilibrium-conditions in debris-laden streams Eos, Transactions American Geophysical Union 14 (1): 497-505

Rubey, W.W. 1933. Settling velocity of gravel, sand, and silt particles. American Journal of Science. 25:325-338

Ruddiman, W. F. 2004. The role of greenhouse gases in orbital-scale climatic changes. Eos 85: 1, 6-7

Ruddiman, W.F. 2008. Earth's Climate: Past and Future. 388 p BOOK

Ruddiman, W.F. 2008 The challenge of modeling interglacial CO2 and CH4 trends, Quaternary Science Reviews, 27: 445- 448.

Salgado N. C.; Coelho, A. C. S. 2003. Moluscos terrestres do Brasil (gastrópodes operculados ou não, exclusive Veronicellidae, Miladicae e Limacidae). Revista de Biología Tropical 51(Suppl. 3): 149-189.

Santos C.A.R. dos. 2012. Eolianitos de Fernando de Noronha: Processos deposicionais e pós-deposicionais. Dissertação de Mestrado, Pós-graduação em Geociências, Universidade Federal dePernambuco. 58p

Satyamurty P, Mattos Lf, Nobre Ca \& Silva Dias Pl. 1998. Tropics - South America. In : Meteorology of the Southern Hemisphere, Ed. Kauly, D. J. and Vincent, D. G., Meteorological Monograph. American Meteorological Society, Boston, 119-139.

Sawakuchi, A.O. 2003. Sistemas deposicionais eólicos na costa centro-sul catarinense: relações com o nível do mar. Dissertação de Mestrado. (inéd.), São Paulo, Instituo de Geociências, Universidade de São Paulo. 86 p

Sawakuchi, A.O. 2006. Morfometria e Simulação Numérica de Campos de Dunas Costeiros Estudo Baseado em Exemplos Brasileiros. Tese de Doutorado (inéd.).São Paulo, Instituto de Geociencias. Universidade de São Paulo. 316p. 
Sawakuchi, A.O.; Kalchgruber, R.; Giannini, P.C.F.; Nascimento Jr, D.R.; Guedes, C.C.F.; Umisedo, N. 2008. The Development Of Blowouts And Foredunes In: The Ilha Comprida Barrier (Southeastern Brazil): the influence of Late Holocene climate changes on coastal sedimentation. Quaternary Science Reviews, 27: 2076-2090.

Sayles, R.W., 1931. Bermuda during the ice age. Proceedings of the American Academy of Arts and Science, 66(1):381-468.

Shackleton, N. 1967. Oxygen isotope analyses and Pleistocene temperatures reassessed. Nature 215, 15-17

Scholle, P.A. \& Ulmer-Scholle, D. 2003. Grains: Skeletal Fragments: Annelids and Related Groups. AAPG Memoir 77, Chapter 4

Schmidt, V.; Mcdonald, D.A.; Platt, R.L. 1972. Pore geometry and reservoir aspects of secondary porosity in sandstones. Bulletin of Canadian Petroleum Geology 25 (2): 271-290.

Schmidt, V.; Mcdonald, D. A. 1977. The role of secondary porosity in the course of sandstone diagenesis The Society of Economic Paleontologists and Mineralogists (SEPM). Especial publication 26: 175- 207

Schwan, J. 1988. The structure and genesis of Weichselian to early Holocene aeolian sand sheets in western Europe. Sedimentary Geology, 55: 197-232

Semeniuk, V. \& Johnson,D.P. 1985. Modern and Pleistocene rocky shores along carbonate coastlines, Southwestern Australia. Sedimentary Geology, 44: 225-261.

Serafini, T. Z.; França, G. B.; Andriguetto-Filho, J. M. 2010. Ilhas oceânicas brasileiras: biodiversidade conhecida e sua relação com o histórico de uso e ocupação humana. Revista da Gestão Costeira Integrada, 10: 3 281-301

Short, A.D. 1988. Holocene coastal dune formation in southern Australia: a case study. Sedimentology Geology 55:121-142

Short, A.D. Trembains, A.C. and Turner I.L. 2001. Beach oscillation, rotation and the Southern oscillation, narrabeen Beach, Australia. Coastal Engineering, 276: 24392452

Siddall. M.; Rohling, E.J.; Thompson, W.G.; Waelbroeck, C. 2008. Marine isotope stage 3 sea level fluctuations: Data synthesis and new outlook Reviews of Geophysics, 46(4): 1-29. https://doi.org/10.1029/2007RG000226

Silva, J.B.O. \& Gomes, C.S.F. 2016. Recursos Naturais - ilha do Porto Santo. In: APCA. 2016. Projeto Aprender Madeira, Recursos Naturais. http://aprenderamadeira.net/recursos-naturais-ilha-do-porto-santo/

Simone, L. R. L. 2006. Land and freshwater mollusks of Brazil. EGB/FAPESP, São Paulo, 390 pp. 
Sivan, D.; Gvirtzman, G.; Sass, E. 1999. Quaternary Stratigraphy and Paleogeography of the Galilee coastal plain, Israel. Quaternary Research 51 (3): 280-294

Smith, E.A.1890. Mollusca. Journal of the Linnean Society of London 20: 483503.

Souza, M. J. 2000. Bases naturais e esboço do zoneamento geoambiental do Estado do Ceará. In: Lima, L. C.; Morais, J. O. ; Souza, M. J. org. Compartimentação Territorial e Gestão Regional do Ceará. Editora: FUNECE: Fortaleza, 6-98

Strikis, N. S. 2011. Paleopluviosidade no Norte de Minas Gerais durante o glacial tardío e Holoceno com base em registros de espeleotemas. Dissertação de mestrado, Instituto de Geociencias, Universidade de Sao Paulo.

Strikis, N. S.; Cruz, F.W.; Cheng, H.; Karmann, I.; Edwards, R.L.; Vuille, M.; Wang, X.; De Paulo, M.S.; Novello, V.F.; Auler, A.S. 2011. Abrupt variations in South American monsoon rainfall during the Holocene base don speleothem record from central-eastern Brazil. Geology, 39: 1075-1078

Strikis, N. S. 2015. Atividade do Sistema Monção Sul-americana na porção central do Brasil durante o ultimo período glacial a partir da aplicação de isótopos de oxigênio em espeleotemas. Tese de Doutorado (inéd.), São Paulo, Instituto de Geociências Universidade de São Paulo 289p

Suguio, K., Angulo, R.J., Carvalho, A.M., Corrêa, I.C.S., Tomazelli, L.J. Vilwock, J.A., Vital, H. 2005. Paleoníveis do mar e paleolinhas de costa. In: Souza, C.R.G., Suguio, K., Oliveira, A.M.S., Oliveira, P.E. (orgs). Quaternário do Brasil. Ribeirão Preto: Abequa / Holos Editora, 382p.

Suguio, K, Bezerra, F.H.R., Barreto, A.M.F. 2011. Luminescence dated Late Pleistocene wave-built terraces in northeastern Brazil. Anais da Academia Brasileira de Ciências 83(3): 907-920

Teixeira, W.; Cordani, U. G.; Menor, E. A.; Teixeira, M. G.; Linsker, R. 2003. Arquipélago Fernando de Noronha o paraíso do vulcão. São Paulo: Terra Virgem, $167 \mathrm{p}$.

Thom, B.G.; Bowman, G.M.; Roy, P.S. 1981.Late Quaternary evolution of coastal sand barriers, Port Stephens-Myall lakes area, central N.S.W. Autralia.Quaternary Research, 15: 345-364.

Tomazelli, L.J. 1990. Contribuição ao estudo dos sistemas deposicionais holocênicos do Nordeste da província costeira do Rio Grande do Sul, com ênfase no sistema eólico. Tese de Douroramento. (inéd). Porto Alegre, Universidade Federal Rio Grande do Sul. 270p.

Tsoar, H. 1990. The ecological background, deterioration and reclamation of deset dune sand. Agriculture Ecosystems and Envionment. 33: 147-170 
Tsoar, H 2005. Sand dunes mobility and stability in relation to climate. Phisica a: Statistical Mechanics and Its Applications 357: 50-56

Tsoar, H. 2008. Land use and its effect on the mobilization and stabilization of NW Negev sand dunes. In: Breckle SW, Yair A, Veste M (eds.) Arid dune ecosystems of ecological studies. 200: 79-90. Springer, Berlin.

Tsoar, H; Blumberg, D. G. 2002. Formation of parabolic dunes from barchan and transverse dunes along Israel's Mediterranean coast. Earth Surface Processes and Landforms 27: 1147-1161

Tsoar, H; Levin, N; Porat, N; Maia, L.P; Hermann, H.J; Tatumi, S.H; Sales, V.C. 2009. The effect of climate change on the mobility and stability of coastal sand dunes in Ceará State (NE Brazil). Journal Quaternary Research,71: 217-226.

Tucker, M. E. \& Wright V.P. 1990. Carbonate Sedimentology. Blackwell Scientific Publications, Oxford, $479 \mathrm{p}$.

Ulbrich, M. N. C. 1993. Petrography of alkaline volcanic-subvolcanic rocks from the Brazilian Fernando de Noronha Archipelago, Southern Atlantic Ocean. Geochimica Brasiliensis 8: 21-29.

Uvo, C. B. 1989. A Zona de Convergência Intertropical (ZCIT) e sua relação com a precipitação na região Norte do Nordeste Brasileiro. Dissertação (Mestrado em Meteorologia) - Instituto Nacional de Pesquisas Espaciais, São José dos Campos. $88 \mathrm{p}$.

Valença, M.L.M., Neumann, V.H., Menor, E.A.\& Santos, C.E.R.R. 2005. Eolianitos de Fernando de Noronha: uma anánile integrada de estudos petrográficos e geoquímicos. 10 Congresso Brasileiro da Abequa, Resumos, p 37-39, Guarapari, ES, Brasil.

Van Andel, T. H.. 1955. Sediments of the Rhone delta, pt. II, Sources and deposition of heavy minerals. Verh. Koninkl. Nederlandsch geol. Mijnb. Genoot. 15: 515-543

Vasconcelos, D.L., Silva Filho, W.F.,Bezerra, F.H.R., Boski, T., Lima-Filho, F.P.,Mesquita, A.F.2. 2014. Indicadores do nível relativo do mar e evolução costeira durante o Holoceno tardio na costa do Ceará, Brasil. 47 Congresso Brasileiro de Geologia, Salvador, BA

Vieira, M.M. 2005. Aspectos Sedimentológicos e petrológicos dos Beach Rocks do Estado do Rio Grande do Norte. Tese de Doutorado (inéd.) Porto Alegre, Pósgraduação em Geociências, Universidade Federal de Rio Grande do Sul 243p

Vital, H., Silveira, I.M Da., Amaro, V.E. 2005. Carta sedimentológica da plataforma continental brasileira-b Área Guamaré a Macau (NE Brasil), utilizando intergração da dados geológicos e sensoriamento remoto. Revista Brasileira de Geofísica 23: 233-241 
Waelbroeck, C.; Labeyrie, L. Michel, E.; Duplessy, J.C.; McManus, J.F.; Lambeck, K.; Balbon, E.; Labracherie, M. 2002. Sea-level and deep water temperature changes derived from benthic foraminifera isotopic records. Quaternary Science Reviews 21(1-3): 295-305

Walker, R.J. 1976. An evaluation of recent quantitative magnetospheric magnetic field models. Reviews of Geophysics, 14(3): 411-427

Walker, R.G. 1992. Fácies, fácies models and modern stratigraphic concepts.In: Walker, R.G. \& James, N.P. eds. Fácies Models: Response to Sea Level Change. Geological Association of Canada, St John's, Newfoundland, p. 1-14.

Wang, X.F., Auler, A.S., Edwards, R.L., Cheng, H., Cristalli, P.S., Smart, P.L., Richards, D.A., 2004. Wet periods in northeastern Brazil over the past $210 \mathrm{kyr}$ linked to distant climate anomalies. Nature 432: 740-743.

Wang, X.F., Auler, A.S., Edwards, R.L; Hai, C.; Ito, E.; Maniko, S. 2006. Interhemispheric antiphasing of rainfall during the last glacial period. Quaternary Science Reviews 25: 3391-3403

Weldeab, S.; Schneider, R.R.; Kolling, M. 2006. Deglacial sea surface temperature and salinity increase in the western tropical Atlantic in synchony with high latitude climate instabilities. Earth and Planetary Science Letters, 241: 699-706.

Wentworth, C. K. 1922. A scale of grade and class terms for clastic sediments. The Journal of Geology, 377-392

White, B. \& Curran, H.A. 1989. The Holocene carbonate eolianites of North point and modern environments between North Point and Cut Cay, San Salvaor Island, Bahamas, In Curran, H.A. ed., Pleistocene and Holocene carbonate environments on San Salvador island, Bahamas: $28^{\text {th }}$. International Geological Congress Field Trip Guidebook 175: 17-22

Wildner, W.; Ferreira, R. V. 2012. Geoparque Fernando de Noronha (PE) - proposta. In: Geoparques do Brasil/Propostas $\quad-\quad$ volume1. CPRM.http://www.cprm.gov.br/publique/media/gestao_territorial/geoparques/nor onha1/index.php?GEOPARQUE=10

William, A.H. \& Walkden, G.M. 2002. Late Quaternary highstand deposits of the southern Arabian Gulf: A record of sea-level and climate change. Geological Society London Special Publications 195(1):371-386

Yizhag, H., Ashkenazy, Y.;Tsoar, H., 2009. Sand dune dynamics and climate change: a modelling approach. Journal. Geophysics Research. 114: 10-23.

Young, A. R. M.; Young, R.. 2002, Solis in the Landscape. Oxford University Press, Melbourn, 272pp

Zhang, Y., Chiessi, C. M., Mulitza, S., Zabel, M., Trindade, R. I. F., Hollanda, M. H. B. M., et al. 2015. Origin of increased terrigenous supply to the NE South American 
continental margin during Heinrich Stadial 1 and the Younger Dryas. Earth and Planetary Science Letters, 432: 493-500. https://doi.org/10.1016/j.epsl.2015.09.054

Zular, A. 2016. Variações da Zona de Convergência Intertropical e do nível relativo do mar durante o Quaternário tardio registradas em depósitos eólicos do nordeste e norte do Brasil. Tese de Doutorado (inéd.)São Paulo, Instituto de Geociencias, Universidade de São Paulo 44p

Zular, A.; Sawakuchi, A.O.; Guedes, C.C.F.; Mendes, V.R.; Nascimento, D.R., Jr.; Giannini, P.C.F.; Aguiar, V.A.P., Dewitt, R. 2012. Late Holocene intensification of colds fronts in southern Brazil as indicated by dune development and provenance changes in the São Francisco do Sul coastal barrier. Marine Geology, 335: 64-77

Zular, A.; Utida, G. ; Cruz, F. W. ; Sawakuchi, A. O. ; Wang, H. ; Bícego, M. ; Giannini, P.C.F. ; Rodrigues, S. I. ; Garcia, G.P.B.; Vuille, M.; Sifeddine, A.; Zocatelli, R.; Turcq, B.; Mendes, V. R. . 2018. The effects of mid-Holocene fluvio-eolian interplay and coastal dynamics on the formation of dune-dammed lakes in NE Brazil. Quaternary Science Reviews, 196: 137-153. 


\section{APÊNDICE 1}

Granulometria, Separação de Minerais Pesados e Teor de Bioclastos dos Eolianitos Continentais 


\begin{tabular}{|c|c|c|c|c|c|c|c|c|c|c|c|c|}
\hline \multirow{2}{*}{$\begin{array}{l}\text { ESTAD } \\
\text { O/ } / \text { Data }\end{array}$} & \multirow{2}{*}{ AMOSTRA } & \multicolumn{8}{|c|}{ FRAÇÃO DE AREIA } & \multirow{2}{*}{ LEVES } & \multirow{2}{*}{\begin{tabular}{|c} 
PESADOS \\
MAGNEII \\
COS
\end{tabular}} & \multirow{2}{*}{\begin{tabular}{|c} 
PESADOS \\
NÃO \\
MEGNÉTI \\
COS
\end{tabular}} \\
\hline & & $\geq 0,5 \phi$ & $1.0 \phi$ & $1.5 \Phi$ & $2.0 \phi$ & $2.5 \Phi$ & $3.0 \phi$ & $3,5 \phi$ & $4,0 \phi$ & & & \\
\hline \multirow{20}{*}{\begin{tabular}{|c} 
Rio \\
Grand \\
e do \\
Norte \\
$/ 2017$
\end{tabular}} & ERN 02E & 7,36 & 4,59 & 12,45 & 19,19 & 34,36 & 9,42 & 1,46 & 0,42 & 0,044 & 0,37 & 0,42 \\
\hline & ERN 02C & 7,78 & 29,1 & 23,88 & 23,47 & 34,46 & 11,36 & 3,16 & 1,62 & 0,29 & 2,72 & 1.053 \\
\hline & ERN 02W & $\geq$ & 36,74 & 24,4 & 9,11 & 6,42 & 3,99 & 1,04 & 0,08 & 0,163 & 0,54 & 0,084 \\
\hline & ERN 03 & 1,12 & 12,25 & 11,9 & 3,39 & 55,98 & 10,91 & 0,37 & 0,078 & 0,19 & 0,151 & 0,096 \\
\hline & ERN 06A & 51,74 & 92,83 & 29,43 & 18,27 & 15,32 & 3 & 0,86 & 0,4 & 0,32 & 0,66 & 0,255 \\
\hline & ERN 06B & 12,66 & 31,4 & 21,22 & 16,65 & 6,26 & 0,16 & 0,25 & & 2,45 & 0,032 & 0,075 \\
\hline & ERN 07A & 29,06 & 36,36 & 7,14 & 5,66 & 7,93 & 7,79 & 2,47 & 0,98 & 1,27 & 1,48 & 0,6 \\
\hline & ERN 07B & 5,99 & 60 & 11,82 & 4,7 & 6,37 & 0,28 & 0,065 & & 0,032 & 0,023 & 0,015 \\
\hline & ERN 08 & 12,66 & 55,08 & 12,62 & 0,89 & 25,6 & 12,06 & 2,37 & 0,75 & 0,096 & 0,35 & 0,29 \\
\hline & ERN 09 & 19,97 & 49,25 & 11,11 & 10,14 & 16,88 & 2,79 & 2,34 & 0,2 & 1,87 & 0,39 & 0,26 \\
\hline & \begin{tabular}{|l|} 
ERN 11 \\
\end{tabular} & 10,45 & 10,09 & 8,94 & 20,58 & 32,65 & 0,9 & 1,44 & 0,02 & 1,44 & 0,004 & 0,0064 \\
\hline & ERN 14 & 1,68 & 5,4 & 15,55 & 23,93 & 29,05 & 9,64 & 0,36 & 0,06 & 0,27 & 0,027 & 0,13 \\
\hline & \begin{tabular}{|l|} 
ERN 15 \\
\end{tabular} & 50,35 & 34,18 & 20,17 & 20,93 & 22,3 & 4,77 & 0,47 & 0,1 & 0,5 & \begin{tabular}{|l|}
0,033 \\
\end{tabular} & 0,027 \\
\hline & \begin{tabular}{|l} 
ERN 17 \\
\end{tabular} & 3,57 & 7,37 & 10,08 & 20,87 & 26,36 & 3,67 & 0,58 & \begin{tabular}{l|l}
0,037 \\
\end{tabular} & 0,58 & $\begin{array}{ll}0,011 \\
\end{array}$ & 0,023 \\
\hline & ERN 18 & 28,55 & 21,93 & 16,1 & 9,12 & 3,82 & 0,12 & 0,1 & $\begin{array}{ll}0,017 \\
\end{array}$ & 0,111 & 0,0029 & 0,0053 \\
\hline & ERN 19E & 15,16 & 79,42 & 41,89 & 51,36 & 36,58 & 20,17 & 7,81 & 1,51 & \begin{tabular}{|l|}
9.189 \\
\end{tabular} & $\begin{array}{l}0,029 \\
\end{array}$ & 0,047 \\
\hline & ERN 19W & 17,08 & 42,44 & 20,28 & 9,25 & 10,14 & 1,69 & 0,17 & \begin{tabular}{l|l}
0,018 \\
\end{tabular} & 0,14 & 0,009 & 0,034 \\
\hline & ERN 20 & 9,98 & 10,29 & 5,8 & 8,38 & 11,42 & 9,28 & 10,6 & & 10,52 & 0,009 & 0,045 \\
\hline & ERN 21E & 0,87 & \begin{tabular}{ll|}
48,75 \\
\end{tabular} & 21,36 & 18,77 & 21,91 & 15,16 & 5,42 & 0,77 & 5,71 & $\begin{array}{ll}0,169 \\
\end{array}$ & 0,284 \\
\hline & ERN 21W & 32,32 & \begin{tabular}{|l|}
14,33 \\
\end{tabular} & 9,31 & 8,94 & \begin{tabular}{|l|}
10,48 \\
\end{tabular} & 3,4 & 0,07 & \begin{tabular}{l|l}
0,008 \\
\end{tabular} & \begin{tabular}{l|l|}
0,062 \\
\end{tabular} & \begin{tabular}{l|l|}
0,008 \\
\end{tabular} & 0,014 \\
\hline \multirow{15}{*}{$\begin{array}{l}\text { Piauí } \\
\text { /2015 }\end{array}$} & EPI 06 & 46.95 & 99,4 & 20,46 & 10,1 & 5,1 & 30,92 & 9,85 & 1,21 & \begin{tabular}{|l|}
9.007 \\
\end{tabular} & \begin{tabular}{l|l|}
0.986 \\
\end{tabular} & 0.988 \\
\hline & \begin{tabular}{|l|} 
EPI 07 \\
\end{tabular} & 12,32 & 33,47 & 26,51 & 4,65 & 2,76 & 2,02 & \begin{tabular}{|l|}
0,086 \\
\end{tabular} & \begin{tabular}{|l|}
$, 1,21$ \\
0,005
\end{tabular} & \begin{tabular}{|c|}
0.05 \\
\end{tabular} & $\begin{array}{l}, 0019 \\
0,019\end{array}$ & 0,023 \\
\hline & \begin{tabular}{|l} 
EPI $08 \mathrm{E}$ \\
\end{tabular} & 8,74 & \begin{tabular}{|l|}
27,87 \\
\end{tabular} & 15,39 & 24,91 & \begin{tabular}{|c|}
92,08 \\
\end{tabular} & 88,33 & 10,55 & 0,63 & \begin{tabular}{|l|}
9.873 \\
\end{tabular} & 0,427 & 0,752 \\
\hline & \begin{tabular}{|l} 
EPI 10E \\
\end{tabular} & 0,43 & 15,84 & 17,43 & 34,48 & \begin{tabular}{ll|}
134,7 \\
\end{tabular} & 42,54 & 5,55 & 0,28 & \begin{tabular}{|l|l|}
5.429 \\
\end{tabular} & 0,12 & 0,221 \\
\hline & EPI 11 & 0,43 & 23,95 & 31,53 & 43,56 & 72,95 & 64,66 & 11,11 & 0,38 & 11.008 & $\begin{array}{l}0,089 \\
\end{array}$ & 0,311 \\
\hline & EPI 12 & & 75,48 & 51,45 & 36,52 & 64,57 & 58,8 & 4,01 & 0,061 & 3.808 & $\begin{array}{ll}0,043 \\
\end{array}$ & 0,133 \\
\hline & EPI $14 \mathrm{E}$ & 0,24 & 61,01 & 17,32 & 34,03 & 54,52 & 41,01 & 1,78 & $\begin{array}{ll}0,102 \\
\end{array}$ & \begin{tabular}{|l|}
1.628 \\
\end{tabular} & 0,064 & 0,156 \\
\hline & EPI16E & \begin{tabular}{|l|}
56,63 \\
\end{tabular} & 110,65 & 22,65 & 15,96 & 19,84 & 16,69 & 1,37 & \begin{tabular}{l|l|}
0,096 \\
\end{tabular} & 1.171 & \begin{tabular}{|l|l|}
0,037 \\
\end{tabular} & 0,081 \\
\hline & EPI 18 & 0,64 & 17,08 & 14,44 & 29,04 & 94,02 & 82,7 & $\begin{array}{ll}9,02 \\
\end{array}$ & 0,28 & 8.456 & \begin{tabular}{l|l|}
0,253 \\
\end{tabular} & 0,31 \\
\hline & EPI 19 & 2,59 & 47,11 & 53,34 & 63,45 & 28,05 & 6,57 & 0,42 & $\begin{array}{ll}0,015 \\
\end{array}$ & 371,000 & 0,005 & 0,036 \\
\hline & EPI 20 & 9,68 & 10,46 & 11,5 & 0,36 & 33,94 & 12,84 & 0,71 & $\begin{array}{ll}0,058 \\
\end{array}$ & $\begin{array}{ll}0,012 \\
\end{array}$ & 0,011 & 0,033 \\
\hline & \begin{tabular}{|l|l} 
EPI 24 \\
\end{tabular} & 15,97 & 11,25 & 7,74 & 13,75 & 22,88 & 9,76 & 0,48 & $\begin{array}{ll}0,015 \\
\end{array}$ & \begin{tabular}{l|l}
0,468 \\
\end{tabular} & 0,0075 & 0,014 \\
\hline & EPI 31 & 5,4 & 12,4 & 31,95 & 16,7 & 11,76 & 15,27 & 2,78 & $\begin{array}{ll}0,127 \\
\end{array}$ & 2,67 & 0,012 & 0,17 \\
\hline & EPI 39 & 2,13 & 11,12 & 27,21 & 1,98 & 50,63 & 2,57 & 0,06 & & 0,022 & 0,008 & 0,032 \\
\hline & EPI 41 & 6,68 & 15,09 & 8,89 & 4,41 & 35,54 & 0,26 & 0,026 & 0,0025 & 0,019 & 0,0028 & 0,0063 \\
\hline \multirow{8}{*}{$\begin{array}{l}\text { Ceará } \\
\text { /2015 }\end{array}$} & ECE 46 & 1,19 & 8,46 & 22,58 & 50,33 & 22,02 & 5,98 & 0,12 & 0,021 & 0,084 & 0,029 & 0,029 \\
\hline & \begin{tabular}{|l} 
ECE 49 \\
\end{tabular} & 35,85 & 39,93 & 6,4 & 4,26 & 3,78 & 0,84 & 0,43 & 0,041 & 0,36 & 0,011 & 0,082 \\
\hline & \begin{tabular}{|l} 
ECE 51FB \\
\end{tabular} & 0,38 & 1,47 & 14,85 & 49 & 39,45 & 9,77 & 0,09 & 0,0039 & \begin{tabular}{l|}
0,062 \\
\end{tabular} & 0,0077 & 0,022 \\
\hline & ECE 53 & 9,11 & 5,21 & 13,12 & 26,9 & 22,76 & 14,62 & 1,75 & 0,11 & 1,81 & 0,0089 & 0,023 \\
\hline & ECE 55 & 14,06 & 36,57 & 18,42 & 12,46 & 10,66 & 0,42 & 1,66 & 0,02 & 1,36 & 0,019 & 0,24 \\
\hline & ECE 58 & 9,34 & 34,66 & 18,55 & 8,29 & 14,06 & 6,42 & \begin{tabular}{|c|}
6,46 \\
\end{tabular} & 0,62 & 0,033 & 0,33 & 0,21 \\
\hline & ECE 62 & 29,16 & 32,3 & 8,9 & 9,48 & $\begin{array}{ll}6,25 \\
\end{array}$ & 0,68 & 0,127 & & 0,36 & 0,04 & 0,39 \\
\hline & ECE 63 & 7,05 & 54,1 & 26,09 & 8,53 & 18,16 & 6,63 & 0,37 & 0,092 & 0,053 & 0,275 & 0,116 \\
\hline
\end{tabular}

\begin{tabular}{|c|c|c|c|c|c|}
\hline \multirow{2}{*}{ AMOSTRA } & \multicolumn{5}{|c|}{ TEOR DE BIOCLASTOS POR FRAÇÃO } \\
\hline & $1.0 \phi$ & $1.5 \phi$ & $2.0 \phi$ & $2.5 \phi$ & $3.0 \phi$ \\
\hline ERN 02E & 8 & 5 & 10 & 8 & 8 \\
\hline ERN 02C & 15 & 12 & 10 & 7 & 10 \\
\hline ERN 02W & 8 & 5 & 18 & 15 & 10 \\
\hline ERN 03 & 5 & 8 & 5 & 8 & 5 \\
\hline ERN 06A & 20 & 18 & 20 & 18 & 23 \\
\hline ERN 06B & 12 & 10 & 18 & 22 & 22 \\
\hline ERN 07A & 20 & 25 & 33 & 28 & 25 \\
\hline ERN 07B & 8 & 15 & 12 & 10 & 30 \\
\hline ERN 08 & 12 & 18 & 20 & 25 & 22 \\
\hline ERN 09 & 10 & 15 & 18 & 20 & 18 \\
\hline ERN 11 & 40 & 15 & 10 & 15 & \\
\hline ERN 14 & 25 & 18 & 8 & 8 & \\
\hline ERN 15 & 4 & 5 & 7 & 8 & 7 \\
\hline ERN 17 & 25 & 20 & 12 & 5 & 18 \\
\hline ERN 18 & 35 & 40 & 50 & 20 & 20 \\
\hline ERN 19E & 25 & 25 & 25 & 25 & 20 \\
\hline ERN 19W & 20 & 18 & 25 & 23 & 18 \\
\hline ERN 20 & 10 & 13 & 18 & 20 & 22 \\
\hline ERN 21E & 15 & 20 & 23 & 20 & 18 \\
\hline ERN 21W & 5 & 80 & 70 & 40 & 40 \\
\hline EPI 06 & 15 & 20 & 22 & 25 & 10 \\
\hline EPI 07 & 8 & 10 & 25 & 22 & 15 \\
\hline EPI 08E & 8 & 8 & 15 & 23 & 10 \\
\hline EPI 10E & 20 & 25 & 20 & 23 & 10 \\
\hline EPI 11 & 25 & 30 & 35 & 27 & 15 \\
\hline EPI 12 & 10 & 8 & 12 & 12 & 8 \\
\hline EPI 14E & 15 & 17 & 25 & 20 & 12 \\
\hline EPI16E & 5 & 7 & 10 & 15 & 15 \\
\hline EPI 18 & 10 & 7 & 15 & 10 & 8 \\
\hline EPI 19 & 20 & 12 & 15 & 15 & 10 \\
\hline EPI 20 & 8 & 10 & 18 & 15 & 6 \\
\hline EPI 24 & 8 & 15 & 15 & 10 & 15 \\
\hline EPI 31 & 20 & 15 & 30 & 35 & 10 \\
\hline EPI39 & 18 & 10 & 35 & 30 & 35 \\
\hline EPI41 & 10 & 8 & 8 & 5 & 8 \\
\hline ECE 62 & 15 & 17 & 20 & 18 & 14 \\
\hline ECE 63 & 18 & 14 & 20 & 12 & 10 \\
\hline & & & & & \\
\hline $\begin{array}{l}\text { Observas } \\
\text { incluidas }\end{array}$ & $\begin{array}{l}\text { o: As a } \\
\text { as ana }\end{array}$ & $\begin{array}{l}\text { tras do } \\
\text { e grá } \\
\text { de b }\end{array}$ & $\begin{array}{l}\text { drado } \\
\text { de gr } \\
\text { sttos }\end{array}$ & $\begin{array}{l}\text { melho } \\
\text { ometr }\end{array}$ & $\begin{array}{l}\text { of foran } \\
\text { teore }\end{array}$ \\
\hline
\end{tabular}




\section{APÊNDICE 2}

Granulometria e Separação de Minerais Pesados dos Eolianitos Insulares 


\begin{tabular}{|c|c|c|c|c|c|c|c|c|c|c|c|c|c|}
\hline $\begin{array}{c}\text { ESTADO } \\
\text { /Data }\end{array}$ & AMOSTRA & $\begin{array}{c}\text { Peso } \\
\text { inicial } \\
\text { (antes d } \\
\text { elutr,) }\end{array}$ & $\begin{array}{c}\text { Peso } \\
\text { inicial } \\
\text { (após d } \\
\text { elutr,) } \\
\end{array}$ & $\begin{array}{c}\text { FRAÇÃO } \\
1,0 \phi \\
\end{array}$ & $\begin{array}{c}\text { FRAÇÃO } \\
\mathbf{1 , 5} \phi\end{array}$ & \begin{tabular}{|c|} 
FRAÇÃO \\
$\mathbf{2 , 0} \phi$
\end{tabular} & $\begin{array}{c}\text { FRAÇÃO } \\
\mathbf{2 , 5} \phi \\
\end{array}$ & \begin{tabular}{|c|} 
FRAÇÃO \\
$\mathbf{3 , 0} \boldsymbol{\phi}$
\end{tabular} & $\begin{array}{c}\text { FRAÇÃO } \\
\mathbf{3 , 5} \boldsymbol{\phi} \\
\end{array}$ & \begin{tabular}{|c} 
FRAÇÃO \\
$\mathbf{4 , 0} \phi$ \\
\end{tabular} & LEVES & $\begin{array}{c}\text { PESADOS } \\
\text { MAGNETICOS }\end{array}$ & $\begin{array}{c}\text { PESADOS } \\
\text { NÃ̃O } \\
\text { MEGNÉTICOS } \\
\end{array}$ \\
\hline \multirow{16}{*}{$\begin{array}{l}\text { AFN-PE } \\
/ 2015\end{array}$} & EFN 01 & 61,75 & 57,28 & 2,41 & 1,9 & 4,57 & 24,5 & 14,3 & 3,65 & & 2,27 & 0,49 & 0,87 \\
\hline & EFN $02 \mathrm{E}$ & 85,8 & 65,06 & 11,28 & 8,98 & 15,36 & 13,1 & 3,84 & 6,42 & 0,81 & 7,01 & 0,023 & 0,12 \\
\hline & EFN $02 \mathrm{~F}$ & 50,61 & 41,26 & 5,66 & 7,27 & 2,68 & 15,55 & 4,91 & 2,12 & 1,38 & 3,41 & 0,008 & 0,037 \\
\hline & EFN 03 & 59,2 & 42,6 & 9,87 & 5,96 & 7,76 & 6,67 & 1,8 & 2,6 & 0,8 & 3,06 & 0,044 & 0,29 \\
\hline & EFN $04 \mathrm{~A}$ & 60 & 55,85 & 12,69 & 5,23 & 0,17 & 29,16 & 7,33 & 0,91 & 0,13 & 0,15 & 0,36 & 0,29 \\
\hline & EFN $04 \mathrm{C}$ & 100,23 & 82,8 & 3,45 & 4,32 & 8,43 & 18,89 & 12,67 & 2,55 & & 0,52 & 0,79 & 1,04 \\
\hline & EFN $05 \mathrm{C}$ & 81,3 & 55,27 & 12,18 & 9,96 & 10,96 & 9,26 & 9,32 & 2,6 & 0,9 & 1,9 & 0,57 & 0,85 \\
\hline & EFN 05 E & 75,5 & 56,69 & 13,68 & 10,58 & 0,91 & 18,9 & 6,47 & 0,97 & 0,067 & 0,68 & 0,064 & 0,29 \\
\hline & EFN $05 \mathrm{~J}$ & 132,22 & 85,88 & 23,4 & 22,43 & 20,31 & 3,3 & 0,058 & 0,1 & 0,03 & 0,11 & 0,0085 & 0,005 \\
\hline & EFN 06 B & 101,23 & 68,9 & 11,13 & 13,43 & 13,81 & 9,7 & 6,73 & 2,24 & 0,22 & 2,45 & 0,032 & 0,075 \\
\hline & EFN 07 & 60,85 & 59,76 & 0,45 & 0,66 & 6,68 & 34,82 & 12,99 & 2,53 & & 0,95 & 0,87 & 0,63 \\
\hline & EFN $08 \mathrm{~A}$ & 60,57 & 59,49 & 1,98 & 2,37 & 8,58 & 34,88 & 7,33 & 0,73 & 0,09 & 0,114 & 0,52 & 0,17 \\
\hline & EFN 15A & 121,45 & 84,15 & 20,16 & 11,01 & 13,07 & 8,39 & 1,09 & 0,14 & 0,011 & 0,14 & 0,0018 & 0,0034 \\
\hline & EFN 15C & 122,09 & 53,54 & 19,95 & 10,03 & 1,14 & 6,72 & 0,28 & 0,078 & 0,019 & 0,095 & 0,0033 & 0,0031 \\
\hline & EFN $15 \mathrm{E}$ & 117,36 & 63,2 & 15,74 & 10,37 & 9,07 & 14,26 & 4,97 & 0,24 & 0,034 & 3,18 & 0,13 & 0,11 \\
\hline & EFN $15 \mathrm{~F}$ & 126,93 & 96,66 & 19,37 & 16,39 & 12,9 & 7,3 & 4,92 & 0,77 & 0,0085 & 0,795 & 0,011 & 0,024 \\
\hline
\end{tabular}


APÊNDICE 3

Petrografia dos Eolianitos 


\begin{tabular}{|c|c|c|c|c|c|c|c|c|c|c|c|c|c|c|c|c|c|c|c|c|c|c|c|}
\hline \multirow[b]{2}{*}{ AMOSTRA } & \multicolumn{4}{|c|}{ Estimativa modal de componentes } & \multicolumn{10}{|c|}{ ARCABOUÇO-TIPO DE GRÃO } & \multicolumn{8}{|c|}{ TEXTURA-TRAMA DE CIMENTOS CALCÍ́IICOS } & \multirow[b]{2}{*}{$\begin{array}{l}\text { RAZÃo } \\
\text { PELOIDES- } \\
\text { ALGAS }\end{array}$} \\
\hline & Arcabouço & cimento & Porosidade & Matriz & $\begin{array}{c}\text { Algas } \\
\text { vermelhas }\end{array}$ & $\begin{array}{c}\text { Fragmentos } \\
\text { de } \\
\text { moluscos. }\end{array}$ & $\mid \begin{array}{c}\text { Fragmentos } \\
\text { de } \\
\text { Bryozoarios }\end{array}$ & $\left\{\begin{array}{c}\text { Foraminife } \\
\text { ros } \\
\text { bentônicos }\end{array}\right.$ & $\begin{array}{c}\text { Pellets } \\
\text { fosfáticos }\end{array}$ & Peliodes & \begin{tabular}{|c|} 
Substitui \\
ção \\
parcial \\
ou total
\end{tabular} & Quartzo & $\mid \begin{array}{c}\text { Minerais } \\
\text { transpare } \\
\text { ntes }\end{array}$ & $=\begin{array}{l}\text { Opacos- } \\
\text { liticos }\end{array}$ & Mosaico & $\begin{array}{c}\text { Franja } \\
\text { envolvent } \\
\text { e isopaca }\end{array}$ & \begin{tabular}{|c} 
Franja \\
envolven \\
te \\
anisopac \\
a
\end{tabular} & $\begin{array}{c}\text { Revestim } \\
\text { ento de } \\
\text { poros }\end{array}$ & Menisco & $\left|\begin{array}{c}\text { tendencia } \\
\text { subvertical }\end{array}\right|$ & \begin{tabular}{|} 
tendencia \\
horizontal
\end{tabular} & Geopetal & \\
\hline CHAPEU 01 & 40 & 50 & 10 & 0 & 20 & 9 & 6 & 5 & 10 & 40 & 10 & & & & 10 & 57 & 8 & 8 & 17 & & & & 66,67 \\
\hline CHAPEU 02 & 35 & 35 & 15 & 15 & 3 & & & & 28 & 48 & 3 & & & 18 & 10 & & 30 & 30 & 30 & & & & 94,12 \\
\hline CHAPEU 03 & 30 & 45 & 15 & 10 & 4 & & & & 12 & 61 & 17 & & 2 & 4 & 40 & & 30 & 15 & 15 & & & & 93,85 \\
\hline CHAPEU 04 & 40 & 25 & 30 & 5 & 5 & 2 & 2 & & 15 & 43 & 20 & & 3 & 10 & 15 & & 50 & 20 & 15 & & & & 89,58 \\
\hline I. do MEIO 1 & 50 & 43 & 7 & 0 & 15 & 10 & 5 & 10 & 10 & 30 & 5 & & 7 & 8 & 30 & & 40 & 15 & 15 & & & & 66,67 \\
\hline I. do MEIO 3 & 40 & 50 & 10 & 0 & 20 & 10 & 7 & 10 & 8 & 8 & 25 & & 4 & 8 & 25 & & 50 & 15 & 10 & & & & 28,57 \\
\hline I. do MEIO 4 & 45 & 35 & 20 & 0 & 17 & 7 & 5 & 10 & 3 & 38 & 8 & & 5 & 7 & 12 & & 54 & 22 & 12 & & & & 69,09 \\
\hline I. RATA B & 40 & 40 & 20 & 0 & 18 & 5 & 5 & 10 & 17 & 26 & 4 & & 5 & 10 & 17 & & 57 & 16 & 10 & & & & 59,09 \\
\hline I. RATA 1 & 50 & 30 & 20 & 0 & 32 & 5 & $\frac{1}{1}$ & 10 & 7 & 35 & 7 & & $\frac{1}{1}$ & 2 & 10 & 45 & 20 & 10 & 15 & & & & 52,24 \\
\hline I. RATA 2 & 40 & 20 & 40 & 0 & 14 & 9 & 6 & 10 & 2 & 50 & 5 & & 2 & 2 & 15 & 45 & 25 & 10 & 5 & & & & 78,13 \\
\hline I. RATA 3 & 40 & 25 & 35 & 0 & 19 & 6 & 3 & 12 & & 48 & 10 & & & 2 & 35 & 5 & 25 & 15 & 20 & & & & 71,64 \\
\hline I. RATA 4 & 40 & 25 & 30 & 5 & 18 & 2 & 3 & 5 & 5 & 50 & 15 & & & 2 & 20 & & 60 & 10 & 5 & 5 & & & 73,53 \\
\hline EFN 02E & 50 & 45 & 5 & & 18 & 2 & & 1 & 23 & 53 & 1 & & 1 & 1 & 60 & & 20 & 20 & & & & & 74,65 \\
\hline EFN 02 F & 25 & 25 & 50 & 0 & 15 & 10 & & 5 & 15 & 50 & 3 & & 1 & 1 & 25 & & 65 & & & 10 & & & 76,92 \\
\hline EFN 03 & 35 & 35 & 30 & 0 & 21 & 2 & & 3 & 11 & 58 & & & & 5 & 20 & & 70 & 25 & & & & & 73,42 \\
\hline EFN 03C C & 35 & 45 & 20 & 0 & $\frac{21}{14}$ & 5 & & $\frac{3}{5}$ & $\frac{11}{10}$ & $\frac{30}{46}$ & & & 10 & 10 & 25 & 30 & 35 & 10 & & & & & 76,467 \\
\hline EFN 01 & 50 & 15 & 35 & 0 & 13 & 3 & & 2 & 14 & 55 & & & 10 & 3 & 25 & & 40 & 10 & 10 & 15 & & & 80,88 \\
\hline EFN 04A A & 50 & 10 & 40 & 0 & 10 & 5 & & 3 & 10 & 57 & & & 7 & 8 & 10 & & 70 & 20 & & & & & 85,07 \\
\hline EFN 04 B B & 50 & 10 & 40 & 0 & 13 & 5 & & 7 & 8 & 45 & & & 12 & 10 & 5 & & 80 & 15 & & & & & $\frac{03,01}{77,59}$ \\
\hline EFN $04 \mathrm{C}$ & 50 & 35 & 15 & 0 & 12 & 5 & & 5 & 8 & 46 & & & 9 & 15 & 25 & & 45 & 20 & & & 10 & & 79,31 \\
\hline EFN 07 & 40 & 20 & 40 & 0 & 10 & 3 & & 3 & 9 & 64 & & & 5 & 6 & 10 & & 45 & 30 & 5 & 10 & & & 86,49 \\
\hline EFN 08 A & 40 & 20 & 40 & 0 & 20 & 8 & & $\frac{3}{2}$ & 13 & $\frac{04}{42}$ & & & $\frac{3}{7}$ & 8 & & & $\begin{array}{ll}45 \\
80\end{array}$ & 20 & & & & & $\frac{80,49}{67,74}$ \\
\hline EFN 05 B & 45 & 20 & 35 & 0 & 5 & 3 & 2 & 10 & 13 & 40 & 7 & & 10 & 10 & 10 & & 40 & & 30 & 20 & & & 88,89 \\
\hline EFN 05C C & 35 & 30 & 35 & 0 & 5 & 2 & 2 & 7 & 10 & 49 & 10 & & 5 & 10 & 35 & & 40 & 5 & & 20 & & & 90,74 \\
\hline EFN 05 D D & 30 & 30 & 40 & 0 & 17 & 8 & & 13 & 8 & $\frac{45}{33}$ & 16 & & 1 & 4 & 40 & & 30 & 20 & 10 & & & & $66,0,00$ \\
\hline EFN 05 Da & 35 & 25 & 40 & 0 & 25 & 6 & 4 & 8 & 6 & 35 & 11 & & 1 & 4 & 30 & & 45 & 15 & & 10 & & & 58,33 \\
\hline EFN $05 \mathrm{E}$ & 25 & 25 & 50 & 0 & 29 & 2 & 6 & 5 & 9 & 27 & 20 & & 1 & 1 & 55 & & 45 & & & & & & 48,21 \\
\hline EFN $05 \mathrm{~F}$ & 35 & 30 & 35 & 0 & 10 & 8 & 4 & 5 & 9 & 40 & 18 & & 2 & 4 & 35 & & 35 & 15 & & 15 & & & 80,00 \\
\hline $\begin{array}{l}\text { EFFN } 05 \mathrm{~F} \\
\text { EFN }\end{array}$ & $\frac{35}{30}$ & 30 & 35 & 0 & $\frac{10}{18}$ & 8 & $\frac{4}{7}$ & $\frac{3}{15}$ & $\frac{9}{7}$ & $\frac{40}{28}$ & $\frac{18}{9}$ & & $\frac{2}{3}$ & $\frac{4}{8}$ & $\frac{33}{60}$ & & $\frac{35}{20}$ & $\frac{15}{10}$ & & 15 & 10 & & $\frac{80,00}{60,87}$ \\
\hline EFN 051 & 35 & 25 & 40 & & 14 & 4 & 2 & 6 & 5 & 53 & 10 & & 1 & 5 & 60 & & 20 & 18 & 2 & & & & 79,10 \\
\hline EFN 05J & 45 & 40 & 10 & 5 & $\frac{14}{23}$ & 4 & 1 & 8 & 8 & 32 & 9 & & $\frac{1}{7}$ & 8 & 60 & & 25 & $\frac{10}{8}$ & 7 & & & & 58,18 \\
\hline PONTA CARACAS 01 & 40 & 20 & 40 & 0 & 10 & 3 & & 1 & 7 & 73 & & & 1 & 5 & 20 & & 50 & 20 & 10 & & & & 87,95 \\
\hline EFN 06 & 35 & 45 & 10 & 10 & 11 & 7 & 1 & 6 & 2 & 56 & 9 & & 3 & 5 & 70 & & 10 & 20 & & & & & 83,58 \\
\hline EFN 06 B & 30 & 40 & 25 & 5 & 14 & 8 & 2 & 5 & 10 & 51 & 3 & & & 7 & 70 & & 10 & 10 & 10 & & & & 78,46 \\
\hline $\begin{array}{l}\text { EFN } 06 \mathrm{C} \\
\text { EF }\end{array}$ & $\frac{30}{25}$ & $\frac{40}{45}$ & $\frac{23}{30}$ & $\frac{3}{0}$ & $\frac{14}{12}$ & & & & & $\frac{31}{62}$ & & & & & 75 & & 12 & 13 & & & & & $\begin{array}{r}80,40 \\
83,78 \\
-10\end{array}$ \\
\hline EFN $15 \mathrm{~A}$ & 35 & 45 & 15 & 5 & 8 & 2 & 5 & 5 & 2 & 59 & 19 & & & & 40 & & 30 & 15 & 15 & & & & 88,06 \\
\hline EFN $15 B$ & 35 & 35 & 30 & 0 & 12 & 5 & & 5 & 3 & 70 & 5 & & & & 50 & & 30 & 10 & 10 & & & & 80,05 \\
\hline EFN $15 \mathrm{C}$ & 50 & 35 & 15 & 0 & 16 & & 4 & 8 & 2 & 56 & 10 & & 1 & 3 & 25 & & 50 & 15 & 10 & & & & 77,78 \\
\hline EFN 15D D & 65 & 15 & 20 & 0 & 15 & 1 & & 1 & 2 & 75 & & & 1 & 5 & & & 100 & & & & & & 83,33 \\
\hline EFN $15 \mathrm{E}$ & 45 & 45 & 10 & 0 & 13 & 5 & 3 & 11 & 10 & 41 & 6 & & $\frac{1}{2}$ & 9 & 25 & & 45 & 20 & & & & & $\frac{73,93}{75,93}$ \\
\hline $\begin{array}{l}\text { EFN } 15 \mathrm{~F} \\
\text { EF }\end{array}$ & 40 & $\frac{45}{37}$ & $\frac{10}{25}$ & 3 & $\frac{13}{25}$ & $\frac{3}{6}$ & $\frac{3}{3}$ & $\frac{11}{10}$ & 7 & $\frac{41}{23}$ & 16 & & $\frac{2}{2}$ & $\frac{9}{8}$ & $\frac{23}{23}$ & & $\frac{45}{58}$ & 10 & 9 & & & & $\begin{array}{l}47,93 \\
7,92\end{array}$ \\
\hline EFN 151 & 40 & 15 & 45 & 0 & 17 & 7 & 4 & 8 & 4 & 37 & 18 & & 2 & 3 & 25 & & 50 & 10 & 15 & & & & 68,52 \\
\hline ERN O & 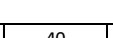 & 10 & 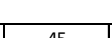 & 5 & 2 & 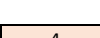 & & 4 & 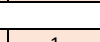 & 15 & 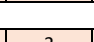 & 5 & 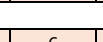 & 10 & & & 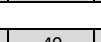 & 30 & & & & & 8824 \\
\hline $\begin{array}{l}\text { ERN OLE } \\
\text { ERN } 02 C\end{array}$ & 40 & $\frac{10}{7}$ & 48 & $\frac{5}{0}$ & $\frac{2}{6}$ & $\frac{4}{2}$ & & $\frac{4}{5}$ & $\frac{1}{1}$ & $\frac{15}{10}$ & $\frac{2}{3}$ & $\frac{56}{63}$ & $\frac{6}{2}$ & $\frac{10}{8}$ & & & $\frac{40}{35}$ & $\frac{30}{15}$ & $\frac{15}{30}$ & 10 & & $\frac{15}{10}$ & $\frac{88,24}{62,50}$ \\
\hline ERN 02W & 40 & 15 & 45 & 0 & 5 & 2 & & 4 & 3 & 15 & 5 & 49 & 3 & 14 & & & 20 & & 10 & 25 & 45 & & 75,00 \\
\hline$\frac{1}{\text { ERN } 03}$ & $\frac{40}{50}$ & $\frac{15}{10}$ & 40 & 0 & $\frac{3}{4}$ & $\frac{2}{2}$ & & & $\frac{3}{3}$ & $\frac{13}{10}$ & $\frac{5}{3}$ & $\frac{49}{65}$ & $\frac{3}{5}$ & $\frac{14}{8}$ & & & 20 & 15 & $\frac{10}{15}$ & $\frac{23}{45}$ & & 5 & $\begin{array}{l}71,00 \\
71,43\end{array}$ \\
\hline ERN 06B & 55 & 5 & 40 & 0 & 7 & 7 & & 6 & 3 & 14 & 4 & 48 & 2 & 9 & & & 90 & & & & & 10 & 66,67 \\
\hline ERN 08 & 60 & 5 & 35 & 0 & 10 & 5 & & 6 & 1 & 10 & 7 & 49 & 2 & 10 & & & 90 & & & & & 10 & 50,00 \\
\hline ERN 09 & 40 & 15 & 25 & 20 & 7 & 2 & & $\frac{0}{5}$ & 1 & 9 & 4 & $\frac{45}{55}$ & 4 & 13 & & & 20 & 20 & 15 & 10 & 35 & & 56,25 \\
\hline ERN 15 & 43 & 7 & 30 & 20 & 6 & 4 & & 3 & 1 & 7 & 1 & 74 & 1 & 3 & & & 30 & 35 & 35 & & & & 53,85 \\
\hline ERN 16-17 & 55 & 15 & 30 & 0 & 5 & 7 & 1 & 4 & 4 & 10 & 3 & 58 & 1 & 7 & & & 80 & 10 & 10 & & & & 66,67 \\
\hline ERN 18 & 40 & 15 & 25 & 20 & 10 & 8 & 7 & 10 & 2 & 10 & 7 & 34 & 2 & 10 & 20 & & 40 & 20 & 20 & & & & 50,00 \\
\hline ERN 19W & 40 & 20 & 40 & 0 & 10 & 5 & 2 & 10 & 1 & 8 & 6 & 50 & 1 & 7 & 20 & & 25 & 20 & 20 & & 15 & & 44,44 \\
\hline ERN 20 & 42 & 33 & 25 & 0 & 10 & 10 & & 10 & 10 & 10 & 7 & 38 & 2 & 3 & 50 & & 15 & 15 & 15 & & & & 50,00 \\
\hline ERN 21W & $\frac{42}{52}$ & 18 & 30 & 0 & 10 & $\frac{10}{5}$ & & 10 & 2 & 10 & $\frac{1}{7}$ & 50 & 1 & 5 & 10 & & 30 & 30 & 30 & & & & 50,00 \\
\hline
\end{tabular}




\section{APÊNDICE 4}

Contagem de Minerais Pesados nos Eolianitos Continentais 


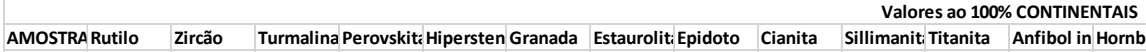

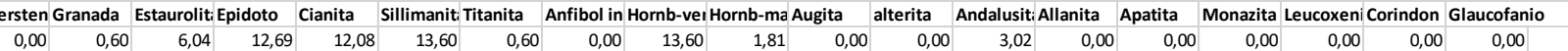

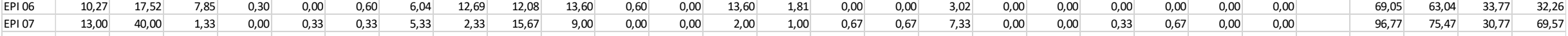

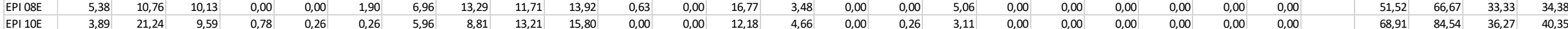

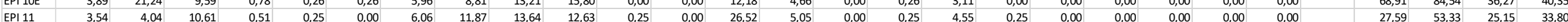

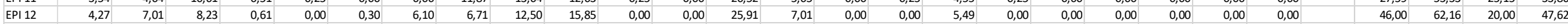
$\begin{array}{llllllllllllllllllllllllllll}\text { EPI 14E } & 5,68 & 19,24 & 6,94 & 1,89 & 0,32 & 0,32 & 5,05 & 9,15 & 12,93 & 10,73 & 0,32 & 0,95 & 13,25 & 6,31 & 0,00 & 1,89 & 5,05 & 0,00 & 0,00 & 0,00 & 0,00 & 0,00 & 0,00 & 73,49 & 77,22 & 26,19 & 35,56\end{array}$

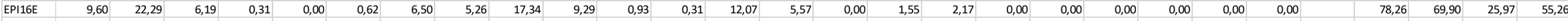

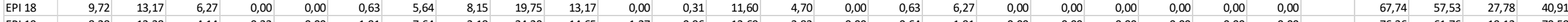

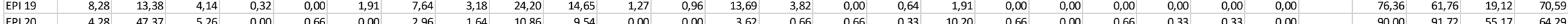

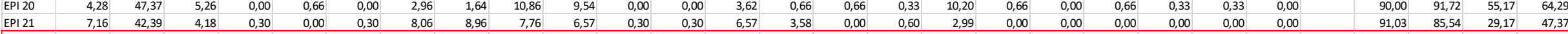

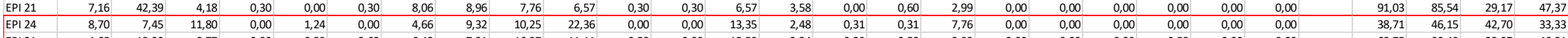

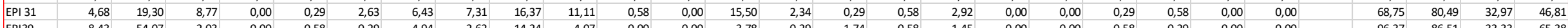

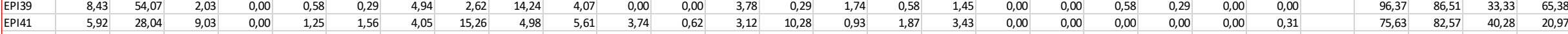

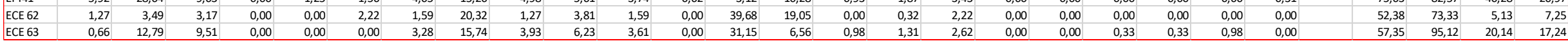

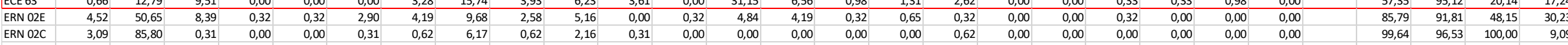

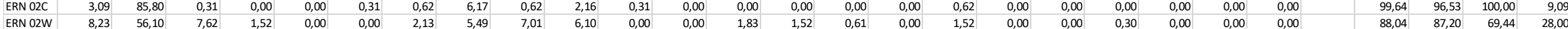

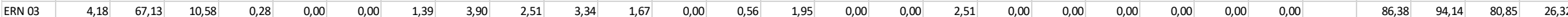
$\begin{array}{llllllllllllllllllllllllllll}\text { ERN 06A } & 8,20 & 66,88 & 5,68 & 0,00 & 0,00 & 0,00 & 0,63 & 6,31 & 2,84 & 2,84 & 1,89 & 0,00 & 0,32 & 2,84 & 0,00 & 0,00 & 1,26 & 0,00 & 0,00 & 0,32 & 0,00 & 0,00 & 0,00 & 92,17 & 89,08 & 64,29 & 9,09\end{array}$

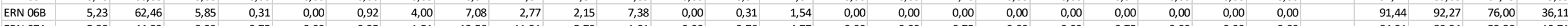

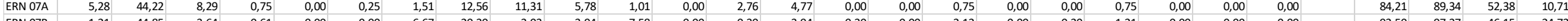

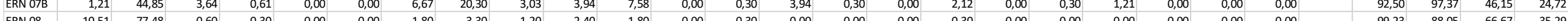

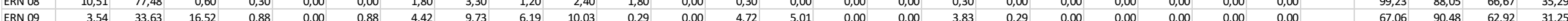

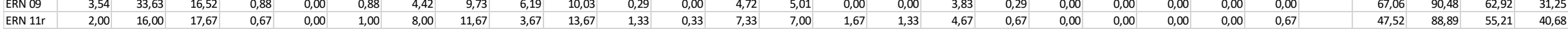

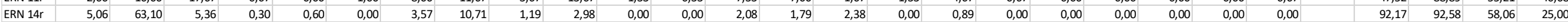

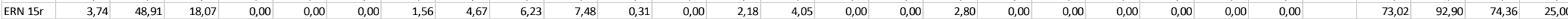

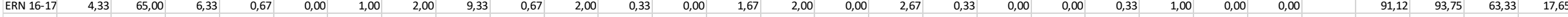

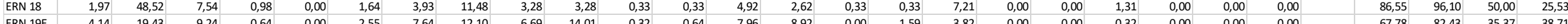

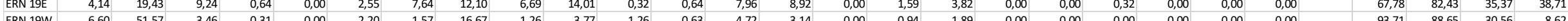

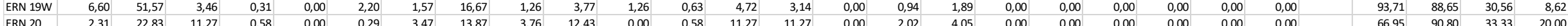

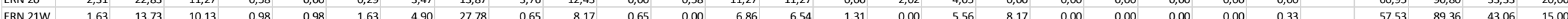

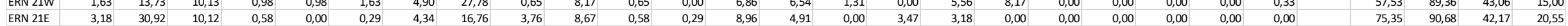


APÊNDICE 5

Contagem de Minerais Pesados nos Eolianitos Insulares 
Valores ao $100 \%$ INSULARES

INDICES

\begin{tabular}{|c|c|c|c|c|c|c|c|c|c|c|c|c|c|c|c|c|c|c|c|c|c|}
\hline AMOSTRA & vskit: & rsten E & atita & livina & Granada & Epidoto & Titanita & Anfibol in $\mathrm{H}$ & ab-vel I & nnb-ma & anoaug & gita & Diopsidio a & & Allanita & Apatita & Monazita & TiOli & TiAui & HbAui & TiAli \\
\hline EFN 01 & 0,00 & 2,07 & 0,30 & 22,19 & 0,89 & 1,18 & 9,76 & 0,00 & 0,30 & 17,75 & 17,75 & 17,46 & 2,66 & 0,00 & 4,73 & 2,37 & 0,30 & 30,56 & 35,87 & 50,42 & 67,35 \\
\hline EFN 04A & 0,00 & 1,20 & 0,00 & 20,96 & 0,00 & 1,80 & 17,66 & 0,00 & 0,60 & 13,77 & 14,67 & 19,16 & 2,99 & 0,00 & 3,29 & 2,69 & 1,20 & 45,74 & 47,97 & 41,82 & 84,29 \\
\hline EFN 04B & 0,96 & 1,60 & 0,64 & 13,74 & 0,64 & 0,96 & 14,38 & 0,00 & 0,64 & 14,70 & 19,17 & 23,32 & 3,83 & 0,00 & 2,88 & 1,92 & 0,64 & 51,14 & 38,14 & 38,66 & 83,33 \\
\hline EFN $04 C$ & 0,00 & 1,41 & 0,56 & 0,85 & 0,00 & 0,28 & 14,37 & 0,00 & 0,85 & 18,31 & 29,30 & 25,07 & 3,38 & 1,13 & 3,94 & 0,28 & 0,28 & 94,44 & 36,43 & 42,21 & 78,46 \\
\hline EFN 07 & 0,00 & 3,07 & 1,12 & 25,14 & 0,28 & 0,84 & 12,57 & 0,00 & 0,56 & 14,80 & 10,89 & 20,39 & 2,79 & 1,12 & 3,63 & 2,23 & 0,56 & 33,33 & 38,14 & 42,06 & 77,59 \\
\hline EFN 08A & 0,85 & 1,13 & 0,85 & 15,58 & 0,57 & 0,28 & 8,78 & 0,00 & 0,28 & 22,10 & 17,28 & 18,70 & 2,27 & 0,85 & 7,93 & 2,27 & 0,28 & 36,05 & 31,96 & 54,17 & 52,54 \\
\hline EFN 05 B & 0,00 & 2,05 & 0,29 & 9,06 & 0,00 & 0,58 & 1,46 & 0,00 & 0,29 & 25,73 & 24,27 & 28,07 & 1,75 & 1,75 & 3,22 & 0,29 & 1,17 & 13,89 & 4,95 & 47,83 & 31,25 \\
\hline EFN $05 \mathrm{C}$ & 0,00 & 3,28 & 1,49 & 12,84 & 0,00 & 0,60 & 2,99 & 0,00 & 0,30 & 16,72 & 18,81 & 32,24 & 5,97 & 0,00 & 3,58 & 0,60 & 0,60 & 18,87 & 8,47 & 34,15 & 45,45 \\
\hline EFN 05 D & 0,00 & 2,30 & 0,77 & 10,23 & 0,51 & 0,26 & 4,86 & 0,00 & 0,00 & 11,25 & 27,11 & 32,48 & 3,58 & 0,77 & 4,60 & 0,77 & 0,51 & 32,20 & 13,01 & 25,73 & 51,35 \\
\hline EFN $05 \mathrm{E}$ & 0,29 & 1,17 & 0,29 & 13,41 & 0,58 & 0,58 & 2,92 & 0,00 & 0,00 & 14,58 & 11,95 & 45,48 & 1,46 & 1,75 & 4,37 & 0,29 & 0,87 & 17,86 & 6,02 & 24,27 & 40,00 \\
\hline EFN $05 \mathrm{~F}$ & 0,26 & 1,83 & 0,78 & 18,80 & 0,00 & 0,52 & 2,61 & 0,00 & 0,00 & 15,40 & 17,75 & 33,94 & 1,83 & 0,78 & 3,92 & 0,78 & 0,78 & 12,20 & 7,14 & 31,22 & 40,00 \\
\hline EFN $05 \mathrm{G}$ & 0,27 & 2,39 & 0,80 & 14,59 & 0,53 & 0,53 & 3,71 & 0,27 & 0,27 & 15,38 & 18,04 & 31,03 & 3,71 & 1,33 & 6,37 & 0,53 & 0,27 & 20,29 & 10,69 & 33,14 & 36,84 \\
\hline EFN $05 \mathrm{H}$ & 0,30 & 1,82 & 0,61 & 12,73 & 0,00 & 0,30 & 6,06 & 0,00 & 0,00 & 14,55 & 15,45 & 37,58 & 1,52 & 1,82 & 5,45 & 1,52 & 0,30 & 32,26 & 13,89 & 27,91 & 52,63 \\
\hline EFN 05 I & 0,00 & 1,14 & 0,85 & 10,80 & 0,00 & 0,85 & 6,25 & 0,00 & 0,00 & 16,48 & 17,05 & 36,36 & 3,41 & 0,85 & 5,11 & 0,57 & 0,28 & 36,67 & 14,67 & 31,18 & 55,00 \\
\hline EFN 05 J & 0,27 & 3,30 & 1,37 & 9,34 & 0,27 & 0,27 & 4,95 & 0,00 & 0,00 & 18,13 & 17,86 & 30,49 & 5,22 & 1,37 & 5,22 & 1,65 & 0,27 & 34,62 & 13,95 & 37,29 & 48,65 \\
\hline EFN 06A & 0,28 & 2,82 & 0,85 & 2,25 & 0,00 & 0,28 & 9,86 & 0,00 & 0,28 & 18,59 & 37,18 & 12,96 & 9,86 & 0,85 & 2,82 & 0,28 & 0,85 & 81,40 & 43,21 & 58,93 & 77,78 \\
\hline EFN 06B & 0,56 & 4,21 & 0,56 & 1,97 & 0,56 & 0,28 & 18,82 & 0,84 & 0,84 & 29,78 & 17,98 & 7,58 & 4,21 & 1,12 & 7,87 & 2,53 & 0,28 & 90,54 & 71,28 & 79,70 & 70,53 \\
\hline EFN $15 A$ & 0,00 & 1,92 & 1,64 & 7,67 & 1,37 & 0,00 & 13,70 & 0,27 & 0,27 & 35,34 & 14,52 & 15,34 & 3,84 & 0,55 & 0,82 & 1,92 & 0,82 & 64,10 & 47,17 & 69,73 & 94,34 \\
\hline EFN 15B & 0,00 & 3,45 & 1,88 & 16,93 & 0,31 & 0,94 & 7,84 & 0,00 & 1,88 & 31,97 & 11,60 & 11,91 & 5,02 & 1,57 & 2,51 & 1,57 & 0,63 & 31,65 & 39,68 & 72,86 & 75,76 \\
\hline EFN $15 C$ & 0,62 & 1,24 & 1,24 & 16,15 & 1,24 & 0,31 & 12,11 & 0,00 & 1,24 & 31,37 & 10,87 & 12,42 & 5,90 & 0,31 & 0,93 & 3,42 & 0,62 & 42,86 & 49,37 & 71,63 & 92,86 \\
\hline EFN 15D & 0,00 & 0,29 & 0,29 & 2,86 & 0,57 & 0,29 & 66,29 & 0,00 & 1,14 & 7,14 & 4,29 & 3,71 & 2,00 & 0,57 & 1,43 & 7,14 & 2,00 & 95,87 & 94,69 & 65,79 & 97,89 \\
\hline EFN 15E & 0,65 & 1,62 & 0,97 & 4,21 & 4,85 & 0,65 & 26,21 & 0,65 & 0,32 & 25,24 & 3,24 & 15,53 & 1,94 & 0,65 & 1,29 & 11,65 & 0,32 & 86,17 & 62,79 & 61,90 & 95,29 \\
\hline
\end{tabular}


APÊNDICE 6

Datações por ${ }^{14} \mathrm{C}$ sem calibrar 


\begin{tabular}{|c|c|c|c|}
\hline Amostra-Continentais & Idade $14 C$ & Amostra-Insulares & Idade $14 C$ \\
\hline ERN $02 \mathrm{Yb}$ & $6120 \pm 35 \mathrm{BP}$ & Ilha Rata 3c & $29300 \pm 90 \mathrm{BP}$ \\
\hline ERN 02Yc & $1910 \pm 50 \mathrm{BP}$ & Ilha Rata 3b & $26040 \pm 70 \mathrm{BP}$ \\
\hline ERN 03b & $470 \pm 30 \mathrm{BP}$ & Ilha Rata $5 c$ & $41060 \pm 210$ BP \\
\hline ERN 03c & $2130 \pm 30 \mathrm{BP}$ & Ilha Rata 5b & $25300 \pm 70 \mathrm{BP}$ \\
\hline ERN 06Bb & $2330 \pm 30 \mathrm{BP}$ & llha do meio $1 \mathrm{~b}$ & $18080 \pm 45 \mathrm{BP}$ \\
\hline ERN 08b & $2900 \pm 30 \mathrm{BP}$ & Ilha do meio 1c & $21000 \pm 55 \mathrm{BP}$ \\
\hline ERN 08c & $102.75 \pm 0.31 \mathrm{pMC}$ & Chapeu do Sueste 02 & $9810 \pm 30 \mathrm{BP}$ \\
\hline ERN 09b & $5375 \pm 30 \mathrm{BP}$ & Chapeu do Sueste 05 & $13680 \pm 40 \mathrm{BP}$ \\
\hline ERN 09c & $1415 \pm 30 \mathrm{BP}$ & EFN 02 & $9840 \pm 50 \mathrm{BP}$ \\
\hline ERN 14b & $4175 \pm 30 \mathrm{BP}$ & EFN 03Cc & $12960 \pm 50 \mathrm{BP}$ \\
\hline ERN $14 c$ & $595 \pm 30 \mathrm{BP}$ & EFN $03 \mathrm{Cb}$ & $12190 \pm 50 \mathrm{BP}$ \\
\hline ERN 17b & $5125 \pm 35 \mathrm{BP}$ & EFN 04Bc & $15210 \pm 70 \mathrm{BP}$ \\
\hline ERN 17c & $1080 \pm 30 \mathrm{BP}$ & EFN 04Bb & $7370 \pm 35 \mathrm{BP}$ \\
\hline ERN 19 & $22760 \pm 170 \mathrm{BP}$ & EFN 07b & $8340 \pm 40 \mathrm{BP}$ \\
\hline ERN 18c & $16160 \pm 70 \mathrm{BP}$ & EFN 07c & $14240 \pm 70 \mathrm{BP}$ \\
\hline ERN 18b & $21620 \pm 110 \mathrm{BP}$ & EFN 08Ab & $4640 \pm 35 \mathrm{BP}$ \\
\hline ERN 19 & $22760 \pm 170 \mathrm{BP}$ & EFN 08Ac & $6770 \pm 40 \mathrm{BP}$ \\
\hline ERN 21Ec & $27000 \pm 160 \mathrm{BP}$ & EFN 05B & $12440 \pm 60 \mathrm{BP}$ \\
\hline \multirow[t]{20}{*}{ ERN 21Eb } & $22800 \pm 110 \mathrm{BP}$ & EFN 05Cc & $20460 \pm 120 \mathrm{BP}$ \\
\hline & & EFN $05 \mathrm{Cb}$ & $19920 \pm 120 \mathrm{BP}$ \\
\hline & & EFN 05E & $24590 \pm 180 \mathrm{BP}$ \\
\hline & & EFN 05Eb & $24930 \pm 70 \mathrm{BP}$ \\
\hline & & EFN 05Ec & $30440 \pm 100 \mathrm{BP}$ \\
\hline & & EFN 05F & $27100 \pm 250 \mathrm{BP}$ \\
\hline & & EFN 05Hc & $36800 \pm 600 \mathrm{BP}$ \\
\hline & & EFN $05 \mathrm{Hb}$ & $34800 \pm 500 \mathrm{BP}$ \\
\hline & & EFN 05Jc & $37500 \pm 600 \mathrm{BP}$ \\
\hline & & EFN 05Jb & $28900 \pm 250 \mathrm{BP}$ \\
\hline & & EFN 06Bc & $28080 \pm 270 \mathrm{BP}$ \\
\hline & & EFN 06Bb & $31900 \pm 500 \mathrm{BP}$ \\
\hline & & EFN 15Ac & $28800 \pm 250 \mathrm{BP}$ \\
\hline & & EFN $15 \mathrm{Ab}$ & $31400 \pm 300 \mathrm{BP}$ \\
\hline & & EFN 15B & $25260 \pm 200 \mathrm{BP}$ \\
\hline & & EFN 15Cc & $39100 \pm 600 \mathrm{BP}$ \\
\hline & & EFN $15 \mathrm{Cb}$ & $34400 \pm 350 \mathrm{BP}$ \\
\hline & & EFN 15D & $31600 \pm 400 \mathrm{BP}$ \\
\hline & & EFN 15Ec & $41000 \pm 1000 \mathrm{BP}$ \\
\hline & & EFN 15Eb & $39200 \pm 600 \mathrm{BP}$ \\
\hline
\end{tabular}




\section{APÊNDICE 7}

Datações por LOE nos eolianitos continentais 


\begin{tabular}{|c|c|c|c|c|c|c|c|c|c|c|c|c|c|c|c|c|}
\hline Sample & Lab Code & $\begin{array}{l}\text { Dose } \\
\text { (Gy) }\end{array}$ & $\begin{array}{l}\text { Error } \\
\text { (Gy) }\end{array}$ & $\begin{array}{l}\text { Dose Rate } \\
\text { (Gy/ky) }\end{array}$ & \begin{tabular}{|l} 
Error \\
(Gy/ky)
\end{tabular} & Age (y) & Error (y) & \begin{tabular}{|l}
$\beta$-Dose \\
Respon \\
se \\
("lin"/" \\
exp") \\
\end{tabular} & \begin{tabular}{|l|} 
Beta \\
Source \\
Dose \\
Rate \\
(Gy/s) \\
\end{tabular} & $\begin{array}{l}\mathbf{N} \\
\text { Aliquot }\end{array}$ & OD (\%) & $\begin{array}{l}\text { Model } \\
\text { (CAM/ } \\
\text { MAM/ } \\
\text { AVERA } \\
\text { GE) } \\
\end{array}$ & $\begin{array}{l}\text { Recycli } \\
\text { ng } \\
\text { (averag } \\
\text { e) }\end{array}$ & Error & \begin{tabular}{|l} 
Recup \\
eratio \\
n \\
(aver \\
age) \\
\end{tabular} & Error \\
\hline ERN $18 \mathrm{eol}$ & L0982 & 25,60 & 2,10 & 0,39 & 0,05 & 65214,95 & 10327,41 & $\exp$ & 0,08 & $23 / 48$ & 37,70 & CAM & 1,01 & 0,02 & 0,29 & 0,17 \\
\hline ERN 09 & L0983 & 1,70 & 0,10 & 0,66 & 0,06 & 2594,21 & 296,35 & $\exp$ & 0,08 & $19 / 25$ & 21,90 & CAM & 0,97 & 0,04 & 3,07 & 0,40 \\
\hline ERN 06B & L0984 & 0,12 & 0,01 & 1,52 & 0,12 & 80,47 & 10,58 & lin & 0,08 & $14 / 24$ & 22,70 & CAM & 0,96 & 0,05 & 2,99 & 0,70 \\
\hline ERN $02 Z$ & L0985 & 8,20 & 0,40 & 2,85 & 0,23 & 2877,08 & 272,44 & exp & 0,08 & $22 / 24$ & 22,30 & CAM & 0,99 & 0,01 & 0,65 & 0,06 \\
\hline ERN 02X & L0986 & 7,10 & 0,50 & 4,80 & 0,39 & 1478,73 & 160,05 & exp & 0,08 & $16 / 24$ & 29,80 & CAM & 0,99 & 0,02 & 0,75 & 0,11 \\
\hline ERN 08 & L0987 & 0,03 & 0,01 & 1,87 & 0,15 & 14,40 & 4,93 & $\operatorname{lin}$ & 0,08 & $6 / 21$ & 0,00 & CAM & 0,94 & 0,06 & 6,56 & 1,10 \\
\hline ERN 06A & L0988 & 0,11 & 0,01 & 1,39 & 0,11 & 82,04 & 9,60 & $\operatorname{lin}$ & 0,08 & $14 / 24$ & 0,00 & CAM & 0,95 & 0,06 & 5,08 & 0,84 \\
\hline ERN 02Y & L0989 & 7,40 & 0,50 & 3,33 & 0,27 & 2224,30 & 235,98 & $\exp$ & 0,08 & $20 / 24$ & 26,50 & CAM & 0,97 & 0,02 & 0,80 & 0,07 \\
\hline ERN 07B & L0990 & 0,27 & 0,02 & 5,68 & 0,47 & 47,18 & 5,14 & $\operatorname{lin}$ & 0,08 & $28 / 48$ & 27,50 & CAM & 1,01 & 0,03 & 4,89 & 0,50 \\
\hline ERN 07A & L0991 & 0,28 & 0,02 & 4,11 & 0,34 & 66,94 & 6,91 & lin & 0,08 & $13 / 22$ & 16,10 & CAM & 0,96 & 0,03 & 2,04 & 0,35 \\
\hline ERN 19W & L1009 & 33,40 & 2,40 & 0,61 & 0,05 & 54673,52 & 5746,34 & exp & 0,08 & $14 / 24$ & 25,30 & CAM & 1,00 & 0,20 & $-1,37$ & 0,17 \\
\hline ERN 21W & L1010 & 35,10 & 2,50 & 0,61 & 0,05 & 57835,66 & 6140,44 & $\exp$ & 0,08 & $16 / 23$ & 22,80 & CAM & 1,00 & 0,02 & 0,24 & 0,07 \\
\hline ERN 20 & L1011 & 34,40 & 5,50 & 0,69 & 0,07 & 49702,45 & 9233,97 & $\exp$ & 0,08 & $17 / 24$ & 64,70 & CAM & 0,98 & 0,03 & $-0,50$ & 0,26 \\
\hline ERN 21E & L1012 & 59,30 & 4,80 & 1,00 & 0,07 & 59429,27 & 6518,52 & $\exp$ & 0,08 & $18 / 24$ & 33,40 & CAM & 1,00 & 0,02 & 0,21 & 0,10 \\
\hline ERN 19E & L1013 & 37,20 & 3,40 & 0,48 & 0,04 & 76825,06 & 9462,59 & $\exp$ & 0,08 & $15 / 24$ & 34,40 & CAM & 1,01 & 0,03 & $-1,33$ & 0,21 \\
\hline ERN 21W sat & L1010 sat & 72,60 & 2,11 & 0,61 & 0,05 & 119625,91 & 10039,90 & $\exp$ & 0,08 & $5 / 23$ & 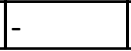 & AVERA & 0,96 & 0,02 & 0,09 & 0,06 \\
\hline
\end{tabular}

